\title{
O DIREITO DA COMUNICAÇÃO: RECONSTRUÇÃO DOS PRINCÍPIOS NORMATIVOS DA ESFERA PÚBLICA POLÍTICA A PARTIR DO PENSAMENTO DE JÜRGEN HABERMAS
}

TESE DE DOUTORADO

PROFESSOR ORIENTADOR:

EDUARDO CARLOS BIANCA BITTAR

UNIVERSIDADE DE SÃO PAULO

FACULDADE DE DIREITO

DEPARTAMENTO DE FILOSOFIA E TEORIA GERAL DO DIREITO

São Paulo - 2012 


\section{O DIREITO DA COMUNICAÇÃO: RECONSTRUÇÃO DOS PRINCÍPIOS NORMATIVOS DA ESFERA PÚBLICA POLÍTICA A PARTIR DO PENSAMENTO DE JÜRGEN HABERMAS}

Professor Orientador: Eduardo Carlos Bianca Bittar

Tese de Doutorado apresentada ao Programa de PósGraduação da Faculdade de Direito da Universidade de São Paulo, para obtenção parcial do título de Doutor em Direito pelo Departamento de Filosofia e Teoria Geral do Direito (FDUSP).

UNIVERSIDADE DE SÃO PAULO

São Paulo - 2012 
Banca Examinadora

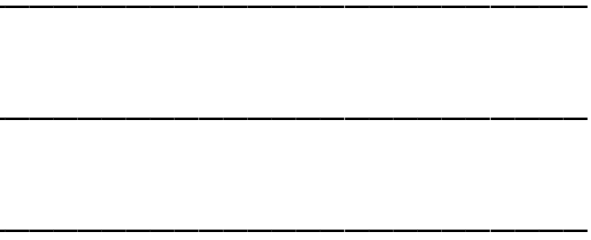




\section{AGRADECIMENTOS E DEDICATÓRIA}

Agradeço primeiramente ao Professor Doutor Eduardo Bittar, que com muita sabedoria me indicou os melhores caminhos a tomar e me ofereceu todas as condições para que eu pudesse realizar um trabalho que, assim espero, possa efetivamente oferecer uma contribuição relevante para o tema.

Agradeço a toda minha família, que desde sempre me apóia em todas as minhas iniciativas, que torceu e me ajudou de modo incondicional durante o período de estudos.

À Clarice, agradeço por ter me acompanhado de perto em todos os momentos, com dedicação e paciência, tornando meu percurso muito mais leve e feliz.

Agradeço também a todos meus queridos amigos, especialmente alguns especiais de São Paulo e de Frankfurt, que me apoiaram com entusiasmo e muito me ajudaram a chegar até aqui.

Pelo período de estudos realizado na Universidade Goethe de Frankfurt, agradeço imensamente aos Professores Doutores Klaus Günther, Axel Honneth e Rainer Forst, que muito colaboram com as ideais aqui desenvolvidas, e não somente por suas grandes obras, mas pela gentileza e seriedade acadêmica com que me receberam em seus colóquios em reuniões de orientação no semestre de verão de 2010. Agradeço também à Dra. Sidonia Blättler, do IfS, que também muito gentilmente e com entusiasmo tem auxiliado nas relações acadêmicas entre o IfS e o NEV-USP.

Agradeço aos professores-coordenadores, colegas e funcionários do Núcleo de Estudos da Violência da USP e da Associação Nacional de Direitos Humanos, por acreditar em meu potencial, e pela compreensão quanto aos últimos meses de trabalho.

Agradeço também à Fundação de Amparo à Pesquisa do Estado de São Paulo pelo apoio. Ao Parecerista da Fundação, devo meus sinceros agradecimentos e confesso que espero suas opiniões sobre o resultado final com a mesma ansiedade e seriedade acadêmica com que espero a argüição dos professores membros da banca avaliadora.

Este trabalho é dedicado a todos aqueles que lutam por comunicações mais livres e uma esfera pública mais democrática no Brasil. Mas é também dedicado a Eduardo Bittar, por acreditar e apostar em minha ideia, e por tudo o que representa para mim. 
"A liberdade de um começa onde

começa a liberdade dos outros"

(Ferraz Júnior. Erosion of subjective

rights by reason of technical

development (Patent, Copyright),

2011:59. trad. Livre do inglês).

"It is an extremely paiful thing to be ruled by laws that one does not know"

(Franz Kafka, The Problem of Our Laws, 1917) 


\section{SUMÁRIO}

INTRODUÇÃO

PARTE I - A ESFERA PÚBLICA POLÍTICA: DA MUDANÇA ESTRUTURAL À FUNDAMENTAÇÃO DA TEORIA DISCURSIVA DO DIREITO E DA DEMOCRACIA

1. Mudança Estrutural da Esfera Pública: raízes históricas e teóricas

2. Análise de Mudança Estrutural e algumas de suas críticas

a) origem da esfera pública burguesa ................................................................. 31

b) mudança estrutural da esfera pública burguesa................................................

c) princípios normativos da esfera pública burguesa e sua mudança estrutural ....... 76

3. Uma breve história da esfera pública política no Brasil

a) o surgimento de espaços públicos rudimentares na problematização do Brasil colonial-imperial

b) politização e "refeudalização" da esfera pública na consolidação da República até meados do século XX

c) ampliação da esfera pública a partir dos meios de comunicação de massa e politização da sociedade civil no questionamento do regime militar de 19641985

d) novas interpretações da esfera pública política a partir da redemocratização e da emergência das novas tecnologias de informação e comunicação na passagem do século XX ao XXI

4. Dos públicos às pretensões: fundamentação epistemológica e metodológica para um diagnóstico do presente da esfera pública política brasileira

a) a esfera pública política e o inevitável resíduo prático da racionalização social..

b) a esfera pública política a partir da teoria crítica comunicativa

c) a esfera pública política na teoria discursiva do direito e da democracia ....

d) diferenciação analítica da esfera pública política

PARTE II - DIAGNÓSTICO DO PRESENTE DA ESFERA PÚBLICA POLÍTICA NO BRASIL: A DIALÉTICA DA VIOLAÇÃO E DA AFIRMAÇÃO DE PRETENSÕES DE COMUNICAÇÃO E RECONHECIMENTO

5. Expressões técnico-científicas e informativas da esfera pública política

5.1. Economia e esfera pública política: obstáculos e avanços das pretensões à descentralização da propriedade e da produção de informação e comunicação ..... 
a) concentração econômica e concessões de meios de comunicação de massa. 168

b) novas tecnologias e críticas à propriedade intelectual .............................. 175

5.2. A economia do olhar na esfera pública política: mercantilização do olhar, estetização da economia e algumas de suas críticas

a) propaganda comercial e a mercantilização do olhar

b) problematizações e políticas contra a mercantilização do olhar $e$ estetização da economia

5.3. Comunicação informativa e esfera pública política: diagnósticos da pretensão à busca cooperativa pela verdade

a) teoria consensual da verdade e naturalismos cientificistas: a busca cooperativa pela verdade como pressuposto cognitivo e ético do discurso científico

b) objetividade e correção: a busca cooperativa pela verdade como exigência teórica e prática do discurso informativo-jornalístico

5.4. A factualidade da violência e a violência da factualidade: a pluralidade de visões de mundo contra formas dominantes de produção da verdade

a) a factualidade da violência: entre estatística e espetáculo

b) a violência da factualidade: a pressa é inimiga da correção

6. Expressões prático-morais da esfera pública política

6.1. Liberdade de expressão e regulação da comunicação: reflexos das relações entre autonomia individual e autonomia política na esfera pública política

a) liberdade de expressão, liberdade de imprensa e liberdade de comunicação comercial: imprecisões conceituais, excessos da autoregulamentação e a circulação constitucionalmente regulada da comunicação

b) razões de fato e de direito da regulação democrática de conteúdos: o PNDH-3, discursos de ódio e um elogio aos fundamentos do "politicamente correto"

6.2. Novas pretensões de comunicação e participação na formação da opinião e da vontade políticas: direito à comunicação e à informação como garantias fundamentais da autonomia política

a) rádios livres e comunitárias e redes sociais digitais ............................... $\quad 246$

b) escândalos midiáticos e manifestações políticas ...................................... 252

6.3. Iniciativas de intersubjetivização do direito a partir da esfera pública política: procedimentalização da soberania popular e publicização do direito ....

a) políticas de procedimentalização da soberania popular

b) políticas de publicização do direito

7. Expressões estético-expressivas da esfera pública política

7.1. Comunicação icônica, visibilidade e publicização da autoridade política ........ 271

a) predominância da comunicação icônica como elemento de desestabilização e crítica da racionalidade na esfera pública política..... 
b) visibilidade como fator de publicidade do direito: problematizando as políticas de publicização do direito a partir da expressão estética da esfera pública política

7.2. Invasões da privacidade por técnicas de mercado e vigilância: desafios à proteção constitucionalmente justificada da esfera privada

a) privacidade mercadorizada: incorporação de novas expressões da subjetividade individual pelos discursos técnico-econômicos

b) privacidade vigiada: associações entre os discursos econômicos e políticos pela administração da sensação da (in)segurança individual e social

7.3. Auto-expressões existencial e cultural como experiências de reconhecimento e suas problematizações na esfera pública política

a) tolerar pode significar insultar, mas a recíproca não verdadeira: relações $e$ tensões entre liberdade religiosa e liberdade de orientação sexual ...

b) auto-expressões existencial e cultural e políticas de reconhecimento: por uma lógica complementar à racionalidade das políticas públicas de cultura

\section{PARTE III - O DIREITO DA COMUNICAÇÃO: FUNDAMENTAÇÃO TEÓRICA E PRÁTICA}

\section{Teoria do discurso, teoria discursiva do direito e suas atualizações no presente} debate da teoria crítica: passos em direção a compreensões mais intersubjetivas do direito

8.1. Teoria do discurso, teoria discursiva do direito e o retorno incompleto do princípio da esfera pública política

a) fase a.DD: a transferência da fonte de legitimação democrática da esfera pública política para o procedimento deliberativo

b) fase d.DD: reforço às pretensões de identidade existencial e cultural e a esfera pública política como terceiro pressuposto do Estado democrático de Direito

8.2. Tendências de intersubjetivização do direito no diagnóstico do presente da teoria crítica: o nascedouro teórico do direito da comunicação

a) emancipação dos "filhos probos": as obras de Honneth e Forst como ramificações intersubjetivas da teoria crítica em direção a Hegel e Kant ....

b) o "filho fiel" e a recepção dos emancipados pelo pai: a obra de Klaus Günther como aplicação jusfilosófica da ética do discurso e o lugar do direito da comunicação

\section{Conceitos estruturais e jusfilosóficos do direito da comunicação}

9.1. Teoria discursiva do direito e o direito da comunicação: da co-originalidade entre autonomia individual e política à relação interna entre direito e esfera pública política 
a) deslocamento complementar do objeto da teoria procedimental do direito: mas por que a esfera pública politica?

b) o duplo-movimento institucional do direito da comunicação

9.2. Implicações jusfilosóficas do direito da comunicação na dogmática jurídica: aprofundando a recepção de teorias intersubjetivas do direito pela filosofia moderna do direito

a) pretensões normativas de direitos de comunicação no Brasil e alguns impactos sobre conceitos da filosofia moderna do direito

b) pretensões normativas de comunicação do direito no Brasil e alguns impactos sobre conceitos da filosofia moderna do direito 


\section{INTRODUÇÃO}

Somente comunicações livres tornam possível um direito legítimo e democrático. Mas tão fundamental quanto garantir essa pressuposição é a sua recíproca, pois só um direito legítimo e democrático torna possíveis comunicações livres.

Esta tese de doutoramento tem como objetivo geral discutir os problemas teóricos e práticos extraídos dessa proposição a partir de um aprofundamento das relações entre comunicação e direito propostas por Jürgen Habermas ao enfrentar o problema da legitimidade de ordens constitucionais e democráticas, especialmente nas obras Mudança Estrutural da Esfera Pública (Strukturwandel der Öffentlichkeit, 1962) e Direito e Democracia (Faktizität und Geltung, 1992) ${ }^{1}$.

A teoria do Direito da Comunicação pretende ser o resultado de um processo de intersubjetivização teórico e prático do direito, cuja necessidade teria ficado clara, mas não suficientemente aprofundada na teoria discursiva do direito elaborada por Habermas em Direito e Democracia. Em seus estudos mais recentes sobre o tema, no entanto, como em Entre Naturalismo e Religião (2007) e atuais debates sobre filosofia política dentro da Teoria Crítica da Sociedade ${ }^{2}$, essa tendência a uma maior intersubjetivização tem se mostrado cada vez mais presente. ${ }^{3}$

É por isso que o pensamento de Habermas será aqui trabalhado em relação às atualizações de sua teoria discursiva do direito e em diálogo com importantes

\footnotetext{
${ }^{1}$ Embora citada no estudo como Direito e Democracia, ou $D D$, utiliza-se especialmente a versão em língua inglesa, traduzida por William Rehg (Between Facts and Norms. Contribution to a Discourse Theory on Law and Democracy, MIT, 1996).

${ }^{2}$ A obra Dialectical Imagination, de Martin Jay (1996) é considerada uma das melhores obras sobre a história e a forma de pensamento teórico e social conhecida como Teoria Crítica da Sociedade, surgida a partir das obras e trabalhos comuns dos teóricos que passaram pelo Institut für Sozialforschung (IfS) o Instituto de Pesquisa Social da Universidade de Goethe de Frankfurt am Main, fundado em 1923 e até hoje atuante no debate acadêmico alemão. Recomenda-se também Honneth, Disrespect, 2007; Nobre, A Teoria Crítica, 2004; Id. A Dialética Negativa de Theodor Adorno, 1998; Bittar, Democracia, Justiça e Direitos Humanos: estudos de teoria crítica, 2011; Blotta, Habermas e o Direito, 2010.

${ }^{3}$ A abertura da linha de estudo sobre uma "teoria intersubjetiva dos direitos subjetivos" (intersubjektive Theorie der subjektiver Rechte) é citada por Klaus Günther como uma das questões principais enfrentadas durante os encontros do grupo de trabalho que discutiu com Habermas a elaboração de Direito $e$ Democracia, em "Im Umkreis von Faktizität und Geltung" ["No Circuito de Direito e Democracia", tradução livre do alemão]. in. Blätter für deutsche und internationale Politik. 6, Berlin: Blätter Verlagsgesellschaft mbH, 2009, p.60. Habermas vem aventar ainda a necessidade de continuação dessa investigação em Entre Naturalismo e Religião (2007:299): “A individuação de pessoas naturais ocorre pelo caminho da socialização. E indivíduos socializados desta maneira só conseguem formar e estabilizar sua identidade no interior de uma rede de relações de reconhecimento recíproco. Esse fato tem consequiências para a proteção da integridade da pessoa de direito - e para uma ampliação intersubjetivista do próprio conceito, que até o momento era tecido de uma forma demais abstrata (e talhado conforme as dimensões de um individualismo possessivo)".
} 
interlocutores e aprofundadores de seu pensamento, cujas teorias apontam também para compreensões mais intersubjetivas da sociedade, da moralidade, da política e do direito. ${ }^{4} \mathrm{O}$ esforço para a elaboração teórica do direito da comunicação responde também, portanto, a uma busca por atualizar o pensamento de Habermas em meio ao debate mais recente da teoria crítica na filosofia política e na filosofia do direito.

$\mathrm{O}$ argumento teórico da tese pode ser resumido a partir da seguinte analogia: se em Direito e Democracia a esfera pública política é vista como o espaço social onde a legitimidade da ordem democrática pode ser intersubjetivamente identificada, problematizada e justificada (Habermas, 1997-I:213-214), isso significa que, apesar de teoricamente oposta ao conceito de mundo da vida (Lebenswelt) ${ }^{5}$ - pois assume formas mais ou menos discursivas -, a esfera pública política desempenha em relação ao direito o mesmo papel do mundo da vida em relação à teoria do discurso habermasiana.

Isso porque especialmente a partir de Direito e Democracia, mas de certo modo já em Mudança Estrutural, a esfera pública política é entendida como pressuposto fundamental de um direito democrático, da mesma forma que a intersubjetividade compartilhada do mundo da vida é um pressuposto do discurso. Isto é, formado a partir de problematizações, violações e afirmações de pressuposições inevitáveis de comunicação e reconhecimento presentes nas interações e tensões entre público e privado a partir do surgimento da modernidade ocidental. Em seu caso específico, essas pressuposições colaboram especialmente para compreensão, a racionalização e a justificação legítima da ação política.

É, portanto, sobre a esfera pública política que o direito da comunicação atuará, tendo-a como objeto de análise que complementa o procedimento de deliberação democrática, sobre o qual incide o paradigma procedimental do direito de Habermas (v. Habermas, 1992:446). Com isso, procura colaborar, portanto, como forma de institucionalizar a proteção e o estímulo para uma formação racional da opinião e da vontade políticas.

\footnotetext{
${ }^{4}$ É especialmente o caso da teoria do reconhecimento de Axel Honneth (2003; 2011), da teoria da justificação de Rainer Forst (2004; 2007) e da teoria do direito de Klaus Günther (2004; 2005), que serão aqui aproveitadas na medida em que problemas suscitados no decorrer da pesquisa sugerirem diálogos críticos e aproximativos com o pensamento de Habermas.

5 "If communicative action were not embedded in lifeworld contexts that provide the backing of a massive background consensus, such risks would make the use of language orientated to mutual understanding an unlikely route to social integration. From the very start, communicative acts are located within the horizon of shared, unproblematic beliefs; at the same time, they are nourished by these resources of the always already familiar. The constant upset of disappointment and contradiction, contingency and critique in everyday life crashes against a sprawling, deeply set, and unshakable rock of background assumptions, loyalties, and skills." Habermas, 1996:22).
} 
Assim, enquanto a teoria do discurso pretende reconstruir, por meio de um estudo contínuo das dinâmicas do mundo da vida, as pretensões inevitáveis de racionalidade da interação social, o direito da comunicação pretende também reconstruir, mas agora por um diagnóstico crítico e diferenciado da esfera pública política, as pretensões normativas ${ }^{6}$ que devem ser asseguradas como pré-condições institucionais para um exercício mais amplo dos potenciais de integração social e de individuação através do direito e da política, sem os quais a própria racionalidade da legitimação do procedimento democrático se torna prejudicada.

Esse foco do direito da comunicação exigirá por sua vez um deslocamento complementar do status do domínio objetual da teoria do direito e da democracia de Habermas, acrescentando à reconstrução do procedimento de deliberação democrática a necessidade de também se reconstruir o conteúdo normativo da esfera pública política, como exercício constitutivo de um direito democrático e como atividade imprescindível de sua justificação legítima. Ao final, trata-se também de uma busca por colaborar a um aprofundamento dos critérios de avaliação da qualidade democrática do processo de legitimidade do direito contemporâneo.

Assim, os princípios estruturais e os conteúdos normativos do direito da comunicação encontrados na esfera pública política e institucionalizados parcial, implícita ou expressamente em atuais constituições democráticas como a brasileira, poderão influenciar a formação de novos arranjos institucionais, mas eles só serão possíveis se forem adotadas interpretações intersubjetivas de alguns dos mais importantes conceitos da filosofia do direito, como dignidade humana, validade jurídica e legitimidade, sujeito de direitos, direitos subjetivos e objetivos, justificação política e jurídica.

O último esforço do estudo se destina, portanto, a desenvolver essas novas interpretações por meio de uma leitura dos presentes debates de filosofia política e filosofia do direito dentro da teoria crítica da sociedade, sugerindo alguns dos possíveis impactos de uma teoria do direito da comunicação na teoria do direito e na jurisprudência brasileira das áreas referidas.

\footnotetext{
${ }^{6}$ A idéia de "pretensões normativas" traz consigo a idéia de "normatividade", que será aqui utilizada no sentido habermasiano do termo, isto é, como o levantamento inevitável de ideais contra factuais que orientam a ação social, seja ela teórica, prática ou estético-expressiva. No caso da razão comunicativa, além de seus pressupostos pragmáticos, em toda comunicação humana levantam-se pretensões de verdade, justiça e sinceridade/autenticidade, mesmo quando se trata de negar sua existência na realidade fática. Os sentidos mais específicos de normatividade utilizados durante este estudo serão definidos no próprio texto. Para mais sobre o que significa falar de normatividade em cada fase da obra habermasiana, ver Blotta, 2010.
} 
O tema da esfera pública política será tratado na parte I deste estudo desde a obra Mudança Estrutural da Esfera Pública (MEEP) à sua concepção como parte integrante da justificação da teoria discursiva do direito e da democracia de Habermas.

A partir desse esforço para reconstruir o conceito de esfera pública política no pensamento atual do autor, fica clara para a teoria do direito a necessidade de uma reconstrução dos princípios normativos da esfera pública política em situações históricas concretas, os quais podem, em relação com princípios do estado democrático de direito reconstruídos nos capítulos 3 e 4 de Direito e Democracia, oferecer melhores condições de análise e implementação de uma circulação mais legítima do poder político.

No primeiro capítulo, as raízes históricas e teóricas de Mudança Estrutural serão brevemente apresentadas, especialmente em relação ao processo de redemocratização na Alemanha, e a influência da teoria da indústria cultural nos estudos de Habermas sobre a apatia do movimento estudantil no começo dos anos 60. Em seguida, as teses principais de Mudança Estrutural serão analisadas em relação às suas revisões em um estudo detido, a partir do qual se poderá identificar não só as raízes do que viria a ser a teoria política de Habermas, mas também as primeiras pistas de uma teoria do direito da comunicação (parte II).

A importância de se desenvolver um novo diagnóstico da esfera pública política ficará evidente deste então, mas agora por meio do estatuto teórico maduro ${ }^{7}$ de Habermas, que volta a abordar o tema da esfera pública política trinta anos depois, no prefácio da edição alemã de 1990 de Mudança Estrutural da Esfera Pública (in. Calhoun (ed), 1992:441-457).

Após essa revisão crítica, ser apresentado, sob a mesma abordagem histórica e sociológica de Mudança Estrutural e uma seleção de literatura nacional e internacional sobre tema ${ }^{8}$, um breve histórico da formação da esfera pública política no Brasil (cap.3).

Os eventos sumariamente discutidos são: o nascimento da imprensa no Império (3 “a”); o surgimento de um público informado na consolidação da República (3 "b"); a mediatização da esfera pública nacional de veículos monopolizados pelo estado a concentrados meios "semi-públicos" de imprensa e concessionárias privadas comunicação

\footnotetext{
${ }^{7} \mathrm{O}$ estatuto teórico maduro de Habermas, que compreenderia a estruturação do paradigma da teoria crítica comunicativa como uma forma distinta e original de teórica crítica elaborada a partir da teoria dos interesses que guiam o conhecimento até a formulação da ética do discurso, passando pela pragmática formal e a teoria do agir comunicativo, pode ser analisado histórica e teoricamente em Blotta, 2010:108-273.

${ }^{8}$ Ao lado especialmente dos quatro volumes de História da Vida Privada (Novais. Coord. Geral, 19971998), obra condutora do histórico, serão citadas obras como a de Meirelles, J. Imprensa e Poder na Corte Joanina, 2008; Pinheiro, Estratégias da Ilusão, 1992; Ribeiro, O Povo Brasileiro, 1995.
} 
eletrônica, em meio ao fortalecimento da sociedade civil na alternância entre regimes democráticos e autoritários do século XX (3 “c”); e as novas interpretações da ideia de esfera pública com a emergência das novas tecnologias de informação e comunicação do final do século XX ao XXI (3 “d”).

A proposta por trás do capítulo é mostrar que mesmo com uma abordagem metodológica de certo modo mais histórica e sociológica de Mudança Estrutural, torna-se claramente possível conceber, em termos de problematizações de pretensões normativas entre público e privado, a existência uma esfera pública política no Brasil, desde o período colonial até democracia de massa orientada por uma economia de mercado, no contexto de um capitalismo monopolista/oligopolista. Mas mesmo com esse primeiro diagnóstico histórico de politizações do público a partir do privado, quando se tenta seriamente dar conta das múltiplas lutas sociais e movimentos que influenciaram a consolidação do regime democrático brasileiro, e que agora parecem supervisioná-lo crítica e midiaticamente, uma abordagem mais atualizada e sistemática ao problema se torna urgente e justificada.

É por isso que a passagem do breve histórico da esfera pública política no Brasil para a elaboração de um diagnóstico crítico de sua situação presente demandará uma reflexão teórico-metodológica inicial para assentar as pressuposições deste diagnóstico, a partir de interpretações do paradigma crítico-comunicativo da teoria crítica, da esfera pública política na teoria discursiva do direito e da democracia e da diferenciação analítica da esfera pública política.

Neste capítulo teórico (4), revisões do conceito de esfera pública política promovidas por Habermas (1990, prefácio; Id, 1996) e textos mais recentes no tema, como os presentes no livro Ay, Europa! (2009), destacam a necessidade de se dar condições teóricas para um diagnóstico distinto de seu tempo presente.

O método peculiar da teoria crítica de conectar filosofia com estudos empíricos com o objetivo de identificar reconstrutivamente pretensões normativas e suas violações na realidade social ${ }^{9}$, combinado com uma abordagem crítica e atualizada dos conceitos de racionalidade e esfera pública em Habermas, formará a estrutura epistemológica e metodológica do diagnóstico crítico da esfera pública política a ser realizado nesta tese.

\footnotetext{
9 “Among Hegel's left-wing disciples, i.e., from Karl Marx to Georg Lukács, it was considered self-evident that a theory of society could engage in critique only insofar as it was able to rediscover an element of its own critical viewpoint within social reality; for this reason, these theorists continually called for a diagnosis of society that could bring a degree of intramundane transcendence to light." (Honneth, 2007:63-66. Itálicos nossos).
} 
Isso significa que, ao fundamentar a relação peculiar da teoria crítica entre teoria e práxis, bem como a possibilidade de combinar seus diferentes paradigmas para melhor interpretar o tempo presente de fenômenos sociais, será possível elaborar o diagnóstico da parte II a partir de uma diferenciação analítica teoricamente justificada da esfera pública política em três expressões da comunicação pública, primeiramente influenciada pela diferenciação das pretensões de validade da razão comunicativa. ${ }^{10}$

Ao mesmo tempo, a atualização da razão comunicativa e sua combinação com a abordagem de Axel Honneth para conflitos sociais e de identidade (Habermas, 2007), por exemplo, pretende resultar num enquadramento teórico sensível o suficiente para não somente criticar as violações de pretensões de validade da razão comunicativa e suas relações entre si e com outras experiências humanas, mas também permitir a identificação de pretensões de reconhecimento na esfera pública política, por exemplo, que nem sempre emergem na forma de violações ou problematizações discursivas de pretensões de validade (Honneth, 2009:356ss).

Em seguida, a parte II deste estudo, dedicada a um diagnóstico do presente da esfera pública política no Brasil, buscará realizar uma reconstrução da dialética da violação e da afirmação das pretensões de comunicação e reconhecimento presentes na comunicação pública ${ }^{11}$ brasileira.

A ideia é tentar situar o presente impacto de cada expressão diferenciada da comunicação pública e sua influência na formação da esfera pública política, por meio de uma análise de suas relações com outros discursos, as problematizações discursivas e as pretensões de reconhecimento que enfrentam em problemas práticos, bem como as pretensões comunicativas e de reconhecimento que elas violam ou afirmam.

\footnotetext{
$10 "(\ldots)$ The only protection against an empiricist abridgement of the rationality problematic is a steadfast pursuit of the tortuous routs along which science, morality, and art communicate with one another. In each of these spheres, differentiation processes are accompanied by countermovements that, under the primacy of one dominant aspect of validity, bring back in again the two aspects that were at first excluded. Thus nonobjectivistic approaches to research within the human sciences bring viewpoints of moral and aesthetic critique to bear - without threatening the primacy of questions of truth; only in this way is critical social theory made possible." (Habermas,1984-II:398). Para uma idéia inicial desta diferenciação da esfera pública política, ainda que com outro propósito, v. Blotta, 2010a:56-80.

${ }^{11}$ Será utilizada a expressão comunicação pública neste estudo para designar não somente a comunicação dos meios não-comerciais e não-estatais, ou mesmo o termo jurídico brasileiro "comunicação social", mas sim toda e qualquer comunicação que assume relevância pública, no sentido de um interesse coletivo, ainda que se trate da proteção e delimitação daquilo que é "privado". Além das plataformas mais consolidadas da esfera pública, como as mídias eletrônicas (rádio, televisão, telecomunicações, internet) e a imprensa escrita, serão abordadas também esferas públicas informais da sociedade civil e espaços públicos formais do estado, de onde emerge o que se entenderá por comunicação política. Desse modo, a expressão "comunicação pública" designa o entrecruzamento entre comunicação social e comunicação política, campos específicos de atuação do direito da comunicação. De modo introdutório, v. Habermas, 1973:62-69.
} 
As primeiras expressões da esfera pública política a serem analisadas são os domínios técnico-científico e informativo da comunicação pública (cap. 5). Eles são conectados com a racionalidade instrumental e o discurso teórico, que se tornam visíveis na forma de atos de fala constativos ou representações de visões de mundo, e se especializam em expressões das ciências empírico-nomológicas na esfera pública, como a economia e a biologia, além do caráter descritivo-informativo do jornalismo, tanto na imprensa quanto nos media de massa ${ }^{12}$.

Alguns dos problemas sociais concretos a serem analisados nessa expressão da esfera pública política no Brasil serão as relações entre economia e esfera pública (5.1), entre "comunicação icônica" e a esfera pública econômica (5.2), algumas relações entre comunicação científica e informativa e esfera pública (5.3) e uma discussão sobre a “factualidade da violência e a violência da factualidade” na comunicação pública (5.4).

A partir desse diagnóstico crítico, as pretensões normativas que deverão ser objeto do direito da comunicação poderão ser identificadas como pretensões que estão no "pano de fundo", isto é, revelam-se pressupostas (de modo negativo ou afirmativo) nessas problematizações discursivas e pretensões de reconhecimento.

Algumas das pretensões normativas que se depreendem das análises dessa expressão da esfera pública brasileira a serem trabalhadas são a descentralização da propriedade da informação e das condições de sua produção, o direito à informação, à cultura e ao conhecimento, a pluralidade de visões de mundo e a busca cooperativa pela verdade.

A segunda expressão da esfera pública política a ser analisada é aquela relativa aos problemas práticos (cap. 6), isto é, que lidam com inter-relações entre as autonomias individual e política, quando questões da moral e da autocompreensão ética alcançam ou visam a alcançar o nível de problematizações públicas. Elas estão conectadas com os inevitáveis aspectos da racionalidade prática, e podem ser identificados em expressões de justiça, de ética e de pretensões de reconhecimento.

\footnotetext{
${ }^{12}$ A concepção de mídia de massa aqui trabalhada segue a definição de Marilena Chauí (2006:35-36), para quem o termo designa, a partir de Mcluhan e Benjamin, "objetos tecnológicos capazes e transmitir a mesma informação para um vasto público ou para a massa". Inserem-se neste quadro a imprensa, o rádio, a televisão, mas a atual massificação dos computadores e da internet, apesar de seus déficits de acesso e novas formas de comunicação interpessoal, torna possível considerá-los também meios de comunicação "massificantes". V. Blotta, 2008. v. também Benkler, 2006. Ao tratar de modo mais abrangente o conjunto de meios de comunicação eletrônicos que, liderados pela imprensa (incluída a impressa), formam o espaço da "comunicação pública" no Brasil, não será utilizado aqui o termo em inglês media, e sim "mídia", como indica a recepção do termo pela literatura corrente em comunicação no Brasil. V. Lima, 2011. Para evitar ambigüidades, no entanto, quando utilizado o termo, procurar-se-á especificá-lo com algum predicado, como "mídia de massa", "mídia impressa", ou "mídia digital".
} 
Na esfera pública política mediada pela comunicação pública, surge um grande leque de problemas relacionados, dos quais se buscarão destacar na presente esfera pública brasileira a batalha entre a liberdade de expressão de indivíduos ou grupos e pretensões a um fluxo constitucional e democraticamente de regulado da informação e da comunicação; novas formas de comunicação e suas tentativas de influenciar a formação da opinião e da vontade da sociedade civil, especialmente aqueles ligados à internet, rádios comunitárias, televisão pública, manifestações, desobediência civil e escândalos midiáticos; e novas tentativas de participação pública na formulação de políticas públicas e na condução e fiscalização do aparato do estado.

As primeiras pretensões normativas pressupostas nesses problemas a serem trabalhadas são liberdade de expressão e o direito a um fluxo constitucionalmente regulado da comunicação pública, o direito à comunicação e o direito à autodeterminação informacional, bem como o direito a uma formação discursiva da opinião e da vontade política da sociedade civil.

Por fim, como última parte do diagnóstico do presente da esfera pública política (cap. 7), suas manifestações estéticas e expressivas são aquelas relacionadas às condições das expressões e manutenção das subjetividades ou à autocompreensão existencial de indivíduos e grupos. A idéia de uma racionalidade estético-expressiva e suas relações com a esfera pública política, que evoluem para uma crítica e aprofundamento da teoria da racionalização em combinação com outros paradigmas da teoria crítica, terão de enfrentar problemas relacionados a expressões existenciais, culturais e artísticas e a fenômenos psicológicos e estéticos presentes na comunicação pública, bem como as relações entre políticas de segurança e de mercado relacionadas à esfera privada.

As análises desses problemas procurarão ser feitas por meio de interpretações intersubjetivas da estética, derivadas da teoria crítica, no intuito de compreender de maneiras expressões públicas de uma racionalidade expressiva e estético-comunicativa, supostamente pouco desenvolvida por Habermas ${ }^{13}$, influenciam o processo de legitimidade de estados democráticos constitucionais como o Brasil.

Esta abordagem permitirá uma nova forma de se identificar o impacto da “comunicação icônica” (Habermas, 2006a) na esfera pública e sua relação com outros discursos, como o científico-informativo e o prático. O diagnóstico de uma esfera pública atravessada por e quase dominada por conteúdos imagéticos, afetivos e inconscientes, que

\footnotetext{
${ }^{13}$ Sobre este tema, serão utilizados trabalhos como os de Duvenage, 2003 e Wellmer, 2003. Para uma análise antecipada V. Blotta. The Fascination of Authority and the Authority of Fascination, 2011 (manuscrito).
} 
será brevemente apresentada nesta tese a partir de literatura atual relacionada ${ }^{14}$, demandará uma tentativa de se trabalhar as possibilidade de uma discursivização da imagem e da estética na esfera pública brasileira.

Uma compreensão mais profunda do forte poder semântico das imagens e de outras expressões estéticas em comparação à comunicação escrita e falada poderá destacar aspectos importantes de presentes pretensões de comunicação e de reconhecimento que não são apreendidas pela racionalidade discursiva normal, isto é, pela práxis convencional de legitimação de estados democráticos constitucionais.

De modo mais concreto, serão analisadas formas com as quais a comunicação política se "auto-representa" na esfera pública, políticas culturais em face de tentativas de expressões da autocompreensão ética e existencial de indivíduos ou grupos e suas violações, e o uso injustificado do discurso estético para influenciar a esfera privada a partir de normatividades práticas e instrumentais na esfera pública política.

Algumas das pretensões normativas pressupostas neste último diagnóstico são, numa perspectiva teórica, as pretensões estéticas de publicização do direito, que mede a capacidade da comunicação política ampliar suas racionalidades a ponto de identificar suas relações com os discursos estético-expressivos, bem como o direito à diferença, o direito à auto-representação existencial e cultural, dentro dos quais se encontram direitos a condições propiciadoras de experiências de reconhecimento e o direito a uma proteção constitucionalmente justificada da esfera privada.

A partir da complexidade desse cenário que emergem não só as pretensões normativas mais substanciais do direito da comunicação, mas também as demandas de fundamentação teórica capazes de estabelecê-lo como uma teoria do direito diferenciada, posto que, para fins de aprofundar seu processo de intersubjetivização, descansa a avaliação da qualidade do processo de legitimidade do direito não somente no seu procedimento, mas naquilo cuja consideração é imprescindível para avaliação de nível democrático: a esfera pública política.

A fundamentação teórica e prática do direito da comunicação, que marca o início da parte III (e última) da tese, será iniciada por uma tematização do caminho tomado por Habermas desde sua teoria do discurso até sua teoria do direito e da democracia. Em outras palavras, será uma tentativa de explicar porque Habermas passa a ver numa teoria do direito e da democracia uma forma de efetivamente implementar sua teoria e ética do

\footnotetext{
${ }^{14}$ Habermas, 2006, Id, 2002c; Bucci, 2002; Bucci \& Kehl, 2004; Schwartz, 2006, Wellmer, 1998, Duvenage, 2003.
} 
discurso, bem como o conceito de ação comunicativa na arena política (cap. 8). Além das razões históricas por esse caminho tomado, as fundamentações teóricas serão aquelas que vão especialmente guiar a discussão ao segundo tópico desta parte, que trabalhará com as críticas e atualizações da teoria do direito de Habermas dentro do presente debate em filosofia política e filosofia do direito realizado pela teoria crítica.

Junto com suas próprias revisões e atualizações da teoria do direito, especialmente em textos e discussões envolvendo obras como Entre Naturalismo e Religião (Zwischen Naturalismus und Religion, 2007:115-168 e 279-392), a tematização desses debates se utilizará principalmente de seus possíveis diálogos com os estudos de filosofia política e de filosofia do direito de Axel Honneth (2003; 2011) Rainer Forst (2004; 2007), e Klaus Günther (2004; 2005), que buscam atualizar o pensamento de Habermas de acordo com suas áreas de atuação e perspectivas específicas.

A hipótese que fundamenta a realização desse debate é a de que apesar de seguirem diferentes abordagens e conceitos, as abordagens de cada autor compartilham com Habermas um objetivo comum: o de promover um processo de intersubjetivização do direito, o que é também um dos objetivos teóricos do direito da comunicação.

Nesse sentido, já que a distância entre as perspectivas de Honneth e Forst permite abranger todo o leque de abordagens que derivam de Hegel à Kant nos temas da filosofia moral e a filosofia política, e os trabalhos de Klaus Günther parecem aplicar, em claro diálogo com essas duas perspectivas ${ }^{15}$, o pensamento de Habermas à filosofia do direito, a tematização dessas distintas abordagens e uma combinação crítica de suas discussões pretende dar esteio a uma teoria do direito da comunicação que seja capaz de lidar com os mais recentes debates dentro das teorias intersubjetivas da teoria crítica.

De modo mais claro, o direito da comunicação pretende ser um possível resultado desse processo mais aprofundado de intersubjetivização que Habermas parece estar procurando para sua teoria do direito, dadas suas mais novas reflexões sobre o tema (Habermas, 2007; 2009).

Mais especificamente, um dos esforços teóricos do direito da comunicação que abrem o capítulo 9 será a proposta de um deslocamento complementar do âmbito da legitimidade do direito: do procedimento democrático para a esfera pública política, onde se encontram as origens da normatividade política através da qual o próprio procedimento legal pode ser testado como legítimo ou não.

$\overline{{ }^{15} \text { Ver Günther, 2005:246; Id., 2009a. }}$ 
Esse deslocamento certamente causará impactos na teoria da democracia deliberativa de Habermas, pois essa nova abordagem propõe, por exemplo, que o conteúdo normativo dos estados democráticos constitucionais, isto é, a co-originariedade entre autonomias individual e política, só pode ser democraticamente equilibrada dentro do próprio direito se suas respectivas pretensões normativas tiverem as condições institucionais de ser democraticamente formuladas na própria esfera pública política.

Essa crítica se torna necessária porque apesar de a esfera pública política ser uma pedra de toque da teoria habermasiana do direito e da democracia, seu conteúdo normativo não é apropriadamente reconstruído em Direito e Democracia (capítulos 7 e 8, quando o tema é especialmente tratado), em comparação com a reconstrução historicamente situada dos conteúdos normativos do sistema de direitos e dos estados democráticos constitucionais da Alemanha e dos Estados Unidos (capítulos 3 a 6).

Assim, apesar de salientada sua importância, a esfera pública política volta a servir somente como um parâmetro teórico para criticar a qualidade da formação da opinião vontade políticas por meio da identificação empírica de desvios em relação aos ideais comunicativos do processo de legitimação do direito.

Sem abandonar essa importante característica teórica, no entanto, o direito da comunicação pretende não só reconstruir esse conteúdo normativo da esfera pública política, ainda que na historicamente situada realidade brasileira (parte II), mas também sugerir desenvolvimentos procedimentais internos à teoria do direito que respondem à pretensão normativa por uma maior interpenetração entre direito e esfera pública política.

Um desses desenvolvimentos será a proposta do duplo-movimento do direito da comunicação, que deve ser considerado pela teoria discursiva do direito se o deslocamento complementar de seu domínio objetual e a relação interna entre direito e esfera pública política se fizerem fundamentadas. Esse duplo-movimento, como sugestões para os possíveis desenvolvimentos institucionais de um direito que assume essa estrutura teórica, consiste na garantia de (1) direitos de comunicação $e$ de reconhecimento e (2) a publicização ou a comunicação do direito.

Com a finalidade de cumprir suas tendências presentes de intersubjetivização, o último tópico da pesquisa lidará com as implicações mais técnicas do direito da comunicação na teoria do direito, tomado também como um esforço para aprofundar a recepção de teorias jurídicas intersubjetivas pelo direito moderno. 
Esse debate será promovido especialmente por um diálogo do direito da comunicação com estudos jurídicos mais dogmáticos ligado às áreas da comunicação social e da comunicação política no direito brasileiro.

Com essa discussão, pretende-se firmar os últimos fundamentos teóricos do direito da comunicação para que ele possa ser utilizado não somente como uma teoria que fornece padrões procedimentais e normativos para uma crítica social da violação de pretensões de comunicação e de reconhecimento na esfera pública política; ou mesmo como uma contribuição teórica às teorias da filosofia do direito, mas também como uma teoria jurídica operativa que pode ser aplicada no sistema jurídico e na jurisprudência de um estado democrático quando se trata de problemas envolvendo sua esfera pública política, como será o caso novamente com o Brasil no capítulo final da tese.

Os últimos objetivos da tese são, portanto, de oferecer uma leitura mais sistemática dos conteúdos normativos reconstruídos no diagnóstico da parte II com a ajuda da estrutura teórica do direito da comunicação, lançando ao debate algumas de suas possíveis implicações específicas no sistema jurídico brasileiro e na jurisprudência sobre o tema.

Nesse sentido, as pretensões normativas e direitos específicos que foram identificados nesses diagnósticos poderão ser interpretados também através do duplomovimento do direito da comunicação e das novas interpretações intersubjetivas da filosofia do direito trabalhadas nos capítulos 8 e 9 .

De modo mais concreto, isso significará fornecer fundamentos jusfilosóficos para institucionalização de novos - e o aumento da legitimidade e aplicabilidade dos já existentes - princípios constitucionais que institucionalizam a proteção e a potencialização de uma esfera pública pluralista, critica e inclusiva no Brasil, como um complemento ao processo de legitimação da ordem jurídica - cujo foco na teoria discursiva do direito de Habermas é a garantia institucional das condições de racionalidade da deliberação democrática. ${ }^{16}$

\footnotetext{
${ }^{16}$ Uma formulação clara desta tese é dada por Habermas em "Further Reflections on the Public Sphere (1992): "Within a discourse-centered theoretical approach, this idea is carried further to give rise to the notions that additionally the law is applied to itself: $i$ t must also guarantee this discursive mode by means of which generation and application of legislative programs are to proceed within the parameters of rational debate. This implies the institutionalization of legal procedures that guarantee an approximate fulfillment of the demanding preconditions of communication required for fair negotiations and free debates. These idealizing preconditions demand the complete inclusion of all partiers that might be affected, their equality, free and easy interaction, no restrictions of topics and topical contributions, the possibility of revising the outcomes, etc. In this context the legal procedures serve to uphold within an empirically existing community of communication the spatial, temporal and substantive constraints on choices that are operative within a presumed ideal one." (Habermas, 1992:449. Itálicos nossos).
} 
Não se trata, portanto, de somente justificar o direito de todos à comunicação como direito humano, pois apesar de urgente, constitucional e internacionalmente previsto como extremamente importante para a revitalização de processos de emancipação social (Fischer, 1984; Ferreira, 1997; Brittos \& Collar, 2008; Intervozes, 2006), esse direito dificilmente se concretizará se ele não for também concebido como uma das pretensões normativas do conjunto de direitos e deveres de comunicação e de reconhecimento que garantem a esfera pública política, isto é, sem os quais carece de fundamento a legitimidade democrática do Estado de direito.

Se a liberdade de expressão e o direito à informação não se realizam eqüitativa e materialmente sem o direito à comunicação ${ }^{17}$, este também não ganha sua facticidade esperada sem o direito $d a$ comunicação, como um conjunto de pressupostos, direitos, deveres e instituições que devem garantir uma formação democrática e emancipatória da esfera pública política.

Enfim, pode-se dizer que este estudo se alinha de modo normativo não somente com as teorias que buscam maior intersubjetivização da filosofia política e do direito na perspectiva da teoria crítica da sociedade, mas pretende também colaborar para a fundamentação e possível concretização de pretensões políticas de diversos setores da sociedade civil, do Estado brasileiro e de uma crescente esfera pública internacional por mais reconhecimento e respeito aos direitos e deveres de comunicação e de reconhecimento em sentido amplo, como passos inevitáveis para o desenvolvimento de sociedades mais livres, igualitárias e democráticas.

\footnotetext{
17 “A grande maioria dos ordenamentos jurídicos do mundo reconhece dois direitos fundamentais ligados à comunicação: o direito à informação e o direito à liberdade de expressão. No entanto, o reconhecimento de tais direitos não assegura, por si só, a capacidade de se comunicar livremente, nem impede que se concentrem nas mãos de poucos os meios próprios para isto." (Brittos e Collar, 2008:71).
} 
PARTE I

A ESFERA PÚBLICA POLÍTICA: DA MUDANÇA ESTRUTURAL À FUNDAMENTAÇÃO DA TEORIA DISCURSIVA DO DIREITO E DA DEMOCRACIA 
Esta primeira parte do trabalho é composta por quatro capítulos que procuram revisar e atualizar a obra Mudança Estrutural da Esfera Pública (MEEP, original de 1962), com vistas a fornecer as bases históricas e teórico-metodológicas do diagnóstico do presente da esfera pública política brasileira, a ser realizado na parte seguinte.

Primeiramente, são apresentadas as raízes históricas e teóricas de MEEP (cap.1), seguidas de uma análise detalhada de suas teses e algumas de suas críticas (2). Após, pretende-se fazer uma breve historicização da esfera pública política no Brasil com base em literatura especializada ${ }^{18}$ (3). Por fim, serão trabalhadas as revisões e atualizações da obra e do conceito de esfera pública política a partir dos estudos e debates mais recentes de Habermas sobre o tema, apresentando ao final a sugestão de um método para diagnósticos do presente da esfera pública política (4).

O primeiro capítulo trata do contexto histórico e biográfico de Habermas de onde teriam surgido as teses de $M E E P$, seguido de uma detida análise da obra no tópico seguinte. Essa revisão aprofundada se justifica na medida em que é uma obra de grande importância para a compreensão do pensamento do autor, especialmente nos temas referentes a esta tese.

A complexidade de seus conceitos, diagnósticos e estrutura, bem como sua única tradução para o português feita por Flávio Kotche e lançada pela editora Tempo Brasileiro (Rio de Janeiro) pela primeira vez em 1984, também dificultam uma recepção da obra em todo seu potencial pela literatura nacional ${ }^{19}$. No caso do capítulo 2 , a revisão será feita à luz de uma possível atualização para a proposta de uma teoria do direito da comunicação, formulada no terceiro e último capítulo deste estudo.

O capítulo 3, destinado uma breve historicização da esfera pública no Brasil, pretende abordar o tema ainda a partir da perspectiva metodológica utilizada em MEEP, isto é, por meio de um diagnóstico interpretativo, porém descritivo de fatos históricos que retratam surgimento, a institucionalização e a mudança estrutural da esfera pública no

\footnotetext{
${ }^{18}$ Especialmente a partir dos estudos contidos nos quatro volumes de História da Vida Privada no Brasil, com organização da coleção por Fernando A. Novais, mas também a partir de estudos relativos à história da esfera pública e da comunicação social no Brasil, como de Bucci, 2000; Pinheiro, 1992; Meirelles, 2008 e Lavalle, 2001.

${ }^{19}$ Estudos brasileiros que mais precisamente retratam o tema, com interessantes repercussões práticas, como a análise da influência dos meios de comunicação de massa em experiências de democracia deliberativa no Brasil, são Gomes \& Maia, Comunicação e democracia, 2008; Maia (org.), Mídia e Deliberação, 2010. Estes textos e outras pesquisas do grupo de Rousiley Maia Mídia e Esfera Pública, da Faculdade de Comunicação da UFMG, serão retomados e discutidos no segundo capítulo da tese (esp. tópico 2.2). Para outras leituras críticas sobre Mudança Estrutural na literatura nacional, V. Lavalle, A. G. Habermas e a Virtualização da Publicidade. In. Margem. São Paulo. No 16. Dez. 2002, pp. 65-82; Id. Espaço e vida públicos: reflexões teóricas e sobre o pensamento brasileiro. Tese de doutorado. Faculdade de Filosofia, Letras e Ciências Humanas da USP, 2001.
} 
Brasil nos períodos do capitalismo liberal e tardio. Seus protagonistas são os diversos públicos que interagiram e se transformaram em meio aos efeitos desses dois processos históricos no país.

Também da mesma forma que feito em MEEP (caps. IV e VII da obra), essa breve historicização buscará reconstruir as pretensões normativas ${ }^{20}$ da esfera pública política brasileira. Se este esforço traz questionamentos sobre a existência de fato de uma esfera pública politicamente ativa no Brasil, servirá também para demonstrar a necessidade de uma abordagem diferenciada para novos diagnósticos de seu tempo presente, como a que será utilizada no capítulo seguinte. O capítulo termina, portanto, com a proposta de uma nova metodologia para a realização de diagnósticos da esfera pública política, a partir do estatuto teórico maduro de Habermas e seus mais recentes debates na teoria crítica e na filosofia do direito $(1.4)^{21}$.

Com essa nova proposta de abordagem, pretende-se reconstruir no segundo capítulo os conteúdos normativos de expressões da esfera pública política brasileira, ao invés de fazê-lo a partir das posições dos públicos na estrutura social e suas funções políticas, como Habermas faz em MEEP e em seus estudos posteriores sobre o tema, bem como muitos de seus interlocutores (Negt 2006:4; Negt \& Kluge, 1993; Fraser, 1992).

\section{Mudança Estrutural da Esfera Pública: raízes históricas e teóricas}

A obra Mudança Estrutural da Esfera Pública: Investigações acerca de uma categoria da sociedade burguesa (Strukturwandel der Öffentlichkeit. Untersuchungen zu einer Kategorie der bürgerlichen Gesellschaft, 1962), origina-se da tese de "livredocência" (o Habilitationschrift, trabalho de pós-doutorado exigido para se poder lecionar na Alemanha) que Habermas, então com 32 anos de idade apresentou e defendeu em 1961 na Universidade de Marbug, Alemanha, sob a supervisão de Wolfgang Abendroth. ${ }^{22}$

\footnotetext{
${ }^{20}$ Craig Calhoun divide em duas as pretensões de Habermas com a crítica da esfera pública em MEEP: "...showing both (1) its internal tensions and the factors that led to its transformation and partial degeneration and (2) the element of truth and emancipatory potential that it contained despite its ideological misrepresentation and contradictions." (Calhoun, 1992:2).

${ }^{21}$ Serão trabalhadas atualizações da discussão de Habermas sobre esfera pública até escritos posteriores à Direito e Democracia, como "O Caos da Esfera Pública" (2006) e "Tiene la Democracia aún un valor epistêmico?" (in. Habermas, Ay, Europa, 2009), bem como atualizações a partir estudos de interlocutores, como Honneth (2011), Günther (2005) e Forst (2007). Para aprofundamento no "estatuto teórico maduro" de Habermas, que será brevemente apresentado no tópico 1.4 a partir de sua inserção nos mais recentes debates sobre a esfera pública política, v. Blotta, 2010:108-273.

${ }^{22}$ Jurista e cientista político que detinha então a cátedra de ciência política da Universidade desde 1950, e a quem $M E E P$ é dedicada, não somente por ter recebido o trabalho de Habermas, mas também por suas
} 
Grande parte da tese fora escrita em Frankfurt am Main, no entanto, enquanto Habermas era ainda assistente pessoal de Adorno (1956-1961), mas as críticas do mesmo e de Max Horkheimer ao trabalho, além de desavenças políticas com Horkheimer, impediram-no de defendê-la na Universidade Goethe de Frankfurt. ${ }^{23}$

Para ambos seus mestres e predecessores, o estudo de MEEP seria por demais utópico ao ressaltar um potencial emancipatório numa categoria do esclarecimento burguês no contexto de uma sociedade de massas, e ao mesmo tempo muito radical em sua proposta por uma politização da esfera pública política como necessária a uma integração social democrática no Estado de bem estar social (Calhoun, 1992:4).

Mesmo assim, apesar de Habermas revelar que a Teoria Crítica da Sociedade havia lhe dado condições para a identificação da esfera pública política "no contexto mais amplo do processo de modernização social" (Habermas, 2007:28), seu objeto de estudo e suas pretensões normativas certamente já indicavam o caminho teórico distinto que começava a tomar em relação a Horkheimer. ${ }^{24}$

Esse caminho distinto se tornou também uma separação física, e já então não mais como assistente de Adorno e investigador do Instituto de Pesquisa Social (Institut für Sozialforschung) da Universidade Goethe de Frankfurt am Main, Habermas finalizou o trabalho com bolsa da Associação Alemã de Pesquisa (DFG) na Universidade de Marburg,

contribuições à institucionalização e consolidação de um Estado democrático na Alemanha do pós-guerra. Seus trabalhos sobre o Estado democrático de direito e a capacidade de uma influência extra-econômica democrática sobre a intervenção da economia no Estado alemão, como "Sobre o Conceito dos Estados de Direito Democráticos e Sociais" ("Zum Begriff des demokratischen und sozialen Rechtsstaates" in. Forsthoff. Rechtsstaatlichkeit und Sozialstaatlichkeit, Darmstadt, 1968. Apud. Habermas, 1992:435) influenciam declaradamente algumas das teses de $M E E P$, como atestou Habermas no prefácio da edição de 1990, apesar de atualmente não mais pactuar com esse diagnóstico sem ressalvas importantes, como a diferenciação dos subsistemas sociais (Habermas, 1992:435-436).

${ }^{23}$ Fatos mais específicos sobre a história que envolveu a MEEP são narrados por Barbosa (1996:20-22), citando e fazendo menção a um texto de Habermas chamado "Uma geração separada de Adorno" (Trad. livre de: "Eine Generation Von Adorno getrennt", publicado na obra Geist gegen den Zeitgeist. Erinnern an Adorno. Früchtl e Calloni (orgs). Frankfurt: Suhrkamp, 1991), e à obra de Wiggershaus sobre a "Escola de Frankfurt" (2002). Kellner (2010:3) também ressalta como Wiggershaus relatou nesta obra as diferenças entre as posições de Horkheimer e Adorno em relação ao estudo de Habermas. Enquanto Adorno teria aceitado receber a tese na Universidade Goethe, Horkheimer teria sugerido alterações inaceitáveis às suas primeiras versões, o que levou finalmente ao desligamento de Habermas do Instituto de Pesquisa Social e da Universidade, até seu retorno, em 1964, para assumir a cadeira de filosofia social do próprio Horkheimer, com o reconhecimento deste e a bênção de Adorno.

${ }^{24}$ Essas distinções entre especialmente em relação ao pensamento de Adorno seriam trabalhadas mais precisamente somente em Theory of Communicative Action (1984-I:366-399), mas segundo Habermas, a percepção plena de seu distanciamento em relação à Adorno teria ocorrido somente quando da leitura do texto "Comunicação e Reconciliação: crítica de Habermas à Adorno", de Axel Honneth. Este texto de Honneth é originalmente de 1976, mas pode ser encontrado em sua versão completa como "Von Adorno zu Habermas. Zum Gestaltwandel kritischer Gesellschaftstheorie”. In. Bonss e Honneth, (orgs). Sozialforschung als Kritik: zum sozialwissenschaftliche Potential der kritischen Theorie. Frankfurt: Suhrkamp, 1982. (apud. Barbosa, 1996:23). 
apresentando-a a Wolfgang Abendroth, após recusar convite de Hans-Georg Gadamer e Karl Löwith para fazê-lo na Universidade de Heidelberg (Barbosa, 1996:21-22).

Outra grande influência sobre a orientação e o conteúdo de $M E E P$ foi o processo de redemocratização da Alemanha, que de 1945 aos anos 60 demonstrava ainda dificuldades de incorporar os novos ideais democráticos. Habermas escreve MEEP durante este período, com a preocupação do não-retorno dos autoritarismos do passado e da consolidação de uma cultura democrática que teria de ser formada a partir da autocompreensão ética dos cidadãos do Estado, gerando uma esfera pública política capaz de integrar a sociedade e ao mesmo tempo fiscalizar o poder. Essas preocupações o acompanhariam até os anos 80 - e se pode dizer, ainda o acompanham - como motivações diretas de seu trabalho científico. ${ }^{25}$

Além da história controvertida de MEEP, os estudos de Adorno e Horkheimer sobre a Indústria Cultural e um estudo empírico realizado pelo próprio Habermas com colegas do Instituto de Pesquisa Social sobre a consciência política dos estudantes da Universidade Goethe de Frankfurt ${ }^{26}$, foram também determinantes na atenção que teria dado a determinadas expressões da esfera pública das democracias de massa em seu estudo. $^{27}$

\footnotetext{
${ }^{25}$ Habermas fala sobre essas influências históricas em discurso realizado em ocasião do recebimento do Prêmio-Tokyo, em 2004, em texto denominado "Espaço Público e Esfera Pública Política. Raízes biográficas de dois motivos de pensamento". Este interessante texto foi originalmente publicado no jornal Neue Zürcher Zeitung, 11/12 de dezembro de 2004. Aqui será utilizada a versão publicada em Entre Naturalismo e Religião (2007:17-30). Para esta tese, cabe aqui destacar o seguinte trecho: "Naquela época, isto é, no final dos anos 50, a cultura política ainda não possuía entre nós raízes muito sólidas. Não havia garantias de que os princípios de uma ordem democrática, que de certa forma foram impostos a partir de fora, iriam deitar raízes nas cabeças e nos corações das pessoas. (...) Tal processo só poderia ser alavancado por uma formação vital $e$, dentro das possibilidades, pública e discursiva da opinião. // Por isso, minha atenção teórica dirigiu-se para a esfera pública política. Sempre me interessei pelo fenômeno geral do 'espaço público' que surge até mesmo em interações simples porque nele a intersubjetividade possui uma força misteriosa capaz de unir elementos distintos mantendo, mesmo assim, a sua identidade. A análise de espaços públicos permite decifrar estruturas da integração social. A constituição dos espaços públicos revela, de preferência, características anômicas de decomposição ou fraturas de uma socialização repressiva." (Habermas, 2007:28. Itálico nosso).

${ }^{26}$ Student und Politik. eine soziologische Untersuchung zum politischen Bewusstsein Frankfurter Studenten, original de 1961, escrito em co-autoria com Ludwig von Friedeburg, Christoph Oehler, Friedrich Weltz.

27 "While on the whole I would stick to my descriptions of the changed infrastructure of a public sphere infiltrated by power, its analysis needs to be revised, especially my assessment of the changes in the public behavior. In retrospect, I discern a number of reasons for the insufficiency of my interpretation: the sociology of voter behavior was only in its beginnings (...). Furthermore, the strong influence of Adorno's theory of mass culture is not difficult to discern. Additionally, the depressing results of the just-finished empirical investigation for Student und Politik may have contributed to an underestimation of the positive influence of formal schooling, especially of its expanding secondary level, on cultural mobilization and the promotion of critical attitudes." (Habermas, 1992:437-438).
} 
Uma série de intervenções de Habermas na mídia impressa e no debate acadêmico alemão sobre burocratização e hábitos de consumo dos cidadãos da época precedeu a publicação de Student und Politik, o que revela sua adoção da orientação dos trabalhos do Instituto de Pesquisa Social em análises empíricas interdisciplinares sobre as diferenças entre a sociedade de massas do capitalismo de bem estar social e aquela do capitalismo liberal pós-revolucionário, linha esta também seguida em $M E E P{ }^{28}$

Estudos como o de Erich Fromm sobre as atitudes de apatia política e conservadorismo na classe trabalhadora na ascensão do nazismo (original de $1936^{29}$ ), que influenciou a célebre pesquisa de Adorno sobre personalidade autoritária da sociedade alemã do pós-guerra (1950), entre outros (Pollock, 1955) ${ }^{30}$, traziam índices de potenciais anti-democráticos semelhantes àqueles que Habermas vinha identificando no público estudantil ao tempo da publicação de Student und Politik. ${ }^{31}$

Além disso, especialmente esses últimos diagnósticos operavam sob a grande influência da obra Dialética do Esclarecimento (Dialektik der Aufklärung, 1947), de Adorno e Horkheimer, cuja reflexão teórica e análise do processo de industrialização da cultura gradativamente dificultavam o acesso das pesquisas seguintes a potenciais emancipatórios iluministas presentes na sociedade de massa. ${ }^{32}$

A "sociedade administrada" era construída especialmente a partir do controle da cultura pela razão instrumental ${ }^{33}$, o que estendia o processo de reificação material do ser

${ }^{28}$ Ver. Kellner, 2010:3-4. Desses textos, podemos citar: Habermas. "Können Konsumenten spielen?" [Can Consumers Play?], in Frankfurter Allgemeine Zeitung, (April 13). 1957; Id. "Für und Wider. Der Mensch zwischen den Apparaten" [For and Against: The Humans Between the Apparatuses]. Süddeutsche Zeitung, (September 6-7). 1958; Id. "Zum Einfluß von Schule und Hochschulbildung auf das politische Bewußtsein der Studenten" [On The Influence of School and University Education on the Political Consciousness of Students], in Verhandlungen des Deutschen Soziologentages (Tübingen) 14, 1959, p. 217ff. Referências encontradas em Douramanis, 1999:13-14.

${ }^{29}$ Fromm; E. Schachtel; A. Hartoch-Schachtel; P. Lazarfel. "The Authoritarian Character Structure of German Workers and Employees Before Hitler“. Unpublished (apud. Fromm, 1974:46 e 80).

${ }^{30}$ Pollock, ed. Gruppenexperiment. Frankfurt: Institut fur Sozialforschung, 1955 (apud. Kellner, 2010).

31 Kellner destaca de Student und Politik (1961:234) as estatísticas dos surveys utilizados, tendo como resultado: uma percentagem "extremamente baixa" (4\%) de estudantes "genuinamente democráticos" em contraste com 6\% extremamente autoritários. Somente $9 \%$ exibiram o que se considerou "potencial definitivamente democrático", enquanto 16\% mostravam um "potencial definitivamente autoritário". Importante destacar que Habermas pensara os critérios para essas avaliações a partir de suas primeiras concepções de democracia direta e participativa inspiradas nas democracias gregas e das democracias constitucionais contemporâneas, em comparação com a democracia de massa dos Estados de bem estar social. Tais concepções iniciais, que certamente influenciaram aquelas de $M E E P$, foram apresentadas no texto "Über den Begriff der politischen Beteiligung" [Sobre o conceito de participação política], um dos capítulos da obra Student und Politik. (Kellner, 2010:2).

${ }^{32}$ Sobre a influência do diagnóstico do tempo de Dialética do Esclarecimento no abandono do método interdisciplinar trabalho na primeira fase da primeira geração da chamada "Escola de Frankfurt", ver Habermas, 1987-II:378-382.

${ }^{33}$ A racionalidade instrumental é concebida por Adorno e Horkheimer a partir da teoria da racionalização de Weber e da teoria da reificação de Marx como uma forma de pensamento e organização social baseada no 
humano sobre a esfera de suas relações simbólicas. Plataformas da esfera pública trabalhadas por Habermas em MEEP como a mídia impressa, o rádio, o cinema e até mesmo espaços públicos físicos, já haviam sido pensados por Adorno e Horkheimer como sendo reprodutores da lógica instrumental do esclarecimento sobre todos os campos da vida, inclusive a psiquê humana. ${ }^{34}$

Assim, apesar de ter uma abordagem normativa do conceito de esfera pública, que é claramente distinta do diagnóstico de Adorno e Horkheimer, o fenômeno da mudança estrutural seria também para Habermas outra forma de provar a passagem do binômio ser humano privado - cidadão pelo ser humano privado - consumidor ou cliente passivo, presente no célebre ensaio "A Indústria Cultural: o esclarecimento como mistificação das massas" (Calhoun, 1992:5 -6 e 22).

No entanto, apesar da própria crítica e a revisão do diagnóstico totalizante da razão instrumental de Adorno e Horkheimer - elaboradas especialmente em Técnica e Ciência como Ideologia (1968), Conhecimento e Interesse (1968), The Theory of Communicative Action (TCA, 1981) e O Discurso Filosófico da Modernidade (1985) - levarem Habermas à elaboração dos pressupostos crítico comunicativos da segunda geração da teoria crítica ${ }^{35}$, este esforço teórico monumental acabou não sendo seguido de um novo diagnóstico da esfera pública, embora sua necessidade também tenha ficado clara ao final de $T C A{ }^{36}$

cálculo de adequação entre meios e fins que tem por base o controle eficiente da natureza, tornando-se uma objetificação e instrumentalização do outro (natureza externa), enquanto objetificação de si mesmo (natureza interna). Daí a ideia do entrelaçamento entre mito e esclarecimento como um "beco sem saída" da própria crítica, o que exigiria uma radicalização de seu exercício em busca de novas possibilidades de relações entre sujeito e objeto (Cf. Adorno e Horkheimer, 1985; Horkheimer, Eclipse da Razão, 2007). Este tipo de racionalidade será discutido com mais aprofundamento no tópico 2.1 desta tese.

34 "A racionalidade técnica hoje é a racionalidade da própria dominação. Ela é o carácter compulsivo da sociedade alienada de si mesma. Os automóveis, as bombas e o cinema mantêm coeso o todo e chega o momento em que seu elemento nivelador mostra sua força na própria injustiça à qual servia. Por enquanto, a técnica da indústria cultural levou apenas à padronização e à produção em série, sacrificando o que fazia a diferença entre a lógica da obra e a do sistema social. Isso, porém, não deve ser atribuído a nenhuma lei evolutiva da técnica enquanto tal, mas à sua função na economia actual. A necessidade que talvez pudesse escapar ao controle central já é recalcada pelo controle da consciência individual. A passagem do telefone ao rádio separou claramente os papéis. Liberal, o telefone permitia que os participantes ainda desempenhassem o papel do sujeito. Democrático, o rádio transforma-os a todos igualmente em ouvintes, para entregá-los autoritariamente aos programas, iguais uns aos outros, das diferentes estações." Adorno e Horkheimer, Dialética do Esclarecimento.1947, p. 57. Versão em português disponível na revista digital Antivalor (http://antivalor.vilabol.uol.com.br/. Último acesso: 26/08/2010).

${ }^{35}$ Sobre este percurso de Habermas, v. Blotta, 2010:45-173.

${ }^{36}$ Nas notas conclusivas de TCA, quando Habermas apresenta linhas de pesquisa que poderiam retomar o projeto interdisciplinar abandonado pelo Instituto de Pesquisa Social no pós-guerra, agora sob o paradigma crítico comunicativo, é tecida uma breve crítica à teoria da cultura de massas de Adorno, cujas reflexões tocam especialmente problemas ligados à formação de esferas públicas: "Insofar as mass media one-sidedly channel communication flows in a centralized network - from the center to the periphery or from above to below - they considerably strengthen the efficacy of social controls. But tapping this authoritarian potential is always precarious because there is a counterweight of emancipatory potential built intro communication structures themselves" (Habermas, 1987-II:390). Essas reflexões de Habermas sobre mídia de massa e suas 


\section{Análise de Mudança Estrutural e algumas de suas críticas}

A estrutura geral da obra $M E E P$ pode ser dividida em quatro partes, com dois estudos histórico-empíricos (caps. I a III e V a VI) e dois teórico-normativos interrelacionados (caps. IV e VII). Essa divisão da obra revela que Habermas pretendia não somente interpretar diferenças entre categorias sociais no capitalismo liberal e no capitalismo tardio, mas também fazê-lo por meio da tensão entre teoria e prática que é peculiar à teoria crítica, ainda que de modo já devidamente mais sistemático e normativo do que nos trabalhos de Adorno e Horkheimer. ${ }^{37}$

A parte inicial da obra (caps. I, II e III), seu primeiro estudo histórico-empírico, tem como objetivo principal descrever o surgimento da esfera pública burguesa como a formação de uma instância mediadora do processo de diferenciação entre o Estado e a sociedade de indivíduos privados na passagem do capitalismo mercantil para o industrial na França, Alemanha e Inglaterra dos séculos XVII a XIX. Essa instância é composta por diversos públicos e instituições que se formam a partir de transformações técnicas e sociais do período e passam discutir publicamente a administração da economia e a produção cultural, até chegar às relações da sociedade civil com a autoridade política. O produto dessas interações é a opinião pública ${ }^{38}$, cuja previsão é em seguida institucionalizada no Estado de direito como autoridade inafastável de legitimação do poder (Habermas, 2003:27-41; Calhoun, 1992:4-10).

A segunda parte da obra apresenta seu primeiro estudo teórico-normativo, intitulado "Esfera pública burguesa: ideia e ideologia" (cap. IV). Nele Habermas analisa durante o mesmo processo de formação da esfera pública burguesa o desenvolvimento das concepções de opinião pública e publicidade (Öffentlichkeit) em Locke, Kant, Hegel e Marx, passando por Mill, Tocqueville e outros (Habermas, 2003:110-168). A intenção

diferenças em relação à teoria da cultura de Adorno e mesmo suas próprias reflexões em MEEP serão retomadas no tópico 1.4 .

${ }^{37}$ Essa característica de MEEP é reconhecida como de grande importância até mesmo aos historiadores que trabalham temas originalmente discutidos pela obra. O estudo da Habermas como filósofo social, capaz de buscar justificar teses normativas imanentes aos seus diagnósticos históricos, é ressaltado por Kramer (1992:249-258). Para mais sobre essa característica do método habermasiano, v. tópico 1.4. deste estudo.

${ }^{38} \mathrm{O}$ estudo específico sobre o fenômeno da opinião pública será retomado por Habermas 46 anos depois de $M E E P$, no capítulo "A Razão da Esfera Pública", na coletânea de textos políticos Ach, Europa! (Suhrkamp, 2008). Este recente trabalho é o de maior fôlego e que mais atualiza o pensamento de Habermas sobre a esfera pública política após sua revisão de MEEP feita em 1992. Este texto será analisado no tópico $1.4 \mathrm{e}$ perpassará também os estudos dos capítulos seguintes desta tese. 
inicial parece ser a mesma deste trabalho: analisar as pretensões normativas latentes no diagnóstico da esfera pública daquele tempo presente.

A terceira parte de MEEP (caps. V e VI), seu segundo estudo histórico-empírico, tem como objetivo demonstrar o processo de "desintegração", ou de alteração estrutural ${ }^{39}$ das funções da esfera pública que ocorre do início até a metade do século $\mathrm{XX}$, quando o espaço do público passa a ser cada vez mais tomado por negócios privados, levando sua "cultura da discussão" a uma "cultura do consumo", enquanto que a problematização da autoridade política a uma aceitação passiva do sistema de compensações oferecido pelo Estado social (Calhoun, 1992:21-29).

A quarta e última parte da obra, seu segundo capítulo teórico intitulado "Para o conceito de opinião pública" (cap. VII), Habermas apresenta a partir de uma discussão com a literatura da época o que para ele restariam de condições de concretização prática e apreensão teórica de uma opinião pública informada e crítica, em meio ao estado da comunicação pública de meados do século $\mathrm{XX}$. O número reduzido de páginas deste segundo capítulo teórico em relação ao primeiro (16 e 58) pode indicar que Habermas não só sentia falta de perspectivas teóricas para uma apreensão satisfatoriamente objetiva da opinião pública, mas também de teorias normativas capazes de ressaltar seu potencial crítico, como no caso de sua contribuição para a manutenção de regimes democráticos em sociedades de massa (Habermas, 1992:457).

Neste capítulo, os dois estudos histórico-empíricos da obra serão inicialmente analisados e relacionados a algumas de suas principais críticas (a e b). Em seguida, serão abordados de modo conjunto os estudos teórico-normativos (c), compondo uma divisão a semelhante àquela feita por Habermas em sua revisão da obra trinta anos depois (Habermas, 1992:422). Os estudos analisados em (a) e (b) retratam respectivamente os processos de formação (caps. I a III) e de desintegração (caps. V a VI) da "estrutura social" e das "funções políticas" da esfera pública, enquanto que a parte (c) tratará dos capítulos IV e VII de MEEP, dedicados aos mesmos processos, só que na perspectiva mais filosófica de uma "história das ideias" (c).

\footnotetext{
${ }^{39}$ Entende-se "estrutural" para Habermas no sentido materialista - e portanto também funcionalista - do termo, como trabalhado por exemplo, em Bourdieu ao tratar dos sistemas ideológicos: "Os sistemas ideológicos que os especialistas produzem para a luta pelo monopólio da produção ideológica legítima - e por meio dessa luta -, sendo instrumentos de dominação estruturantes pois que estão estruturados, reproduzem sob forma irreconhecível, por intermédio da homologia entre o campo de produção ideológica e o campo das classes sociais, a estrutura do campo das classes sociais". Bourdieu, 1989. p. 12. grifos nossos.
} 
a) origem da esfera pública burguesa

Cap. I. Introdução e delimitação do tipo esfera pública burguesa

$\mathrm{Na}$ "questão inicial” da obra (§1), Habermas apresenta a esfera pública (do alemão Öffentlichkeit, termo cunhado somente no século XVIII em analogia com o francês publicité e o inglês publicity, mas cujo conteúdo normativo greco-romano geral até hoje persistiria), como a delimitação do espaço de atuação daquilo que é "público", isto é, acessível a qualquer um, em oposição ao que é fechado e privado. O público seria o “sujeito da esfera pública" e detentor da opinião pública, sendo publicidade (no sentido do alemão Publizität) a "função crítica" que a opinião pública deveria normativamente exercer, como na publicização de debates judiciais ou de opiniões de um público judicante ${ }^{40}$, em contraposição à função publicitária de dar visibilidade ao mercado ou à ao eleitorado, como o diagnóstico de uma sociedade de massas em MEEP haverá de destacar (Habermas, 2003:13-17).

A introdução de $M E E P$ ( $\S \S 2$ e 3 ) pretende em seguida reconstruir as raízes históricas da esfera pública burguesa que, ao modo de Marx, está presente em suas formas embrionárias $^{41}$ no sistema feudal da baixa Idade Média européia. Da ideia de "publicidade" como "representação" de títulos sociais em espaços públicos, digna somente dos nobres e clérigos - e cuja decadência Habermas mostra em Wilhelm Meister de Goethe $^{42}$-, passa-se a pensar na comunicação pública como aquela transmitida pelos governos dos recém-formados Estados nacionais a seus súditos, especialmente para dar publicidade às constantes normativas sobre a economia, como os impostos e taxações (Habermas, 2003:32).

\footnotetext{
40 "Adelung [do dicionário de alemão Mundart, Viena, 1808] diferencia o público que se reúne como multidão em torno de um orador ou de um ator em locais públicos, do público-leitor; mas em ambos os casos trata-se de um 'público que julga'. O que é submetido ao julgamento do público ganha "publicidade". Habermas, 2003:40-41. Grifos nossos

41 "O chamado desenvolvimento histórico repousa em geral sobre o fato de a última forma considerar as formas passadas como etapas que levam a seu próprio grau de desenvolvimento (...). Como, além disso, a própria sociedade burguesa é apenas uma forma opositiva do desenvolvimento, certas relações pertencentes a formas anteriores nela só poderão ser novamente encontradas quando completamente atrofiadas, ou mesmo disfarçadas; por exemplo, a propriedade comunal" (Marx, 1982:18-17. grifos nossos). Ver Habermas, 2003:9-11.

${ }_{42}$ Esse processo ambivalente de queda da representatividade pública e surgimento de uma publicidade tipicamente burguesa é para Habermas simbolizado na tentativa do burguês Wilhelm buscar essa notoriedade no palco do teatro. Em outro registro, isso pode ser também retratado na venda de títulos da nobreza italiana decadente aos burgueses no período da unificação do país (Risorgimento, 1815-1871), retratada na obra $O$ Leopardo (Il Gattopardo, 1958), de Giuseppe Tomasi di Lampedusa (adaptado para o cinema por Luchino Visconti em 1963).
} 
Com isso, ocorre uma espécie de publicização das formas regulatórias da economia burguesa, e os primeiros jornais de caráter efetivamente "público" - isto é, potencialmente acessível a todos (Id.op.cit:14) -, também passam a incorporar, "por força do governo ou espontaneamente", contribuições de indivíduos de uma sociedade civil (Bürgerlichegesellschaft) de proprietários privados e chefes de família que começa a se formar, em oposição àquela que se manifesta na publicidade do poder político, isto é, em crítica às investidas do poder público sobre seus negócios privados. (Id. op. cit:38-39). ${ }^{43}$

O "público" substitui na Inglaterra do século XVII o que se referia por "mankind" ou "world", numa clara ligação com a categoria da humanidade nas antropologias filosóficas que se desenvolveriam no século seguinte. O "Publikum" na Alemanha também substitui a ideia de "mundo dos leitores". Mesmo no português corrente a expressão "todo mundo" pode sinalizar essa influência. Seja ele um público que se reúne em torno de oradores, ou o "público-leitor", sua característica mais distintiva é que se trata de um público capaz de julgar, e aquilo que passa por seu julgamento ganha "publicidade", do inglês "publicity" ou do francês "publicité" do final do século XVII.

Já a ideia de "opinião pública” (“Öffentliche Meinung”, na Alemanha de meados do século XVIII), refere-se à própria crítica (cultural ou política), e deriva do contemporâneo francês "opinion publique" e do inglês "public opinion", também do anterior "general opinon". A opinião pública se torna a expressão deste público judicante que se diferencia do Estado por razões econômicas, culturais e políticas e passa a fiscalizar e criticar o exercício dos poderes constituídos. A publicidade passa então a ser o critério medidor de quanto o poder se dispõe à crítica que se expressa na opinião pública.

\footnotetext{
${ }^{43}$ Diversas são as tentativas de censura dos governos sobre as contribuições cada vez mais independentes dos membros dessa sociedade civil, incluindo capitalistas a intelectuais de universidades, mas no aproximar-se da Revolução Francesa, a persistência de um lado na Prússia de controlar as comunicações públicas se opunha ao modelo já atuante na Inglaterra, em que as tentativas de proibição revelam negativamente o caráter "público" da crítica. Segundo Habermas, "Esses juízos interditados são chamados de 'públicos' em vista de uma esfera pública que, indubitavelmente, tinha sido considerada uma esfera do poder público, mas que agora se dissociava deste como o fórum para onde se dirigiam as pessoas privadas a fim de obrigar o poder público a se legitimar perante a opinião pública. O publicum se transforma em público, o subjectum em sujeito, o destinatário da autoridade em seu contraente." (2003:40 negrito nosso)
} 


\section{Cap. II. Estruturas sociais da esfera pública}

O segundo capítulo de MEEP trata do processo de formação das estruturas sociais da esfera pública, e busca delimitar o lugar que ela passa a ocupar entre outras instituições sociais e suas relações com elas, bem como as instituições próprias que a compõem. $\mathrm{Na}$ introdução do capítulo (§4), a esfera pública continua a ser identificada como espaço em que pessoas privadas se reúnem em um público com a especial finalidade de discutir com os governos o alcance da regulamentação que incide sobre a esfera privada da economia, isto é, sobre as trocas mercantis e o trabalho social empregado pelos burgueses (Id. op. cit:42-43). ${ }^{44}$

No tópico sobre a formação das instituições da esfera pública (§5), Habermas descreve como ocorre o processo de autonomização dos públicos em relação às instituições de representação e teológicas que até então prevaleciam na reprodução simbólica da sociedade. Novos espaços e novos públicos são formados, especialmente em cidades como Paris, Londres e Berlim: editores substituíam mecenas, intelectuais e cientistas burgueses se equiparavam à aristocracia em respeitabilidade de opinião, artistas não eram mais vinculados economicamente à classe nobre e a imprensa e a crítica profissional se estabilizam como novos espaços de debate e mediação de interesses.

Por meio da liberdade formal e da livre iniciativa, que compunham a "ideologia da troca justa" (Id. op. cit:63), membros de corporações de ofício, associações publicas e privadas, frequentadores de salões (os "herdeiros espirituais da corte") cafés, clubes de leitura e teatros, colaboradores e consumidores da imprensa passam a demandar reciprocamente a devida publicidade de suas mercadorias, obras de arte, notícias, expressões e argumentos filosóficos e políticos para tomadas de decisão.

A esfera pública que discute a política provém de uma esfera pública literária, que passa a ser influenciada também por temas econômicos, mas apesar de cada esfera eleger seus critérios normativos próprios - o que se torna possível a partir de seus processos de

\footnotetext{
${ }^{44}$ Numa representação gráfica (p. 45), Habermas situa a esfera pública na fronteira entre "setor privado" (Privatbereich) e "esfera do poder público" (Sphäre der öffentliche Gewalt). No setor privado estaria a diferenciação entre a sociedade civil (bürgerliche Gesellschaft), ou o "setor das trocas de mercadorias e trabalho social", e o espaço da intimidade da família, de onde também deriva a "intelectualidade burguesa" (bürgerliche Intelligenz). Ao lado do poder público estaria o Estado no sentido de detentor do monopólio legítimo da violência ("polícia"), e o que restaria da corte aristocrática. A esfera pública propriamente dita faria parte do setor privado, já que se constitui de pessoas privadas. A sociedade civil, no entanto, diferenciase da esfera pública por se restringir à atividade econômica. (Id. op.cit:45-46).
} 
secularização $^{45}$-, os três tipos de esfera pública preservam uma lógica normativa subjacente de publicização que passa pela qualificação de seus critérios, a compreensão de suas relações e influência recíproca ${ }^{46}$ e a generalização de seu acesso (Id. op.cit:44-45). ${ }^{47}$

A abertura dos salões para o público feminino também teria marcado a abertura da discussão pública para novos temas como a universalização do acesso de públicos anteriormente excluídos às artes e a validade de seu julgamento sobre elas, por exemplo. Ideais até então pertencentes à subjetividade da família burguesa como liberdade, amor, privacidade e dignidade individual, pretensões normativas à emancipação psicológica no âmbito privado passam à esfera pública, seja por meio dos costumes, das artes ou por sua recém-conquistada garantia jurídica. A partir de então, a esfera pública se torna um espaço em que a sociedade civil, como outrora a aristocracia, podia se auto-refletir. ${ }^{48}$.

Isso mostra que as possibilidades de alteração da noção de público não se davam somente em função da "mercadorização" da cultura e sua contribuição para o trabalho social, mas também como reflexo de pretensões existenciais de autonomia individual expressas na literatura romântica, como em Sofrimentos do Jovem Werther, de Goethe (1774); pretensões que visavam garantir formação de estruturas da personalidade individual, e não somente habilidades técnicas necessárias à reprodução material da sociedade (Id. op.cit:63) ${ }^{49}$. É por isso que inicialmente a esfera pública também se

${ }^{45}$ As referências de Habermas a teorias da racionalização social para explicar a autocompreensão da modernidade poderiam ser resumidas no pensamento de Weber sobre a secularização da razão cognitivoinstrumental (Habermas, TCA, vol. I, cap.), em Habermas mesmo para a secularização do conteúdo normativo da modernidade (Id, 2002a), e em Benjamin a secularização da estética e da religião pela a perda da aura da obra de arte e do sagrado (Benjamin, 1975). Ver também capítulos 4 e 7 deste estudo.

46 "Por um lado, a filosofia só é possível como uma filosofia crítica, enquanto que a literatura e a arte só são possíveis ligadas à crítica literária e à crítica de arte; (...) Por outro lado, só mediante a apropriação crítica da filosofia, da literatura e da arte é que também o público chega a se esclarecer, até mesmo a se entender como processo vivo de Iluminismo." (Habermas, 2003: 58).

${ }^{47}$ A questão da racionalidade da esfera pública será discutida posteriormente (caps 4, 5.2, e 7). Por enquanto, pode-se dizer que para Habermas uma das mais importantes novidades trazidas pela evolução da esfera pública burguesa é o critério de justificativa que se busca para a dominação política: uma inédita forma de "racionalização pública" (öffentliche Räesonnement), marcada pela ideias de razão (Vernunft) e de lei (Gesetzes). Isso mostra como o surgimento da esfera pública pressiona para uma mudança substancial na própria dominação política enquanto tal. Segundo Habermas, no entanto, os sentidos empregados aos termos razão e lei só seriam entendidos de modo mais preciso se fossem tomados como oriundos de pretensões do processo de autocompreensão subjetiva dos indivíduos pertencentes à esfera privada, ainda que permanecessem numa tensão entre concepções de uma razão plenipotenciária kantiana ou de uma autoridade hegeliana, capaz de estabilizar as inevitáveis tensões e contradições entre o universal e o concreto

48 "A compreensão que o tirocínio público tem de si mesmo é dirigido especificamente por tais experiências privadas que se originam da subjetividade, em relação ao público, na esfera íntima da pequena-família. Este é o local em que historicamente se origina a privacidade, no sentido moderno de uma interioridade livre e satisfeita." (Habermas, 2003:43). V. nota 1 do capítulo II de MEEP.

${ }^{49}$ Esse processo de libertação momentânea da subjetividade na forma da esfera pública burguesa será ressaltado no diagnóstico estético-expressivo da esfera pública política brasileira, com estudos de casos na esfera pública política brasileira ligados à religião, arte, estética e psicanálise. Para referências teóricas antecipadas sobre o tema, cf. Blotta, 2009, Id. 2010a; Honneth, 2010:251-306. 
determina pelo afastamento do poder público sobre um aspecto do privado, sem o qual haveria não uma publicização, mas sim uma "indiscrição" de temas privados e até mesmo íntimos. Em outras palavras, pretende-se uma proteção contra a publicização de opiniões que invadem excessivamente e injustificadamente a subjetividade moderna das esferas privadas. $^{50}$ (Id. op.cit:67).

Em seguida, a esfera pública política passa a se destacar da esfera pública literária (§7) na medida em que influencia a alteração substancial da natureza da dominação política ao acrescentar à legalidade das leis a exigência de sua legitimidade, isto é, passa a se formar a partir da esfera pública o fino equilíbrio entre autonomia individual e autonomia política característico do direito moderno que Habermas reinterpretará como cooriginários em Direito e Democracia (BFN, 1996:84-104), ainda que neste período o equilíbrio era visto como a realização de uma ordem natural. A esfera pública moderna se caracterizava mais por uma associação de civis debatendo publicamente do que de cidadãos agindo coletivamente, característico da liberdade no sentido mais clássico, ou republicano (Habermas, 2003:68-70).

As capacidades de generalização e abstração da lei dariam à sociedade civil condições de realização da liberdade individual daqueles que pertencem à sociedade civil. Ao mesmo tempo, a pretensão de publicização da lei contesta de uma vez por todas a prerrogativa absolutista de governos que ainda praticavam atos secretos e tomavam suas populações como politicamente imaturas. A ideia de uma identificação da publicidade com a racionalidade e a justiça é defendida especialmente pelos fisiocratas, que viam na opinião pública uma oportunidade da demandar das leis garantidoras das novas diferenciações entre o público e o privado também uma ratio argumentativa como fonte de legitimidade política (Habermas, 2003:71-72)

A relação entre a esfera pública literária e a esfera pública política apresentada em MEEP reflete a mesma relação entre o que posteriormente Habermas poderia pensar como "mundo da vida" e "discurso" em seu pensamento teórico maduro. Em um importante trecho, essa relação fica clara, o que colabora para as teses teóricas a serem defendidas especialmente no segundo capítulo deste estudo:

\footnotetext{
50 Esta pretensão de uma proteção constitucionalmente justificada da esfera privada será analisada no diagnóstico da esfera pública do presente deste estudo. V. tópico 2.2.4.
} 
“a esfera pública aparece naturalmente à opinião pública como una e indivisível. Assim que as pessoas privadas não se entendem entre si apenas enquanto seres humanos no plano de sua subjetividade, mas gostariam de determinar, enquanto proprietários, o poder público em seu interesse comum, a humanidade da esfera pública literária serve de instância mediadora à efetividade da esfera política. A esfera pública burguesa desenvolvida baseia-se na identidade fictícia das pessoas privadas reunidas num público em seus duplos papéis de proprietários e de meros seres humanos" (Habermas, 2003:73-74. Itálicos do original)

As críticas mais frequentes a este estudo inicial de Habermas sobre a formação das estruturas sociais da esfera pública se dirigem especialmente à ausência de aprofundamento na questão da discriminação de gênero na esfera pública política ${ }^{51}$ e na relação entre grandes públicos e aqueles que compõem esferas públicas marginais, ou "plebéias" como cita Habermas na revisão de MEEP trinta anos depois. A alegação é de que o autor teria ignorado uma maior diversidade entre esferas públicas diferenciadas, pois apesar dos déficits de acesso aos meios de participação e influência no grande público, elas eram atuantes e distintas das esferas públicas mais institucionalizadas. ${ }^{52}$

Como se verá na breve análise da última parte da obra (c), houve de todo modo uma preocupação teórica final de Habermas ao tentar propor que a opinião pública fosse medida por análises comparativas da comunicação perpassa diferentes públicos influentes, sejam eles de esferas públicas informais ou quase-públicas, como também daquelas mais institucionais como as do mercado da cultura e da política (Habermas, 2003:287-288). Essa forma de análise, que também está presente nos mais novos estudos de Habermas sobre o tema (Ay, Europa!, 2009:165-166), foca mais na identificação e no grau de interação entre públicos do que nas diversas expressões das esferas públicas. Essa abordagem será reconsiderada no capítulo 4 deste estudo.

Apesar de sua discussão sobre o elitismo da esfera pública em MEEP, com a exclusão de mulheres, não-proprietários e outros públicos, Habermas chega a reconhecer em sua revisão "Further Reflections on the Public Sphere" que teria desconsiderado

\footnotetext{
${ }^{51}$ A importância da crítica feminista à MEEP é revista pelo próprio Habermas como sendo motivadora de uma modificação estruturante na esfera pública, na medida de permitir políticas de identidade, ou de reconhecimento. Fraser, 1996:115. Essa perspectiva de incluir práticas de formação da personalidade e reconhecimento na esfera pública é trabalhada nos últimos debates de Habermas sobre religião e direito, e será também incorporada de modo teórico pelo direito da comunicação. V. caps. 2.3 e 3.

${ }^{52} \mathrm{O}$ interessante estudo de Oskar Negt, Alexander Kluge e Peter Labanyi, Public Sphere and Experience: Toward an Analysis of the Bourgeois and Proletarian Public Sphere (Theory and History of Literature). University of Minnesota Press, 1993 é essencial para se pensar na ausência de análise de determinados públicos no segundo estudo histórico-normativo de $M E E P$, que trata mais propriamente da mudança estrutural da publicidade. V tópico 1.2 (b) deste estudo. V. também Fraser (1996:109-142) e Habermas, Further Reflections on the Public Sphere, 1992:227-229. Para outras críticas nesse sentido, v. também Calhoun (ed.), 1992.
} 
algumas expressões menos centrais da esfera pública burguesa, tomando-as como que dependentes das centrais. Os obstáculos econômicos que impediam o acesso à esfera pública de muitos trabalhadores não-proprietários ou aqueles sem a devida formação educacional, eram claras causas do fracasso de concretização de suas promessas normativas de "acesso a todos" institucionalizadas nos Estados constitucionais, o que foi à época ressaltado por Habermas. Mas é a importância estrutural da exclusão do público feminino que ele considera pouco explorada na época de $M E E P$, especialmente porque o movimento feminista no século XX teria alterado a lógica própria da esfera pública ao levar pretensões identitárias, e não somente sócio-econômicas ao debate político (Habermas, 1992:426-441).

Essa perspectiva é claramente incorporada em sua significância histórica em Direito e Democracia (BFN, 1996:409-427) e em A Inclusão do Outro (2007:303-305) a partir de uma revisão sobre o sentido do movimento feminista no século XX. Ainda assim, como a análise teórica do capítulo 3 deste estudo procurará demonstrar, os elementos mais abstratos dessa discussão colaboram para uma melhor compreensão da relação entre autonomia individual e autonomia política, mas não são incorporados na forma jurídica de um direito procedimental em Direito e Democracia, isto é, como um direito que também deve garantir condições propiciadoras de relações de reconhecimento recíproco nas esferas públicas e privadas, capazes de possibilitar a formação e a estabilização identidades pessoais e coletivas. ${ }^{53}$

\section{Cap. III. Funções políticas da esfera pública}

O terceiro e último capítulo do estudo sobre a formação da esfera pública burguesa trata de suas funções políticas, descrevendo o processo de incorporação da opinião pública e da publicidade como princípios jurídicos das constituições e codificações que seguiram as revoluções do final do século XVIII na Europa e nos EUA. Ao mesmo tempo, a esfera pública passa ter o status de "órgão do Estado", cuja função é impedir o retorno do absolutismo por meio da crítica permanente exercida pela opinião pública (Habermas, 2003:76-77).

O caso inglês é utilizado para pensar esse desenvolvimento que se inicia pela opinião pública como elemento de pressão para alteração de leis indesejadas que

\footnotetext{
${ }^{53}$ Este desafio será enfrentado pelo direito da comunicação na discussão teórica sobre o direito às condições propiciadoras de relações de reconhecimento (v. caps. 8 e 9 deste estudo).
} 
regulavam o espaço privado, e pela proibição da censura da imprensa, que fazia oposição ao governo por meio de uma opinião pública associada a um jornalismo autônomo. Essa imprensa satírica e crítica pressiona para a publicização plena dos atos governamentais na passagem do século XVII ao XVIII, e a esfera pública política passa a ser considerada uma espécie de órgão do Estado, num movimento de "parlamentarização do poder estatal"54. $\mathrm{Na}$ Inglaterra somente a Bill of Rights tornou definitivamente públicos os debates parlamentares. Isso não alterou a estreita relação já conservada entre representantes da burguesia e da nobreza, que teria passado a Revolução Gloriosa sem sofrer os grandes abalos do continente, o que os leva até hoje a terem poderes semelhantes no Parlamento (Id. op. cit:75-81).

As grandes tensões entre governo e oposição no início do século XVIII na Inglaterra deram condições às minorias parlamentares de recorrer à opinião pública para conseguirem se tornar maiorias. A mediação das disputas políticas com o público era feita pela literatura e pela imprensa, e permitia a ampliação do debate sobre diversos assuntos políticos, como divisão de poderes, liberdades individuais, partidos políticos, legitimidade da relação entre governo e oposição etc (Id. op. cit:82).

Ao mesmo tempo, a força dos eleitorados que se ampliavam e seu uso político ficam evidentes na consagração de termos como sense of the people e public spirit, presente em discursos e debates parlamentares que institucionalizam a opinião pública como "parceiro de discussão altamente qualificado", pressionando até mesmo para a alteração de decisões do rei da Inglaterra no final do século XVIII. As chamadas "ligas políticas", associações e clubes se institucionalizam cada vez mais, conseguindo até mesmo influenciar o Parlamente com petições e intervenções. $\mathrm{O}$ direito à participação política por meio do voto é também ampliado para a classe média, o que permite à opinião pública se tornar mais ainda o produto de interações entre argumentos que derivam de um common sense, mas que não podem se furtar à crítica ou à possibilidade de manipulação por iniciativas plebicitárias (Id. op. cit:82-85).

$\mathrm{Na}$ França e na Alemanha, apesar da esfera pública burguesa não estar tão desenvolvida politicamente como na Inglaterra no início do século XVIII, a institucionalização dos princípios da publicidade, os direitos de livre expressão, crítica e

\footnotetext{
${ }^{54}$ Sobre a esfera pública francesa, Habermas destaca o sentido de seus atos de publicização: A esfera um público criado no meio da nobreza que era sustentada, socialmente representativa, mas sem função econômica nem política, torna-se, com a ajuda de intelectuais que haviam tido uma certa ascensão social, agora definitivamente a esfera em que a sociedade burguesa chega a expor refletidamente os seus interesses." (Habermas, 2003:88).
} 
associação como na constituição francesa de $1791^{55}$, e a existência de uma esfera pública literária consolidada e imprensas que publicizam e criticam os governos facilitam a politização de suas esferas públicas como forma de impedir o retorno dos absolutismos. A luta argumentativa pela produção da opinião pública se desenvolve na Alemanha somente depois de meados do século XIX, quando as centenas de grupos de leitura espalhados pelas cidades passam a contribuir na imprensa e publicizar seus debates (Id. op. cit:86-92).

Exemplos de censura e reações críticas do poder político à imprensa e ao público demonstram negativamente a força da opinião pública que se desenvolveu na França e na Alemanha na passagem do século XVIII para o XIX. Seja após o golpe de Estado de Napoleão no início de 1800, quando proibiu a liberdade de imprensa no país - retomada e institucionalizada só 15 anos depois -, ou na reação de violência de príncipes alemães a jornalistas políticos, que são presos e morrem no cárcere no final do século XVIII (Id. op. cit:90 e 93), é por meio dessa análise negativa que a esfera pública pode ser mais precisamente analisada. Por isso, essa perspectiva será adotada como método do diagnóstico da esfera pública política brasileira nos capítulos 5, 6 e 7 desta tese. ${ }^{56}$

O tópico seguinte do capitulo (\$10) trata de descrever o processo de institucionalização da sociedade civil burguesa como a constitucionalização de direitos e garantias que permitiam a reprodução e a expansão do capitalismo industrial. A autonomia privada é então pensada dentro desse desenvolvimento de uma classe com influência política a partir de sua propriedade e seu capital. Institutos do direito privado como capacidade jurídica, livre-concorrência, livre iniciativa e até mesmo a limitação de taxas ao comércio promovia igualdade entre os proprietários e a intelectualidade burguesa e nobre na esfera pública (Id. op. cit:93-95).

A crítica advinda da economia política marxista a esses estatutos jurídicos formais é precisa e vem revelar como a institucionalização da sociedade civil se dá em função de prerrogativas econômicas. ${ }^{57} \mathrm{O}$ direito dos contratos, a regulamentação de salários, impostos e posteriormente o direito do trabalho, o direito comercial e o direito das

\footnotetext{
${ }^{55}$ Segundo Habermas o parágrafo 11 da declaração de direitos do homem e do cidadão é que sustenta a base da institucionalização da esfera pública na constituição francesa pós-revolução: “A livre comunicação de ideias e opiniões é um dos mais preciosos direitos do ser humano. Por isso, cada um pode falar, escrever e imprimir livremente, resguardando-se a responsabilidade quanto ao mau uso dessa liberdade nos casos previstos em lei."” (Habermas, 2003: 89-90).

${ }_{57}^{56} \mathrm{~V}$. também tópico 1.4 deste capítulo.

${ }^{57}$ Para uma crítica marxista precisa ao princípio da igualdade jurídica desenvolvido neste período, com base na inter-relação que o tcheco Pachukanis criticou entre direito e o mercado burguês do capitalismo liberal, v. Kashiura, c. 2009.
} 
indústrias delimitavam a interferência do setor público no privado enquanto regulavam-no publicamente (Id. op. cit:97).

Mas se a prevalência do fator econômico sobre a regulação pública pode ser deduzida com facilidade na perspectiva da crítica da economia política (Habermas, 2003:149-151), isso não se afirma mais com tanta certeza na teoria crítica habermasiana, até mesmo a de $M E E P$, posto que, no caso, a opinião pública se institucionaliza nesse mesmo processo de autonomização do privado em relação ao público, e legitima a regulamentação da vida civil proposta por códigos como o napoleônico de 1804, ou os códigos de terras e leis gerais da Prússia e Áustria da passagem do século XVIII ao XIX. Em Berlim e Viena, as tentativas de codificação são também apresentadas a um público politicamente ativo, composto por juristas, filósofos, jornalistas, comerciantes entre outros que pretendem assegurados os direitos referentes à sua autonomia privada (Id. op. cit:96 e 98).

Mesmo assim, a liberalização do comércio ocorre na Inglaterra somente em meados do século XIX, o que não significa dizer que a ideologia da livre concorrência dispensava qualquer tipo de regulação e intervenção pública do Estado, cujo grau deveria ser submetido ao crivo de uma opinião pública que é constitucionalmente estimulada e protegida. A autonomia privada da sociedade civil burguesa é então garantida quanto mais a esfera pública política se institucionaliza como mediadora do processo de regulação das relações entre sociedade civil e Estado. ${ }^{58}$

Essa inter-relação de fenômenos é explicada no último tópico do capítulo (§11) como reflexo das ambivalências da institucionalização da esfera pública no Estado de Direito burguês, já que a ideia de um poder racionalizado pela publicidade deveria ser vista como uma ordem natural que é traduzida pela opinião pública, e ao mesmo tempo correspondente às leis do Estado de direito. Ao final do primeiro estudo histórico-empírico de MEEP, Habermas já demonstra uma pretensão teórico-normativa fundamental da esfera pública política, que se buscará reconstruir dentro do diagnóstico da esfera pública política brasileira deste estudo: a de um vínculo necessário entre lei e opinião pública (v. caps. 2 e $3)$.

\footnotetext{
58 "Sim, criou-se o hábito de derivar a essência do capitalismo dessa configuração específica do capitalismo concorrencial. Em relação a isso é preciso recordar que, na longa história do desenvolvimento capitalista, ele só dura um feliz instante, pois deriva de uma constelação histórica única na Inglaterra do final do século XVIII. Os demais países não concretizaram sem reservas, nem sequer no apogeu da era liberal - metade do século XIX - , os princípios do laisser faire no comércio internacional. Mesmo assim, a sociedade burguesa enquanto esfera privada só se emancipa das diretrizes do poder público à medida que, então, a esfera pública política pode chegar a se desenvolver plenamente no Estado de Direito burguês." (Habermas, 2003:98-99).
} 
A ambivalência da institucionalização da relação entre lei e opinião pública é a mesma daquela entre vontade e razão. A emancipação do privado em relação ao público mediada pela opinião pública não deveria caracterizar um novo tipo de dominação, isto é, seria marcada por uma ausência de coerção na interação social. Nesse momento, a própria questão da soberania é colocada em cheque, ao passo que não há lei legítima se não for aprovada pela opinião pública. ${ }^{59}$

As constituições firmam as estruturas próprias da esfera pública, como os direitos à livre expressão e associação, imprensa e reunião e direitos de participação política de um lado, e direitos referentes à proteção da família e da vida privada, e das atividades econômicas dos proprietários burgueses de outro. O princípio da publicidade aplicado aos debates legislativos, aos atos do executivo e também ao judiciário, pressionava para o fim de políticas de segredos e privilégios dos governos e fiscalizava o poder à medida que dele exigia mais transparência e acesso público.

Mesmo assim os limites históricos às exigências da publicidade ficam claros com a falta de acesso de públicos que são afetados pela política, embora nela não possam influenciar. Só participava da esfera pública o público leitor com formação cultural e propriedade, mas essa esfera pública falseava a si mesma quando se pretendia legítima ao mesmo tempo em que tinha déficits de acesso (Id. op. cit:103-105). Do mesmo modo, pressupunha a ideia de superação da dominação e das exclusões apesar de não conseguir realizá-la, como dirá Habermas em seguida (Id. op. cit:108). ${ }^{60}$

No entanto, o próprio pensamento liberal, derivado e protegido pelo direito privado enquanto sendo "natural", só poderia ser pensado como ideologia, como na crítica promovida pela economia política de Marx ou a foucaultiana, na medida em que se admite que a realidade burguesa interpretada e promovida pela opinião pública tenha sido aceita como um interesse normativo geral em algum momento, isto é, como uma racionalidade

\footnotetext{
${ }^{59}$ Em uma abordagem já ligada a uma racionalidade comunicativa, Habermas continua: “A 'hegemonia' da esfera pública é, de acordo com a sua própria concepção, uma ordem em que a própria dominação se dissolve; veritas non auctoritas facit legem. Esta inversão da frase de Hobbes se perde tanto na tentativa de entender a função da opinião pública com o auxílio do conceito de soberania quanto na construção dos pouvoirs no Direito Público. Pouvoir enquanto tal é posto em debate através de uma esfera pública que funcione politicamente. Esta deve levar a 'voluntas' a uma 'ratio' que se produz na concorrência pública dos argumentos privados como consenso sobre o praticamente necessário no interesse geral.” (Habermas, 2003:102-103. Itálicos do original)

60 “À base da contínua hegemonia de uma classe sobre as outras, esta classe desenvolveu, contudo, instituições políticas que implicavam, como seu sentido objetivo, de modo crível a ideia de sua própria superação: veritas non auctoritas facit legem, a ideia da dissolução da dominação naquela leve coação que, tanto mais, se impõe na visão vinculante de uma opinião pública.” (Habermas, 2003:108).
} 
livre de dominação, ainda que se trate de um diagnóstico falseado empiricamente (Id. op. cit:108 e Id, 1992:428-429). ${ }^{61}$

A livre passagem da comunicação entre as esferas do privado e do público tinham também relação com uma dominação que se pretende dissolver em pura racionalidade. Essa pretensão ocorre na medida em que a realidade concreta da esfera pública se distancia de seus pressupostos burgueses. É o que ocorre gradativamente na passagem do século XIX para o século XX. Quanto mais se alteravam as relações comunicativas da sociedade, mais ficava clara a ficção constitucional da esfera pública (Id, 2003:108-109). Sua distância em relação à realidade social não obsta, todavia, que ela se identifique com pretensões normativas atuais da comunicação pública, exigidas com base em pressupostos jurídicos diagnosticados como deficitários em esferas públicas políticas concretas.

\section{b) mudança estrutural da esfera pública burguesa}

Esta parte da revisão de MEEP analisa o segundo estudo histórico-empírico da obra (caps. V e VI), destinado a um diagnóstico da mudança estrutural propriamente dita das estruturas sociais e funções políticas das esferas públicas nas mesmas democracias ocidentais analisadas na primeira parte da obra. Esse processo teria ocorrido na passagem do Estado liberal para o Estado de bem-estar social, e sua análise pode ser resumida na explicação de como esfera pública burguesa deixa gradativamente de ser uma esfera mediadora da diferenciação entre Estado e sociedade civil que obriga o poder a se legitimar, para assumir feições claras de uma indústria cultural (Roberts and Crossly, 2004:6), especialmente com o desenvolvimento dos meios de comunicação de massa em meados do século $\mathrm{XX} .^{62}$

\footnotetext{
${ }^{61}$ Essa importante tese de Habermas, que demonstra seu método negativo de análise, por meio do qual se torna possível identificar potenciais de racionalidade e formas de dominação não coercitivas subjacentes a formas concretas de sua negação, também está presente no ensaio Técnica e Ciência como Ideologia (1968), quando se aduz que as ideologias modernas só existem na medida em que a crítica da ideologia, advinda da filosofia da práxis, denuncia o descompasso entre as relações sociais e as condições materiais da produção capitalista. (Habermas, 2006:66). Sobre a discussão Habermas - Foucault, v. Habermas, O Discurso Filosófico da Modernidade, 2002, pp. 333-372.

62 "O mundo criado pelos meios de comunicação de massa só na aparência ainda é esfera pública, mas também a integridade da esfera privada, que ela, por outro lado, garante a seus consumidores, é ilusória. No transcorrer do século XVIII, o público-leitor burguês pôde cultivar, tanto na correspondência íntima quanto na leitura de romances e novelas psicológicas daí oriunda, uma subjetividade literariamente habilitada e correlata à publicidade. (...) À medida que hoje os meios de comunicação de massa eliminam os bolsões literários da consciência que os burgueses tinham de si mesmos e utilizam a sua própria representação como forma corrente para a prestação de serviços públicos da cultura dos consumidores, inverte-se o sentido originário." (Habermas, 2003:202-203). Para mais sobre a relação entre indústria cultural e as concepções de Habermas sobre a comunicação de massa, V. Blotta, 2008.
} 


\section{Cap. V. Mudança na estrutura social da esfera pública}

No primeiro tópico do capítulo V de MEEP (§16), Habermas procura demonstrar que o "crepúsculo" do período liberal do capitalismo, no último quarto do século XIX, é marcado por uma recíproca interpenetração entre setores do público e do privado, o que inicia o processo de alteração das estruturas sociais da esfera pública burguesa. As crescentes práticas de oligopolização e cartelização de mercados, na Inglaterra ou na Alemanha, revelam cada vez mais os antagonismos sociais e o descompasso entre os preceitos da economia política clássica e as condições materiais de reprodução da esfera privada. Essas contradições têm como respostas alterações legislativas que procuram administrar os conflitos internos a essa espécie de poder social que surge do setor privado a partir da diferenciação entre Estado e sociedade produtiva (Id. op. cit:169-171).

O poder econômico das sociedades empresariais busca se traduzir diretamente em poder político influenciando normas que garantam a continuidade do modelo free-trade, mesmo sob a evidência das desigualdades e desequilíbrios entre proprietários e nãoproprietários. ${ }^{63}$ Enquanto isso, as massas trabalhadoras, que passavam a constituir importante mercado consumidor e se organizar em plataformas institucionais como os sindicatos, também pressionam o setor público, o que lhes permite angariar direitos políticos, como o sufrágio universal, e de seguridade social (Id. op. cit:172-174).

Se o direito privado teria sido um dos resultados jurídicos do processo de formação da esfera pública burguesa, é o direito social, ou direito trabalhista que marca esse novo momento de desdiferenciação entre Estado e sociedade civil. Seus tipos jurídicos rompem os limites claros entre direito público e direito privado, revelando o que se entendeu como um processo de publicização do direito privado (Id. op. cit:178). Ao mesmo tempo, na medida em que o setor público assume funções de equilíbrio da concorrência e também de gerenciamento de contratos com entes privados, ocorre o que se passa a entender como uma privatização do Direito público ${ }^{64}$ (Id. op. cit:180)

\footnotetext{
${ }^{63}$ É citando Franz Neumann que Habermas identifica a dimensão intervencionista do Estado liberal, ainda que neste período ela servisse à manutenção da regulação do trabalho social nas mãos da autonomia privada. V. Neumann, F. Der Funktionswandel des Gesetzes im Recht der bürgerlichen Gesellschaft (A mudança de função das leis no direito da sociedade burguesa. Trad. Livre). In. Zeitschirft für Sozialforschung, vol. VI, p. 542 ss. Apud. Habermas, 2003:327.

${ }^{64}$ Esse fenômeno de "privatização do público" é também marcado pela tendência cada vez mais evidente do Estado empreender políticas promocionais, destinadas a garantir condições para uma vida socialmente produtiva à população. Esse tipo de política passa a figurar como característica da atuação do Estado junto às
} 
A partir dessas novas configurações das relações entre público e privado, a esfera pública já não se apresenta da mesma daquela formada a partir de uma separação clara entre os dois setores, cuja expressão teria permitido uma "racionalização neutra" da dominação. O "inchaço" de uma "esfera social" que mescla o empreendedorismo do setor privado com uma regulação ostensiva pelo Estado, mostra de modo ainda mais claro como a esfera pública passa a ter de administrar o que Habermas entenderá trinta anos depois em sua teoria do direito como a co-originariedade entre autonomia individual e autonomia política.

“O momento 'publicitário' (publizistische) do interesse público liga-se, nessa medida, com o momento jurídico privado da formulação contratual, com o que surge uma nova esfera, com concentração de capital e intervencionismo, a partir do processo correlato de uma socialização do Estado e de uma estatização da sociedade. Esta esfera não pode ser entendida completamente nem como sendo puramente privada nem como sendo genuinamente pública; também não pode ser univocamente classificada no âmbito do Direito Privado ou do Direito Público" (Habermas, 2003:180)

Essa indefinição da natureza e do estatuto jurídico de uma esfera social redimensionada reflete também uma indefinição semelhante em relação à esfera pública política, o que se procurará contornar neste estudo de modo teoricamente justificável e dogmaticamente aplicável no ordenamento jurídico brasileiro (v. parte III).

Isso porque, quando o direito da comunicação assume a esfera pública política como seu domínio objetual - complementando a análise do procedimento democrático realizado pela teoria discursiva do direito de Habermas -, ele colabora para o aprofundamento das teorias jurídicas que visam revelar o pano de fundo intersubjetivo que fundamenta as relações internas e a própria validade dos direitos subjetivos e objetivos. Essa tarefa, no entanto, só poderá ser realizada de modo satisfatório por meio de uma discussão dos estudos mais recentes de Habermas sobre o tema, e de diálogos com seus mais importantes interlocutores na área, como é o caso da teoria do direito de Klaus Günther ${ }^{65}$.

O segundo tópico do capítulo ( $(17) \mathrm{V}$ de $M E E P$ procura descrever como essa nova esfera social se delimita em relação à esfera da intimidade, e como essa relação é marcada por um enfraquecimento da autoridade da instituição família. Essa nova relação entre

convencionais políticas defensivas e destinadas à manutenção da ordem. V. notas 15 a 20 deste capítulo de MEEP. Habermas, 2003:327-328.

${ }^{65}$ V. capítulo 3 deste estudo. V. também Günther, 2005:245-258. 
privacidade e intimidade, de onde até então se originava a esfera pública literária, expressão mais autêntica da subjetividade formada dentro da família burguesa, marcava também sua transformação numa esfera do lazer ${ }^{66}$, permeada por "instâncias semipúblicas”, como são os (à época) incipientes meios de comunicação de massa. ${ }^{67}$

Do ponto de vista da institucional, a privatização da família corresponde à objetivação jurídica do trabalho social - com o direito do trabalho, o sistema de saúde e a seguridade social etc - na medida em que a estrutura da produção e da administração de empresas não se regula mais a partir do trabalho profissional privado. A separação entre gestores, proprietários e acionistas dava condições para a formação da grande empresa moderna, que passava a funcionar muito mais a partir de normas do mercado e dos setores produtivo, trabalhista e fiscal do que pelo modelo liberal da autonomia privada da família burguesa capitalista (Id. op.cit:180-182).

As empresas passam a promover ações sociais e políticas de investimento nos funcionários, o que representa uma forma de publicização do oikos anteriormente regulado somente pela autonomia privada. Enquanto isso ocorre uma "mudança estrutural da família" que, isolada em uma privacidade invadida constantemente pelo público, vive uma "aparência de liberdade", no sentido de perda da capacidade de expressar a subjetividade humana de seus indivíduos, como teria feito nas primeiras formações de uma esfera privada autônoma em relação ao público analisados em (a). Trata-se, portanto, de uma falsa privacidade, revelada também na substituição que o ser humano moderno faz dos custos das tomadas de decisão políticas e de representação social da família pelos benefícios e compensações dos setores privado e público que o trabalho social passava a garantir (Id. op.cit:183-185; Id, 2006:67-72).

A própria arquitetura urbana das cidades e das casas modernas refletia o que Habermas entende como "perda da esfera privada" em troca do "acesso seguro à esfera pública”. A diminuição de espaços públicos nas cidades e a individualização de espaços

\footnotetext{
${ }^{66}$ Essas conclusões de Habermas são especialmente influenciados pelo seu estudo anteiror "Zum Verhältnis von Arbeit und Freizeit" (Para uma Relação de Trabalho e Tempo Livre) in. Festschrift für Rothacker, Bonn, 1958, e também repercutiria em seu diálogo com Marcuse, especialmente de O Homem Unidimensional (1967), discutido no fundamental ensaio Técnica e Ciência como "Ideologia" de Habermas, que é dedicado aos 70 anos de Marcuse. V Habermas, 2006:45-92.

67 Atualizar a compreensão desse fenômeno no diagnóstico da esfera pública que será aqui realizado é importante para se pensar na expressão estético-expressiva da esfera pública política (cap. 7), especialmente no que diz respeito a algumas de suas pretensões normativas identificadas, como a individuação pela socialização e a solidariedade negativa (a partir da identificação com o "sofrimento do outro"), especialmente por meio de imagens, auto-representações e biografias pessoais nessa dimensão da esfera pública. V. Boltanzki, Distant Suffering, 2005. Para uma análise antecipada dessa expressão da esfera pública, v. Blotta, V. The Fascination of Authority and the Authority of Fascination, 2010 (manuscrito).
} 
nas casas eram uma exigência das formas de trabalho social, mas não ficava livre de momentos de intersecção com o privado, o que relativiza os critérios de racionalidade de ambos os espaços. Novas "feudalizações" são realizadas, como repolitizações esporádicas de um público tecnificado ${ }^{68}$, mas isso é provocado por um privado que sofre invasões de instâncias semi-públicas, como são concessionários públicos de comunicação e seus anunciantes, que produzem uma cultura de mais lazer e entretenimento do que de crítica e expressão da subjetividade presente. ${ }^{69}$

\section{§18. Do público pensador de cultura ao público consumidor de cultura}

Os dois últimos tópicos que descrevem a mudança das estruturas sociais da esfera pública burguesa trabalham a ideia da decadência da esfera pública literária, que teria se transfigurado num setor de "consumo cultural". Analisam, além disso, como esse processo destaca essa esfera pública das formas de expressão da relação entre homme e citoyen - de uma esfera privada protegida das exigências da reprodução social - e da esfera pública política, uma vez que os públicos pensantes e críticos se transformam em consumidores e eleitores. (Habermas, 2003:90) ${ }^{70}$

Essa passagem da esfera pública literária para a esfera do consumo relativiza os limites entre a autonomia individual e a autonomia política, pois converte a vida privada numa instância novamente dependente da reprodução social e ao mesmo tempo politicamente passiva, pois torna o público um receptor de uma comunicação política plebiscitária. $^{71}$

\footnotetext{
${ }^{68}$ V. Habermas, Política Cientificada e Opinião Pública (original de 1963), texto publicado junto ao ensaio Técnica e Ciência como 'Ideologia", em Habermas, 2006:107-128. Este texto será novamente mencionado no tópico 1.4., com a atualização do método de $M E E P$ para a realização do diagnóstico da esfera pública política brasileira deste estudo.

${ }^{69}$ Vale à pena reproduzir a citação que Habermas faz de Plessner, que havia escrito dois anos antes de MEEP que “'Já que os meios cada vez mais intensos de comunicação de massas estão abertos a toda e qualquer influência propagandística, produzem no próprio lar uma esfera pública como jamais o ousaram jornais e livros: a desestabilização da esfera privada leva, ao menos no plano afetivo, a um crise". (Plessner, Das Pro. 1960, p. 9, 4. Apud. Habermas, 2003:331)

70 "A cultura burguesa não era mera ideologia. Porque o raciocínio das pessoas privadas nos salões, clubes e associações de leitura não estava subordinado de modo imediato ao ciclo da produção e do consumo, ao ditame da necessidade existencial; porque, no sentido grego de uma emancipação das necessidades existenciais básicas, possuía muito mais um caráter 'político' também em sua forma meramente literária (para se poder entender as novas experiências da subjetividade), é que aqui pôde cristalizar-se essa ideia, posteriormente então degradada a mera ideologia - ou seja: humanidade." (Habermas, 2003:190).

71 "O ideal-tipo burguês previa que, a partir de uma esfera íntima bem fundada na subjetividade correlata ao público, se cristalizasse uma esfera pública literária. Ao invés disso, esta se torna hoje uma porta aberta por onde entram as forças sociais sustentadas pela esfera pública do consumismo cultural dos meios de comunicação de massa, invadindo a intimidade familiar." (Habermas, 2003:192)
} 
O resultado é que processos de individuação, que ocorrem por meio de práticas de socialização nessa esfera privada, não tem mais a proteção de antes para se desenvolverem livremente, pois as normas públicas que garantem esse espaço de subjetividade e sua livre passagem para o público não são mais objetos da crítica e da discussão pública. Elas são, ao contrário, legitimadas por instrumentos de manipulação da opinião pública, instâncias semi-públicas que buscam influência direta ou indireta da esfera pública política, sejam elas associações privadas de empresários ou partidos políticos (Id.op.cit:91-194).

Enquanto isso, a decadência do público leitor e pensante dos séculos XVIII e XIX ${ }^{72}$ estaria ligada à "abstinência quanto ao raciocínio literário e político". A força institucional $^{73}$ das atividades de grupo que levavam às pessoas aos espaços comuns é gradativamente substituída por uma presença vazia de indivíduos que reproduzem no público um privado super exposto, não compartilham a cultura consumida e agem de modo a justificar somente a liberdade individual. Com a privatização do agir, perdem-se também os produtos da autonomia política, como uma opinião pública formada por uma publicidade crítica, que poderia em última instância corporificar o princípio da soberania popular (Id.op.cit:192-193). ${ }^{74}$

Uma forma de discussão pública continua a existir, no entanto, mas ela é agora realizada por "pseudo-públicos", como emissoras de rádio, editoras e associações, que administram a conversação por meio de regras assépticas de programas de auditório, debate ou entrevista, transformando-a também em mercadoria. ${ }^{75}$ A crítica contundente de

\footnotetext{
${ }^{72}$ Habermas destaca que os clubes de livro, populares na Alemanha nos séculos XVII e XVIII aumentam suas tiragens no início do século XX. Em 1955, no entanto, em mais um terço de todas as casas da Alemanha Federal não havia livros. Em 58\% delas havia somente um livro (Habermas, 2003:333). Dados citados do estudo de 1957 Jahrbuch der öffentlichen Meinung ("Livro anual da opinião pública”. Allensbach, 1957, p. 102).

${ }^{73}$ Esse tema remete ao trabalho de Jean Cohen e Andrew Arato Civil Society and Political Theory, um dos mais importantes estudos da atualidade sobre a sociedade civil a partir do pensamento alemão. Muito citados por Habermas em Direito e Democracia, Cohen e Arato trabalham uma abordagem declaradamente influenciada por uma concepção política da ética do discurso, pensando a sociedade civil como ganhos institucionais da autonomia privada por meio de normas públicas, o que ressalta como Habermas a complementaridade entre direitos individuais e legitimação democrática. Esse estudo será retomado nos tópicos 1.3 e 2.2 da tese. V. Cohen e Arato, 1992:351.

${ }^{74} \mathrm{O}$ diagnóstico da mudança estrutural da esfera pública se demonstra também, portanto, como uma crise da cidadania e da participação política, trabalhada em vasta literatura após MEEP (Cohen e Arato, 1992; Peters, 2007; Avritzer, 2004). No diagnóstico do tempo presente a ser realizado neste estudo, essa discussão será retomada a partir das novas possibilidades de retomada desse "vazio" da esfera pública política com um tópico dedicado a novas formas de comunicação e participação na opinião pública, como as redes sociais digitais (v. tópico 1.3.2.2). Por hora, recomenda-se. Benkler, 2006; Münker, 2009; Blotta, 2008.

${ }^{75}$ Uma análise interessante desse tipo de programa televisivo de entrevista é apresentada em Sobre a Televisão, de Bourdieu, no tópico sobre "debates verdadeiramente falsos ou falsamente verdadeiros". Em relação aos primeiros, Bourdieu destaca que tratam de espaços que promovem a auto-representação de convidados permanentes, forjando situações discursivas quando na realidade se tratam de debates prémontados, com vistas a reafirmar posições e papéis dos convidados perante os telespectadores. Já em relação
} 
Habermas à industrialização e massificação da cultura se segue quando as interpreta como responsáveis pela perda dos critérios de racionalidade da esfera pública literária. Isto é, o gosto, a livre-escolha e a preferência, que guiavam anteriormente uma opinião crítica e estética independentes das necessidades de consumo, perdiam a força sobre o imperativo mercadológico. Este invade também a racionalidade do próprio fazer artístico, afetando especialmente sua busca por autenticidade ${ }^{76}$ (Id.op.cit:194-195).

Essas transformações atendem às duas funções do mercado de bens culturais: de facilitar econômica e psicologicamente o acesso de públicos cada vez mais amplos. Seja por meio do mimetismo que invade as obras em seus primeiros estágios de criação, em busca de facilitar o consumo das massas, ou por meio de técnicas de impressão massiva, como os livros de bolso, os sinais de uma dissolução da esfera pública e sua substituição por uma cultura consumista ficam cada vez mais evidentes. Com isso, a opinião e a crítica advinda dos clubes de leitura se desinstitucionalizam ao perder sua ligação com editores e a imprensa na composição de uma esfera pública literária que discute politicamente (Id.op.cit:196-197).

A massificação de exemplares da imprensa e sua associação com modelos dos EUA também levam à criação dos jornais sensacionalistas, que aliam as numerosas tiragens com técnicas como o "cartoon", o "news picture" e as "human interest stories" derivadas da "imprensa de fim de semana", de revistas ilustradas mais "psicologicamente acessíveis" às massas. A perda do caráter político dessa esfera pública é correlata ao momento em que a massificação técnica e a acessibilidade psicológica se tornam fins do processo produtivo. $\mathrm{O}$ "público consumidor de cultura" ganha então preponderância sobre o público leitor e a imprensa pensante (Id.op.cit:198-199).

Outras técnicas de produção minam o caráter investigativo e opinativo da imprensa escrita, já que ela passa a tentar compensar os recursos óticos e auditivos da televisão e do rádio com mais ilustrações, colunas mais atraentes e alarmantes e notícias-relatos que rompem importantes fronteiras entre "fact" e "fiction", "reportagem" e "romance". Essas interpenetrações de discursos ${ }^{77}$, anteriormente separados por critérios claros de

aos debates "falsamente verdadeiros", as regras para cada fala, velocidade exigida às respostas e as intervenções do entrevistador dificultam a espontaneidade e a livre troca de argumentos nas entrevistas, dando importâncias diferentes às opiniões dos entrevistados. V. Bourdieu, P. Sobre a Televisão, 1997:42-54. Como se verá mais à frente, Habermas haverá de concordar com essa constatação ao argumentar que os talkshows e programas de entrevistas levam os atores mais à auto-representação de si mesmos do que à debates com argumentos descentrados. V. Habermas, 2006a.

${ }^{76}$ V. o indispensável Benjamin, 1975. Sobre este texto, Habermas, 1975. V. também tópico 7.1 deste estudo.

77 Essa importante característica de uma esfera pública mediatizada será especialmente destacada no diagnóstico do presente esfera pública política brasileira deste estudo. No caso, a interpenetração, a confusão 
racionalidade, agora se tornam regra no rádio, no cinema e na televisão. Elas alteram a natureza da comunicação pública enquanto tal, pois eliminam o raciocínio privado com o qual a esfera pública literária havia um dia tornado possível uma publicidade crítica (Id.op.cit:200-202). ${ }^{78}$

A falsa autonomia privada de uma intimidade à mercê desse novo público é acompanhada de uma privatização da esfera pública na própria consciência do público consumidor. Cada vez mais ganham publicidade relatos de biografias pessoais, e sua aparência de expressão autônoma ligada à subjetividade do privado se torna evidente, na medida em que as personificações e individualizações da comunicação tomam o lugar dos argumentos públicos ${ }^{79}$. O privado publicizado é tratado com sentimentalismo, enquanto que o debate público se privatiza num combate cético de opiniões particularizadas (Id. op. cit:203).

Habermas ressalta nas mídias uma capacidade de oferecer respostas aos conflitos de identidade das pessoas, substituindo o recurso à família para a resolução de problemas de formação da personalidade (Id. op. cit:204). Numa leitura psicanalítica, como a realizada por teóricos atuais da comunicação no Brasil, são oferecidas pela comunicação especialmente áudio-visual - representações concretas dos desejos das massas, o que

e a superposição entre os discursos presentes na esfera pública geram violações das pretensões comunicativas da sociedade civil brasileira, a serem aqui identificadas a partir de diagnósticos empíricos negativos. v. capítulo 2. Para um ensaio prévio, v. Blotta, 2010a.

78 "Rádio, cinema e televisão levam gradualmente ao desaparecimento da distância que o leitor precisa guardar ante a letra impressa - uma distância que a privacidade da assimilação tanto solicitava quanto uma esfera pública de uma troca de ideias sobre o que havia sido lido acabava possibilitando. (...) Os programas que os novos mídias emitem, se comparados com comunicações impressas, cortam de um modo peculiar as reações do receptor. Eles cativam o público enquanto ouvinte e espectador, mas ao mesmo tempo tiramlhe a distância da 'emancipação', ou seja, a chance de poder dizer e contradizer'. (Habermas, 2003:202. Grifos nossos). Essa importância característica da emancipação relaciona-se ao conceito de liberdade comunicativa trabalhado por Habermas em Direito e Democracia, a partir de sua interlocução com os estudos jusfilosóficos de Klaus Günther. Sobre esse conceito, que será trabalhado com detalhe no tópico 2.3 deste estudo, v. Günther, 1998:234-254; Id, 2005:246-248.

${ }^{79}$ Interessante pesquisa sobre este fenômeno é presentemente realizada no Instituto de Pesquisa Social da Universidade Goethe de Frankfurt. Coordenado pelo Prof. Klaus Günther e liderado pela pesquisadora Ophelia Lindemann, o projeto denominado Recht, Kampf um Anerkennung als Opfer (Direito, Luta por Reconhecimento como Vítima) visa analisar experiências de reconhecimento e "falso-reconhecimento" pelo trato de biografias pessoais na mídia. v. www.ifs.uni-frankfurt.de. Esse problema se torna importante para o presente estudo, no momento em que a mera garantia de espaços nos meios de comunicação de massa e a possibilidade de se publicar uma biografia parecem ainda não ser suficientes para provocar processos de individuação e formação da personalidade. V. tópicos 7.3 e 8.1 "b" desta tese. V. também o texto de Honneth "Anerkennung als Ideologie" [Reconhecimento como Ideologia. Trad. livre] In. Id. Das Ich im Wir, 2010, pp. 103-130. 
dificulta sua capacidade de crítica perante os fatos e opiniões transmitidas, pois compõem um amálgama quase inquestionável de pretensões de verdade e justiça. ${ }^{80}$

Apesar das diferentes abordagens, que levam a problemas teóricos importantes (v. tópico 5.4 desta tese), ambas as perspectivas destacam que esse processo de transformação de um público pensador de cultura num público consumidor de cultura não se limita à divisão de classes sociais, ainda que a universalização do acesso a bens culturais também não tenha se consolidado plenamente com os meios de comunicação de massa ${ }^{81}$. Essa semelhança serviria para demonstrar que a degradação da esfera pública não teria causa no novo acesso a ela por públicos antes excluídos - como uma "proletarização da esfera pública burguesa", mas sim no processo de reeducação dos públicos promovido pelos padrões de racionalidade, cultura e comportamento que passam a ser transmitidos pela comunicação pública de meados do século XX (Id. op. cit:205).

O rearranjo da intelectualidade numa esfera pública regida pelas mídias de massa é contemporâneo à própria crise de seu reconhecimento público, que os leva ao status de meros "funcionários da cultura". Apesar de ainda "influenciar" o grande público, especialmente quando se trata de "legitimar" grupos e tendências em ascensão, esse grupo passa a fazê-lo agora por meio de técnicas de visibilidade propagandística de obras culturais, ideias políticas e notícias (Id. op. cit:206-207).

A perda das funções da crítica de arte e da imprensa de opinião e investigativa ocorre junto à autonomização da intelectualidade em relação às grandes massas consumidoras de cultura. Uma comunicação livre entre ambas as camadas, no entanto, que teria sido essencial para a formação do público próprio da esfera pública literária não se realizaria mais no presente (Id. op. cit:207). A industrialização da cultura no século XX, resultado de um processo histórico que teria libertado a esfera privada da esfera íntima dos burgueses e gerado a esfera pública literária, não só degrada esta última, mas a destaca da esfera pública política, gerando a crise de legitimidade do capitalismo tardio e aprofundando a ficção constitucional da esfera pública.

\footnotetext{
${ }^{80}$ Sobre essas leituras na comunicação atual no Brasil, que questionam algumas premissas da esfera pública habermasiana e serão especialmente discutidas nos tópicos 2.1.2 e 2.3.2., v. Bucci, 2002; Bucci e Kehl, 2004; Bucci, 2009.

81 Para uma análise desse processo na ótica da economia política da informação e da comunicação, que destaca o caráter de maior concentração do capitalismo em fase monopolista, v. Bolaño, 2000:69-117.
} 
O último tópico que trata das mudanças na estrutura social da esfera pública (§19) abre caminho à reflexão sobre a transfiguração de sua função política, realizada em seguida (cap. VI). As "grandes linhas da decadência da esfera pública burguesa" são traçadas a partir do momento em que ela passa a assumir "funções de propaganda". ${ }^{82}$ Isso ocorre na medida em que a sociedade civil organizada deixa de mediar criticamente a comunicação relativa à regulação de áreas como a economia e a cultura, e cede esse papel a empresas, associações, partidos e administração pública. Mas como esses novos atores mais institucionalizados procuram transformar diretamente interesses privados em plataformas políticas, diferente de um público de pessoas privadas cuja autocompreensão resultava naturalmente em crítica e vigilância do poder, a comunicação pública perde seu veio crítico e se torna somente uma publicização da ordem à maneira de um public relations (Id. op. cit:207-208). ${ }^{83}$

Até mesmo Marx teria buscado com sua teoria da práxis política revitalizar a esfera pública a partir da realização prática de sua pressuposição jurídica nos Estados constitucionais. Mas a interpenetração dessa esfera por não-proprietários, que criou entidades civis semi-públicas e órgãos públicos privatizados, teria levado à própria desdiferenciação entre Estado e sociedade responsável por dar acesso do público à esfera pública somente de maneira plebiscitária e aclamatória (Id. op. cit:209).

No plano econômico, os antigos produtores privados em regime de concorrência livre se tornam de um lado a grande massa de consumidores, e de outro, poucos proprietários de grandes empresas e oligopólios capitalistas. Em termos tecnológicos, a comunicação unilateral embora ampliada dos media eletrônicos, fragmenta e enfraquece a opinião pública, deslegitimando-a gradativamente como o fundamento da lei e palco de crítica da sua autoridade (Id. op. cit:202 e 212).

\footnotetext{
${ }^{82}$ A ambigüidade da esfera pública que assume função de propaganda é descrita por Habermas no seguinte trecho de MEEP: "A esfera pública assume funções de propaganda. Quanto mais ela pode ser utilizada como meio de influir política e economicamente, tanto mais apolítica ela se torna no todo e tanto mais aparentar estar privatizada." (Habermas, 2003:207-208).

${ }^{83}$ Em importante passagem do tópico 19, Habermas atesta: "A publicidade é desenvolvida como que do alto a fim de cria uma aura de good will para certas posições. Originariamente, a publicidade garantia a correlação do pensamento público tanto com a fundamentação legislativa da dominação como também com a supervisão crítica sobre o seu exercício. Entrementes, ela possibilita a peculiar ambivalência de uma dominação sobre a dominação da opinião não-pública: serve à manipulação do público na mesma medida que à legitimação ante ele. O jornalismo crítico é suprimido pelo manipulativo." (Habermas, 2003:210. Grifos nossos).
} 
Ou seja, não se encontra mais no diagnóstico do presente de Habermas expressões de um modelo de circulação do poder político que pressuponha uma opinião pública criticamente formada como fundamento inafastável da legitimidade da dominação. Essa pressuposição jurídica é transformada em normas da democracia formal que reduz o público judicante em eleitorado, enquanto que a necessidade de intervenções rápidas na economia transfigura funções originais dos três poderes, cujas políticas são aprovadas sem mediação de um público pensante de indivíduos privados (Id. op. cit:210-211).

Abre-se porta para uma nova fase do positivismo jurídico, que é também descrita por Habermas em outro momento pelos processos de tecnificação da política e cientificização da opinião pública. ${ }^{84}$ Ambos ocorrem pelo enfraquecimento do princípio jurídico da publicidade, cujo sentido originário propugnava um vínculo interno entre lei e uma opinião pública criticamente formada, garantidor das pressuposições de generalidade e verdade legal. ${ }^{85}$ Este sentido se buscará reconstruir e atualizar por meio do direito da comunicação ${ }^{86}$.

Ao contrário disso, a facticidade da lei passaria a ser garantida por sua obrigatoriedade, e a formalidade seria critério suficiente para medir sua convergência com o interesse geral, uma vez que a opinião pública não pode mais ser auferida numa sociedade de massas, a não ser de modo mediatizado e aclamatório (Id. op. cit:212). Apesar de ainda presente nas atuais constituições de Estados democráticos, o diagnóstico

\footnotetext{
${ }^{84}$ V. os importantes textos "Política Cientificada e Opinião Pública" (original de1963) e "Progresso Técnico e Mundo Social da Vida" (original de 1965) em Habermas, 2006:93-128. As reflexões de ambos os trabalhos revelam que o a esfera pública política permanece como apanágio da resistência da razão prática na crítica do positivismo e das formas dominação no capitalismo tardio. Ao final do segundo ensaio, Habermas afirma: "Através da formação de uma vontade colectiva, que se ligue ao princípio de uma discussão geral e livre de domínio. A racionalização da dominação só podemos esperá-la de situações que favoreçam o poder político de um pensamento ligado ao diálogo. A força libertadora da reflexão não pode ser substituída pela difusão de um saber tecnicamente utilizável" (Habermas, op.cit:105-106).

85 "Como, com o princípio da publicidade, ao mesmo tempo se modifica a ideia de esfera pública politicamente ativa e a sua função, mostra-se no fato de a ligação - ainda pretendida pelo liberalismo - de discussão pública e norma legal se dissolver e não mais ser pretendida. O conceito liberal de norma legal, em que Executivo e Justiça estão comprometidos na mesma medida, ainda que não do mesmo modo, implicava nos momentos de universalidade e de verdade (justiça - o justo). A sua estrutura espelha a da esfera pública burguesa, pois, por um lado, o caráter genérico das leis em sentido estrito só está garantido enquanto a autonomia intata da sociedade como esfera privada permite excluir da matéria tratada legislativamente certos interesses muito especiais, limitando o trabalho de codificação às condições gerais necessárias ao equilíbrio desses interesses. Por outro lado, a 'verdade' das leis só é garantida enquanto uma esfera pública, elevada no Parlamento a um órgão do Estado, permite que, através de discussões públicas, seja comunicado o que praticamente é necessário para o interesse geral. Que, nisso, exatamente a formalidade daquele caráter genérico da lei assegurava a 'verdade' como adequação no sentido material do interesse de classes burguês, pertencia à dialética logo descoberta dessa concepção de lei: baseava-se na dialética da própria esfera pública burguesa." (Habermas, 2003:210).

${ }^{86}$ V. capítulo 3.2 deste estudo.
} 
de Habermas ao final do tópico é claro quanto à dissolução do sentido originário do princípio da publicidade:

“À estrutura modificada da lei é preciso atribuir que não seja mais colocado no princípio da publicidade a tarefa de uma racionalização da dominação política. Certamente, o público mediatizado, dentro de uma esfera pública imensamente ampliada, é incomparavelmente mais citado de diversos modos e com maior freqüência para fins de aclamação pública, mas, ao mesmo tempo, ele está tão distante dos processos de exercício do poder e da distribuição do poder que a racionalização deles mal pode ser ainda estimulada através do princípio da publicidade, do tornar público. Muito menos se pode, então esperar que ele possa ser garantido (nosso itálico. Do original: “denn gewährleistet werden kann” (Id. 1990:274) [“que possa resultar verdadeiro”. Trad. livre do alemão] (Habermas, 2003:210).

As críticas mais freqüentes a esta parte de $M E E P$ derivam justamente de aprofundamentos de perspectivas que Habermas pretende abandonar em suas revisões (1990) e em escritos mais recentes sobre o tema. Uma delas, com influência da conhecida obra Public Opinion (1922), de Walter Lippmann, questiona o conceito e a expectativa normativa da sociedade em relação à opinião pública, a partir do argumento de que a imprensa que não pode acessar a "verdade" propriamente dita, ou formar opiniões esclarecidas nos públicos. Isso revelaria uma "mistificação" do poder que a sociedade atribui à opinião pública, que deveria ser formada a partir da imprensa (Lippmann, 2008:282-287).

Apesar de considerar princípios para uma esfera pública liderada pela imprensa, como o questionamento da verdade, o estímulo à ciência e exigir que políticos criem instituições mais transparentes, críticas como as de Lippmann, bem como outras análises sociais de uma esfera pública "mediatizada" (Warner, 1992:382; Debord, 1997), parecem ter continuado na perspectiva mais "negativista" do segundo estudo histórico da mudança estrutural esfera pública do trabalho seminal de 1962. Isso por que pretendem descrever a sociedade e a esfera pública como estados de coisas totalmente reificados - seja na tese do "capital tornado imagem" ou da impossibilidade de racionalidade ou verdade no espaço público - e ao mesmo tempo salvaguardar-se dessa mesma reificação. 
Como se defenderá ao longo deste estudo, essas teorias não aprofundam em termos de críticas mais cognitivistas o conceito de opinião pública, isto é, apresentando uma normatividade mais esclarecida ${ }^{87}$, como já procura fazer Habermas em "Further Reflections on the Public Sphere" (1992) e mais recentemente em "Does democracy still enjoy an epistemic dimension?" (2009, original de $2006^{88}$ ). Com isso, incorreriam na aporia da chamada "crítica auto-referencial da razão", que leva ao enfraquecimento da própria crítica, que supervaloriza o componente do poder sobre a racionalidade; ou a abordagem epistemológica do observador, que teria acesso privilegiado à verdade e estaria imune aos efeitos da reificação mesma que procura descrever. ${ }^{89}$

Nessas revisões de trinta, e de praticamente cinqüenta anos depois da primeira edição de $M E E P$, Habermas já busca realizar diagnósticos empírico-descritivos da opinião pública a partir do conceito normativo de agir comunicativo, identificando as condições inevitáveis de possível entendimento mútuo em meio a expressões negativas ou afirmadoras de racionalidade na esfera pública. Apesar de essa perspectiva descartar a possibilidade de uma apreensão objetiva ou demonstrativa do fenômeno da opinião pública, ela torna inapelável sua influência na formação da opinião e da vontade políticas em sociedades de massa de Estados de bem estar social (ou neoliberal). Ou seja, não se pode negar a capacidade da esfera pública assumir formas mais ou menos arrazoadas e ressoar em debates e deliberações públicas (Habermas, 2009:144-151; Id, 1992:438-439).

Nos mais recentes estudos de Habermas, como se verá mais à frente, a esfera pública política, representada pelo "governo da opinião pública" é elevada a terceiro pressuposto institucional de Estados democráticos de direito, junto à garantia dos direitos de autonomia dos indivíduos e dos direitos que compõem sua autonomia política como cidadãos (Habermas, 2009:139). Essas novas considerações, que também não são isentas de críticas, terão importante impacto na elaboração da teoria do direito da comunicação, especialmente nos estudos do terceiro capítulo desta tese.

\footnotetext{
87 Sobre como a razão comunicativa pode ser lida como uma teoria de normatividade esclarecida ou consciente, em oposição àquelas "pseudo-normativas", v. Blotta, 2010:273-336.

${ }^{88} \mathrm{O}$ texto referente publicado na coletânea de "Pequenos Escritos Políticos" Ay, Europa! (2009. Ach, Europa, 2008), vem de conferência em inglês denominada "Does democracy still enjoy na epistemic dimension?" The impact of normative theory on empirical research". Publicada em Communication Theory 16/4 (2006), pp. 411-426. Este texto será analisado com detalhe no tópico 1.4 e retomado no terceiro capítulo desta tese.

${ }^{89}$ Sobre a crítica auto-referencial da razão e o fenômeno da segunda reflexividade do esclarecimento, v. Habermas, O Discurso Filosófico da Modernidade, 2002, pp. 169-186. Para a crítica à perspectiva do "observador" e a defesa da posição do "participante", cuja abordagem esta tese procura aplicar, v. Habermas, 1996:287-328; Blotta, 2010:293-336.
} 
De todo modo, as questões mais interessantes que podem ser destacadas das críticas recentes nessa perspectiva mais "contextualista" 90 são as que procuram revelar os limites da teoria da esfera pública de $M E E P$ em captar pretensões sociais que estão no registro de processos de individuação (Honneth, 2003) e experiências pessoais e coletivas, como expressões socioculturais e existenciais que influenciam a política, representados pelos movimentos feminista e de liberdade de preferência sexual, pelas esferas públicas “diaspóricas" e transnacionais, ou mesmo em novos "públicos contemporâneos" como as organizações não-governamentais, as redes sociais digitais etc. (Fraser, 2007; Crossley \& Roberts, 2007; Münker, 2009).

Segundo essas críticas, cujos diagnósticos esta tese partilha embora proponha uma abordagem distinta para enfrentar seus problemas (v. 1.4), apesar de o movimento feminista ter sido incorporado por Habermas como "política de identidade", seus pressupostos de racionalização em Direito e Democracia (1996:409-426) e outros textos políticos são de modo geral os mesmos procedimentos criados para a formação da opinião e da vontade políticas, ou seja, o princípio da democracia ${ }^{91}$

Com isso, passam a ser identificadas limitações na teoria política de Habermas, na medida em que ela ainda privilegia uma concepção de racionalização da esfera pública em termos de argumentação e descentramento dos participantes, enquanto que processos de identificação e simbolização estética e psicológica são tidos como desviantes e patológicos (Habermas, 2003:254). Isso impediria o autor de identificar em pretensões de formação de identidades, culturas e personalidades lógicas distintas daquelas das racionalidades prática e instrumental, e por isso seriam submetidas aos mesmos procedimentos jurídicos formais ou práticos de argumentação da teoria discursiva do direito e da democracia.

Embora essa abordagem passe a ser alterada a partir dos escritos de Entre Naturalismo e Religião (v. Habermas, 2007:115-168 e 279-392; capítulo 4 desta tese), será importante destacar a partir da última parte do estudo histórico de MEEP como Habermas

\footnotetext{
90 "Contextualismos pós-modernos" é o termo que Habermas utiliza tanto em Pensamento Pós-Metafísico (1981) quanto em $O$ Discurso Filosófico da Modernidade (1985) para designar a perspectiva de críticas radicais da razão, como aquelas derivadas de Nietzsche, como Foucault, Lyotard e Derrida. Do mesmo modo que filósofos marxianos e até mesmo alguns ligados à psicanálise e estética, como a escola francesa, todos de certo modo atualizam no presente a chamada "segunda reflexividade do esclarecimento", promovida pela última fase da primeira geração da teoria crítica (Habermas, 2002d:151-182; 2002a:166-183; V. também Blotta, 2010:75-108).

${ }^{91}$ O princípio da democracia é o princípio básico da teoria do direito de Habermas, com o qual aplica sua teoria do discurso à política: só é legítima a lei que se assentar no consentimento de todos que são por ela real ou possivelmente afetados, e que passar por processos de normatização discursiva abertos à crítica. (Habermas, 1996:103-104. V. capítulo 3 desta tese). Para mais críticas à MEEP nessa perspectiva mais contextualista, v. textos contidos em Crossley, N. \& Roberts, J. (Eds.) After Habermas. New perspectives on the public sphere, 2004.
} 
realmente pensava na "esfera pública mediatizada" como provocadora de "identificações" e "simbolizações" inconscientes e auto-representações não racionais, ora retomando o sentido pré-burguês da esfera, ora expressando a mera irracionalidade de impulsos de satisfação imediata dos desejos (Habermas, 2003:254-258).

\section{Cap. VI Mudança de função política da esfera pública}

\section{\$20. A propaganda como função da esfera pública}

O sexto e último capítulo do estudo histórico que retrata a mudança estrutural da esfera pública é centrado na transformação sofrida por sua "função política", na passagem do século XIX ao XX. Para enfrentar a questão, Habermas procura inicialmente traçar as transformações da imprensa nesse processo ( $\$ 20$ da obra), pois ela constituiria a “instituição por excelência” da esfera pública (Id. op. cit:213).

Enquanto que, por um lado, a imprensa teria sido responsável em grande medida pela formação da esfera pública política a partir de desdobramentos da esfera pública literária (v. subtópico “a”, acima), por outro, sua "mudança estrutural" viria colaborar também com a transformação do princípio da publicidade em propaganda ( $\S 21)$. O resultado seria um fenômeno que Habermas denominará refeudalização da esfera pública, pelo qual não mais se forma espontaneamente, mas é fabricada uma esfera de autorepresentação do poder social e político cuja lógica se assemelha àquela destinada à representação pública da nobreza nas cortes européias analisada no $§ 2$ de $M E E P$.

As mudanças ocorridas na estrutura e no funcionamento interno dos jornais e periódicos dão sinais do caráter cada vez mais empresarial assumido pela imprensa no processo de ampliação e despolitização da esfera pública, que se acentua na passagem do capitalismo liberal para o capitalismo tardio. Essa tendência pode ser inicialmente visualizada nas transformações das funções e relações entre proprietários de jornais, editores e redação.

Enquanto que, num primeiro momento a imprensa teria surgido da necessidade de correspondência individual entre comerciantes que visavam ao lucro, organizados em pequenas corporações artesanais, seu desenvolvimento para um "jornalismo literário" e uma “imprensa de opinião" se dá justamente a partir do momento em que seus proprietários garantem suas bases econômicas a ponto de valorizarem a publicização de 
suas ideias e argumentos tanto quanto, ou às vezes até mais do que sua capacidade de auferir lucros (Habermas, 2003:213-214).

Uma figura representativa desse momento em que a imprensa teria se libertado do reino das necessidades é a redação. Enquanto ainda não se diferencia do editor, e este passa a exercer novamente uma limitação do mercado à imprensa, a redação assume a função institucional de conferir ao jornal uma "opinião", legado dos "hebdomadários moralistas" e "revistas políticas", especialmente na Inglaterra dos séculos XVII e XVIII (v. Id.op.cit:3841). De um jornalismo literário, que tematizava a nova condição social e existencial do burguês e difundia também interesses pedagógicos, a imprensa passa a publicizar argumentos e interesses políticos das redações e do público leitor em relação ao interesse geral, tornando-se não mais uma mera transportadora de notícias, e sim "instituição do público" que forma no espaço da imprensa a sua opinião (Id. op. cit:215-216).

Mas esse equilíbrio que a imprensa angaria entre interesse público e interesse econômico começa a se enfraquecer, segundo Habermas, a partir do momento em que os Estados constitucionais institucionalizam a esfera pública politicamente ativa. Apesar do autor não apontar suas causas, em termos políticos, isso pode ter ocorrido porque na medida em que foram garantidas as liberdades de imprensa e de opinião e a observância do princípio da publicidade pelo Estado contra práticas de censura e segredos, o movimento de politização de certo modo "espontâneo" da esfera pública que lhes havia precedido até então não se faz mais necessário.

Com isso, a imprensa volta a ceder aos imperativos econômicos e, ao seguir o desenvolvimento técnico-científico a partir de meados do século XIX que amplia exponencialmente sua reprodução e distribuição, pode se transformar definitivamente em empresas comerciais, vendedoras de notícias e de espaços de anúncios como regra, e portadoras e fomentadoras de opinião como exceção (op.cit.216-217).

As funções do editor, que envolvem a intermediação da imprensa com o mercado, dissociam-se definitivamente daquelas do redator dos jornais, mas este passa também a ter de atuar de acordo com os interesses de uma empresa privada que visa ao lucro. Com essa nova diferenciação e a tomada cada vez maior dos espaços anteriormente destinados à redação por propagandas dos anunciantes, dá-se um complexo e indistinto entrelaçamento de interesses econômicos com interesses de informação e de opinião, de modo que os primeiros determinem e os outros dois. Essa constatação pode ser feita a partir da 
importante passagem deste tópico, que fornece condições para se identificar até hoje manipulações, ou ao menos algumas seletividades ${ }^{92}$ na esfera pública (v. 1.4):

“A história dos grandes jornais na segunda metade do século XIX demonstra que a própria imprensa se torna manipulável à medida que ela se comercializa. Desde que a venda da parte redacional está em correlação com a venda da parte dos anúncios, a imprensa, que até então fora instituição de pessoas privadas enquanto público, torna-se instituição de determinados membros do público enquanto pessoas privadas - ou seja, pórtico de entrada de privilegiados interesses privados na esfera pública.” (Habermas, 2003:217-218. Grifos e itálicos nossos).

Uma visão mais técnica do jornalismo é implementada na imprensa que se industrializa e se torna uma empresa capitalista. Isso esvazia gradativamente suas raízes literárias e mesmo as diretamente políticas, como ainda continham as publicações realizadas por grupos políticos e de interesse social na França, Alemanha e Inglaterra até meados do século XX.

Mas se a industrialização e a organização empresarial da imprensa colaboram desde o final do século XIX para os processos de cientifização da opinião e pública e tecnificação da política (Habermas, 2006), tornando-se parte de um movimento mais estrutural de monopolização e oligopolização do capitalismo, a evolução tecnológica que levou ao desenvolvimento das telecomunicações e à emergência dos meios de comunicação de massa acelerou ainda mais esses processos (Id, 2003:218).

Habermas torna claro o poderio diferenciado que representam as telecomunicações e os meios de comunicação de massa da indústria cultural pelo fato de receberem dos Estados um tratamento jurídico claramente distinto em relação à imprensa. Sob o argumento de que os bens utilizados por esses meios, como as ondas radiofônicas, eletromagnéticas e redes de telecomunicação são bens públicos, em diversos EstadosNação eles foram criados sob a exploração direta do poder político (Id, op. cit:219-220).

\footnotetext{
92 O termo "seletividade", que será utilizado neste trabalho ao se referir genericamente à sobreposição de pretensões normativas a outras na esfera pública (ou especificamente à seletividade editorial da imprensa, no sentido do "what is fit to print" de Chomsky, ou mesmo o fenômeno do agenda setting [Chomsky, 1998:88-91]), permite uma abordagem mais ambivalente e, portanto, mais produtiva cientificamente, do que o sentido atribuído por Habermas ao termo "manipulação" da esfera pública em MEEP. Enquanto este parece mais próximo de uma ideia de dominação em oposição à empancipação, o termo seletividade não implica uma carga normativa necessariamente negativa, pois também pode significar uma política de comunicação democraticamente criada para estimular e inserir na agenda pública tópicos de discussão entendidos como anteriormente suprimidos e ou excluídos. Neste caso, uma seletividade "positiva" procura compensar uma seletividade "negativa". Para mais sobre o tema na filosofia política de Habermas, v. Habermas, 1996:373379.
} 
No caso do Brasil, como se verá mais à frente, o poder de exploração de telecomunicações e da radiodifusão (serviços telecomunicações, rádio e televisão) é hoje outorgado pela Constituição Federal de 1988 à União Federal, podendo sua exploração delegada a ente privado por meio de contrato de autorização, concessão ou permissão de serviço público (art. 21, X, XI, XII “a”, CF/88).

Apesar dessa clara competência dos Estados e até mesmo de regras anti-monopólio visarem justamente fazer frente ao mercado e manter o sentido original do caráter público e político da comunicação pública, prevalece o modelo de exploração indireto, feito por empresas privadas concessionárias ou permissionárias que, apesar de prestarem um serviço público, tem a permissão de fazê-lo submetendo-se a um regime comercial de empresas privadas que visam ao lucro.

A ambígua institucionalização da esfera pública politicamente ativa permite o predomínio do modelo privado ao mesmo tempo em que oferece as condições para limitálo politicamente. Mas isso não seria um grande problema para a filosofia política se a mudança estrutural da esfera pública não levasse também a uma alteração da natureza própria da publicidade e, portanto, do modo de atuação das pessoas privadas enquanto um público. Com os meios de comunicação de massa, a esfera pública se expande, porém inclui novos públicos mais pelo consumo e pelo entretenimento (publicidade comercial) do que para promover uma discussão pública mais ampla (publicidade crítica) (Id. op. cit:221).

A regulação mercado pelas leis antitruste deu condições para uma cientificização da publicidade comercial, que diminui a distancia e assegura a relação entre empresas e consumidores combinando avançadas pesquisas de mercado e processos de constituição de marcas. Ao mesmo tempo, Habermas deixa claro como a publicidade comercial funciona pela realização daquilo a que se opõe a publicidade crítica: a produção de “intransparências". A publicidade comercial trabalha para ressaltar os pontos positivos dos produtos e dissimular os negativos. Por isso, pode-se dizer que sua "manipulação jornalístico-publicitária" (do original "psychologische Werbemanipulation", que significa mais precisamente "manipulação psicológica de propaganda" Id., 1990:285) torna-se a partir de então fundamental para determinar o valor de troca das mercadorias. Além disso, a penetração da publicidade comercial nas mídias de massa fez com que ela transcendesse 
a expressão econômica da esfera pública, figurando também no discurso político e em produções culturais, como é o caso do merchandising em telenovelas (Id., 2003:222-223) ${ }^{93}$

Segundo Habermas, a ampliação da esfera pública provocada pelo desenvolvimento da comunicação de massa representou efetivamente uma democratização do acesso à comunicação pública. Esse acesso, no entanto, era marcado especialmente por uma maior exposição da publicidade comercial aos públicos economicamente mais frágeis, recém ingressados na esfera pública. Os resultados são formações de públicos e compreensões de publicidade restritas à esfera do consumo.

Nos anos 50 na Alemanha, as publicações destinadas à publicidade comercial de empresas chegam a somar $50 \%$ de todas as revistas do país, e o conteúdo da imprensa também se altera. Anúncios tomam o lugar de redações e de espaços antes reservados para opiniões de pessoas privadas enquanto público, um exemplo da "invasão da esfera pública pela publicidade comercial" (Id. op. cit:224-225).

Quando isso acontece, a esfera pública se torna um espaço para a satisfação de interesses privados não declarados, como interesses políticos que se passam por interesses meramente econômicos. O public relations que se cria então é uma das formas de veicular interesses econômicos através de um discurso supostamente feito para um público enquanto pessoas privadas, e não somente consumidores privados; um discurso que clama pela legitimação desses públicos enquanto interfere na formação de sua opinião, mobilizando temas e eventos e muitas vezes produzindo as próprias notícias. (Id. op. cit:226-227)

Anúncio e notícia passam a se confundir no public relations e assessorias de imprensa, e a partir da manipulação da opinião de pessoas privadas que imaginam atuar significativamente como público, fabrica-se um consenso em relação à legitimidade daquilo que ganha notícia, pois facilita sua aceitação como sendo portador de um interesse geral. O retorno de uma esfera pública política representativa provocada pela transfiguração do princípio da publicidade, é identificada por Habermas a partir das seguintes constatações:

\footnotetext{
${ }^{93}$ Constatação muito semelhante a esta é feita pelo diagnóstico da esfera pública de Bucci (2002:270-276), quando propõe que num espaço público dominado pela televisão, o valor de uma mercadoria é determinado pelo número de pessoas que podem tomar contato visual (psicológico-publicitário) com ela. A ênfase de Bucci na questão da imagem é especialmente o que distingue seu diagnóstico da comunicação com aquele feito por Habermas em MEEP. Essas proposições teóricas de Bucci, como a "economia do olhar", ou a ideia de "valor de gozo" da mercadoria serão discutidos mais propriamente no tópico 2.1.2 desta tese. Para mais sobre o merchandising na produção cultural da televisão brasileira, com aporte nesta teoria de Bucci, v. Alves, Clarice G., O merchandising comercial e a busca pelo olhar na telenovela, 2010.
} 
"Naturalmente, o consenso fabricado não tem a sério muito em comum com a opinião pública, com a concordância [Einstimmigkeit] final pós um laborioso processo de recíproca 'Aufklärung', pois o 'interesse geral', à base do qual é que somente seria possível chegar a uma concordância [Übereistimmung] racional de opiniões em concorrência aberta, desapareceu exatamente à medida que interesses privados privilegiados adotaram para a fim de se autorepresentarem [Selbstdarstellung] através da publicidade. (...) A crítica competente quando a questões publicamente discutidas cede lugar a um mudo conformismo, com pessoas ou personificações publicamente presentificadas; consent coincide com o good will provocado pela publicity. Outrora, 'publicidade' significa a desmistificação da dominação política perante o tribunal da utilização pública da razão; publicity subsume as reações de um assentimento descompromissado.” (Habermas, 2003:228-229).

\section{§21. A subversão do princípio da "publicidade" (Öffentlichkeit)}

No §21 do capítulo VI de MEEP Habermas procura caracterizar esse processo de transfiguração do princípio da publicidade como traço fundamental das novas relações estabelecidas entre os setores privado e público. De um lado, uma imprensa amplificada e concentrada em função do desenvolvimento tecnológico de reprodução e distribuição, aumenta seu público na medida em que diminui a veiculação de opiniões. De outro, a publicidade de setores públicos, órgãos associativos e empresas privadas não jornalísticas passam a se utilizar cada vez mais de técnicas de publicity, pelas quais se auto-representa na esfera pública de modo a não permitir aberturas para crítica (Id. op. cit:230).

Uma das formas de aceder à esfera pública e ao mesmo tempo dificultar a crítica e a racionalização da dominação é justamente diminuir a distância entre Estado e sociedade civil por meio de um poder executivo inchado e diretamente associado com interesses de associações e partidos. Essa aproximação gera inversamente um enfraquecimento dos parlamentos enquanto órgãos estatais da esfera pública (Id. op. cit:231).

A esfera pública politicamente ativa, que assegurava a discussão e deliberação pública a respeito de questões de interesse comum entre o setor privado e o público, passa a trabalhar mais questões técnicas e processos estratégicos de barganha entre interesses individuais do que servir de palco para embates argumentativos com base em princípios como interesse geral e soberania popular. Sua previsão constitucional ainda condiciona essas novas funções a pressupostos de racionalização do poder, mas isso não impede o aumento de tomadas de decisão "extra-parlamentares" que tem fundamentos mais 
econômicos que políticos: tornar pública a composição mais vantajosa entre interesses individuais irredutíveis é suficiente.

Estão presentes neste momento em MEEP tanto a tese que Habermas haveria de apresentar em The Theory of Communicative Action (1981) sobre um predomínio do agir estratégico em relação ao agir comunicativo na esfera pública, quanto a fórmula que sugere em Direito e Democracia (1992) para solucionar teoricamente esse predomínio: o exercício da autonomia individual não submetido às regras do "mandamento democrático de agir publicamente" (autonomia política) leva a uma esfera pública tecnificada, pois ela reduz ou elimina o caráter prático das tomadas de decisão e acordos realizados entre poder público e entes privados e deles entre $\mathrm{si}^{94}$ (Habermas, 2003:233-234).

É por isso que se trata de uma entrada privilegiada de interesses privados na esfera pública. Enquanto se vêem na condição de entes privados, empresas e associações não submetem suas decisões e acordos ao escrutínio do público, apesar de suas atividades afetarem-no direta ou indiretamente. Com uma esfera pública política enfraquecida, sua atuação diante da opinião pública se opõe às exigências de adequação a um interesse geral aberto à crítica. Busca-se uma legitimação aclamatória e passiva, condicionada a compensações econômicas. O que se expõe na esfera pública são representações das opiniões das organizações e órgãos públicos, que clamam por prestígio ao invés de se abrirem à crítica (Id., 2003:233-234).

Esse retorno das características de uma esfera pública representativa significa claramente para Habermas uma diminuição do potencial de racionalidade da opinião pública decorrente. Como se verá mais à frente, na medida em que os espaços contemporâneos formados pela comunicação pública são cada vez mais tomados pela linguagem icônica ou imagética da televisão e de outros meios digitais, a questão da autorepresentação se torna fundamental para se pensar as condições atuais de racionalidade da esfera pública. Se a auto-representação facilita a fabricação de espaços públicos com opiniões "não-públicas", isto é, gera uma "predisposição à concordância" passiva (Id. op. cit:235), torna-se fundamental pensar por que isso ocorre, e quais as possibilidades de se infundir crítica a esse tipo de comunicação. ${ }^{95}$

\footnotetext{
${ }^{94}$ Sobre as articulações do agir estratégico no contexto político de $M E E P$, marcado pela despolitização da imprensa e da esfera pública de modo geral, v. também importante nota de rodapé nas páginas 343 e 344 da versão brasileira. V. também Habermas, 2006:68-72.

95 A discussão sobre a "aura da autoridade" (Habermas, 2003:235), provocada pelo retorno da autorepresentação de interesses individuais na esfera pública contemporânea, e mais atualmente pela comunicação icônica (Habermas, 2006a) e seus desafios ao potencial de racionalidade da esfera pública, será
} 
As relações entre público, partidos e parlamentos também refletiam a alteração das funções da esfera pública política. Enquanto que na esfera pública burguesa públicos de pessoas privadas e a própria imprensa faziam reuniões locais para exigir prestações de contas aos deputados, e a parca organização dos partidos permitia uma canalização mais intensa da comunicação entre público interessado e parlamento, na nova esfera pública tanto a imprensa quanto os partidos se organizam de modo a atingir uma massa cada vez maior de consumidores e eleitores (Id. op. cit:236-237).

As prestações de contas dos deputados são substituídas por propagandas regulares dos partidos. Os lugares físicos das reuniões em comunidades locais e a comunicação argumentativa nelas desenvolvidas cedem espaço à imprensa comercial e aos meios eletrônicos, e a um discurso voltado somente para angariar fidelidade eleitoral da população. O princípio do "livre mandato" dos deputados não correspondia a uma carta branca para que fizessem o que bem entendessem. Sua independência estava ligada muito mais à necessidade de responder aos interesses de todos os afetados por sua atuação do que a blindagens contra críticas ou condições privilegiadas de auto-representação (Id. op. cit:237-239).

O desenvolvimento de partidos voltados para as massas eleitorais são especialmente responsáveis pela fragmentação dos públicos. Ao passo que os deputados utilizam suas imunidades como privilégios em relação ao escrutínio do público, subordinam-se cada vez mais às direções dos partidos, contra as quais dificilmente se opõem. Saem de cena os parlamentares "juristas", "advogados do povo", e tomam seu lugar funcionários e burocratas com mandatos fechados em relação aos partidos. Nesse momento, torna-se significativamente prejudicada a função constitucional da publicidade crítica que, segundo Habermas, deveria assegurar a "continuidade da discussão préparlamentar com a discussão parlamentar" (Id. op. cit:239-241).

Ao invés disso, os parlamentos se tornam espaços para a apresentação de propostas de governo e debates entre partidos de oposição e situação. $\mathrm{O}$ foco da resolução de questões se desloca do plenário para as comissões parlamentares e facções, facilitando os lobbies e acordos à sombra da discussão pública. A publicidade dos argumentos se dá de modo muito mais demonstrativo do que crítico, e os meios eletrônicos de comunicação viriam colaborar com essa mudança, já que torna o público um receptor de notícias sobre as decisões tomadas. A visibilidade dos argumentos se torna mais importante do que sua 
razoabilidade, o que segundo Habermas dificulta a contra-argumentação. Só seria possível responder a esse tipo de comunicação com "identificações" (Id. Ibid.)

Nesse sentido, pode-se entender como as transmissões pelo rádio ou pela televisão dos debates políticos e/ou jurídicos eram vistas tanto por Habermas quanto outros teóricos e políticos da época como estimuladoras de uma publicidade no sentido de publicity. Isso porque produziriam "shows" demonstrativos pela exploração midiática de casos polêmicos, ao invés de apresentar informações e relatos precisos e importantes ao esclarecimento e à formação da opinião dos públicos interessados (Id. op. cit:241-243). ${ }^{96}$

Seriam justificadas então restrições à transmissão por rádio ou televisão de sessões do júri e das audiências do Parlamento Alemão, sobretudo em coberturas ao vivo, em resposta reguladora diante dos excessos da publicidade liberal. Segundo Habermas "Não se trata de interditar o livre acesso aos debates, mas deve-se impedir que, (...) se faça uma grande demonstração político-partidária e que, (...) se faça um show processual para a diversão dos consumidores não-participantes" (Id. op. cit:242).

O interessante argumento de Eberhard Schmidt (1959), que procura distinguir publicidade de publicity, citado por Habermas, reforça a impressão de que uma veiculação pelas mídias de massa de imagens e outros elementos estéticos e expressivos de debates parlamentares e sessões de julgamento prejudicariam uma formação racional da opinião pública, e por isso deveriam sofrer limitações de publicidade. Nota-se que o argumento não toca na questão da proteção da esfera privada dos acusados, mas sim do prejuízo da exposição pública de gestos e imagens em transmissões ao vivo à racionalidade da opinião pública. $^{97}$ 96 Novamente fica claro como uma comunicação não pautada por argumentos é entendida por Habermas
como acrítica e produtora de manipulações. Conforme este estudo procurará demonstrar, essa posição do
autor refletirá na elaboração de um conceito de racionalidade por demais afeito à comunicação
argumentativa, o que lhe renderá diversas críticas (Cf. Rorty, 2005:103-162; Honneth, 2003; Id. 2007) e
futuras reformulações. Atualmente, embora ainda considere esse tipo de comunicação como potencialmente
mais racional, após revisões de sua teoria da racionalidade (em Verdade e Justificação, por exemplo),
Habermas não desconsidera mais quanto estão imbricadas às condições de racionalidade outros elementos
cognitivos não-argumentativos, como a "abertura de mundo" (Habermas, 2002b:10), ou mesmo as visões
religiosas de mundo (Habermas, 2009). Conforme já dito anteriormente, essa discussão será retomada nos
tópicos $1.4,2.1 .4$ e 2.3 deste estudo.
97 São as palavras de Schmidt: "O que se perde, afinal de contas, quando não se consegue ver na imprensa
fotos de acusados ou de testemunhas? Pode haver um justificado interesse da esfera pública em saber de
que atos são acusadas personalidades contemporâneas, o que se esclarece quanto a isso no processo e qual
$e ́$ a sentença. Estes são momentos importantes para formar a opinião dos cidadãos interessados na vida
pública e que, através de um confiável relato sobre o processo, também podem ser levados ao conhecimento
de quem não participa das negociações. Mas qual é a expressão fisionômica [do original: Gesichter und
Zeugen - rostos e olhos] do acusado e das testemunhas durante a audiência principal, os interrogatórios ou o
veredito, é algo completamente indiferente a todo interesse justo [do original: berechtigte
Informationsinteresse]. Só quem estiver dominado por essa desalmada inclinação à publicity, pela qual é
atropelado tudo quanto um pensamento humanista se sinto obrigado em termos de cuidados naturais, pode 
Essas regulações que buscam reduzir os excessos "publicitários" da esfera pública, no entanto, não seriam suficientes para retomar as funções políticas originais da esfera pública. Num contexto de interpenetração da sociedade civil no Estado e do Estado na sociedade, não bastaria dar condições institucionais para uma formação racional da opinião pública e exigir publicidade somente em relação aos atos do Estado, mas também promovê-los e exigi-los nas associações, sindicatos, partidos e meios de comunicação politicamente relevantes, que são entes privados mas contém grande poder social, exercem funções públicas e interferem diretamente na política (Id. op. cit:243-244).

Essa importante análise de Habermas se apresenta claramente como um desafio os objetivos deste estudo, pois levanta a pergunta sobre como garantir juridicamente os processos de formação democrática da opinião e da vontade política e as exigências de publicidade não só do Estado, mas de todas as instituições e atores que atualmente influenciam a esfera pública política. Cabe aqui uma longa, porém fundamental transcrição dessa reflexão:

'Na Alemanha Federal, quanto a tais exigências de 'publicidade' dos partidos garante-se, pela lei fundamental a possibilidade de estendê-las também para as associações públicas, pois também elas estão legitimadas no sentido de co-atuar, sob a garantia constitucional da 'liberdade de opinião pública institucionalizada no "Estado de partidos", na formação da opinião e da vontade do povo. Mesmo o jornalismo político deve, como todas as instituições que exercem uma influência privilegiada, de modo demonstrativo ou manipulativo, na esfera pública, por sua vez estar subordinado a mandamento democrático de ser abertamente público. Seja como for que isto se coloque juridicamente, sob o aspecto sociológico tais exigências colocam em discussão o relevante aspecto de uma democratizaçãa de organizações sociais cuja atividade se relacione com o Estado. Não só os órgãos do Estado, mas todas as instituições da imprensa atuantes na esfera pública política estão, neste caso, presas ao mandamento da 'publicidade', pois o processo da transformação do poder social em político precisa tanto de crítica e controle quanto o exercício legítimo do poder político sobre a sociedade. A ideia da esfera pública institucionalizada na social democracia de massas, de um modo não-outro que no Estado de Direito burguês é, primeiro: a racionalização da dominação no âmbito do pensamento público das pessoas privadas só pode ser, agora, ainda realizada como uma racionalização - certamente limitada pelo pluralismo dos interesses privados organizados - do exercício social e político do poder sob o controle mútuo de organizações rivais, presas à esfera pública em sua estrutura

ainda querer falar aí de uma justa necessidade de informação da esfera pública"'. Schmidt, E. Öffentlichkeit oder Publicity, in: Festschrift für Walter Schmidt, Berlin, 1959, p. 351 s. Apud Habermas, 2003:347 (Grifos e itálico nossos). 
interna bem como no relacionamento com o Estado e delas entre si." (Habermas, 2003:244-245.

Grifos e itálicos nossos)

Fica clara a partir de então a necessidade de se expandir e especificar a regulação da comunicação referente às relações entre as instituições públicas e privadas que influenciam a formação de esferas públicas, ampliadas e diversificadas nas democracias de massa, supervisionando-as regularmente, e não somente em períodos eleitorais. $\mathrm{O}$ direito da comunicação procurará responder a essa necessidade de expansão e especificação institucional da esfera pública política a partir de um diagnóstico negativo do caso brasileiro, isto é, a partir de descrições de experiências de violação de pretensões de comunicação e reconhecimento atualmente presentes na esfera pública política nacional (parte II). Esse recurso metodológico é utilizado por Habermas em MEEP para pensar o ideal da esfera pública como o oposto da eficácia da comunicação mediatizada ${ }^{98}$, e em Direito e Democracia como uma "ficção metodológica" que opõe uma esfera pública idealizada às "inércias" e "assimetrias", ou seletividades concretas nela presentes (Habermas, 1996:321-328).

\section{§22. "Publicidade pré-fabricada e opinião não-pública}

No $\S 22$, penúltimo tópico do capítulo VI, as esferas públicas mediatizadas de democracias de massa são analisadas a partir do exemplo de sua "fabricação" em períodos eleitorais. Para Habermas esse momento representava bem a decadência da esfera pública burguesa, tornada transparente na forma de uma esfera pública política encenada, que carrega uma “opinião não-pública” e influencia psicologicamente os eleitores. Estes acabam se comportando regularmente como consumidores de serviços públicos e compensações profissionais, e esporadicamente como massa que é convocada para legitimar acordos e programas políticos sem mesmo poder participar e decidir sobre eles (Id. 2003:251-259).

\footnotetext{
98 "Um processo de comunicação pública que se desenvolve no seio dos partidos e das organizações está, evidentemente, numa relação inversa quanto à eficácia demonstrativa e manipuladora de uma publicidade que procure mobilizar o explosivo potencial aclamativo de amplas camadas da população e, principalmente, atingir sua parte politicamente mais indiferente." (Habermas, 2003:246. Itálico nosso). V. tópico 1.4.
} 
O método utilizado por Habermas para essa análise é o acima citado. A própria necessidade dos partidos "estabelecerem" (do original herzustellen, que pode ser traduzido em termos jurídicos como "propor”) uma esfera pública política, e sobretudo fazê-lo de modo "jornalístico-publicitário" (publizistischen), são sinais do quanto ela já não se apresenta mais como um espaço institucionalizado onde a troca pública e ininterrupta de opiniões de todos os eleitores é garantida (Id. op. cit:246-247).

Os marcos jurídicos que garantem a esfera pública política continuam em vigor, no entanto, mas essa ficção constitucional colabora muito mais para influenciar a formação de um perfil psicológico do "bom eleitor" e atribuir a ele as demandas culturais e políticas de uma vida cívica, do que para exigir publicidade das instituições que atuam na esfera pública política e condições simétricas para uma formação livre da opinião pública (Id. op. cit:247).

Apesar das diferenças, o eleitorado das democracias de massa mantém certas semelhanças com o público de pessoas privadas dos Estados liberais do século XIX. Apesar da generalização sufrágio e da massificação do eleitorado, continuavam a votar mais os homens e aqueles com maior nível educacional e de renda. A maior concentração do público votante entre 35 e 55 anos de idade, o que significa uma maior participação política dos indivíduos que fazem parte de alguma categoria profissional, isto é, de atores coletivos da sociedade civil organizada (Id. op. cit:248).

Essa participação organizada, no entanto, contrasta com o potencial de influência dos "formadores de opinião" (opinion leaders) - frequentemente os mais bem informados e com maior renda - sobre os outros cidadãos. Essa verticalidade também se explica pelo fato de que pesquisas identificam uma relutância maior dos primeiros em alterar suas opiniões diante de melhores argumentos. Esses atores normalmente entram na esfera pública para reafirmar suas posições, fazendo com que os menos informados e mais apáticos determinem ao final se um fluxo de comunicação interno a grupos efetivamente se transformará em opinião pública (Id. op. cit:249).

Diante da evidência de uma imobilidade nos fluxos de opinião entre membros de partidos e herdeiros de tradições e fortes convicções ético-políticas, a camada menos informada e desinteressada da população, que representa aproximadamente metade dos eleitores, acaba se tornando o maior alvo dos gestores públicos e candidatos. Sua inclusão na esfera pública é, no entanto, muito mais próxima de uma adequação ao perfil de um "consumidor apolítico" do que de um indivíduo competente para formar de modo 
autônomo sua opinião a partir de suas convicções e das informações e argumentos disponíveis (Id. op. cit:250).

Novamente, as esferas públicas formadas a partir de disputas eleitorais em democracias de massa são descritas por Habermas como produtos de identificações de eleitores com as imagens dos candidatos construídas por campanhas de marketing, e não pelas relações entre participação eleitoral e programas de governo. Citando Adorno ${ }^{99}$, o autor descreve o novo tipo de ideologia que envolve essa "encenação" da esfera pública. Ela pretende não representar uma ideologia, e por isso se propõe apolítica (ou "pseudo normativa"). Mas na verdade, sua orientação normativa se encontra subreptícia a essa própria dissimulação. ${ }^{100}$

Ao abandonar a feição de um sistema de convicções claras que buscam assentimento em relação à validade de seus pressupostos, a cultura política envolvida pela "cultura de consumo" se torna um sistema de adequação do comportamento. A consciência que ela cria está eivada pela "reprodução pseudo-realista do existente ao seu nível de superfície". O eleitor se torna um consumidor político, já que suas opiniões não tem a capacidade de atingir o status de "ação política", isto é, de compor uma opinião pública politicamente influente (Id. op. cit:251-253).

Se o rádio e a televisão se tornam somente veículos de propagandas políticas cientificamente conduzidas, a imprensa também perde sua capacidade de sediar a formação da opinião pública. Mas ao mesmo tempo em que deixa de servir como plataforma das pretensões políticas dos partidos, não perde a capacidade de veicular interesses de seus proprietários ou de indivíduos e grupos que nela influenciam. Até mesmo as assembléias de partidos e parlamentos teriam se tornado para Habermas demonstrações da comunicação política transformada em publicidade comercial (Id. op. cit:253).

É nessa esfera pública que se produz o que o autor denomina “opinião nãopública": trata-se de uma "concordância plebiscitária", resultado de uma "atmosfera de aclamação". A eficácia da identificação simbólica aumenta na medida em que essa identificação se distancia de argumentos e princípios programáticos. A visibilidade das lideranças políticas é extremamente importante nesse caso. Para Habermas, os índices de

\footnotetext{
${ }^{99}$ Do texto "Ideologie". In. Exkurse. Frankfurt: 1956, p. 158. Habermas também indica para a compreensão desse tipo de ideologia a obra Dialética do Esclarecimento (1947), de Adorno e Horkheimer (Habermas, 2003:349).

${ }^{100}$ No importante ensaio "Técnica e Ciência como "Ideologia"” (Technik und Wissenschaft als Ideologie, 1968), Habermas procura demonstrar como a eficácia da ideologia do capitalismo tardio depende de quanto ela consegue ocultar suas orientações normativas e se apresentar como um sistema social "natural" ou inevitável (Habermas, 2006:74).
} 
popularidade dos governos indicam justamente quanto a opinião não-pública está por eles controlada (Id. op. cit:254-255).

Não se trata de opinião pública propriamente dita porque esses índices e as ofertas desconsideram processos de formação racional da opinião e da vontade. Apresentando motivos de caráter mais psicológico e estético do que ações e princípios objetivos das lideranças, o público não alcança a "maioridade" do esclarecimento a partir da publicidade, mas mantém-se num estado de heteronomia. São muito mais receptores de políticas do que participantes ativos em seus processos de elaboração e legitimação (Id. op. cit:255).

Ainda assim, Habermas indica que a conexão entre a política e necessidades reais do público não se perde completamente com a publicidade fabricada, já que a popularidade dos governantes depende de certo modo da satisfação dessas necessidades (Id. op. cit:257). Esses "limites naturais" da manipulação ainda são descritos de modo mais sociológico do que filosófico, o que o autor posteriormente demonstrará na teoria a partir da tese da impossibilidade de uma desconexão absoluta entre "sistema e mundo da vida", ou entre ação estratégica e agir comunicativo (Habermas, 1996:197). Até então, no entanto, continua forte a convicção do autor de que as propostas e políticas oferecidas pelo Estado não passariam pela "vontade e a consciência dos cidadãos", e sim pelo seu "subconsciente" (Id. 2003:254-255).

A satisfação de necessidades reais da população não seria suficiente para a formação de uma opinião pública propriamente dita, pois o princípio da publicidade exige que os Estados de direito não só garantam a possibilidade de todos expressarem seus desejos e vontades na esfera pública, mas também as condições e procedimentos necessários para que opiniões atomizadas possam "evoluir para uma opinião pública no raciocínio de um público - tornando-se opinion publique."101 (Id. op. cit:255-256).

Além disso, na medida em que se exclui a possibilidade de se discutirem as propostas e ofertas dos governos e candidatos como questões práticas, com seus detalhes e alternativas conhecidos e passíveis de serem consideradas corretas ou incorretas num processo público de comunicação, as justificativas para o apoio ou desaprovação dos

\footnotetext{
${ }^{101}$ Apesar de destacar esta importante característica do princípio da publicidade, Habermas não a aprofunda em MEEP. Ela ressurge em Direito e Democracia como pretensão de procedimentalização da formação da opinião e da vontade políticas, condição de efetivação do princípio da soberania popular (Habermas, 1996:127). Mesmo assim, entende-se que essa questão merece um tratamento mais preciso e aprofundado, o que se buscará fazer no capítulo 3 desta tese a partir da fundamentação da relação interna entre direito e esfera pública política, e da formulação dos movimentos institucionais do direito da comunicação (v. tópico 3.2).
} 
cidadãos em relação às políticas e propostas continuam circunscritas à mera opinio da esfera privada $^{102}$ (Id. op. cit:257-258).

O resultado dessa configuração da esfera pública política se distingue claramente de sua origem burguesa: aumentam as condições privadas de existência, mas as formas com que o Estado as regula impede o desenvolvimento de uma autonomia plena nessa esfera, especialmente porque a autonomia privada depende da possibilidade de se discutir suas características, abrangência e limites dentro de espaços públicos, isto é, da possibilidade de se tornarem "temário da opinião pública" (Id. op. cit:258-259).

§23. A esfera pública política no processo de transformação sócio-estatal do Estado liberal de Direito

No último tópico do capítulo VI (§23), Habermas procura demonstrar como a mudança estrutural das funções políticas da esfera pública se evidencia no descompasso entre seu estado presente e suas previsões nas constituições dos Estados democráticos. Se o que garantia o funcionamento da esfera pública burguesa como instância de mediação entre sociedade civil e Estado era um setor privado autônomo e uma co-gestão da ordem pública, nas democracias sociais a alteração das relações entre ambos caracterizam as dimensões da mudança estrutural da esfera pública política (Id. op. cit:259-260).

Por isso que Habermas concentra os últimos esforços de seu diagnóstico do presente da esfera pública política na tentativa de descrever as novas relações institucionais entre autonomia individual e autonomia política nas democracias de massa, tema este que será também fundamental para sua teoria do direito. A correlação entre ambas as autonomias estaria presente na própria natureza dos direitos fundamentais, de modo que eles deveriam garantir não só uma não-interferência do Estado no setor privado, mas também as condições para uma participação igualitária “... no processo de criação tanto da riqueza social como também da opinião pública" (Id. op. cit:260). O direito privado, instituído publicamente, é claro sinal desta correlação.

Uma separação mais radical entre direitos de autonomia individual e direitos de autonomia política só passa a ocorrer na medida em que se percebem as desigualdades e privilégios na ordem social, como Marx haverá de denunciar (v. tópico “c”, abaixo). Como

${ }^{102}$ Esse problema exige uma discussão sobre a inalienabilidade do caráter prático da esfera pública política, o que será realizado no tópico 2.1.2 desta tese. Ele remonta, no entanto, a um debate sobre a crítica da normatividade da razão moderna, já que, segundo Habermas, um de seus resultados seria uma relativização absoluta da validade das proposições de justiça. Cf. Habermas, 2002a:166-183; Id. 1984-I:349; Blotta, 2010. 
resposta a esse descompasso entre direito formal e direito de fato, o Estado começa a assumir a responsabilidade por uma intervenção social "justa”, isto é, passa a empreender políticas distributivas. Apesar da importância dessa "transformação sócio-estatal" das democracias de massa, que erige a efetividade dos direitos sociais como compromisso do Estado, ela não é acompanhada na mesma medida por normas e ações que visem a obrigar as organizações sociais com influência pública a respeitar e garantir direitos fundamentais (Id. op. cit:261-262).

De fato, a função do Estado de garantir condições sociais aos indivíduos já estava prevista em declarações de direitos e constituições do século XIX e início do século XX, o que leva Habermas a entender como equivocadas as concepções que opõem o Estado liberal e o Estado social. O autor cita a constituição de Weimar, a constituição francesa e 1946 e a própria Declaração Universal dos Direitos Humanos ${ }^{103}$. É de se notar, no entanto, que a Declaração dos Direitos do Homem e do Cidadão admitidos pela Convenção Nacional em 1973 e afixada no lugar das suas reuniões já prevê direitos sociais, como direito à subsistência, assistência aos pobres, doentes e menores, direito à educação e direito ao trabalho. ${ }^{104}$ Em função da inexistência de acesso à participação igualitária em “indenizações sociais e instituições políticas”, os direitos sociais gradativamente assumidos pelo Estado passam a representar a continuidade da previsão constitucional de uma esfera pública politicamente ativa (Id. op. cit:262-263).

Mais ainda, em função do novo contexto, o próprio sentido normativo dos direitos liberais precisou se modificar para preservar suas finalidades originais. Os imperativos de uma democracia efetiva demandam essa mudança do sentido meramente negativo para uma concepção positiva e pública das liberdades e direitos que garantem uma esfera pública politicamente ativa, isto é, como "garantia de participação" (ou direitos de acesso à participação, do alemão Teilhaberechten. Id. 1990:333) igualitária na formação da opinião pública. Isso fica claro a partir do momento em que organizações sociais ligadas à

\footnotetext{
${ }^{103}$ Neste momento a tradução brasileira de $M E E P$ apresenta grave erro no seguinte trecho: “...na Declaração dos Direitos do Homem feita pela ONU a 10 de dezembro de 1848." (Habermas, 2003:263). O título oficial em português da declaração é Declaração Universal dos Direitos Humanos, e a versão original de MEEP traz a data correta de 10 de dezembro de 1948.

${ }^{104}$ Segundo a recepção da Declaração francesa por esta Convenção: "V - Todos os cidadãos são igualmente admissíveis aos empregos públicos. Os povos livres não conhecem outros motivos nas suas eleições a não ser as virtudes e os talentos. (...) XXI - Os auxílios públicos são uma dádiva sagrada. A sociedade deve a subsistência aos cidadãos infelizes, quer seja procurando-lhes trabalho, quer seja assegurando os meios de existência àqueles que são impossibilitados de trabalhar. (...) XXII - A instrução é a necessidade detodos. A sociedade deve favorecer com todo o seu poder o progresso da inteligência pública e colocar a instrução ao alcance de todos os cidadãos" (Altavila, J. 1989:293-296)
} 
comunicação passam ganhar influência política, a praticar seletividades e a mediatizar apenas opiniões individualizadas (Id. op. cit:263).

Habermas concorda com a formulação de Ridder $^{105}$ de que a função social da liberdade individual de opinião pode ser concebida como uma "liberdade pública de opinião", desdobrada de um lado em garantias de participação na comunicação pública, e de outro em exigência do cumprimento de mandamentos constitucionais por organizações sociais de comunicação e pela própria administração pública. Isso significa que os direitos de comunicação devem ser garantidos, e não somente respeitados pelo Estado e pelas organizações sociais que exercem atividades públicas. As liberdades de associação e reunião também precisam ser reinterpretadas como garantias de participação igualitária de seus membros e demais interessados, devendo atender a normas de estruturação e procedimento que permitam uma consideração satisfatória de suas demandas (Id. op. cit:264-265).

A tese da co-originariedade entre autonomia individual e autonomia privada, à qual Habermas se debruçará insistentemente em Direito e Democracia, já está claramente presente nessas últimas reflexões sobre a mudança estrutural da função política da esfera pública. Os direitos sociais passam então a revelar a necessidade dos direitos da era liberal atender às suas "funções sociais", como é o caso da propriedade. Até mesmo as proteções em relação à esfera privada, na qual o direito ao "livre desenvolvimento da personalidade" só pode se satisfazer plenamente se sua inviolabilidade é garantida publicamente, “...através da participação democrática". ${ }^{106}$

Ao invés de se pensar em um Estado que exerceria pela tributação a limitação social da propriedade, Habermas se junta a Wolfgang Abendroth ${ }^{107}$ para propor que esta própria atividade estatal, bem como outros processos de reprodução social e de formação da opinião pública deveriam se sujeitar ao escrutínio do público. Isso não representaria, então, uma espécie de invasão autoritária do Estado na esfera da reprodução social, mas

\footnotetext{
105 Habermas cita do autor a obra Meinungsfreiheit [liberdade de opinião]. In. Neumann, Nipperdey, Scheuner. Die Grundrechte. Vol. II. Berlin, 1954, p. 342 ss.

106 "A autonomia privada só é, então, certamente possível como uma autonomia derivada; também os direitos sociais ou sócio-estatais quanto a segurança, indenização e livre desenvolvimento, tendo suas funções redefinidas, não se baseiam mais per se num Direito Público estabilizado mediante interesse da troca burguesa de mercadorias; repousam, pelo contrário, numa integração, a ser efetivada em cada caso, dos interesses de todas as organizações ativas democraticamente relacionadas com o Estado, fazendo-se isso conforme padrões ditados pelo Estado da social-democracia" (Habermas, 2003:266. Grifos nossos). 107 Citando a o texto "Zum Begriff des demokratischen und sozialen Rechtsstaats im Grundgesetz der Bundesrepublik Deutschland" [Para o conceito dos Estados democráticos e sociais na lei fundamental da República Federal da Alemanha]. In. Sultan e Abendroth. Bürokratischer Verwaltungsstaat und soziale Demokratie [Estado de gerenciamento burocrático e democracia social]. Hannover, Frankfurt, 1955, p. 97 ss.
} 
sim uma ampliação do controle público sobre as novas interpenetrações entre Estado e sociedade, cujas atividades semi-públicas ou semi-privadas tem se dado sem os auspícios de uma publicidade crítica (Id. op. cit:266-267).

Essa posição tem consequências diretas sobre a proposta do direito da comunicação a ser aqui trabalhada, pois como se verá mais à frente, trata-se de pensar as condições de uma institucionalização da esfera pública política que não prejudique a espontaneidade da formação de espaços públicos. Habermas encena neste momento algumas linhas gerais desse esforço:

"Fixar constitucionalmente uma esfera privada pré-estatal e intermediadora entre a sociedade e o Estado, ou seja, uma esfera pública politicamente ativa, passa a ser reavaliado à medida que Estado e sociedade se interpenetram mutuamente (...), vendo alterada a sua função por uma normativização constitucional concorrente em seu sentido sociológico e real, pois o que não pode mais ser garantido indiretamente por exclusão precisa agora, positivamente, de garantias: a participação no produto social e nas instituições da esfera pública política. Ao mesmo tempo, o âmbito de competência dessa participação precisa ser ampliado à medida que essa participação deva tornar-se efetiva. (...) o mandamento da 'publicidade' passa a ser estendida através dos órgãos do Estado a todas as organizações que ajam relacionadas intimamente com o Estado. À medida de sua realização, no lugar de um público não mais intato de pessoas privadas que interajam individualmente, apareceria um público de pessoas privadas organizadas." (Habermas, 2003:268-269. Grifos e itálicos nossos).

$\mathrm{Na}$ medida em que se atém ao mandamento constitucional de manter uma esfera pública politicamente ativa, as democracias sociais conteriam, portanto, as condições institucionais para garantir que o "público de pessoas privadas organizadas" pudesse promover a partir de suas mediações associativas "um processo crítico de comunicação pública". Ao mesmo tempo, essa exigência concorre com a fabricação de uma esfera pública "demonstrativa e manipulativa", formada em instâncias de interpenetração entre Estado e sociedade ausentes ou blindadas da discussão e do julgamento prático dos públicos interessados (Id. op. cit:269-270).

O nível do desenvolvimento democrático dos Estados sociais, isto é, sua capacidade de racionalizar o exercício do poder social e político, seria medido pela prevalência de um tipo de publicidade sobre o outro. Novamente, a mera existência de parlamentos e partidos, bem como a interpretação somente negativa das liberdades fundamentais de informação e comunicação seriam insuficientes para promover uma publicidade crítica capaz de fazer frente à esfera pública fabricada (Id. op. cit:270). 
Se uma esfera pública política crítica precisaria ser fomentada num processo de "autogeração" em constante concorrência com a publicidade manipulativa, a questão se volta mais uma vez para a capacidade de se submeter os atores e instituições que influenciam na esfera pública ao crivo de uma publicidade crítica. No momento, para Habermas, isso significaria perguntar se a esfera pública seria capaz de racionalizar tanto problemas econômicos a partir do pluralismo de interesses privados em relação ao interesse geral, quanto problemas burocráticos de modo que a própria estrutura interna dos partidos e parlamentos permita relacionar seus aspectos técnicos com discussões e deliberações práticas ${ }^{108}$ (Id. op. cit:270-271) ${ }^{109}$.

Por trás desses desafios, Habermas torna evidentes dois pressupostos teóricos cuja história conceitual $^{110}$ trabalha nos capítulos IV e VII de $M E E P$, e que haverá de desenvolver com maior profundidade e precisão em suas obras posteriores: a aposta na persistência de um consenso possível na comunicação pública, sem a qual o próprio pluralismo de interesses de organizações sociais e políticas não se sustentaria em face das exigências de uma racionalização democrática do poder, e a constatação de que a denúncia da ideia de esfera pública burguesa como mera ideologia e sua decadência em face da publicidade manipulada são provas negativas de que a publicidade crítica pode transcender à própria ideologia (Id. op. cit:271-273). ${ }^{111}$

\footnotetext{
${ }^{108}$ Essas duas perguntas revelam uma das pretensões normativas teóricas mais importantes da esfera pública política, e que transparecerá no diagnóstico do presente do capítulo dois: a inevitabilidade do caráter prático da esfera pública política, que se opõe às tendências de cientificização da opinião pública, de tecnificação da política (Habermas, 2006), e de uma preponderância do caráter informativo e demonstrativo da comunicação sobre seus aspectos opinativos, interpretativos e argumentativos. V. especialmente tópicos 2.1 e 2.2 desta tese.

${ }^{109}$ Habermas destaca neste momento em importante nota de rodapé como as associações de consumidores revelam indícios de uma tentativa de "controle jornalístico do mercado de bens de consumo", isto é, uma interferência, ainda que na época parca, de uma publicidade crítica na esfera do mercado (v. Habermas, 2003: 352, nota 125). Para uma análise mais aprofundada do tema, v. a discussão de Honneth sobre "Mercado e Moral", que é em muitos momentos "contra Habermas" (Honneth, 2011:317-469; Id. 2008).

${ }^{110}$ História conceitual é uma forma de se fazer teoria social a partir do desenvolvimento de conceitos em relação à sociedade e à história (v. Palonen, K. History of Concepts as a Style of Political Theorizing. In. European Journal of Political Theory July 2002 vol. 1 no. 1 91-106). A obra MEEP seria um exemplo desse tipo de estudo, tanto quanto Kritik und Krise [Crítica e Crise] de Reinhart Koselleck (Freiburg-München, 1959), um dos fundadores desse tipo de estudo. Na esteira da filosofia política de Carl Schmitt, Kritik und Krise pode ser considerada semelhante, embora teórica e politicamente oposta à MEEP. Mesmo assim, Habermas não deixa de citar este trabalho seminal de Koselleck como uma de suas mais importantes fontes de pesquisa à época. V. nota n. 2 do capítulo IV da obra (Habermas, 2003:314).

${ }^{111}$ Neste momento, Habermas apresenta uma breve, porém interessante reflexão de como a o princípio da publicidade poderia ser utilizado não só dentro de Estados Nação, mas também nas relações internacionais. A idéia kantiana da "paz perpétua" se ligaria então ao princípio da publicidade crítica, "...naquela época à expectativa de um reino do Direito moralmente responsável, hoje com a esperança de uma pacificação do intercâmbio internacional estrategicamente forçada; a meta permaneceu, contudo, a mesma - a liquidação do cada vez mais precário estado de natureza entre os povos." (Habermas, 2003:354. Nota 131).
} 
As críticas a este último estudo histórico de $M E E P$ também remontam àquelas feitas aos capítulos anteriores. Apesar de Habermas demonstrar as dificuldades de se realizar uma publicidade crítica em meio a uma esfera pública política esvaziada de conteúdo prático e mediatizadora de um público cuja participação se resume a de um consumidor político, a crença que ainda mantém no potencial de racionalidade dessa esfera e na impossibilidade de um destacamento completo da burocracia estatal e o do pluralismo de interesses em relação às expectativas constitucionais de legitimidade democrática, gera reações de diversos interlocutores.

De um lado, tanto em termos empíricos quanto teóricos, críticas importantes derivam do problema do "fato do pluralismo", que o próprio Habermas recepcionará mais à frente em seu debate com Rawls. Nesse debate, a crítica de Seila Benhabib (1992:93-95) ao problema de como seria possível publicizar criticamente valores mais concretos da esfera privada e outros que dificilmente ascendem à esfera pública sem uma indesejada "juridificação" (Verrechtlichung) do mundo da vida, complementa-se com a interlocução mais teórica de Tomas McCarthy, que dirá que o fato do pluralismo revela uma fraqueza do próprio modelo habermasiano de esfera pública, também objeto de crítica da ética do discurso habermasiana: a separação entre ética e moral, ou valores e normas em nome de possíveis consensos políticos gerais. Essa separação levaria a uma teoria "não-realista" de democracia (McCarthy, 1992:52).

Numa orientação semelhante está a mais recente obra de Axel Honneth Das Recht der Freiheit (2011. "O Direito da Liberdade". Trad. livre do alemão), que dedica um aprofundado tópico ao tema da "esfera pública democrática" (Id. op. cit:470ss). Ao concordar com Habermas na premissa de que é nesta esfera onde a formação da vontade política dos cidadãos deve tomar forma e ser recepcionada pelos poderes políticos (Honneth, 2011:471), Honneth entende que se limitar a uma representação somente “procedimental” (“"prozeduralistische' Vorstellung”) das pretensões presentes nos nas esferas das "relações pessoais" (persönlicher Beziehungen) e da "economia mediada pelo mercado ("marktvermittelten Wirtschaftsverkehrs"), pode fazer com que as "precondições libertadoras" das quais dependem essas pretensões normativas sejam ignoradas ou empiricamente subestimadas na esfera pública política (Id. op. cit: 472).

Como se verá no capítulo 4, as críticas de Honneth à concepção de esfera pública política apresentada por Habermas em Direito e Democracia auxiliará na fundamentação da nova abordagem para seus diagnósticos do presente (parte II), com impactos significativos na fundamentação teórica do direito da comunicação (parte III). 
c) princípios normativos da esfera pública burguesa e sua mudança estrutural

Cap. IV. Esfera pública burguesa: idéia e ideologia

A análise das teses e algumas das críticas à obra Mudança Estrutural da Esfera Pública chega à sua parte final, destinada a uma revisão conjunta dos dois estudos teóriconormativos desenvolvidos por Habermas MEEP. Este tópico tratará de modo mais panorâmico da história conceitual que é desenvolvida pelo autor nos capítulos IV e VII, uma vez que as ideias e conceitos filosóficos então reconstruídos terão novamente especial atenção no capítulo 4 deste capítulo. Nesse momento, as discussões, revisões e atualizações do conceito de esfera pública política de $M E E P$, sobretudo na elaboração da teoria discursiva do direito (1992), em intervenções na imprensa (2006a; 2007a) e em textos teóricos mais recentes sobre o tema (2009), servirão de base para a sugestão de uma nova abordagem de diagnósticos de esferas públicas políticas, a ser aplicada ao caso brasileiro no capítulo seguinte desta tese.

O capítulo IV de MEEP descreve primeiramente o surgimento da ideia de opinião pública como um instrumento exigência de publicização das comunicações entre as estruturas e instituições da sociedade civil e do Estado (\$12). Em seguida, discute-se como essa opinião se institucionaliza na forma do princípio da soberania popular no novo Estado de direito burguês, a partir das obras de filósofos contratualistas e iluministas, com especial destaque para Kant (§13). Essa análise é depois contrastada com uma interpretação das críticas histórico-sociais de Hegel e Marx, que revelam a distância entre discurso e prática da esfera pública liberal, dando início à dialética histórica da esfera pública (§14). Por fim, é feita uma discussão sobre as ambivalências da esfera pública na atualização da concepção liberal em Mill e Tocqueville (§15), na qual Habermas conclui que as concepções mais liberais, como as desses autores, seriam mais avançadas e científica e politicamente válidas que as sociais por considerar não só os excessos do modelo liberal, mas também os limites da soberania popular necessários à democracia (Habermas, 2003:155-156 e 162-165). 


\section{§12. Opinião Pública: para a pré-história do topos}

A análise do $\S 12$ se inicia com uma discussão sobre como Locke pensou numa Law of Opinion, que marca a passagem da ideia de opinião como mera doxa ou preconceitos, para aquele conjunto de convicções e julgamentos provindos de debates mais ou menos racionais que seriam entendidos como formadores de opiniões públicas. Assim, a mera "opinion", como hábitos não refletidos, passa a se contrapor a uma noção de "Opinion" que de certo modo controlaria os excessos da autonomia privada e do "puro preconceito". É por isso que, apesar de não ser ainda "pública" e não exigir níveis de escolaridade, gênero específico ou propriedade para acessá-la, esta Law of Opinion é também chamada de Law of Private Censure (Id. op. cit:110-112).

O caráter público dessa "opinion" que se diferencia da doxa passa a tomar forma a partir da influência de Bayle, que diferencia "opinion" de "critique". Mas é Rousseau utiliza pela primeira vez o termo "opinion publique", ainda que para criticar os excessos dos críticos do Ancién Regime, estes que, por querer destruir todas as "virtudes e elementos sagrados do homem", estariam contra a "opinion publique” (Id. op. cit:114).

Mesmo que ainda sem efeitos sobre a política, essa ideia se assemelha à "conscience" de Hobbes, e só a partir de sua recepção pela imprensa que pensa politicamente começa a se derivar em "öffentlichen Meinung" na Alemanha, e em "public spirit" na Inglaterra do final do século XVIII. Esse movimento faz surgir a idéia de opinião pública como uma corrente de opiniões que vão da crença ao julgamento, certificando a capacidade do cidadão comum de praticar o último, e mais importante, o que justificaria para Edmund Burke a relação que faz entre opinião pública (então, "general opinon”, ou consideração pela opinião da sociedade civil, e legislação ${ }^{112}$ (Id. op. cit:113-116).

Este importante vínculo entre opinião pública e legislação destacado por Burke passa a se afirmar ao mesmo tempo em que a opinião pública começa a ser entendida mais claramente como um processo de racionalização, ou "purificação" da mera opinião em opinião pública, e mais adiante da própria dominação, que ocorre a partir de debates críticos em espaços públicos. Embora ainda presos a imperativos de reprodução social do Ancién Regime, são especialmente os fisiocratas que levam adiante a idéia de uma

\footnotetext{
${ }^{112}$ Habermas destaca trecho da carta "On the Affairs of America" de Burke, que vale a pena ser aqui transcrito: "I must beg leave to observe that it is not only the invidious branch of taxation that will be resisted, but that no other given part of legislative right can be exercised without regard to the general opinion of those who are to be governed. That general opinion is the vehicle and organ of legislative omnipotence" (Burke, E. On the Affairs of America. In. Hoffman \& Levack (Eds.). Burke's Politics. New York, 1949, p. 106. apud. Habermas, op. cit:116. Grifos nossos).
} 
"autonomia legislativa da sociedade civil" frente ao Estado. Esta era ainda determinada por eruditos e transmitida aos governantes, mas eles que não podiam mais dispensá-la, já que de seus atos passa-se a esperar racionalidade e persuasão (Id. op. cit:117-118).

É nesse contexto que Rousseau publica o Contrato Social, firmando as bases da opinião pública como expressão da volonté général, princípio de autodeterminação democrática que deveria devolver ao homem seu verdadeiro potencial de liberdade, negado por uma socialização que separava homme de citoyen. Mas segundo Habermas, Rousseau não teria preconizado uma soberania popular que fosse promovida por uma esfera pública argumentativa, mas somente aclamativa, ainda que essa aclamação em praça pública representasse a volonté général e o fundamento da Constituição. O consenso público de uma sociedade política alargada, que não daria espaço para a autonomia individual conquistada pela burguesia, é mais um "consenso dos corações" do que um consenso argumentativo, isto é, sua autoridade deve poder "arrebatar sem violência e persuadir sem convencer" (Id. op. cit:119-121).

Claramente influenciado pelas ideias gregas de democracia, Rousseau dirige seu libelo contra os fisiocratas, que propugnavam uma opinião esclarecida pela discussão pública, ainda que feita pelos cultos e limitada a estruturas pré-modernas de reprodução social. A representação da vontade popular seria, portanto, inconcebível para Rousseau, pois toda lei que não tivesse a ratificação presencial do povo em praça pública padeceria de nulidade. ${ }^{113}$

Ainda assim, Rousseau teria sido um dos incentivadores da ideia de uma relação inseparável entre soberania popular e Estado de direito, que se institucionaliza pela primeira vez na Constituição francesa de 1791, com a previsão de uma esfera pública politicamente ativa na figura do parlamento. Mas segundo Habermas, é Jeremy Bentham quem vinculará mais claramente a noção de opinião pública com a publicidade das negociações parlamentares. Essa correlação é explicada pela necessidade do público supervisionar o trabalho legislativo para legitimá-lo (ou não), enquanto que a transparência desse trabalho deve ao mesmo tempo garantir as condições para que o público se informe e possa então fazer essa supervisão (Id. op. cit:122-123).

Essa forma de se conceber a inter-relação entre direito e esfera pública política influencia diretamente uma das teses centrais deste estudo (v. introdução), mais

${ }^{113}$ Habermas reproduz a interessante reflexão de Rousseau (Contrat Social, III, 14. p. 81. Apud. Habermas, 2003:317. nota 35): “A soberania não pode ser exercida de modo representativo... Ela consiste, em sua essência, na vontade comunitária e a vontade é irrepresentável; ela é ela mesma ou ela é uma outra... É nula toda lei que o povo não tenha pessoalmente ratificado". 
especificamente a proposta da "dupla função institucional" do direito da comunicação (v. tópico 9.1 "b"). Isso porque, de modo simplificado, trata-se de pensar por meio de uma reconstrução normativa, em que sentido uma comunicação pública mais livre pode permitir uma legitimação mais democrática do direito, e ao mesmo tempo como somente um direito efetivamente legítimo é capaz de garantir uma comunicação livre e, com isso, as condições para uma reprodução social mais democrática. Parte dessa proposta já está presente na seguinte leitura que Habermas faz de Bentham e Burke a respeito da esfera pública política:

"Bentham entende os debates públicos do Parlamento apenas como uma parte dos debates abertos do público em geral. Só a publicidade dentro e fora do Parlamento pode assegurar a continuidade do raciocínio político e a sua fundação: ou seja, como Burke o havia formulado, transformar a dominação, de uma matter of will em uma matter of reason" (Habermas, 2003:123124. Itálico nosso).

Em seguida, Habermas ressalta alguns nuances desse debate sobre a relação entre parlamento e esfera pública na Inglaterra e na Alemanha, com a recepção tardia da última do termo "Öffentliche Meinung" (com tradução literal do alemão "opinião aberta") a partir dos escritos de Forster em 1793. Para os fins deste estudo são importantes as recuperações históricas que Habermas faz do debate acerca da definição de opinião pública, como as aulas de direito burguês do francês Guizot, publicadas em 1851, sobre o "domínio da opinião pública", das quais Habermas transcreve o seguinte interessante trecho:

“...é característico do sistema, que não admite de jeito nenhum a legitimidade do poder absoluto, obrigar (do original em francês "oblige") todos os cidadãos a procurar incessantemente e em toda ocasião a verdade, a razão, a justiça, que devem regular o poder de fato. É isto o que faz o sistema representativo: 1. Pela discussão que obriga aos poderes procurar em comum a verdade; 2. Pela publicidade que põe os poderes encarregados dessa busca sob os olhos dos cidadãos; 3. Pela liberdade de imprensa que estimula os cidadãos a procurarem eles mesmos a verdade e a dizê-la ao poder." (Guizot, 1851. Apud Habermas, 2003, p. 124. Itálicos nossos).

Essas definições normativas são complementadas pelos estudos alemães de Forster e Wieland sobre a opinião pública (Öffentliche Meinung) que teriam permitido revelar a face excludente de sua formação, visto que muitos concernidos, por não buscar outra coisa senão a satisfação de seus bens corpóreos, não teriam tempo ou disposição para participar 
da formação de espaços públicos. ${ }^{114}$ Essas críticas à distância entre igualdade formal e a material, que se desenvolveriam em sua radicalidade com Marx em relação à teoria liberal da esfera pública são retomadas no $§ 14$ do capítulo ${ }^{115}$.

\section{$\$ 13$ Publicidade como princípio de mediação entre política e moral}

Por enquanto, no §13, Habermas realiza uma concentrada análise sobre as concepções de publicidade em Kant como o princípio de racionalização da política. Sua filosofia moral é uma filosofia política, posto que a política deveria sempre "homenagear a moral" ${ }^{\prime 16}$, representada pelo imperativo categórico. Ela motivava ao mesmo tempo a formação do público burguês de cidadãos, que interagiam em espaços nos quais as novas pretensões de publicidade de seu raciocínio público poderiam ser exercidas - veritas non auctoritas facit legem. A publicidade das razões públicas é então vista como um processo de esclarecimento moral e, sobretudo, político da sociedade burguesa (Id. op. cit:126-128).

Muito importante para a fundamentação teórica deste estudo é interpretação de que Kant veria a publicidade tanto como princípio da ordem jurídica quanto como "método iluminista" (Habermas, 2003:128. Methode der Aufklärung, do original Id. 1990:180). Isso porque se para Kant a publicidade (Öffentlichkeit), ou a esfera pública ${ }^{117}$ em sua expressão política deveria ser garantida juridicamente como exigência da base moral de legitimação moderna do poder, o direito da comunicação buscará colaborar justamente para o aprofundamento das condições dessa institucionalização, enquanto procura apreender e justificar seu sentido normativo diante de um novo diagnóstico do presente.

\footnotetext{
${ }^{114}$ Da coletânea de escritos de Wieland, Habermas transcreve o seguinte trecho, em outra importante nota de rodapé: "Enquanto a moral for um departamento exclusivo do prelado e a política for o segredo reservado às cortes e aos gabinetes governamentais, ambas acabam sendo deturpadas enquanto instrumentos do engodo e da opressão; o povo torna-se a vítima de hediondos jogos de palavras e o poder se permite tudo e ele tudo pode permitir-se impunemente, já que depende de seu arbítrio rotular a injustiça como justiça, a justiça como injustiça, transformando num crime aquilo que ele mais teme: divulgar a verdade - o que ele pune como um crime. Isso não ocorre quando a razão volta a se apoderar de seus direitos eternos e imprescritíveis, para trazer novamente à luz todas as verdades, cujo conhecimento é, em tudo, vital a todos e, com a ajuda das musas de todas as artes, arranjar para todas elas a máxima popularidade, sob todas as configurações e roupagens imagináveis. Daí, uma grande quantidade de conceitos e fatos corretos passam a circular; uma porção de preconceitos caem como escamas dos olhos..." (Wieland. Sämmtliche Werke. Liepzig, 1843, p. 208, apud. Habermas, 2003:319).

${ }^{115}$ Id. op. cit:124-125. v. análise do $\$ 14$ em seguida.

${ }^{116}$ Do apêndice do esboço de Kant à "Paz Eterna" transcrito por Habermas "der Moral gehuldigt zu haben", cujo verbo huldigen, além de "homenagear", pode ser traduzido também como "cultuar". Hoepner, L; Kollert, A. M. Weber. A. Langenscheidt Taschenwörterbuch Portugiesisch Müchen: Langenscheidt, 2001, p. 880 .

${ }^{117}$ Neste momento, os termos "publicidade" e "esfera pública" são tomados aqui como sinônimos.
} 
A colaborar com esse esforço está a interpretação de Habermas de que Kant teria pensado a partir do princípio da publicidade uma forma de racionalidade moral e política cujo caráter intersubjetivo e fundamento prático derivavam da mesma possibilidade de seu uso público, em partilha com outras opiniões dos participantes (Id. op. cit:128).

Mas é também muito claro para Habermas como Kant ainda teria visto essa esfera pública ou "publicidade" como um espaço elitizado, a que poucos filósofos, literatos e intelectuais, bem como juízes, padres e médicos teriam acesso a um debate para melhor nomear em categorias as práticas comuns da sociedade sobre as quais “...reconhecemos nada conhecer..." (Id. op. cit:129).

Não deixa de estar presente de todo modo a opinião de que Kant teria identificado as ambivalências do conceito normativo da esfera pública ${ }^{118}$, pensando que no trânsito de razões e motivos entre os espaços públicos e privados estaria a possibilidade de um uso público da razão, capaz de levar tanto a uma concepção verdadeira de "mundo" quanto a uma organização justa do Estado liberal de direito. ${ }^{119}$ Esse caráter de justiça, por sua vez, deveria ser comprovado e atribuído pela opinião pública, quando ganha status de regra “universal e racional". A condição para a realização do princípio da publicidade seria, portanto, a promoção e a proteção de espaços públicos institucionalizados capazes de assegurar um equilíbrio entre os direitos de autonomia individual e da soberania popular no processo de formação da opinião pública, isto é, a garantia institucional de uma esfera pública politicamente ativa (Id. op. cit:130-132).

\footnotetext{
118 “As liberdades civis são asseguradas através de leis gerais; à liberdade do 'homem' corresponde a igualdade dos cidadãos perante a lei (abolição de todos os 'direitos natos'). A própria legislação se baseia na 'vontade do povo decorrente da razão', pois leis têm sua origem empiricamente na 'concordância pública' do público pensante (öffentlichen Zusammenstimmen 'des räsonierenden Publikums', Id. 1990:183) (...) o princípio da soberania popular só pode ser realizado pressupondo-se um uso público da razão. 'Em cada sistema comunitário (...) precisa haver um espírito de liberdade, já que cada um, no que tange o dever universal humano, quer ser convencido através da razão, e que essa coação seja de acordo com a lei, para que ele não caia em contradição consigo mesmo" (Habermas, 2003:231-232. A transcrição que faz de Kant é de Cassirer, E. (ed.) Kants Werke, vol. IV, p. 172).

${ }^{119} \mathrm{O}$ importante diálogo de Habermas com Kant vale a pena ser novamente transcrito "A unidade inteligível da consciência transcendental corresponde a (sic) concordância de todas às consciências empíricas que se efetua na esfera pública. Mas tarde, na Filosofia do Direito, essa 'concordância de todos os juízos independente da diversidade dos sujeitos entre si' garantida pela publicidade, para a qual em Kant só falta ainda o nome 'opinião pública', recebe, para além de seu valor pragmático, um significado constitutivo: as ações políticas, ou seja, as ações voltadas para o direito dos outros, só devem poder, elas mesmas estar em concordância com o Direito e a Moral à medida que as suas máximas podem ter publicidade e mesmo a exigirem" (Habermas, 2003:132. Itálico nosso). Em nota seguinte Habermas destaca que Kant definiria esta situação como 'unanimidade da política com a moral conforme o conceito transcendental de Direito Público’. Kant. In. E. Cassirer. (ed) Werke. Vol. VI, p. 468 ss. Apud. Habermas, 2003:320. Itálico nosso.
} 
Apesar de conceber a publicidade burguesa e os direitos que a garantem como uma ordem natural, e, portanto, "apolítica", Kant estava também preocupado que essa institucionalização da esfera pública política acabasse significando somente ganhos de legalidade, e não refletisse também um amadurecimento moral da sociedade (Id. op. cit:133). A tese da juridificação do mundo da vida que Habermas desenvolverá a partir de Weber em The Theory of Communicative Action mostrará preocupação semelhante, ainda que se busque uma abordagem "pós-metafísica", isto é, no caso, o que se opõe às tendências de juridificação seria o fato de que o direito ainda manteria uma ligação com um mundo da vida linguisticamente estruturado (Id, 1987-II:367). Mais à frente, em Direito e Democracia, essa tese se somará a de que uma legitimação democrática do procedimento jurídico pressupõe um potencial de racionalidade na esfera pública política. $^{120}$

Seja como ordem natural moral, como co-originariedade entre autonomia individual e autonomia política (Id, 1996:135) ou, como se pretende propor mais à frente, a partir da proposta de um vínculo interno entre direito e esfera pública política (v. parte III), a questão de como institucionalizar o potencial de racionalidade política da esfera pública sem juridificá-la já teria sido pensada como desafio na filosofia política de Kant (Habermas, 2003:133).

Mas na tentativa de aproximar sua máxima da razão pura e da razão prática na política por meio do princípio da esfera pública, Kant chegaria a pensar no perfil do “assalariado-livre" e, portanto, na precondição de proprietário privado como garantia de acesso ao espaço de livre discussão de idéias políticas que lhe permitiria sair da minoridade e avançar para a maioridade política. Nessa perspectiva claramente liberal, Kant teria entendido que o pressuposto do livre-intercâmbio de mercadorias seria aquilo a definir a capacidade dos indivíduos passarem de "homens privados a cidadãos", ou de meros receptores a autores das leis. Estas, por sua vez, deveriam garantir condições para que eles fossem "felizes", ou para que os cidadãos estejam "satisfeitos com sua situação" (Id. op. cit:132-137).

\footnotetext{
120 "It is not the legal form as such that legitimates the exercise of governmental power but only the bond with legitimately enacted law. At the posttraditional level of justification, as we would say today, the only law that counts as legitimate is one that could be rationally accepted by all citizens in a discursive process of opinion-and wil-formation. // A popular sovereignty that is internally laced with individual liberties is interlaced a second time with the governmental power, and in such a way that the principle that 'all governmental authority derives from the people' is realized through the communicative presuppositions and procedures of an institutionally differentiated opinion-and will-formation". (Habermas, 1996:135. Itálicos do autor).
} 
Mas a própria transformação do Estado de direito num Estado social na passagem dos séculos XIX ao XX, e a incapacidade da política ser pensada somente como uma forma de moralidade calcada em garantia jurídica de liberdades negativas, levará Habermas a atestar a incapacidade do sistema kantiano em dar conta de uma teoria política para o momento histórico de MEEP. Nesse novo contexto, o direito precisa incentivar e institucionalizar também condições para o exercício de liberdades positivas, formando espaços de construção de consensos sobre as relações entre os arbítrios individuais de modo que estes não se autoexcluam mais do que convivam e se reforcem mutuamente.

Essa tarefa também motiva a teoria discursiva do direito de Habermas, que se origina da necessidade de uma "interpretação intersubjetiva" dos processos de formação da vontade política dos cidadãos, de modo que sua consequente institucionalização seja levada a cabo a partir dessa interpretação (Id, 1999:116). Nesta tese será defendido o argumento de que apesar de fundamentar teoricamente essa exigência jurídica (Id, 1996:135), Habermas não a realiza em termos de uma reflexão da filosofia do direito, mas somente numa filosofia política somada a uma teoria social direcionada aos princípios do Estado democrático, que o leva à tese sobre a co-originariedade entre os direitos da autonomia individual e da autonomia política (Id. 1996:135-136; v. capitulo 4, 5.1 e 5.2 deste estudo). Uma teoria intersubjetiva dos direitos subjetivos demandaria, no entanto, revisões de categorias fundamentais de direitos subjetivos por meio de sua correlação com princípios e pretensões de publicidade cujos diagnósticos de violações e afirmações possam induzir novas interpretações sobre seus sentidos originais. ${ }^{121}$

A questão fundamental que permanece desde Kant sobre a distinção entre o ideal e o empírico da publicidade, ou o caráter ao mesmo tempo natural e construtivista de um Estado de direito que derive da moral, mas que precisa efetivar-se como política é posta da mesma forma aos críticos mais diretos de Kant e a Habermas (Id, 1996:137).

$\mathrm{Na}$ forma de uma pergunta, uma moralidade somente construtivista e procedimental, que deverá fornecer para Habermas a base dos princípios do Estado de democrático de direito em Direito e Democracia (Id, 1996:xli-xliii), teria abandonado definitivamente o evolucionismo da filosofia do sujeito de Kant, ou se enredaria numa concepção de opinião pública que colabora somente para a consciência histórica da falibilidade da publicidade, como teria feito a filosofia do direito de Hegel?

${ }^{121}$ Os derradeiros tópicos da tese (2.2 e 2.3) buscarão trazer uma discussão neste sentido, aproveitando-se do diagnóstico do presente da esfera pública política no Brasil (cap. 2). Trata-se de uma reflexão final que visa a contribuir com a busca de Habermas e de seus presentes interlocutores por processos de intersubjetivização do direito. 
No diagnóstico de $M E E P$, a alteração das estruturas da esfera pública política teriam claramente colocado em cheque a capacidade do princípio da publicidade em mediar e equilibrar a distinção entre homem e cidadão, entre esfera da reprodução social e da política, especialmente quando esse princípio se aferra a concepções somente negativas e econômicas da liberdade burguesa. Sem base numa cultura política que atenda às exigências normativas da esfera pública estruturalmente modificada pelas contradições internas dos sistemas de reprodução material e social, o direito tende ao legalismo a que Kant se vê fadado a defender (Habermas, 2003:137-138 e 141-142). Nesse sentido, como se verá mais à frente (1.4), a crítica de Hegel à concepção kantiana de publicidade já levanta uma suspeita contra ao próprio paradigma procedimental do direito desenvolvido por Habermas em Direito e Democracia.

\section{§14. Para a dialética da esfera pública (Hegel e Marx)}

O $\$ 14$ do capítulo trata das críticas de Hegel e Marx à concepção liberal de esfera pública, que partem de um diagnóstico das contradições da sociedade burguesa, incluindo a opinião pública e esfera pública. Dialogando primeiramente com a interessante reflexão da Filosofia do Direito de Hegel sobre esfera pública e opinião pública ${ }^{122}$, Habermas entende que apesar das pretensões de publicidade e justificação determinarem a aceitabilidade universal do direito ${ }^{123}$, a opinião pública encerraria justamente as ambivalências do público burguês. Enquanto possível espaço de formação de uma racionalidade de pretensões normativas que o direito deveria reconhecer, a opinião pública também expressaria a injustiça, o preconceito e o engano ${ }^{124}$ (Habermas, 2003:142-143).

$122 \S \$ 219-229,300-319$ da obra. Aqui utilizadas as versões original (Hegel, W. G. F. Grundlinien der Philosophie des Rechts. Reclam: Stuttgart, 2009), e a tradução para o espanhol (Hegel, W. G. F. Principios de la Filosofia del Derecho o Derecho Natural y Ciencia Política. Trad. Juan Luis Vermal, 1988.

123 "(...) Das Recht der Öffentlichkeit beruht darauf, dass der Zweck des Gerichts das Recht ist, welches als eine Allgemeinheit auch vor die Allgemeinheit gehört; dann aber auch darauf, dass die Bürger die Überzeugung gewinnen, dass wirklich Recht gesprochen wird." (Hegel, 2009:365. Itálicos do autor). [“O direito da publicidade (ou esfera pública, V. B.) depende portanto, que a finalidade do tribunal do direito seja escutada tanto como uma generalidade (Allgemeinheit, que pode ser traduzido também como "público". V. B) quanto para a generalidade (Allgemeinheit); mas também que os burgueses (cidadãos) ganhem o convencimento de que efetivamente o direito foi falado". Tradução livre. negritos nossos].

124 "La opinión pública contiene por tanto en sí los eternos princípios sustanciales de la justicia - el verdadero contenido y el resultado de toda la constitución, de la legislación y de la situación universal - em la forma del sentido común en cuanto fundamento ético que penetra en todo bajo la forma de prejuicios, así como las verdaderas necesidades y tendencias correctas de la realidade. Pero al mismo tiempo así como este elemento interior aparece en la conciencia y llega a la representación en proposiciones universales, en parte para si, en parte al efecto del razonar concreto sobre acontecimientos, ordenanzas y relaciones del Estado y necesidades sentidas, así tambíen se presenta toda la contingencia del opinar, su ignorancia y extravio, su falso conocimiento y juicio.” (\$317, Hegel, 1988:768). 
As grandes desigualdades e divisões da sociedade burguesa, como a que distingue a classe dos proletariados e econômica e legalmente daquele público pensante e leitor, e quanto maiores essas desigualdades entre cidadãos, mais inverificável na prática se torna o pleito de generalidade dos interesses do público de proprietários privados. Nesse contexto, a opinião pública passa a não mais representar, ou fazer jus ao predicado "geral" do interesse da sociedade civil, embora continue como espaço em que seria possível julgar racionalmente questões práticas e políticas, bem como limitar o individualismo. Ainda assim, serviria somente como um "meio de formação para a massa", e "um dos maiores" (do original Bildungsmittel [für der Menge]. Hegel, 2009:470) (Habermas, 2003:144-145).

A pretensão iluminista de que a esfera pública pudesse racionalizar a dominação é abandonada por Hegel e substituída pela concepção de um Estado que interfere nesse processo para elevar ao conceito a capacidade contingente que a opinião pública tem de refletir a opinião subjetiva do Monarca, esta sim, portadora de uma ética substancial por poder traduzir concretamente o espírito do povo. ${ }^{125} \mathrm{O}$ modelo de um Estado reativo que trabalha para estabilizar as contradições inerentes da sociedade burguesa não é visto por Hegel, no entanto, como reflexo de "avanços na sociedade civil", especialmente no sentido de uma subjetividade concreta da opinião pública que exige tal modelo e a sua publicidade (Id. op c cit:146-148). Pelo contrário, segundo Hegel, a concordância da subjetividade do monarca com o espírito do povo não tinha até então ganhado expressão material ou mesmo de direito (Hegel, 2009:478. $\$ 320^{126}$ ).

O jovem Marx já refutará essa constatação, aponta Habermas, pois entende como benéfica a separação entre sociedade civil e Estado, já que o deslocamento do caráter diretamente político das relações sociais "pré-burguesas" para um espaço de liberdade dos agentes econômicos garantida politicamente, significaria uma espécie de libertação da esfera privada. Mas quando esse recém conquistado espaço de liberdade passa a receber a "função política de uma mediação entre Estado e sociedade" - em espaços de legitimação política -, trata-se de uma tentativa de politização reducionista do indivíduo em sua condição privada (Habermas, 2003:148).

\footnotetext{
125 “\$320 'Transición a la próxima subsección: la contingencia de la manifestación raciocinante y la subjetividad del monarca'// La subjetividad, que como disolución de la vida estatal existente tiene su manifestación más exterior en el opinar y raciocinar que quieren hacer valer su contingencia y que precisamente por ello se destruyen, tiene su verdadera realidad en su contrario, la subjetividad en cuanto idéntica con la voluntad sustancial que constituye el concepto del poder del príncipe y que - como idealidad del todo - en lo dicho hasta ahora todavia no há alcanzado su derecho y su existência.” (Hegel, 1988:775).

${ }^{126} \mathrm{~V}$. nota de rodapé 106 , supra.
} 
Citando a obra trabalhos reunidos de Marx e Engels ${ }^{127}$, Habermas demonstra como o primeiro denuncia a opinião pública como forma de ocultamento do interesse particular da classe burguesa sob a roupagem das pretensões de igualdade formal entre os indivíduos economicamente diferenciados. Ou seja, ela desconsidera a ausência de condições sociais para que a esfera pública pudesse transcender sua configuração burguesa. A extração da mais-valia, as desigualdades materiais entre assalariados e um mercado cada vez mais oligopolizado que regula politicamente os preços, faz com que a sociedade civil emancipada de uma legitimação diretamente política não possa racionalizar o poder como propõe a doutrina kantiana da publicidade; a institucionalização das relações sociais capitalistas leva, ao contrário, a novas formas de dominação oculta entre indivíduos em condições materiais desiguais (Id. op. cit:149-150).

Descrições sobre as pressões sociais na Inglaterra de 1830 por reformas eleitorais e pelo sufrágio universal na França são descritas por Marx como pretensões de maior acesso à esfera pública política. Estas se contrapõem a tendências de aumento dos recursos de oratória que fazem menção à "decisão da maioria" ou à "opinião popular" nos parlamentos, especialmente porque as grandes maiorias se encontram fora dos espaços de decisão política. A partir desse contexto de reformas eleitorais, Marx formula a tese de que essa ampliação da esfera pública pela entrada e participação dos "não-proprietários" seria eliminar a diferenciação entre sociedade civil e Estado e, portanto, a forma mesma de ambos os elementos, já que um seria o oposto do outro. Indícios da mudança estrutural da esfera pública, como a problematização e posterior regulação da esfera privada da reprodução social outrora emancipada da política, são levados ao extremo com a proposta de que a universalização do acesso à esfera pública levaria à substituição da "sociedade civil burguesa fictícia" (fiktiven bürgerlichen Geselschaft) pela "sociedade real" (wirkliche Gesellschaft) ${ }^{128}$, na qual a "autoridade política" se transforma em uma autoridade efetivamente “pública” (do original ‘öffentliche', Habermas, 1990:207) (Id, 2003:152154).

\footnotetext{
${ }^{127}$ Marx \& Engels. Ges. Werke. Berlin, 1958. apud. Habermas, 2003:322.

${ }^{128}$ Nota-se outro erro na tradução brasileira de $M E E P$, quando se inverte os elementos desta substituição dentro da própria citação de Marx. A frase “"die die wirkliche Gesellschaft der fiktiven bürgerlichen Gesellschaft der gesetzbebenden Gewalt substituiren will"” (Marx \& Engels, op. cit:325, apud. Habermas, 1990) é traduzida como "que quer substituir a sociedade real pela sociedade civil burguesa fictícia, aquela do poder legislativo" (Habermas, 2003:153). Uma tradução mais precisa seria: "que quer a sociedade real substituir a sociedade civil burguesa fictícia, aquela do poder legislativo".
} 
Habermas interpreta essa reflexão de Marx como a proposta de um "antimodelo socialista" da esfera pública burguesa. A semelhança com a teoria política de Rousseau é clara, na medida em que propõe não só a necessidade de uma fundamentação pública da autonomia privada do ser humano, em contraposição à propriedade privada como sua base, mas também que a definição desta autonomia se dê a partir do papel exercido pelo “citoyen”. Com essa inversão, o caráter originalmente público e coletivamente controlado da autonomia individual determinaria a sua extensão. Mais do que um mero jogo de palavras, na leitura de Habermas, Marx defende que "As pessoas privadas serão antes pessoas privadas de um público do que o público será um público de pessoas privadas."129

Dessa "sociedade real" que precisa se fundamentar e se controlar publicamente, a política se transformaria em mera questão "administrativa", e a reprodução social poderia finalmente atingir uma almejada autonomia ao viver privadamente sem as coerções do trabalho social. Essa esfera diminuta da liberdade privada, no entanto, não poderia ser assunto da sociedade, e menos ainda objeto de legislação (Id. op. cit:154-155).

Contra essa proposta de esfera pública socialista que, apesar da crítica precisa às promessas não realizadas da esfera pública burguesa, parece levar aos perigos da abordagem rousseauniana como desdobramentos normativos (v. acima), Habermas finaliza o capítulo discutindo as reflexões do filósofo e economista inglês John Stuart Mill e do teórico político francês Alexis de Tocqueville sobre as ambivalências do modelo liberal de esfera pública.

\section{\$15 A ambivalente concepção de esfera pública na teoria do liberalismo}

Embora não chegassem a uma crítica estrutural das condições sociais para a realização de uma "soberania da opinião pública", os defensores do modelo liberal conseguiriam questionar melhor que o modelo socialista os fundamentos normativos da esfera pública presente em ambas as concepções, quais sejam, a possibilidade de uma racionalização da dominação e a garantia de uma esfera privada autônoma em relação à política e ao "reino das necessidades" (Id. op. cit:155-156).

Já que a dialética socialista da esfera pública não havia se realizado plenamente, e a consagração dos direitos sociais e a orientação cada vez mais intervencionista do Estado na economia eram provas disso, os teóricos liberais passam a problematizar a tal "base

\footnotetext{
${ }^{129}$ Do original "Die Privatleute werden eher Privatleute eines Publikums sein als das Publikum eines von Privatleuten.” (Habermas, 1990:208).
} 
natural" sobre a qual deveria erigir-se a esfera pública. A partir de uma perspectiva mais "construtivista" 130 passa-se a discutir de que modo seria possível a racionalização do poder e a proteção da esfera da autonomia privada (Id. op. cit:155-157).

Se no curto período de consolidação da Revolução Francesa e no movimento cartista na Inglaterra era possível identificar um "público" relativamente afeito a realizar discussões públicas em busca de uma racionalidade mais argumentativa do que orientada por afetos, amizades ou representações de papéis sociais, numa esfera pública ampliada pela industrialização da imprensa e profissionalização da propaganda, as demandas de regulação da reprodução social levam a uma nova efervescência política que se traduz, no entanto, em espaços de discussão marcados pela busca de satisfação de interesses privados concorrentes $^{131}$ (Id. op. cit:157-158).

Isso porque quanto mais intensas as pressões sociais de grupos anteriormente excluídos da esfera pública para acessá-la, como nos movimentos por reformas eleitorais do século XIX, maiores as dificuldades dos órgãos do Estado de transformá-las debates orientados pela publicidade e pelo melhor argumento. Os argumentos se tornam, ao contrário, motivos de coerção da "opinião dominante" sobre as outras. A opinião pública é apropriada pelas pretensões da maioria e deixa de ser princípio de racionalização capaz de provocar sua própria “autotematização" (Id. op. cit:158-159).

Em On Liberty, original de 1859, Mill alerta para essa espécie de subversão do princípio da opinião pública, que passa a representar as massas mais do que a pretensão de racionalização do poder. E do mesmo modo Tocqueville demonstra como a esfera pública colabora mais para uma conformação geral com a opinião dominante do que como força de crítica à própria dominação. É a partir dessas reflexões que a tese do "despotismo da maioria", que oprime a possibilidade de opiniões e pretensões individuais é formulada. Se a opinião pública representaria somente a opinião da maioria, ela deveria também ter

\footnotetext{
${ }^{130}$ Para um exemplo de construtivismo moral, que remete à Rawls e à tradição Anglo-saxônica derivada de Kant, com foco numa teoria moral da justiça, v. Rainer Forst, Das Recht auf Rechtfertigung, 2007:23-188. Esta obra e o pensamento de Forst serão discutidos nos tópicos 2.1, 2.2. e no capítulo 3 desta tese.

${ }^{131}$ Essa passagem mostra sinais daquilo que Habermas denominará ação estratégica em The Theory of Communicative Action, forma de ação cuja racionalidade é teleológica, orientada por princípios éticos de validade universal (Habermas, 2006:57-60) acessíveis ao indivíduo, como em Kant e Weber, mas que busca somente o sucesso pessoal do agente (Id, 1984-I:86-88). Como se verá mais à frente, em Direito $e$ Democracia, depois de revisões da teoria da razão comunicativa (Id, Verdad y Justificación, pp.99-131), a ação estratégica passará a ser assumida por Habermas como capaz de gerar acordos dotados de racionalidade, porque firmados na base de entendimentos comuns quanto a planos de ação (Id, 1996:cap. 5). No entanto a ação orientada somente para o sucesso coloca não só os atores, mas também os teóricos numa posição de objetificação do outro, o que traria riscos à integração de sociedades democráticas, que vivem sob a administração de um alto grau de dissenso (Id, 1996:caps. 1 e 7). V. tópico 3.1 desta tese.
} 
condições de ser limitada tanto quanto pretende limitar a ação do Estado sobre a reprodução social e a condução da máquina administrativa. (Id. op. cit:159-160 e 165).

Sob a denominação de um princípio de "não concordância" ou de "tolerância" da opinião pública em relação a opiniões individuais, especialmente em casos de liberdade de expressão e pensamento, Mill e Tocqueville chegam à importante reflexão sobre o que presentemente Habermas considera, em diálogo com Klaus Günther, o conceito de liberdade comunicativa ${ }^{132}$ : em última instância, a possibilidade de se dizer "não", tomada como fundamental tanto para a realização de procedimentos deliberativos democráticos quanto em outras instâncias de discussão pública que pretendem garantir liberdades fundamentais de comunicação ${ }^{133}$ (Id. op. cit:161).

A defesa de uma opinião pública que constituísse um poder capaz de não suprimir todos os demais, atuando contra sua tendência à massificação e à homogeneização, tem por trás de si não só pleito em favor das liberdades individuais, mas também a salvaguarda do princípio da racionalização da dominação para além de uma composição de interesses conflitantes. $\mathrm{O}$ conceito de tolerância apregoado por Mill ${ }^{134}$ é utilizado para suscitar este debate, que será objeto dos diversos textos e obras posteriores de Habermas dedicados à crítica da razão, à formulação de seu conceito de racionalidade comunicativa e da teoria do discurso $^{135}$. A opinião pública reduzida somente à limitação do poder impede a percepção da necessidade de fundamentação de um interesse geral de consenso ou concordância de fundo, sobre o qual os interesses conflitantes podem se sustentar como sendo possivelmente racionais, e não meros produtos de crença ou ideologia (Id. op. cit:161-162).

\footnotetext{
${ }^{132}$ V. Günther, 1998 e 2005 e Habermas, 1996:cap. .3. Este conceito será retomado e discutido de modo aprofundado no tópico 2.2 e no terceiro capítulo desta tese.

133 "In respect to all persons whose pecuniary circumstances make them independent of the good will of other people, opinion, on this subject, is as efficacious as law; men might as well be imprisoned, as excluded from the means of earning their bread. Those whose bread is already secure, and who desire no favours from men in power, or from bodies of men, or from the public, have nothing to fear from the open avowal of any opinions, but to be ill-thought of and ill-spoken of, and this it ought not to require a very heroic mould to enable them to bear. There is no room for any appeal ad misericordiam in behalf of such persons. But though we do not now inflict so much evil on those who think differently from us, as it was formerly our custom to do, it may be that we do ourselves as much evil as ever by our treatment of them." Mill, On Liberty, 2009, pp. 94.

${ }^{134}$ Habermas haverá de retomar esse conceito muito tempo depois em Entre Naturalismo e Religião (2005), mas a partir da mesma base histórica da tolerância religiosa trabalhada por Mill para pensar os conflitos de opinião na esfera pública. No caso, Habermas pensará como esse conceito influencia os direitos culturais. Essa importante reflexão, que sinaliza ampliações da própria teoria política e do direito de Habermas, serão retomadas nos tópicos 1.4, 2.3 e no terceiro capítulo deste estudo.

${ }^{135}$ V. para tanto, Habermas, O Discurso Filosófico da Modernidade (2002); Id, On the Pragmatics of Social Interaction (2001); Id, The Theory of Communicative Action (1984-I); Id, Racionalidade e Comunicação (1996); Id, Consciência Moral e Agir Comunicativo (1989). Para uma leitura tematização sistemática sobre o desenvolvimento do conceito de razão comunicativa de Habermas e os debates que travou nesse percurso, v. Blotta, Habermas e o Direito (2010).
} 
É por essa incapacidade de fundamentar sem uma base metafísica o interesse geral pressuposto nos conflitos de interesses particulares que Habermas considerará os teóricos liberais como os primeiros a demonstrar o dualismo do Estado de direito burguês: ele precisa garantir o pluralismo de interesses privados e ao mesmo tempo a base democrática sobre a qual esses interesses possam aceitos como legítimos por todos os concernidos ${ }^{136}$ (Id. op. cit:162-163).

A saída de Mill e de Tocqueville para este problema é o Representative Government, cujos membros reduzidos e bem informados teriam condições de elevar as pretensões das massas a teses argumentativas capazes de convencer sem seduzir ou impedir a crítica. Trata-se da formação de uma "classe" diferenciada de pessoas e instituições capazes de realizar esta tarefa, como na esfera pública representativa o faria os nobres e aristocratas. Os representantes e intermediários das massas constituiriam uma elite a determinar a opinião pública, oferecendo-lhe mais exigências de publicidade na medida em que uma opinião minoritária pudesse se tornar majoritária.

O que diferencia os posicionamentos de Mill e Tocqueville é que aquela pensa na representação política mais centrada na qualidade e nos talentos pessoais dos representantes que argumentam e contra argumentam numa esfera pública sem classes, enquanto que Tocqueville defende a criação de instituições estatais intermediárias capazes de realizar essa representação. Mas apesar dessa visão de certo modo mais elitista de opinião pública em Mill, Habermas ressalta que o inglês teria ido além de Tocqueville ao pensar não somente nos perigos de um "despotismo da opinião pública", mas na necessidade de exigir mais publicidade também de um "fenômeno complementar": o "despotismo de um Estado cada vez mais burocratizado", ou para Habermas, uma “juridificação do mundo da vida" (Id. op. cit:165).

Como já visto em "b", contra essa tendência dupla acabam se centrando as propostas de Habermas do capítulo VI de MEEP por maiores condições de supervisão e exigências de publicidade tanto ao Estado quanto às organizações privadas que atuam em

\footnotetext{
${ }^{136}$ Como se sabe, esse dualismo será reinterpretado por Habermas na forma de uma co-originariedade entre a autonomia individual e a autonomia política dos cidadãos, pressupostos estes que seriam as bases do Estado democrático de direito. Essa é uma das teses mais importantes da teoria do direito de Habermas, e como se verá aqui, será abordada constantemente e de várias maneiras em Direito e Democracia (v. especialmente tópicos 2.2 e 3.2)
} 
espaços públicos e exercem influência sobre eles, às vezes ao ponto de "fabricar" a opinião pública (Id. op. cit:268-269) (v. "b" acima). ${ }^{137}$

Mill também alerta para que essa burocratização do Estado não se torne uma juridificação de espaços antes garantidos à liberdade individual, o que levaria a um paternalismo do Estado que mantém os indivíduos numa condição de "infância cívica", algo próximo à minoridade kantiana, ou em caso extremo ao totalitarismo de esquerda. Mas optar pela alternativa de Marx, com a proposta de realização da esfera pública socialista pela dissolução da máquina burocrática do Estado e do parlamento num sistema de conselhos que julga somente coisas e processos produtivos a partir das leis da economia política, seria ainda incorrer numa concepção de uma ordem natural sem distorções e alienações, representada na imagem da "comuna".

\section{Cap. VII. Para o conceito de Opinião Pública}

Habermas acaba por concluir que nem o modelo liberal ou o social de esfera pública seriam capazes de assegurar ao mesmo tempo o princípio da publicidade crítica e a inviolabilidade da esfera privada. Diante de espaços públicos ampliados pela invasão da esfera pública no setor privado e uma gradativa privatização dos espaços sociais e institucionais de comunicação pública, ambas as perspectivas teórico-normativas só seriam capazes de revelar parcialmente essas tendências ${ }^{138}$ como contradições inevitáveis de uma esfera pública cujas expectativas normativas são proteger a privacidade e ao mesmo tempo politizar a publicidade, isto é, um modelo que pretende assegurar a autonomia individual tanto quanto a autonomia política de todos os cidadãos do Estado (Habermas, 2003:167$168)$.

Talvez não seja por outras razões que no último esforço teórico da obra, o derradeiro capítulo VII "Para o conceito de opinião pública", Habermas procura descrever o que entende como uma autonomização da opinião pública em relação à política e às teorias normativas da sociedade, e sua limitação a estudos empíricos de psicologia social, ciência política e ciência da administração em meados do século XX (Id. op. cit::274-279).

\footnotetext{
${ }^{137}$ De modo semelhante, como se verá a partir do capítulo dois desta tese, um novo diagnóstico destas tendências na presente esfera pública política brasileira deverá levar à necessidade se pensar na proposta teórica e normativa de um duplo movimento institucional do direito da comunicação (v. tópico 9.1).

138 "Mas nem o modelo liberal nem o modelo socialista são adequados para o diagnóstico de uma dimensão pública que, de modo peculiar, flutua entre ambas as constelações estilizadas no modelo. Duas tendêncas, dialeticamente interrelacionadas, assinalam uma decadência da dimensão pública: ela penetra esferas cada vez mais extensas da sociedade e, ao mesmo tempo, perde sua função política, ou seja, submeter os fatos tornados públicos ao controle de um público crítico.” (Habermas, 2003:167)
} 
Posicionando-se contrariamente a esses estudos, Habermas indica no início do §24 que a publicidade crítica e a publicidade manipulativo-demonstrativa ${ }^{139}$ coexistem na formação da opinião pública. A coexistência não significa, por um lado, que estariam respectivamente numa condição de "norma e fato", pois ambas tendências ocorrem simultaneamente e precisariam ser cautelosamente distiguidas em diagnósticos da esfera pública, já que indicam perspectivas de comportamentos alternativos dos públicos. A distinção entre opinião pública (öffentliche Meinung) e opinião não-pública (nichtöffentliche Meinung) trabalhada no capítulo VI (v. "b" acima) seria um indicativo para se buscar fazer essa distinção (Id. op. cit::274-275).

Além disso, como a publicidade não deixa de ser norma constitucional e fundamento de legitimação da ordem democrática, que exige a devida "abertura" ações políticas e da organização estatal para o escrutínio de um público crítico da qual é destinatário, e por isso poder transcender a publicidade factual servindo como seu critério normativo, Habermas entende que ela deveria ser analisada nos "setores" (Bereichen) específicos nos quais é exigida, junto ao "volume"141 e às condições dos públicos neles presentes (Id. op. cit::275).

Somente a partir de então seria possível mensurar o nível de legitimidade do poder vigente sem perder o potencial democrático que é dado pela ficção constitucional da opinião pública, isto é, pelo fato de haver a previsão jurídica constitucional da soberania popular como mandatária da legitimidade do poder ${ }^{142}$, mas de ela carecer de verificabilidade e possibilidade de aplicação institucional concreta, especialmente para a visão mais liberal, que mais alerta sobre a possibilidade de manipulação da publicidade do que em relação à sua função de constituir espaço de uso público da razão e de racionalização da dominação (Id. op. cit:275-276).

Essa falta de aplicação institucional se justificaria pela impossibilidade de mensuração científica da opinião pública, o que mostra uma conexão clara desse problema

\footnotetext{
${ }^{139}$ Neste momento, Habermas utiliza o term Publizität ao invés de Öffentlichkeit.

${ }^{140}$ Do alemão Öffentlichung, derivada de öffen, do adjetivo "aberto" ou do verbo "abrir", da qual se deriva Öffentlichkeit.

${ }_{141}$ Do alemão Umfang, traduzido também como "envergadura" ou "extensão". V. Langescheidt. Taschenwörterbuch. Portugiesisch. Belim/Munique, 2001, p. 1123.

142 “Opiniões não-públicas funcionam em grande número e 'a' opinião pública é, de fato, uma ficção; mesmo assim, é preciso fixar-se no conceito de opinião pública num sentido comparativo, pois a realidade constitucional da social-democracia precisa ser entendida como um processo em cujo transcurso uma esfera pública politicamente ativa passa a ser tornada real, ou seja, passa a ser efetivamente subordinada ao mandamento democrático de ser público [demokratischen Öffentlichkeitsgebot, que pode também ser traduzido como "mandamento democrático de publicidade". V. B] todo o exercício do poder social [Soziale Gewalt] e de dominação política [politische Herrschaft]." (Habermas, 2003:283-284. Itálicos nossos. Termos em alemão do original. Id. 1990:353).
} 
jurídico-político com o positivismo dos estudos empírico-nomológicos da psicologia social ou dos trabalhos de sociologia institucional na ciência política que Habermas indica surgirem no pensamento científico de então (Id. op. cit:276-278) .

Apesar de todas as críticas que receberá quanto a não menção de diversos públicos periféricos (da esfera pública "plebéia" à esfera pública "proletária") ${ }^{143}$, a recepção por Habermas da crítica socialista à esfera pública está posta: ela deve somar à exigência de uma publicidade crítica uma pretensão de generalidade (Allgemeinheit), isto é, deve abstrair-se de determinados papéis sociais e institucionais que representariam os públicos privilegiados a produzir uma opinião pública bem informada e combativa a partir da garantia de "acessibilidade universal" (allgemeine Zugänglichkeit), especialmente em relação às esferas do "intercâmbio de mercadorias e do trabalho social" (Id. op. cit:276277. Termos em alemão do original $I d$. 2003:346).

À tendência de redução científica ${ }^{144}$ da opinião pública a um conjunto de opiniões individualizadas ou de opiniões de grupos determinados, provocadas pelo ceticismo liberal que visa frear o "absolutismo da maioria" - agora uma massa que toma a opinião pública como "lugar-comum" naturalizado - são contrapostas visões mais institucionalizantes do conceito, o que leva a se apostar nas posições dos partidos como sendo representantes da opinião pública (278-280). Mas enquanto ambas as abordagens deixarem de pensá-la a partir de critérios normativos a orientar o debate público, as liberdades de comunicação e a práxis política, a opinião pública continuará a se identificar mais com o poder do que com a racionalização de suas expressões social e política (Id. op. cit::282-283).

É por isso que no último parágrafo da obra (\$25) Habermas deposita suas esperanças em estudos comparativos dos níveis de abertura dos fluxos comunicativos entre o que ele chamará esferas públicas informais, mais periféricas que compõem as massas de indivíduos privados, que evoluem em organização nas entidades associativas públicas e privadas de representação de interesses, como as próprias mídias de massa, partidos políticos, empresas, fundações e ONGs, e as esferas públicas formais como os

\footnotetext{
${ }^{143}$ Essas críticas à MEEP, como a feita também por Oskar Negt em Öffentlichkeit und Erfahrung, orginal de 1972 [Public Sphere and Experience, 1993], Habermas responde em Further Reflections on the Public Sphere (Habermas 1992a:425-427. In Calhoun (ed). V. tópico. 1.4 em seguida.

144 “Se uma vez o sujeito da opinião pública - neste ponto a expressão de uma mudança estrutural e não só o seu conceito - estiver reduzido a uma grandeza neutra em relação à diferença entre esfera pública e esfera privada, ou seja, o grupo, e se a própria opinião pública estiver dissolvida numa relação grupal neutra frente à diferença entre comunicação racional e conformismo irracional, então também a relação entre as opiniões grupais e poder público só pode ser ainda articulada no âmbito de uma ciência auxiliar da Administração" (Habermas, 2003:282. Itálicos nossos). Essa constatação de Habermas terá clara conexão com os estudos sobre teorias de sociologia empírica da legitimidade do direito, cuja única função do termo legitimidade seria medir a "estabilidade" do poder político (v. Habermas 1996:caps 1 e 7).
} 
parlamentos, congressos e outros poderes estatais das democracias ocidentais (Id. op. cit:283-288).

Mais detidamente, as esferas públicas informais seriam compostas por três níveis de comunicação que muito claramente se assemelham à comunicação não questionada e recheada de conhecimento de fundo mutuamente compartilhado que Habermas denominará mundo da vida (Lebenswelt) em The Theory of Communicative Action: primeiramente a comunicação envolvida por certezas culturais e morais não problematizadas; em seguida as experiências biográficas que levam a opiniões individuais sobre temas comuns; e por fim a comunicação formada pela indústria cultural, que mobiliza desejos inconscientes de consumo cultural por imperativos mercadológicos. As opiniões dessa esfera pública informal são consideradas opiniões não públicas, porque confirmadas pela coerção cultural de familiares e grupos sociais, e transmitidas por "clichês culturais". Seriam meras opinions individualizadas ou formatadas pela indústria cultural de um "pseudo público", que não mais constituem expressões públicas da formação de personalidades individuais, como teriam feito os burgueses nas produções literárias das esferas públicas do século XVIII.

De outro lado, seguindo as teorias institucionais da esfera pública estariam as esferas públicas formais, produtoras de uma opinião “quase pública”. Seria a comunicação realizada por instituições reconhecidas, que circula anúncios, informações, explicações e opiniões, como a imprensa política, o jornalismo informativo e órgãos públicos e privados que exercem relevantes funções públicas. Essa opinião não atinge uma publicidade crítica justamente porque, apesar de ter potencial de difusão na massa, suas aberturas para transparência e crítica profissionalizam-se e se tornam informações privilegiadas, desconectando-se da massa informal de concernidos das esferas públicas informais.

A mediação mais frequente entre ambos os setores informal e formal da esfera pública seria aquela desempenhada pelos meios de comunicação de massa, cujas condições de mediatização seriam predominantemente objeto de interesses de grupos, corporações e instituições mais influentes de cada âmbito. Ainda haveria uma certa resistência do exercício de uma publicidade crítica (do original "kritische Publicizität". Habermas, 1990:357) e indivíduos que buscam formar suas opiniões a partir de processos de individuação pela socialização provindos do que restaria da esfera pública literária, mas mesmo assim, suas opiniões tanto quanto as opiniões circulando nos meios de comunicação de massa não seriam propriamente públicas, somente opiniões publicadas, ou "publicamente manifestas" (“öffentlich-manifestierten Meuinungen”. Id, Ibid). 
Como Habermas destacou no final do capítulo VI, no entanto, a possibilidade de contrapor-se a uma formação somente manipulativo-informativa da opinião pública se daria somente quando um processo de "publicidade crítica" pudesse ser iniciado internamente às organizações da esfera pública informal, isto é, em conexão discursiva das opiniões de indivíduos que compõem as massas de representados com aquelas publicadas pelas organizações sociais, e fosse capaz de ser recepcionada externamente pelas formações da opinião nas esferas públicas formais por meio da comunicação de massa que, como organização social também deve se submete internamente a esse princípio de publicidade crítica (Id. 2003:288).

É evidente neste momento a tentativa de Habermas de abstrair dos diferentes públicos, então já denominados setores da esfera pública, as diversas instâncias de formação de opinião como forma de produzir uma circulação mais livre da comunicação. Essa abstração se procurará aprofundar no capítulo 4 deste estudo, na discussão do método do diagnóstico da esfera pública política brasileira a ser aplicado no segundo capítulo. $\mathrm{O}$ critério mais objetivo até então sugerido pelo autor para se fazer a medição da publicidade de uma opinião pública é o que ele destaca em seguida:

“O grau de caráter público de uma opinião pode ser medido pelo seguinte: até que ponto esta provém da esfera pública interna à organização de um público constituído por associados e até que ponto a esfera pública interna à organização se comunica com uma esfera pública externa que se constitui no "intercâmbio jornalístico-publicitário através dos mídias (publizistischen Verkher über die Massenmedien [Id, 1990:358], possivelmente traduzido também por "tráfego publicístico sobre os mídia de massa". itálico nosso) e entre organizações sociais e instituições estatais." (Habermas, 2003, p. 288).

O que o leitor fica sem saber na reflexão final de Habermas, no entanto, é se realmente não existiria mais possibilidade de uma comunicação livre entre essas esferas públicas, ou se são os próprios modelos teóricos de apreensão que estão prejudicando sua mensuração de forma mais precisa, a ponto dela não mais influenciar tanto a política quanto a crença numa autoridade moral da opinião pública.

De todo modo, se a intermediação das opiniões não-públicas e quase-públicas entre esferas públicas formais e informais por uma publicidade crítica não é possível sem a garantia constitucional de uma esfera pública politicamente ativa entre ambas as esferas, mediatizada especialmente pela imprensa e pelos meios de comunicação de massa, ao menos já seria possível analisar em diagnósticos desses meios, de outras organizações ou 
do Estado, violações dessa publicidade na forma de expressões negativas de exigências de legitimidade do poder em democracias de massa (Id. op. cit:288-290).

\section{Uma breve história da esfera pública política no Brasil}

Após essa longa revisão analítica da obra Mudança Estrutural da Esfera Pública, este capítulo parte para a tentativa de uma breve historicização da esfera pública política no Brasil. A abordagem é ainda inspirada na de MEEP, isto é, busca caracterizar os diversos públicos e suas inter-relações, bem como suas funções sociais e políticas em determinados períodos históricos de sociedades modernas.

A investida parte de algumas obras escolhidas para essa historicização que dialogam diretamente com clássicos do pensamento brasileiro, como Gilberto Freyre, Sérgio Buarque de Holanda, Caio Prado Júnior, Celso Furtado, entre outros. A proposta é tentar identificar e compreender a formação, a existência de fato e as características da esfera pública política no Brasil.

a) o surgimento de espaços públicos rudimentares na problematização do Brasil colonialimperial

Uma recente obra publicada pela editora do Arquivo Nacional pode ser interessante para se retratar a origem de uma esfera pública política no Brasil. É o caso de Imprensa e poder na corte joanina (2008), resultado da tese de doutorado de Juliana Gesuelli Meirelles, defendida em 2007 no Instituto de Filosofia e Ciências Humanas da Unicamp, e eleita primeiro lugar no prêmio Dom João VI de Pesquisa, organizado pela Universidade Federal do Estado Rio de Janeiro em 2007.

$\mathrm{Na}$ obra, a autora historia o surgimento da Gazeta do Rio de Janeiro, o primeiro jornal impresso institucional do Brasil, que circulou entre 1808 e 1821, período em que D. João VI residiu na cidade, influenciando não só na consolidação de uma estratégia de poder da corte sobre a colônia, mas também na formação de um primeiro público leitor crítico que passava a se representar politicamente na circulação de palavras impressas nesse jornal e em outros, como o Correio Braziliense, que não compartilhava da opinião dominante da coroa no Brasil (Meirelles, 2008:235-238). 
Meirelles destaca que apesar de a Gazeta do Rio de Janeiro refletir majoritariamente a opinião oficial, em muitos momentos abriu espaço para debates referentes a problemas comuns da sociedade, além de já apregoar a imparcialidade na produção de notícias e pluralidade de fontes como critérios de qualidade da informação. A participação gradativa de leitores em seções do jornal permitiu uma publicização de debates envolvendo direitos relativos a problemas privados, anteriormente circunscritos só a espaços institucionalizados como fóruns judiciais (Id. op. cit:236).

Isso demonstra como a institucionalização da imprensa escrita no Brasil pode representar a origem da esfera pública política no país, quando espaços de discussão formados pela imprensa tornam possível a circulação de informações e pretensões normativas entre espaços públicos formais e não formais cada vez mais abertos à crítica. Mas esse processo não ocorreu de modo pacífico no Brasil. Segundo Meireles, com base em estudos de Lúcia Maria das Neves ${ }^{145}$, é a Revolução do Porto, de 1820 que continha as primeiras reivindicações por liberdade de imprensa e fim de censura no país, sendo por isso responsável pela formação de uma primeira "esfera pública de poder" nacional (Id. op. cit:24).

A obra Mudança Estrutural é citada em Imprensa e Poder na corte joanina para retratar a ampliação da esfera pública gerada pela transformação das notícias em mercadoria, já em torno de 1820. Nesse momento, a autora descreve a seção "Avisos" da Gazeta do Rio de Janeiro como um espaço já compreendido pelos leitores onde seria possível a narração e a legitimação pública de interesses privados. ${ }^{146}$

É de se notar também que as interessantes descobertas de Meireles abordam a formação de uma opinião pública no final do período colonial no Brasil por meio da caracterização dos públicos de participantes e leitores que debatiam em seus espaços, método também realizado em MEEP por Habermas. São tratados tanto os papéis dos redatores da Gazeta, desde sua fundação em 1808 até sua mudança em 1821 com a demissão do redator régio, bem suas relações com outros jornais e com os públicos leitores

\footnotetext{
${ }^{145}$ Meireles cita a obra de Neves, L. "Um silêncio perverso: censura, repressão e esboço de uma primeira esfera pública de poder (1820-1823)". In. : tucci, Maria Carneiro (org.) Minorias silenciadas: história da censura no Brasil. São Paulo: Edusp, 2002.

${ }^{146}$ Meireles fala num "poder de pulverização" das notícias, ao circularem como produtos nas cidades: "A imprensa mediava essas questões e passava também a ser compreendida pela sociedade como uma arena de debates capaz de legitimar as ações da vida privada, antes restritas senão à esfera do lar e da família, apenas ao mundo jurídico. Quanto ao público, este começava a acompanhar tais querelas, tornando-se um personagem importante na defesa ou ataque de certas causas. Neste sentido, notamos que a "opinião do público' já começava a ser validada pela própria 'ação' e 'iniciativa' dos leitores da Gazeta que, na posição de narradores de suas próprias histórias, contavam os fatos da maneira que lhes interessava." Meirelles, 2009:165-166.
} 
que vão se formando em torno de seu espaço, seja para facilitar negócios mercantis, seja para manifestarem-se publicamente como pessoas privadas sobre temas comuns (Id. op. cit:209-210).

Apesar de ficar evidente traços embrionários de uma esfera pública política, especialmente por sua mediação pela institucionalização da imprensa no Brasil de D. João VI, a pergunta sobre a existência de uma esfera pública política no Brasil perdura em estudos filosóficos e mais científicos nacionais sobre comunicação, democracia e esfera pública. ${ }^{147}$ A tese de doutoramento de Adrián Gurza Lavalle intitulada Espaço e vida públicos: reflexões teóricas e sobre o pensamento brasileiro defendida em 2001 na Faculdade de Filosofia da USP discute as teorias nacionais sobre espaço público, e propõe a necessidade de se pensar a esfera pública no Brasil mais em termos de "vida pública" do que em espaço público, em função do último se tratar de fenômeno mais complexo de se identificar no Brasil, com seus característicos entrelaçamentos entre religião, política, economia e cultura representativos de seu processo de modernização ${ }^{148}$ (Lavalle, 2001:18).

A cultura política, ou como denomina Lavalle a partir de Sérgio Burque de Holanda e Gilberto Freyre, o "ethos público" da identidade nacional brasileira teria sido gerado como um antimodelo do espaço público como aquele que se origina na Europa do século XVII a partir de uma emancipação de indivíduos privados em relação ao poder político e à satisfação das necessidades imediatas, que passavam a expressar sua condição e a problematizar a organização do poder social e político. O Brasil derivado da Colônia era aquele que privilegiava o pratriarcado sobre a cidadania, das relações familiares em oposição à vida social, da privatização ao invés da publicização, dos valores tradicionais em oposição à razão argumentativa. Em suma, a formação da identidade dos espaços públicos políticos nacionais teria sido marcada pelos traços do ruralismo, do tradicionalismo, e de uma "sociabilidade familística" e, portanto, "pré-política". ${ }^{149}$

\footnotetext{
${ }^{147}$ V. Bittar, O Direito na Pós-Modernidade. Reflexões frankfurtianas, 2009:471-479; Avritzer, Cultura Política, Atores Sociais e Democratização. Uma crítica às teorias da transição para a democracia. 1995; Lavalle, 2002.

148 “A "tardia" edificação do Estado e o vigor dos poderes regionais a obstarem o processo de centralização política levantam sérias dificuldades para se pensar na origem do espaço público no país, se levado em consideração o pressuposto da consolidação do Estado nacional. A isso é preciso aunar as formidáveis tensões e defasagens entre as questões nacional e do Estado: a continuidade da estrutura econômica colonial e, por conseguinte, do regime de trabalho compulsório, põem em xeque o caráter vinculante das instituições políticas ao longo do século XIX e apontam para o conflito entre as tarefas da integração social - nação - e os imperativos do ordenamento político estável - Estado.” (Lavalle, 2001:110)

149 "A reflexão de Buarque de Holanda é mais eloqüente ao esmiuçar as seqüelas indesejáveis acarretadas pelo "predomínio esmagador do ruralismo". Esse predomínio instaurou o império do Brasil tradicional, ou seja, patriarcal, sobre o Brasil racional ou urbano; do espírito de facção sobre o interesse geral; da visão regional e limitadamente paroquial sobre a compreensão citadina e cosmopolita das coisas; do corpóreo e
} 
O conceito de "vida pública" utilizado por Lavalle para explicar a formação do espaço público brasileiro se assemelha a uma expressão da "publicidade representativa" da Idade Média, como retratada por Habermas nos capítulos I e II de MEEP. (Habermas, 2003:13-74 v. capítulo 2 deste estudo), o que leva Lavalle a avaliar com um aparente ceticismo as novas formas se teorizar os movimentos de associativismo do final do século XX no Brasil, como a noção de "nova sociedade civil" (Id. op. cit:253-257), visto que poderia excluir de sua concepção novamente formas de particularismo ainda arraigadas nessas novas configurações da vida pública nacional (Id. op. cit:321-323). ${ }^{150}$

No movimento de revisão das tradições herdadas dos diagnósticos de Buarque de Holanda e Gilberto Freyre para a caracterização das origens de uma esfera pública politicamente ativa no Brasil, a grande obra coletiva de quatro volumes História da Vida Privada no Brasil, organizada pelo historiador Fernando Novais (Companhia das Letras, publicados entre 1997 e 1998), representa talvez um dos maiores e mais importantes esforços historiográficos desde então para se discutir o problema. A obra $M E E P$ é citada em praticamente todos os volumes, e inspira teórica e historicamente diversos textos. ${ }^{151} \mathrm{~A}$ partir de uma breve passagem por alguns dos estudos contidos nos dois volumes primeiros, alguns fatos e análises parecem particularmente interessantes para essa breve tentativa de historicização da esfera pública política no Brasil do período colonial imperial.

No que se refere ao surgimento de espaços públicos a partir do questionamento das formas de dominação colonial do início do século XIX até a proclamação da República no Brasil, no primeiro volume, intitulado "Cotidiano e Vida Privada na América portuguesa", Fernando Novais cita no primeiro texto o estudo de Habermas para propor que a diferenciação entre as esferas do público e do privado no Brasil não só não teria se

sensível, dos sentimentos e lealdades sobre o abstrato e intangível, sobre os interesses e as idéias; da teia hierárquica das relações familiares, ou seja da pessoa, sobre a trama igualitária do direito, isto é, do indivíduo; da imaginação ornamental sobre o empenho e esforços práticos; da linha curva, enlaçada de forma caprichosa com a paisagem no traçado das cidades, sobre a geometria uniformizadora da linha reta; da rotina sobre a antecipação; da imprevidência sobre o rigor do método; enfim, do complexo universo de valores, práticas, instituições e interesses patriarcais sobre a incipiente emergência de formas de vida modernas, de tendências urbanas e democráticas no econômico, no político e no social. Particularmente no que diz respeito ao âmbito político, suas feições aparecem marcadas pela fatalidade

de receber determinações fundamentais de uma sociabilidade familística, e portanto pré-política, o que leva a caraterizar o espaço público enquanto emanação desse universo de práticas e valores culturais familiares, isto é, também de forma prépolítica, como sociabilidade ou mero ethos público (...)” (Id. Op. cit:189-190).

${ }^{150}$ Lavalle também realiza uma interessante reflexão teórica para se pensar no conceito de "vida pública" aplicada ao caso brasileiro a partir de uma atualização de MEEP com base nas novas caracterizações do conceito de esfera pública de Habermas em Direito e Democracia (Lavalle, 2001:15-134). Em função deste estudo também buscar uma atualização do conceito de esfera pública política especialmente a partir dessas duas obras, a discussão teórica de Lavalle será novamente retomada no tópico 1.4 deste estudo.

${ }^{151}$ V. Sevcenko, 1998 e Angela Castro Gomes, 1998. As relações desses textos com o estudo de Habermas serão discutidas no tópico seguinte. 
realizado conforme o descrito pelo filósofo na Inglaterra e na França em $M E E P$, como ainda parecia ser o modelo habermasiano visto "inversamente". Tratava-se de uma colônia, e "no mundo colonial, as coisas aparecem 'trocadas', e isso causa estranheza; e se causam estranheza, é porque não 'deviam’ aparecer desse modo.” (Novais, 1997:16).

Analisar, portanto, as esferas "ainda imbricadas" do público e do privado no Brasil demandaria estudos concretos em torno de "delimitações" da vida privada, que sempre ocorrem em paralelo à sua conformação pública, a ser promovida pelo Estado moderno (Novais, 1997:16). Há um foco na delimitação de experiências da vida privada de determinados estratos sociais que de algum modo refletem ou se relacionam com a publicidade e formam espaços públicos em toda obra História da Vida Privada no Brasil. Apesar de não abstrair esses espaços públicos em termos de "fluxos comunicativos", como destaca Lavalle da concepção de esfera pública política de Habermas em Direito $e$ Democracia (Lavalle, 2001:45-51) ${ }^{152}$, os ensaios tratam de certo modo também de experiências negativas desse princípio como afirmações de uma dialética entre o público e o privado (Sevcenko, 1998:30-31).

Outro ensaio do primeiro volume, "O que se fala e o que se lê: língua, instrução e leitura" de Luiz Carlos Villalta, enfatiza como a falta de recursos na escola pública da época provocou um aumento da educação privada, ligada aos profissionais e seus ofícios e aprendizes. As grandes bibliotecas cujos donos eram professores, médicos, advogados, e muitas vezes centros de grandes debates, tornam-se cada vez mais privados. Mas se colaboram apenas para uma formação educacional e de leitura de elite, teria sido suficiente para uma integração social conforme as expectativas da "civilidade das aparências" do Antigo Regime (Villalta, 1997:383).

Isso mostra como, ainda que não tivessem nunca antes se diferenciado, as relações entre público e privado no Brasil colônia também já apresentavam características de uma publicidade "refeudalizada", descrita por Habermas no capítulo V de MEEP, na passagem de um público pensador e debatedor de cultura (e por isso, político) para um público privado restrito de proprietários produtores de informação e cultura que moldam a esfera pública de um lado, e outro público massificante e despolitizado de consumidores privados de outro (Habermas, 2003:189-206).

Em "A sedução da liberdade", István Jancsó procura demonstrar que as sedições contra o poder estabelecido daquela época, ou "rebeldias organizadas", "transgressões",

\footnotetext{
${ }^{152}$ Como se procurará em seguida aqui também sugerir (v. tópico 1.4), quando será retomada esta reflexão de
} Lavalle. 
que emergem no espaço da vida pública "politizando a vida privada", como em Minas Gerais (1789) e na Bahia (1798), teriam ocorrido após a conquista de um espaço privado pelos indivíduos. São no mínimo curiosas as conexões dessa nova privacidade com as buscas pelo rompimento com a noção de público de então. (Jancsó, 1997:389-390).

Isso porque não teria sido por outro motivo senão a possibilidade de reunião no espaço privado de suas casas que os mineiros teriam conseguido se organizar e discutir sua particular sedição. E se muitos na Bahia dez anos mais tarde não teriam tido essa possibilidade, fizeram-no em locais ermos e becos da cidade. Membros de associações, como a Sociedade Literária do Rio de Janeiro, apesar de interferir no debate sobre a escravidão e a democracia, revelavam que era a privacidade das residências particulares o "espaço efetivo da prática da liberdade ${ }^{153}$ ", onde se organizavam os "ensaios de ruptura com a vida pública" (Id. op. cit:394) ${ }^{154}$.

Já do volume II da História da Vida Privada, intitulado A Corte e a Modernidade Ocidental, no texto do organizador Luiz Felipe de Alencastro, a institucionalização do escravismo e seu gradativo questionamento político e econômico em meados do século XIX - quando várias nações desenvolvidas já haviam abolido as práticas - são vistos como exemplos de uma mobilização de comunicações críticas entre esferas sociais e políticas do Império, inclusive de proporções internacionais (Alencastro, 1997:28-29). Mais à frente em seu estudo, Alencastro apresenta outros motivos de publicidade ligada à esfera do comércio mobilizavam anúncios de aluguel de "amas de leite", preferencialmente que estiverem "um mês parida e sem filhos", conforme notícia publicada em abril de 1952 no Jornal do Comércio (Id. op. cit:65).

No mesmo volume, Ana Mauad ressalta em seu texto "Imagem e auto-imagem do segundo reinado" a eficiência da publicidade da corte no Rio de Janeiro dos anos de 1850, mas agora já em relação ao aumento de anúncios de produtos de mercado em jornais e

\footnotetext{
153 “A profunda diferença que aflora do significado de liberdade para os envolvidos nas sedições mineira e baiana revela-se radicalmente nesses dois projetos particulares, e que não se explica apenas pelos dez anos que medeiam entre ambas, com todas as implicações históricas daí derivadas. O que ressalta poderosamente é que, para uns, liberdade significava, para além da reiteração das diferenças num universo de desigualdades, o reforço de seu poder mediante a supressão do jugo colonial que limitava seu pleno exercício. Tratava-se, aí, da liberdade sonhada por senhores de escravos. No segundo caso, o do escravo baiano, a liberdade era tida por condição da igualdade, o que implicava, cabalmente, a supressão da própria relação escravista constitutiva da subordinação colonial e, portanto, a supressão também desta última (Jancsó, 1997:428).

${ }^{154}$ Ao tratar das sedições na Bahia, analisa Jancsó: "No caso das reuniões sabidamente realizadas na casa do tenente avesso aos rituais da Igreja, ou nas de outros sediciosos, tudo indica que aí já se tratava de sociabilidade política. É possível perceber nesses acontecimentos a maneira como o ensaio de ruptura dos limites da esfera pública da vida na Colônia (pois é disso que se trata ao se falar de sedição) se engendrava no interior da esfera privada, redefinindo-lhes os significados. (...) // Mas essas reuniões, que esboçavam a cultura política antiabsolutista pautadas por uma nova sociabilidade, desdobravam-se, no cotidiano da cidade e de seus arredores, em variada exteriorização (1997:414 e 416).
} 
revistas, que passavam a ser um indicador de um "mercado consumidor bastante movimentado" (Mauad, 1997:202). Mais uma vez fica presente uma ligação desses fatos com sinais de uma esfera pública representativa (ou talvez "refeudalizada") no Brasil imperial. Em seu impulso inicialmente mercantilista, ela se fazia presente em sinais de uma cultura da auto-representação do status na imprensa institucionalizada da corte do Rio de Janeiro, inclusive já consolidada em termos de propaganda de produtos e informações de comércio.

O século XIX, visto como o "século das abolições" por Hebe Mattos de Castro e por isso um século de grandes transformações do mundo político, especialmente quando o direito civil, que havia anteriormente legitimado a propriedade do escravo como direito privado sobre coisa em 1824, precisa conferir a autonomia individual anteriormente concedida somente ao proprietário, a todos os filhos nascidos de escravos com a Lei do ventre livre 1871 e consequentemente, liberdade individual e igualdade a todos como cidadãos com a lei Áurea (1888) e a proclamação da República $1889^{155}$ (Castro, 1997:338$341)$.

O volume II de História da Vida Privada acaba com um curto "Epílogo" de Luiz Felipe de Alencastro, sobre a foto da capa do volume, organizado por ele. A imagem de 1860 de um menino, cujo olhar "...voa no devaneio da inocência e das coisas postas em seu devido lugar...”, apoiado à sua ama que, “...ao contrário, não se moveu...”, e revelaria com isso um sinal de sua "liberdade", ainda presa às expectativas de publicidade do senhorio. ${ }^{156}$

As contradições do surgimento da modernidade no Brasil, à custa das chagas de gradativas conquistas de liberdade individual e igualdade de direitos dos escravos alforriados, mostram algumas pistas do contexto de surgimento de uma esfera pública política no país, no qual um processo de modernização mobilizado pela economia se origina e se estabelece sem grandes rupturas jurídicas e mesmo culturais (Mello e Souza, 1997:444-445), do fim de uma monarquia escravista e teocrática a uma república marcada

\footnotetext{
155 “A universalização de um padrão de comportamento senhorial pressuporia o reconhecimento da primazia do senhor. A universalização de um padrão de comportamento senhorial pressuporia o reconhecimento e direitos (também universais) aos escravos, o que em si, é incompatível com a dominação escravista. Os escravos negociados no tráfico interno, ao propugnar a efetivação de práticas costumeiras, vigentes em suas regiões de origem, questionavam o poder de reinterpretar, como concessão seletiva do arbítrio senhorial, o acesso a recursos que permitissem maior autonomia no cativeiro, como também perspectivas, mesmo que remotas, de acesso à liberdade. Ao fazê-lo, punham em xeque as bases de reprodução da dominação escravista." (Castro, 1997:356-357).

156 “O mistério dessa foto feita há 130 anos chega até nós. A imagem de uma união paradoxal mas admitida. Uma união fundada no amor presente e na violência pregressa. Na violência que fendeu a alma da escrava, abrindo o espaço afetivo que está sendo invadido pelo filho de seu senhor. Quase todo o Brasil cabe nessa foto.” (Alencastro, 1997a:438-440).
} 
pela centralização do poder e a busca pela instauração de um estado constitucional de direito.

b) politização e "refeudalização" da esfera pública na consolidação da República até meados do século XX

A análise de Darcy Ribeiro em O povo brasileiro talvez seja ainda mais reveladora das contradições entre o "moderno e o arcaico" que se deram na diferenciação entre o público e o privado na passagem de um Brasil colonial-imperial a republicano. $\mathrm{O}$ antropólogo, que foi Ministro da Casa Civil do Presidente João Goulart antes do golpe militar defende que o imbricamento de esferas do poder do estado e do poder privado se dá naquele momento histórico somente até o limite da manutenção dos objetivos da economia escravista e latifundiária da Coroa, isto é, até que passassem a ser questionados pelos plantadores anárquicos, mineiros e contrabandistas. ${ }^{157}$

Ou seja, as pretensões de liberdade de escravos africanos, do caipira, do sertanejo ou do caboclo teriam influenciado menos essas transformações do marco jurídico do que as questões econômicas, o que permitiu uma influência da Corte no poder ainda por mais oitenta anos, tempo em que esta "enfrenta e vence todos os levantes populares, matando seus líderes ou os anistiando e incorporando sem ressentimento ao grupo dominante." (Ribeiro, 1995:256) ${ }^{158}$

Apesar de voltada para interpretar antropologicamente o "povo brasileiro", essa perspectiva parece ainda influenciada pela leitura do Brasil-Colônia da economia política de Caio Prado Júnior, da qual já parecem se afastar os textos de História da Vida Privada no Brasil. Analisando a crise financeira que acometeu o país recém tornado República, Caio Prado Júnior afirma em Formação Econômica do Brasil (original de 1945) que a

\footnotetext{
${ }^{157}$ Em seu conhecido livro Bandidos, Hobsbawm cita o nordeste brasileiro como local onde o banditismo social "...forma de rebelião individual ou minoritária nas sociedades camponesas..." se tornou "epidêmico" em 1870, atingiu seu apogeu no primeiro terço do século XX, extinguindo-se 1940 pelo combate das forças policiais da República. V. Hobsbawm, Bandidos, 1976:10 e 18.

158 "Evitou-se assim, que viessem a operar, como uma secessão, tanto as diversificações regionais como as crises de transfiguração da formação socioeconômica de colonial-escravista em neocolonial e a transição de colônia a nação politicamente independente.// A contraparte dessa tarefa unificadora foi a ordenação da sociedade nacional em cada uma de suas formações, com estreita obediência aos interesses oligárquicos, diante dos quais o próprio poder central sempre claudicou, incapaz de enfrentá-los, apesar da oposição flagrante entre seus interesses e os da população trabalhadora. Isto é o que torna as classes dirigentes brasileiras tão parecidas aos consulados romanos, como representantes locais de um poder externo, primeiro colonial, depois imperialista, a que servem como agentes devotados e de quem tiram sua força impositiva. E, sobretudo, como consulados socialmente irresponsáveis pelo destino da população que, a seus olhos, não constitui um povo, mas uma força de trabalhão, ou melhor, uma fonte energética desgastável nas suas façanhas empresariais." (Ribeiro, 1995:255-256).
} 
transição política do Império à República sem grandes transformações no sistema econômico, deu possibilidade ao país se manter num equilíbrio no mercado internacional, ainda que na posição "semicolonial" de uma economia latifundária, exportadora de matéria prima e financeiramente endividada. ${ }^{159}$

Retomando os dois últimos volumes de História da Vida Privada, na introdução do organizador do III volume, Nicolau Sevcenko, Mudança Estrutural da Esfera Pública já é citada para balizar sua posição, quando propõe que havia no Brasil do início da República diversas formas de privacidade, e essas eram encontradas nas tensões existentes entre os estratos sociais do período, marcadas por sua forte herança colonial e escravista. Se houve, portanto, a formação de subjetividades privadas, que seriam sempre referenciadas à esfera pública no Brasil da época, na expansão do "progresso" da República até as relações internacionais, nos episódios de Canudos e na Revolta da Vacina - alguns dos muitos exemplos negativos dessa invasão violenta do público no privado -, não se pode negar que ambos representam a formação de um público que se politizava na medida em que articulava pela publicidade expressões e práticas de sua privacidade (Sevcenko, 1998:2830)

Mesmo que em termos de história concreta a esfera pública política era privilégio de poucos, as pressões de diversos indivíduos como profissionais da cultura, intelectuais e "publicistas" e outros grupos anteriormente excluídos para acessar as esferas da publicidade econômica, de direitos e de cultura que se desenvolviam no país, demonstravam que o período de início da República teve como marca uma efervescência nesses campos e a ativação de uma esfera pública política, especialmente em função da articulação de diversas demandas de autonomia individual na imprensa e outros meios de comunicação (Id. op. cit:30-31). ${ }^{160}$

A consolidação da República se deu de modo a excluir e destruir diversas formas de convivência e práticas sociais provindas de comunidades religiosas não católicas, de

\footnotetext{
159 "A abolição da escravidão e a conseqüente transformação do regime de trabalho (com a imigração estrangeira por corolário); o rompimento dos quadros conservadores da monarquia e a eclosão de um nôvo espírito de negócios e especulação mercantil; a acentuação e consolidação do domínio da finança internacional na vida econômica do país (e são êstes, em sua, os fatôres que direta ou indiretamente interferem na vida brasileira desde os últimos anos do século passado e vão provocar a crise de transformação por que passou), êstes fatores não são senão passos preliminares e preparatórios que farão do Brasil uma nação ajustada ao equilíbrio mundial moderno, e engrenada, se bem que no lugar próprio de semicolônia para que a preparara a evolução anterior, no círculo internacional do imperialismo financeiro." (Prado Júnior, 1970:224).

160 "A história da vida privada nesse início do período republicano deve ficar na interseção dessas múltiplas tensões e tentar avaliar a ampla gama de ações pelas quais diferentes criaturas, em contingências as mais diversas, procuraram dar substância aos seus anseios, inventando meios e lutando para ampliar seus sentidos de pertencimento à coletividade e de autonomia individual." (Sevcenko, 1998:31).
} 
culturas diversas e aquelas espacialmente separadas dos centros urbanos, o que levava à criação de práticas clandestinas de comunicação não sujeitas ao controle da autoridade pública, como jargões, jogos de silêncio e gestos indecifráveis e até tatuagens e pichações. (Id. op. cit:32).

Mas a política centralizadora de tentativa de estabilização das contas públicas que se desdobraria na política do "café-com-leite" fazia parte de um movimento mais geral de impacto da revolução científico-tecnológica no Brasil, que impulsionaria o país à sua Belle Époque, dos anos 1870 aos 1900, entrando no século XX com uma produção cultural dinamizada por práticas esportivas, cinema, revistas, rádio e publicidade comercial (Id. op. cit:37).

Apesar de História da Vida Privada no Brasil favorecer a abordagem do surgimento de uma esfera pública política no Brasil a partir de publicização de públicos privados, não se pode deixar de mencionar questões importantes da história política do país que também revelam problematizações da ordem política que acenderam a esfera pública nacional do período como as disputas entre movimentos comunistas e constitucionalistas e as repressões policiais e exceções legais entre os anos 20 e 30 do século XX que alçaram Vargas ao poder. Essa disputa é trabalhada por Paulo Sérgio Pinheiro em Estratégias da Ilusão (1991). ${ }^{161}$

Já no período do primeiro governo de Vargas, a formação de uma publicidade nas tensões entre público e privado se revelava na tentativa de associar o desenvolvimento da nação à figura do presidente. Teria sido uma forma de produção de consenso político que, gerado a partir das aparições de Vargas no rádio, no cinema e em espaços públicos "por meio de apelos sensoriais e conotações afetivas, se mostrava muito mais eficiente que a racionalidade dos discursos" (Id. op. cit:38). ${ }^{162}$

Apesar da ditadura, a diminuição do analfabetismo e o desenvolvimento de um mercado ativo dirigido pelas elites formadoras tendências da vida social, a passagem do Brasil pela "era dos extremos" foi finalmente selada com a chegada da televisão, que teria

\footnotetext{
161 “O jogo da revolução no centro e à direita é extremamente elitista e, nas margens mais à esquerda (ou nas bordas populares), profundamente enquadrado pela repressão policial ilegal, pelo arbítrio e pelo terror. Podese dizer, como Michel Debrun, que a violência do Estado na sociedade brasileira determinou a forma de expressão do protesto no período que estudamos. E, ao mesmo tempo, assegurou seu fracasso, dado o formidável hiato na sociedade brasileira entre dominantes e dominados, garantindo que o autoritarismo desmobilizador prevalecesse sob a forma do Estado Novo, que fecha o ciclo do inconformismo revolucionário." (Pinheiro, Estatégias da ilusão, 1991:12).

${ }_{162}$ Para mais sobre a relação íntima entre a figura do presidente Vargas e a população brasileira durante o Estado Novo, v. dos ensaios do IV volume da História da Vida Privada Gomes, A. de Castro (1998:511$558)$.
} 
"levado a República para dentro de cada casa". Conforme a propaganda da General Electric, o anúncio: "Você já ouviu falar...Agora vá ver TELEVISÃO”. (Id. op. cit:39-41).

No segundo texto do III volume, "Da escravidão à liberdade: dimensões de uma privacidade possível”, de Maria Cristina Wissenbach propõe que as experiências de liberdade dos escravos alforriados nunca foram desprezíveis na conformação da cultura nacional do período imperial ao republicano, especialmente porque no início constituíram comunidades de ribeirinhos, índios, em ranchos e mocambos, sem uma inserção no espaço público, e portanto sem um reconhecimento social pleno como sujeitos de direito. Não é preciso dizer aqui sobre deplorável continuidade de práticas ligadas a condições de escravidão ou servidão no tempo presente. ${ }^{163} \mathrm{~A}$ mobilidade dos processos de migração teria sido da mesma forma influenciada por esse processo de libertação jurídica da abolição (Wissenbach, 1998:72-73).

Essas comunidades mantinham, contudo, visões de mundo compreensivas sobre suas regiões e a relação entre seres humanos e natureza eram influenciadas por aspectos mágicos e sobrenaturais, mas também formavam identidades e práticas culturais muito características (Id. op. cit:72-73), como as muitas que se mantém até hoje, discriminadas ou não, e outras que tem sido recentemente tombadas como patrimônio imaterial do Brasil. $^{164}$

A formação de habitações e processos de urbanização que seguiram os ajuntamentos de homens livres da abolição teriam reconfigurado a privacidade do brasileiro ao longo dos últimos dois séculos mais ligada à "sobrevivência" do que à "domesticidade", ampliando a intimidade que era entrelaçada pela identificação com formas de associação cultural, religiosa e social. Esse novo tipo de privacidade gerada pelo fim da escravidão carregava em suas expressões de uma projeção pública. ${ }^{165}$

No texto "Habitação e Vizinhança", de Paulo César Marins, os processos de urbanização de São Paulo, Rio de Janeiro e Recife são descritos, e em certo momento do

\footnotetext{
${ }^{163}$ A área de atuação do Ministério Público do trabalho divulga notícia de 12 de agosto de 2011 sobre a descoberta de 69 trabalhadores em condições análogas às de escravo em carvoarias de dez fazendas no interior de Goiás. Como se pode ver, esse problema se estende até hoje presente no Brasil, um século depois do período aqui analisado. V. notícia em www.mpt.gov.br (último acesso em 18/09/2011).

164 Para mais sobre as políticas de registro do patrimônio imaterial no Brasil como patrimônio cultural nacional, instituídas pelo decreto federal n. 3551/2000 que criou o Programa Nacional do Patrimônio Imaterial. v. informações no endereço eletrônico da Coordenadora do Patrimônio Cultural http://www.patrimoniocultural.pr.gov.br/modules/conteudo/conteudo.php?conteudo=259 (último acesso 03/10/2011).

${ }^{165}$ Sobre essa nova noção de privacidade analisa Wissenbach ao final de seu texto: "Noção que muitas vezes levava a ser recomposto no espaço público o que havia sido desarticulado com o domínio escravista, reequacionando o que era tradicionalmente colocado nos limites de quatro paredes. Contraditoriamente ou não, a privacidade popular se orientava em direção ao mundo das ruas." (Wissenbach, op. cit:130)
} 
estudo sobre São Paulo, o autor compara a disposição e a divisão do espaço das residências, especialmente as das elites, com seus longos jardins, recuo com os vizinhos do bairro e até zoneamento, com a projeção pública que procurava representar o proprietário. Por isso, “A normatização do privado acabava, pois, entrelaçando-se com a própria configuração dos espaços 'públicos”" (Marins, 1998:178).

De outro lado, vem a análise do texto seguinte, "Imigrantes: a vida privada dos pobres do campo", que enfatiza as marcantes diferenças das relações entre público e privado dos milhares de diferentes imigrantes que aportaram no Brasil entre o fim do século XIX e o início do século XX com aquelas das elites proprietárias, que são muitas vezes tema de estudos sobre a vida privada (Alvim, 1998:216-217).

A transformação dos costumes que levou os imigrantes formarem novos modos de intimidade e privacidade, em função da precariedade de suas condições de vida e das necessidades de adaptação e sobrevivência, é significativa para o surgimento de públicos de trabalhadores de diversas nacionalidades e etnias que acabarão se formando nos primeiros pólos industriais dos grandes centros urbanos, pois muito desses trabalhadores eram imigrantes ${ }^{166}$, que interagiam com os negros, caboclos e índios, e mesmo que nem sempre de modo amistoso, com sua ajuda estabeleceram seus meios de sobrevivência nas terras brasileiras de norte a sul (Id. op. cit:254-283).

Nesse contexto, a cultura da economia familiar acaba adentrando as primeiras indústrias e empresas, especialmente porque os imigrantes teriam parado de trabalhar diretamente para (e com) sua família, e passado a trabalhar diretamente a um empregador. No início as indústrias absorvem as pretensões dessa cultura e empregam diversos membros da mesma família, enquanto que no setor de serviços o parentesco era na maioria das vezes a norma. ${ }^{167}$

Essa publicidade orientada por imperativos de uma cultura privada da economia familiar passa a ser um traço das pretensões deste público de imigrantes e residentes de diversas regiões do país que migram para os centros urbanos e passaram a incorporar as massas de operários das grandes fábricas e indústrias, residindo em suas periferias. Nessa "esfera pública plebéia", o germe da "esfera pública proletária", ou da experiência, como

\footnotetext{
${ }^{166}$ Em 1920, Zuleika Alvim informa que 35\% dos habitantes da capital de São Paulo eram do exterior, entre italianos, espanhóis e portugueses, bem como poloneses em menor número e posteriormente os japoneses. Em 1934 se identifica que imigrantes e filhos nascidos no país seriam 50\% da população paulista. (Marins, 1998:286).

${ }^{167}$ É destacado o caso das lojas Mappin, primeira loja de departamentos de São Paulo que, até os anos 1940 empregava em torno de 35\% de seus funcionários entre parentes (Saliba, 1998:287).
} 
dirá Oskar Negt em Public Sphere and Experience (1993), estava em gestação, na base daquilo que tornará o Brasil uma sociedade de massa: o processo de industrialização.

No que diz respeito à formação de uma esfera pública política a partir das manifestações culturais da época, o Movimento Modernista e os artistas envolvidos na Semana de Arte Moderna de 1922 talvez possam ser considerados os maiores exemplos da busca por uma autocompreensão da identidade brasileira, que emerge do privado em experiências públicas artísticas que questionam o aculturamento e a incorporação acrítica de influências do velho mundo, como o parnasianismo, a forma culta, a métrica e outras formalidades, como o cientificismo e a burocracia estatal. ${ }^{168}$

Escrevendo sobre o Movimento Modernista em texto homônimo de sua obra Aspectos da literatura brasileira (original de 1942), Mário de Andrade revela por meio de um relato pessoal e reflexivo sua inserção no movimento, sua história e diversos personagens, como Vitor Brecheret, Anita Malfati, Oswald de Andrade, Manuel Bandeira, Tarsila do Amaral, com interessantes análises sobre o sentido do modernismo na revisão daquilo que seria a "Inteligência nacional", algo como o espírito da nação, ou uma opinião pública tipicamente brasileira. Após ler o testemunho de Mário de Andrade fica difícil negar a formação de uma esfera pública política autêntica no Brasil, isto é, provinda de uma esfera pública literária originada espontaneamente da autocompreensão individual, estética e cultural daquele "grupinho de intelectuais paulistas" que até os anos 30 tomou o país (Andrade, 1974:232).

A afirmação constante de que o Movimento Modernista era "destruidor" não impede o modernista, então a três anos de sua morte em 1945, de traçar proposições normativas em termos de princípios de política cultural que buscavam potencializar "o direito à pesquisa estética, a atualização da inteligência artística brasileira e a estabilização de uma consciência criadora nacional" (Id. op. cit:242). A partir dessa liberdade de pesquisa sobre inquietações estéticas o artista influencia esse estado de espírito revolucionário que torna a arte uma "expressão interessada da sociedade”, e a inteligência

\footnotetext{
${ }^{168}$ Ou nas palavras do próprio Mário de Andrade: "Manifestado especialmente pela arte, mas manchando também com violência os costumes sociais e políticos, o movimento modernista foi o prenunciador, o preparador e por muitas partes o criador de um estado de espírito nacional. A transformação do mundo com o enfraquecimento gradativo dos grandes impérios, com a prática européia de novos ideais políticos, a rapidez dos transportes e mil e uma outras causas internacionais, bem como o desenvolvimento da consciência americana e brasileira, os progressos internos da técnica e da educação, impunham a criação de um espírito novo e exigiam a reverificação e mesmo a remodelação da Inteligência nacional. Isto foi o movimento modernista, de que a Semana de Arte ficou sendo o brado coletivo principal." (Andrade, O Movimento Modernista, 1974:231).
} 
artística um esforço público de conhecimento da história cultural do país (Id. op. cit:251252).

Mais importante ainda para este trabalho é que Andrade propõe não só esse conceito duplo de modernismo, como destruição e proposição pela arte, mas também a necessidade de se realizar diagnósticos do tempo, o que parecia realmente antecipar aproximações recentemente feitas de suas pesquisas com as de Theodor Adorno ${ }^{169}$. Ainda que com severas autocríticas, como o individualismo e o absenteísmo dos quais se autoacusa no final do texto, as reflexões do autor sobre o movimento trazem uma conotação quase "tragicômica" da vida, também com mensagens de esperança proféticas ${ }^{170}$ (Id. op. cit:255).

O volume III da História da Vida Privada no Brasil traz texto relacionado, sobre “A Dimensão cômica da vida privada na República”, Elias Saliba defende que o humor acaba sendo uma tentativa de retomada do brasileiro por um espaço público que foi prometido mas nunca realizado durante o período de efervescência republicano; "para que não perca a esperança e afugente a morte" (Saliba, 1998:364-365). O costume do brasileiro de parodiar a si mesmo remete o autor aos estudos de Bergson sobre a paródia (Id. op. cit:305-307), que seria a forma de expressar as descontinuidades e paradoxos da vida ao mesmo tempo moderna e arcaica, “...cosmopolita e provinciana (...) liberal e oligárquica” que se vivia no Brasil (Id. op. cit:297).

\footnotetext{
169 "O terrível é que talvez ainda nos seja mais acertada a discreção, a virarmos por aí cacoeterios de atualidade, macaqueando as atuais aparências do mundo. Aparências que levarão o homem por certo a maior perfeição de sua vida. Me recuso a imaginar na inutilidade das tragédias contemporâneas. O Homo Imbecilis acabará entregando os pontos à grandeza do seu destino." (Id. op cit:254-255. Itálico do autor). A comparação com Adorno é referente à recente compilação e digitalização dos dados e cadernetas da "Missão de Pesquisas Folclóricas", lançada em 2011 pela Secretaria de Cultura da Prefeitura de São Paulo. A pesquisa encomendada por Mário de Andrade, então Diretor do Departamento de Cultura da cidade de São Paulo, fundado por ele mesmo, são comparadas com os estudos sobre cultura de massa do teórico alemão, especialmente por parecerem antever a supressão de culturas populares em função da industrialização e massificação da cultura. Note-se, no entanto, que a menção dá a entender que na expedição de pesquisas folclóricas de 1937 de Mário de Andrade teria possivelmente inspiração em Adorno, enquanto que este publicou seu capítulo sobre a "Indústria Cultural" em Dialética do Esclarecimento em 1947. Neste caso, somente Adorno poderia ter se inspirado em Mário de Andrade, e não o contrário.

170 "Eu creio que os modernistas da Semana de Arte moderna não devemos servir de exemplo a ninguém. Mas podemos servir de lição. O homem atravessa uma fase integralmente política da humanidade. Nunca jamais êle foi tão 'momentâneo' como agora. Os abstencionismos e os valores eternos podem ficar pra depois. E apesar da nossa atualidade, da nossa nacionalidade, da nossa universalidade, uma coisa não ajudamos verdadeiramente, duma coisa não participamos: o amilhoramento político-social do homem. E esta é a essência mesma da nossa idade. (...) // Aos espiões nunca foi necessária essa 'liberdade' pela qual tanto se grita. Nos períodos de maior escravização do indivíduo, Grécia, Egito, artes e ciências não deixaram de florescer. Será que a liberdade é uma bobagem?... Será que o direito é uma bobagem!... A vida humana é que é alguma coisa a mais que ciências, artes e profissões. E é nessa vida que a liberdade tem um sentido, e o direito dos humanos. A liberdade não é um prêmio, é uma sanção. Que ha-de vir.” (Andrade, 1974:255).
} 
No momento do efeito cômico da paródia, seja na música com Adoniran Barbosa, na poesia e na política com o Barão de Itararé (Id. op. cit:357), na literatura com Machado de Assis (Id. op. cit:301-302) rádio ou o cinema brasileiro com Mazzaropi (Id. op. cit:358$359)$, os brasileiros encontraram seu modo próprio de realizar o público no privado ${ }^{171}$, ainda que para mostrar a desconexão entre um e outro. Isso não deixava de ser também sinal de uma busca simultânea pela compreensão de uma identidade privada e de uma identidade nacional própria do país: a "comunidade imaginada" do Brasil (Id. op. cit:297).

Até mesmo a imagem da República é parodiada em diversas revistas de sátiras políticas como $O$ Malho e $O$ Pirralho, com uso de elementos da vida privada, associando-a à imagem que tinha a mulher na sociedade, com clara discriminação de seu papel no espaço privado ${ }^{172}$, em conversas íntimas e em caricaturas com duplo-sentido às vezes com feições masculinizadas ou com "traços negativos de sedutora" (Id. op. cit:312-315).

Nesse texto, a esfera pública política do período aparece através de afirmações estéticas de conteúdo político altamente crítico, especialmente com a transfiguração do público a partir do privado. Ao mesmo tempo, no entanto, o brasileiro é criticado por cultivar uma ética que é avessa a qualquer fundo que não seja emotivo ${ }^{173}$, o que talvez explique a tentativa do próprio poder político se auto-representar em formas midiáticas (Id. op. cit:354-357), seja cerceando excessos pelo Departamento de Imprensa e Propaganda (DIP), que centralizava em Vargas o controle sobre os meios de comunicação, ou mesmo 'sugerindo' ou 'aconselhando' artistas e escritores a condenar a “vadiagem” e exaltar os valores do trabalho em suas obras (Id. op. cit:353).

\footnotetext{
171 “A própria vida pública será associada, sob forma paródica, com a vida privada ou com elementos da vida familiar, íntima ou individual; em muitos casos, o público só se tornará legível mediante a transposição paródica - o que era, no fundo, uma outra maneira de torná-lo próximo e familiar. Como jogo que mistura e embaralha os registros, numa indistinção notável, que se desdobrava do próprio processo aleatório da República brasileira, a representação pelo humor paródico ajudava a corroer por dentro quaisquer possibilidades de consistência, tanto do público quanto do privado.” (Saliba, 1998:312)

${ }^{172}$ A propósito dos espaços sociais ocupados pelas mulheres nos primeiros trinta anos do século XX, no texto "Recônditos do Feminino", que segue o de Saliba no III volume de História da Vida Privada, Mariana Maluf e Maria Lúcia Mott procuram mostrar as transformações no comportamento das mulheres da época, que deixavam a redoma do espaço privado e adentravam a esfera pública, seja no trabalho, nas artes ou mesmo na política. Logicamente, essas mudanças causariam desconforto entre conservadores, e os debates entre opiniões feministas e contrárias tomavam os espaços de diversas publicações da época, como a Revista Feminina. Em relação à esfera pública política formal, as pressões femininas por direitos políticos em $1920 \mathrm{e}$ as críticas à continuidade de um direito civil extremamente patriarcal com o código de 1916, revelavam como o princípio de generalidade da esfera pública ainda se mantinha também somente como ficção (Maluf \& Mott, 1998:370-373, 379-384, 420-421).

${ }^{173}$ Aqui Saliba cita Sérgio Buarque de Holanda de Raízes do Brasil, a respeito do: “"o horror às distâncias que parecia constituir o traço mais específico da sociedade brasileira - aquela atitude que não suporta os trâmites e abstrações sociais, desconhecendo qualquer forma de convívio que não fosse ditada por uma ética de fundo emotivo." (Holanda, S. B. de. Raízes do Brasil. Ed. José Olympio, 1988:140. Apud. Saliba, 1998:364).
} 
O desenvolvimento tecnológico dos meios de comunicação, que culminaria na popularização da televisão, não teria vindo para esclarecer as intricadas relações entre público e privado no Brasil, mas sim para acelerar e consequentemente embolar o processo de diferenciação que deveria de outro modo ocorrer lentamente, com delimitações claras entre as duas esferas (Id. op. cit:356-358).

Essa confusão, que provavelmente leva o brasileiro a orientar suas expressões e ações políticas mais por questões de afeto e cultura do que de ciência e abstração, podem ser relacionados com os mesmos tipos de desvios de racionalidade da formação de "climas de opinião" e a estetização das mensagens publicitárias em campanhas políticas e debates parlamentares, incapazes de serem respondidas com argumentos, mas somente identificações do público, dos estudos sobre a publicidade pré-fabricada e opinião não pública de Habermas em MEEP, isto é, identificados nas democracias de massa européias de meados do século XX (cap. VI. v. revisão acima).

O penúltimo texto do III volume, "Cartões-Postais, álbuns de família e ícones da intimidade”, de Nelson Schapochnik, também traz interessantes considerações a respeito da formação de uma esfera pública política no Brasil no período, especialmente porque dialoga com Walter Benjamin para destacar como as imagens dos cartões postais e álbuns de família passam a assumir um caráter determinante, e não mais acessório à comunicação por correio.

Esse "valor de exposição" da imagem revelaria como ocorre no Brasil a autonomização da estética em relação a determinadas criações humanas, como a religião e a arte, colaborando para comprovar sinais do fenômeno de "refeudalização" da publicidade no país. Ao adentrar as esferas da representação pública da privacidade familiar, da propaganda comercial e política e da produção cultural, o valor de exposição da imagem torna a ostentação, o exibicionismo e a plasticidade características da esfera pública política nacional da primeira metade do século XX (Schapochnik, 1998:431, 493-494). ${ }^{174}$

\footnotetext{
${ }^{174}$ Esse cenário fica evidente com a leitura do seguinte trecho: "A emancipação psicológica dos indivíduos celebrada no interior das habitações e centrada na apropriação simbólica e utilização seletiva de objetos decorativos tinha por correlato, aparentemente, sua emancipação econômica e política. No entanto, esses indivíduos não estavam de todo livres das coações engendradas pela sociedade; dessa maneira, as recepções oferecidas nos salões dos palacetes urbanos permitem entrever uma tênue fronteira entre o privado e o público, entre uma convivialidade eletiva, regrada pelos indivíduos, e uma sociabilidade obrigatória, imposta pelos interesses associativos e conflitos restritivos dos grupos sociais. Nas salas e salões, a recepção adquiria a função de veículo informação pela disputa de cargos e privilégios, na qual estreitavam-se alianças financeiras, tramavam-se candidaturas e plataformas políticas, estimulavam-se intrigas entre concorrentes, estabeleciam-se compromissos matrimoniais" (Schapochnik, 1998:500-501).
} 
c) ampliação da esfera pública a partir dos meios de comunicação de massa e politização da sociedade civil no questionamento do regime militar de 1964-1985

Neste tópico, a discussão sobre a existência de uma esfera pública política no Brasil avança e trata especialmente da evolução dos meios de comunicação de massa e da reação da sociedade civil ao regime militar de 1964 a 1985. Os textos de base serão especialmente o último do volume III de História da Vida Privada no Brasil, "A Capital Irradiante: técnica, ritmos e ritos do Rio", de Nicolau Sevcenko e alguns textos do volume IV da coleção.

$\mathrm{O}$ século XX representou um avanço sem precedentes nas formas de reprodução material das sociedades industriais. Já os efeitos desse avanço sobre as formas de sociabilidade são objeto de interpretações divergentes, especialmente no que se refere à neutralidade ideológica da técnica ${ }^{175}$ e à consolidação da modernidade no Brasil. $\mathrm{O}$ que fica difícil negar é o impacto do desenvolvimento das forças produtivas capitalistas, agora associadas à ciência e à técnica, sobre a compreensão de mundo dos brasileiros (Sevcenko, 1998a:518-519).

A visão da paisagem de dentro de um trem, a construção de máquinas e obras e antes inimagináveis, como o avião, o automóvel e outras destinadas ao transporte urbano, como os bondes, a máquina fotográfica, a máquina de escrever, o telefone, o rádio, a imprensa ilustrada, o cinema e a televisão desestabilizam as noções de tempo e espaço, trabalho, moral e cultura, alterando a visão de mundo do brasileiro, e com isso as relações entre a privacidade e esfera pública no país (Id. op. cit:516-517 e 522).

No caso do cinema, a primeira projeção de imagens em movimento ocorreu no Rio de Janeiro em 1896, com um “omniógrafo”, máquina com uma lente objetiva que permitia só uma pessoa por vez observar as sequências de imagens. Recebida pela imprensa como grande maravilha da científica a partir de então, passou a se desenvolver para as projeções em tela em ambientes escuros, estimulando cada vez mais a fantasia, a imaginação e a fascinação das pessoas. Nesse momento, Sevcenko traz a interessante afirmação de Benjamin, de que a câmara cinematográfica “"nos abre, pela primeira vez, a experiência do

175 Esse debate foi enfrentado na teoria crítica especialmente nos estudos de Marcuse ( $O$ Homem Unidimensional, original de 1967) e de Habermas (Técnica e Ciência como "Ideologia", original de 1968). A divergência em relação à neutralidade da técnica opõe Marcuse e Habermas a Heidegger e Weber. Para um estudo compreensivo sobre a questão, que é dedicado aos 70 anos de Marcuse e dialoga diretamente com sua obra citada, v. Habermas, Técnica e Ciência como "Ideologia”, 2006. 
inconsciente visual, assim como a psicanálise nos abre a experiência do inconsciente instintivo" (Benjamin, Câmaras cinematográficas de Lumière, 1895. Apud. Sevcenko).

As obras de arte que retratam a ligação entre tecnologia com questões míticas e filosóficas, como Frankenstein, Metrópolis e muitos outros que deles derivam, podem dizer muito sobre os impulsos humanos que são despertados a partir de seu estranhamento diante dos novos potenciais da técnica e da ciência (Sevcenko, 1998a:520-521)

As semelhanças com o diagnóstico de Habermas em MEEP são claras. Os meios de comunicação de massa possibilitam cada vez mais a manipulação de desejos inconscientes, e a comunicação pública passa a se tornar um espaço envolvido mais por identificações do que argumentos, influenciando alterações profundas em comportamentos privados e públicos. $^{176}$

Sevcenko toma o Rio de Janeiro como palco dessas transformações e textos de escritores brasileiros como o próprio Machado de Assis para auxiliá-lo em sua descrição e análise. $\mathrm{O}$ crescimento da cidade e seu desenvolvimento urbano e sócio-cultural enquanto ainda capital da República tornam-na um exemplo do espírito moderno do tempo que se formava no país. Dos costumes singelos em espaços públicos, como fumar e tomar café, inovar no estilo das vestimentas e nas artes, influenciado pelo glamour francês, à entrada no ritmo veloz de trabalho da produção industrial inglesa ${ }^{177}$ e no oportunismo individual do American way of life, o panorama da metrópole carioca se modela como uma das "vitrines" do mundo moderno (Id. op.cit:522-535).

A "indeterminidade" do brasileiro moderno o fazia fundir diversos estilos ao mesmo tempo, e com a perda de referenciais históricos que determinam os papéis sociais, o que passava a ser considerado um vetor do comportamento estético era aquilo que se publicava nos jornais, mas neste caso nas colunas sociais, cada vez mais acessíveis ao público por sua produção em massa. O teatro também era fonte de inspiração para novas

\footnotetext{
${ }^{176}$ Diferentemente da crônica de Machado sobre o motorista do bonde, que fumava ao dirigir, mas somente antes de chegar e após distanciar-se do centro da cidade, o que pode representar o uso da liberdade individual no espaço público (1998a:525-526), Sevcenko reflete sobre como a publicidade comercial de outro modo se aproveita dessa possibilidade de privacidade no espaço público do bonde para passar suas mensagens. Essa invasão de uma publicidade direcionada (às vezes pelo próprio privado) em uma privacidade ampliada que se desenvolverá cada vez mais a partir do rádio e da televisão aparece no seguinte trecho: "A luta na refrega dos bondes era por um respeito mínimo à privacidade de cada um, mantida como última defesa naquele veículo público, e às vezes demarcada pelos próprios limites do corpo de cada um. Isolar-se na privacidade significava em geral absorver-se no silêncio das próprias reflexões ou, na falta delas, do mero tédio. Era dessa disponibilidade da imaginação que a publicidade carecia, captando-a com truques sensoriais, cativando-a pelas promessas e seduzindo-a pelo desejo". (Sevcenko, 1998a:551-552)

177 A passagem do estilo de caminhar errático mas curioso do flâneur ao "passo inglês" do businessman brasileiro, rápido e introspectivo, reflete a gradativa substituição da influência francesa que marcou a vida pública brasileira do século XIX pelo ritmo acelerado e pragmático dos ingleses e norte-americanos. v. Sevcenko. 1998a:550-551.
} 
configurações da vida privada burguesa e nas peças o público comparava seus estilos e roupas às dos personagens. Enquanto se forma uma esfera pública a partir da possibilidade do gosto $^{178}$, amplia-se a noção de liberdade individual e, portanto, de um espaço privado para a formação da subjetividade protegido do autoritarismo do poder político (Id. op. cit:536-544).

Em termos da ampliação da esfera pública a partir do desenvolvimento tecnológico dos meios de comunicação, o telefone passa a representar para Sevcenko o contrário do rádio. Apesar de ambos possibilitarem uma comunicação de alcance nunca antes imaginado, o primeiro aprofundaria o processo de privatização dos espaços públicos desencadeado pelo avanço das tecnologias - como a ausência de interação entre privados que compartilham os mesmos espaços de transportes públicos -, elitizando e particularizando a comunicação. Já o segundo permite uma comunicação de grande alcance social, especialmente porque religa no espaço privado das residências um público ampliado, ainda que somente como receptor (Id. op. cit:584-585).

Para o poder público, o rádio teria representado desde os anos 20 sua "pedra filosofal”, tamanha a influência que exercia na formação de um público “...da massa amorfa de ouvintes na força agregada da paixão política”. Esse poder de propaganda política recepciona da propaganda comercial o apelo estético que procura induzir ao consumo de um bem não importa qual seja, ou no caso, à aceitação e legitimação da dominação mais pela afetividade com o interlocutor do que com seus argumentos e propostas (Id. op. cit:587-589).

É por isso que desde o seu surgimento no Brasil, o espaço eletromagnético que é ocupado pelas ondas de telefone, rádio e em seguida sinais de televisão, isto é, o espaço em que trafegam as telecomunicações e a comunicação social foi institucionalizado como bens públicos, porém cuja competência para regular, controlar e outorgar seria exclusiva da União. Por suas ondas circulam não só comunicação política, mas a música, as radionovelas, os eventos esportivos os noticiários e diversas outras produções culturais nacionais e internacionais. Hollywood, Mazzaropi, Carmen Miranda, Zé Carioca, o carnaval, a "hora do Brasil" a copa do mundo e outros símbolos circulam pelos meios de

\footnotetext{
${ }^{178}$ Sevcenko cita o poeta João do Rio, para quem “'ter gosto pode ser uma profissão, dada a raridade do gosto'. Neste caso portanto, o gosto não se refere a nenhum padrão estético ou estável de excelência, típico de uma sociedade aristocrática, mas ao empenho dos recém-chegados às benesses do consumo em se diferenciar e distanciar do menos afortunados e dos despossuídos, de cujo seio vieram. O que passa por gosto é na verdade a moda, que deve mudar sempre para impedir a emulação e, por meio dela, qualquer indesejável identificação." (Sevcenko, 1998a:537-538. Transcrição de João do Rio. A profissão de Jacques Pedreira. São Paulo: Scipione, 1992).
} 
comunicação e na comunicação de públicos cada vez mais amplos que os acompanham, comentam e com eles se identificam.

Organizando a rotina e envolvendo o público ouvinte e telespectador naquilo que estudiosos de comunicação chamarão de agenda setting ${ }^{179}$, o rádio compete com o cinema ao posto de representante da nova era do século XX. Isso porque se tornam, junto com a televisão após os anos 50, instituições concretas da esfera pública responsáveis pela ampliação da publicidade comercial, da comunicação política e da produção cultural nacional e internacional no país. A popularização da televisão nos anos 60 e a mudança da capital da República do Rio de Janeiro para Brasília não seriam então meros fatos desconectados. É pela TV que a esfera pública se amplia gradativamente por todo o país e assiste à distância - impotente e indiferente - a política a se realizar em Brasília. Ambos representam o início de um novo Brasil (Sevcenko, 1998a:598-619)

No último volume da História da Vida Privada no Brasil, a televisão é vista como responsável por ampliar os efeitos do rádio, pois se torna acessível a diferentes classes e papéis sociais, regiões do país, adentrando espaços da privacidade em maneiras que outras instituições de integração social como o Estado, igrejas, organizações e associações civis e escolas nunca teriam atingido. No ensaio "Diluindo fronteiras: a televisão e as novelas no cotidiano", Esther Hamburger aborda o impacto da televisão na formação de um novo espaço público no país a partir da popularização da televisão. Especialmente as telenovelas são vistas como tendo contribuído para a construção de uma identidade nacional (Hamburger, 1998:442) ou, nos termos de Maria Immacolata de Lopes, uma "narrativa popular sobre a nação". ${ }^{180}$

Mas a relação entre televisão, integração social e esfera pública política na "nova República" ganha sua expressão mais aguda durante o regime militar. Ao mesmo tempo em que a regulação autoritária e o investimento maciço do Estado na infra-estrutura da

\footnotetext{
179 "Quando é impossível deixar de noticiar algum fato depreciativo em relação ao complexo políticoempresarial dominante, o debate público é desde logo falseado, com a utilização da técnica que os norteamericanos denominam agenda-setting; ou seja, passa-se a noticiar outras matérias, em geral sensacionalistas, para desviar a atenção pública do assunto incômodo." (Komparato, F. A democratização dos meios de comunicação de massa. In. Bucci, E. (org.). A TV aos 50, 2000, pp. 192. Para um estudo crítico sobre os poderes e limites do agenda setting, v. Colling, L. Agenda-setting e framing: reafirmando os efeitos limitados. In. Revista FAMECOS • Porto Alegre • $\mathrm{n}^{\circ} 14 \cdot$ abril 2001, pp. 88-101.

${ }^{180} \mathrm{Em}$ recente texto, trabalhando já o impacto internacional da telenovela brasileira, sugere a teórica da ECA-USP e coordenadora do Centro de Estudos de Telenovela da mesma Universidade: “...a narrativa ficcional televisiva surge como um valor estratégico na criação e consolidação de novas identidades culturais compartilhadas, configurando-se como uma narrativa popular sobre a nação. (...) A ficção passa a ser um lugar privilegiado onde se narra a nação, nação representada, nação imaginada (Anderson, 1983), nação disseminada (Bhabba, 1997, 2001)". As citações de Anderson e Bhabba são respectivamente das obras Imagined Communities: reflections on the origines and spread of nationalism (London: Verso) e Nazione e narrazione (Roma: Meltemi).
} 
indústria televisiva serviram diretamente aos propósitos de unificação nacional e consolidação ideológica do regime, os questionamentos da sociedade civil e os movimentos sociais e culturais de oposição política também ganharam uma expressão cada vez mais robusta. Em contraposição a uma esfera pública fabricada por empresas privadas concessionárias de canais de TV e rádio, subsidiadas e ao mesmo tempo controladas pela censura estatal, emerge da repressão política uma esfera pública altamente crítica e politizada, capitaneada especialmente por uma das mais marcantes produções culturais da história do país.

Essa esfera pública politicamente ativa derivaria então de uma espécie de esfera pública "literária" gerada no interior do sistema de comunicação de massa, que questiona os padrões comportamentais, culturais e políticos da época. A violência do Estado contra as liberdades individuais durante o regime militar, no entanto, parece ser sua principal fonte de inspiração. Isso porque segundo Maria Hermínia de Almeida e Luiz Weis, quando o regime reprimia a manifestação política na esfera pública, a política era deslocada para o espaço privado, onde uma publicização pode ocorrer na forma autêntica, isto é, a partir de expressões das autocompreensões individuais e coletivas de pessoas que viviam sob tempos em que os limites entre o público e o privado no país se esfumaçam, tornam-se instáveis e muitas vezes hostis entre si.

Os relatos e discussões reveladores de Almeida e Weis em "Carro-zero e pau-dearara: o cotidiano da oposição de classe média ao regime militar" são esclarecedores e reveladores. Também do IV volume de História da Vida Privada no Brasil, trata d as resistências de um público específico do país ao regime militar, a classe média universitária e profissional e outros atores que compunham a "sociedade civil".

Os autores partem de uma aparentemente fictícia história dos sentimentos de um grupo de jovens universitários e profissionais entre seus trinta anos de idade que decidira torcer contra a seleção brasileira de futebol na final da copa do mundo de 1970 por entender que a derrota prejudicaria o regime político autoritário que eles tanto repudiavam. ${ }^{181}$

\footnotetext{
181 "Embora fluidas, as fronteiras do universo oposicionista talvez sejam mais simples de demarcar do que propriamente a esfera - pública ou privada - das ações de oposição e seu entrelaçamento com o cotidiano dos opositores. É consenso considerar privado, em sentido amplo, o âmbito da chamada sociedade civil: as atitudes, atividades, relações, instituições e formas de organização não voltadas para o sistema político, ou, mais especificamente, não orientadas para influenciar, conquistar ou exercer o governo. Assim, fazem parte do universo privado: a família, o círculo de amizades, as relações amorosas, a experiência religiosa ou mística, o trabalho, o estudo, o lazer, o entretenimento e a fruição da cultura." (Almeida \& Weis, 1998:326327).
} 
Um dos grupos de maior destaque nessa problematização pública irrompida do reencontro inevitável de pretensões políticas com o espaço privado foi aquele ligado à produção artística e cultural do país. Os diversos exemplos de membros dessa classe profissional que foram censurados, exilados, presos, torturados e até lobotomizados destacam de modo negativo a força da esfera pública artístico-cultural que se formara então, com capacidade de expressar questões públicas em histórias da vida privada ${ }^{182}$, ganhando por isso grande capilaridade e interação com o grande público nacional, especialmente com os Festivais da Música Popular Brasileira, transmitidos pelas TVs Record, Excelsior, Rio e Globo entre 65 e $85 .^{183}$

O movimento artístico-cultural Tropicália, liderado por Gilberto Gil, Caetano Veloso, Nara Leão, os Mutantes, Gal Costa, Tom Zé, entre outros é característico para sinalizar a tentativa de ruptura com formas convencionais da arte da época, especialmente porque eram considerados apolíticos demais para os movimentos estudantis e as elites intelectuais, e musicalmente muito experimentais em comparação com a Jovem Guarda. Em sua busca por uma identidade artística autenticamente brasileira, Caetano e Gil propunham a Tropicália como "o avesso da bossa-nova", uma arte que seria ao mesmo tempo contracultura. Acabaram sendo presos e exilados em Londres em 1968, após utilizarem em show uma bandeira feita pelo artista plástico Hélio Oiticica com os escritos "Seja Marginal, Seja Herói” (Moreira, 2010:14). Mas retornaram para se tornar artistas renomados, e Gilberto Gil inclusive Ministro da Cultura durante os seis primeiros anos do governo Lula (2003-2008).

As censuras preferiam pecar pelo excesso no rigor do na flexibilidade de seus pareceres, mas às vezes criavam cenas esdrúxulas, como os diversos interrogatórios do DOPS e os pareceres da censura às músicas de Chico Buarque (344-347). ${ }^{184}$ Por outro lado, a repressão à liberdade de expressão artística nacional se desdobrou também em

\footnotetext{
${ }^{182}$ A música "Panis et circencis", gravada em 1968 pela banda Mutantes, cuja letra repete diversas vezes o verso "mas as pessoas da sala de jantar, são ocupadas em viver e morrer", é um exemplo desse tipo de criação que revela a partir do espaço privado o estado de espírito de uma juventude que procura sair a público de modo inovador. V. letra completa em www. http://letras.terra.com.br/mutantes/47544/ (último acesso: 23/09/2011.

${ }^{183}$ Para mais sobre o movimento tropicalista, v. Moreira, R. Tropicália. Coleção Estadão: Grande Discoteca Brasileira, v. 1. São Paulo: Moderna, 2010. Para mais sobre a sociedade brasileira do período e sua produção cultural, v. Ventura, Z. 1968. O ano que não terminou/ O que fizemos de nós. Ed. rev. São Paulo: Planeta do Brasil, 2008; Wisnik, J. M. Caetano Veloso. Série Folha Explica. São Paulo: Publifolha, 2005.

${ }^{184}$ Alguns dos documentos públicos, como pareceres da censura analisando as canções de Chico Buarque foram disponibilizados na exposição "Registros de uma Guerra Surda", no Arquivo Nacional do Rio de Janeiro, inaugurada em $1^{\circ}$ de abril de 2011. Para acessar algumas delas, v. sobre a iniciativa, do projeto "Memórias Reveladas" do Ministério da Justiça em http://www.direitoshumanos.gov.br/2011/04/04-mar2011-exposicao-registra-os-47-anos-do-inicio-da-ditadura-no-pais (último acesso:23/09/2011).
} 
cenas extremamente tristes e violentas, como quando o elenco da peça "Roda Viva", composta por Chico Buarque e dirigida por José Celso de Souza Martins foi espancado pelo Comando de Caça aos Comunistas (CCC) em São Paulo, em julho de 1968, tendo seu teatro de ensaio e cenário depredados. Apesar do sucesso com o público, a peça teve de ser interrompida em função da repressão do CCC (Moreira, R. Tropicália, 2010:16).

Outro espaço de tensões entre público e privado tratado no ensaio de Almeida e Weis é na relação da imprensa com a política do regime. Nesses tempos de censura e repressão das liberdades individuais e políticas, a atividade jornalística teria se alterado profundamente, exigindo dos profissionais condutas de neutralidade, objetividade e velocidade na produção de notícias e furos, sob o risco de perderem seus empregos. As censuras públicas e privadas a que eram acometidos os repórteres e redatores, levavam aqueles que ainda queriam manter um posicionamento político e de liberdade de informação a utilizar artifícios estilísticos e criptografados para driblar a censura e seus próprios chefes (Almeida \& Weis, 1998:348-350).

Os editores e donos das grandes mídias, por outro lado, entre conservadoras e oposicionistas, mantinham delicadas relações com a censura estatal, mas também se comportavam como censores de seus próprios jornais e de outras publicações menores que derrubavam no processo de concentração dos meios de comunicação característico do país (Id. op. cit:351-357). Exemplo desse caso seria a passagem de uma aparente concorrência entre a TV Tupi, primeira televisão brasileira fundada em 1950 por Assis Chateaubriant cuja concessão, cassada em Silvio Santos obteve do governo em 1981 para fundar o SBT e a mais liberal TV Excelsior, para a extinção de ambas e o reinado da Rede Globo em $1970 .^{185}$

Havia apesar de tudo um jornalismo crítico "de oposição", especialmente ligado a publicações comunistas ou profissionais da imprensa que se mantinham nos jornais maiores pelos contatos e sagacidade na escrita. ${ }^{186}$ A pressão do regime e das próprias

185 "É sabido que a Rede Globo foi a maior beneficiária das novas políticas. A nova rede cresceu rapidamente, movida por uma combinação de diversos fatores, como relações amistosas com o regime, sintonia com o incremento do mercado de consumo, uma equipe de produção e administração preocupada em otimizar o marketing e a propaganda, um grupo de criadores e esquerda vindos do cinema e do teatro" (Hamburger, 1998:445). A autora cita importantes textos para o conhecimento da história da hegemonia da Rede Globo, que vale a pena serem aqui reproduzidas para fins de aprofundamento: Maria Rita Kehl "Eu vi um Brasil na TV", in. Kehll, A. H. da Costa e I. F. Simões (Eds). Um país no ar; H. Guimarães, "Literatura em televisão"; e S. Mattos. Um perfil da TV brasileira. Recomenda-se também importante referência sobre a história da rede globo, o documentário da BBC inglesa "Muito Além do Cidadão Kane", até hoje proibido de exibição e reprodução no país.

186 “....a oposição jornalística não consistia em outra coisa senão em querer transmitir ao público os fatos que contavam, com precisão o objetividade, e as diversas idéias que pudessem iluminá-los. Ao trazer dentro de si 
condições do jornalismo industrializado levaram muitos a desistir de seus ideais e assumir os novos imperativos como regra, tornando-se cética e destrutiva em relação à esquerda. (Almeida \& Weis, op. cit:358-359). Isso demonstra que mesmo com os constrangimentos de uma imprensa vigiada e censurada pelo Estado, faziam-se presentes neste período no país as mesmas tendências opostas que Habermas identificara no diagnóstico de MEEP: de um lado a fabricação da esfera pública como um clima de opinião aclamatório, e de outro um jornalismo investigativo e literário de profissionais e leitores críticos que ainda procuram se comunicar a partir de tentativas de auto-compreensão subjetiva. (v. Habermas, 2003:254-255). Mesmo não conseguindo se manter com a tecnificação do jornalismo, tablóides como $O$ Pasquim procuravam denunciar a falácia dos jornalistas limitados à técnicos da neutralidade ou da objetividade.

Da mesma forma, neste final dos anos 70 estavam inscritas as marcas de uma esfera pública política - de modo tanto afirmativo quanto negativo na realidade social brasileira nas tensões e rebeldia da vida universitária ${ }^{187}$, na solidão e solidariedade dos exilados e foragidos, na dor e humilhação de $\operatorname{presos}^{188}$ e torturados e na ruptura de padrões no interior das famílias a partir de novos ideais políticos e morais, especialmente dos mais jovens e militantes. Essas formas de problematização das relações entre público e privado representaram um inegável momento de grande agitação política na história do país, com a definição e a polarização de ideologias e invasões do Estado na sociedade e da sociedade em direção ao Estado ${ }^{189}$ (Almeida \& Weis, 1998:362-409).

a denúncia do autoritarismo, as idéias e fatos divulgados conteriam também a semente da restauração democrática." (Almeida \& Weis, 1998:358).

187 "A hostilidade do regime ao mundo acadêmico, em especial aos cursos de humanidades, tidos como 'antros de subversão', só fazia aumentar o poder de sedução da vida universitária sobre os jovens e o 'espírito de corpo' que se formava naturalmente nas escolas, ao qual era quase impossível ficar alheio. Sob o autoritarismo, a universidade era o ambiente onde política e vida privada se confundiam numa experiência única - e inédita - para um número expressivo de estudantes. Pois naqueles anos, a política tinha a ver com tudo o que representava para um jovem o fato de entrar numa faculdade: novos hábitos, novas amizades, novos gostos, novos conhecimentos, novas convicções." (Id. op. citi, 1998:364).

${ }^{188}$ Das 4.124 pessoas processadas durante o regime militar, $60 \%$ tinha curso universitário concluído ou em andamento. "Das 3698 cuja ocupação é conhecida, 906 - praticamente uma em cada quatro do total, formando o maior grupo - eram estudantes. Seguem-se os 599 profissionais liberais com formação superior $(16,2 \%)$ e os 319 professores, representando 8,6\% do conjunto." (Id. op. cit:326).

189 Para aprofundamento na contextualização da política brasileira durante o regime militar e na transição para a democracia, recomenda-se o excelente documentário Cidadão Boilesen (2009, Direção: Chaim Litewski), que retrata esse momento da história política do Brasil por meio de depoimentos e pesquisas sobre a vida do empresário Henning Boilesen, então presidente do grupo Ultragás, assassinato em 1971 por movimentos revolucionários nacionais por sua ligação e apoio à OBAN (Operação Bandeirante), formada por militares e agentes oficiais que perseguiram, prenderam e torturaram civis suspeitos e participantes de atividade de oposição ao regime. 
d) novas interpretações da esfera pública política a partir da redemocratização e da emergência das novas tecnologias de informação e comunicação na passagem do século $X X$ ao $X X I$

No momento em que a polarização das ideologias políticas da última década do regime militar passa a ser mediada por uma imprensa e por meios de comunicação eletrônica cada vez mais avançados tecnologicamente - embora mais concentrados nas mãos de poucos proprietários civis, ou mesmo de membros do corpo político ${ }^{190}{ }^{-}$, ela se intensifica, desdobrando-se nas pressões para o processo de redemocratização.

É significativo que o primeiro ato público de protesto contra o regime após a edição do Ato Institucional n. 5, que revogara entre outras liberdades a de manifestação política, o ato ecumênico convocado e celebrado pelo arcebispo Dom Evaristo Arns, que reuniu oito mil pessoas na praça da Sé em São Paulo em 1975, tenha se dado especialmente como repercussão da morte do jornalista Vladmir Herzog, que se posicionava contra um jornalismo apolítico e refém da neutralidade e da técnica. Para muitos, foi quando se comprovou de fato a toda a sociedade a prática institucionalizada de tortura pelo regime, dando o estopim dos movimentos populares que pressionariam pela queda, a ocorrer de modo definitivo dez anos depois.

Analisar o processo de redemocratização tendo por base a emergência das novas de tecnologias de informação e comunicação permite uma caracterização peculiar das ambivalências da re-institucionalização de uma esfera pública democrática no país. Isso porque os dois fenômenos descritos por Habermas para caracterizar a esfera pública política de meados do século XX em MEEP, a ficção constitucional da esfera pública e a transfiguração do princípio da publicidade, podem de encontrar expressão tanto na amplificação que a imprensa e os meios de comunicação deram aos grandes debates e fatos políticos como a Constituinte de 88 e a morte de Tancredo Neves, como também em sua colaboração para construção da legitimação política na transição para o novo regime, e.g.

\footnotetext{
${ }^{190}$ Em A Televisão Brasileira na Era Digital (2007), Bolaño e Brittos destacam dados atuais das principais redes de TV aberta do país, em que há clara maioria dos meios em mãos privadas, liderada por cinco famílias com mais da metade que as geradoras e retransmissoras do Estado: Marinho (121 geradores), seguido por Abravanel (91), Macedo (76), Saad (43) e outras, seguidas de longe por emissoras educativas do Estado (20 geradores). Bolaño \& Brittos, 2007, p. 217. "Geradores são emissoras comercializáveis localmente, observam os autores, com dados do Grupo de Mídia de São Paulo. Mídia dados 2006. São Paulo, 2006, p. 162. Dados sobre concentração da propriedade no rádio, o modelo de oligopólios fica também claro com a região Sudeste (1.346 emissoras) liderando, seguida da Sul (876), Nordeste (847), Centro-oeste (359) e Norte (240), e as emissoras líderes a Gaúcha Sat AM em primeiro (127 emissoras), seguida da American Sat FM (70), a Jovem Pan Sat AM (76), a Rede Bandeirantes Am/FM (60), Jovem Pan Sat FM (51) Transamérica (49) e outras (Bloaño \& Brittos, 2007:264. Novamente citação de fonte do Grupo Mídia de São Paulo, dados de 2006).
} 
na reacomodação das forças políticas nacionais a partir das concessões de rádio e televisão distribuídas nos governos democráticos (Bolaño, 2000:275).

No último caso, a expressão “coronelismo eletrônico" continua pertinente para caracterizar esse processo de reacomodação do poder político que ocorreu durante a ditadura e na redemocratização. Ela é utilizada por teóricos da comunicação social desde o início dos anos 90 para caracterizar as formas de perpetuação e concentração de poderes locais de agentes públicos e grandes empresários a partir das políticas de concessão pelo governo de canais de rádio e televisão e seus retransmissores. Essas concessões se tornam moeda de troca política, e por isso seu mapeamento pode servir para esclarecer momentos importantes da história política do país. ${ }^{191}$

A idéia da ficção constitucional da esfera pública no Brasil, como disparidade entre a previsão da soberania popular e as condições materiais de controle público da administração e das organizações sociais de influência política, ganhou seus contornos durante a consolidação da República. Nesse momento, tal o descompasso poderia ser caracterizado como aquele entre as expectativas normativas de uma ordem republicana e democrática, com procedimentos impessoais e direitos e garantias coletivas e individuais fruídas e fiscalizadas por cidadãos competentes e racionais, e uma realidade política marcada por traços da autoridade tradicional, personalista e afetiva dos sistemas anteriores que se entrelaçam com essas expectativas e procedimentos e dificultam sua realização (Gomes, A, 1998:499).

Essa ambiguidade entre as pretensões modernas e tradicionais de separação entre público e privado em comparação com a realidade nacional impede justamente que se tenha uma visão dicotômica entre ambos; mesmo porque o "público" e "moderno" não representam somente o "correto e o bem", e o privado e tradicional o "incorreto e o mal". Essa percepção de um entrelaçamento constitutivo entre ambos os lados, no entanto, não seria só uma necessidade do caso brasileiro, pois ela parece orientar análises empíricas e normativas da filosofia política do presente. A importância de que diferentes tradições de

\footnotetext{
${ }^{191}$ A importante questão das concessões de rádio e televisão será devidamente tratada no tópico 2.1.1 desta tese. Para um importante estudo sobre o tema do coronelismo eletrônico, v. Costa \& Brener, Coronelismo Eletrônico", 1997. Para mais sobre o tema, e como atualmente as concessões de canais de rádios comunitárias seriam utilizadas como um "coronelismo eletrônico de novo tipo", v. o aprofundado estudo de Venício A. de Lima e Cristiano A. Lopes. Coronelismo Eletrônico de Novo Tipo (1999-2004). As autorizações de emissoras como moeda de barganha política. In. Observatório da Imprensa. 2007. Disponível em:

www. http://www.observatoriodaimprensa.com.br/download/Coronelismo_eletronico_de_novo_tipo.pdf (último acesso: 27/09/2011). Para um estudo que discute os usos e imprecisões do termo "coronelismo eletrônico", v. Farias, R. Coronelismo "Eletrônico". Por um reposicionamento do problema, 2009.
} 
autoridade política e social não mais se oponham, mas realizem processos de aprendizagem recíproca, como é o caso da relação entre religião e esfera pública destacados por Habermas e Entre Naturalismo e Religião (2007:115-168 e 279-392), parece já estar presente a partir da seguinte análise de Ângela de Castro Gomes sobre a autocompreensão da esfera pública política nacional:

“...esse amplo consenso quanto à situação de fronteira em que vive a política brasileira ganha o sentido de uma 'ambiguidade constitutiva', que não poderia nem deveria ser completamente desfeita, em razão de fatos e valores que marcam nossa formação nacional. Se essa característica é a causa de nossos males, é por meio de seu remanejamento que se poderiam encontrar novos caminhos para percorrer. A modernização política do país teria, portanto, que recorrer a procedimentos sofisticados, por não poder realizar descartes categóricos e divisões maniqueístas entre o bem, público, e o mal, privado.” (Gomes, A. de, 1998:501-502. Itálico nossos).

A ideologia do nacionalismo impulsionou o aumento de políticas sociais e de intervenção do estado na economia do país. As políticas de modernização da indústria brasileira privilegiaram a produção de bens de consumo que, apesar de centrada em fábricas de multinacionais, permitiu uma elevação do padrão de consumo da população, malgrado os grandes índices de desigualdade social. ${ }^{192}$

Inspirados em Celso Furtado de Um projeto para o Brasil (1968), João Manuel Cardoso de Mello e Fernando Novais no texto "Capitalismo Tardio e Sociabilidade Moderna" do volume IV de História da Vida Privada no Brasil, entendem que na segunda metade do século XX, o Brasil poderia ser dividido entre uma elite empresarial e ocupantes de altos cargos públicos que desfrutam benesses do primeiro mundo, uma crescente classe média intelectual e empregada por essa elite que alcança um notável espaço privado com benesses semelhantes, e uma grande massa de trabalhadores com salários baixos e muitas vezes em condições de subemprego nas grandes cidades e nos centros urbanos (Mello \& Novais, 1998:635-636).

Apesar dessa configuração social e um aumento da dependência financeira internacional, algumas pretensões normativas democráticas chegam a se cristalizar até o

\footnotetext{
192 Mello e Novais recuperam dados de 1980 de estudo "Ciclos e mudanças estruturais na economia brasileira do pós-guerra”, de José Serra, in. Belluzzo \& Coutinho (orgs.) Desenvolvimento Capitalista no Brasil (1983), para indicar que no período, $20 \%$ dos trabalhadores mais qualificados do país eram responsáveis por uma renda de $66,1 \%$ do total, enquanto que os $60 \%$ menos qualificados detinham $17,8 \%$. Esses dados sinalizam um aumento das desigualdades sociais em relação aos anos 60: neste período, enquanto os mais abastados detinham 54,8\% da renda, os trabalhadores subalternos e do campo tinham 24,9\% (Mello \& Novais, 1998:633-634).
} 
início do regime militar: reforma agrária e políticas de intervenção na economia para a redução das desigualdades sociais e fluxos migratórios, escolas públicas (acessíveis a todos) e republicanas (formadoras dos valores democráticos), aumento de salários e políticas sociais, "controle do poder econômico privado, representado antes de tudo pelo capital multinacional”, bem como um "controle público dos meios de comunicação de massa" (Mello \& Novais, 1998:616-617).

Isso porque é por esses meios que os diferentes interesses e orientações políticas que marcaram o período são difundidos. A universalização do acesso à televisão e a profissionalização e vetorização da força política de determinados veículos de imprensa, embora mais concentrados (Id. op. cit:638-639), levavam essas mídias a assumir cada vez mais a função de conectar os diferentes extratos sociais com as ideologias políticas que oscilavam até o início do período autoritário. Entre um liberalismo frágil e dicotômico e o apoio a regimes mais intervencionistas, e contra o "fantasma do "comunismo ateu", o consenso mesmo parecia ser a favor da afirmação de uma cultura nacionalista, que integrava o país junto aos "milagres" de um crescimento econômico e populacional que o elevaria à posição de oitava economia mundial (Mello \& Novais, 1998:615-618).

Os anos 70 representam um período importante para o desenvolvimento da indústria cultural no Brasil, numa espécie de "entressafra" do processo de desenvolvimento das instituições democráticas iniciado na República ${ }^{193}$, diferentemente da Europa, onde já se vive desde o pós-guerra em processo de redemocratização. Essa peculiaridade colabora para uma degradação peculiar do princípio da publicidade em propaganda, pois a televisão se estabelece como meio hegemônico em meio ao avanço das técnicas de produção e disseminação de informação operado dentro do regime autoritário. Em função disso, a esfera pública política mediatizada deste período tem por característica uma opinião pública carente do embate de ideias, e portanto, refém das opiniões dominantes. ${ }^{194}$

\footnotetext{
193 “....no período liberal-democrático de 1945 a 1964, a escola, a universidade, os sindicatos, os partidos políticos, os movimentos culturais, todos eram palco do debate de idéias e da controvérsia política, todos iam ajudando a constituir um público que adquiria, pouco a pouco, capacidade de julgamento independente. Mais ainda: a diversidade do público embrionário tendia a se refletir nas diferentes orientações dos órgãos de imprensa. Sob o império da ditadura, o fechamento do espaço público e o abastardamento do ensino dão surgimento a um leitor de jornais e revistas que os tem como uma única fonte de informação, submetida à censura e presa aos interesses - materiais, políticos ou culturais - do proprietário." (Mello \& Novais, 1998:639).

194 "Para além da censura imposta pelo autoritarismo, a preeminência, na TV, do entretenimento sobre a educação, de um lado, e, de outro, a liquidação do embrião de opinião pública associado ao triunfo da empresa jornalística gigante levam a um esquecimento dos valores substantivos: a verdade cede o passo à credibilidade, isto é, ao que aparece como verdade; o bem comum subordina-se inteiramente aos grandes interesses privados; a objetividade abre espaço à opinião, isto é, à opinião dos formadores de opinião, em
} 
O espaço vazio deixado pela eliminação do debate público é preenchido por uma publicidade comercial crescente ${ }^{195}$ e a própria transformação da política em propaganda (Mello \& Novais, 1998:640 e 652), especialmente quando a esfera pública formal, como os partidos e parlamentos, cedem espaço para a grande imprensa e os meios de comunicação de massa como lugares de uma política transfigurada em "espetáculo de TV" (Id. op. cit::651-652). Ao final, o diagnóstico de Novais e Cardoso se assemelha ao de Habermas em $M E E P$, pois também denuncia a transfiguração da racionalidade política a partir do desenvolvimento e da concentração dos meios de comunicação de massa no Brasil.

“O domínio da grande empresa da indústria cultural, estabelecido à sombra do autoritarismo plutocrático, caracteriza um monopólio tecnológica e organizacionalmente avançado, o dos novos meios de comunicação social, que escapa inteiramente ao controle público. Mas não é um monopólio qualquer: difunde valores - morais, estéticos e políticos - que acabam por determinar atitudes e comportamentos dos indivíduos e da coletividade. Exposta ao impacto da indústria cultural, centrada na televisão, a sociedade brasileira passou diretamente de iletrada e deseducada a massificada, sem percorrer a etapa intermediária de absorção da cultura moderna. Estamos, portanto, diante de uma audiência inorgânica que não chegou a se constituir como público; ou seja, que não tinha desenvolvido um nível de autonomia de juízo moral, estético e político, assim como os processos intersubjetivos mediante os quais se dão as trocas de idéias e de informações, as controvérsias que explicitam os interesses e as aspirações, os questionamentos que aprofundam a reflexão, tudo aquilo, enfim, que torna possível a assimilação crítica das emissões imagéticas da televisão e o enfrentamento do bombardeio da publicidade.” (Mello \& Novais, 1998:639-640. Itálicos dos autores).

Essa análise se mostra diversa daquela realizada por Ângela de Castro Gomes em “A política brasileira em busca da modernidade” (Gomes, A. de, 1998:551-558), cujo excerto anteriormente transcrito traz uma concepção menos linear e evolucionista de modernidade. Isso porque quando se pensa que a esfera pública política de uma sociedade massificada teria como pré-condições uma separação clara entre público e privado, ou uma

geral membros da elite ligados direta ou indiretamente aos grandes interesses." (Mello \& Novais, 1998:639. Grifos nossos).

${ }^{195} \mathrm{O}$ estudo de Mello e Novais também trabalha como Habermas a profissionalização das indústrias da propaganda comercial e seus efeitos sobre a racionalidade econômica e da cultura utilitária do consumo, embora sem tratar da publicidade transformada pelo fenômeno das relações públicas: "Nos anos 60, a publicidade no Brasil muda de natureza e se sofistica. Os 'criadores' tomam o lugar dos redatores, e a concepção dos anúncios passa a envolver uma noção global, isto é, a unidade criativa, pois 'o título' passa a ser subordinado à 'arte'. O apelo à emoção e a mobilização do inconsciente desalojam a argumentação racional. A americanização da publicidade brasileira tem um papel fundamental na difusão dos padrões de consumo moderno e dos novos estilos de vida. Destrói rapidamente o valor da vida sóbria e sem ostentação." (Mello \& Novais, 1998:641). 
cultura política "acostumada à liberdade", corre-se o risco de uma relativização de exemplos históricos de formação de públicos de pessoas privadas na história brasileira, como se tem identificado ao longo deste breve histórico.

Além disso, como o próprio Habermas analisa ao final de seu diagnóstico sobre ideia de esfera pública em MEEP (cap. IV), mesmo constatando que seus princípios não se efetivam da forma que se espera na realidade política, como exercício crítico que é, essa própria constatação negativa se apresenta como uma forma de limitar o uso da esfera pública como mera ideologia (Habermas, 2003:273).

Mas a leitura de Mello e Novais sobre a esfera pública brasileira das últimas quatro décadas do século XX ainda encontra respaldo empírico e teórico para se sustentar como uma abordagem crítica que denuncia sua ficção constitucional como distância entre teoria e prática. Em termos empíricos, a emergência de políticas neoliberais cumpre importante papel em seu argumento. Elas se fortalecem com a crença de que a origem de todos os males sociais seria o regime estatal e, portanto, quanto menos intervenção do Estado na economia, melhor para o país. Como consequência, tem-se uma degradação das políticas sociais e uma transferência de tarefas para o setor privado, submetendo as políticas positivas de garantia de direitos sociais à lógica do mercado capitalista (Mello \& Novais, 1998:651-652).

O aumento das desigualdades sociais e de um "individualismo de massas" decorrentes da financeirização da economia mundial e nacional nos anos 80 e 90 leva inevitavelmente a uma explosão da violência urbana e dos conflitos de classe (Id. op. cit:652). Isso faz com que se possa pensar exatamente no contrário daquilo que fundamentara o próprio neoliberalismo: que a ordem social militar teria garantido mais políticas sociais, distribuição de renda e controle da violência do que a recém implantada democracia.

Os efeitos desse contexto sobre a cultura política brasileira seriam então previsíveis. A apatia e a sensação de inferioridade abatem ainda mais os muitos cidadãos que lutam para não ter uma vida de privações, enquanto que aqueles capazes de desfrutar de uma privacidade referida ao público estão envolvidos diretamente na cultura do consumo, do sucesso individual, da meritocracia e diversos outros valores utilitários difundidos pela indústria cultural, que se naturalizam ao não serem mais questionados. 
A família estaria "sitiada", pois invadida constantemente pela propaganda e a cultura do consumo e da "competição livre" disseminada nos meios de comunicação. As realizações pessoais e formações de personalidades são cada vez mais orientadas pelos limites de uma liberdade que é somente negativa, e por isso individualista, estratégica e cética em relação a ações de solidariedade social, de ativismo cívico e de participação na formação da opinião pública (Id. op. cit:653-656).

Em termos teóricos, Mello e Novais citam Theodor Adorno para finalizar seu estudo. Curiosamente, no entanto, é o diagnóstico do filósofo sobre a cultura alemã no final dos anos 70 - sobre uma vida reificada pela indústria cultural que parece negar qualquer possibilidade de autonomia do indivíduo -, que cai como uma luva para retratar o avesso da esfera pública política "inexistente" no Brasil (Id. op. cit:658).

De fato, o problema da existência ou não de autonomias individuais capazes de gerar a força de integração social de esferas públicas politicamente ativas não é só brasileiro. Estudos recentes que se propõem a compreender o impacto das novas tecnologias de informação e comunicação na reprodução da ordem capitalista comprovam que a mudança estrutural da esfera pública burguesa é um processo global, pois a expansão do capitalismo monopolista a partir do desenvolvimento das indústrias de informática, temática, robótica e cibernética, e suas aplicações na indústria da cultura e da comunicação requer a fabricação de esferas públicas na forma de indústrias culturais capazes de garantir a continuidade da legitimação do sistema de reprodução material e social. ${ }^{196}$

A chamada "economia política da informação e da comunicação", que atualiza para o final do século XX os diagnósticos de Marx sobre a economia capitalista, não descarta a importância da indústria pesada e de bens de consumo no condicionamento dessa reprodução material. Mesmo em modelos econômicos de informatização brusca da economia nesse período, como o dos EUA, que influenciam o neoliberalismo brasileiro a partir do "Consenso de Washington", ainda há uma dependência da indústria manufatureira, esteja ela localizada em outra parte do planeta (Bolaño \& Mattos, 2004).

De todo modo, o inchaço que o setor de serviços conhece a partir dos anos 70, com vultosos investimentos e um incremento tecnológico que otimiza significativamente a

\footnotetext{
${ }^{196}$ César Bolaño discute essa questão em sua obra Indústria Cultural: Informação e Capitalismo (2000), quando procura caracterizar como as tendências mundiais de segmentação e especialização das indústrias culturais não dispensam a fabricação de esferas públicas mediatizadas: "Ora, se há uma tendência a um avanço da diferenciação, exigindo maior segmentação dos públicos, pelo grande capital monopolista, e se o próprio Estado busca uma ação social mais dirigida a grupos específicos, incorporando ainda o referencial publicitário na sua relação com as massas, isso não elimina a necessidade de uma esfera pública nacional que garanta as condições de legitimação do Estado pós-liberal.” (Bolaño, 2000:274).
} 
acumulação do capital e a expansão de mercados, faz com que diversos estudiosos da área entendam o momento como uma fase de reestruturação das forças produtivas capitalistas; em alguns casos, fala-se num "capitalismo informacional" (Hardt \& Negri, 2000:280-303; Castells, 2005:17-30).

$\mathrm{O}$ advento da rede mundial de computadores, a Internet, aparece nesse contexto como uma ampliação e aceleração das transformações em curso, isto é, as contradições e assimetrias da economia globalizada se amplificam com o surgimento e a expansão da rede. Ao mesmo tempo, as novas possibilidades de comunicação interativa proporcionadas pela internet, como o correio eletrônico pessoal, os portais de notícias e vídeos, os diários virtuais e as redes sociais promovem importantes transformações nas relações entre público e privado, especialmente no sentido de uma ampliação sem precedentes da esfera pública, já que não são só mercadorias e bytes a trafegar pela rede, mas também expressões estéticas e pessoais, pleitos políticos, distribuição e compartilhamento de informações e visões de mundo. Com isso, novas problematizações entre as esferas do público e do privado são promovidas em todo o globo, seja nos planos da economia e da cultura, com a "produção social” e a produção peer to peer (Benkler, 2006), na política, com a chamada Primavera Árabe e o Wikileaks, ou nas relações da intimidade, com diversas formas de superexposição do privado no público e invasões violentes do público sobre o privado.

No caso brasileiro não é diferente. Com uma economia mais estabilizada interna e internacionalmente desde os anos 2000, uma percentagem crescente de acesso à internet nos anos 2000 semelhante e agora proporcionalmente superior ao acesso mundial ${ }^{197}$ - e índices elevados de utilização das mais conhecidas redes sociais digitais, o país caminha pari passu com a tendência mundial para se constituir uma "sociedade da informação" (Xavier \& Mattos, 2007). Como se verá no diagnóstico do segundo capítulo, esse movimento tencionará ainda mais as interpenetrações entre público e privado, suscitando formas peculiares de problematização em cada uma de suas esferas de integração social.

\footnotetext{
${ }^{197}$ Em dezembro de 1998, 3,67\% da população mundial (150 milhões) tinha acesso à internet, mas em maio de 2002 esse número subiu para 9,5\% (580,78 milhões). No Brasil, também em 2002, 7,74\% (13,62 milhões de pessoas) tinham acesso à internet. Atualmente (dados de 12/09/2011) o Brasil é o quinto país do mundo com mais acesso à internet: 81,3 milhões tem tido algum tipo de acesso à rede, ainda que na chamada lan house, enquanto que $38,8 \%$ da população tem acesso regular. Dados disponíveis no endereço eletronico http://tobeguarany.com/internet no brasil.php (último acesso: 29/09/2011). Para um estudo aprofundado de acesso à internet, v. Acesso à internet e posse de telefone móvel celular para uso pessoal, 2005. Minstério do Planejamentor publicado pelo IBGE, http://www.ibge.gov.br/home/estatistica/populacao/acessoainternet/internet.pdf
} 
Essas problematizações, quando têm por objeto pretensões de comunicação e de reconhecimento ligados à garantia da legitimidade dos direitos de autonomia individual, constituem a possibilidade da emergência de uma esfera pública política. Tomada nesse sentido, e ainda que neste breve histórico a partir das afirmações e negações dos diversos públicos que emergiram no país desde o questionamento das formas de dominação coloniais, torna-se difícil negar no Brasil a existência (e a persistência) daquelas aspirações a uma privacidade protegida do público e a uma racionalização da dominação política que Habermas identificara no surgimento da modernidade ocidental.

\section{Dos públicos às pretensões: fundamentação epistemológica e metodológica para o diagnóstico do presente da esfera pública política brasileira}

Após este esforço para uma breve historicização da esfera pública política no Brasil, este último tópico do capítulo se dedicará a apresentar uma atualização teórica da esfera pública nos textos posteriores de Habermas sobre o tema. Serão destacadas algumas críticas de Mudança Estrutural da Esfera Pública com o objetivo de formular uma nova metodologia para diagnósticos da esfera pública política, que será aplicada ao contexto brasileiro no segundo capítulo da tese. Este foco na esfera pública política nacional não impede, todavia, a possibilidade de se discutir sua aplicação em outros países ou mesmo no plano internacional. ${ }^{198}$

Os subtópicos seguintes visam traçar o caminho das novas concepções de Habermas que levam a essa possibilidade de sugerir como método de diagnóstico uma diferenciação analítica da esfera pública política, abstraindo a formação de públicos específicos para concentrar a análise da esfera pública a partir das pretensões de comunicação e de reconhecimento desses públicos que são violadas, afirmadas e problematizadas e, ao refletirem princípios filosóficos e garantias de participação na reprodução social, na formação da opinião pública e na formação da personalidade, passam a ativar politicamente a esfera pública, a partir da qual se poderá identificar e incidir o direito da comunicação.

\footnotetext{
198 Habermas chega a propor e discutir com diversos interlocutores e obras posteriores à MEEP a possibilidade de uma aplicação de sua concepção de esfera pública em formações internacionais. V. os estudos reunidos em Niesen \& Herborth (orgs.), Anarchie der Kommunicativen Freiheit, 2007, especialmente o último capítulo de Habermas, intitulado "Kommunikative Rationalität und grenzüberschreitende Politik: eine Replik" [Racionalidade comunicativa e política transnacional: uma réplica. Trad. livre]. V. também a parte III da obra Der Sinn von Öffentlichkeit [O sentido da esfera pública. Trad. livre], de Peters (2007:283376), dedicada ao tema da "Transnationale Öffentlichkeit und demokratische Legitimität" [Esfera pública internacional e legimitidade democrática. Trad. livre].
} 
A proposta é fazer aqui, então, uma passagem também panorâmica pelos textos e obras principais de Habermas e seus críticos para a atualização de Mudança Estrutural da Esfera Pública, que darão base teórica para fundamentar o método do diagnóstico do presente da esfera pública política no Brasil. Algumas das questões mais importantes desse método que o aprofundam e o inserem no debate contemporâneo sobre o tema serão retomadas e em cada um dos tópicos da parte II, bem como na discussão mais específica sobre o direito da comunicação na parte III.

a) a esfera pública política e o inevitável resíduo prático da racionalização social

Serão feitas neste subtópico passagens pelas primeiras críticas e atualizações de MEEP por Habermas em Teoria e Prática (1968) e Técnica e Ciência como "Ideologia" (1968). Retoma-se aqui então o estudo teórico, para no segundo capítulo analisar o presente da esfera pública política no Brasil, mas de maneira diferente do que feito na reconstrução de $M E E P$ e na tentativa de historicização acima. Ao invés de ter foco na formação dos públicos e suas relações, será proposta uma abordagem a partir de uma diferenciação analítica de expressões da esfera pública política que, como se verá, são formadas por violações e afirmações de pretensões de comunicação e de reconhecimento. É a partir do diagnóstico dessas expressões que se pretende fazer no segundo capítulo as reconstruções dos conteúdos normativos e dos princípios procedimentais do direito da comunicação no Brasil.

Antecipando o debate do segundo e terceiro capítulos, um dos estudos mais antigos sobre esfera pública e direito de Habermas, "Direito Natural e Revolução" (in. Id. Teoría y Práxis, 1987:87-123), original de 1963, já apresenta algumas reflexões iniciais sobre os direitos ligados a essas pretensões de comunicação e de reconhecimento, que seriam responsáveis pela "garantia de uma da opinião pública atuante" e pelo "livre desenvolvimento da personalidade". No caso, eles são pensados como dois dos grupos de direitos participativos e liberdades positivas complementares aos direitos civis e liberdades negativas da era liberal. Numa espécie de esboço do que somente 29 anos depois em Direito e Democracia Habermas denominará “forma do direito" (Id, 1996:122123), isto é, os direitos fundamentais que precisam ser garantidos quando pensados por meio da teoria do discurso, o autor elenca três grupos de liberdades positivas que complementam suas concepções liberais negativas de modo a garantir uma legitimação democrática das liberdades individuais: 
1. Así pues, aquello que ya no puede garantizarse indirectamente por médio de la demilitación, requiere la garantia positiva: la participación en las producciones sociales y la intervención en las organizaciones de la opión pública política. El grupo de derechos fundamentales que, junto con la garantia institucional de la propiedad como su núcleo, sancionan las libertades fundamentales del derecho privado y que también garantizan la libre elección de profesión, de puesto de trabajo y de educación, adoptan en parte el carácter de derechos de participación y en parte son limitados por otras garantias sócioestatales.

2. Aquel outro grupo de derechos fundamentales que garantizan uma opinión pública políticamente actuante, [que] también se transforma funcionalmente en una garantía positiva de participación y se complementa por médio de princípios jurídicos para la organización de los médios de comunicación de masas, de los partidos y de los consorcios públicos.

3. Incluso los derechos fundamentales que garantizan la integridad de la intimidad familiar y el status de libertad personal pierden, em conexión con un derecho materialmente interpretado sobre el libre desarrollo de la personalidad, aquel carácter meramente negativo, del cual representaban el protótipo en el tránsito de los más antiguos derechos de libertad corporativos a los burgueses. (Habermas, 1987:118-119. Grifos e itálicos nosso).

Nota-se que além de tentar conciliar desde então autonomia individual com autonomia política, Habermas já demonstra estar consciente da reflexão que voltará a sugerir muito depois e de modo mais teórico em Entre Naturalismo e Religião (2007), um tema cuja importância pode ser considerada lateralizada em Direito e Democracia: como o direito pode garantir condições para a formação e a estabilização de identidades pessoais $e$ coletivas (Id. 2007:273). Como visto no terceiro grupo de direitos, essa pretensão é tratada num sentido positivo por Habermas no mesmo "Direito Natural e Revolução", e será pensada não somente como a garantia de um direito cultural coletivo, mas também num sentido individual em Naturalismo e Religião,

A questão dos direitos relacionados à formação da esfera pública política será retomada mais à frente. Agora parte-se para uma análise de alguns dos textos contidos no volume de ensaios intitulado Técnica e Ciência como "Ideologia" (TCI, 1968) de Habermas, publicado em versão portuguesa pela Editora 70 (Lisboa). Neste subtópico serão tratados tanto ensaio que dá título ao volume como os textos "Política Científicada e Opinião Pública”, de 66 e "Progresso Técnico e Mundo Social da Vida”, de 1964. 
Em relação ao texto $T C I$, a mais interessante reflexão que Habermas faz em relação ao tema é o problema da inevitabilidade do caráter prático da esfera pública política, que revela em seu diagnóstico que a violação desse princípio ocorre pela aparência de neutralidade da ideologia objetivista da técnica e da ciência aplicados à política (Habermas, 2006:73-74). ${ }^{199}$ A eficácia de penetração dessa ideologia poderia ser medida exatamente por sua capacidade de eliminar o caráter prático e público das tomadas de decisão política, isto é, quanto ela consegue impedir que os concernidos critiquem e fiscalizem aquilo que se realiza no público e em nome do público.

A profissionalização dos agentes políticos e a cientificização de suas atividades se opõem a uma massa voltada para as compensações sociais do estado de bem estar social, criando um espaço vazio na esfera pública, que passa a impressão de neutralidade a partir da cultura "tecnocrata" do capitalismo tardio (Id. op. cit:70-82 e 122-123).

Ao final do texto, o destaque à questão de uma "opinião pública administrada pelos meios comunicação" é sinal de que é nessa esfera pública mediatizada que ocorre a separação entre técnica e prática capaz de naturalizar a primeira como neutra e a última como pura ideologia. A publicidade se limita à escolha dentre algumas formas de vida como objetos de consumo, e não à discussão sobre como se quer viver a vida em relação a como se poderia vivê-la. Os meios de comunicação de massa aparecem novamente como espaços privilegiados onde ocorre a ocultação da dimensão prática da esfera pública, a única salvaguarda da ideologia tecnocrata. ${ }^{200}$ Mas se podem ocultar essa dimensão pela omissão, ao ser demandada deles tanto quanto de outras instituições uma revitalização da

199 “A consciência positivista comum põe fora de acção o sistema de referência da interacção mediante a linguagem ordinária, no qual a dominação e a ideologia surgem sob as condições $\mathrm{d}$ euma comunicação distorcida e no qual também podem ser penetrados pela reflexão. A despolitização das massas da população, que é legitimada pela consciênca tecnocrática, é ao mesmo tempo uma autoprojecção dos homens em categorias, tanto da acção instrumental como do comportamento adaptativo: os modelos coisificados das ciências transmigram para um mundo sociocultural da vida e obtêm ali um poder objectivo sobre a autocompreensão. O núcleo ideológico desta consciência é a eliminação da diferença entre práxis e técnica (...) // A nova ideologia viola assim um interesse que é inerente a uma das duas condições fundamentais da nossa existência cultural: à linguagem ou, mais exactamente, à forma da socialização e individualização determinada pela comunicação mediante a linguagem comum. Esse interesse estende-se tanto à manutenção de uma intersubjectividade da compreensão como ao estabelecimento de uma comunicação liberta da dominação." (Habermas, 2006:82. Grifo nosso. Itálico do autor).

200 "Uma nova zona de conflitos, em vez do virtualizado antagonismo de classes e prescindindo dos conflitos que as disparidades provocam nas margens do sistema, só pode surgir onde a sociedade tardo-capitalista tem de imunizar-se por meio da despolitização das massas da população contra a impugnação da sua ideologia tecnocrática de fundo; justamente no sistema da opinião pública administrada pelos meios de comunicação. Pois só aqui se pode garantir um ocultamento necessário ao sistema da diferença entre o progresso dos subsistemas de acção racional dirigida a fins e as mutações emancipadoras do marco institucional - entre questões técnicas e questões práticas. As definições publicamente admitidas referem-se ao que queremos para viver, mas não ao como queríamos viver se, relativamente ao potencial alcançável, descobríssemos como poderíamos viver." (Habermas, 2006:89). 
razão prática na esfera pública, isto é, servindo de palco e caixa de ressonância aos debates, esses meios poderiam também servir de espaços em que se problematizam as conexões entre técnica, ética e processos de individuação pela socialização necessários à integração social.

Em seguida no texto "Política Cientificada e Opinião Pública", Habermas parece querer apresentar de modo mais sistemático o que desenvolveu histórica e conceitualmente em MEEP. Isso facilitará o destacamento dos pressupostos básicos dessa atualização do conceito de esfera pública política que serão discutidos na elaboração do método para o diagnóstico do capítulo dois. Destaque é dado para a questão da reaproximação da cultura dos experts com a cultura popular, entre o conhecimento dos profissionais dos políticos ou cientistas e a comunicação cotidiana dos demais cidadãos concernidos, que teriam se separado na instauração da cultura tecnocrática, mas que precisariam manter uma comunicação para a legitimação de suas práticas. Isso só seria possível pelo fomento de uma comunicação mais ampla e intensa entre esferas públicas institucionais e as sociais, cujas trocas de informações mais precisas, opiniões, argumentos e decisões seriam garantidas como públicas (Habermas, 2006:121).

O estado de coisas da opinião pública diagnosticado por Habermas reflete na distância entre ciência e prática vital. A especialização do conhecimento e a dificuldade de diálogo entre os próprios membros da "esfera pública científica" deriva de uma ocupação da esfera pública por índices de empresas de medição "científica” da opinião pública. Com isso, as tendências de especialização da ciência se somam a uma exclusão de uma "opinião pública política", propondo possível verificar suficientemente a opinião pública ou a legitimidade do poder político a partir de uma abordagem somente científica (Habermas, 2006:127).

Ao mesmo tempo, com essa indistinção entre ideologia e normatividade, ou entre poder e validade, abre-se oportunidade para um decisionismo político e jurídico, submetido ao arbítrio individual daquele que tem a competência. De um relativismo ético preocupado com a "ditadura da maioria", chega-se a um ceticismo em relação à autoridade de uma opinião pública política que representaria a soberania popular (Id. op. cit:128).

A partir de uma necessidade de se conferir não só publicidade, mas uma comunicação inteligível e proveitosa entre a ciência, a política e a opinião pública, Habermas propõe um trabalho cooperativo entre as três, o que auxiliaria não só a formação de espaços de expressão da opinião e da vontade políticas, mas também a tradução entre os diferentes saberes necessária para resolver problemas comuns e próprios de cada área, 
incluindo a autocompreensão dos cientistas e dos políticos como cidadãos e a relação de seu trabalho com a opinião pública. O crescimento do jornalismo científico seria importante exemplo de uma forma de comunicação comum entre as áreas e o público leitor. (Id. op. cit:126-127).

No texto "Progresso Técnico e Mundo Social da Vida", Habermas utiliza o texto de P. C. Snow sobre a separação entre as culturas da ciência empírica e a literatura que engloba as "ciências do espírito" para descrever como o desenvolvimento da técnica como forma de "disposição da natureza" aos seres humanos, também não elimina de todo a necessidade de se determinar como será sua inserção no mundo das interações práticas (Id. op. cit:93-96).

A essa tradução entre a disposição da natureza como técnica e o mundo social novamente incumbe uma forma de justificação pública das escolhas e decisões dadas, de modo que o ser humano não perca o controle do progresso técnico-científico, e que possa orientá-lo, por exemplo, a promover melhoras nas suas condições de vida da população (Habermas, 2006:101-106). Estão claras aqui as preocupações de Habermas em relação ao desenvolvimento de energia nuclear, que à época já eram alvos de movimentos da sociedade civil pelo desmantelamento de suas indústrias. ${ }^{201}$

A esfera pública política cumpre aqui também papel fundamental na promoção desse processo de justificação pública, capaz de dissolver a confusão entre "poder e validade" dada pela ausência de reflexão ou a concentração do poder decisório sobre a passagem do conhecimento técnico à vida prática na mão de especialistas. Estava mantida ainda a esperança de Habermas em relação à esfera pública política como espaço de racionalização do poder social, como forma de questionar o avanço da técnica e da ciência e sua determinação irrefletida sobre o marco institucional da política. ${ }^{202}$ 201 As importantes contribuiçães dos movimentos estudantis na formação intelectual de Habermas e em sua
atuação como professor merecem destaque, especialmente com sua colaboração no debate sobre o uso da
energia nuclear, bandeira política até hoje presente na Alemanha. Para mais sobre o tema, a citação de carta
de Horkheimer à Adorno dizendo para que tome cuidado com estudantes como Habermas, na época ainda
seu assistente, que participara de atividades do "movimento anti-átomo", v. Müller-Doohm, S. M.
Parteilichkeit für Vernunft (Parcialidade em favor da Razão. Trad. livre). In. Forschung Intensiv, 2/2009, p.
6; V. também texto Habermas, "Scheinrevolution unter handlungszwang" (Revolução aparente sob
necessidade de ação. Trad. livre) publicado na revista Der Spiegel. N. 24, 1968. Disponível em:
http://www.spiegel.de/spiegel/print/d-46020971.html (último acesso em 03/10/2011), na qual Habermas
critica as técnicas de protesto estudantil, tendo agido em alguns momentos como um "radicalismo autoritário
de esquerda". Ele se referia claramente a protestos como a manifestação de estudantes em aula de Theodor
Adorno na época.
202 "Esta dialéctica de poder e vontade realiza-se hoje de modo irreflectido, ao serviço de interesses para os
quais não se exige nem se faculta uma justificação pública. Só quando conseguíssemos levar a cabo esta
dialéctica com consciência política, poderíamos controlar a mediação do progresso técnico com a prática da
vida social, mediação essa que, até agora se impõe em termos de história natural. Mas, porque isso é um 
Na obra Crise de Legitimação no Capitalismo Tardio (CLCT, 1975), Habermas sugere no capítulo sete uma recepção precoce de elementos das tradições "pré-burguesas", até então ofuscados pela ação orientada ao sucesso do individualismo liberal. Seria o caso de uma "moralidade comunicativa" de um lado e uma "arte desprovida de aura" de outro, que não seriam passíveis de análise pela ótica privatista, já desgastada (2002c:103). Essa tripartição da ação social de grupos específicos como aqueles encontrados nos diagnósticos de $M E E P$, caracterizados por clivagens econômicas, educacionais e culturais, para formas de ação social detentoras de pretensões de validade cujos debates podem atingir acordos racionais, isto é, aceitos por todos e abertos à crítica, identificados por Habermas no processo de racionalização social permitirá se pensar em diferenciações semelhantes para a esfera pública política, a compor o método do diagnóstico a ser aqui proposto (v. suptópico "d" abaixo).

Da mesma forma no capítulo quatro, “O fim do indivíduo?”, é destacada, ainda que não expressamente, a ficção constitucional da esfera pública política por meio da identificação de um "pluralismo de elites" que substitui a "autodeterminação do povo" e permite ao "poder exercido privadamente" não ter fiscalização e se proteger contra o "princípio da formação racional da vontade." (Habermas, 2002c:156).

O debate para revitalizar a razão prática na sociologia e na teoria política segue entre Habermas e Luhmann, e encontra alguns pontos de diálogo interessantes com MEEP no plano semântico, como quando o diagnóstico luhmaniano analisado em CLCT se aproxima da ideia da necessidade de fabricação de uma esfera pública política, a partir da mediatização da opinião desse "pluralismo de elites" com o restante dos consumidores passivos de informação e opinião. Na linguagem de Luhmann, trata-se de uma forma reflexiva de administração da legitimação, cuja "indeterminação" pressuposta ao processo lembra também a ideia trabalhada por Marcelo Neves sobre a necessidade de se garantir antes o princípio do dissenso do que o consenso na esfera pública política. ${ }^{203}$

assunto de reflexão, não incumbe apenas à competência dos especialistas. A substância da dominação não se evapora apenas diante do poder de disposição técnica; pode muito bem entrincheirar-se por detrás desse poder. A irracionalidade da dominação, que se converteu hoje num perigo vital colectivo, só poderia ser dominado através da formação de uma vontade colectiva, que se ligue ao princípio de uma discussão geral e livre de domínio. A racionalização da dominação só podemos esperá-la de situações que favoreçam o poder político de um pensamento ligado ao diálogo. A força libertadora da reflexão não pode ser substituída pela difusão de um saber tecnicamente utilizável." (Habermas, 2006:106).

203 “A política não mais pressupõe sua base de decisão e sim precisa por si mesma criá-la. É necessário realizar sua própria legitimação numa situação, e é definida enquanto aberta e estruturalmente indeterminada com respeito às chances de consenso e aos resultados" (Luhmann, "Komplexität und Demokratie", p. 316. Apud. Habermas, 2002c:165). Para mais sobre a questão do dissenso como garantia do pluralismo de 
b) a esfera pública política a partir da teoria crítica comunicativa

A análise da atualização do princípio da esfera pública política por Habermas e interlocutores continua, trabalhando alguns temas da opus magnum Theorie des Kommunikativen Handelns ${ }^{204}$ relacionados à teoria da racionalidade comunicativa, à esfera pública e à atualização da teoria crítica que Habermas sugere para tentar reativar o materialismo interdisciplinar proposto por Max Horkheimer em 1931 em seu discurso de $\operatorname{posse}^{205}$. Esses temas são especialmente importantes para se trabalhar uma ampliação da base de legitimidade do direito a partir da atualização do conceito de esfera pública política e os fundamentos da diferenciação analítica da esfera pública política a ser proposta em seguida.

No primeiro volume de $T C A$ os tópicos mais importantes para discutir o impacto da racionalidade comunicativa no conceito de esfera pública política são os números 2 e 3 do capítulo I, dedicado à compreensão da articulação interna e aos fundamentos do agir comunicativo - junto à ação estratégica e/ou instrumental e a ação dramatúrgica - como um dos produtos do processo de racionalização social das compreensões de mundo ocorrido desde a modernidade. No capítulo III a discussão com Weber sobre a racionalização do direito oferece também algumas pistas sobre o lugar dado à esfera pública política em TCA.

Apesar de demonstrar em seu diagnóstico da racionalidade moderna fenômeno semelhante à degradação do princípio da esfera pública política: uma supervalorização da razão cognitivo-instrumental e da ação orientada para o sucesso individual sobre a razão regulada por expectativas normativas gerais acessíveis à opinião e à vontade políticas e a racionalidade possível da ação dramatúrgica (Habermas, 1984-I:346-350), é curioso que Habermas não utiliza diretamente durante todo o volume o conceito de esfera pública como forma possível de expressão concreta das tensões entre esses tipos de razão e ação sociais.

interesses na esfera pública, v. Neves, M. Entre Têmis e Leviatã, 2006, pp. 148 e ss. Esse debate será retomado no capítulo 3 .

${ }^{204}$ Será utilizada aqui a versão em inglês traduzida por Thomas McCarthy, intitulada The Theory of Communicative Action (II vols 1984/87 - TCA).

${ }^{205}$ Ver trechos desse discurso, intitulado Die gegenwärtige Lage der Sozialphilosophie und die Aufgaben eines Institut ( $\mathrm{O}$ situação contemporânea da Filosofia social e o trabalho de um Instituto. Trad. livre), em Palermo, R. Uma organização itinerante: O Instituto de Pesquisa Social de Frankfurt. In. DE MASI, D. (org.). A Emoção e a Regra, 2000, pp. 271-274. 
A inspiração nas Três Críticas de Kant e nas esferas de valor da teoria da racionalização de Weber está todavia expressa no diagnóstico crítico da racionalidade moderna que leva Habermas a formular o conceito de razão comunicativa (Id. op. cit:376). O que ele acaba por acrescentar a essas teorias em especial, e que interessa à atualização do conceito de esfera pública política, é a teoria reconstrutiva da pragmática formal como conexão entre teoria e prática para análise de potenciais de racionalidade da interação social - no caso entre a psicologia ontogenética de Piaget e a teoria da competência comunicativa (Id. op cit:67-74) -, e sua peculiar virada linguística da teoria crítica, que desloca definitivamente a instância de possível emancipação social da esfera da "produção" para a esfera da linguagem e da comunicação intersubjetiva.

Em termos da pragmática formal e seu método reconstrutivo, a discussão ainda mais abstrata realizada em “O que é a Pragmática Universal?” (1979) é recepcionada em TCA para o interior do diagnóstico da razão e da ciência moderna, dando condições para Habermas reconstruir da secularização das compreensões míticas de mundo os pressupostos normativos de cada uma das formas de racionalidade, que teriam resistido às pressões e aos desequilíbrios do processo de racionalização: seriam elas as pretensões inevitáveis de validade, levantadas em todos os juízos de verdade, de justiça e de autenticidade e sinceridade, que formam possíveis ligaduras sociais a partir da comunicação e se desdobram nos discursos diferenciados e problematizantes da ciência e da economia, da moral e do direito e da arte e da crítica de arte. ${ }^{206}$

De um lado, essa passagem significava pensar a autonomia individual como uma pressuposição de atribuições recíprocas de competências comunicativas para exercer os três tipos de discurso mesmo na linguagem comum do cotidiano. Essas competências também pressuporiam um critério de abertura para crítica e exigências de defesa dos argumentos de cada discurso, isto é, um critério de generalidade normativa não só garantidor da legitimidade de ordens sociais, mas também da produção válida do

\footnotetext{
206 "When cultural systems of action like science, law, and art are differentiated out, arguments that are institutionally stabilized and professionally organized, carried out by experts, relate to such higher-level validity claims, which are attached not to individual communicative utterances but to cultural objectivations to works of art, to moral and legal norms, to theories. It is at this level of culturally stored and objectivated knowledge that we also find technologies and strategies in which theoretical or professional knowledge is organized with a view to specific practical contexts such as medicine and public health, military technology, business management, and the like. Despite this difference in level, the analysis of individual expressions uttered with communicative intent remains a heuristically productive starting point for systematizing validity claims, since no validity claim appears at the level of cultural objectivations that would not also be contained in communicative utterances." (Habermas 1984-I:40. Itálicos nossos).
} 
conhecimento científico que se faz sobre ela. ${ }^{207}$ Nesse sentido, Weber teria se equivocado ao pensar a legitimidade da ordem social somente como crença social na existência legalidade do poder. A legalidade precisaria se pensada então somente como indício de legitimidade, mas não garantiria sua existência per se. A legalidade pressuporia de todo modo a possibilidade de identificação constante da existência de um livre acordo prévio sobre sua generalidade (Id. op. cit:254-271).

A dimensão da razão comunicativa que é menos explorada por Habermas em TCA é a racionalidade estético-expressiva, que segundo o autor levaria à ação dramatúrgica como expressão individual, relacionada ao "mundo interno" e sujeito ao critério avaliativo da autenticidade ou expressivo da sinceridade pessoal. Sua dimensão performativa, isto é, a função comunicativa e não só representativa de linguagem estético expressiva é a autorepresentação, e ela está ligada à expressão de sentimentos internos, desejos, necessidades e expressões estéticas, artísticas e culturais (Id. op. cit:20-21).

A partir dos estudos de Goffman ${ }^{208}$ sobre auto-representação, Habermas atribui os encontros em que participantes formam um público visível a cada um e performam uns para os outros, ligados tanto a aparição em público do artista quanto à aparência do interlocutor. Por se tratar da expressão de um mundo cujo acesso é privilegiado ao sujeito, torna-se difícil o teste de sinceridade e autenticidade. Por isso, os gestos e valores culturais não seriam universalizáveis como a verdade e a justiça. Elas não deixam no entanto de influenciar essas outras pretensões de modo quase "parasita", já que atingem padrões comuns de beleza como nas "modas" e a ação moral pode ser justificada por apelos afetivos (Habermas, 1984-I:92).

O extremo dessa relação entre mundo interno e mundo externo é o uso estratégico de uma dissimulação da assimetria entre os dois, como no engano, na manipulação de imagens ou gestos próprios da passagem da subjetividade pessoal para o público (Id. op. cit:90-95). A partir desse exemplo negativo seria novamente possível comprovar a necessidade de se saber como atuar para que essas três formas diferenciadas da razão se desenvolvam com suas lógicas próprias, apesar de suas intersecções naturais e a pressuposição de um princípio de aceitabilidade geral entre os participantes.

207 "Expressions are linked with claims to normative rightness or subjective truthfulness in a way similar to that in which other acts are linked with claims to propositional truth and to efficiency satisfy the central presupposition of rationality: they can be defended against criticism. This holds true event for a type of expression that is not invested with a clear-cut validity claim, namely evaluative expressions, which are not simply expressive - that is, manifesting a merely private feeling or need - nor do they lay claim to be normatively binding - that is, to be in agreement with normative expectations." (Habermas, 1984-I:16).

${ }^{208}$ Habermas cita a obra de Goffman. The Presentation of Self in Everyday Life (New York, 1959) (Habermas, 1984-I:420). 
Essa dificuldade de Habermas em trabalhar os potenciais de racionalidade da ação dramatúrgica deriva talvez de seu diagnóstico negativo em relação à comunicação imagética e aos apelos da propaganda na própria esfera pública tornada indústria cultural. Não se pode esquecer que em MEEP a auto-representação do poder político ou social na esfera pública é vista como prejudicial à racionalidade argumentativa (v. acima, capítulo 2).

O segundo volume de TCA dá pistas de quais são as possíveis consequências dessa menor atenção dada por Habermas em relação à dimensão pública da expressão pessoal e da produção estética no agir comunicativo, como o fato de ela minar mais do que estimular potenciais de racionalidade da integração social. Será dada a devida importância abaixo a esse espaço social formado pelas pretensões afetivas, expressivas e estéticas, como são as biografias pessoais e as manifestações artísticas e imagéticas do poder social e político (v. suptópico "d"), que cada vez mais se imiscuem com as racionalidades prática e cognitivoinstrumental.

Antes de iniciar a passagem pelo volume II de $T C A$, cumpre destacar a atenção dada por Habermas aos meios de comunicação de massa, que seriam estruturas discursivas mais ou menos diferenciadas, mas sempre ligadas à comunicação do mundo da vida, e portanto, diferentes dos media do dinheiro e do poder. A ampliação das contribuições individualizadas e difusas proporcionadas pelas novas mídias impelem para uma crítica da cultura de massas mais direcionada à capacidade dos meios de manter os sujeitos em seus auto-isolamentos, do que à já conhecida e combatida problemática da concentração e desigualdade do acesso (Habermas, 1984-I:370-372). A discussão sobre os meios de comunicação, a indústria cultural e a esfera pública é retomada ao final do volume II.

Ainda no final do volume I de TCA, depois de demonstrar uma tendência de Adorno para a adoção de um conceito de intersubjetivo mímese, Habermas procura realizar o "caminho de volta" da racionalidade negativa, substituindo seu ponto de partida epistemológico irrefletido do sujeito individual por uma intersubjetividade de fundo sem a qual não seriam possíveis a linguagem e a comunicação comuns e especializadas. ${ }^{209} \mathrm{~A}$ intenção é abandonar alguns problemas da filosofia do sujeito, como a questão da

209 "Because de mimetic capacity escapes the conceptual framwork of cognitive-instrumentally determined subject-object relations, it counts as the sheer opposite of reason, as impulse. Adorno does not simply deny to the latter any cognitive function. In his aesthetics he attempts to show what the work of art owes to the power of mimesis to unlock, to open up. But the rational core of mimetic achievements can be laid open only if we give up the paradigm of the philosophy of consciousness - namely, a subject that represent objects and toils with them - in favor of the paradigm of linguistic philosophy - namely, that of intersubjective understanding or communication - and puts the cognitive-instrumental aspect of reason in its proper place as part of a more encompassing communicative rationality.” (Habermas, 1984-I:390. Itálicos do autor). 
fundamentação última e a filosofia da história. Mas se esses objetivos foram realmente alcançados, isso não o isentou de novas questões que sua filosofia da comunicação precisaria responder, ao pretender se afirmar como um novo paradigma da teoria crítica, como (Id. op. cit:386-399).

Essas questões são enfrentadas pela "virada comunicativa",210 de Habermas no segundo volume de TCA a partir de uma leitura crítica dos estudos de Mead sobre a comunicação intersubjetiva e a teoria de Durkheim sobre a sociologia da religião, para entender como a filosofia moral da aceitabilidade racional - ou por motivos - substitui as formas tradicionais de legitimação da dominação e permitem a integração social na modernidade.

Da análise desse processo de secularização das visões tradicionais de mundo como processos de linguistificação, é importante destacar como sua autoridade social e política seria gradativamente substituída pelo conjunto de pretensões validade e as competências comunicativas presentes na linguagem e na comunicação humana, capazes se orientar pela força não forçada do melhor argumento. Mas apesar de terem ficado "acessíveis a nós" (Habermas, 1987-II:403), seriam ainda sempre ameaçados por abstrações como do valor de uso para o valor de troca, da legitimidade como aceitabilidade racional para a legalidade do poder investido, ou da autenticidade e da sinceridade para a visibilidade e a identificação com formas não racionais de convencimento.

Nesse processo de secularização, a discussão de Habermas com a sociologia da religião de Durkheim ao primeiro fazer a passagem da integração social pré-moderna à integração social simbolicamente mediada, sujeita a um princípio geral de accountability (do original Zerechnungsfähigkeit, que poderia ser traduzido como "capacidade de imputação legal”, Habermas, 1981:117): da estabilização das tensões entre indivíduo e sociedade a partir de visões religiosas e tradicionais de mundo que, embora comunicativas, eram dotadas de elementos ritualísticos blindados contra a crítica e a problematização, passa-se para a instabilidade dos diversos momentos razão que se dividem em pretensões de validade orientadas ao entendimento (Verständigung) e abertas à crítica num contexto de pluralismo de interesses. Essa racionalização das compreensões tradicionais de mundo, feita na forma de sua "linguistificação" em pretensões de validade normativa, concentra,

210 "If we assume that the human species maintains itself through the socially coordinated activities of its members and that this coordination has to be established through communication - in certain central spheres through communication aimed at reaching agreement - then the reproduction of the species also requires satisfying the conditions of a rationality that is inherent in communicative action. These conditions have become perceptible in the modern period with the decentration of our understanding of the world and the differentiation of various universal validity claims.” (Habermas, 1984-I:397). 
no entanto, as tensões entre indivíduo e sociedade mais na filosofia moral do que na racionalidade finalística da razão instrumental ou na racionalidade afetiva e culturalmente arraigada da razão estético-expressiva. ${ }^{211}$

Uma leitura atenta dos processos de racionalização social descritos por Habermas em TCA e também em Direito e Democracia fará notar que Habermas utiliza o termo "fascinação" em ambas as obras para caracterizar o tipo de poder que era exercício pela autoridade de sociedades tradicionais; poder este que, apesar de impedir espaços de crítica em função da constituição ritualística de comunicação da ordem, não deixavam de provir de contextos comunicativos.

Essa fascinação, que causaria uma cristalização das pretensões de validade em "síndromes" objetivas de facticidade, era também responsável pelo sentido performativo da ação e, portanto, carregador de uma normatividade. É por isso que ao transpor junto a Habermas os sentimentos ambíguos da fascinação, como a atração, reverência, temor e repulsa que outrora geravam processos de identificação e garantiam a integração social em sociedades tradicionais, somente para as tensões entre indivíduo e coletividade da razão prático-moral, acaba-se por limitar a extensão do caráter prático e performativo também da racionalidade estético-expressiva, bem como da razão teleológica-instrumental dentro da modernidade, que prejudicam a razão prática ao invés de se relacionarem com ela a partir de processos de aprendizagem. ${ }^{212}$ Essa questão terá importante impacto para o método proposto para a realização do diagnóstico estético-expressivo da esfera pública política. ${ }^{213}$

A autonomização dos subsistemas sociais da economia (instrumentalização) e da política (burocratização) e a transformação da ação cognitiva em ação instrumental a serviço do princípio da auto-preservação, minam as possibilidades de que ações coordenadas por planos comuns superassem ações direcionadas para o sucesso individual, competitivas e sistêmicas. O resultado é a visualização de uma sociedade funcionalista e

\footnotetext{
${ }^{211}$ Para uma pesquisa detalhada sobre o tema, que refletirá especialmente no diagnóstico estético-expressivo da esfera pública política (tópico. 2.3 desta tese), v. Blotta, v. The Fascination of Authority and the Authority of Fascination. Rationalization and Legal Theory in Habermas Revised (manuscrito). Paper apresentado na conferência Philosophy and the Social Sciences, na academia de Humanidades da República Checa, Praga (abril), e no Congresso Internacional de Filosofia do Direito (agosto), ambos em 2011.

212 "From a genetic standpoint, the performative attitude can be understood, perhaps, as the result of a secularization and generalization of that emotionally ambivalent attitude toward sacred objects that originally secured the recognition of moral authority. This transformation becomes necessary to the degree that the illocutionary components of speech acts are released from their symbiotic entanglement with archaic institutions and differentiated so that assertoric and expressive sentences are also endowed with illocutionary forces, and in this way modalized and incorporated in communicative actions.// If it is the performative attitude that secures unity through changes in mode, then practical self-consciousness has a certain priority over epistemic and affective self-consciousness. The reflective relation to self is the ground of the actor's accountability." (Habermas, 1987-II:76).

${ }^{213}$ Tópico 2.3. desta tese. V. também o subtópico "d" abaixo.
} 
administrada pelos meios "deslinguistificados" e objetivantes de comunicação, como o dinheiro e o poder, que teriam se destacado de suas origens no mundo da vida privado e político e submetendo ambos à lógica sistêmica do mercado. (Habermas, 1987-II:325).

Não é por acaso que a esfera pública é trabalhada no volume II de TCA como espaços discursivos derivados do mundo da vida que são infiltrados pelas lógicas do dinheiro e do poder a partir das teses da perda de sentido e da perda de liberdade de Weber, isto é, cuja lógica deixa de ser influenciada pela moralidade, padrões estéticos ou até religiosos para a legalidade e a troca proba entre consumidores no mercado. Isso não ocorre no entanto, sem provocar patologias sociais, como crises de legitimidade (Habermas, 1987:323-331).

Esse diagnóstico inicial de uma incapacidade de se gerar uma esfera pública politicamente ativa é contrastada algumas funções conferidas às esferas privada e pública, como a capacidade de manter uma ligação constante entre sistema e mundo da vida, quando não são invadidas pela lógica da economia ou do Estado interventor ${ }^{214}$. Do mesmo modo, com as propostas que Habermas fará nas conclusões finais da obra, o programa de estudos para revitalizar o materialismo interdisciplinar de Horkheimer em termos de uma teoria crítica comunicativa sugerirá temas práticos referentes à diminuição dos potenciais de protesto e as ambivalências no poder de mediatização da esfera pública pela comunicação de massa nas democracias sociais ${ }^{215}$, entre outros (v. Habermas, 1987-II:378383 e 389-403). Da mesma forma, o conceito de esfera pública sofrerá uma guinada na

214 "The institutional core of the private sphere is the nuclear family, relieved of productive functions and specialized in tasks of socialization; from the systemic perspective of the economy, it is viewed as the environment of private households. The institutional core of the public sphere comprises communicative networks amplified by a cultural complex, a press and, later, mass media; they make it possible for a public of art-enjoying private persons to participate in the reproduction of culture, and for a public of citizens of the state to participate in the social integration mediated by public opinion. From the systemic perspective of the stat, the cultural and political public spheres are viewed as the environment relevant to generating legitimation. (...)// Because the private and public sphere are communicatively structured spheres of action, which are not held together by systemic means - that is, not by steering media - interchange relations can develop only by way of two such media. From the perspective of the lifeworld, various social roles crystallize around these interchange relations: the roles of the employee and the consumer, on the one hand, and those of the client and the citizen of the state, on the other (For the sake of simplicity, I shall leave to one side here the role structures of the artistic enterprise and of the artistic-literary public sphere.)" (Habermas, 1987-II:319. Itálicos do autor).

${ }^{215}$ As ambivalências dos meios de massa em produzir a mediatização ou uma expressão crítica da esfera pública política são trabalhadas em TCA a partir da caracterização desses meios como veículos de integração entre o mundo da vida e o sistema, já que sua atuação está sempre sujeita às reações do público que assiste, mas também interage criticamente com as produções. Esquematicamente, são ambivalências: 1. $A$ variabilidade de fatores que influenciam a produção de informação e a evolução técnica dos meios; 2 . A existência de produções que não somente reafirmam os conteúdos pasteurizados e repetitivos da indústria cultural; 3. A capacidade de crítica e requalificação das informações pelos contextos culturais de recepção; 4. O poder da comunicação oral e cotidiana em se contrapor à influência político-ideológica dos meios. V. Habermas, 1987-II:389-391. Para um estudo aprofundado da concepção de mídia de massa em TCA, de onde se cita essas ambivalências sistematizadas, v. Blotta, Mídia e Cidadania, 2008. 
segunda edição de MEEP trinta anos mais tarde e na elaboração da teoria discursiva do direito e da democracia, como se verá em seguida.

A separação entre sistema e mundo da vida denota justamente o enfraquecimento do conceito de esfera pública que passa a ficar claro em TCA, possivelmente ainda influenciado pelo diagnóstico de MEEP. Assim, apesar dos novos estudos sobre recepção televisiva e psicologia social influenciarem Habermas a manter a aposta em diagnósticos da esfera pública política formada a partir dos meios de comunicação de massa (Habermas, 1992:3, práticas sociais comunicativa parece ainda resistir pragmaticamente somente para salvaguardar a razão prática na esfera pública, ao menos "sitiando" o mundo da vida contra uma colonização plena pelo sistema na forma de uma complexificação social desmedida ${ }^{216}$ (Habermas, 1987-II:330-331).

As críticas de Craig Calhoun mostram uma impressão semelhante sobre o desenvolvimento do conceito de razão comunicativa de Habermas, como uma derivação do conceito de esfera pública para uma forma muito mais abstrata e inevitável de comunicação presente no gênero humano em função da dificuldade cada vez maior que o filósofo encontra de extrair exemplos de formação de uma publicidade crítica em meio a uma esfera pública mediatizada pelos meios de comunicação de massa (Calhoun, 1992:31$32)$.

As críticas que Habermas receberá em relação a essa divisão entre sistema e mundo da vida para estruturar sua teoria social, como a de que teria visto o âmbito da ação instrumental da economia como anormativo ${ }^{217}$, ou o plano da cultura como esfera reificada, ressoarão também na tentativa de retomada conceito de esfera pública feita por pelo autor em "Further Reflections on the Public Sphere" (Habermas, 1992:437-438), prefácio da segunda edição alemã de $M E E P$, de 1990, publicado nas respostas à coletânea de ensaios sobre esfera pública e Habermas organizada por Craig Calhoun (1992). A

\footnotetext{
216 "The revaluation of the particular, the natural, the provincial, of social spaces that are small enough to be familiar, of decentralized forms of commerce and despecialized activities, of segmented pubs, simple interactions and dedifferentiated public spheres - all this is meant to forster the revistalization of possibilities for expression and communication that have been buried alive." (Habermas, 1987-II:395. Itálico nosso).

${ }^{217}$ Honneth traça essa crítica em texto para a revitalização da categoria de trabalho na teoria crítica, em oposição aos efeitos da separação habermasiana entre sistema e mundo da vida: “...a idéia de uma libertação do trabalho da heteronomia e da alienação sofreu vexame face à realidade, a estruturação das relações de trabalho de ora em diante é delegada às forças globalizantes do mercado capitalista de trabalho. Com esta mudança de rumo, marcada em termos fundamental- conceituais possivelmente de modo mais claro pela fala Habermasiana da auto-regulação "livre de normatização" do sistema capitalista, foi preparado o caminho para a situação diante da qual hoje abaladamente nos encontramos; situação em que as necessidades de todos aqueles que não apenas temem por seu posto de trabalho, mas também pela qualidade dele, não encontram mais ressonância no vocabulário de uma teoria crítica da sociedade." (Honneth, Trabalho e reconhecimento. Tentativa de uma redefinição, 2008:3).
} 
análise desse texto inicia o próximo tópico desta atualização do conceito de esfera pública política na obra de Habermas. Parece ficar claro a partir de então que uma das formas de garantir essa resistência do agir comunicativo na integração social seria por meio de uma teoria da democracia, na qual o princípio da esfera pública política cumpriria papel fundamental. ${ }^{218}$

c) a esfera pública política na teoria discursiva do direito e da democracia

A fundamentação do método de diagnóstico do presente da esfera pública política segue para sua discussão com a teoria do direito e da democracia de Habermas. A proposta é que a esfera pública política possa ser tomada como espaço social formado pela manifestação da opinião e vontade políticas e por iniciativas de publicização do direito. Ao lado do procedimento deliberativo, a esfera pública política se torna um dos fundamentos da teoria discursiva do direito e da democracia de Habermas, pois possibilita a concretização do princípio da soberania popular através da formação da opinião pública referida à política, isto é, ligada a problematizações e legitimações de violações e afirmações de direitos de comunicação e de reconhecimento.

Antes de iniciar o estudo sobre o conceito de esfera pública política em Direito $e$ Democracia, no texto "Further Reflections on the Public Sphere" Habermas faz um resumo da obra de modo semelhante ao feito nesta tese, isto é, revisitando sua discussão sobre a origem e a mudança estrutural da esfera pública nos dois primeiros tópicos, e um terceiro tópico sobre a discussão teórica. Ao mesmo tempo em que reconhece formações de públicos específicos em suas interpretações históricas, como as esferas públicas plebéias e mais à frente os movimentos feministas e as ambivalências da comunicação de massa (Habermas, 1992:433-441), Habermas também procura revisitar temas teóricos, como a alteração que a teoria da esfera pública sofreria quando trabalhada a partir do registro da teoria do agir comunicativo. São especialmente essas atualizações teóricas que interessam este estudo, como a seguinte proposta do autor:

\footnotetext{
218 "Debate on the relationship between public communication and democracy is still dominated by the free press model. This model remains an essentially idealist transposition of the model of face-to-face communication to that of mediated communication (...) Habermas, on the contrary, distinguishes the public sphere from both state and market and can thus pose the question of the threats to democracy and the public discourses upon which it depends coming both from the development of an oligopolistic capitalist market and from the development of the modern interventionist welfare state." Garnham, N. The Media and the Public Sphere, 1992:361.
} 
"O ônus da prova se desloca da moralidade de cidadãos para a condução de processos específicos de formação democrática da opinião e da vontade, presumidos de ter o potencial para gerar resultados racionais, de realmente levar a tais resultados.// É por isso que 'esfera pública política' é apropriada como o conceito quintessencial que denota todas as condições de comunicação sob as quais se pode surgir uma formação discursiva da opinião e da vontade da parte de um público composto de cidadãos do Estado. É por isso que ela é apropriada como o conceito fundamental de uma teoria da democracia cujo intento é normativo." (Habermas, 1992:446. Itálico e negrito nossos). ${ }^{219}$

É por isso que se o princípio do discurso aplicado à política estiver fundado numa legitimidade conferida por todos aqueles que são afetados pela ordem, atuando como participantes de debates racionais, ele passará a requerer formas de "institucionalização de práticas de debate público racional", arranjos institucionais capazes de permitir a continuidade e a falibilidade do debate público, desde debates legislativos a atividades dos partidos e outras organizações sociais cuja atuação no espaço público também demanda maior transparência e accountability.

O potencial auto-regulativo da sociedade só seria possível, no entanto, se as pessoas passassem a fazer uso de seus direitos de comunicação e de participação, ainda que fosse garantida a liberdade individual de não fazê-lo. Mas como garantir esse uso numa sociedade de massas, na qual a propriedade privada não é pressuposto de entrada na esfera pública, porém ainda garante sua eficácia (Habermas, 1992:434)? A crise de legitimidade é então consequência da diferença entre a generalidade do princípio e a generalidade do acesso à esfera pública política, isto é, dos públicos na condição de cidadãos do Estado, e não somente como seus consumidores e clientes.

Essa presunção de resultados falíveis e racionais do debate público só poderia ser garantida por uma incorporação do princípio da soberania popular agora já na forma de “exigentes formas de comunicação assujeitadas que regulam o fluxo da formação da opinião e da vontade políticas", que seriam responsáveis por atribuir legitimidade às decisões e acordos políticos (Id. op. cit:451-452).

\footnotetext{
${ }^{219}$ Tradução livre do inglês: “...the burden of proof shifts from the morality of citizens to the conduciveness of specific processes of the democratic formation of opinion and will, presumed to have the potential for generating rational outcomes, of actually leading to such results.// This is why 'political public sphere' is appropriate as the quintessential concept denoting all those conditions of communication under which there can come into being a discursive formation of opinion and will on the part of a public composed of the citizens of a state. This is why it is suitable as the fundamental concept of a theory of democracy whose intent is normative." (Habermas, 1992:446. Itálicos nossos).
} 
Essa é a nova concepção de esfera pública política que Habermas passará a adotar deste texto para frente, especialmente em Direito e Democracia. Os riscos de uma fabricação da esfera pública e de seletividades na comunicação de massa não deixam de estar presentes, mas essa forma mais abstrata de conceber a esfera pública política serviria como um modelo de comunicação ideal capaz de ser analisado a partir de reconstruções normativas, posto que negativamente presente em desvios de práticas comunicativas historicamente situadas. ${ }^{220}$ (Habermas, 1996:321-328).

O impacto dos meios de comunicação de massa e as possibilidades de se produzir uma opinião pública em busca cooperativa pela verdade e em respeito às liberdades de comunicação de públicos privados atuantes politicamente, como igrejas, associações, universidades e partidos políticos, seria ainda analiticamente mais bem estudado a partir do “conceito de uma esfera pública operativa no domínio político" que Habermas teria desenvolvido em MEEP. Por isso teriam Jean Cohen e Andrew Arato trabalhado, por exemplo, o tema da sociedade civil a partir da teoria do agir comunicativo (Cohen \& Arato, 1992:345ss). É considerando esse impacto psicológico e político causado pela mídia de massa que Habermas aponta ao final para questões que movem também este presente estudo:

“Assim, os media de massa têm efeitos contraditórios em outras dimensões também. Há evidência considerável atestando para a natureza ambivalente do potencial democrático de uma esfera pública cuja infraestrutura é marcada por crescentes e seletivas restrições impostas pela comunicação eletrônica de massa. // Portanto se hoje eu fizesse outra tentativa de analisar a mudança estrutural da esfera pública, eu não sei ao certo qual seria seu resultado para uma teoria da democracia - talvez um que pudesse dar causa para uma avaliação menos pessimista e para uma

\footnotetext{
220 "To be sure, the normative content of a concept of democracy that refers to processes of norm and value formation taking the form of discursive public communication is not restricted to appropriate institutional arrangements at the level of the democratic constitutional state. Rather, it pushes beyond formally instituted processes of communication and decision making. Corporatively organized opinion formation resulting in responsible decision making can serve the goal of a cooperative search for truth only to the extent to which it remains permeable to the free-floating values, topics, topical contributions, and arguments of the surrounding political communication. (...) ...the expectation deriving from a discourse-centered theoretical approach, that rational results will obtain, is based on the interplay between a constitutionally instituted formation of the political will and the spontaneous flow of communication unsubverted by power, within a public sphere that is not geared toward decision making but toward discovery and problem resolution and that in this sense is nonorganized. If there still is to be a realistic application of the idea of the sovereignty of the people to highly complex societies, it must be uncoupled from the concrete understanding of its embodiment in physically present, participation, and jointly deciding members of a collectivity." (Habermas, 1992:451. Itálicos do orginal).
} 
visão geral que vai além da formulação de postulados que meramente se desafiam." (Habermas, $1992: 455-456) .{ }^{221}$

Em Direito e Democracia, a esfera pública política é diretamente trabalhada no capítulo 8 inicialmente num diagnóstico sobre as teorias sociológicas da democracia, especialmente a teoria dos sistemas. Ali, Habermas transpõe a ideia epistemológica da passagem da perspectiva do observador ao participante que trabalha normativamente seu objeto de pesquisa, para o problema prático da incapacidade da esfera pública política ressoar problematizações e tematizações sociais, pois estaria, junto com o público de cidadãos, "tomado pelo código do poder e aplacada por políticas simbólicas" (Habermas 1996:343-348).

Mas se mesmo na teoria dos sistemas estariam pressupostas pretensões de verdade e cientificidade, torna-se possível propor uma reflexão normativa imanente à teoria. Habermas trabalha esse diálogo discutindo a idéia de um "direito reflexivo" que atuaria de modo inter-relacionado com a formação de uma esfera pública política, a partir da teoria do Estado de Willke com apoio de Teubner. ${ }^{222}$ Esse tipo direito seria aquele capaz de promover "programas relacionais", políticas visando a "modificações auto-monitoradas" que redirecionam politicamente orientações de sistemas cuja autonomização em relação ao mundo da vida passam a prejudicar a integração social. Isso significa que até na perspectiva da teoria dos sistemas, é necessário pressupor algum tipo de regulação política capaz de realizar transferências de pretensões e respostas entre cidadãos e subsistemas sociais (Id. op. cit:344-349).

Embora a noção de legitimidade formada a partir dessas teorias acabaria sendo vista como uma adequação entre pretensões de barganha constitucionalmente garantidas, se esse conceito não puder denunciar uma estabilidade social constituída de modo ilegítimo por corporações que cada vez mais representam interesses de modo profissionalizado e excludente de um processo geral de comunicação pública, coloca-se em risco a própria integração social. A partir de uma concepção normativa de legitimidade, portanto, o novo conceito de esfera pública política aparece como expressão da soberania popular que

${ }^{221}$ Livre tradução do original em inglês: "Thus the mass media have contradictory effects in other dimensions as well. There is considerable evidence attesting to the ambivalent nature of the democratic potential of a public sphere whose infrastructure is marked by the growing selective constraints imposed by electronic mass communication. // Thus if today I made another attempt to analyze the structural transformation of the public sphere, I am not sure what its outcome would be for a theory of democracy maybe one that could give cause for a less pessimistic assessment and for an outlook going beyond the formulation of merely defiant postulates." (Habermas, 1992:455-456).

${ }^{222}$ Habermas cita a obra de Günter Teubner, Juridification of Social Spheres (Berlin, 1987, pp 3-48 apud. Habermas, 1996:555). 
submete a política deliberativa aos processos de problematização e argumentação entre "experts" e "contra-experts" "monitorados pela opinião pública" (Id. op. cit:350-351).

A esfera pública promove a interlocução entre as esferas de reprodução social, como a cultura, a educação e a família, a política, a ciência ou a economia, pois impede que elas se autonomizem totalmente em relação aos seus contextos comunicativos, isto é, as expectativas normativas do público afetado em relação ao seu desenvolvimento. E se a constitucionalização da esfera pública política é o que garante politicamente a manutenção dessa conexão, o direito teria a função de ativar politicamente a esfera pública, sendo capaz traduzir numa linguagem inteligível a comunicação entre as esferas privadas e públicas mais ligadas ao mundo da vida e aquelas cada vez mais especializadas na reprodução social e política (Id. op. cit:353-354).

A partir dos estudos de Bernard Peters, Habermas trabalha a esfera pública política também na questão sobre como engendrar uma circulação do poder constitucionalmente regulada. Na concepção de Peters, um modelo de legitimidade democrática deve pôr em curso um processo de formação da opinião e da vontade em que a periferia e o centro do sistema político, representados respectivamente pela esfera pública e a esfera pública política, pudessem ter uma comunicação com a qual os níveis intermediários de formação da opinião e da vontade se tornassem "decisivos para o desenvolvimento político" (Peters, Die Integration moderner Gesellschaften, 1993:340ss. apud. Habermas, 1996:356) (v. Peters, Der Sinn von Öffentlichkeit, 1998).

Se essa comunicação recíproca e pública entre centro e periferia do sistema político seria a "tradução sociológica" da teoria discursiva do direito e da democracia, a unidade empírica a caracterizar a formação da esfera pública política é a problematização $o^{223}$. Esse tipo de intensificação da comunicação, da denúncia e da dramatização de problemas e injustiças sociais e institucionais, define os contornos das esferas públicas, formadas por

\footnotetext{
223 "Up to now, I have generally dealt with the public sphere as a communication structure rooted in the lifeworld through the associational network of civil society. I have described the political public sphere as a sounding board for problems that must be processed by the political system because they cannot be solved elsewhere. To this extent, the public sphere is a warning system with sensors that, though unspecialized, are sensitive throughout society. From the perspective of democratic theory, the public sphere must, in addition, amplify the pressure of problems, that is, not only detect and identify problems but also convincingly and influentially thematize them, furnish them with possible solutions, and dramatize them in such a way that they are taken up and dealt with by parliamentary complexes. Besides the 'signal' function, there must be an effective problematization. The capacity of the public sphere to solve problems on its own is limited. But this capacity must be utilized to oversee the further treatment of problems that takes place inside the political system." (Habermas, 1992:359. Itálicos nossos).
} 
grupos de públicos da periferia ${ }^{224}$ ao centro que pressionam para esforços políticos e soluções rápidas, determinando a distribuição de responsabilidades administrativas a serem tomadas pelo sistema político.

Com um parlamento novamente capaz de influenciar junto ao judiciário um processo de formação da opinião e da vontade políticas e se relacionar com uma formação mais ou menos espontânea das esferas públicas periféricas, a circulação do poder teria condições de realizar um processo mais amplo de legitimação e sem grandes interferências na autonomia individual. Segundo Habermas, no entanto, as possibilidades de formação de sentido e capacidade de auto-organização política não estariam diretamente "à disposição da vontade dos cidadãos" (Id. op. cit:358-359).

O desenvolvimento dessa capacidade estaria na formação de estruturas do mundo da vida que, embora devessem ser estimuladas juridicamente, não careceriam de regulação diretamente política. São as esferas públicas, que exigem um uso democrático do poder comunicativo $^{225}$, impedindo a "independência ilegítima" de poderes públicos e organizações sociais.

As esferas públicas periféricas "ativadas", semelhantes ao que Habermas denomina esferas públicas informais em MEEP, precisam tanto encontrar formas de introduzir suas pretensões de validade nos discursos parlamentares, judiciais e administrativos, "perturbando sua rotina", quanto problematizar e interpretar de modo "inovador, chamando a atenção". Essas problematizações seriam feitas por "associações voluntárias da sociedade civil enraizadas em padrões liberais de uma cultura política e socialização", racionalizando o mundo da vida a ponto dele se condensar em opiniões públicas capazes de influenciar as esferas públicas formais (Habermas, 1996:358-359).

A esfera pública é concebida então por Habermas como uma rede de comunicação de opiniões, argumentos e informações que expressam atitudes negativas ou afirmativas, não podendo ser reduzida a uma instituição, uma coletividade ou um conjunto de normas. Originada no mundo da vida, a esfera pública se forma entre as instituições como religião, educação e família, responsáveis pela reprodução cultural, a integração social e a socialização, e os conteúdos próprios do agir comunicativo: verdade, correção ou

224 "The spectrum extends from associations (with goals recognizably defined by party politics) and cultural establishments (such as academies, writers' associations, which specialize in issues and contributions and are generally designed to generate public influence, belong to the civil-social infrastructure of the public sphere dominated by the mass media. With its informal, highly differentiated and cross-linked channels of communication, this public sphere forms the real periphery." (Habermas, 1996:355-356).

${ }^{225}$ Breves discussões sobre o conceito de "poder comunicativo" serão realizadas nos tópicos 8.2 e 9.1 desta tese. Para análise inicial, v. Günther, Communicative Freedom, Communicative Power and Jurisgenesis, 1998. 
veracidade, que formam sistemas como a ciência, a moral e a arte.

Quanto

atua politicamente, a esfera pública deixa o tratamento especializado dos problemas comuns para o sistema político, exercendo por isso outra faceta do agir comunicativo: ao invés de consistir nas funções ou conteúdos do agir comunicativo, trabalhados pelas instituições e pretensões que emergem do mundo da vida, a esfera pública atua entre eles, formando o espaço social gerado na comunicação voltada para o entendimento mútuo possível (Id. op. cit:360).

Diferentemente de quando agem estrategicamente, quando dois ou mais atores sociais se encontram, interpretam visões de mundo e tomam decisões pelos mesmos fundamentos em processos de argumentação e deliberação marcados por atribuição recíproca de liberdades comunicativas, dão-se as condições para o surgimento de "espaços públicos linguisticamente constituídos".

Guardadas as proporções e diferenças entre os discursos, isso remete curiosamente à parábola bíblica do "quando dois ou mais estiverem reunidos em meu nome, estarei lá" ${ }^{226}$, ou de modo mais apropriado como o conceito de Espírito em Hegel ${ }^{227}$ (Habermas, 2006:17-22): a esfera pública se dá como possibilidade para Habermas nas abstrações e generalizações dos espaços públicos formados a partir da experiência concreta na qual dois ou mais se comunicam visando se entender sobre algo no mundo e coordenar suas ações conforme esse entendimento. ${ }^{228}$

Apesar de sua condensação em espaços institucionais como parlamentos, cortes e assembléias, remetendo muitas vezes a espaços físicos e utilizando categorias dicotômicas como esferas públicas periféricas e de centro, a esfera pública política tem sido capaz de se abstrair de públicos específicos para as correntes de comunicações prenhes de pretensões de validade, cujos graus de generalização contextual, inclusão anônima, explicação e

${ }^{226}$ V. o provérbio bíblico em Matheus 18:20.

227 As aulas de Hegel em Iena sobre a Filosofia do Espírito (1804-1806), que trataram da dialética da autoconsciência, podem ser consideradas um dos estudos que mais inspiraram a teoria crítica, posto que dele derivam as teorias sociais de Marx, Habermas e Honneth, cada um privilegiando um dos elementos da formação do espírito concreto: respectivamente o trabalho, a linguagem e o reconhecimento, sendo os dois últimos componentes do que Habermas denomina "interação". V. Habermas, Trabalho e Interação, 2006:pp 11-44; Hegel, Frühe Politische Systeme [Sistemas Políticos de Juventude. Livre tradução do alemão]. Frankfurt /M - Berlin - Wien, 1974, pp. 291-335. V. também Honneth, 2003.

228 "Unlike success-oriented actors who mutually observe each other as one observes something in the objective world, persons acting communicatively encounter each other in a situation they at the same time constitute with their cooperatively negotiated interpretations. The intersubjectively shared space of a speech situation is disclosed when the participants enter into interpersonal relationships by taking positions on mutual speech-act offers and assuming illocutionary obligations. Every encounter in which actors do not just observe each other but take a second-person attitude, reciprocally attributing communicative freedom to each other, unfolds in a linguistically constituted public space. This space stands open, in principle, for potential dialogue partners who are present bystanders or could come on the scene and join those present." (Habermas, 1996:360-361). 
tradução determinam uma capacidade de ampliação dessa politização da publicidade. Para obter influência direta na esfera política, no entanto, essas pretensões precisam ser traduzidas para a linguagem corrente da política, isto é, juridicamente (Habermas, $1996: 360-361){ }^{229}$

A partir das novas tecnologias de informação e comunicação, torna-se possível contemplar de modo mais efetivo o princípio da legitimidade de todos os virtualmente concernidos ("potencialmente afetados"), abstraindo do contexto as pretensões de validade dos proferimentos que se condensam em opiniões públicas na medida em geram controvérsia e ganham aceitação. É por isso que a opinião pública não pode ser medida por meio de um conjunto de opiniões individualizadas, como em pesquisas de opinião pública quantitativas, ao menos que sejam seguidas de um debate público que se oriente para uma formação livre da vontade dos participantes (Id. op. cit:361-362).

A qualidade discursiva da formação da opinião e da vontade se mede pela abertura para um "processamento exaustivo de propostas, informações e razões" que buscam a unanimidade. Se atingem essa qualidade esperada, trata-se de uma "variável empírica", mas se pensadas de modo normativo, tornam-se uma base para medir o nível de legitimidade da influência da opinião pública no poder político, ao qual contrasta com a imagem de uma esfera pública política que exclui esclarecimentos e revisões e é por isso formada de modo a não dar publicidade aos procedimentos das instituições (Id. op. cit:362). ${ }^{230}$

\footnotetext{
229 "Founded in communicative action, this spatial structure of simple and episodic encounters can be expanded and rendered more permanent in an abstract form for a larger public of present persons. For the public infrastructure of such assemblies, performances presentations, and so on, architectural metaphors of structured spaces recommend themselves: we speak of forums, stages, arenas, and the like. These public spheres still cling to the concrete locales where an audience is physically gathered. The more they detach themselves from the public's physical presence and extend to the virtual presence of scattered readers, listeners, or viewers linked by public media, the clearer becomes the abstraction that enters when the spatial structure of simple interactions is expanded into a public sphere. // Processes of opinion-formation, especially when they have to do with political questions, certainly cannot be separated from the transformation of the participants' preferences and attitudes, but they can be separated from putting these dispositions into action." (Habermas, 1996:361-362. Itálicos nossos).

${ }^{230}$ A importante citação fundamenta a proposta de realização de um diagnostico da esfera pública política como forma de medir a qualidade e a legitimidade da influência da opinião pública na política: "The 'quality' of public opinion, insofar as it is measured by the procedural properties of its process of generation, is an empirical variable. From a normative perspective, this provides a basis for measuring the legitimacy of the influence that public opinion has on the political system. Of course, actual influence coincides with legitimate influence just as little as the belief in legitimacy coincides with legitimacy. But conceiving things this way at least opens a perspective from which the relation between actual influence and the procedurally grounded quality of public opinion can be empirically investigated." (Habermas, 1996:362-363).
} 
Habermas, no entanto, não dispensa considerações em relação às distinções entre públicos que procuram influenciar estratégica ou comunicativamente a esfera pública e a opinião pública. Segundo ele, um público de composição igualitária deve aprovar as influências de atores privilegiados na esfera pública, sejam aqueles que chegam à esfera pública a partir de politizações do privado ou os que já ocupam espaços públicos e procuram influenciar na opinião pública. A incapacidade de uma manipulação ou fabricação completa da esfera pública mantém a importância do conceito para a teoria discursiva do direito e da democracia. Especialmente em momentos de politização, as regras que mais ou menos governam a esfera pública ficam latentes em sua expressão política (Habermas, 1996:363-364).

A esfera pública política deve problematizar e tematizar problemas comuns sempre a partir da comunicação que ocorre entre os potencialmente afetados, o que significa a garantia efetiva do princípio da generalidade. Ao mesmo tempo, Habermas se mostra ciente da expressão da esfera pública política que será tomada neste estudo como estéticoexpressiva (cap. 7 e abaixo). Derivada de experiências da vida privada e de biografias pessoais que emergem de o que restou de uma esfera pública literária, essa expressão da esfera pública formada partir da religião, da arte, da literatura e da expressão pessoal realiza críticas da publicidade a partir de histórias de vida pessoais dos afetados. Neste momento, torna-se possível uma influência dessa diferenciação do mundo da vida, especializada na "articulação de valores e abertura de mundo", com a esfera pública política (Id. op. cit:365).

O importa para Habermas é então fundamentar a resistência da comunicação entre esferas públicas políticas e literárias a partir da própria conexão interna entre público e privado. Essas esferas são então vistas então como diferentes condições de comunicação que mantém linguagens comuns apesar de sua generalização e abstração para a comunicação entre estranhos. Isso porque muitas vezes essa comunicação é constituída por debates que partem de argumentos formados em experiências pessoais de vida.

Para serem canalizadas na esfera pública política e a gerar influência decisiva na legitimação do poder, como já dito, essas pretensões comunicativas e de reconhecimento que emergem do privado ao público precisam se articular na linguagem especializada do direito. A comunicação política, por sua vez, não perde sua conexão com o mundo da vida na medida em que precisa ao mesmo tempo publicizar-se nos contextos comunicativos dos afetados, responsáveis por conferir legitimidade social à dominação (Id. op. cit:366). 
As últimas reflexões de Habermas do capítulo 8 de $D D$ em relação à sociedade civil (8.3.2) serão retomadas na parte III (cap. 9) desta tese, para fundamentar junto à análise dos outros capítulos de Direito e Democracia a relação interna entre esfera pública política e direito e os conceitos estruturais do direito da comunicação. Já o papel que os meios de comunicação de massa desempenham em relação à esfera pública política, também tratados nos últimos tópicos do capítulo 8 , será discutido no tópico seguinte em relação aos mais recentes textos de Habermas sobre esfera pública política e comunicação social.

O que fica claro ao final deste tópico, é que apesar de Habermas já elevar a esfera pública política ao lado dos poderes constituídos como um dos pressupostos do Estado democrático de direito a partir da discussão com o modelo de sistema político de Peters (Habermas, 1996:354) - o que virá a fazer também em seu mais recente texto analítico sobre o tema ${ }^{231}$-, bem como fundamentar a conexão inextrincável dessa esfera com estruturas do mundo da vida, ainda há um foco de análise na dinâmica dos públicos, o que poderia dificultar a possibilidade interpretá-los como pretensões comunicativas e de reconhecimento capazes de adentrar a linguagem mais especializada do direito, isto é, de constituir liberdades e deveres institucionalizados de comunicação, participação e reconhecimento.

Além disso, ao avançar somente na direção da definição de desobediência civil como caso extremo de reconexão entre esfera privada e esfera pública, e na necessidade de uma esfera pública liberal que se beneficia de uma cultura política formada por instituições ativas da sociedade civil para impedir déficits de legitimidade (Habermas, 1996:366-387), Habermas não realiza uma reconstrução dos princípios da esfera pública política, como faz com o sistema de direitos e os princípios do estado democrático do direito nos capítulos 3 e 4 de Direito e Democracia.

Isto é, o autor não realiza um diagnóstico histórico daqueles direitos de comunicação, participação política e reconhecimento que formariam esse terceiro pilar da legitimidade dos Estados democráticos constitucionais, o que pode levar a uma compreensão insuficiente das condições de legitimidade democrática do Estado de direito, ou mesmo a uma proposta muito presa à forma e pouco capaz de oferecer condições institucionais capazes de estimular uma publicidade crítica necessária a essa legitimidade.

\footnotetext{
${ }^{231}$ Será utilizada a versão espanhola "La Razón de la Esfera Pública: tiéne la democracia aún una dimensión epistêmica?” In. Habermas, Ay, Europa, 2009, traduzida por José Luis López de Lizaga, Pedro Madrigal e Francisco Martín. V. discussão sobre o texto neste tópico "d".
} 
Este esforço se buscará realizar na parte II deste estudo a partir do caso brasileiro, tendo como resultado na parte III a formulação do direito da comunicação, uma teoria legal que complementa o paradigma procedimental do direito de Habermas e procura contribuir para se pensar nas condições de produção de uma legitimidade mais democrática a partir da garantia de uma circulação constitucionalmente regulada entre comunicação social e política.

\section{d) diferenciação analítica da esfera pública política}

A proposta deste tópico é fazer a análise final da atualização do conceito de esfera pública política na obra de Habermas e, num diálogo com perspectivas de alguns críticos internacionais e nacionais que debatem essa atualização, fundamentar e apresentar o método para diagnósticos da esfera pública política a ser aplicado no contexto brasileiro na parte seguinte desta tese.

A abertura para se sugerir uma diferenciação analítica da esfera pública política a partir do tópico 8.3.3 de Direito e Democracia aparece quando Habermas apresenta sua aposta na possibilidade da sociedade civil influenciar através da esfera pública e da opinião pública uma "inversão" dos procedimentos da circulação oficial do poder. Novamente, apesar de inserir a esfera pública entre o sistema político e os setores privados do mundo da vida e dos sistemas funcionais numa espécie de racionalização, são os públicos (literários, religiosos, artísticos, feministas, alternativos, ambientalistas etc.) que determinam como atores a problematização da opinião pública, em relação com espectadores e público leitor (Habermas, 1996:373-374).

Em termos de "densidade de comunicação" de esferas públicas episódicas, como em bares, cafés e outros espaços públicos, ocasionais, no caso de festivais, encontros e eventos e abstratas, como as mediadas pela mídia de massa, todas continuam porosas entre si, construindo pontes frequentes entre seus discursos, como a afirmação da regra da ausência de exclusão, trazida especialmente após os movimentos trabalhistas e feministas, que teriam alterado a estrutura básica da esfera pública a partir da revelação de seu "outro" (Id. op. cit:374).

A pergunta sobre a racionalidade da esfera pública, que sempre deve responder ao risco de se converter em "poder", assume a tentativa de investigação a partir da proposta de que processos de comunicação podem ser menos distorcidos na medida em que eles se desenvolvam pela dinâmica própria de uma "sociedade civil que emerge do mundo da 
vida”. Dentro dela há aqueles que emergem de públicos organizados, e ao mesmo tempo aqueles que só estão "aparecendo perante o público". Na intervenção dos atores e na formação de grupos de pressão na esfera pública política há, no entanto, momentos de auto-afirmação e identificação política junto com as pautas próprias dos movimentos. Essas diferenciações e imbricamento entre as esferas prática e estético-expressiva é uma das sobreposições entre discursos da esfera pública política que serão discutidas no diagnóstico do segundo capítulo.

São caracterizados os públicos dos representantes de grupos de pressão e outras organizações privadas, movimentos sociais e grupos marginalizados emergindo na esfera pública ou nela já incrustados, servem como sensores a ameaças a direitos de comunicação. A potencialização desses grupos e da própria esfera pública política que formam depende ao mesmo tempo da garantia da utilização e da radicalização desses direitos para legitimar seus planos de vida individuais (Id. op. cit:375-376).

Ao lado desses públicos especial atenção é dada para a imprensa e os meios de comunicação de massa. A centralização dos processos mediáticos, capaz vez mais encarecidos, pressionam para uma seletividade da informação e que passa a se entender como o poder da mídia. Este se torna objeto de regulamentações, como o equilíbrio entre grupos de interesse público e privado na República Federativa Alemã (Id. op. cit:376), e na Constituição da República do Brasil entre os sistemas público, privado e estatal de comunicação (art. 223, Constituição de 88).

Outros dois importantes textos de Habermas que atualizam o conceito e o diagnóstico da esfera pública com especial foco para sua mediação pelos meios de comunicação de massa são "Os Caos da Esfera Pública" (2006) e "Meios, Mercados e Consumidores" (2007). Ambos jornalísticos, oferecem breves porém precisas e impactantes interpretações da esfera pública mediada pelos meios de comunicação de massa, que complementam a análise empírica e normativa sobre a mídia ao final do capítulo sobre a esfera pública política em Direito e Democracia.

Se em "Meios, Mercados e Consumidores" a imprensa de qualidade é vista junto aos meios de comunicação de massa como a medula da esfera pública política, e assume-se uma proposta normativa clara em relação à necessidade de subsídios estatais transparentes para garantir a existência de meios de comunicação críticos e independentes contra imperativos do mercado jornalístico, em Direito e Democracia, Habermas lista os princípios que Michael Gurevitch e Jay Blumler formularam para uma mídia que colabore 
para a problematização de temas comuns, a livre circulação de informações e a promoção de processos de formação da opinião pública. ${ }^{232}$

Outro argumento normativo de Habermas no texto de 2007 é que a "energia comunicativa" produzida na esfera pública política deveria ser garantida aos cidadãos pelo Estado da mesma forma que é a energia elétrica, pois ambos são direitos fundamentais à integração e à reprodução de sociedades de massa (Habermas, 2007:133-134). ${ }^{233}$ Esse argumento complementa a discussão em Direito e Democracia sobre a mídia de massa, pois esta recebe o mandado de um público que busca esclarecimento sobre questões comuns, e deve, como os poderes públicos e partidos considerar a opinião, as críticas e sugestões dos concernidos. Sua entrada na esfera pública política se daria, então, na medida em que apresenta problematizações e contribuições convincentes para a solução de questões sociais (Id, 1996:378-379).

Por outro lado, o diagnóstico das ambivalências de uma esfera pública amplificada e ao mesmo tempo fragmentada no contexto das tecnologias da informação e da comunicação, como realizado em "O caos da esfera pública" (2006a) - primeiro texto em que Habermas trata diretamente da internet ${ }^{234}$ - parece ser antecipado ao final do capítulo 8

\footnotetext{
${ }^{232}$ As "tarefas que a mídia deve desempenhar em sistemas políticos democráticos" elegidos por Gurevitch e Blumler no texto "Political Communication Systems and Democratic Values" (in. J. Lichtenberg, ed., Democracy and the Mass media. Cambridge, Mass., 1990) são: 1. Vigilância do ambiente sociopolítico, noticiando questões a impactarem positiva ou negativamente no bem estar dos cidadãos; 2. Agenda-setting significativo, tocando em questões chave do dia, incluindo aqueles que as propuseram e podem resolvê-las; 3 . Plataformas para a defesa inteligível e iluminadora de causas por políticos e seus representantes; 4 . Diálogo que alcança diversas visões, entre detentores do poder e públicos de massa; 5. Mecanismos de accountability da conduta de oficiais; 6 . Incentivos para os cidadãos aprenderem, escolherem e se envolverem, ao invés de atuarem somente como espectadores da política; 7. Resistência às tentativas externas de subverter a independência, integridade e capacidade da mídia servir à sua audiência; 8. Respeito ao membro da audiência, como potencialmente concernido e capaz de compreender seu ambiente político. (Habermas, 1996:378).

${ }^{233}$ Não é por menos que o mesmo artigo 22 da Constituição da República de 1988 declara no mesmo inciso que compete privativamente à União legislar sobre "IV - águas, energia, informática, telecomunicações e radiodifusão”. Com Habermas: “...la esfera pública política sólo es una pieza de unión. Ella es la que sirve de intermediaria entre los discursos y negociaciones institucionalizados en los foros estatales, por um lado, y las esporádicas e informales conversaciones cotidianas de los votantes potenciales, por outro. (...) // ...la comunicación pública despliega uma fuerza estimuladora a la par que orientadora en favor de la formación de la opinón y de la vonluntad de los cuidadanos, mientras que, al mismo tiempo, obriga al sistema político a adaptarse y a ser más transparente. Sin los impulsos procedentes de uma prensa que tenga la capacidad formar opiniones, de informar con fiabilidad y de comentar com escrupulosidad, la esfera pública puede dejar de suministrar esse tipo especial de energia. Cuando se trata del gas, de la electricidad o del agua, el Estado está obligado a garantizar el abastecimiento de energía para la población. ?No debería estar obligado igualmente a hacerlo cuando lo que está em juego es este outro tipo de 'energía', cuya ausencia provocará perturbaciones que terminarán perjudicando al própio Estado? Cuando o Estado intenta proteger el bien público que es la prensa de calidad en un caso particular no estamos ante ningún 'fallo del sistema'. Saber cómo se puede conseguir esto de la mejor manera posible es tan solo uma cuestión pragmática." (Habermas, 2009:134).

234 "Por um lado, a reorientação da comunicação, da imprensa e do jornalismo escrito para a televisão e a internet conduziu a uma ampliação insuspeitada da esfera pública midiática e a uma condensação ímpar
} 
de Direito e Democracia. Mas apesar de não pensar mais na tese de uma cultura passiva e manipulativa de recepção da comunicação social, ainda permanece a questão sobre as tensões entre poder e racionalidade na esfera pública política, pois mesmo sabendo como as mídias operam e o jogo dos atores que nelas intervêm, ainda não seria claro como ela interfere nos circuitos da esfera pública política (Habermas, 1996:377-378).

O que se sabe é que apesar de diversos diagnósticos céticos em relação à capacidade dessa intervenção levar a processos de tradução da opinião e da vontade gerados no seio de esferas privadas protegidas da intervenção do público ${ }^{235}$, é possível encontrar exemplos desse tipo de formação da esfera pública política em atores internos ao sistema político, em mobilizações sociais e até mesmo em contribuições de grupos marginalizados que conseguem atuar nos meios de comunicação, dramatizar e convencer outras redes de públicos a apoiarem suas pretensões (Id. op. cit:380-382).

Uma das dificuldades de produzir essa circulação da comunicação política da periferia ao centro do sistema político viria também da potencialização de um novo tipo de comunicação, que se torna dominante na esfera pública mediada pelas mídias: as contribuições não-escritas, isto é, a comunicação imagética que a televisão instaurou como linguagem preponderante da comunicação social, capaz de provocar confusões entre processos de convencimento por argumentos e experiências de identificação com as autorepresentações dos atores presentes em programas televisivos (Habermas, 2006a).

Essa esfera da "visibilidade pública" proporcionada pelos meios de comunicação de massa e generalizada com as possibilidades interativas da internet, continua a perseguir as reflexões Habermas a respeito das condições de uma comunicação discursiva e racional na esfera pública capaz de adentrar a esfera pública política e tornar “judicantes” os públicos

das redes de comunicação" // "A esfera pública, na qual os intelectuais se moviam como os peixes na água, tornou-se mais includente, o intercâmbio é mais intenso do que em qualquer época anterior." // Por outro lado, os intelectuais parecem morrer sufocados diante do transbordamento desse elemento vivificador, como se ele lhes fosse administrado em overdose. A bênção parece transformar-se em maldição. As razões para isso me parecem ser uma informalização da esfera pública e uma indiferenciação dos correspondentes papéis." // "A utilização da internet simultaneamente ampliou e fragmentou os nexos de comunicação." // "O preço do aumento positivo do igualitarismo, com o qual a internet nos brinda, é a descentralização dos acessos a contribuições não-redigidas. Nesse meio, as contribuições de intelectuais perdem a força necessária para formar um foco." (Habermas, 2006a).

235 Essas leituras, que mantém ligação com a teoria da indústria cultural de Adorno e Horkheimer, desdobram-se de um lado em estudos marxianos de economia política da informação e da comunicação, e de outro em estudos mais relativistas, como os denominados "contextualismos pós-modernos" de Foucault Habermas. Alguns desses teóricos serão retomados nesta tese, mas de modo geral pode-se dizer que Habermas considera seus diagnósticos como precisos para uma crítica do presente, mas a impossibilidade de se pensar em propostas normativas a partir deles faz com que Habermas opte pelo método da reconstrução normativa, que procura descrever as pretensões normativas que estão pressupostas em experiências concretas de comunicação e reconhecimento. Para mais sobre o método reconstrutivo, v. Habermas, Racionalidade e Comunicação, 1996; Honneth, Disrespect, 2007. 
"assistentes". De fato, a proposição de um capitalismo otimizado pelo elemento da imagem, como na "Sociedade do Espetáculo" de Guy Debord (1997), a "Iconomia" ou “economia política do audiovisual” de Gilson Schwartz (2006), ou a "economia do olhar" de Eugênio Bucci (2002), são formas de retratar a reorganização dos processos de reprodução material a partir de uma esfera pública dominada pela imagem, que se utiliza especialmente da mobilização de conteúdos inconscientes e afetos do público. ${ }^{236}$

Mas se Habermas pretende distinguir sua posição daquelas que dispensam a possibilidade de produção de uma esfera pública política autônoma, em função de não abandonar a tese da conexão interna entre as esferas públicas formais e as estruturas menos diferenciadas do mundo da vida, a esfera pública da visibilidade precisa ser recepcionada dentro dos potenciais de comunicação discursiva dos públicos que se expressam politicamente a partir de manifestações estético-expressivas.

A proposta de Wilson Gomes para essa caracterização da esfera de "visibilidade pública política" é a de que os meios de comunicação de massa ampliaram a "esfera de visibilidade pública" que se inter-relacionaria com esfera pública argumentativa desde seu surgimento. Trata-se das condições de exposição e publicização das opiniões e dos debates públicos, sem as quais não é possível pensar uma concepção ideal de esfera pública, já que a publicidade só ocorre com alguma forma de exposição pública (Gomes \& Maia, 2008:115-162).

Ao mesmo tempo, quando pensada ao lado de uma "esfera de discussão pública", que privilegia as condições de realização e qualidade dos debates e argumentação, a esfera de visibilidade pública tornaria mais realista o diagnóstico da esfera pública política, pois muitos processos de formação da opinião e da vontade políticas se dão mais pela "exposição" e a visibilidade das ideias do que por sua própria "discussão".

Os excessos dessa esfera de visibilidade pública são conhecidos e amplificados a partir das tecnologias de informação e comunicação, compondo o que Gomes denomina “cena pública". Nesta, a intervenção na circulação da informação política se dilui em instâncias midiáticas de comunicação, como nas imagens, no tempo de exposição e quantidade de acesso na televisão e internet, gerando processos de identificação mais afetivos e imagéticos do que éticos ou argumentativos com o público. Seria por isso necessária uma teoria da imagem pública política para tentar entender as ambivalências dessa prevalência de elementos da "cena pública" sobre a esfera pública da discussão. A

\footnotetext{
${ }^{236}$ Estudos desses autores, que também realizam diagnósticos do presente da esfera pública, serão discutidos durante a segunda parte, especialmente nos capítulos 5 e 7.
} 
partir da ideia de uma política de controle das aparências públicas, Gomes retrata então diversos casos da história política brasileira (Gomes, 2004:239ss).

Apesar de pensar nas funções democráticas da esfera de visibilidade pública, como a publicização devida dos debates, opiniões e argumentos, especialmente para um público mediado pelos meios de comunicação de massa, e inclusive como a própria forma, intensidade e extensão da exposição das ideias podem contribuir para a formação discursiva de opiniões, Gomes não trabalha essa expressão da esfera pública política no sentido de formas possivelmente emancipatórias da imagem, do olhar, dos afetos, da cultura ou mesmo para identificar ou elaborar critérios especificamente jurídicos de visibilidade pública da comunicação social e política necessários a uma esfera pública politicamente ativa (Gomes \& Maia, 2008:158-162).

Essa proposta será feita a partir do diagnóstico da expressão estético-expressiva da esfera pública política (v. capítulo 7, abaixo). Isso porque se torna cada vez mais necessário salvaguardar as possibilidades dos indivíduos e coletividades manifestarem suas personalidades, crenças, afetos e posições pessoais em contextos pluralistas e de respeito recíproco. Essas expressões são capazes de desencadear processos de individuação pela socialização, como o livre desenvolvimento da personalidade, e ações de solidariedade social, como a obediência à lei e a defesa de direitos que não somente os individuais. Ao mesmo tempo, as possibilidades de utilização estratégica da "imagem pública" revelam por outro lado a exigência de uma "visibilidade" da ordem como requisito para sua efetiva publicidade. $^{237}$

Outra tentativa de atualização do conceito de esfera pública de Habermas na literatura brasileira é a de Adrian Lavalle (2001). Com influência de Hannah Arendt, Koselleck, e utilizando Richard Sennet, Jean Cohen e Andrew Arato, Lavalle procura entender a recepção que o pensamento brasileiro tem do conceito.

Para tratar dessa publicidade burguesa como "aquilo que não teria sido" no processo de formação da modernidade brasileira, seria preciso então pensar no espaço público em três dimensões: uma primeira de "institucionalização pública do dissenso", quando a publicidade ganha previsão constitucional a partir do capitalismo liberal; uma segunda em que se trata dos "processos comunicativos competentes" para definir o caráter

\footnotetext{
${ }^{237}$ Apesar de não considerar a discussão de Habermas em The Theory of Communicative Action e outros textos em que o autor trata das ambivalências da comunicação de massa (Habermas, 2006a), as propostas de Gomes são interessantes para uma atualização da esfera pública política capaz de dar a devida consideração a essa esfera da visibilidade pública como critério democrático da própria discutibilidade. Seus estudos serão por isso retomados no capítulo 7 desta tese, especialmente no tópico 7.1.
} 
público de informações e ações políticas e sociais, e uma terceira que problematiza a ideia de "vida pública" como forma específica daquilo que em momentos da teoria social brasileira se denominou "sociedade civil", especialmente quando é relacionada somente com a institucionalização de espaços públicos que lhes dão corpo (Lavalle, 2001:75). ${ }^{238}$

Nesse caso, a questão da concentração das condições de acesso à esfera pública se torna primordial, pois a proposta é pensar numa esfera pública política capaz de se desvencilhar de algumas pré-condições históricas e determinados atores sociais originários, entendo-a como nas mais recentes formulações de Habermas, no sentido de "fluxos comunicativos" que emanam do mundo da vida ao problematizar questões comuns (Id. Ibid).

Essa proposta de se pensar na esfera pública política como um fluxo assujeitado de comunicações que circulam entre poder administrativo e poder comunicativo (Habermas, 1996:301) ${ }^{239}$, ou melhor, uma corrente de comunicação intersubjetiva cujas pretensões de validade podem transcender os contextos e públicos específicos de onde emergem ou são captadas, responde a essa mesma necessidade normativa de generalização do acesso, que significa não só a entrada irrestrita, mas também o equilíbrio normativo entre todas as pretensões: todas deveriam ter peso igual, seja por natureza ou correção política.

Assim, ao invés de se pensar em esferas públicas periféricas e centrais, que são disputadas por diversos atores sociais, como Habermas continuará a fazer no texto "Tiene la democracia una dimensión epistémica" (2009:138-183), propõe-se aqui interpretar as pretensões de validade dos públicos e atores de modo mais abstrato e específico, como

\footnotetext{
238 “A definição daquilo que tem ou é investido de estatuto público articula interesses sociais, condições de institucionalização política e expedientes de intermediação comunicativa, tal e como contemplado a partir de ênfases e perspectivas diferentes pelas grandes abordagens do espaço público - notadamente pela versão original da publicidade em Habermas e pelos desenvolvimentos mais recentes do programa de pesquisa desse autor na área da teoria do discurso aplicada ao direito. Porém, nestas páginas propõe-se uma compreensão do espaço público como produto da convergência de distintas dimensões com suas respectivas problemáticas, as quais não podem ser reconduzidas a um princípio ou pólo de articulação único; quer dizer, a produção do espaço público não pode ser carregada "no lado" da sociedade civil - tampouco apenas do Estado ou da mídia. Diga-se de passagem que, embora existam hoje razões estratégicas para apostar na sinergia desencadeada pelas iniciativas da consociação civil, não parece analiticamente proveitoso se pensar em um "espaço público social" como alternativa à "falência" e autoritarismo de um "espaço público estatal", pois semelhantes descrições induzem ao equívoco de conceber como possível um espaço público que não seja simultaneamente condensação de interesses sociais cristalizada mediante direitos e expedientes diversos de institucionalização e reconhecimento políticos - como se o "público estatal", por exemplo, não fosse também expressão de determinados interesses sociais, ou como se a afirmação da sociedade civil operasse, necessariamente, minando a capacidade de imposição política do Estado." (Lavalle, 2001:76-77).

239 "Once one gives up the philosophy of the subject, one needs neither to concentrate sovereignty concretely in the people nor to banish it in anonymous constitutional structures and powers. The 'self' of the selforganizing legal community disappears in the subjectless forms of communication that regulate the flow of discursive opinion -and-will-formation in such a way that their fallible results enjoy the presumption of being reasonable. This is not to denounce the intuition connected with the idea of popular sovereignty but to interpret it intersubjectively." (Habermas, 1996:301. Grifos nossos).
} 
expressões da esfera pública política analiticamente divididas com base nas diferenciações da razão comunicativa. Com isso, torna-se possível não só a tradução das pretensões de comunicação e reconhecimento na linguagem mais específica do direito, mas também busca satisfazer esse pressuposto geral de acessibilidade, cujas violações continuam a prejudicar a base normativa da esfera pública política.

No mesmo texto supracitado, Habermas realiza uma diferenciação entre níveis de condensação institucional da esfera pública política: no discurso institucionalizado do poder político, nos meios de comunicação de massa e na comunicação cotidiana da sociedade civil. Segundo o autor, os diagnósticos de um caráter abstrato da esfera pública política formada nos meios de massa e de assimetrias nas relações entre atores, emissores e seus públicos não impedem a possibilidade da esfera pública política colaborar para a qualidade das deliberações democráticas (Habermas, 2009:158).

É por isso que Habermas entende então a esfera pública política como "un sistema de comunicación intermediador entre, por un lado, as deliberaciones y negociaciones en el centro del sistema político y, por otro lado, las organizaciones y las conversaciones informales de la sociedad civil en los márgenes del sistema político." (Habermas, 2009:158-159).

A importância de se entender que a própria disputa entre os atores pela representação mais autêntica da opinião pública é o que mantém sua reflexividade (Habermas, 2009:164-166), fica também mantida nesse modelo de análise, pois não há pretensão de validade que dispense sua necessidade legitimar-se em comunicações concretas entre sujeitos historicamente situados. Essa garantia de reflexividade, problematização, pluralismo ou dissenso na esfera pública situa-se já no plano de pressuposições intersubjetivas, no entanto, ou nas condições de comunicação que precisam institucionalizadas nas áreas da comunicação social e da comunicação política (v. parte III deste trabalho).

É com a finalidade de abordar a esfera pública política a partir dessa perspectiva mais intersubjetiva e voltada para a possibilidade de sua aplicação na linguagem do direito que se propõe, enfim, reconstruir os pressupostos institucionais e conteúdos normativos que se desatacam de presentes problematizações, violações e afirmações de pretensões de comunicação e de reconhecimento na esfera pública política brasileira.

A partir dessa atualização do conceito de esfera pública política em Habermas, no entanto, que a eleva junto aos direitos de autonomia individual e dos direitos de autonomia política à condição de pressuposto do Estado democrático de direito (Habermas, 2009:138- 
143), esse esforço de reconstrução passa a se tornar uma atividade obrigatória quando se pretende compreender de modo mais preciso as condições da legitimidade da autoridade política de Estados constitucionais e de outras instituições democráticas.

As expressões da esfera pública política, analítica e resumidamente diferenciadas abaixo resumem, portanto, o método para o diagnóstico do presente da esfera pública política no Brasil, a ser realizado nas próximas páginas. A fundamentação dos pressupostos e conceitos mais importantes desse método será retomada de modo mais preciso em cada um dos tópicos do diagnóstico. Ao longo do percurso de revisão e atualização do conceito de esfera pública política desde o início desta primeira parte e neste tópico, as razões para a adoção desse novo método apareceram de modo mais assistemático. ${ }^{240}$

De toda forma, espera-se que tenha ficado clara a necessidade de um método capaz de diagnosticar o inalienável fundo prático da esfera pública política, sua conexão com a pretensão de legitimidade democrática do poder, os bloqueios técnicos e econômicos à realização do princípio da generalidade do acesso e a importância e a permeabilidade da comunicação estético-expressiva na ampliação de uma esfera pública "refeudalizada" a partir das novas tecnologias de informação e comunicação.

Expressões técnico-científicas e informativas da esfera pública política. Trata-se do espaço de social formado pela comunicação informativa, como nas discussões em torno do discurso científico, nas notícias e descrições de fatos pela imprensa, ou nas informações necessárias à disposição técnica da natureza, como na economia ou na biologia. A racionalidade cognitiva da ciência e da produção jornalística informativa, e a razão instrumental da economia caracterizam essa expressão da esfera pública política, na qual se confrontam pretensões cognitivas de verdade e pretensões de apropriação técnica da informação, do conhecimento e da comunicação. Essas pretensões se desdobram por sua vez em reivindicações pelo pluralismo de fontes de informação ou visões objetivas de mundo, por uma "busca cooperativa pela verdade", e pela descentralização da propriedade, do acesso e da produção de informação, comunicação, conhecimento e cultura.

Expressões prático-morais da esfera pública política. Esse espaço comunicativo é aquele constituído pelas problematizações em torno das liberdades individuais e as liberdades políticas que emergem das relações entre público e privado em democracias de massa. Essas pretensões são expressões da racionalidade prático-moral, que se orientam pelos princípios de justificação normativa da ética do discurso habermasiana: a validade das normas depende do consentimento de

${ }^{240}$ Para outra uma tentativa de sistematização este método de diferenciação analítica da esfera pública política, no caso para sugerir um método de educação em direitos humanos através da mídia, v. Blotta, Esfera Pública Política e Mídia, 2010. 
todos os possivelmente afetados por seus resultados, enquanto participantes de deliberações nas quais se atribuem reciprocamente competências comunicativas, sob pena de consensos ou decisões ilegítimas. Serão tratadas nessa expressão da esfera pública política as relações entre liberdades negativas e positivas de comunicação, como a liberdade de expressão e de imprensa e suas tentativas de regulação constitucional, novas formas de tentativa de participação na formação da vontade política, bem como movimentos institucionais que buscam recepcionar essa soberania popular de modo a legitimar sua autoridade.

Expressões estético-expressivas da esfera pública política. Trata-se do espaço social formado pelas pretensões de expressão individual e coletiva de conteúdos estéticos, artísticos, religiosos, culturais, afetivos, existenciais e psicológicos ligados à esfera privada e fomentadores do desenvolvimento livre da personalidade. Liga-se também à questão das condições em que o direito se publiciza, no sentido de sua visibilidade ao debate público. Nessa diferenciação da esfera pública política, será proposta uma divisão entre as manifestações estéticas e expressivas. No primeiro caso, elas se desdobram em pretensões estéticas de imagem e visibilidade, e no segundo em pretensões de individuação pela auto-expressão no público e impulsos para uma "solidariedade negativa", no caso da possibilidade de identificação com experiências de sofrimento do outro. 
PARTE II

DIAGNÓSTICO DO PRESENTE DA ESFERA PÚBLICA POLÍTICA NO BRASIL: A DIALÉTICA DA VIOLAÇÃO E DA AFIRMAÇÃO DAS PRETENSÕES DE COMUNICAÇÃO E RECONHECIMENTO 
Depois de uma tentativa de atualização do conceito de esfera pública política a partir do pensamento de Habermas, e da busca por comprovar a existência desse fenômeno em diversos momentos da história do Brasil, o diagnóstico do presente da esfera pública política brasileira a ser realizado nesta parte do trabalho se pretende distinto daquele apresentado por Habermas em Mudança Estrutural da Esfera Pública em três aspectos centrais. Primeiramente, como visto ao longo da primeira parte, ele se propõe elaborado à luz de uma leitura crítica das mais atualizadas reflexões de Habermas que compõem o paradigma crítico comunicativo da teoria crítica em relação ao conceito de esfera pública política.

A atualização de MEEP feita até agora procurou mostrar que a abordagem desse paradigma, que ressalta os pressupostos formais da racionalidade e da coordenação da ação orientadas para o possível entendimento mútuo presentes em toda comunicação humana (Habermas, 1984-I:391-392), não significa, no entanto, um abandono da aposta em estudos historicamente situados sobre as condições de uma formação racional da opinião e da vontade políticas, como se chegou aventar a partir dos rumos tomados pela obra habermasiana após MEEP (Calhoun, 1992:31-32; Kellner, 2010).

Ao contrário, trata-se de pensar, junto com a revisão de Habermas realizada 30 anos após a primeira edição da obra, que somente por meio do estatuto teórico maduro de seu pensamento é possível realizar diagnósticos históricos da esfera pública política capazes de apreender satisfatoriamente as pretensões normativas de seu tempo presente (Habermas, 1992:441-452). Do contrário, há o perigo de se incorrer em problemas semelhantes aos de $M E E P$ reconhecidos pelo próprio autor, como de não conseguir resolver questões sobre uma teoria da democracia que deveria seguir de sua teoria da esfera pública política. ${ }^{241}$

A segunda distinção importante em relação ao diagnóstico de MEEP é de caráter metodológico, e segue os desdobramentos teóricos da primeira distinção. Apesar de Habermas já utilizar em MEEP um método reconstrutivo, por meio da adoção de conceitos que são tanto descritivos quanto normativos, como esfera pública, público e opinião

\footnotetext{
241 “....it is necessary to demonstrate how it may be possible, in our type of society, for 'the public... to set in motion a critical process of public communication through the very organizations that mediatize it' (Structural Transformation, p. 232). This question drew me back, at the close of the book, to the problem on which I had touched but failed to address properly. The contribution of Structural Transformation to a contemporary theory of democracy had to come under a cloud if 'the unresolved plurality of competing interests ... makes it doubtful whether there can ever emerge a general interest of the kind to which a public opinion could refer as criterion' (Structural Transformation, p. 234). On the basis of the theoretical means available to me at the time, I could not resolve this problem. Further advances were necessary to produce a theoretical framework within which I can now reformulate the questions and provide at least the outline of an answer." (Habermas, 1992:441. negritos nossos).
} 
pública, e cuja distinção - e ao mesmo tempo pressuposição nos debates fragmentários da comunicação pública - permitem a própria crítica (Kramer, 1992:239, 250ss.), é somente em suas revisões da obra que ele reconhece o potencial de um novo estudo sobre o tema, sugerindo abordagens de esferas públicas diferenciadas especialmente a partir da estrutura teórica que compõe a teoria do agir comunicativo (Habermas, 1992:439-452). ${ }^{242}$

Assim, se a teoria do agir comunicativo permitiu acesso ao potencial de racionalidade da comunicação cotidiana, por meio de uma ciência social interpretativa que procede de modo a reconstruí-lo em todo o "spectrum" de processos de racionalização modernos, os diagnósticos empíricos da esfera pública política deste estudo podem ser abordados dentro de um processo de diferenciação da racionalidade moderna que se expressa na esfera pública política. ${ }^{243}$

É por isso que metodologicamente, este estudo trabalhará não só com a ambivalência entre o caráter normativo e descritivo dos conceitos que informam a esfera pública política e com um diagnóstico da formação de seus diversos públicos e plataformas, mas especialmente na forma de expressões gerais da comunicação pública que refletem factual e peculiarmente as pretensões de validade da teoria da razão comunicativa de Habermas - verdade, correção/justiça e sinceridadelautenticidade, as quais remontam também aos três momentos da razão moderna, primeiramente distinguidos por Kant $(1995 ; 2003 ;$ 2010), criticados e tensionados por Hegel (1974), e diagnosticados pela teoria da racionalização de Weber (Habermas, 2002a:35-72; Id. 1984-I:143-272).

Essa diferenciação analítica da esfera pública política, que foi trabalhada no final do primeiro capítulo, dará condições para novas interpretações das tensões entre os diversos discursos presentes no diagnóstico da esfera pública política brasileira, a serem analisados em diálogo com outras teorias sociais que problematizam e expandem as

242 "The only protection against an empiricist abridgement of the rationality problematic is a steadfast pursuit of the tortuous routs along which science, morality and art communicate with one another. In each of these spheres, differentiation processes are accompanied by countermovements that, under the primacy of one dominant aspect of validity, bring back in again the two aspects that were at first excluded. Thus nonobjectivist approaches to research within the human sciences bring viewpoints of moral and aesthetic critique to bear - without threatening the primacy of questions of truth; only in this way is critical social theory made possible." (Habermas, 1987-II:398).

243 "As we have seen, in the modern period culture gave rise of itself to those structures of rationality that Weber then discovered and described as value spheres. With modern science, with positive law and principled secular ethics, with autonomous art and institutionalized art criticism, three moments of reason crystallized without help from philosophy. Even without the guidance of the critique of pure and practical reason, the sons and daughters of modernity learned how to divide up and develop further the cultural tradition under these different aspects of rationality - as questions of truth, justice, or taste. (...) two questions must be answered: (i) whether a reason that has objectively split up into its moments can still preserve its unity, and (ii) how expert cultures can be mediated with everyday practice." (Habermas, vol. II, 1984:397398). 
pretensões de validade da razão comunicativa ou as próprias dimensões da comunicação intersubjetiva para além de suas formas discursivas, como é o caso da teoria do reconhecimento de Axel Honneth. ${ }^{244}$

A terceira e última distinção entre o diagnóstico da esfera pública política de $M E E P$ e o deste trabalho será substancial, especialmente por analisar o contexto brasileiro no tempo presente, ao invés da Inglaterra, França e Alemanha dos séculos XVIII ao XX. As problematizações dos elementos teóricos que compõem a esfera pública serão então interpretadas partir das afirmações e violações de suas pretensões normativas em casos específicos brasileiros, dando de certo modo continuidade ao diagnóstico da esfera pública política realizado no primeiro capítulo.

Porém, ao refletirem movimentos globais em discursos como os da ciência, da economia e da política, no entanto, por meio de paradigmas teóricos que apesar de conscientes de sua historicidade procuram descrever potenciais universalizantes da razão e da interação social, não se pode excluir de antemão a capacidade dessa abordagem teórica ser utilizada em diagnósticos de outros países, ou mesmo em expressões transnacionais da opinião pública.

Ao final, as pretensões normativas específicas da esfera pública política brasileira, que compõem os conteúdos normativos do direito da comunicação no Brasil, poderão sugerir por sua vez transformações nas próprias teorias que as fundamentam, como será o caso da possível contribuição da teoria do direito da comunicação aos processos de intersubjetivização da filosofia, da moralidade e do direito empreendidos por Habermas e interlocutores como Günther, Forst e Honneth (parte III).

\section{Expressões técnico-científicas e informativas da esfera pública política no Brasil}

O primeiro diagnóstico do tempo presente da esfera pública política brasileira se concentra nas suas expressões técnicas, científicas e informativas, isto é, nas expressões e problematizações de informações referentes ao de controle e ao conhecimento da natureza exterior, como na economia e na biologia, e à comunicação informativa, como no jornalismo e em outros discursos cuja pretensão normativa é a da verdade: de oferecer

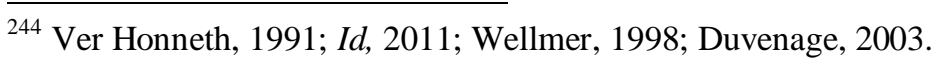


descrições e explicações verificáveis de objetos e eventos ligados por relações de causalidade.

Expressões de problematizações públicas desses dois tipos de discurso serão analisadas abaixo em quatro tópicos, sendo os dois primeiros relativos às relações entre $\mathrm{e}$ economia e comunicação social e política, sob o aspecto das novas críticas das formas de reprodução material da sociedade (5.1), e de seu entrelaçamento com elementos estéticoexpressivos da comunicação (5.2). Já a discussão sobre a comunicação informativa trabalhará o problema de seu predomínio em relação aos discursos prático-moral e estéticoexpressivo, a ponto de muitas vezes instrumentalizá-los na esfera pública política, como no caso do discurso científico (5.3). Isso leva tanto ao problema da influência da imprensa na construção da verdade sobre o que de fato ocorre no mundo quanto às questões práticas e estéticas envolvidas nesse processo (5.4).

5.1. Economia e esfera pública política: obstáculos e avanços das pretensões à descentralização da propriedade e da produção de informação e comunicação

O princípio da generalidade ${ }^{245}$ do acesso parece ter sido finalmente incorporado pelo conteúdo normativo da esfera pública política, especialmente após a crítica socialista da esfera pública (v. acima no cap. 2 "c" desta tese, "Cap. IV. Esfera Pública burguesa: idéia e ideologia"), isto é, não é mais necessário ter propriedade privada ou educação mínima para se adentrar a esfera pública e exercer a soberania popular.

Basta a idade suficiente para se poder obter do Estado garantia da prática de atos públicos como o voto secreto (art. 14, CF), direitos de resposta, petição e ação (art. $5^{\circ}, \mathrm{V}$, XXXIII, XXXIV e XXXV, CF), direito ao acesso a informações públicas (art.5 $5^{\circ}$ XXXIII e

245 “'Generalidade' da norma é, no sentido estrito do conceito burguês de lei, algo que já não é preenchido pelo critério formal da universalidade; este sentido só é atendido se a formulação geral, que exclui dispensas e privilégios, também não é endereçada, de fato, sob dadas condições sociais, a algum grupo determinado dentro da sociedade. $\mathrm{O}$ efeito jurídico de uma lei geral segundo critérios materiais não pode ser seletivo; precisa ser 'elementar' ou 'por princípio', de tal modo que ela se volte para os fundamentos da ordem social global e, nessa medida, ao circulo de pessoas potencial constituído por todos os membros da sociedade. Fórmulas jurídicas que normem não só princípios do intercâmbio social como um todo mas situações concretas dentro do âmbito da ordem global, são considerados 'específicos', diferenciando-se dos princípios gerais, mesmo que em sua formulação sejam concebidos genericamente. Só na fase liberal do capital é que a sociedade burguesa esteve 'separada' do Estado a ponto de ser uma esfera privada autônoma, de tal modo que a legislação se limitava tendencialmente a um sistema de normas genéricas; e só nessa fase é que a universalidade da formulação tinha de implicar também a generalidade da efetiva eficácia jurídica." (Habermas, 2003:337. Nota 86 do V capítulo). Habermas sugere para aprofundamento nessas questões as obras de Neumann, Der Funktionswandel des Gesetzes im Recht der bürgerlichen Gesellschaft [A transformação da função da lei no direito da sociedade burguesa. trad. livre],1938; seu ensaio sobre Direito natural e Revolução (1968). Para uma "distinção conceitual”, sugere de Schneider, Über einzelfallgesetze [Sobre as leis do caso individual. trad. livre], in. Gestschrift für Carl Schmitt, Berlin, 1959. 
LXXII, CF) à participação direta ou indireta na Administração (art. 37, XXII, § 3º, CF), e outros direitos e deveres ligados à esfera pública política. As discriminações econômicas e culturais que impediam institucionalmente o acesso de todos à esfera pública desde as críticas do capitalismo liberal no final do século XIX são gradativamente retiradas dos princípios constitucionais e substituídas por direitos e garantias sociais nas democracias ocidentais no século XX, incluindo o Brasil apesar de seus períodos autoritários.

Mas o que se vê na prática após o primeiro decênio do século XXI é a continuidade de uma determinação econômica da esfera pública política, organizada pela racionalidade técnico-estratégica do capitalismo, que se otimiza a partir das novas tecnologias de informação e comunicação e permite a financeirização da economia mundial. Estudos de economia política da informação, tanto de autores latino-americanos (Bolaño, 2000; Herscovici, 2004), como anglo-saxões (Chomsky, 2002), reforçam essa interpretação a partir de análises do impacto desse avanço tecnológico nas formas de reprodução material da sociedade, ou como diria Habermas, desde a incorporação da técnica e da ciência como as novas forças produtivas do capitalismo tardio (Habermas, 2006:72-76; Bolaño \& Brittos, 2007:85-86; Bolaño, 2000). A relação de seus diagnósticos com alguns casos práticos podem auxiliar na discussão sobre as novas tensões entre pretensões públicas e privadas nessa expressão da esfera pública política nacional.

\section{a) concentração econômica e concessões de meios de comunicação de massa}

O primeiro foco de discussão que se ressalta desses estudos é, portanto, a questão da continuidade e otimização dos oligopólios econômicos ${ }^{246}$ sobre a comunicação social e política após o advento das novas tecnologias de informação e comunicação (TICs). Se a esfera pública política tem como uma de suas plataformas mais importantes os meios de comunicação de massa (Habermas, 2009:154), a questão aqui se volta sobre a concentração econômica desses meios, e em que medida ocorre a transposição de suas conhecidas assimetrias de propriedade e acesso às formas de comunicação no espaço cibernético. ${ }^{247}$

Sobre o primeiro problema, não há exemplo mais claro das interpenetrações de público e privado descritas por Habermas como um dos aspectos da mudança estrutural da

\footnotetext{
${ }^{246}$ V. dados sobre a concentração de emissoras de rádio e televisão na primeira nota de rodapé do tópico 1.3. "d" desta tese, acima. ${ }^{247}$ v. "b", $\log$ abaixo.
} 
esfera pública do que as concessões de canais de rádio e televisão, institucionalmente controladas desde a Constituição brasileira de 1937 pelo poder administrativo central.

Na Constituição de 88, a competência de outorga é também exclusiva da União, condicionada a exame do Congresso Nacional que, caso não reprove renovação ou outorga por pelo menos $2 / 5$ de seus membros, elas se renovam automaticamente $\left(\S 2^{\circ}\right.$, art. 223 , $\mathrm{CF})^{248}$, e neste caso sem passar por nova licitação pública. Mas apesar de o regime jurídico do contrato ser uma prestação de "serviços [públicos] de radiodifusão sonora e de sons e imagens" (art. 21, XII, “a”, CF), a maioria dos concessionários são empresas privadas de comunicação, ou na terminologia de $M E E P$, empresas "semi-públicas". 249

O que torna essa interpenetração entre poder econômico e político no setor ainda mais impressionante é que essas empresas semi-públicas são muitas vezes de propriedade direta ou indireta de políticos membros de parlamentos municipais, estaduais ou federal, o que é proibido também pela Constituição Federal (art. 54, CF). A corrupção neste caso se dá a partir de uma subversão dissimulada do interesse público por interesses privados.

Dados de pesquisa da ONG "Transparência Brasil" mostram que em torno de 10,7\% (55) dos deputados federais controlam direta ou indiretamente canal ou retransmissor de rádio ou televisão no país. O Nordeste lidera com 30 concessionários $\left(19,9 \%\right.$ dos deputados da região) e o Sudeste segue com 15 (8,4\% da região). ${ }^{250}$ Já o endereço eletrônico do projeto "Donos da Mídia", com uma amostra mais recente, tem o número atual de 271 políticos como diretores ou sócios de 324 veículos de comunicação, sendo que o Estado de Minas Gerais lidera com 38 políticos, seguido por São Paulo com 28, Bahia com 24 e Paraná com 23. O partido DEM lidera com 21,7\% de todos os políticos

\footnotetext{
${ }^{248}$ Segundo Fábio Konder Comparato, esta norma deveria ser revogada, para permitir mais condições de vigilância dos públicos em relação ao cumprimento dos contratos de concessão de meios de radiodifusão e telecomunicações. V. Comparato (Prefácio. in. Lima, Liberdade de Expressão x Liberdade de Imprensa, 2010:14).

${ }^{249}$ Apesar de a CF de 88 exigir a complementaridade entre os modelos público, estatal e privado aos meios de comunicação (art. 223, caput), é clara a preponderância de meios privados em comparação com os públicos ou estatais. Em relação à televisão, o projeto "Donos da Mídia" indica que a Empresa Brasil de Comunicação, de canais públicos e estatais detém 95 veículos, ficando na quinta colocação em quantidade, atrás das privadas Globo (com 340), SBT (195), Band (166) e Record (142). Isso sem contar os retransmissores de rádio e televisão (a EBC tem 323 registros, enquanto que e a Globo tem 3305) (v. www.donosdamidia.com.br. Data de acesso: 23/10/2011. O Ministério das Comunicações divulgou dados sobre outorgas de radiodifusão (rádio, televisão e retransmissores) atualizados em 30/09/2011, sendo 9.730 meios comerciais, 4.377 comunitários e 243 educativos.

${ }^{250}$ V. Transparência Brasil. Projeto Excelências, Como são nossos parlamentares, Janeiro/2008, pp. 12-13. Disponível em http://www.transparencia.org.br/docs/excelencias.pdf (último acesso: 20/10/2011).
} 
donos de meios de comunicação, enquanto que $17 \%$ são do PMDB e $15 \%$ do PSDB. O PT tem só $3,69 \%$ do total dos meios nas mãos de seus políticos. ${ }^{251}$

O Ministério das Comunicações tem reagido de modo pontual diante desse cenário, especialmente após denúncias recentes feitas pela imprensa sobre a existência de rádios comerciais e comunitárias sob a propriedade de "laranjas" de políticos, líderes religiosos e empresários (Reportagem de capa da Folha de S.Paulo, 17/03/2011 252), como uma cabeleireira e um aposentado que não tinham bens suficientes para arcar com os custos dos contratos. Dessas denúncias e seus debates seguiram medidas do Ministério determinando em conjunto com a Comissão de Ciência e Tecnologia do Senado a suspensão da análise de todos os novos processos de outorga até que os presentes fossem concluídos, a exigência de comprovação prévia de recursos suficientes para se arcar com os custos do serviço e parecer de capacidade técnica. ${ }^{253}$

Além de disponibilizar novos dados sobre as outorgas no endereço eletrônico do Ministério das Comunicações, num movimento para o aumento da transparência dos processos, no caso das outorgas de retransmissores de rádio e televisão com "fins exclusivamente educativos", a Portaria n. 950 de 14/10/2010 do Ministério parece querer estabelecer uma espécie de triagem dos pedidos, que é feita pela Secretaria de Serviços de Comunicação Eletrônica do Ministério com a fiscalização da Anatel. ${ }^{254}$ Após aprovação, elas devem seguir para o Congresso.

${ }^{251}$ V. http://donosdamidia.com.br/levantamento/politicos. (último acesso: 23/10/2011. Dados apresentados como referentes à data do acesso). As estatísticas entre domínio de partidos se altera entre cada estado, com $40 \%$ da mídia de políticos do Rio de Janeiro pertencentes a políticos do PT, por exemplo.

${ }^{252}$ Outras seguidas reportagens e editoriais do Jornal discutiram e explicaram o tema, como editorial, a coluna de Carlos Heitor Cony e notícia do dia 29/03/2011 nos cadernos “Opinião" e "Poder".

${ }^{253}$ Para mais aprofundamento na legislação de concessões de radiodifusão, v. Lei que organiza atualmente os serviços de telecomunicações e criou a Agência Nacional de Telecomunicações (Anatel, Lei 9.472/97). A competência para outorga continua da União (art. 21, XI, CF; art. 1². Lei 9.472/97), apesar de algumas tentativas de regionalização dessa competência (v. notícia de 28/04/2011 sobre a criação de um Conselho Estadual de Comunicação na Bahia em www.direitoacomunicação.org.br). O Código brasileiro de telecomunicações, Lei 4.117 de 1962 que desde então regula a matéria, foi revogado pela Lei 9.472/97, exceto nas questões penais e nas normas sobre radiodifusão. Para mais sobre o tema, v. Costa \& Brener, 1997; Lopes, 1997; Blotta, 2005.

${ }^{254}$ A portaria estabelece: “Art. $2^{\circ}$ Caberá à Secretaria de Serviços de Comunicação Eletrônica - SCE realizar a análise preliminar dos pedidos a que se refere o art. 1o, bem como da conformidade da documentação que os instrui, podendo proceder ao indeferimento e arquivamento daqueles que não se encontrarem devidamente instruídos. // $§$ único. Poderão ser também indeferidos e arquivados os pedidos de outorga sempre que for constatada, pela SCE, a indisponibilidade de canal no Plano Básico de Distribuição de Canais, administrado pela Agência Nacional de Telecomunicações - Anatel. (...) //Art. $4^{\circ}$ Da decisão que determinar o indeferimento e arquivamento do pedido de outorga caberá recurso administrativo, em face de razões de legalidade e de mérito. // $\S 1^{\circ} \mathrm{O}$ prazo para interposição de recurso administrativo é de trinta dias e será contado a partir da ciência da decisão recorrida. $/ / \S 2^{\circ} \mathrm{O}$ recurso será dirigido à autoridade que proferiu a decisão, a qual, se não a reconsiderar, o encaminhará à autoridade superior." Disponível em: http://www.mc.gov.br/o-ministerio/legislacao/portarias (último acesso em: 22/10/2011). 
Essa nova norma traz, no entanto, parcas contribuições para aumentar a transparência dessas concessões de exploração de canais educativos, há tempos denunciados como instrumentos de moeda de troca política do governo, como no caso de emenda constitucional que permitiu a reeleição do Ex-Presidente Fernando Henrique Cardoso em 1998 (Costa \& Brener, 1997). Há somente a garantia do princípio do contraditório em caso de recursos das decisões, embora isso fosse ainda menos que exigir procedimentos já previstos na lei de licitações (8.666/93) para os contratos de concessão, autorização ou permissão de serviços públicos (art. 37, XXI, CF). ${ }^{255}$

O que se espera de mais ousado em políticas para a área é a divulgação da proposta de marco regulatório para o setor, a ser apresentado pelo Executivo ao Congresso, cujo texto diz-se ter sido elaborado pela Secretaria de Comunicação Social da Presidência da República, criada a partir de uma reformulação da secretaria de comunicação da Presidência no último mandato de Lula, que deu status de Ministro de Estado ao jornalista Franklin Martins. ${ }^{256}$

O Ministério das Comunicações sinaliza também para propostas futuras de alterações nas normas de comunicação. Dentre elas está a intenção de ampliar a competência da Anatel para incorporar junto às telecomunicações a fiscalização estrutural e de conteúdo do setor de comunicação social, tornando-se Agência Nacional de Comunicação. As questões econômicas, especialmente referentes à concentração dos meios e às ameaças à concorrência no setor deverão ficar mais a cargo do Conselho Administrativo de Defesa Econômica, o CADE, o que já é previsto pela legislação. ${ }^{257}$

Enquanto isso, recente notícia na imprensa revela que sessão da Comissão de Constituição e Justiça (CCJ) da Câmara dos Deputados em 22/09/2011, aprovou em três minutos e com quórum de dois deputados (um votando e um presidindo) 38 pedidos de

\footnotetext{
${ }^{255}$ O artigo 210 da lei sobre organização dos serviços de telecomunicações, que criou a Anatel em 1997 (Lei 9.472/97), excetua as concessões de serviços de telecomunicações e radiodifusão das disposições dos diplomas convencionais sobre prestação de serviços públicos, tratando-os de modo específico junto com o código brasileiro de telecomunicações, de 1962. Alguns dos diplomas excluídos desses serviços são as Leis federais 8.666/93, de licitações; 8.987/95, de concessão e permissão da prestação de serviços públicos; e 9.074/95, com normas para outorga e prorrogações das concessões e permissões.

${ }^{256}$ Essa reformulação da secretaria de comunicação da Presidência da República foi feita por meio da Medida Provisória 360/2007 do ex-presidente Lula, convertida na Lei 11.497/07 em texto de promulgação do senador Renan Calheiros. Os recentes documentos da área estão respectivamente disponíveis em: http://www.planalto.gov.br (último acesso: 23/10/2011).

${ }^{257}$ Essas medidas foram noticiadas no endereço eletrônico do Ministério das Comunicações, em 28/04/2011. Disponível em: http://www.mc.gov.br/noticias-do-site (último acesso: 21/10/2011).
} 
outorga e 65 de renovação de meios de comunicação, além de seis acordos internacionais e nove projetos de lei. ${ }^{258}$

As respostas do presidente da Câmara aos pedidos de anulação da sessão feitos por entidades da sociedade civil foram de que o regimento não prevê quórum mínimo de deputados presentes. No caso, já havia número suficiente de assinaturas (31) para abertura da sessão, pois como é de praxe na Câmara em todas as quintas-feiras, os deputados já haviam assinado cedo pela manhã e ido embora. E porque a Comissão de Ciência e Tecnologia já havia analisado os pedidos, não se fazia necessário discuti-los na CCJ antes de aprová-los. ${ }^{259}$

Esses atos são acintes ao princípio democrático e carecem de legitimidade ou legalidade, pois violam tanto a exigência de análise constitucional das questões, dispensada pela CCJ, quanto a soberania popular ao realizar ato legiferante com uma assembléia concretamente ausente. Obviamente, não é desse tipo de prática que Habermas e a teoria do direito da comunicação se referem quando tratam a esfera pública política como fluxos "assujeitados" de comunicação, informação e argumentos; especialmente quando aqui se propõe interpretá-la a partir de uma abstração das características e influência de seus públicos concretos, com a intenção de reconstruir e analisar as pretensões de validade de seus discursos.

Casos como esse retratam de modo violentamente negativo pretensões normativas presentes na esfera pública política nacional, como as que a sociedade civil que apresenta em documento derivado da I Conferência Nacional de Comunicação (2010), discutindo vinte recomendações para um novo marco regulatório ao setor. ${ }^{260}$ Pede-se aqui permissão

\footnotetext{
${ }^{258}$ Ver notícia sobre o caso que, inclusive, detalha as conversas entre os parlamentares e funcionários na sessão: http://www.direitoacomunicacao.org.br (último acesso: 25/10/2011).

${ }^{259}$ Segundo divulgou o portal Observatório do direito à comunicação, o presidente da Comissão de Constituição e Justiça João Paulo Cunha, do PT, ainda chegou a fazer as lamentáveis declarações sobre o procedimento: "os projetos aprovados não fazem referência 'à vida do povo' e que o quórum estava baixo porque era uma votação 'tranquila'. 'Nenhuma matéria votada na quinta-feira incide sobre a vida do povo', comentou." Notícia Priscilla Mazenotti - Agência Brasil. Disponível www.direitoacomunicacao.org.br (último acesso em 25/10/2011).

${ }^{260}$ Para melhor explicação sobre o referido texto, que contextualiza a articulação da sociedade civil na histórica conferência, cabe um interessante trecho de sua introdução: "Este texto é fruto de debates acumulados ao longo das últimas décadas, em especial da I Conferência Nacional de Comunicação (CONFECOM), sistematizados no seminário Marco Regulatório - Propostas para uma Comunicação Democrática, realizado pelo Fórum Nacional pela Democratização da Comunicação (FNDC), com a participação de outras entidades nacionais e regionais, em 20 e 21 de maio de 2011, no Rio de Janeiro. (...) Essa é a referência que este setor da sociedade civil, que atuou decisivamente na construção da I CONFECOM, propõe para o conteúdo programático deste debate que marcará a agenda política do país no próximo período." V. texto FNDC, Plataforma para um novo Marco Regulatório das Comunicações no Brasil. disponível em www. http://www.comunicacaodemocratica.org.br/ (último acesso 22/10/211). Para mais sobre o importante tema, v. de Venício A. de Lima, Marco Regulatório. Mais de duas décadas depois. In. Observatório da Imprensa, 12/04/2011.
} 
para uma tentativa de reorganização das vinte a partir da metodologia deste diagnóstico: Os números preservam sua ordem original do texto e a pretensão em negrito é a que mais contrasta com o caso acima relatado. O fato de ela não estar presente na expressão técnicocientífica da esfera pública política mostra como as decisões sobre a distribuição da propriedade dos meios de comunicação, a princípio técnico-econômicas, não podem dispensar uma justificação de conteúdo prático-moral:

Expressão técnico-científica e informativa: 1. Arquitetura institucional democrática; 4. Garantia de redes abertas e neutras; 5. Universalização dos serviços essenciais; 6. Adoção de padrões abertos e interoperáveis e apoio à tecnologia nacional; 10. Limite à concentração nas comunicações; 16. Estabelecimento de normas e códigos que objetivem a diversidade de pontos de vista e o tratamento equilibrado do conteúdo jornalístico; 17. Regulamentação da publicidade

Expressão prático-moral: 2. Participação social; 3. Separação de infraestrutura e conteúdo; 7. Regulamentação da complementaridade dos sistemas e fortalecimento do sistema público de comunicação; 8. Fortalecimento das rádios e TVs comunitárias; 9. Democracia, transparência e pluralidade nas outorgas; 11. Proibição de outorgas para políticos; 12. Garantia da produção e veiculação de conteúdo nacional e regional e estímulo à programação independente; 14. Criação de mecanismos de responsabilização das mídias por violações de direitos humanos.

Expressão estético-expressiva: 13. Promoção da diversidade étnico-racial, de gênero, de orientação sexual, de classes sociais e de crença; 15. Aprimoramento de mecanismos de proteção às crianças e aos adolescentes; 18. Definição de critérios legais e de mecanismos de transparência para a publicidade oficial; 19. Leitura e prática críticas para a mídia; 20. Acessibilidade comunicacional

Casos ligados às duas últimas expressões serão discutidos no capítulo 7. Em relação à primeira e aos temas deste tópico 5.1, portanto, é possível notar que as pretensões relacionadas procuram publicizar e controlar democraticamente o cenário de interpenetração e a influência recíproca dos poderes econômico e político na comunicação social, sob pena de se perder o controle político sobre os processos produtivos e a proteção da autonomia privada (liberdades comunicativas) que torna possível uma legitimação democrática desse mesmo controle.

Não se pode excluir, no entanto, o impacto das novas tecnologias digitais sobre as formas de reprodução material da sociedade e seus novos problemas práticos. Isso porque, apesar das inovações e dos novos espaços comunicação interativa proporcionados pela internet, o processo de informatização da economia mundial, incluindo a brasileira, não 
estaria levando a uma descentralização estrutural da propriedade e do acesso aos meios de produção de informação e comunicação.

Essa informatização teria estimulado, ao contrário, uma aceleração e o barateamento da produção e da circulação de bens e serviços, otimizando o processo de concentração econômica que, somado a políticas de desregulamentação do mercado financeiro e flexibilização do mercado de trabalho, dão condições à formação dos grandes conglomerados globais de imprensa, telefonia, internet, televisão e rádio (Bolaño, 2007:8594). Esses grupos se tornam cada vez mais incorporados por grandes redes, e assim interligados econômica e tecnologicamente; em muitos casos em função da propriedade cruzada dos meios de comunicação, isto é, a possibilidade de se ter propriedade sobre meios de comunicação diferentes.

Essa forma de concentração econômica, que resulta na eliminação da concorrência e, portanto, possivelmente a monopólios e oligopólios, apesar de poder ser deduzida de modo relativamente fácil a partir das normas antitruste do CADE, não é institucionalizada ou aplicada no Brasil. Projeto de lei (PL 6667/09), de autoria do deputado federal Ivan Valente propõe a criação do instituto, mas o governo fundamenta sua não aprovação ou apoio à iniciativa em função do cenário inevitável de convergência de mídias. Até mesmo nos EUA, conhecidos por normas restritivas a essas práticas, têm sofrido processos de desregulamentação pelos mesmos motivos. Ou seja, a convergência midiática ${ }^{261}$ modifica o marco institucional, revelando o domínio da racionalidade técnica e econômica sobre a razão prática nas áreas da comunicação social e da comunicação política. ${ }^{262}$

\footnotetext{
${ }^{261}$ Reflexões sobre o tema da convergência midiática são realizadas pelo Observatório Íbero-Americano de Ficção Televisiva (Obitel), coordenado pela profa. Maria Immacolata V. de Lopes. Com aporte nos estudos de Henry Jenkins, especialmente a obra Cultura da Convergência (2008), as teses sobre o processo de acoplamento tecnológico entre diferentes mídias refletem nos estudos culturais de comunicação com o fenômeno da transmídia, pelo qual conteúdos de diferentes programas e meios circulam entre si e estendem sua capacidade de interação com os públicos. V. Lopes, Bredarioli, Alves e Freire. Transmediação, Plataformas Múltiplas, Colaboratividade e Criatividade na Ficção Televisiva Brasileira, 2009, pp. 395-432. Um exemplo mais ligado à questão tecnológica e comercial é a nova oferta de um "combo" de TV a cabo (NET), com telefonia estatal (Embratel) e celular (Claro), que integram TV, telefone fixo, celular e banda larga. V. www.combomulti.com.br (último acesso: 04/11/2011).

${ }^{262}$ V. o endereço eletrônico do projeto de monitoramento da mídia "Donos da Mídia", com diversas bases de dados sobre propriedade e processos de outorga de meios de comunicação. Dados recentes do grupo mostram a propriedade de diversos meios pelas mesmas principais redes. Segundo o levantamento, as organizações Globo detêm, por exemplo, 14 tipos diferentes de meios de comunicação (340 no total), e não só canais de televisão e rádio, como também jornais e revistas e até rádio comunitária. V. www.donosdamidia.com.br/inicial (último acesso 23/10/2011).
} 


\section{b) novas tecnologias e críticas à propriedade intelectual}

O chamado digital divide é uma analogia das assimetrias mundiais de acesso a bens materiais com aquelas relativas aos bens informacionais, como o acesso à Internet. ${ }^{263}$ Organizações não governamentais e associações civis que monitoram políticas de inclusão digital no mundo, como a campanha Communication Rights in the Information Society (CRIS. Direitos de comunicação na sociedade da informação. www.cris.org), têm buscado identificar a dimensão dessa desigualdade, bem como medidas para tentar reduzi-la.

A obra coletiva Direitos à Comunicação na Sociedade da Informação, organizada por José Marques de Melo e Luciano Sathler (2005), trabalha o tema nas perspectivas internacional e nacional, e se pretende ampliador no Brasil do debate promovido por essa campanha mundial para os direitos à comunicação, mobilizada por diversas ONGs internacionais como a WACC (World Association for Christian Communication). Em seu texto no volume, Melo destaca, com dados do início dos anos 2000, como a prevalência das mídias de massa no Brasil teria significado uma diminuição proporcional dos leitores (em torno de 10 milhões em 2000) da imprensa, que teria crescido $40 \%$ enquanto que a população aumentara 300\% de 1950 a 2000 (Melo, 2005:241).

Nesse cenário, a internet aparece então para o autor com a tendência de acentuar essa "exclusão comunicacional", isto é, os gaps já presentes entre a informação, a comunicação e a cultura produzida e compartilhada por elites, e aquela disseminada à massa, com acesso menor e menos intenso a meios de produção e compartilhamento de comunicação e informação. ${ }^{264}$

Mas apesar dessas assimetrias, os programas governamentais e iniciativas privadas que, de modo independente ou em conjunto monitoram e realizam políticas de inclusão digital, têm colaborado junto ao crescimento econômico do país nos últimos anos para um acesso crescente à world wide web, que dobrou de 2005 a 2009, segundo o IBGE. ${ }^{265}$

\footnotetext{
${ }^{263}$ Para mais sobre o tema, v. White, Mapping the Global Digital Divide (manuscrito. Disponível em: http://interactivemedia.bradley.edu. Último acesso 23/10/2011). V. também Alencar, A infoinclusão e as estatísticas para a América Latina, 2008.

${ }^{264}$ V. Melo \& Sathler (orgs.), 2005, pp. 7-10 e 237-244.

${ }^{265}$ Nesse período, houve a passagem de acesso permanente de 13,7\% a 27,4\% dos domicílios. Fonte: IBGE, Diretoria de Pesquisas, Coordenação de Trabalho e Rendimento, Pesquisa Nacional por Amostra de Domicílios 2005 a 2009 (disponível em: http://seriesestatisticas.ibge.gov.br (último acesso 23/10/2011). Mas como já visto no tópico 1.3 acima, dados mais recentes de outras fontes indicam que o Brasil é atualmente o quinto país do mundo com mais acesso à internet, já que pouco menos de $40 \%$ da população teria acesso regular à rede. Dados disponíveis no endereço eletrônico http://tobeguarany.com/internet_no_brasil.php (último acesso: 29/09/2011). Ver informações em: http://www.mc.gov.br/pnbl (último acesso em
} 
O Programa Nacional de Banda Larga, iniciado em 2011, é outra iniciativa importante do Governo Federal nesse sentido. Ele pretende garantir acesso à internet banda larga a preços módicos a 40 milhões de domicílios até 2014, operacionalizando suas atividades por meio da holding de estatais de telefonia Telebrás e contratos com empresas de telecomunicações privadas que pretendem oferecer o serviço.

Apesar de críticas nas primeiras atividades do projeto, especialmente em relação à velocidade de um $1 \mathrm{MB}$ por segundo e ao valor de $\mathrm{R} \$ 35,00$ aos quais as empresas do setor privado interessadas deverão se comprometer ao oferecerem o serviço, o programa é fundamentado na ideia do acesso de qualidade à rede como um direito fundamental de informação e comunicação, e mais importante para a questão institucional, o espaço digital é considerado pelo programa como bem de domínio público e a internet banda larga como serviço de interesse público, prestado em regime público. ${ }^{266}$

O Ministério das Comunicações também está capitaneando a iniciativa, mas procurará executá-lo também em parceria com a iniciativa privada. É nesse entrecruzamento entre as iniciativas pública e privada para o oferecimento das novas plataformas de comunicação e informação que devem se voltar as atenções e monitoramento em relação à devida transparência e publicidade das atividades de contratação e execução dos serviços. ${ }^{267}$

23/10/2011). Sobre a exclusão digital no Brasil e discussões sobre orientações das políticas de inclusão digital, v. Mattos \& Chagas, 2008.

${ }^{266}$ Ver informações em: http://www.mc.gov.br/pnbl (último acesso em 23/10/2011). V. informações sobre esse debate em http://www.mc.gov.br/perguntas-e-respostas (último acesso: 29/10/2011). Para uma crítica recente à implementação do prejeto, v. Brittos \& Meneses. "Dois pesos e apenas uma medida". In. Observatório da Imprensa. Ed. 669, 22/11/2011. V. decreto que cria o PNBL. em: V. também a publicação "Brasil Conectado - documento-base do Programa Nacional de Banda Larga", de 30/11/2010 em: www4.planalto.gov.br/brasilconectado (último acesso 25/11/2011).

${ }^{267}$ Vê-se, no entanto, que sobre esse aspecto o governo se posiciona de maneira dúbia, ao afirmar a importância de institucionalização do serviço como público, mas ao mesmo sugerir que o caráter público do serviço pode prejudicar seu desenvolvimento técnico. Na seção "perguntas e respostas" sobre o PNBL no endereço eletrônico do Ministério das Comunicações, fica presente esse posicionamento: A banda larga no Brasil só será universalizada se for declarada como um serviço de telecomunicações em regime público, com metas de universalização, controle de tarifas e garantia de continuidade? // A banda larga é um serviço de interesse público e está sendo tratada como tal. É explorada pelas empresas privadas, mediante autorização do Estado. Mesmo quando prestados sob o regime privado, os serviços de telecomunicações podem sujeitar-se a rígidas metas de qualidade e a compromissos de abrangência, graças a dispositivos da própria Lei Geral de Telecomunicações. Embora existam meios jurídicos para transformar a Internet em banda larga em um serviço prestado no "regime público", essa mudança tende a trazer impactos econômicos que, em vez de acelerar a expansão do serviço, acabem por acarretar efeitos indesejáveis: corre-se o risco, por exemplo, de reduzir os níveis de investimentos e afastar novos agentes econômicos interessados em ofertar o serviço e competir com as atuais empresas. Ou seja, regime público versus regime privado no caso da banda larga é uma falsa polêmica. É importante ter em mente que no momento em que todos os municípios brasileiros tiverem redes intermediárias chegando até sua sede, ampliar a capacidade desta infraestrutura será muito mais fácil e barato." (endereço eletrônico do MC referente ao PNBL. http://www.mc.gov.br/perguntase-respostas. último acesso 29/10/2011). 
A expectativa em torno de um marco legal para comunicação eletrônica, que também trará normas para a internet junto ao seu novo marco civil, também em votação, coincide então com proposta de Bolaño e Brittos (2007:85ss), para quem a evolução tecnológica e o conseqüente barateamento da circulação de informação e comunicação precisariam ser gerenciados por uma política nacional geral de comunicação capaz de ser permeável aos interesses variados da sociedade civil, distribuindo a todos os benesses desse desenvolvimento da microinformática.

A internet pode ser considerada a última grande revolução tecnológica do século $\mathrm{XX}$, pois ao fundir formas da comunicação de massa com telecomunicações e outros meios de informação, rompeu em diversos espaços a unilateralidade entre emissor e receptor dos meios de comunicação de massa tradicionais. ${ }^{268}$ Apesar disso, a rede ainda tem diversas desigualdades em termos de acesso e no seu interior (Herscovici, 2004) ${ }^{269}$, e é por isso vista por esses estudiosos como uma nova forma de expansão da lógica de acumulação do capital, reproduzida nas redes de informação e comunicação do "ciberespaço" (Bolaño, 2007).

Para romper essas assimetrias, movimentos pelo chamado software livre no Brasil, inclusive incorporados pelas políticas do Ministério da Cultura quando chefiado por Gilberto Gil (2003-2008), tiveram influência direta de alguns movimentos na teoria do direito e da comunicação na área específica da economia política, especialmente a partir da rediscussão da propriedade intelectual gerada pelas novas tecnologias de informação e comunicação. Uma obra seminal e outra recente que impulsionam esses movimentos são The Future of Ideas (2001) e The Wealth of Networks (2006), escritas respectivamente pelos teóricos do direito ligados à filosofia do commons Lawrence Lessig e Yochai Benkler, professores da Harvard Law e do Berkman Center for Internet and Society de Harvard.

\footnotetext{
268 “...con la comunicación en Internet la world wide web parece compensar las debilidades del caráter anônimo y asimétrico de la comunicación de masas, toda vez que permite que reinstalen elementos interactivos y deliberativos en un intercambio no reglamentado entre compañeros y colaboradores que se comunican entre si virtualmente, pero en pie de igualdad. De hecho, Internet no solo há producido cibernautas curiosos, sino que también há reanimado la figura históricamente periclitada de um público igualitário de participantes en la conversación y de compañeros epistolares que se escriben y se leen." (Habermas, 2009:156).

269 “As redes eletrônicas não podem ser concebidas apenas como redes abertas, as quais seriam sinônimas da instauração de uma democracia digital e de um espaço concorrencial globalizado. Pelo fato de constituírem uma ferramenta desta "nova economia", elas apresentam as seguintes características: (a) a informação é, por natureza, assimétrica à medida que as modalidades de acesso não são iguais para todos os agentes; as modalidades concretas da concorrência capitalista só podem ser explicadas a partir da assimetria da informação e das rendas que correspondem à este tipo de situação (b) conseqüentemente, as redes eletrônicas são redes fechadas, ou semi-fechadas, dentro das quais circulam informações semi-privadas." (Herscovici, 2004:147).
} 
O Creative Commons, exemplo do chamado "Copyleft ${ }^{270 ", ~ c o m ~ " s o m e ~ r i g h t s ~}$ reserved", é uma forma alternativa de registro e cessão de direitos de propriedade intelectual criada por Lessig, em cujos termos podem ser previstas formas não comercializáveis de divulgação e cessão da obra, inclusive para estimular trabalhos colaborativos que podem gerar renda no futuro. Outros representantes do software livre são aqueles que utilizam o sistema operacional Linux, que trabalham a partir da possibilidade de compartilhamento e recriação do código fonte, o source code, pressupondo também a recriação e a utilização livre do sistema, diferentemente do Windows ou da Apple, por exemplo, que só permitem a utilização. ${ }^{271}$

As pretensões normativas da filosofia do commons e do software livre presentes nessa nova forma de registro e utilização das criações do espírito mais voltadas para o trabalho colaborativo do que mercantil, chamam a atenção para a necessidade de democratização dos novos meios de produção de informação e comunicação, e fazem isso por meio de uma nova crítica ao conceito de propriedade, especialmente a partir dos problemas atuais relacionados à propriedade intelectual, como as discussões a função social da propriedade intelectual, que entrecruzam direito privado, direito público e direitos humanos. ${ }^{272}$

270 Trabalhando a partir da definição dos registros GNU (General Public License), da Free Software Foundation, Ferraz Júnior identifica a idéia jurídica de copyleft como possível de ser realizada dentro do paradigma do copyright, pois ambos podem proibir certos usos da derivação de sua obra: "The legal regime of the assumption that free software is not limited to open source, including besides the right to run the program and study its source code, the right to reproduce, modify and redistribute the software. These permissions to third parties, which consist of primary standards, are added to the so-called copyleft, in other words the requirement that any derivations developed by third parties be licensed with the same rights, or what is the same thing, the prohibition of altering, in the derivations, the open use regime of the original work. Therefore, copyleft is the revocation of the third party competence regarding the disposition of the derivative work. This prohibition (or revocation) acts at the secondary-normative level." (Ferraz Júnior, 2001:19).

${ }^{271}$ Para mais sobre o Linux e como os programas de software livre representariam o efeito de "clube inclusivo", como uma publicização democrática no sentido de esfera pública habermasiana,v. Herscovici, 2004:148ss.

${ }^{272}$ V. Moraes, A função social da propriedade intelectual na era da informação, 2006; Para visão aplicada ao direito à comunicação, Brittos \& Collar, 2008:83-87. V. também interessante discussão sobre esta pretensão normativa à descentralização da propriedade e da produção de informação e comunicação no texto de Venício A. de Lima "Pela máxima dispersão da propriedade", que destaca estudo de jurista C. Edwin Baker da Universidade de Pennsylvania sobre importância dessa descentralização a partir do princípio da "maximum dispersal of media ownership" (Lima, 2010:110-112). V. deste Baker. Viewpoint Diversity and Media Ownership. In. Federal Comunications Law Journal. V. 60. N. 3, 6751-671, 2009; Id. Media Concentration and Democracy: why ownership matters. Cambridge University, 2007, este último citado por Lima (Id. Ibid). 
Essa crítica revitaliza novamente o conteúdo prático igualitário da crítica da economia política. ${ }^{273}$ Conceitos como produção social, formulado por Benkler, é um dos exemplos dessa discussão sobre a infraestrutura da economia política da informação, pois procura salientar a existência e a importância das formas atuais de produção "nãoproprietárias", como a "P2P" (peer to peer), por definição aquelas não voltadas para venda e circulação imediata no mercado. Sua finalidade é gerar trabalhos colaborativos e criativos dotados de propriedade imaterial, como programas de computador, sistemas, projetos, ideias, produções culturais e outras tecnologias de informação e comunicação, criados a partir do compartilhamento de condições igualitárias de comunicação e participação desde a infra-estrutura técnica do espaço digital (Benkler, 2006:26). ${ }^{274}$

Como procura demonstrar Benkler, esse tipo de intervenção técnico-científica colaborativa no mundo exterior tem produzido riqueza e crescimento econômico consideráveis, ${ }^{275}$ embora o que os torna possíveis independe da exclusividade e de assimetrias de informação e acesso à produção características do capitalismo.

É por isso que surge essa pretensão a mais autonomia em relação à disponibilização ao acesso público a criações do espírito como a ciência, a cultura, a comunicação pública e outras estruturas diferenciadas do mundo da vida. Começando pela decisão individual do autor sobre como e em que condições pretende divulgar sua obra. Ele ou ela podem disponibilizar certos usos de modo prévio como acesso sem fins lucrativos ou a

\footnotetext{
${ }^{273}$ Sobre a importante tese de Habermas de que há por trás da crítica da economia política, e especialmente no jovem Marx, um conteúdo normativo jusnaturalista e portanto, prático de igualdade das condições de reprodução material da vida, v. Habermas, O Discurso Filosófico da Modernidade, 2002:92-93; Id, Teoría y Práxis, 1987:113-116; Id. Conhecimento e Interesse, 2002, cap. 2-3.

274 "A series of changes in the technologies, economic organization, and social practices of production in this environment has created new opportunities for how we make and exchange information, knowledge, and culture. These changes have increased the role of nonmarket and nonproprietary production, both by individuals alone and by cooperative efforts in a wide range of loosely or tightly woven collaborations. These newly emerging practices have seen remarkable success in areas as diverse as software development and investigative reporting, avant-garde video and multiplayer online games. Together, they hint at the emergence of a new information environment, one in which individuals are free to take a more active role than was possible in the industrial information economy of the twentieth century." (Benkler, 2006:2). Ao final da obra, Benkler apresenta uma das muitas dificuldades que enfrenta para defender a tese acima: "Despite the continued importance of nonproprietary production in information as a practical matter, the conceptual nuance required to acknowledge its importance ran against the grain of the increasingly dominant thesis that property and markets are the roots of all growth and productivity." (Benkler, op. cit:461. Grifos nossos).

${ }^{275}$ Em relação à economia do conhecimento, ou "economia criativa" que pode ser relacionada à produção social de Benkler, o Ministério da Cultura lançou em outubro de 2011 o plano nacional de economia criativa, no qual traz dados sobre seu crescimento no mundo: "Segundo estimativas da UNESCO o comércio internacional em bens e serviços culturais cresceu, em média, 5,2\% ao ano entre 1994 (US\$ 39 bilhões) e 2002 (US\$ 59 bilhões). No entanto, esse crescimento continua concentrado nos países desenvolvidos, responsáveis por mais de $50 \%$ das exportações e importações mundiais. Ao mesmo tempo, pesquisas da Organização Internacional do Trabalho apontam para uma participação de $7 \%$ desses produtos no PIB mundial, com previsões de crescimento anual que giram em torno de $10 \%$ a 20\%" (Ministério da Cultura. Plano da Secretaria da Economia Criativa, 2011, p. 14).
} 
possibilidade de reutilização por outrem na composição de outra obra ou processo. Não seria necessário nesse caso dar autorização individual a cada pedido e utilização específica, como é previsto pela atual lei de direitos autorais (art. 29 da Lei 9.610/98).

Isso porque não se pode negar que proibir a disponibilização voluntária de uma obra pelo autor, ou garantir seu direito pela exclusão de seu acesso ao público acabe por dificultar uma divulgação maior do seu trabalho, ganhar maior notoriedade e, consequientemente mais rentabilidade econômica. A partir de formas alternativas de uso, distribuição e reprodução das obras proporcionadas pelas tecnologias digitais, estimula-se de outro modo parcerias e trabalhos colaborativos, potencialmente mais criativos e inovadores, que também são importantes insumos da economia. ${ }^{276}$

Com um olhar atento, também é possível identificar como o grande lobby internacional destinado à manutenção do modelo de exclusividade do copyright é realizado mais pelos agentes das indústrias culturais do que pelos próprios autores. ${ }^{277}$ Embora se justifiquem como defensores dos direitos de propriedade intelectual são as editoras, gravadoras, produtoras, suas associações e organizações e outros intermediários quem mais se interessam pela manutenção dessa orientação exclusivista do copyright, ainda predominante na área. Como se sabe, o tratado internacional de propriedade intelectual (TRIPS, 1994), é derivado dos princípios do tratado de comércio de 1947 que levou à criação da OMC (e já previa um "Conselho TRIPS” em seu art. IV.5), o que pode revelar o

\footnotetext{
276 Em nota importante do texto da conferência "Erosion of subjective rights by reason of technical development (Patent, Copyright)" (Frankfurt, agosto de 2011), o professor Tércio Sampaio Ferraz Júnior atesta: "Although there is the possibility of privatistic (exclusive) exploration, this is not the only way to benefit from intellectual creation. The benefit may be granted by the very interaction of an undetermined number of programmers who can enhance the creation, testing the work and developing it to solve new problems and adapt the original program to new requirements. In turn, this communication and the spread of use of software to create condition for that computing knowledge to be standardized, which could mean a gain for the creator as it dominates the standardized technology.” (Ferraz Júnior, 2011:60).

277 Alguns autores ainda participam dessa investida de proteção ao copyright. Artigo publicado na Folha de S.Paulo em 26/02/2011 (caderno Ilustrada), de autoria de representantes do Sindicato de Autores dos EUA, o conhecido romancista Scott Turow (presidente), Paul Aiken (diretor executivo) e James Shapiro (membro do conselho de direção do sindicato), alerta: “A ascensão da internet levou à visão, por parte de muitos usuários e empresas que operam na rede, de que os direitos autorais são uma relíquia adequada apenas às necessidades de gigantes corporativos que estão fora de sintonia com a atualidade. //Basta pensar nos dedicados 'compartilhadores de arquivos' que transmitem e recebem material protegido sem o menor sentimento de culpa. // Eles são encorajados e assistidos por um punhado de professores de direito e outros especialistas que se tornaram peritos em formular argumentos contraintuitivos segundo os quais os direitos autorais constituem empecilhos à criatividade e ao progresso.// A teoria deles é que se enfraquecermos gravemente as proteções dos direitos autorais, a inovação irá florescer de fato. // É uma ideia sedutora, mas que ignora séculos de progresso científico. // Uma cultura rica requer contribuições de autores e artistas que dediquem milhares de horas a uma obra e a vida inteira a seu trabalho."
} 
viés mercadológico da propriedade intelectual nessa instituição da esfera pública política internacional. $^{278}$

Os debates acalorados em torno da nova proposta de reforma da lei de direitos autorais, já desatualizada em relação às exigências de diversos adeptos da filosofia do commons, demonstram como o direito ainda não conseguiu se adaptar ao regime de produções cooperativas e criações imateriais, como os softwares, os games, os sistemas de informação, bancos de dados e outras obras cuja produção é otimizada pelas TICs.

Em recente texto, o professor Tércio Sampaio Ferraz Júnior discute o impacto das novas tecnologias de informática e robótica sobre o direito, especialmente no que se refere às disputas por propriedade intelectual de bens imateriais, como os softwares. Isso porque, como a propriedade intelectual dispensa cada vez mais o suporte físico, compartilhá-la não significa perdê-la, de modo que tê-la não precisaria redundar em sua exclusão em relação aos outros, já que restringe o acesso ao conhecimento. ${ }^{279}$

Porém, valendo-se de amparo na legislação em vias de reformulação e nas pressões dos intermediários da indústria cultural - seriamente impactados pelas novas tecnologias digitais ${ }^{280}$-, as políticas nessa área acabam criminalizando o acesso online de obras para uso privado e não comercial, bem como os compartilhamentos gratuitos de arquivos,

\footnotetext{
278 “Não é por uma obra ou prestação ser colocada na Internet que se extinguem os direitos de autor e direitos conexos que sobre ela recaiam. Se alguém a reproduzir para a explorar comercialmente está a desrespeitar o direito intelectual. Mas o uso privado é livre, e quem colocou a mensagem em rede naquelas condições está justamente a disponibilizá-la para o uso privado pelos interessados sem subordinação a qualquer autorização. // Aquilo a que assistimos é apenas um começo. Amanhã, as grandes empresas de comunicação quererão fazer a exploração comercial; como fazem já os produtores de inúmeras bases de dados. Seguramente que tomarão providências que restrinjam a liberdade de acesso à base." Ascensão, Direitos de autor e conexos inerentes à colocação de mensagens em rede informática à disposição do público, 2000, 413.

${ }^{279}$ Essa importante reflexão, que leva Ferraz Júnior a uma crítica mais geral dos direitos subjetivos em função desse avanço da técnica e de questões mais normativas como direitos de acesso à informação e à cultura, será retomada na terceira parte desta tese, especialmente quando se procura discutir os impactos de uma interpretação intersubjetiva do direito nos conceitos da filosofia moderna do direito.

${ }^{280}$ A indústria da música é a mais notoriamente impactada pelo advento da internet. A pesquisa "Indústria da Música - uma crise anunciada", de Herschmann \& Kischinhevsky (2005), indica que esse setor da indústria cultural encolheu 50\% de 1997 a 2003 no Brasil, enquanto que o mercado informal e ilegal chegou a representar 52\% do total de R \$601 milhões no período, somando CDs DVDs e vídeos musicais. É consultada a obra Mercado brasileiro de música 2003, Associação Brasileira dos Produtores de Discos (ABPD), Rio de Janeiro: 2004 (Herschmann \& Kischinhevsky, 2005:5). Mais recentemente, documento da International Federal of Phonographic Industry (IFPI), que representa a indústria em 75 países, procura demonstrar quanto a indústria musical ou editorial tem sofrido com o compartilhamento não autorizado de músicas e obras. No tópico intitulado "Piracy and Other Creative Industries", inicia-se com a frase "Ultimately, if nothing is done, we just won't be here", e continua: "Available statistics show that film and TV piracy have sharply increased in the last two years. Research in the UK in October 2010 from Harris Interactive found 14 per cent of internet users download both films and television programmes from illegal P2P services." (IFPI, 2010:23).
} 
centrando-se em programas de combate à pirataria que se fundam numa concepção cada vez mais restritiva de propriedade intelectual. ${ }^{281}$

Apesar disso, algumas recentes decisões jurídicas internacionais e propostas legislativas como a reforma da lei de direitos autorais no Brasil tem iniciado um movimento contrário a essa tendência ${ }^{282}$, indicando a possibilidade de se realizar a importante distinção entre pirataria e produção peer to peer, já que a primeira tem a finalidade de comercializar ilegalmente obra ou processo, enquanto que o outro se trata de reprodução não comercial e benéfica em termos de acesso à cultura e seu desenvolvimento. ${ }^{283}$

Enquanto não são propostas e implementadas políticas positivas do direito que possam, por exemplo, garantir recursos àqueles autores, artistas, cientistas, universidades e organizações em troca da disponibilização pública às suas obras e informações sobre processos produtivos, serão desperdiçadas chances de generalização não só do acesso à comunicação pública, mas também à saúde pela quebra de patentes de medicamentos ${ }^{284}$, à educação e ao conhecimento, e mesmo a informações e tecnologias que facilitem novos processos produtivos. Até lá, como diz Lessig, a sociedade continuará produzir uma geração inteira de jovens criminosos (Lessig, 2008).

\footnotetext{
${ }^{281}$ O projeto de Lei 8.052/2011, em análise desde janeiro na Câmara dos deputados, pretende facilitar o combate à pirataria com diversos procedimentos que antecipam a análise, o registro e a destruição do material apreendido pela polícia federal mesmo antes do julgamento. Mas as iniciativas governamentais e empresariais contra a pirataria não são fenômeno só brasileiro. Cardoso (2006:30) aponta com dados da BBC Brasil que em 2003 nos EUA mais de 15 mil pessoas foram processadas em casos semelhantes, e que a própria IFPI processou 3.800 usuários nos três primeiros meses de 2004. Lessig cita o caso de escoteiras mirins que foram processadas pela Composer's Rights Organization, a ASCAP, uma espécie de ECAD dos EUA, por não pagar direitos autorais ao cantar canções de escoteiro (2004:18).

${ }^{282}$ Ver Bucci, A internet não é meio de comunicação. In. Observatório da Imprensa de 25/10/2011. Sobre a reforma da lei de direitos autorais, cujo novo texto estabelece em seu art. 46 diversas possibilidades de compartilhamento e reprodução que não ferem direitos autorais, v. http://www.cultura.gov.br/consultadireitoautoral/consulta/ (último acesso: 26/10/2011).

283 "The source of this confusion is a distinction that the law no longer takes care to draw-the distinction between republishing someone's work on the one hand and building upon or transforming that work on the other. Copyright law at its birth had only publishing as its concern; copyright law today regulates both." Lessig, 2004:19.

${ }^{284}$ Ver. importante estudo sobre acesso ao conhecimento no Brasil do Information Society Project, da Faculdade de Direito de Yale, com foco na questão das quebras de patentes de medicamentos, em Shaver (ed.), Access to Knowledge in Brazil, 2008, pp. 165-199.
} 
5.2 A economia do olhar na esfera pública política: mercantilização do olhar, estetização da economia, e algumas de suas críticas

O diagnóstico do presente de expressões técnico-científicas e informativas da esfera pública política segue com uma discussão sobre as relações entre a economia e a comunicação icônica, ou a comunicação por imagens, linguagem privilegiada das produções audiovisuais. No caso, serão trabalhados como exemplos concretos dessas relações técnicas de propaganda comercial e marketing no Brasil, potencializadas a partir das novas TICs (a), bem como algumas problematizações e ações políticas contra supostos abusos desse movimento de "estetização da economia", que confere uma feição imagética ao capitalismo atual, dificultando as condições de regulá-lo politicamente (b).

\section{a) propaganda comercial e a mercantilização do olhar}

Segundo autores que trabalham de modo interdisciplinar com economia, comunicação, filosofia e psicanálise, como Eugênio Bucci (2002) e Gilson Schwartz, a financeirização do capital global passa a revelar como o sistema produtivo depende cada vez mais de elementos comunicativos não mensuráveis economicamente, mas produzidos simbolicamente, como a propaganda comercial, a credibilidade e a imagem das empresas, a confiabilidade ou a fidedignidade das informações comerciais, entre outras qualidades mais estéticas e afetivas dos atores do mercado.

Nesse contexto, a comunicação aceleradamente veloz ${ }^{285}$ entre os meios eletrônicos em contínua convergência tecnológica desloca o foco da palavra e da discussão para a imagem e o ícone; da leitura crítica para a olhada rápida ou leitura seletiva dos jornais impressos ou online, cujas informações de interesse e de fontes confiáveis são difíceis de distinguir em meio à enxurrada de informações a que os indivíduos estão diariamente acometidos. $^{286}$ ${ }^{285}$ Para mais sobre o tema da velocidade e da aceleração como característica da vida contemporânea, v. Rosa
\& Scheuerman (eds.) High Speed Society: Social Acceleration, Power and Modernity, University Park:
Pensilvania State University, 2008, 1-29; Bittar, E. Cidade e Modernidade: ensaio sobre a constituição da
vida urbana. In. Bittar, E. Democracia, Justiça e Direitos Humanos: estudos de teoria crítica. Rio de Janeiro:
Forense Universitária, 2011, pp. 251 ss.
${ }^{286}$ Bittar trabalha em seu ensaio "Os intelectuais na sociedade da informação" como a "enxurrada" de
informações e seletividades na esfera pública levaria a uma sociedade "autista", no sentido de incapaz de
selecionar as melhores informações e que se comunica de modo fragmentado e somente para si mesmo. "(...)
o individualismo do consumo pós-moderno da informação em dosagem elevada não tem representado uma
forma de incremento do processo de auto-subjetivação consciente e crítica, mas modo de ampliação da
sensação de desprovimento, angústia e melancolia, algo que dá continuidade àquilo que a modernidade 
Vale lembrar como o diagnóstico mais recente de Habermas traz impressão semelhante ao destacar em seu texto "O Caos da Esfera Pública" (2006) o iconic turn, ou a virada icônica como sucessora da virada linguística da filosofia, que teria sido acelerada pela televisão e amplificada - porém fragmentada - pela internet. ${ }^{287}$ Essa transformação cognitiva da racionalidade pelos meios de comunicação teria modificado o próprio "palco", isto é, a própria esfera pública política, pois seria preciso mostrar agora em imagens o que se pretende dizer, numa interferência de pretensões de auto-representação sobre as outras pretensões normativas (Habermas, 2006a). ${ }^{288}$

No que tange aos efeitos dessa transformação no estado atual da economia capitalista mais especificamente, a conclusão a que chega Bucci em sua tese "Televisão objeto: a crítica e suas questões de método" (ECA-USP, 2002), é que a continuidade da acumulação não dependeria somente da mais valia obtida pela diferença entre os valores dados ao trabalho material e trabalho abstrato, mas também da mais valia obtida entre o valor do trabalho material e aquele produzido pela visibilidade de seu produto ao consumidor. A partir de uma recepção da psicanálise lacaniana, Bucci denomina essa otimização da mais valia de "valor de gozo", que eventualmente determinaria o próprio valor de troca. ${ }^{289}$

Esse valor de gozo seria produto de uma "mercantilização do olhar" e sua incorporação nos processos produtivos, movimentando uma "economia do olhar", que se reproduz pela valorização do capital dada a partir de sua exposição ao campo de visão do máximo possível de potenciais consumidores (Bucci, 2002:274-275).

Nos termos teórico-metodológicos desta tese, portanto, se a comunicação dominante na esfera pública política seria a comunicação icônica, gerar processos de

começou por produzir. Assim é que, pelo contrário, o individualismo não leva o indivíduo a sim, mas o trancafia como a um estranho de sua própria jaula, uma jaula interna invisível, mas sombria e doentia. $\mathrm{O}$ estado microbiano da letargia do indivíduo adormecido no interior dos labirintos do individualismo cria, por isso, uma sociedade autista." (Bittar, 2009b:158).

${ }^{287}$ V. tópico 1.4 desta tese.

${ }^{288}$ Não se pode deixar de lembrar aqui das teses de Benjamin sobre a reprodutibilidade técnica da obra de arte, em seu celebrado ensaio de 1936. A reflexão sobre a perda da aura da obra de arte e seu "valor de culto" para remanescer na modernidade como "valor de exibição". V. Duvenage, 2003; Habermas, 1975; Blotta, 2010b. Essa tese será trabalhada no tópico 2.3 pensando as consequiências da perda da aura não só na arte, mas também da autoridade política, o que tem reflexos sobre a comunicação política.

289 “O valor de gozo se constitui da soma do olhar com o trabalho (e aí existe uma via para que se pense no olhar como força produtiva, mas disso não nos ocuparemos). Sem o emprego do olhar social, o valor de gozo não existe. E o olhar social é comprado pelo capital do mesmo modo como a força de trabalho do operário de fábrica é comprada. De que forma se dá essa compra? Essa forma tem variações, mas o paradigma dominante é a forma adotada na televisão, de canal aberto ou de canal fechado. A imagem da mercadoria compra o olhar em tempo para nele se constituir, isto é, para realizar-se no imaginário social. Os preços do olhar já não são mais desprezíveis quando comparados ao salário que compra o trabalho mais elementar na sociedade." (Bucci, 2002:273). 
publicidade crítica depende da capacidade do diagnóstico da esfera pública política identificar as influências recíprocas entre discursos técnico-instrumentais e estéticoexpressivos, de modo que eventuais determinações irrefletidas de um pelo outro possam ser reequilibradas por meio políticas nas áreas da comunicação social e da comunicação política.

Trata-se de pensar aqui, então, como a racionalidade econômica é cada vez mais influenciada pela comunicação por imagens, marcas e ícones ${ }^{290}$ que mobilizam desejos inconscientes e, portanto estéticos e afetivos do público, atualmente cruciais para estimular o consumo necessário à reprodução do sistema econômico. ${ }^{291}$

Assim, será possível compreender algumas interpenetrações dos discursos econômico, estético e psicológico na esfera pública que fogem ao consentimento ou ao controle consciente daqueles que utilizam a televisão e outros meios de comunicação como a internet, especialmente na condição de potenciais consumidores. Em alguns casos, essas interpenetrações veladas ou não discutidas podem configurar violações de direitos do consumidor e de comunicação, como se verá a partir das problematizações e políticas que visam regular politicamente a propaganda comercial no Brasil (v. "b”, abaixo).

Isso porque ao mesmo tempo em que o mercado da propaganda comercial movimenta grandes quantias nos setores público e privado do país, sendo a principal forma de sustento de diversos veículos de imprensa e meios de comunicação de massa ${ }^{292}$, o número de reclamações no Procon, órgão público de defesa do consumidor, tem crescido no que se refere a abusos na utilização de técnicas de propaganda e marketing por

\footnotetext{
290 “A lógica do ícone pode ser remetida tanto à dialética da mercadoria e seu fetiche em Marx quanto à dinâmica de expectativas que desenha no espaço-tempo das redes financeiras de um país uma meta inflacionária que regula as decisões do Banco Central. Até mesmo a engenharia de produção ou a própria linha de produção numa de suas mais icônicas instâncias, que é a bancada do torno, do processamento bruto da matéria prima, tornou-se um momento de um processo de elaboração simbólica que a partir do CADCAM não parou de evoluir no sentido da sua crescente inteligência icônica (especialmente nos modelos conhecidos como "fast prototyping"), entre outros exemplos de conexão entre a linha de produção e a gestão do conhecimento, de símbolos e ícones, orientados por design estratégico no marketing ou nas finanças." (Schwartz, Princípios de Economia, 2006:4).

${ }^{291}$ Depois de identificar aqui a influência de discursos estético-expressivos sobre a racionalidade cognitivoinstrumental, será necessário diagnosticar a influência dos discursos técnico-instrumentais sobre, ou seja, como a razão instrumental influencia a estética, tendo como casos práticos formas e números atuais de industrialização da cultura no Brasil (v. tópico 2.3.1).

292 Relatório de 2003 da Associação Brasileira de Agências de Publicidade indica que indústria da propaganda comercial movimentou 31 bilhões de reais. Abap. A Indústria da Comunicação no Brasil. p. 6. Disponível em: http://www.abap-rio.com.br/downloads/industria.pdf (último acesso: 03/11/2011). O jornal Valor Econômico publica notícia em 22/12/2010 de que o mercado de propaganda dobrou de tamanho em sete anos, chegar a 33 bilhões em 2010. V. notícia em www.valor.com.br (último acesso: 03/11/2011).
} 
empresas, mesmo que seja um número ainda pequeno em comparação com outras queixas. ${ }^{293}$

Para um exemplo empírico desse fenômeno de mercantilização do olhar na televisão, torna-se interessante reproduzir um experimento aproximativo de cálculo do "valor do olhar" realizado por Bucci a partir da propaganda comercial na televisão: dividese o preço de uma inserção publicitária no intervalo de um programa por sua audiência estimada e se terá o valor de cada olhar em potencial em relação ao tempo de exposição do produto a ele.

Ao estimar esse valor no ano de 2001 a partir do Jornal Nacional da Rede Globo, se cada comercial de 30 segundos custavam $\mathrm{R} \$ 159.520,00$, divididos por um público de 25.919.461 pessoas, Bucci chega à conclusão de que uma hora de cada expectativa de olhar individual chegaria à $\mathrm{R} \$ 0,73$ (Bucci, 2002:273-275). Comparado com o valor do salário mínimo de então ( $\mathrm{R} \$ 180,00)$ por hora, chega-se ao valor similar de $\mathrm{R} \$ 0,75$.

Para seguir com o exemplo da Rede Globo em relação à propaganda comercial, o seu "manual de formatos comerciais" oferece a seguinte definição do serviço de merchandising para seus possíveis clientes na área:

“Inserção de produtos, marcas, promoções, serviços ou conceitos, da forma mais natural possível dentro dos programas da Rede Globo, aproveitando a empatia entre personagens/apresentadores e o telespectador. Quanto mais a ação de merchandising se adequar à trama e aos personagens, maior será a sua eficácia.// Por essas características, o merchandising confere autenticidade às cenas, o que possibilita mudanças no comportamento do público/consumidor, por meio de reversão de atitudes e hábitos e consumo.// ... Poderão conter estímulos visuais e textuais, ações conceituais, de compra e de uso/consumo ou eventos especiais." (itálicos nossos). ${ }^{294}$

\footnotetext{
${ }^{293}$ Apesar de o boletim do Conar (Conselho de Auto-regulamentação publicitária) de 2010 apontar, com dados nacionais do Sindec (Sistema Nacional de Informações de Defesa do Consumidor, do Ministério da Justiça), que as reclamações sobre publicidade comercial indevida "continuam sendo poucas" $(1,19 \%$ entre setembro de 2008 e agosto de 2009, isto é, 1.190 das 104.867 mil reclamações registradas), no período de 2007 a 2008 esse número era de 0,86\%, o que indica um aumento das reclamações (boletim acessível em: . último acesso em 03/11/2011). Relatório do Procon da cidade de São Paulo mostra números semelhantes $(1,75 \%$ das reclamações seriam relacionadas à propaganda enganosa), mas revela ao mesmo tempo que $11 \%$ das reclamações referem-se à "venda enganosa", o que não deixa de ser engano do consumidor quanto à oferta realizada pela propaganda (Procon-SP. de janeiro a junho de 2008, pp. 8 e 15. Relatório disponível em último acesso: 03/11/2011). Revista do Procon de Porto Alegre (2010) também aponta como as inúmeras reclamações envolvendo os Serviços de Atendimento ao Consumidor (os "SACs") também dizem respeito à veiculação indevida de mensagem publicitária. V. Procon Porto Alegre. Informando, educando, conscientizando. N. 2 ano. 2 - 15/03/2010, p. 16.

${ }^{294}$ Manual de Formatos Comerciais da Rede Globo. Disponível em: http://comercial.redeglobo.com.br (último acesso: 01/11/2011).
} 
Essa caracterização se encaixa claramente na ideia de que a propaganda comercial procura mobilizar afetos e desejos inconscientes de modo mais "natural possível" para induzir ao consumo, como retratou a recepção da psicologia social desde a primeira geração da teoria crítica, também assumida por Habermas em MEEP. ${ }^{295}$ Esses estudos ganham atualmente uma tentativa de aprofundamento a partir da questão da linguagem imagética e da psicanálise com a leitura de Bucci e Kehl em relação à comunicação televisiva.

Nos termos do comunicólogo e da psicanalista, a propaganda comercial representaria a instauração da imagem e da marca de um produto como uma mercadoria além dela mesma, retirando daí sua lucratividade (Bucci, 2005). ${ }^{296}$ Quando na forma do merchandising definido acima pela Globo, tratar-se-ia, como trabalha Alves em discussão sobre as teses de Bucci, de "uma mercadoria dentro da mercadoria" (Alves, 2010). Isso significa que a autonomização do signo em relação ao bem referido dá condições para que ele o transcenda e seja mais valorizado quanto mais se expõe nos espaços sociais formados pelos meios eletrônicos de comunicação. ${ }^{297}$

Os consumidores, por sua vez, encontram-se numa "situação contratual" fictícia e inconsciente com os produtos e suas técnicas de marketing, como a propaganda comercial, uma relação que Bucci trata como "escambo". De um lado, empresas e o próprio poder público "compram" a possibilidade do olhar ou da atenção ${ }^{298}$ dos consumidores de bens e

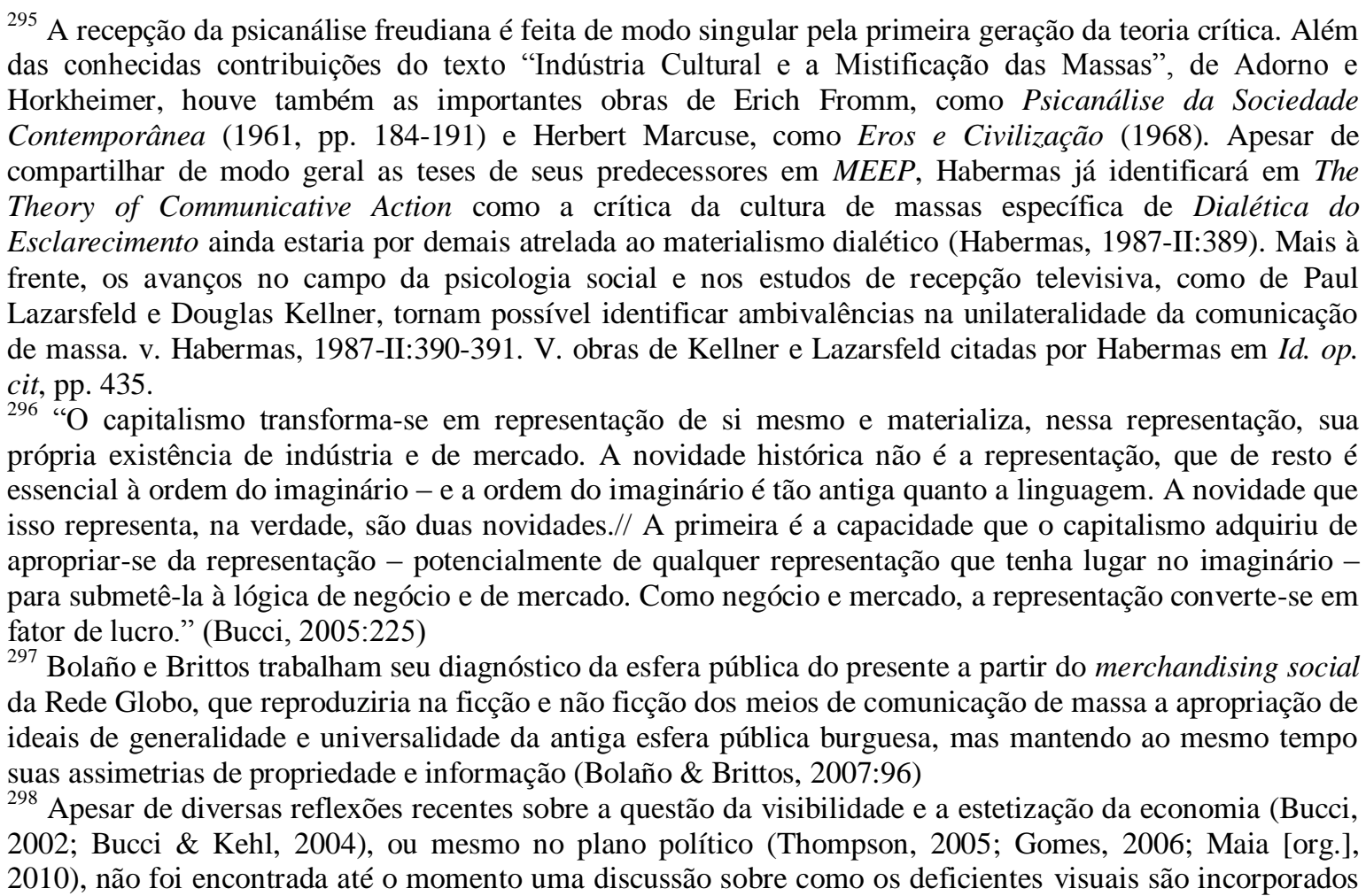


serviços privados e públicos, oferecendo a eles em troca possíveis objetos de seus desejos associados às mercadorias anunciadas. Mas como o desejo do sujeito só se sacia momentaneamente com seu objeto (quando se produz o valor de gozo), trata-se de uma energia, ou uma "força de trabalho psíquico" infindável, que sempre pode potencializar o mercado, como também processos de legitimação política. ${ }^{299}$

Não é só na comunicação televisiva que esse tipo de mercantilização do olhar e estetização da economia ocorrem, obviamente. A imprensa é o primeiro meio de comunicação a revelar o quanto a manutenção de sua autonomia em relação ao poder público desde a industrialização levou a uma dependência financeira crescente em relação aos seus "anunciantes". A evolução histórica do espaço ocupado pelos anúncios nos jornais pode ser vista como um medidor da influência exercida pelo poder econômico sobre eles.

Em MEEP, Habermas indica que pesquisa realizada de 1953 a 1958 na Alemanha, em torno de $60 \%$ dos espaços dos jornais já eram destinados a manchetes, imagens e anúncios (Habermas, 2003:335-336) ${ }^{300}$. Para uma comparação aproximativa com o presente, um dos jornais de maior tiragem do Brasil, a Folha de S.Paulo exibiu no dia 02/11/2011, uma quarta-feira, 12 páginas das 28 totais inteiramente dedicadas à propaganda ( $42 \%$ das páginas do caderno), sendo que somente 6 páginas não têm anúncios. Isto é, além das 12 páginas inteiras, outras dez contêm anúncios de tamanhos variados, o que significa que aproximadamente $78 \%$ das páginas do primeiro caderno são marcadas por anúncios.

nessa discussão. Isso porque, a princípio, uma esfera pública "icônica" ou "imagética" excluiria de saída aqueles que têm problemas de visão. Mesmo assim, é de se pensar que as pessoas com deficiência visual seriam impactados com a comunicação icônica, seja por relatos de outros ou mesmo porque não se trata somente da visibilidade física, mas da capacidade da comunicação captar a atenção ou tomar o tempo do público e dos consumidores em relação a certas questões.

299 “O gozo é incompatível com o pensamento porque ele corresponde exatamente ao momento de pausa na premência da atividade psíquica. // Ora, a produção imaginária oferece continuamente representações para a satisfação do desejo. Diante da TV ligada, isto é, diante de um fluxo contínuo de imagens que nos oferecem o puro gozo, não é necessário pensar. O pensamento é um trabalho, e ninguém aguenta pensar (trabalhar) o tempo todo. Ele só é convocado a pensar quando falha a realização de desejos. (...) diante do fluxo de imagens, paramos de pensar. E quanto mais o fluxo de imagens ocupa espaço na nossa vida real e na nossa vida psíquica, menos é convocado o pensamento.” M. R. Kehl, A Televisão e a Violência do Imaginário, 2004:87-106. V. obra mais recente de Kehl que trata da depressão como forma social de melancolia, gerada por uma sociedade de consumo que demanda o gozo constante do sujeito, este que, impossibilitado de se satisfazer plenamente, leva à ansiedade e possível depressão. Kehl, O Tempo e o Cão. Boitempo, 2009.

${ }^{300}$ Habermas cita o estudo de Thomssen "Zum Problem der Scheinöffentlichkeit, inhaltsanalytisch dargestellt an der Bildzeitung“, Frankfurt a. M., 1960 [Sobre o problema da esfera pública da aparência, análise realizada no interior do jornal ilustrado. Livre tradução do alemão], relatando sua conclusão: "Desse modo, também não espanta a conclusão final da pesquisa, segundo a qual não ocupam mais de um quarto de toda a área das informações as notícias e reportagens de todas as categorias que deveriam ser classificadas como 'publicamente relevantes' (comunicação de acontecimentos ou tomada de posição ante eles que, por sua posição estratégica no processo vital da sociedade adquirem um significado que transcende o caso individual); isso corresponde a uma participação de cerca de um terço no número global de todas as notícias e reportagens." (Habermas, 2003:336. Nota n. 85). 
Dados sobre o valor desses anúncios divulgados pelo Grupo Folha, que detém propriedade sobre o jornal entre outras revistas e endereços eletrônicos, permitem que se realize com a Folha um experimento semelhante ao realizado por Bucci com o programa Jornal Nacional. ${ }^{301}$ Se anunciar sobre uma página inteira do jornal em dia de semana custa $\mathrm{R} \$ 271.440^{302}$, e sua tiragem é de 284.914 exemplares por dia $^{303}$, a expectativa de cada possível olhar do consumidor/leitor do jornal custa por dia ao anunciante $\mathrm{R} \$ 0,95$. Supondo que cada leitor fique uma hora por dia "exposto" ao jornal, chega-se à conclusão que seu olhar seria R\$0,20 mais caro do que o daquele que assistiu ao Jornal Nacional em 2001. 304

As características estéticas dos anúncios sinalizam a "virada icônica", pois passam de informações escritas do tipo "classificados" para as mensagens e imagens da propaganda comercial que, em alguns casos, procuram simular a própria notícia do jornal. Apesar de levarem os escritos "Informe Publicitário" para indicarem que não se tratam de notícias reais (como exige a rede Globo para o caso de propagandas simularem seus programas), recentes primeiras páginas da Folha de S.Paulo que veicularam esse tipo de propaganda foram objeto de duras críticas de leitores e até mesmo da ombudsman do jornal.

Algumas das reclamações giraram em torno do fato de o jornal ceder espaço tão importante (foi utilizado o termo "sagrado" por um leitor) quanto sua primeira página para a propaganda, e também de permitir que um anunciante imitasse os formatos do jornal com

301 O caráter estimado desse experimento se dá pela expectativa do olhar. Apesar de as mensagens publicitárias estarem claramente mais expostas ao telespectador do que ao leitor do jornal, que precisa virar as páginas para se expor aos anúncios, esses não deixam de ter seus valores também medidos em relação à expectativa do olhar. Do mesmo modo que para se anunciar no metrô são indicados quantos passageiros frequentam as linhas, até mesmo na internet os anúncios têm seu valor aferido pelo número de acessos às páginas. Segundo Bucci, em nota sobre a mercantilização do olhar na internet: "Os sites da Internet também retiram o seu valor de troca (o quanto vale o site na bolsa de valores) pelo critério único do olhar. Um site vale mais ou menos conforme tenha mais ou menos pupilas a ele concetadas. Nesse sentido, alguns sites desenvolvem formas menos veladas de remunerar o olhar. Alguns promovem um sistema de pontuação baseado no número de páginas vistas por usuário e, conforme a pontuação, os usuários têm mais ou menos chances de serem contemplados nos sorteios que acontecem diariamente. Sorteio de dinheiro. Um desses sites é o iwon.com." (Bucci, 2002:276. Nota. 515).

302 Dado da publicação. Grupo Folha. Tabela de Preços. Publicidade. 2011. Disponível em http://www.publicidade.folha.com.br/files/fsp-pt.pdf. (último acesso: 03/11/2011).

${ }^{303}$ Dado obtido do portal Folha online. O termo que o jornal utiliza para a tiragem é "circulação paga", com dados de agosto de 2011. V. http://www1.folha.uol.com.br/folha/conheca/circulacao.shtml (último acesso: 03/11/2011).

${ }^{304}$ Apesar não ser possível aqui uma comparação com os números mais recentes do Jornal Nacional pela falta de dados, a mídia impressa efetivamente mantém um espaço publicitário de grande valorização. Pesquisa recente da Associação Mundial de Jornais e Editores de Notícias (World Association of Newspapers and News Publishers) indica, com um cálculo semelhante aquele para medir valor do olhar utilizado por Bucci, que a renda publicitária gerada com $8 \%$ do tempo gasto com a exposição do leitor à imprensa escrita se equivale a $20 \%$ daquela destinada à imprensa televisiva e à internet juntas. V. análise sobre o relatório em: Albuquerque, Sergio da Motta e. Jornais são mais populares que internet. Observatório da Imprensa. Ed. 665 , de 25/10/2011. 
a seguinte manchete falsa: "Uma capa de jornal só com notícia boa. Você queria, a gente fez primeiro". A ombudsman considerou esta peça intromissão indevida na área editorial. $^{305}$

Por fim, na internet a propaganda comercial ganha um espaço sem precedentes para se difundir e mercantilizar o olhar. Uma das grandes diferenças desse meio é que o internauta troca a disposição de seu olhar e atenção por ferramentas de interatividade na rede, como endereços de e-mail, acesso a redes sociais e outras possibilidades de navegação "livre" em "portais" e outros espaços digitais.

Mas o olhar e a atenção não são as únicas "forças de trabalho psíquico" exigidas pelos meios nessa relação. Na maioria dos casos, quando cientes do que está em jogo, os usuários de contas de e-mail aceitam que o provedor tenha acesso às suas comunicações pessoais para fins publicitários, abrindo mão de seu direito de sigilo de correspondência pessoal, e entendendo que sua privacidade não será exposta para outra finalidade. Mas é assim que esses provedores coletam informações que serão úteis para captar novos anunciantes, os quais, sabendo dos interesses e hábitos de consumo dos internautas, podem direcionar suas políticas de marketing de modo ainda mais preciso. ${ }^{306}$

Resta saber se a nova ampliação técnica da esfera pública política a partir das TICs só será realmente possível ao preço dessas novas interpenetrações e determinações entre pretensões econômicas e estético-expressivas, que influenciam diretamente o marco político. A eficácia dessas determinações depende ainda de sua capacidade de formar uma esfera pública sem ter suas implicações práticas questionadas, isto é, sem levar a público o

\footnotetext{
${ }^{305}$ V. a coluna de 16/10/2011 da ombudsman Susana Singer, que assumiu a função desde abril de 2010. A jornalista trabalhou, no entanto, no mesmo jornal em diversos cargos desde 1987, como a edição do caderno "Cotidiano". Esse tipo de vínculo anterior de tantos anos da ombudsman com o jornal pode tornar questionável a isenção que deve orientar sua crítica.

${ }^{306}$ Ao iniciar a criação de uma conta "gratuita" de e-mail do Gmail, do Google, oferecendo diversos dados pessoais, o usuário deve concordar com os "termos de uso" (TU) e a "política de privacidade" (PP) da empresa em relação ao aplicativo Gmail. Caso todos efetivamente lessem tais disposições contratuais antes de aceitar, talvez alguns poderiam não concordar, ou ao menos problematizar que, por exemplo: "11.1 Ao enviar, publicar ou exibir conteúdo, o usuário concede ao Google uma licença irrevogável, perpétua, mundial, isenta de royalties e não exclusiva de reproduzir, adaptar, modificar, traduzir, publicar, distribuir publicamente, exibir publicamente e distribuir qualquer Conteúdo que o usuário enviar, publicar ou exibir nos Serviços ou através deles."; 11.2 O usuário concorda que essa licença inclui o direito do Google de disponibilizar esse Conteúdo a outras empresas, organizações ou indivíduos com quem o Google tenha relaçães para o fornecimento de serviços licenciados e para o uso desse Conteúdo relacionado ao fornecimento desses serviços." Em relação aos "17. Anúncios 17.1 Alguns dos Serviços são mantidos por receita proveniente de publicidade e podem exibir anúncios e promoções. Tais anúncios podem ser contextuais ao conteúdo da informação armazenada nos Serviços, pesquisas feitas por meio dos Serviços ou outras informaç̃̃es. 17.2 A maneira, modo e abrangência da publicidade do Google nos Serviços estão sujeitos a alterações sem aviso prévio específico ao usuário. 17.3 Considerando a concessão por parte do Google do acesso e uso dos Serviços, o usuário manifesta o seu acordo sobre a possibilidade de o Google colocar tais anúncios nos Serviços." (Termos de Serviço do Google, disponível em https://accounts.google.com/TOS?loc=BR\&hl=pt. Grifos e itálicos nossos. Último acesso: 06/11/2011).
} 
questionamento sobre a melhor opção para todos os possivelmente afetados dentre as alternativas de desenvolvimento econômico.

Como se verá abaixo, no entanto, algumas problematizações e iniciativas legislativas têm procurado retomar essa questão das interferências não consentidas entre economia, estética e psicologia como problemas práticos, isto é, procurando submeter a publicidade comercial aos critérios de transparência e aceitabilidade racional da publicidade no sentido de esfera pública política.

b) problematizações e políticas contra a mercantilização do olhar e a estetização da economia

Já foi discutido no primeiro capítulo a partir de $M E E P$ como o princípio da publicidade se transfigura em propaganda a partir do avanço das técnicas de marketing comercial e sua utilização na área da comunicação política. Foi visto também como a cientificização das pesquisas de mercado se transfere para as pesquisas de opinião pública, de modo que institutos como os conhecidos IBOPE (Instituto Brasileiro de Opinião Pública e Estatística) e Datafolha possam realizar tanto estudos de tendências de mercado quanto de opinião política. ${ }^{307}$

O que ficou claro em ambos os casos e na análise acima foi a centralidade da psicologia e de questões relativas à mobilização de desejos inconscientes no mercado, tanto nas pesquisas de tendências de consumo desses institutos quanto na teoria social que se ocupa de estudar comportamentos de grupos e indivíduos das sociedades de massa, como o consumismo, o autoritarismo individualista ou o conformismo político.

No caso de Bucci, que procura reinterpretar os espaços públicos televisivos a partir da concepção de "valor de gozo" como o valor produzido a partir da identificação inconsciente do receptor com a representação de seu desejo oferecida pela mensagem publicitária, seria possível não só quantificar o valor econômico atribuído ao olhar social, mas também realizar uma crítica às condições de racionalidade da uma esfera pública política, cuja infra-estrutura se forma especialmente a partir da mediação entre discursos

307 A questão da cientificização das formas de se medir a opinião pública, nos casos do IBOPE e do Datafolha por organizações privadas, pode ser novamente submetida à crítica e assumidas como uma das formas de interpretar a formação da opinião pública a partir dos novos estudos de Habermas sobre o tema. Além de indicar as difículdades de medição da opinião pública a partir de conjuntos de opiniões individualizadas e descontextualizadas de momentos de agitação política - e conseqüente tensão e condensação de opiniões -, Habermas defende, no entanto, a permanência e a reflexividade da opinião pública a partir do próprio debate entre os atores que se arrogam seus representantes ou capazes de identificála (Habermas, 2009:164-166). 
informais e formais feita pela imprensa, a comunicação televisiva e outros espaços de comunicação audiovisuais, como a internet.

No telespaço público, atualização que o autor propõe do conceito habermasiano de esfera pública para diagnosticar a comunicação reinante nos meios eletrônicos, a relação de conflito historicamente situada entre significante e significado, que produz a linguagem (com aportes em Saussure e Bakhtin) e permite comunicação, é da ordem do desejo. E se a acumulação da economia atualmente se reproduz sobretudo a partir da propaganda comercial, que utiliza métodos de mobilização dos símbolos e imagens dessa ordem, a racionalidade técnico-estratégica da economia e sua influência sobre a esfera pública política podem também ser explicadas a partir da "lógica do desejo". 308

É com aporte nos estudos de Maria Rita Kehl, com quem assina a obra Videologias (2004), que Bucci trabalha então a comunicação no telespaço público como sendo formada por identificações inconscientes entre aqueles que recebem e trocam imagens e mensagens nos espaços públicos audiovisuais. A precedência dessa comunicação seria o "imaginário social", outra categoria derivada da psicanálise lacaniana que Bucci empresta para pensar uma espécie de "mundo da vida estendido", pois tanto na formação da intersubjetividade quando no telespaço público estaria presente a linguagem imagética do inconsciente, o que não seria o caso em Habermas. ${ }^{309}$

Em função dessa presença de símbolos não racionais do imaginário social na esfera pública mediatizada, a pressuposição de uma racionalidade comunicativa não seria mais requisito necessário da constituição desse domínio. Isso porque se a comunicação icônica é predominantemente movida por desejos inconscientes, ela passaria ao largo do

\footnotetext{
${ }^{308}$ Os problemas de uma suposta subsunção da lógica do desejo à lógica da mercadoria, prova de que ainda pode haver uma continuidade da recepção materialista de Freud em Bucci e Kehl, como em Adorno e Horkheimer, foram discutidos em Blotta. O Direito no Divã, 2010. Essa operação teórica pode ser aduzida a partir da seguinte reflexão de Bucci: "O fetiche da mercadoria deve ser entendido hoje não propriamente como fantasmagoria, ainda que possa legitimamente em $O$ Capital ser visto como um efeito fantasmagórico: deve ser entendido como a representação imaginária da mercadoria, constituindo sua estética, a qual carrega o valor de gozo. (...) // O fetiche, então, não se encontra superado; ao contrário, tornou-se ele mesmo produto industrializado do modo capitalista de produção. (...) Nesse sentido, o fetiche é uma noção tanto marxista quanto freudiana. É o que diz Maria Rita Kehl: „Se estivermos de acordo com Marx, o fetichismo como modo de ocultamento das relações de dominação/exploração entre os homens nasceu com ele, isto é: nasceu com a transformação dos produtos do trabalho humano em mercadorias" "(Bucci, 2002:282-283. grifos nossos).

${ }^{309}$ A pergunta sobre se o conceito de mundo da vida trabalhado por Habermas abrangeria os paleosímbolos, ou a "pré-linguagem" do inconsciente, discuta no capítulo sobre psicanálise de Conhecimento e Interesse (Habermas, 2002d:214-300), é interessante, e poderia levar a um aprofundamento da questão sobre em que medida a esfera pública está envolvida por uma comunicação mais simbólica e inconsciente do que racional. A princípio, o Lebenswelt se trata de conhecimento de fundo linguisticamente compartilhado, e portanto o acesso à esfera da comunicação pública faria justamente o corte entre a linguagem privada do desejo e a linguagem pública da racionalidade socialmente aceita. Para mais sobre o tema, v. Blotta, O Direito no Divã: por uma discursivização do gozo no telespaço público (2010).
} 
pensamento, da palavra ou da discussão indicativa de uma racionalidade argumentativa de uma esfera pública politicamente ativa. Ao menos no espaço social da comunicação televisiva, seria possível não pensar na razão como pré-requisito para a formação de suas narrativas e significações sociais (Bucci, 2002:75).

Muito mais semelhante aos diagnósticos de Adorno e Horkheimer sobre uma indústria cultural cuja lógica se estende para outros setores sociais, ou de Guy Debord em Sociedade do Espetáculo (1968) com a tese do capital tornado imagem ${ }^{310}$ do que a proposta habermasiana de uma esfera pública que se degenera mas se mantém como exigência constitucional e objeto de teoria social, o telespaço público evidencia como $a$ dominação irrefletida do discurso econômico pela linguagem imagética da comunicação eletrônica dificulta uma condução consciente da esfera pública política, no que diz respeito à possibilidade de uma regulação prática dos avanços tecnológicos e do desenvolvimento econômico; no caso, o setor da propaganda comercial.

Ao pensar nos efeitos práticos dessa interpenetração entre os discursos técnicocientíficos e estético-expressivos, seria possível interpretar o diagnóstico de Bucci como expressão de uma forma de injustiça presente na esfera pública política, e não só na brasileira: o apelo velado de propagandas a elementos imagéticos, da ordem do desejo e dos afetos para mobilizar o público ao consumo irrefletido de produtos do mercado, de modo que a exposição ao olhar (ou a visibilidade do produto) dentro dos espaços privados e públicos - às vezes de modo não consentido por aqueles expostos às mensagens - tornase uma das principais formas de valorização do capitalismo contemporâneo. ${ }^{311}$

Uma importante política institucional contra essa forma velada de injustiça resultou na criação da chama "Lei cidade limpa", lei municipal 14.223, criada por decreto que vigora na cidade de São Paulo desde 01/01/2007. A lei proíbe os outdoors publicitários e restringe o tamanho das propagandas e sinalizações externas de empresas. Neste caso, a fundamentação apresentada pela prefeitura da cidade tem cunho também ambiental, pois visa eliminar a "poluição visual" na "paisagem urbana" da cidade.

\footnotetext{
310 Os aforismos 4 e 34 de Debord declaram: “4. O espetáculo não é um conjunto de imagens, mas uma relação social entre pessoas, mediada por imagens; 34 . O espetáculo é o capital em tal grau de acumulação que se torna imagem. (Debord, 1997:14 e 25).

311 "O enorme hiato que se abriu entre o alegado (suposto) valor de uso e o valor de troca não mais pode ser explicado pelo trabalho socialmente necessário, trabalho abstrato, incorporado à „coisa produzida" nesse hiato que se insurge o valor de gozo da mercadoria. E ele é tão grande quanto o abismo que se abriu entre o valor da força de trabalho empregada para compor o trabalho socialmente necessário, abstrato, que marca a mercadoria, e o valor de troca. (...) Para a mercadoria, o valor do trabalho alienado (considerada aí a mais-valia) não é mais o único a lhe determinar o valor de troca. Há agora o valor de gozo, que antes seria um valor pressuposto, mas desprezível - e hoje é o valor central." (Bucci, 2002:262-263. Itálicos e grifos nossos).
} 
A norma gerou grande debate e tentativas de não cumprimento ${ }^{312}$, especialmente porque se tratou de caso atípico, ainda mais em grandes cidades. Enquanto empresas e profissionais do ramo da propaganda criticaram a medida pelos riscos econômicos de seus negócios, muitos que se incomodavam com a exposição não consentida à publicidade e sua invasão nos espaços públicos apoiaram a iniciativa.

Novas regulamentações da lei passaram, no entanto, a flexibilizá-la. Um dos casos é o de incentivar que empresas paguem por obras de arte, como grafites ou murais nas fachadas ou laterais de seus edifícios, podendo estampar em troca sua marca discretamente ou ter seus serviços retratados de modo indireto nas obras. Mais recentemente, a câmara municipal aprovou modificações na norma, como parte de contratos de propaganda para empresas que se responsabilizarem pela restauração e manutenção de pontos de ônibus, lixeiras e relógios de rua. ${ }^{313}$

Apesar desses novos movimentos, a iniciativa demonstra mais uma vez a existência de formas de controle político sobre a interpenetração de poder econômico e linguagens estético-expressivas nos espaços públicos, especialmente no que tange à "poluição visual" produzida pela indústria da propaganda comercial nas grandes cidades.

Outra tentativa interessante de restrição política dos avanços das técnicas de propaganda veio de recente ação civil pública que o Ministério Público Federal (MPF) de São Paulo moveu contra a ANATEL para que esta regulamente e fiscalize a lei 10.222/01, que proíbe os canais de televisão de aumentarem seus volumes na hora dos intervalos comerciais. Por meio de inquérito civil requisitado pelo MPF, havia sido constatado que canais de televisão efetivamente aumentam em até 05 decibéis o volume de seus comerciais, sendo que os volumes eram diferenciados dependendo das marcas anunciadas, e a variação de volume maior em comerciais de programas para crianças.

Segundo o procurador que ajuizou a ação, os consumidores eram lesados com a alteração técnica da programação, pois não tinham a possibilidade de se defender, ficando mais expostos e de modo não consentido à propaganda comercial, seja em momentos de lazer e descanso privado ou em relação às crianças, que não têm pleno discernimento entre o entretenimento e as mensagens de consumo que lhes são transmitidas através das

\footnotetext{
${ }^{312}$ V. interessante matéria sobre a acusação da Prefeitura de vínculo entre interesses publicitários da empresa Natura e artistas na disposição de grandes letreiros na cidade com as palavras "Descanse", "relaxe" e "calma", publicada em 14/07/2009 na Folha de S.Paulo (Caderno Cotidiano, p. C5).

${ }^{313}$ V. notícia e debates sobre as novas normas de propaganda exterior no blog do jornalista Luis Nassif. 22/09/2011 (www.advivo.com.br/blog/luisnassif último acesso: 07/11/2011).
} 
imagens publicitárias, capazes de gerar identificações inconscientes, induzindo os próprios adultos a práticas consumistas. ${ }^{314}$

Até o momento a ação não foi julgada, mas proposta de padronização do setor já foi feita por engenheiros da Sociedade Brasileira de Engenharia de Televisão (SET) ao Ministério das Comunicações, o que poderia contribuir para a devida regulamentação da Lei 10.222/01, como demanda o MPF/SP. Segundo noticia o jornal Folha de São Paulo do dia 07/11/2011, as recomendações de nivelamento dos engenheiros da SET, que trabalham nas principais emissoras e operadoras de televisão do Brasil, sugerem questões de produção, captação, controle e processamento que poderiam auxiliar nas atividades de fiscalização.

Essas movimentações pela regulação política dos avanços técnicos da propaganda comercial revelam que há resistências práticas contra a mercantilização do olhar e a estetização não consentida da economia. Elas assumem o olhar e a atenção dos indivíduos como bens que não deveriam estar expostos a todo o momento a estímulos do mercado, especialmente em ocasiões não justificadas, não publicamente declaradas, não consentidas, ou mesmo inconscientes das pessoas. ${ }^{315}$

Quando se pensa num direito que é ao mesmo tempo do indivíduo, da sociedade e da família de se proteger contra conteúdos de programas de rádio e televisão que violam os princípios da comunicação social, isto é, um direito "transindividual" (arts. 220 e 221, $\mathrm{CF} / 88$ ), torna-se possível ajuizar ações coletivas para defendê-lo, como a Ação Civil Pública acima citada, além diversas outras já movidas pelo Ministério Público Federal, este que tem como atribuição zelar pelo efetivo cumprimento das normas de comunicação social (art. 5º IV da Lei Orgânica do MPF, Lei 75/93). ${ }^{316}$

\footnotetext{
${ }^{314}$ V. cópia da ação civil pública referida pode ser encontrada no endereço eletrônico do Ministério Público Federal. www.prsp.mpf.gov.br.

315 Nesse sentido, essas pretensões normativas se alinham com os movimentos atuais por uma moralização do mercado identificados nas importantes e recém publicadas reflexões de Honneth sobre o tema. Na terceira parte de Das Recht der Freiheit [O Direito da Liberdade. trad. livre], Honneth afirma que: "consumidores e produtores não estão aqui somente nos papéis de demandante em face do ofertador, mas estão ligados de outra forma através de complexas relações de interação, das quais eventuais pretensões normativas, recusa do consumo e protestos possam ser ouvidos; assim querem contribuir os consumidores através de suas próprias tomadas de posição para lembrar os produtores que eles estão obrigados à fundada relação de reconhecimento, qual seja, nas palavras hegelianas, a consciente consideração (Berücksichtigung) das intenções da reciprocidade (Gegenseite) necessária." (Honneth, 2011:367). Tradução livre do original em alemão.

316 V. interessante artigo do Procurador da República Sérgio Suiama, que teve destaque na área da comunicação social em sua passagem pela Subprocuradoria dos Direitos do Cidadão: Suiama, "Teses para a Reconquista de um Espaço Público" (disponível na seção de artigos sobre comunicação social do MPF, em www.prsp.mpf.gov.br). Sua abordagem do art. $220 \mathrm{da} \mathrm{CF} / 88$ como um direito "transindividual", entre outras importantes reflexões da dogmática constitucional que visa garantir direitos de comunicação e informação serão retomadas nas reflexões teóricas sobre o direito da comunicação no capítulo 3 (esp. tópico 3.3).
} 
Ao partir para a discussão sobre a comunicação informativa, especialmente da ciência e do jornalismo, as pretensões de comunicação e reconhecimento até agora encontradas nessas expressões mais técnicas e econômicas da esfera pública política no Brasil podem ser resumidas em uma geral, pela regulação prática do desenvolvimento técnico da intervenção da economia e do mercado na esfera pública. Dentro dela se incluem pretensões à descentralização da propriedade e dos meios de produção de informação e comunicação, e à proteção contra formas veladas e não consentidas de associação entre poder econômico e comunicação icônica e expressiva, as quais podem violar normas do consumidor (arts. 36 e 37 da Lei 8.078/90) e outros direitos individuais, coletivos e transindividuais.

\subsection{Comunicação informativa e esfera pública política: diagnósticos da pretensão à busca cooperativa pela verdade}

A mudança estrutural da esfera pública revelou o enfraquecimento do jornalismo literário e político e a predominância da comunicação informativa dos discursos de verdade, impulsionada de um lado pelos avanços das ciências naturais e de outro pela industrialização e transformação do jornalismo em negócio. Nilson Lage fala na consolidação de um jornalismo informativo na passagem do século XIX ao XX, em substituição do jornalismo publicístico dos séculos XVII e XVIII. Sua abordagem é importante para destacar um esclarecimento do sentido dado ao termo "manipulação", que segue as reflexões de Bucci sobre o tema (2002:94-98). ${ }^{317}$

Aqui também se adota a posição de que seria não só irrealista pensar na hipótese de que poucos agentes conscientes e autônomos - os ditos “donos da mídia" - manipulariam de modo plenamente consciente a massa dos usuários desses meios, estilizando a informação para que ela convirja com seus interesses; seria também uma violação de pressupostos da razão comunicativa, pois dispensa naquele que se observa (figuras

\footnotetext{
317 Segundo Lage, essa concepção extremada leva a uma "bolha ideológica" que confere muito poder aos meios de comunicação e sua influência sobre a sociedade. Sua concepção é: "de que o público é massa inerte que os meios de comunicação manipulam; de que os jornais só publicam aquilo que interessa aos agentes econômicos e políticos dominantes; que esses agentes controlam rigidamente todos os veículos de comunicação e, nestes, a hierarquia é de tal forma perfeita que nada se publica sem que o dono, ou os diretores, tenham aprovado; que as linguagens são arbitrariamente escolhidas, de modo que bastaria veicular discursos eruditos, músicas clássicas e filmes de arte para que o povo se tornasse rapidamente erudito, melômano e cinéfilo." (Lage, N. A bolha ideológica e o destino do jornalismo, 2001:43).
} 
indeterminadas e objetivadas, como "receptor" ou "massa") o potencial de racionalidade necessário à própria validade da crítica como verdade. ${ }^{318}$

Essa concepção radicalizada da crítica da cultura de massa não está presente nem mesmo na teoria da alienação de Marx ou na razão instrumental de Adorno e Horkheimer, pois esses já pensavam num processo de alienação generalizado, que leva a uma autonomização das relações econômicas em relação aos sujeitos: da ação racionalteleológica à razão instrumental e sistêmica do valor de troca. ${ }^{319}$

O radicalismo da crítica está presente também nos discursos informativos da ciência, que procuram identificar a veracidade dos fatos e seus nexos de causalidade. Como se sabe, pareceres de técnicos, cientistas e outros peritos muitas vezes são tomados como base factual para debates argumentativos e decisões judiciais, o que impõe novamente à discussão sobre as relações entre juízos de verdade e juízos de justiça ou de eticidade, ou mesmo entre teoria e prática na esfera pública política, como trabalhadas por Habermas em Verdade e Justificação (2002).

Essa discussão teórica servirá de pano de fundo para as duas análises sobre tensões entre questões de verdade e de justiça presentes nessa expressão científico-informativa da esfera pública política. A primeira fará uma crítica ao naturalismo positivista das ciências naturais e suas relações com as ciências humanas, analisando disputas sobre a validade do

\footnotetext{
${ }^{318}$ Como se verá, essa crítica vale também para as pretensões de verdade do naturalismo cientificista, pois segundo Habermas "Somente uma intersubjetividade invulnerada pode impedir que os desiguais sejam assimilados ao igual. Ela consegue evitar a anexação de um pelo outro e salvaguardar a possibilidade de ambos 'continuarem sendo, numa proximidade consentida, o distante e o diferente, num plano situado além do heterogêneo e do próprio' (citando Negativ Dialektik, de Adorno, 1973, p. 192). De outro lado, o sentido normativo próprio do 'outro' também se manifesta nos posicionamentos do interlocutor, os quais não são manipuláveis. Qualquer tentativa de instrumentalização nega ao outro a posição de uma pessoa insubstituível que toma, por conta própria, posição crítica dizendo 'sim' ou 'não' e que age de forma correspondente, por vontade própria. Não podemos interferir arbitrariamente nos posicionamentos autônomos do outro." (Habermas, 2007:229-230). Ao final desta citação, Habermas evoca o estudo de Klaus Günther intitulado "Grund, der sich selbst begründet. Oder: Was heist eine Person zu sein" [Fundamento, que fundamenta a si próprio. Ou: o que chama uma pessoa a ser. Livre tradução do inglês]. In. Neue Rundschau, 114, 2003, 6681.

${ }^{319}$ Interessante discussão sobre essa autonomia das relações econômicas é realizada no segundo volume de The Theory of Communicative Action, quando Habermas faz crítica à teoria do valor de Marx. Segundo Habermas, uma autonomização total do valor de troca e a substituição de uma vida social conscientemente conduzida por uma "totalidade falsa", levaria ao enfraquecimento da crítica que se radicaliza às últimas conseqüências com a Dialética do Esclarecimento. Isso porque se perde de vista um conceito substantivo e moderno de práxis não alienada, contra o qual se poderia opor o diagnóstico do capitalismo auto-referido. V. Habermas, 1987-II: 332-356. "This concept of alienation remains indeterminate insofar as there is no historical index for the underlying concept, at times Aristotelian, at times Hegelian, of a 'life' that is reduced in its possibilities as a result of violating the ideal of justice inherent in the exchange of equivalents (...) In an extensively rationalized lifeworld, reification can be measured only against the conditions of communicative sociation, and not against the nostalgically loaded, frequently romanticized past of premodern forms of life. (Habermas, 1987-II:341. Itálicos e grifos nossos).
} 
método científico bem como conflitos entre liberdade de pesquisa e questões éticas e bioéticas (a).

Em seguida serão estudadas as relações entre as pretensões de verdade e de justiça no discurso jornalístico, comparando os números de matérias opinativas e informativas e o discurso da neutralidade e da objetividade da imprensa brasileira à época de $M E E P$ com o tempo presente (b). A questão central a ser discutida nos dois subtópicos é se haveria no discurso científico, bem como no jornalismo, uma pressuposta pretensão prática de busca cooperativa pela verdade. Em caso positivo, caberia perguntar também em que medida essa exigência seria afirmada ou violada em cada um desses discursos específicos que fazem parte das expressões técnico-científicas e informativas da esfera pública política nacional.

a) teoria consensual da verdade e naturalismos cientificistas: a busca cooperativa pela verdade como pressuposto cognitivo e ético do discurso científico

O discurso científico não foi mais o mesmo após a revolução epistemológica da filosofia da linguagem e da hermenêutica, impulsionada por Wittgenstein e Heidegger, e consolidada por Gadamer e Habermas no século XX. O caráter pragmático da "teoria consensual da verdade" que Habermas propõe para a crítica do positivismo cientificista, no entanto, é especialmente tributário dos movimentos de "destranscendentalização" e "pragmatização" de Kant realizados pelo lingüista estadunidense Charles Sanders Peirce. $^{320}$

Nos estudos preliminares à teoria do agir comunicativo, Habermas refere-se a Peirce quando procura atualizar o último Wittgenstein no debate sobre a verdade, contrapondo-se à teoria da verdade como representação, como em Frege (Habermas, 2001:87-89). A tese de Peirce sobre o consenso de fundo da comunidade científica que

\footnotetext{
${ }^{320}$ A discussão sobre a perspectiva de Peirce que Habermas realizou em sua crítica do positivismo em Conhecimento e Interesse é fundamental para a guinada pragmática de sua hermenêutica, que retomaria de certo modo a reflexão sobre a epistemologia a partir de uma teoria intersubjetiva, com conceitos como lógica da investigação, comunidade de comunicação ilimitada ou comunidade de interpretação ideal, semelhantes à teoria do discurso e à pressuposição de um mundo da vida linguisticamente estruturado sem os quais não é possível a discussão sobre a verdade ou outras pretensões de validade (v. Habermas, 2002c:91-139). "Whereas for Kant the determinations of transcendental consciousness, forms of intuition and categories of the understanding define the conditions of the objectivity of knowledge and thus the meaning of the truth of statements, for Peirce this concept of truth is not derivable merely from the logical rules of the process of inquiry, but rather only from the objective life context in which the process of inquiry fulfills specifiable functions: the settlement of opinions, the elimination of uncertainties, and the acquisition of unproblematic beliefs - in short, the fixation of belief." (Id. op. cit:119).
} 
orienta a escolha pelos melhores métodos de apreensão da realidade, os quais condicionam por sua vez a produção da verdade como conhecimento mais confiável possível, já havia sido trabalhada por Habermas em Conhecimento e Interesse (2002:cap. 5), sendo retomada em Direito e Democracia (1997-I:26-35) ${ }^{321}$ e Verdade e Justificação (2002).

Essa tese afirma justamente a existência da disposição cognitiva e a pretensão normativa de uma busca cooperativa pela verdade, que orientaria o discurso científico nos sentidos teórico e prático, bem como outras normas de conduta que não ficam alheias à produção do conhecimento, como a honestidade intelectual, a citação fidedigna de fontes, compartilhamento de conhecimentos e outros comprometimentos éticos envolvidos na produção do conhecimento. ${ }^{322}$

Mas como Peirce ainda teria pensado numa "república de eruditos" ao tratar do consenso de fundo de uma comunidade de comunicação ideal pressuposta na comunidade científica, Habermas procura expandi-la também para a comunicação comum e aos outros discursos que compõem as expressões práticas e estético-expressivas da esfera pública política:

"O modo como esse espectro alargado de validade está situado no mundo da vida impõe uma generalização do conceito peirceano da comunidade de comunicação ilimitada e da busca cooperativa da verdade entre cientistas: A tensão entre facticidade e validade, que Peirce descobriu nos pressupostos ineludíveis da argumentação que permeia a prática científica, pode ser detectada também nos pressupostos de diferentes tipos de argumentação e, inclusive, nos pressupostos

321 “...Peirce constrói uma espécie de transcendência a partir de dentro, servindo-se do conceito contrafactual 'final opinioni' de um consenso obtido sob condições ideias: 'The real, then, is that which, sooner or later, information and reasoning would finally result in, and which is therefore independent of the vagaries of me and you. Thus, the very origin of the conception of reality shows that this conception essentially involves the notion of a community, without definite limits, and capable of a definite increase of knowledge'. Peirce entende a verdade como aceitabilidade racional, isto é, como o resgate de uma pretensão de validade criticável sob as condições comunicacionais de um auditório de intérpretes alargado idealmente no espaço social e no tempo histórico." (Habermas, 1997-I:32-33. Itálicos do autor.) A transcrição de Peirce feita por Habermas é da obra Collected Papers. Vol. 5, 1931-35, p. 311. Para aprofundar o debate, Habermas também cita Apel, Der Denkweg von Charles S. Peirce [O Caminho do pensamento de Charles s. Peirce] (1975) e McCarthy, J. E. Semiotic, Idealism. In. Transactions of the Ch. S. Peirce Society, vol. 20, 1984, 395ss.

${ }^{322} \mathrm{O}$ decálogo do pesquisador, formulado por Bittar em Metodologia da Pesquisa Jurídica (2005:237-238) demonstra da mesma forma como a produção científica está norteada por diversas normas éticas que condicionam a própria busca pelo conhecimento objetivo sobre o mundo. Algumas delas são: " 1 . jamais cesses de desbravar as sendas do conhecimento, consciente que estás da infinitude do trabalho científico e de sua importância para a humanidade; 3. jamais descuides da ética na manipulação das fontes de pesquisa, evitando causar danos a outrem, ou mesmo extrair conhecimentos em prejuízo alheio, lesando direitos autorais ou trapaceando projetos de terceiros, sabendo que todo empreendimento científico possui como limite a dignidade humana; 5. esparge teus conhecimentos, não os reservando somente para teu deleite pessoal, mas difundindo-os aos que te cercam; 6. fomenta o estudo naqueles que ainda não se estimularam a desbravar os domínios da ciência e do conhecimento; 7. contribui com tua pesquisa para a solução de carências sociais e para o desenvolvimento de tua nação." 
pragmáticos dos atos de fala singulares e dos contextos interacionais por eles conectados" (Habermas, 1996:34-35).

Essa abordagem mais hermenêutica do conhecimento científico, que não orienta somente abordagens das ciências humanas e sociais ${ }^{323}$ está presente nas atuais iniciativas privadas e públicas de estímulo à produção de conhecimento interdisciplinar, interunidades e mesmo a programas de pós-graduação interinstitucionais no meio universitário brasileiro. $^{324}$

Ocorre que há também outra orientação normativa dentro da comunidade científica que estaria atualizando o positivismo a partir de um naturalismo cientificista, como no caso das neurociências ou mesmo das ciências biológicas, especialmente em iniciativas e projetos de pesquisa que procuram eliminar freios prático-morais ao seu livre desenvolvimento e à liberdade de investigação.

Essa corrente tem seguidores e simpatizantes mesmo nas ciências humanas, como na sociologia e na sociologia do direito. As críticas às antropologias filosóficas, segundo as quais as concepções antropocêntricas poderiam levar ao autoritarismo e a relações objetificantes com a natureza e outros sujeitos, são feitas tanto pelo discurso religioso contra o que se denomina "humanismo secular", como a partir de perspectivas naturalistas ou evolucionistas de sociedade. ${ }^{325}$ Algumas abordagens da teoria dos sistemas defendem para si um lugar intermediário em relação a essas posições. ${ }^{326}$

Ao negar, no entanto, a "conexão de operações de mensuração e dos controlos de resultados", bem como a "autocompreensão inerente à situação inicial do intérprete", a teoria dos sistemas mantém-se num empirismo que acaba por reproduzir essas que são

\footnotetext{
${ }^{323}$ Segundo Habermas, nas ciências que ele denomina histórico-hermenêuticas, “... sugere-se a interpretação de que a investigação hermenêutica abre a realidade, sob a guia do interesse pela conservação e ampliação da intersubjectividade de uma possível compreensão orientadora do agir. A compreensão de sentido dirige-se, segundo a sua estrutura, para o possível consenso dos agentes no âmbito de uma autocompreensão transmitida. Chamamos a isto diferentemente do técnico, o interesse prático do conhecimento." (Habermas, 2006:139).

${ }^{324}$ A Pró-Reitoria de Pesquisa da USP lançou no final de 2010 um edital para apoio a núcleos emergentes e consolidados de pesquisa. As propostas de ambas as modalidades exigia que participações de docentes/pesquisadores de unidades diferentes da universidade estivessem previstas, com a finalidade de estimular pesquisas interdisciplinares (v. edital em http://www.usp.br/prp/arquivos/edital.pdf. último acesso: 10/11/2011). No caso de programas interinstitucionais, a Unicamp mantém desde 2007 programas de mestrado e doutorado interinstitucionais, pelos quais alunos de universidades em regiões economicamente desfavoráveis do país têm a possibilidade de realizar sua pesquisa com orientadores da estadual de Campinas e obterem título da mesma universidade. V. normas no regimento geral da pós-graduação da Unicamp em http://www.dac.unicamp.br/portal/pos/regimento/ (último acesso: 10/11/2011).

${ }^{325}$ V. para tanto, Habermas, Entre Naturalismo e Religião, 2007, pp. 169-278. Sobre a afirmação do secularismo após a Reforma Protestante, v. Taylor, C. A Secular Age (London: Belknap, 2007).

${ }^{326}$ Segundo Neves (2006:3-4), a teoria dos sistemas de Luhmann não se associa ao determinismo da sociobiologia, mas também dispensa o papel condutor dos seres humanos em processos de evolução social.
} 
algumas das deficiências teóricas identificadas por Habermas no positivismo do século XX (Habermas, 2006:139; Id. 1996:48-56 e 289-302).

Obviamente a abordagem naturalista tem seus méritos. Além de levar ao limite a possibilidade de ser decidir tecnicamente algumas questões, dando condições para uma crítica ao decisionismo daí resultante (Habermas, 2006:126-128), ela influencia na teoria política abordagens como o realismo político ${ }^{327}$ ou mesmo o problema de como se garantir o dissenso necessário à institucionalização do pluralismo valorativo na esfera pública (Neves, 2006:148). De todo modo, essas teorias só possibilitam uma crítica negativa, e não dão conta de uma inevitável abordagem prática do desenvolvimento científico (Habermas, 1996:248-250).

Habermas identifica esse debate em Entre Naturalismo e Religião (2007:203-234) e no texto "La biología no conoce ninguna moral.", este com foco nos problemas morais relativos à clonagem humana. ${ }^{328}$ Em ambos os trabalhos, defende a tese de que há decisões relativas ao desenvolvimento de pesquisas que precisam se submeter a padrões éticos e respeitar direitos individuais, isto é, tocam em questões que devem ser decididas politicamente, pelos critérios da aceitabilidade racional de todos os possivelmente afetados, combinados com o respeito ao máximo de liberdades iguais a todos. ${ }^{329}$

Esse problema foi amplamente discutido na esfera pública política nacional com o caso das células-tronco no Supremo Tribunal Federal em 2008, quando se decidiu sobre a constitucionalidade do art. $5^{\circ}$. da Lei de Biossegurança, de 2005, que previa a possibilidade de uso de embriões para pesquisa genética. O STF entendeu que a lei era constitucional,

${ }^{327}$ O realismo político, corrente de pensamento crítico da política se liga a estudos sociológicos do Legal Realism, como os de Mangabeira Unger The Critical Legal Studies Movement (1986), e Loerges, e Trubek, Critical Legal Thought: an American-German Debate, (1989), citados por Habermas em discussão sobre as teorias da aplicação do direito, capítulo V de Direito e Democracia (Habermas, 1996:254-276). Essas teorias ficariam entre a hermenêutica de Dworkin e o positivismo de Kelsen e Hart. Habermas diverge dessa perspectiva e segue ao final para os estudos de Klaus Günther (Der Sinn für Angemessenheit 1988 [Teoria da Argumentação no Direito e na Moral: Justificação e Aplicação, 2004]). Esses trabalhos serão retomados na análise da recepção do pensamento de Habermas feita pela teoria do direito de Günther, que resulta em conceitos caros ao direito da comunicação, como liberdade comunicativa, poder comunicativo, e pessoa deliberativa. V. tópicos 3.1 e 3.3 desta tese.

${ }^{328}$ Publicado orginalmente como Biologie kennt keine Moral. Nicht die Natur verbietet das Klonen. Wir müssen selbst entscheiden in: Die Zeit, N. 9, 19/02/1998, Hamburg, p. 34. Outra obra em que Habermas trata de modo aprofundado o tema é Id. O Futuro da Natureza Humana (M. Fontes, 2004).

329 "Hasta donde pudo ver la clonación de hombres tendría que herir aquella condición de simetria en la relación de personas adultas, sobre la que hasta ahora descansa la idea del respeto recíproco de liberdades iguales. (...) Esta reserva no se extiende, como lo afirma Zimmer, a cualquier tipo de intervenciones terapéuticas en el organismo de alguien dependiente que no es consultado, ni siquiera con respecto a la eliminación preventiva de enfermidades (algo que nunca está prescrito, sino que sólo podría estar permitido). (...) No tengo la impresión de que ya hayamos encontrado las respuestas correctas a las preguntas morales y jurídicas de la técnica genética y de la medicina de la reproducción. Pero eso sí: la biología misma no puede dárnoslas. (Habermas, 1998). 
mas que cada pesquisa que se propusesse a utilizar material genérico daquela espécie deveria passar por um comitê de ética necessariamente interdisciplinar.

Essa descentralização da competência para julgamentos éticos de comitês interdisciplinares acaba de certo modo por institucionalizar as condições para que a busca pela verdade científica seja efetivamente cooperativa, e por isso não deixe de se condicionar também por consensos sobre suas possíveis conseqüências práticas. Na mesma perspectiva foi a opinião do filósofo José A. Giannotti ao analisar a decisão do STF sobre o caso. $^{330}$

Mas enquanto passa a haver uma espécie de "consenso casuístico" sobre a possibilidade de se utilizar material genético que de outro modo seria descartado para o desenvolvimento científico e a cura de moléstias, os abusos econômicos da indústria dos medicamentos continua a demonstrar como a discussão normativa dentro da ciência precisa ser cada vez mais incentivada, seja nos comitês de ética ou mesmo no investimento nas disciplinas de ética e bioética em todos os níveis educacionais, tendo-as como itens indispensáveis para a atuação profissional.

Outra área que aprofunda os naturalismos cientificistas são as neurociências, especialmente quando elas se propõem investigar questões que envolvem ciências humanas e ciências sociais aplicadas, como a sociologia e o direito. É o caso de projeto de pesquisa da área de neurologia da UFRGS, proposto em 2008 em parceria com o Governo do Estado, que visava realizar um estudo dos cérebros de 50 internos da Fundação de Atendimento Sócio-Educativo do RS (FASE-RS), responsável pela aplicação de medidas sócioeducativas em menores em conflito com a lei. A intenção da pesquisa era comparar os cérebros desses menores com os de menores que nunca tinham tido problemas relacionados para verificar a possível existência de predisposições neurológicas de descumprimento da lei.

O projeto foi alvo de duras críticas da comunidade científica, especialmente das ciências sociais. Isso porque ao propor identificar diferenças entre seres humanos cujo ato mesmo da proposta já ferir direitos basilares de igualdade e não discriminação, mesmo sob a alegação de serem análises mais objetivas e capazes de avançar o conhecimento em torno

330 "Era impossível, entretanto, evitar a questão do controle e, sobretudo, que tipo de controle devemos exercer sobre os excessos dos cientistas e a ganância dos laboratórios. Há anos que os cientistas se preocupam com esse problema, e não é à toa que se tem ampliado a discussão sobre as relações entre ética e ciência. (...) O resultado foi muito interessante. Ao derrotar os ministros legisladores, os vencedores terminaram por reconhecer a validade dos comitês de ética, por conseguinte de uma prática ética que se situa além das disputas teóricas. O que vale para esses comitês é a decisão institucionalizada, que, se por certo é influenciada pela disputa sobre os valores éticos, vai além deles na medida em que transpassa sua irremediável diversidade.” (Giannotti, A Decisão Vital. Ilustrada. F. S. P. 08/06/2008). 
da questão, trata-se de uma proposta indesejável do ponto de vista normativo, o que justificaria nesse caso uma limitação da liberdade intelectual e de expressão científica. A norma constitucional que poderia ser aplicada ao caso é a mesma que justifica a possibilidade de se limitar a própria liberdade de expressão, o art. 5, VIII: "ninguém será privado de direitos por motivo de crença religiosa ou de convicção filosófica ou política, salvo se as invocar para eximir-se de obrigação legal a todos imposta e recusar-se a cumprir prestação alternativa, fixada em lei” (itálico nosso).

Do mesmo modo, foi censurado e posteriormente exonerado de seu laboratório em Londres o renomado biólogo James Watson, um dos responsáveis pela descoberta do DNA em 1953, ao fazer alegações públicas de que haveria evidências científicas (com base no teste de QI) indicando que afro-descendentes seriam inferiores aos caucasianos intelectualmente. Mesmo após pedir desculpas publicamente, o cientista todavia continuou a alegar que não seriam racistas pesquisas científicas que visassem identificar diferentes níveis de inteligência entre etnias. ${ }^{331}$

É a obra Raça e História de Lévi-Strauss, publicada na ocasião da fundação da UNESCO em 1952, que afirmará ao mesmo tempo a impossibilidade de comprovação científica em relação a desigualdades étnico-raciais entre os povos e o perigo desse tipo de pesquisa incorrer em discriminações e explorações. ${ }^{332}$ As descobertas das diferenças ínfimas entre genomas de diferentes espécies terrestres auxiliam atualmente na substituição do debate sobre "desigualdade entre raças" pela discussão sobre a "diversidade de culturas" (Lévi-Strauss, 1952:7).

\footnotetext{
${ }^{331}$ Este caso e anteriormente citado foram discutidos em reflexão semelhante sobre os limites éticos da liberdade de expressão científica, em comemoração ao centenário de Lévi-Strauss, em Bittar \& Blotta, Pesquisa científica e discriminação étnica: os limites do conhecimento, nos 100 anos de Lévi-Strauss, 2008. 332 "The original sin of anthropology, (...), consists in its confusion of the idea of race, in the purely biological sense (assuming that there is any factual basis for the idea, even in this limited field - which is disputed by modern genetics), with the sociological and psychological productions of human civilizations. Once he had made this mistake, Gobineau was inevitably committed to the path leading from an honest intellectual error to the unintentional justification of all forms of discrimination and exploitation." Apesar disso, Lévi-Strauss ressalta ao final que "...the nature of diversity must be investigated even at the risk of allowing the racial prejudices whose biological foundations has so lately been destroyed to develop again in new grounds. (...) We cannot therefore claim to have formulated a convincing of the denial of the inequality of human races, so long as we fail to consider the problem of the inequality - or diversity - of human cultures, which is in fact - however unjustifiably - closely associate with it in the public mind." LéviStrauss. Race and History, 1952, pp. 5-7. O documento da UNESCO intitulado "The Race Concept. Results of an Inquiry" (1952:13) chegou a declarar que: "In any case, it has never been possible to separate members of two groups on the basis of mental capacity, as they can be often separated on the basis of religion, skin color, hair form or language. It is possible, though not proved, that some types of innate capacities for intellectual of emotional responses are commoner in one group than in another, but it is certain that, within a single group, innate capacities vary as much as, if not more than, they do between different groups." Agradeço ao prof. José Cardoso de Freitas pela indicação deste importante documento.
} 
Ou seja, é somente na medida em que se concebe a busca pela verdade como ação cooperativa que se torna possível justificar suas eventuais limitações a partir de seu vínculo necessário com questões práticas, especialmente nas ocasiões em os discursos descritivos sobre o mundo exterior passam a violar o mesmo respeito que exigem para se expressarem na esfera pública política.

b) objetividade e correção: a busca cooperativa pela verdade como exigência teórica e prática do discurso informativo-jornalístico

A discussão sobre a pretensão à busca cooperativa pela verdade como exigência normativa das expressões científico-informativas da esfera pública política brasileira segue com uma análise sobre da comunicação informativa do jornalismo. Se a pretensão de verdade da comunicação científica está sujeita a uma abertura interpretativa (busca cooperativa) para atingir mais precisão em seus diagnósticos e prognósticos e não ferir direitos comunicativos ou de reconhecimento, haveria também exigência semelhante em relação à comunicação informativa do jornalismo e noticiários de modo geral? Isto é, o discurso descritivo das notícias e de outras comunicações informativas sobre os fatos, objetos e estados de coisas teria uma exigência de verdade, ou melhor, de empreender esforços no sentido de realizar uma busca cooperativa pela verdade?

Como este diagnostico pretende reconstruir as pretensões normativas do direito da comunicação no Brasil a partir de interpretações de suas afirmaçõos ou violações na esfera pública política nacional, será necessário provar a existência de problematizações desse suposto "dever de verdade" em exemplos concretos da comunicação informativa antes de fundamentar sua normatividade. Assim, será possível verificar se essa pretensão normativa também se aplica a esse tipo específico do discurso e em que sentido.

Primeiramente, para se ter uma medida quantitativa da predominância da comunicação informativa e algumas discussões sobre sua qualidade desde a mudança estrutural da esfera pública de MEEP até o tempo presente no Brasil, a mesma pesquisa indicada então por Habermas como referência para os anos de 1953, 1956 e 1958 (feitas com três grupos de 23 publicações alemãs), trazia as informações que numa primeira impressão se assemelhavam às características da imprensa brasileira atual.

Segundo a pesquisa, a alterações de diagramação teriam deixado $40 \%$ do espaço para textos, $25 \%$ para manchetes e imagens e o restante para propaganda comercial. Desse espaço reservado aos textos, cerca de $50 \%$ seria ocupado por "notícias e relatos", dos quais 
“...pouco mais de um quarto se estende a setores que - no sentido amplo - possam ser considerados politicamente relevantes: à política (inclusive 'artigos de fundo') 19\% e a informações esclarecedoras $8 \%$. A superfície restante está distribuída entre crimes, catástrofes e relatos do cotidiano (32\%), processos (13\%), "sociedade", filme, moda concurso de beleza, etc. (21\%), primeiros socorros e ensino (7\%).” (Habermas, 2003:336).

Em seguida, ao criticar a objetividade no sentido de qualidade da informação apresentada pela imprensa, Habermas ressalta a interpenetração de elementos de outros discursos com o informativo, como os expressivos, dando o exemplo das matérias ao estilo "biografias pessoais", apresentadas numa perspectiva factual, que podem produzir relações de identificação afetiva com o público-leitor:

“Todos esses artigos são aí colocados de tal modo que na primeira metade é o texto que ocupa a maior parte, enquanto que na outra prepondera a ilustração. Só um terço de toda a superfície de notícias é preenchida com colaborações que orientam de forma 'objetiva'; dois terços dela é com aquela que, disfarçadamente e de modo preponderante, são direcionados para o 'human interest'; debaixo dos artigos principais da primeira página, sobe a participação das colaborações, para 72\%, produzidas como 'human interest stories."” (Habermas, 2003:336).

Uma comparação ilustrativa desses resultados pode ser feita com o primeiro caderno de uma edição antiga do jornal já pesquisado aqui, a Folha de S.Paulo, por meio de acesso ao seu acervo original, digitalizado e tornado disponível em 2011, quando o periódico completou 90 anos de existência.

Em edição de 02/11/1958 digitalizada, verifica-se que o primeiro caderno do jornal então intitulado "Folha da Manhã" contém dez páginas, sendo que cinco delas tem mais de $50 \%$ de seu espaço ocupado por textos. Dessas cinco, as duas primeiras são de "assuntos gerais" que englobam desde conflitos internacionais e notícias sobre política a eventos culturais locais. A terceira é destinada a uma entrevista sobre política, a publicações oficiais da Câmara Municipal e às notas de falecimento, cuja sessão é intitulada "Necrologia". Na mesma página, anúncios em forma de textos como o da pomada Nixoderm (com o título "Acabe com as coceiras. Combata espinhas e erupções"), confundem-se com as notícias. A quarta página com mais de $50 \%$ de textos é dedicada ao editorial, às cartas de leitores e às colunas diárias, incluindo uma de autoria do poeta Manuel Bandeira. Por fim, a quinta página contém uma entrevista com o autor da obra 
Doutor Jivago, o ganhador do Nobel de literatura Boris Pasternak, cuja obra teria sido acusada pelos russos de ter caráter burguês, bem como uma matéria sobre as conturbadas relações amorosas entre um piloto da RAF inglesa divorciado e a princesa Margaret de Windsor, que desejava abdicar de seu título para com ele se casar. ${ }^{333}$

Sem contar a primeira página e a seção de cartas dos leitores, o primeiro caderno analisado tem ao todo 71 textos, sendo que 12 deles são artigos de opinião (16,9\%). Desses 12 textos, no entanto, um é da Câmara Municipal, três são entrevistas, dois são editoriais e os sete restantes são de colunistas. Tem-se que, portanto, $83,1 \%$ dos textos são de notícias descritivas.

Já na edição impressa do dia 02/11/2011 do jornal, a mesma utilizada para a medição do número de anúncios comerciais acima (v. 2.1.2 "a"), seu primeiro caderno apresentou somente seis de suas 27 páginas com mais de $50 \%$ de seu espaço dedicado a textos, o que significa $22,2 \%$ do total. Dessas seis, a primeira é o editorial; a segunda é destinada a artigos de autores independentes, a cartas do leitor e errata; a terceira um claro exemplo de "human interest story": notícias sobre o tratamento de saúde do ex-presidente; a quarta com notícias sobre política e uma análise externa sobre economia; a quinta com avisos e publicações oficiais e um artigo de colunista e a sexta com notícias internacionais.

Desconsiderando a primeira página e o espaço de em torno de $50 \%$ da terceira destinado às cartas dos leitores e a errata, há 45 textos no primeiro caderno da edição mencionada, sendo que 13 deles são de opinião (incluindo dois do editorial), isto é, menos de um terço do total. Os restantes $71,1 \%$ de todos os textos do caderno são notícias descritivas sobre fatos.

Como o número de artigos de opinião teve aumento insignificante entre as duas edições, a diminuição da percentagem de notícias descritivas entre elas se dá em razão da grande diferença proporcional no número de textos (71 textos em 09 páginas da edição de 1958, contra 45 textos de 26 páginas da edição recente).

A partir desses exemplos, portanto, fica difícil negar o predomínio da comunicação informativa na imprensa nacional desde a época da publicação de MEEP. A pretensão normativa desse discurso por uma busca cooperativa pela verdade pode ser agora analisada a partir algumas relações entre suas pretensões de objetividade e correção.

No caso do telejornalismo, as Organizações Globo publicaram em 06 de agosto de 2011, 86 anos depois de sua fundação, seus princípios editoriais de imprensa. Neste

\footnotetext{
${ }^{333}$ Essa edição da Folha da Manhã, bem como outras do acervo do jornal Folha de S.Paulo, podem ser acessadas no endereço eletrônico www.acervo.folha.com.br (último acesso: 17/11/2011).
} 
documento de 26 páginas intitulado "Princípios Editoriais das Organizações Globo", tornase possível identificar o que a rede de empresas entende como jornalismo, informação de qualidade e condutas que devem orientar as práticas jornalísticas de seus veículos.

No que diz respeito à objetividade, o termo utilizado é “isenção". Pretensões de uma busca cooperativa pela verdade estão presentes nesse princípio, que vincula os jornalistas à consideração do contraditório e da opinião e explicações dos afetados pela notícia. A partir desse conjunto de informações, deve-se buscar a objetividade dos fatos. ${ }^{334}$ Em seguida, no entanto, o documento apresenta uma confusão entre pretensões de objetividade e correção, reduzindo a última à primeira. Isto é, as tomadas de posição justificadas do jornalismo politizado, que poderiam qualificar ações relatadas como justas ou injustas, corretas ou incorretas, transformam-se em questões de verdade e precisão na apuração dos fatos. Isso porque, segundo esses princípios editoriais,

“Correção é aquilo que dá credibilidade ao trabalho jornalístico: nada mais danoso para a reputação de um veículo do que uma reportagem errada ou uma análise feita a partir de dados equivocados. O compromisso com o acerto deve ser, portanto, inabalável em todos os veículos das Organizações Globo. É evidente que, depois de tudo o que aqui já foi dito sobre o conceito de 'verdade', não é demais dizer que estar correto é procurar descrever e analisar os fatos da maneira mais acurada, dadas as circunstâncias do momento. Nesse sentido, a correção é um processo, uma construção que vai se dando dia após dia.” (Globo, 2011:12. Grifos nossos).

Essa confusão entre correção e verdade é comum na comunicação cotidiana, mas não deveria ser feita por uma empresa de jornalismo, especialmente uma que se pretenda "isenta" no que se refere a posicionamentos políticos. Neste caso, quando a Globo "erra", erra em relação ao dever de buscar a verdade, o que revela seu conteúdo prático.

No entanto, se o princípio da correção não é tomado também no sentido do dever de cumprimento de normas jurídicas relativas à atividade jornalística, como, no caso dos programas de rádio e televisão, a "regionalização da produção cultural, artística e jornalística” (inc. III, art. 221, CF), pode-se ter a impressão que esses e outros deveres não

\footnotetext{
334 “a) Os veículos jornalísticos das Organizações Globo devem ter a isenção como um objetivo consciente e formalmente declarado. Todos os seus níveis hierárquicos, nos vários departamentos, devem levar em conta este objetivo em todas as decisões; // b) Na apuração, edição e publicação de uma reportagem, seja ela factual ou analítica, os diversos ângulos que cercam os acontecimentos que ela busca retratar ou analisar devem ser abordados. O contraditório deve ser sempre acolhido, o que implica dizer que todos os diretamente envolvidos no assunto têm direito à sua versão sobre os fatos, à expressão de seus pontos de vista ou a dar as explicações que considerarem convenientes; // c) Isso não quer dizer que o relato e/ou a análise de fatos serão sempre uma justaposição de versões. Ao contrário, o jornalista deve se esforçar para deixar claro o que realmente aconteceu, quando isso for possível.” (Organizações Globo, 2011, pp.5-6. Itálicos e grifos nossos).
} 
fazem parte da pretensão de correção das Organizações Globo. ${ }^{335}$ Somado a isso, ao pretenderem-se "apartidários", "laicos", “independentes de governos e de grupos econômicos" (Globo, 2011:7-8), correm o risco de conferir ao seu discurso informativo um caráter "criptonormativo". 336

Em matéria de destaque da edição de 06 de agosto de 2011 do Jornal Nacional, foram expostos alguns dos princípios do manual. Inicialmente destacou o apresentador que, segundo o documento, os veículos de jornalismo das Organizações Globo já aplicavam esses princípios "intuitivamente". A importância de fazê-lo agora se devia à vontade de diferenciar o jornalismo de seus veículos da grande produção de informações possibilitada pela internet, e para facilitar o "julgamento do público" em relação ao seu compromisso com esses princípios.

Mesmo publicado somente agora, o documento representa um avanço, como destaca Venício A. de Lima em coluna no portal eletrônico de notícias da revista Carta Maior (8/8/2011). ${ }^{337} \mathrm{O}$ professor aposentado da UnB e coordenador de grupo de pesquisa sobre mídia e política da universidade chama a atenção, no entanto, para o fato de que o lançamento se dá logo após o recente escândalo sobre a manipulação indevida de informações e fontes que levou o jornal britânico News of the World, de propriedade um dos maiores empresários de comunicação social do mundo, Rupert Murdoch, a diversos processos e conseqüente fechamento. ${ }^{338}$

Ainda assim, os princípios editoriais das Organizações Globo comprovam a existência de um "dever de busca pela verdade" no discurso dos meios de comunicação,

\footnotetext{
335 Como destacam ao final do documento, no entanto, as Organizações Globo se comprometem com “a democracia, as liberdades individuais, a livre-iniciativa, os direitos humanos, a república, o avanço da ciência e a preservação da natureza." Além disso, de modo claramente contraditório, afirmam que: “Os limites do jornalista e das empresas de comunicação são as leis do país, e a liberdade de informar nunca pode ser considerada excessiva" (Globo, 2011:25-26. grifos nossos).

${ }^{336}$ As abordagens criptonormativas são aquelas cujas pretensões de objetividade e descrição acabam por desconsiderar posicionamentos valorativos como carentes de justificação, até mesmo a exigência normativa da verdade por trás da própria descrição. Isso resulta numa atitude estratégica e "objetificante" perante o objeto de estudo: "Those who act strategically no doubt also have a liferworld background always behind them; but this background is neutralized in its action-coordinating force. It no longer provides a shared consensus in advance, because strategic actors encounter normative contexts, as well as other participants, only as social facts. In the objectivating attitude of an observer, they can no longer reach an understanding with others as second persons" (Habermas, 1996, p.524. Itálico do autor. grifos nossos). V. também Habermas, 1996:69-70; Strasser.1978:21-29; Blotta, 2010:273-336.

${ }^{337}$ V. Lima, Globo: os princípios, a credibilidade e a prática. In. Carta Maior. 08/08/2011. Disponível em Www.cartamaior.com.br (último acesso: 28/11/2011).

${ }^{338}$ Para uma discussão sobre como escândalos midiáticos, e.g do News of the World levam as indústrias da comunicação a processos rápidos de abertura para legitimação perante o público, para depois fecharem-se novamente, v. Chomsky. Understanding Power, 2002, p. 27-30.
} 
especialmente quando trata o problema não somente como "mera utopia", mas como uma "produção de conhecimento" de base coletiva. ${ }^{339}$

Mas não é somente no processo de "construção das notícias" que a esfera pública política nacional tem exigido uma busca cooperativa pela verdade. Essa pretensão se ampliou a ponto de influenciar também as formas de exposição e publicização da informação, de modo que mesmo os meios de comunicação tradicionais têm alterado seus formatos para aumentar a participação de públicos variados, como experts e indivíduos interessados. $^{340}$

Um exemplo interessante dessa mudança é o novo formato do Jornal da Cultura, apresentado pela jornalista Maria Cristina Poli na emissora pública paulista. Apesar de trazer pautas muito semelhantes às dos telejornais de outras emissoras, a presença de diferentes especialistas convidados que explicam e debatem as notícias e matérias, bem como a abertura para questões e participações de internautas, demonstra como a exposição da informação pode ganhar em "objetividade" na medida em que é acrescida dessas contribuições. $^{341}$

Nesse momento, o telejornal retoma um dos papéis atribuídos por Habermas às instituições da esfera pública política: o de constituir espaços nos quais a comunicação de experts pode retomar seu contato com a comunicação cotidiana do público generalizado (v. capítulo 4 "c", acima). Assim, de meros destinatários das notícias, os públicos passam a contribuir cada vez mais com suas interpretações sobre os fatos, fornecendo muitas vezes informações mais precisas, atualizadas e in loco, auxiliando o trabalho jornalístico e qualificando o caráter cooperativo de sua busca pela verdade.

Como indicou de modo preciso o próprio documento de princípios das organizações Globo, essa tendência tem origem nas novas ferramentas de interatividade

\footnotetext{
${ }^{339}$ No início do documento, em uma "breve definição de jornalismo", aduz-se que: "Antes, costumava-se dizer que o jornalismo era a busca pela verdade dos fatos. Com a popularização confusa de uma discussão que remonta ao surgimento da filosofia (existe uma verdade e, se existe, é possível alcançá-la?), essa definição clássica passou a ser vítima de toda sorte de mal-entendidos. A simplificação chegou a tal ponto que, hoje, não é raro ouvir que, não existindo nem verdade nem objetividade, o jornalismo como busca da verdade não passa de uma utopia. É um entendimento equivocado. // É para contornar essa simplificação em torno da "verdade" que se opta aqui por definir o jornalismo como uma atividade que produz conhecimento. Um conhecimento que será constantemente aprofundado, primeiro pelo próprio jornalismo, em reportagens analíticas de maior fôlego, e, depois, pelas ciências sociais, em especial pela História. (...) Dizer, portanto, que o jornalismo produz conhecimento, um primeiro conhecimento, é o mesmo que dizer que busca a verdade dos fatos, mas traduz com mais humildade o caráter da atividade. E evita confusões." (Globo, 2011:3-4. Itálicos e grifo nosso).

${ }^{340}$ É sintomático dessas transformações a própria entrada de conteúdos da internet nos meios tradicionais. Não só jornais impressos como também a televisão e o rádio noticiam fatos ocorridos no espaço cibernético, mas também reproduzem conteúdos de endereços eletrônicos, como vídeos do conhecido site YouTube.

341 Para mais sobre o programa, visitar seu endereço eletrônico em: http://tvcultura.cmais.com.br/jornaldacultura (último acesso: 17/11/2011).
} 
trazidas pela internet. De um lado, as sensações de dispersão e "avalanche informativa" provocadas pela utilização dessas ferramentas revelam negativamente a procura por informações mais fidedignas e a tentativa de seleção criteriosa das inúmeras fontes disponíveis. Por outro lado, o aumento das possibilidades de produção de informação e geração de conteúdo pelos usuários da rede também mostram que a pretensão à busca cooperativa pela verdade não é exclusiva do discurso informativo do jornalismo, mas, como afirmou Habermas em sua releitura de Peirce, está presente em contextos cotidianos do agir comunicativo (Habermas, 1996:34-35). ${ }^{342}$

$\mathrm{O}$ fato de que essas novas formas de interatividade estejam na maioria das vezes vinculadas à rentabilidade econômica dos meios e seus anunciantes (v. tópico 5.2, acima) é outra forma de comprovar que a pretensão à busca cooperativa pela verdade não é só um pressuposto teórico da informação de qualidade, mas um interesse social que é capaz, inclusive, de gerar novas formas de reprodução material da sociedade. Mais uma vez, torna-se necessário saber em que medida essas novas formas de interação, possibilitadas por avanços tecnológicos que revelam pretensões como a busca cooperativa pela verdade nos discursos científico-informativos, podem ser garantidas independentemente de sua rentabilidade econômica. ${ }^{343}$ Nesse sentido, mantém-se atual a lição de Rui Barbosa sobre a Imprensa e o Dever de Verdade, publicada pela primeira vez em 1920: “... não há, para qualquer sociedade, maior desgraça que a de uma imprensa deteriorada, servilizada, ou mercantilizada." (Barbosa, 1957:23).

\subsection{A factualidade da violência e a violência da factualidade: a pluralidade de visões de mundo contra formas dominantes de produção da verdade}

Este último tópico do diagnóstico das expressões técnico-científicas e informativas da esfera pública política continua a discussão sobre as relações entre a comunicação

\footnotetext{
${ }^{342}$ Um exemplo marcante da pretensão à busca cooperativa pela verdade na internet é a enciclopédia virtual Wikipedia, que possibilita aos usuários iguais condições de produção de conteúdo e de correção de informações imprecisas. Apesar de reações de especialistas que possam entender a descentralização da produção do conhecimento como um decréscimo inevitável da qualidade da informação, como é o caso da obra $O$ Culto do Amador, de Andrew Keen (2009), o Wikipedia reconhece a possibilidade de as informações submetidas não serem verídicas e se abre à correção por outros internautas, especialistas ou não. Segundo recente mensagem de seu fundador em busca de doações para manter o Wikipedia, que não recebe propaganda comercial, o site é o quinto mais acessado do mundo. V. www.donate.wikimedia.org (último acesso: 18/11/2011). Este apelo mostra mais uma vez como a efetivação de pretensões normativas da esfera pública política não pode depender somente de renda proveniente da propaganda comercial.

${ }^{343}$ Para uma discussão sobre alternativas a esse modelo, v. Habermas. Medios, mercados y consumidores: la prensa seria como espina dorsal de la esfera pública política. In. Id. Ach Europa (2009:129-135).
} 
informativa e suas implicações práticas. A pretensão normativa a ser analisada é a pluralidade de visões de mundo, que passa a ser violada na medida em que formas dominantes de comunicação informativa impedem ou dificultam considerações de igual valor a interpretações diversas do mundo ou da autocompreensão dos indivíduos.

Para um delineamento teórico inicial, em recente texto de 67 páginas intitulado "Von den Weltbildern zur Lebenswelt" [Das imagens de mundo ao mundo da vida. trad. livre], Habermas entende que as próprias teorias filosóficas cumprem hoje a função de visões de mundo, as quais, numa perspectiva pós-metafísica, precisariam deixar-se “... justificar como formas de autoentendimento ético". (Habermas, 2009b:203. Trad. livre do alemão).

Mas como sob as condições modernas do "pluralismo de visões de mundo" (weltanschaulichen Pluralismus) não se pode mais pretender validade universal a eticidades determinadas (Id. op. cit:204), essa concepção mais "secularizada" de visão de mundo se aproxima das pretensões de verdade da racionalidade teórico-representativa, como define Habermas no início do texto referido:

“Quando trazemos para o conceito nossa compreensão de mundo e autocompreensão, falamos de imagens de mundo ou visões de mundo. Enquanto que na 'visão de mundo' o processo de compreensão do todo oscila, carrega 'imagem de mundo' antes o resultado, do caráter teórico ou representativo da verdade pretendida a uma interpretação de mundo" (Habermas, 2009b:203. trad. livre do alemão. Itálicos do autor. Grifos nossos). ${ }^{344}$

Essa pretensão normativa é normalmente associada à liberdade de crença e de expressão religiosa ${ }^{345}$, mas num contexto em que não mais a religião, e sim determinados modelos de comunicação informativa predominam na "produção da verdade" 346 sobre os

\footnotetext{
${ }^{344}$ Tradução livre do original: "Wenn wir unser Welt - und Selbstveständnis auf Begriffe bringen, sprechen wir von Weltbildern oder Weltanschauungen. Während in 'Weltanschauung' der Prozess der Erfassung des Ganzen mitschwingt, betont 'Weltbild' eher das Ergebnis, den theoretischen oder darstellenden, Wahrheit beanspruchenden Charakter einer Weltdeutung.". Texto publicado no quinto e último volume dos Textos Filosóficos de Habermas, coletânea de estudos lançados pela editora Suhrkamp em comemoração aos seus 80 anos em 2009.

${ }^{345}$ V. Habermas, 2007:115-168 e 279-392. A discussão sobre a influência da religião na esfera pública política, trabalhada mais recentemente por Habermas em debates com grandes interlocutores, como Ratzinger (Habermas \& Ratzinger, Dialektik der Sekularisierung, 2005), Taylor (The Secular Age, 2007) e Butler (The Power of Religion in the Public Sphere. Madieta \& Van Antwerpen [eds], 2011), será discutida no tópico 2.3.3 desta tese a partir das pretensões de autoexpressão individual e existencial e dos direitos culturais originados da liberdade de crença e da tolerância religiosa.

346 A conhecida obra O Poder Simbólico, de Bourdieu (1989:7-13), relata o processo histórico de concentração do poder de "reprodução simbólica da realidade", isto é, “(...) o poder de constituir o dado pela enunciação, de fazer ver e fazer crer, de confirmar ou de transformar a visão de mundo e, deste modo, a ação sobre o mundo, portanto o mundo" (Id. op. cit:9) Idade Média, que marcou a passagem do mito para religião
} 
fatos, como os meios de comunicação ou a ciência, a pluralidade de visões de mundo complementa a busca cooperativa pela verdade ao ressaltar em experiências negativas o quanto esse predomínio pode levar a formas veladas de violência.

Para comprovar empiricamente essa tese, as coberturas jornalísticas do fenômeno da violência urbana são exemplares. Isso porque elas podem demonstrar que mesmo as abordagens de fatos dificilmente contestáveis, como atos de violência, derivam de escolhas práticas que as empresas jornalísticas precisam realizar, as quais, por sua vez, levam também a consequiências práticas que afetam não só os diretamente os envolvidos nos casos, mas toda a esfera pública constituída pela comunicação informativa.

Serão analisados dois aspectos de coberturas jornalísticas da violência urbana capazes de revelar violações da pretensão à pluralidade de visões de mundo na esfera pública política: um primeiro ligado ao conteúdo e, portanto, às representações da violência na comunicação informativa que predominam nessas coberturas e suas problematizações; e um segundo destinado aos formatos das coberturas, com destaque para a questão da velocidade e da imediaticidade da comunicação informativa e suas problematizações

a) a factualidade da violência: entre estatística e espetáculo

$\mathrm{Na}$ filosofia de Habermas, a violência representa um rompimento da comunicação orientada para o possível entendimento mútuo. Isso não significa de modo algum, no entanto, que o autor diagnostica a modernidade e o tempo presente das democracias de massa como sendo isentos de violência. Pelo contrário, as noções de "patologias da comunicação" e "comunicação sistematicamente distorcida do mundo vida" (Habermas, 2001:129-170) são tidas como fatos sociais sem os quais não é possível comprovar pragmaticamente a existência das pretensões transcendentais de validade da razão e do agir comunicativo.

como forma dominante de visão de mundo. Na modernidade, Fábio Konder Comparto destaca como esse processo de concentração continua, passando aos "intelectuais orgânicos" do Absolutismo às revoluções burguesas, e no século XX aos meios de comunicação de massa. O que teria mudado desde o período liberal seria, no entanto, uma necessidade crescente de legitimação do poder político. V. Comparato, A Democratização dos Meios de Comunicação de Massa, 2000:182-188. 
Ao mesmo tempo, essa perspectiva só admite a "facticidade" da violência, isto é, a própria experiência da injustiça ou coação, na medida em que pressupõe algum tipo de conhecimento de fundo - ainda que não articulado de modo consciente - sobre relações justas ou interações não violentas que são negadas na prática. ${ }^{347}$

Apesar disso, a facticidade da violência urbana parece impor-se de modo imediato aos sujeitos através dos meios de comunicação, ou seja, sem passar por debates públicos sobre sua existência ou como esta é retratada. De modo semelhante, Bento Prado Jr. identifica o sentido de violência na Genealogia da Moral de Nietzsche como "último termo da História”, pois quando ela se realiza, revela a verdade por trás de toda linguagem: a pura vontade de poder. A violência seria então uma forma de comunicação que procura negar-se como tal, e por isso mesmo não careceria de interpretação para ser compreendida como violência. $^{348}$

Porém, mesmo sem adotar a perspectiva da comunicação pragmática de Habermas, a sociologia da violência no Brasil entende seu objeto de estudo como um fenômeno de caráter interpretativo e, portanto, irredutível a uma única forma de leitura da realidade, nem mesmo o conhecimento empírico-factual das estatísticas. ${ }^{349}$

É por isso que a cobertura da violência pela imprensa pode ser vista como uma entre outras fontes de análise científica, e inclusive especialmente importante para se entender a diferença entre sua manifestação real e a violência "ficcional", isto é, aquela

\footnotetext{
${ }^{347}$ Em debate publicado ao final de Habermas and the Public Sphere (Calhoun [ed], 1992), Habermas se diz hesitante em admitir a ideia, inspirada em Foucault, de que discursos seriam sempre formados por relações de poder no sentido de dominação, mesmo que a história tivesse mostrado que todas as tentativas de institucionalização da esfera pública (liberal ou social) teriam levado à exclusões e desigualdades. Diante de alguns contra-exemplos de "auto-correções" nas instituições modernas, e da necessidade de apresentar alternativas para a solução de controvérsias que é demandada do teórico que adota a perspectiva do participante, o autor atesta: "At least the public sphere is an attempt to exclude violence, if only to reproduce some sort of violence internally again but in a criticizable fashion. This may be the best we can achieve in the domain of politics. The core of it is certainly politics: fighting all modes of settlements that are somehow unjust." (Habermas, Concluding Remarks. In . Calhoun [ed], 1992, p.479. itálicos e grifos nossos).

${ }^{348}$ V. Prado Júnior, Bento. "A Força da Voz e a Violência das Coisas". Introdução à edição brasileira da obra Ensaio sobre a Origem das Línguas, de Rousseau. (trad. Fulvia M. L. Moretto. $2^{a}$ ed, 2003:16). Essa discussão sobre as relações entre violência e linguagem foi realizada em: Blotta, A Inclusão pelo Simbólico. Linguagem, dominação e transformação, 2009, pp. 283-300.

349 “... mesmo as chamadas fontes de estatísticas oficiais de criminalidade rigorosamente não são fidedignas. Sabemos que há uma série de dificuldades nessas fontes. // Entendemos que a questão da objetividade do conhecimento científico não se coloca nesse termos porque, para nós, em ciências sociais, a realidade é complexa, múltipla, e tantos fatos 'considerados objetivos' compõem essa realidade, assim como todas representações. Então, consideramos que não podemos estudar a problemática da criminalidade apenas por meio de dados aparentemente objetivos, fidedignos e precisos. A construção da criminalidade como um problema social é sociologicamente significativa, passa no nosso entender pela construção 'marginal' a respeito do crime, do criminoso e da criminalidade e sobretudo pelo conjunto de representações que fazem com que a criminalidade seja hoje um objeto privilegiado de preocupação" (Adorno, 1995:182). V. também Lima \& Paula (orgs) Segurança Pública e Violência, 2008.
} 
representada factualmente f50 $^{350}$ na comunicação informativa. Analisados de modo complementar, portanto, dados empíricos e representações sobre a "verdade da violência" poderiam levar a compreensões mais abrangentes e precisas do fenômeno (Adorno, 1995:182-183).

Essas considerações teóricas e metodológicas iniciais são feitas por Sérgio Adorno em texto intitulado "Violência, Ficção e Realidade", da obra coletiva Sujeito: o lado oculto do receptor (Souza [org] ECA-USP, 1995:181-188). Além disso, o coordenador do Núcleo de Estudos da Violência da USP e do Instituto Nacional de Ciência e Tecnologia "Violência, Democracia e Segurança Cidadã" faz algumas observações sobre os conteúdos da cobertura da violência e da criminalidade na imprensa. Antes, no entanto, reconhece a influência especial da imprensa na formação de uma esfera pública política em torno do tema. $^{351}$

Segundo Adorno, a violência criminal é o tipo mais enfatizado pela imprensa. Dentro desse "gênero", quatro temas são especialmente veiculados: a questão do movimento da criminalidade, que trata da difusão de uma percepção generalizada sobre transformações e a perda do controle social em relação à criminalidade; as causas da criminalidade, que variam de modo geral entre sociais, individuais ou psicológicas, dependendo da conjuntura econômica do país; o perfil social dos delinqüentes, normalmente estereotipando-os como "heróis ou vilões", “desocupados", provenientes de lares desestruturados, a partir de renda, traços étnicos ou mesmo geográficos; e por fim as políticas de segurança pública, o único tema mais propositivo dentre os quatro, mas que geralmente constrói uma imagem negativa das instituições e agentes do setor e se limita a propor medidas redistributivas ou tecnológicas para enfrentar o problema (Adorno, 1995:183-186).

\footnotetext{
${ }^{350}$ Por esse motivo, adota-se aqui a expressão "factualidade" da violência, e não "facticidade", visto que a primeira remete ao espaço social criado pela representação factual da violência na comunicação informativa, enquanto que a última significa a própria prática da violência. A proposta deste tópico, no entanto, é demonstrar como essa factualidade da violência pode ela mesma significar uma prática violadora de pretensões de comunicação e reconhecimento, como a pluralidade de visões de mundo. Para mais sobre o sentido de uma facticidade que se dá pela predominância da perspectiva objetivante daquele que toma o mundo apenas como fatos, v. Bittar, Justiça e Emancipação, 2011:944.

351 "Após essas observações inicias, passo a discorrer sobre a importância da imprensa como fonte indispensável de investigação. Além das questões já colocadas, a complementaridade de informações que ela oferece nos indica que se trata de importante veículo de expressão das percepções sociais quanto à criminalidade, ao crime, ao criminoso, e ao modo pelo qual a sociedade transforma essa questão num problema de interesse público. Nesse sentido a problemática que se coloca hoje, em termos de pesquisa, é conhecer, primeiro, de que modo aquelas percepções são expressas pela imprensa e os dados que ‘expressariam' a chamada criminalidade real.” (Adorno, 1995:183. Itálicos nossos).
} 
Esse quadro que o próprio Adorno considerou em 1995 "genérico e impressionista" ainda encontra respaldo na pesquisa "Mídia e Violência", publicada em 2007 por Silvia Ramos e Anabela Paiva, do Centro de Estudos de Segurança e Cidadania (CESeC), que analisou nove jornais dos Estados de São Paulo, Minas Gerais e Rio de Janeiro em 2004 (“pesquisa Brasil”) e oito jornais do Rio de Janeiro em 2006 (“pesquisa Rio"). ${ }^{352}$

Isso porque, apesar de constatar que os jornais teriam reduzido o uso de "recursos sensacionalistas e noções apelativas" desde os anos 80 , e que o tema da segurança pública é hoje mais recorrente, $63,8 \%$ das matérias da pesquisa Brasil e 77,7\% das da pesquisa Rio foram dedicadas a relatos factuais, sendo que $83,7 \%$ da pesquisa Brasil e $82,5 \%$ da pesquisa Rio trataram de "histórias individuais", isto é, fatos cotidianos isolados e descontextualizados (Ramos \& Paiva, 2007:19).

Já as matérias que podem ser consideradas "de fundo", montadas por iniciativa dos jornais, como entrevistas, editoriais, investigações e reportagens especiais foram de $6,1 \%$ na pesquisa Brasil e de 14,5\% na pesquisa Rio. As autoras concluem, portanto, que esse predomínio da comunicação informativa de relatos isolados em detrimento das contextualizações e artigos de opinião "é um indicador de que os jornais têm ainda reduzida iniciativa no setor e se deixam dominar pela avalanche de acontecimentos do diaa-dia, dando espaço limitado para a análise e a crítica." (Id. Ibid).

Pesquisa semelhante à de Ramos e Paiva com base em relatórios sobre mídia e infância da Agência de Notícias dos Direitos da Infância (ANDI), comparou matérias factuais com matérias especiais sobre o problema da "exclusão social de crianças e adolescentes". Resultados parciais indicaram nas matérias especiais um tratamento mais cuidadoso em relação a terminologias e tratamentos dos envolvidos, bem como um reconhecimento de sua importância social pelos profissionais do ramo. ${ }^{353}$

\footnotetext{
352 O primeiro estudo analisou 2.514 textos dos jornais O Globo, O Dia e JB; Folha de S.Paulo, Estado de S. Paulo e Agora São Paulo Agora; O Estado de Minas, Hoje em Dia e Diário da Tarde. Já o segundo analisou 2.651 textos de O Globo, O Dia, Jornal do Brasil, O Povo, Tribuna da Imprensa, Meia Hora, O Fluminense, Extra. V. amostragens completas das pesquisas em www.ucamcesec.com.br (Ramos \& Paiva, 2007:18).

${ }^{353}$ Segundo os autores Vinícius Neder e Leonel Aguiar, em relação à metodologia do estudo, "A análise comparativa desenvolvida aqui lança mão, no plano do "noticiário factual", do monitoramento de mídia impressa empreendido pela Agência de Notícias dos Direitos da Infância (ANDI). Ano a ano, desde 1996, o relatório 'Infầncia na mídia' procura analisar, quantitativa e qualitativamente, a cobertura de jornais e revistas sobre o tema, oferecendo uma visão ampla da cobertura. No plano das "reportagens especiais", optamos pelo estudo detalhado de um único caso, uma série de reportagens sobre exploração sexual infantil, publicada no jornal O Globo (principal título impresso das Organizações Globo) entre março e abril de 1997." (Neder \& Aguiar, 2010:236-237)
} 
Esses levantamentos permitem sugerir que quando as formas dominantes de produção da verdade nos meios de comunicação promovem esse tipo de seletividade que exclui informações opinativas, analíticas, dados e explicações tidas como indispensáveis para cada um possa estabelecer um juízo próprio sobre os fatos veiculados - ou mesmo no caso em que a imprensa sonega do público determinados fatos de comprovada relevância social $^{354}$-, tem-se como resultados violações do direito de se obter da imprensa informações independentes e de qualidade ${ }^{355}$ sobre os fatos, que são garantidas de modo mais positivo pela exigência da busca cooperativa pela verdade e pela pluralidade de visões de mundo nessa expressão da esfera pública política.

Essa violação se torna ainda mais grave e evidente quando os afetados pela comunicação informativa identificam que a exclusão de outros temas e informações também ocorre por uma superexposição e uma dramatização de alguns casos de violência e criminalidade, bem como tragédias, catástrofes etc. consideradas irrelevantes e indesejáveis para a compreensão dos fatos em suas diversas perspectivas (Adorno, S. 1995:183).

Além dos problemas relativos ao pré-julgamento (v. "b", abaixo) e violações de direitos da personalidade (v. 3.4), esse tipo de cobertura tem entre suas conseqüências práticas a construção de panoramas factuais de emergência que estimulam a legitimação de políticas de endurecimento penal e supressão de garantidas individuais. ${ }^{356}$

Especialmente com os recursos audiovisuais do telejornalismo, o que acaba ocorrendo é uma mistura de elementos informativos e estéticos que dificultam a distinção entre realidade e ficção pelos telespectadores, especialmente crianças e adolescentes. ${ }^{357}$

\footnotetext{
${ }^{354}$ O oportuno Apêndice da obra Videologias intitulado "Direitos do Telespectador" de Bucci, que será retomado na terceira parte deste trabalho, propõe primeiramente que: "Todo telespectador tem o direito de: 1) Ser informado de modo independente, recebendo os dados necessários para que forme sua própria opinião. Atenção: a censura no Brasil existe sim, só não é feita pelo Estado, e sim pelas emissoras e por seus donos, que sonegam determinados assuntos ao público. (...) Concessão pública, o canal de TV deve estar proibido de sonegar fatos de relevância pública evidente. Da mesma forma, deve estar proibido de empregar sua influência junto ao público com finalidades partidárias." (Bucci \& Kehl, 2004:252).

${ }^{355}$ Aqui se pensa a qualidade da informação no sentido dado por Günther ao processo de aplicação do direito, isto é, de uma busca exaustiva pelas melhores e mais fidedignas informações e perspectivas sobre o caso, apesar das conhecidas limitações de tempo e a decidibilidade. O juízo de adequação no plano do direito segue esta mesma lógica das decisões da vida prática, isto é, precisam decidir qual a melhor medida entre alternativas de ação. V. Günther. Teoria da Argumentação no Direito e na Moral: Justificação e Aplicação, 2004, p. 368.

${ }^{356}$ Para estudos sobre o tema, v. Wainberg, Mídia e Terror, 2005; Blotta, 11 de setembro. Mídia, Política e Exceção, 2005; Blotta \& Quirino. Do outro lado do apagão aéreo: a responsabilidade da grande mídia na violência contra rádios de baixa freqüência, 2008.

${ }^{357}$ Estima-se que crianças e jovens de até 14 anos passe 28 horas semanais na televisão enquanto que 23 horas na escola pelo mesmo período. Dados citados de estudo brasileiro de 2002 e dos EUA de 2007 na obra de Wainberg (op.cit:35).
} 
Nesse momento, a pretensão de verdade das matérias deixa de sugerir uma factualidade e impõe-se como facticidade ${ }^{358}$, isto é, como verdade quase irrefutável, como as "verdades auto-evidentes" discutidas por Hannah Arendt em Between Past and Future (1961). ${ }^{359}$

Mas se de um lado essa dramatização das notícias dada pela amplificação da visibilidade dos casos podem levar a conseqüências práticas problemáticas do ponto de vista político - como a Lei de Crimes Hediondos (Lei. 8.072/90), sancionada logo após o seqüestro do empresário Abílio Diniz em $1989^{360}$-, de outro, estudo realizado por Maia \& Neves sobre a cobertura de abrangência nacional dada ao caso de violência policial que ficou conhecido como "Favela Naval" $(1997)^{361}$, sugere que essa mesma superexposição transformou o que talvez fosse tratado como um simples crime em "acontecimento publicamente relevante" (Maia e Neves, 2008, p.323).

Apesar dessas ambivalências da comunicação informativa do jornalismo, o dever de denunciar injustiças não pode significar uma "carta branca" à imprensa, justamente para evitar o "denuncismo" e as conseqüentes violações de direitos de imagem e honra pessoais, que são muitas vezes irremediáveis. ${ }^{362}$

Apesar de a pesquisa de Ramos \& Paiva indicar uma melhora significativa dos anos 90 para a primeira década do século XXI em relação ao uso de conteúdos apelativos e agressivos da imprensa escrita e, no caso da televisão, alguns programas do "gênero mundo-cão" (do policial ao programa de auditório que devassa os problemas da vida

\footnotetext{
${ }^{358}$ Sobre a cobertura do caso "Favela Naval", estudo detalhado de Rifiotis destacou: "A força daquelas imagens era tamanha que embora os dias e as horas em que foram gravadas estivessem registrados no vídeo, apontando para os primeiros dias de março, elas pareciam fora de tempo e de lugar, ganhavam uma estonteante atualidade. Este aparente deslocamento entre passado e presente fazia com que as imagens se confundissem com os "fantasmas" que povoam a nossa percepção do abuso de poder e da ação dos agentes de segurança no Brasil. Assim, naquela edição do Jornal Nacional tudo parecia confundir-se. A tensão das cenas traía a nossa atenção: mostravam-se no dia 31 de março cenas gravadas nos dias 3, 5, 6 e 7 daquele mês. As cenas repetidas na televisão pareciam estar em continuum com tantas outras cenas reais e imaginadas, tomando de assalto nossa imaginação e nossas emoções, transformando o vídeo em atos mostrados "ao vivo", como se costuma dizer. (...) // Em outras palavras, os atos realizados pelos policiais militares de São Paulo, que foram gravados e divulgados pela televisão, parecem ter-se tornado autosuficientes. Mostrar as imagens na televisão não foi apenas, digamos, re-apresentar, mas criar um fato novo, completo em si mesmo." (Rifiotis, 1999:33-34. Grifos e itálicos nossos).

359 "It was after Socrates' death that Plato began to discount persuasion as insufficient for the guidance of men and to seek for something liable to complete them without using external means of violence. Very early in his search he must have discovered that truth, namely, the truths we call self-evident, compels the mind, and that this coercion, though it needs no violence to be effective, is stronger than persuasion and arguments." (Arendt, 1961:107-108. itálicos nossos).

${ }_{360}$ Para um estudo detalhado deste caso, v. Souza, Mídia e criminalidade: o tratamento dos casos Abílio Diniz e Daniela Perez pela imprensa e suas implicações no direito penal brasileiro, 2009.

${ }^{361}$ Cf. Rifiotis, 1999.

${ }^{362}$ Vale lembrar o conhecido caso de calúnia sofrido pelos donos da Escola Base, em 1994. Mesmo após as acusações de pedofilia terem se comprovado falsas e os caluniados indenizados, a restauração de sua imagem social foi seriamente prejudicada. V. Ribeiro, A. Caso Escola Base. Os Abusos da Imprensa (São Paulo, 1995).
} 
privada publicamente) terem deixado de existir, algumas produções do gênero sobrevivem. $^{363}$

O recente caso de um cinegrafista da rede Band de televisão que morreu baleado em 06 de novembro de 2011 por tiro de fuzil em cobertura de operação policial contra milícias armadas, que obviamente teve grande repercussão na imprensa, radicaliza as perguntas feitas após a morte do jornalista Tim Lopes em 2002 sobre que tipo de informação deve compor o discurso informativo-jornalístico, qual a melhor forma de se obtê-la, e quais são os limites da busca pela verdade. A partir da perspectiva adotada neste trabalho, possíveis respostas a essas perguntas não cabem somente aos donos das empresas de comunicação e a soluções técnicas, como melhoria no equipamento de segurança dos jornalistas.

Assim, se a pretensão a uma busca cooperativa pela verdade revela que nem mesmo a estatística sobre violência é representação imediata da violência real - porque a estatística é uma entre outras formas possíveis de apreensão da realidade -, para que seu predomínio junto ao discurso informativo (e às vezes apelativo) da imprensa na construção da verdade factual não se transforme ele mesmo em violência fática, os direitos de informação precisam ser garantidos a partir da pluralidade de visões de mundo.

\section{b) a violência da factualidade: a pressa é inimiga da correção}

Quando se trata de produzir violações de direitos à informação verídica e de qualidade que garantem aos cidadãos condições para a formação de suas próprias opiniões sobre os fatos, os formatos são talvez tão importantes quanto os conteúdos dos discursos da comunicação informativa.

Duas características de formato que tem tido destaque no diagnóstico dessa expressão informativa da esfera pública política são as questões da velocidade e seu caráter imagético. Discussões sobre como trabalhar com a enxurrada de informações factuais expostas aos indivíduos diariamente a partir das tecnologias de informação e comunicação são feitas atualmente em diversos ramos do conhecimento.

\footnotetext{
${ }^{363}$ É o caso do programa Brasil Urgente, apresentado por José Luiz Datena na rede Band e dos programas de auditório Casos de Família e Ratinho do SBT. Diversos programas do gênero já sofreram ações civis públicas do Ministério Público Federal (MPF), em casos de exibição de conteúdo impróprio para os horários, práticas de discriminação, apresentação de informações falsas e pré-julgamentos. V. página do endereço eletrônico do MPF: http://www.prsp.mpf.gov.br/prdc/area-de-atuacao/direito-a-comunicacao-e-tv (último acesso:23/11/11).
} 
A economia e a teoria social podem oferecer base tecnológica e simbólica ao cenário. É Hobsbawm que afirmará em recente entrevista que a velocidade do sistema econômico capitalista é um problema do tempo presente, e por isso seria fundamental a possibilidade de conter politicamente sua aceleração. Aos seus 94 anos, o maior historiador vivo não visualiza, porém, um cenário esperançoso no atual concerto de nações para tanto. $^{364}$

Não por acaso, como já visto, "aceleração" é o termo utilizado pelo filósofo Hartmut Rosa para caracterizar a sociedade contemporânea em sua teoria social. Ele utiliza o também termo "alienação" para explicar as experiências de incapacidade de comunicação com o mundo, o que remete também a um conceito normativo da ordem da estética: a "ressonância", isto é, em relação ao mundo e ao outro seria o oposto de alienação. $^{365}$

Quando trabalhadas no campo da comunicação, questões sobre a influência da velocidade e da imagem nos discursos de verdade da comunicação informativa se relacionam com o conceito de instância da imagem ao vivo de Bucci e a tese de M. Rita Kehl de que a comunicação audiovisual da televisão forma o imaginário social à revelia do pensamento, também já citadas anteriormente (v. tópico 5.2)

Assim, pode-se propor mais verticalmente que quanto ao conceito utilizado por Bucci, não se trata de somente destacar seu apelo estético, derivado de atualizações da teoria do fetichismo da mercadoria de Marx, como na teoria do espetáculo de Guy Debord (1997), mas também estudos mais ligados à teoria da comunicação como do filósofo Paul Virilio. ${ }^{366}$ A questão a instância e do ao vivo são tão importantes quanto a linguagem

364 “... Não acredito que nossa civilização esteja encarando séculos de regressão como ocorreu na Europa Ocidental depois da queda do Império Romano. Por outro lado, devemos abandonar a antiga crença de que o progresso moral e político seja tão inevitável quanto o progresso científico, técnico e material. Essa crença tinha alguma base no século 19. Hoje o problema real que se coloca, o maior deles, é que o poder do progresso material e tecnocientífico, baseado em crescente e acelerado crescimento econômico, num sistema capitalista sem controle, gera uma crise global de meio ambiente que coloca a humanidade em risco. E, à falta de uma entidade internacional efetiva no plano da tomada de decisão, nem o conhecimento consolidado do que fazer, nem o desejo político de governos nacionais de fazer alguma coisa estão presentes. Esse vazio decisório e de ação pode, sim, levar o nosso século para um momento regressivo." ("Trocando Mitos Por História". Entrevista à Erich Hobsbawm. Publicada no jornal Estado de São Paulo em 11/09/2011. Itálicos e grifos nossos).

365 Interessante notar que a palavra "Zustimmung" significa "acordo" em alemão, mas deriva do verbo "stimmen" que pode ser traduzido como "afinar" nos termos da teoria musical. Hartmut Rosa apresentou o trabalho intitulado "The concept of alienation as the opposite of resonance" na conferência Philosophy and the Social Sciences. Praga, 2010. V. de Rosa também. Beschleunigung: die Veränderung der Zeitstrukturen in der Moderne [Aceleração: a transformação da estrutura do termpo na modernidade] (Frankfurt, 2005).

366 Para ressaltar essa autonomização da factualidade em relação à facticidade da violência, segundo entrevista do comunicólogo Paul Virilio, tão importante quanto a guerra no campo de batalha é a guerra no campo da informação. Folha de S.Paulo (FSP 06/04/03, Caderno Mundo). V. do autor, cuja obra destaca o 
imagética da comunicação eletrônica dominante na esfera pública. Elas dizem respeito à imediaticidade e à capacidade de descontextualização da comunicação televisiva, que colaboram para que ela se afirme como verdade (Bucci, 2009:423).

Já Maria Rita Kehl trabalha no registro da psicanálise o problema de como a velocidade das imagens televisivas impedem o funcionamento do pensamento, pois este operaria no registro da linguagem representada, enquanto que a imagem o faria a partir da "lógica do desejo". Como as imagens eletrônicas se confundem com objetos de representação dos desejos dos telespectadores/consumidores, as cadeias de significações necessárias ao pensamento e, portanto, à crítica se enfraquecem na medida em que a circulação e troca de imagens da comunicação televisiva aumenta sua velocidade (Kehl, 2004:.87-93). ${ }^{367}$

Perguntar sobre as razões da velocidade da informação comunicativa, da busca pelo furo jornalístico a qualquer custo e da necessidade de atualização constante das notícias desde a internet pode contribuir para se entender que, por trás desse discurso há uma lógica da produção de informação que atende à imprensa comercial, isto é, em última instância, a necessidade econômica pode sobrepor-se à qualidade da informação ${ }^{368}$ (Blotta \& Quirino, 2008).

Isso não isenta obviamente as responsabilidades de jornalistas, editores e donos das empresas de comunicação por eventuais abusos na liberdade de informar, os quais, apesar de ter legislação específica revogada junto com a lei de imprensa $(5.250 / 67)^{369}$,

sentido de "velocity" na discussão sobre a compressão de espaço e tempo na política a partir da simultaneidade da comunicação informativa, Speed and Politics: essays on Dromology (1977).

${ }^{367}$ V. também ensaio de Maria Rita Kehl no texto "Imaginário e Pensamento", que precedeu a discussão feita do livro Videologias. In. Souza (org.) Sujeito, o lado oculto do receptor, 1995, pp. 169-180. Neste caso, sua ênfase é sobre a recepção da comunicação televisão por crianças e adolescentes.

${ }^{368}$ Esses imperativos econômicos podem conflitar com os princípios de busca pela verdade do jornalismo, como atesta o Código de Ética dos Jornalistas Brasileiros (2007), publicado no endereço eletrônico da Federação Nacional dos Jornalistas (Fenaj): “Art 1․ O Código de Ética dos Jornalistas Brasileiros tem como base o direito fundamental do cidadão à informação, que abrange direito de informar, de ser informado e de ter acesso à informação. Art. $2^{\circ}$. Como o acesso à informação de relevante interesse público é um direito fundamental, os jornalistas não podem admitir que ele seja impedido por nenhum tipo de interesse, razão por que: I - a divulgação da informação precisa e correta é dever dos meios de comunicação e deve ser cumprida independentemente da linha política de seus proprietários e/ou diretores ou da natureza econômica de suas empresas; II - a produção e a divulgação da informação devem se pautar pela veracidade dos fatos e ter por finalidade o interesse público; III - a liberdade de imprensa, direito e pressuposto do exercício do jornalismo, implica compromisso com a responsabilidade social inerente à profissão; IV - a prestação de informações pelas organizações públicas e privadas, incluindo as não-governamentais, deve ser considerada uma obrigação social." (disponível em http://www.fenaj.org.br/federacao/cometica/codigo_de etica_dos_jornalistas_brasileiros.pdf. último acesso 24/11/2011).

${ }^{369}$ V. capítulo III da Lei de Imprensa "Dos abusos no exercício da liberdade de manifestação do pensamento e informação abusos da liberdade de informação". Uma análise sobre os impactos da revogação dessa lei sobre os direitos e deveres ligados à esfera pública política será realizada no tópico 2.2.3 deste trabalho. 
permanecem previstos na Constituição Federal nas obrigações de não-discriminação, de possibilidade de limitação da liberdade de crença e convicção quando estas são utilizadas para violar a Lei (art. 5o, VIII), bem como nos direitos de resposta (art. $5^{\circ}, \mathrm{V}$ ) e de exceção da verdade $\left(138, \S 3, \mathrm{CP}\right.$, pensada em analogia com arts. $5^{\circ}$, XIV, e 221, III, CF). ${ }^{370}$

Antes de finalizar este primeiro capítulo do diagnóstico, as implicações práticas e jurídicas sobre a expressão informativa da esfera pública política serão pensadas por meio de breves interpretações de algumas coberturas de casos relativamente recentes de violência na imprensa televisiva, cujo caráter imagético e espetacular influenciou de certo modo os próprios fatos.

O primeiro é a cobertura do emblemático ataque às Torres Gêmeas do World Trade Center em 11 de setembro de 2001 em Manhattan, que foi transmitida ao vivo para todo o mundo e por dias a fio pela rede $\mathrm{CNN}^{371}$. Apesar de não ter ocorrido no Brasil, a mobilização sem precedentes da imprensa mundial tornou possível uma comparação da cobertura do canal de notícias dos EUA com a do jornal Folha de S.Paulo no estudo "11 de setembro. Mídia, Política e Exceção" (Blotta, 2008).

A hipótese trabalhada foi de que a cobertura da imprensa dos EUA, repetitiva, caótica e dramática, pode ter contribuído para criar o "estado de emergência" que levou à legitimação internacional da campanha de "guerra contra o terror", e aos Patriot Acts e outras políticas internas de "tolerância zero" que sucederam os atentados nos EUA. Do lado do Brasil, as matérias do jornal Folha de S.Paulo seguiram de certo modo o modelo de espetacularização e apelo imagético utilizado na comunicação televisiva.

\footnotetext{
${ }^{370}$ Análises mais detida desses direitos, especialmente do direito de resposta, serão feitas mais à frente neste estudo (tópicos 2.2 .3 e 3.3). É importante notar desde já, no entanto, que esse direito assume caráter procedimental ao assegurar a indenização contra danos às dimensões material, moral e à imagem dos ofendidos, isto é, pode ser utilizado como recurso de argumentação jurídica nas três expressões da esfera pública política.

${ }^{371}$ Em entrevista ao Jornal Estado de São Paulo no dia 18/09/2011, é o mesmo Hobsbawm que responderá à seguinte pergunta: "Como o senhor avalia o poder das imagens de destruição nos ataques do 11/9 a Nova York, tão repetidas nos últimos dias? Tornaram-se o símbolo de uma guinada histórica, apontando novas relações entre Ocidente e Oriente? Por que imagens do cenário de morte de Bin Laden surtiram menos impacto?". Eric Hobsbawm: "A queda das torres do World Trade Center foi certamente a mais abrangente experiência de catástrofe que se tem na história, inclusive por ter sido acompanhada em cada aparelho de televisão, nos dois hemisférios do planeta. Nunca houve algo assim. E sendo imagens tão dramáticas, não surpreende que ainda causem forte impressão e tenham se convertido em ícones. // Agora, elas representam uma guinada histórica? Não tenho dúvida de que os Estados Unidos tratam o 11/9 dessa forma, como um turning point, mas não vejo as coisas desse modo. A não ser pelo fato de que o ataque deu ao governo norte-americano a ocasião perfeita para o país demonstrar sua supremacia militar ao mundo. E com sucesso bastante discutível, diga-se. // Já o retrato de Bin Laden morto (que não foi divulgado) talvez fosse uma imagem menos icônica para nós, mas poderia se converter num ícone para o mundo islâmico. Da maneira deles, porque não é costume nesse mundo dar tanta importância a imagens, diferentemente do que fazemos no Ocidente, com nossas camisetas estampando o rosto de Che Guevara." (grifos nossos).
} 
A construção simbólica da figura de Osama Bin Laden pelo jornal, que pode ser identificada nos cadernos especiais criados para retratar os atentados, é particularmente interessante, especialmente quando o auto-intitulado mentor dos atentados é comparado não só física (com imagens), mas ideologicamente com Antônio Conselheiro, líder religioso do povoado que foi vitimado no massacre de Canudos em 1897 na Bahia. ${ }^{372}$

Outro caso que vale a pena ser citado é da cobertura do seqüestro do ônibus 174 , que ocorreu em 12 de junho de 2000 no Rio de Janeiro, retratado por estudo de Rousiley Maia (2008:297-320). Os desdobramentos do crime também tiveram transmissão ao vivo, mas quando esta cessou (isto é, cessou sua entrada no espaço de visibilidade da mídia), momento da prisão do seqüestrador, foi posto fim em sua vida. Teria sido por acaso, ou a cobertura ao vivo conferiu certa segurança ao seqüestrador? Teria a polícia agido da mesma forma caso o fato não fosse transmitido ao vivo por todo o país? ? $^{373}$

Maia ressalta que, como no caso "Favela Naval", a esfera de visibilidade gerada especialmente pela imprensa televisiva, que transmitiu em "tempo real" quatro horas do seqüestro, tornou-se palco em que autoridades envolvidas (polícia e políticos) puderam exercer o princípio do accountability, tanto no sentido de se fazerem "responsivos" às demandas da população quanto para tornar públicas suas medidas em relação ao caso (Maia, 2008:298-300).

Em produção diferente da jornalística, o documentário “Ônibus 174” (2002) do diretor José Padilha procurou reconstruir o caso a partir de diversas opiniões dos envolvidos no fato. Essa capacidade de propor uma versão do ocorrido a partir da articulação das opiniões dos afetados se assemelha à pretensão de uma busca cooperativa pela verdade, e demonstra que não só a imprensa é capaz de produzir importantes contribuições para a expressão informativa da esfera pública política. Produções culturais e formatos que unem jornalismo e arte, como é o caso do "jornalismo em quadrinhos" dos premiados jornalistas/“quadrinhistas” Art Spiegelman e Joe Sacco, são exemplos de que a comunicação informativa é atividade interpretativa e pode atingir a

\footnotetext{
${ }^{372}$ A matéria referida, de 11/10/01, teve como título "Canudos e Cabul evocam luta do bem contra o mal" e o subtítulo "Semelhança entre Osama Bin Laden e Antônio Conselheiro vai além da fisionomia". Sobre o massacre de Canudos, v. o clássico Os Sertões, de Euclides da Cunha (Laemmert, 1902), que foi correspondente do jornal Estado de São Paulo durante o conflito.

${ }^{373}$ Esses questionamentos sobre o caso foram feitos por Esther Hamburger no vídeo "Direitos Humanos", da Associação Nacional de Direitos Humanos - Pesquisa e Pós-Graduação (ANDHEP). Disponível em www.andhep.org.br (ùltimo acesso: 25/11/2011).
} 
veracidade ao observar, mesmo na interpenetração dos discursos jornalístico e estético, os princípios da busca cooperativa pela verdade e a pluralidade de visões de mundo. ${ }^{374}$

Mas isso não é o que ocorre com o filme "Tropa de Elite" (2007), do mesmo diretor José Padilha. Nesse caso, apesar de ser uma obra de ficção, o ritmo acelerado e as cenas de ação e violência "realistas" podem também gerar um efeito de veracidade ao telespectador, embora muito mais problemático do que o discurso do documentário, em termos políticos e estéticos.

Se na prática o filme pode acabar legitimando a visão de mundo de que a violência é uma forma aceitável de resolução de conflitos, o problema estético ocorre porque ao propor apresentar "a visão da polícia" sobre o problema, numa tentativa de utilizar o recurso do perspectivismo consagrado em obras literárias como Dom Casmurro, de Machado de Assis (1900) e The Catcher in the Rye ("O Apanhador no Campo de Centeios") de J. D. Salinger (1945), o enredo do filme acaba trazendo um narrador onisciente que é o personagem principal da história, o "Capitão Nascimento". Em função desse problema lingüístico, sua narração acaba adquirindo status de verdade por se tornar mais dificilmente questionável. ${ }^{375}$

Outro caso interessante foram as coberturas da imprensa em relação ao assassinato da menina Eloá pelo ex-namorado no dia 15 de outubro de 2008. No caso, a apresentadora Sônia Abrão, do programa da Rede TV! A Tarde é Sua, chegou a falar com o seqüestrador durante o processo de negociações com a polícia, o que leva à pergunta sobre em que medida essa atitude da imprensa interferiu sobre o desfecho trágico do fato. ${ }^{376}$

\footnotetext{
${ }^{374}$ V. as obras: Spiegelman, Maus (II Vols, 1986 e 1991) Sacco, Notas sobre Gaza (2011).

${ }^{375}$ Essa questão estética do filme é analisada por Silas Nogueira no texto Comunicação, Cultura e Violência. Espetáculo, fascismo, tortura e o filme 'Tropa de Elite', publicado na obra coletiva Mídia, Cultura $e$ Violência, Oliveira (org, 2009): “Os recursos da linguagem cinematográfica utilizados no filme, até mais do que o tema central ou o enredo, é revelador de alguns propósitos da obra e lança dúvidas sobre outros anunciados pelo diretor [o autor cita em nota que o diretor teria negado qualquer apologia da tortura e nem seria fascista, mas que pretendia mostrar e discutir a "realidade brasileira". V. B]. Inicialmente podem lembrar, ou serem confundidos com rudimentos do Cinema Novo e sua diretriz 'uma ideia na cabeça e uma câmara na mão'. Mas a lembrança desaparece rapidamente quando salta aos olhos a semelhança com outra fonte, a dos jornais televisivos sensacionalistas, policialescos e que integram o que ficou conhecido como 'mundo cão'. (...) Na sua totalidade, o filme se vale, de modo geral, de um outro fenômeno televisivo recente, o reality show, no qual se efetua a simulação máxima de uma realidade cotidiana, supostamente 'mostrada' de modo fiel, 'tal como ela é'.” (Nogueira, 2009:50).

${ }^{376}$ V. análise do papel da mídia neste caso feita por Venício A. de Lima em Liberdade de Expressão $x$ Liberdade de Impresa, 2010:121-124. Texto originalmente publicado no Observatório da Imprensa, n. 515 de 09/12/2008.
} 
Artigo do psicanalista Renato Mezan publicado pouco tempo depois do caso fez uma espécie de análise da personalidade do autor do crime e concluiu que a cobertura espetacular e ao vivo do seqüestro teria estimulado nele sentimentos de onipotência, além de ter fornecido informações importantes sobre a posição da polícia. ${ }^{377}$

Em dezembro do mesmo ano, a emissora Rede TV seria alvo de ação civil pública pelo Ministério Público Federal por danos morais coletivos no valor de 1,5 milhões de reais, com fundamento na espetacularização midiática do caso pela emissora, que teria se aproveitado do estado de perigo e fragilidade dos adolescentes para ganhar audiência e interferido no processo de negociação. ${ }^{378}$

Como é possível identificar a partir desses breves relatos e comentários, as coberturas ao vivo desses casos e diversos outros transmitidos por imagens repetidas exaustivamente e apresentadas de modo dramático, acabam por redimensionar a própria natureza dos acontecimentos. As formas com as quais os fatos são veiculados podem não só violar diretamente direitos de personalidade, mas também outros dispositivos legais, como a proteção a crianças e adolescentes contra a exposição em veículos de comunicação (art. 17 e 240, Estatuto da Criança e do Adolescente - ECA), o respeito aos mortos e a privacidade de suas famílias ( $\$ 1^{\circ}$. art. 220, CF/88, art. 20, Código Civil, 2002) etc. Além disso, essas coberturas podem acabar influenciando até mesmo políticas de restrição de direitos de informação e comunicação, que são os primeiros a serem suprimidos em momentos de exceção política. ${ }^{379}$

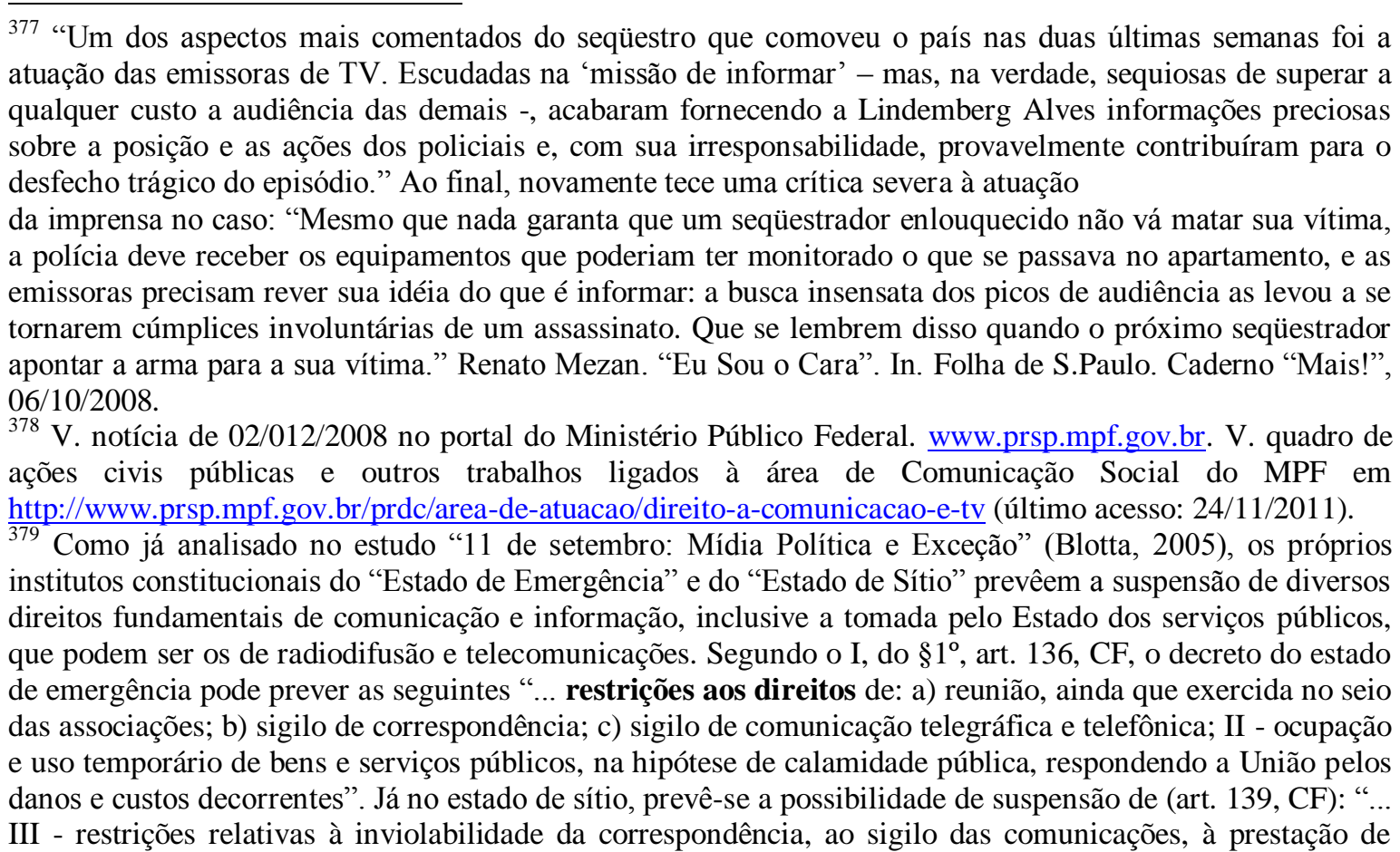


No outro espectro da comunicação informativa, a pretensão de verdade do discurso científico, cuja interpretação radical é de que dados e estatísticas seriam representação aparentemente imediata da realidade (ou de que as seriam "neutros", e não eles mesmos já uma forma de interpretação da realidade), também pode levar a problemas práticos, como uma padronização de expectativas de comportamento com base nessas informações. Essa padronização pode dificultar o desenvolvimento de interações sociais com base na consideração da singularidade da pessoa, isto é, sem que se "objetifiquem" indivíduos a partir de seu papel social ou provável perfil pessoal com base em generalizações estatísticas ou outros dados empíricos.

Para que o debate público possa problematizar essa questão da interpenetração irrefletida do discurso científico e de elementos estéticos na comunicação informativa, quando se trata da pretensão à busca cooperativa pela verdade e pelo respeito à pluralidade de visões de mundo, o direito à exceção da verdade precisa ser pensado não somente em termos de crimes contra a honra e dano moral, mas também para reforçar o debate em torno da comunicação informativa da imprensa e outros discursos de verdade, viabilizando eficazmente o direito de resposta em relação a questões de fato, comprovação, negação e resposta imediata nos mesmos meios e nas mesmas condições.

Ao mesmo tempo, como será desenvolvido nas reflexões finais deste estudo (v. tópico 9.2), torna-se necessário não somente pensar num direito de resposta coletivo, como já propõem Fábio Konder Comparato (2000) e Sérgio Suiama (2002), mas também na exigência que ele seja garantido na forma de tutela antecipada (art. 273, CPC), posto que nesses casos muito provavelmente estarão presentes os requisitos do fumus boni iuris e do periculum in mora.

Essa necessidade pode ser demonstrada de modo negativo por recente cumprimento de decisão judicial que garantiu, somente treze anos depois do fato, que uma pessoa pudesse publicar no mesmo lugar e espaço da Folha de S.Paulo uma nota dizendo que o jornal teria veiculado informações caluniosas em relação a ele, o que lhe ocasionara diversos danos morais e materiais. ${ }^{380}$

informações e à liberdade de imprensa, radiodifusão e televisão, na forma da lei; IV - suspensão da liberdade de reunião; V - busca e apreensão em domicílio; VI - intervenção nas empresas de serviços públicos" (grifo nosso).

${ }^{380}$ V. Retratação obrigatória publicada na edição de 20/10/2011 do caderno "Esporte" do Jornal. 
Ao final deste diagnóstico das expressões informativas da esfera pública política no Brasil, esse caso e os acima retratados revelam como a velocidade da comunicação informativa nos meios de comunicação social e sua capacidade de lesar indelevelmente a imagem e a honra de grupos, indivíduos e coletividades indeterminadas, precisam ser compensadas com recursos jurídicos também velozes. Sejam eles normas que facilitem a problematização discursiva das pretensões de verdade presentes na esfera pública política, ou recursos processuais como liminares e antecipações de tutela ao direito de resposta e à exceção da verdade. Sem essas condições institucionais, as pretensões à busca cooperativa pela verdade e a pluralidade de visões de mundo continuarão a se revelar na esfera pública política somente como vestígios por trás de suas próprias violações.

\section{Expressões prático-morais da esfera pública política no Brasil}

Após tentar reconstruir as pretensões normativas de disposição técnico-científica da natureza e de verdade presentes nos discursos da economia, da ciência e da comunicação informativa da imprensa, este diagnóstico segue para sua segunda parte com o objetivo de analisar algumas pretensões de justiça e correção presentes nos debates públicos nacionais nas áreas da comunicação social e da comunicação política.

Desse modo, procura-se aqui diagnosticar entrecruzamentos e conflitos de iniciativas de exercício de liberdades de comunicação ligadas às esferas da ética, da moral e da política no Brasil e seus respectivos deveres de comunicação e de reconhecimento sem os quais essas liberdades se tornam, cada uma à sua maneira, exercícios arbitrários de suas próprias razões. Além disso, como já previsto, serão discutidas intersecções dessas pretensões prático-morais com expressões técnico-científicas, informativas e estéticoexpressivas da esfera pública política nacional.

Ao pensar questões éticas, morais e políticas na perspectiva da filosofia de Habermas (1989; 1996), designam-se, respectivamente, problemas de autocompreensão, valores e práticas concretas relativas a compreensões compartilhadas de vida boa; temas ligados a decisões sobre a melhor atitude a se tomar diante de todos possivelmente afetados em condições de liberdades iguais; e problematizações sobre a institucionalização e a administração pelo Estado de algumas das pretensões prático-morais de comunicação e de reconhecimento. 
Além de permitir uma análise mais explícita das relações atuais entre a esfera da privacidade e a esfera pública no país, este diagnóstico também revelará com mais clareza uma das características mais importantes do direito da comunicação: que ele não é só uma peça de união entre a comunicação social e a comunicação política, mas vem demonstrar, como faz Habermas com a autonomia individual e a autonomia política, que os princípios normativos de ambas as áreas se pressupõem reciprocamente, isto é, uns só podem ser plenamente garantidos enquanto outros também o forem. ${ }^{381}$

\subsection{Liberdade de expressão e regulação da comunicação: reflexos das relações entre autonomia individual e autonomia política na esfera pública política}

A filosofia política e a teoria do direito de Habermas são especialmente dedicadas a fundamentar e justificar as teses da contradição aparente e da co-originariedade entre os princípios constitutivos do Estado democrático de direito, desenvolvidos na teoria política moderna a partir das obras de Kant e Rousseau: a autonomia individual e a autonomia política. $^{382}$

Como se verá de modo mais detido no capítulo 8 desta tese, pode-se dizer a partir das leituras de Habermas em Mudança Estrutural da Esfera Pública (MEEP) e Direito e Democracia $(D D)$ que, para Kant, a autonomia individual seria composta por todos aqueles princípios de liberdade e proteção da integridade e da dignidade do indivíduo, que se desdobraram no que atualmente se entende como direitos humanos. Já a autonomia política para Rousseau significa a soberania popular de uma comunidade de valores compartilhados, que legitima em práticas de democracia direta o exercício do poder político.

Segundo Habermas, o grande problema de ambas as tradições da filosofia prática iluminista - que se reabilitará na política após as críticas de Hegel e Marx somente a partir da segunda metade do século XX com autores como Arendt (1998) e Rawls (1995) derivaria de interpretações por demais subjetivistas ou objetivistas das relações entre autonomia individual e autonomia política. Embora diagnostiquem suas tensões e

\footnotetext{
${ }^{381}$ Vale relembrar a proposição que inicia esta tese, da qual deriva este argumento: não há direito legítimo e democrático sem comunicações livres, mas também não há comunicações livres sem um direito legítimo e democrático. Outros desdobramentos dessas reflexões para a teoria do direito da comunicação serão desenvolvidos na terceira parte desde estudo (esp. capítulos 9 e 10).

${ }^{382}$ Essas teses são desenvolvidas em outras obras de Habermas sobre o tema além de $M E E P$ e $D D$, como $A$ Inclusão do Outro (2001:13-126), Era das Transições (2003:151-174) e mais recentemente Entre Naturalismo e Religião (2007) e Ay, Europa (2009), além de ensaios importantes como e "Popular Sovereignty as Procedure" (1988. In. Id. 1996:463-490) e "Further Reflections on the Public Sphere" (1992).
} 
procurem de certo modo estabilizá-las, essas teorias ainda acabariam por identificar os princípios da liberdade individual e da soberania do povo como contraditórios, privilegiando com isso um sobre o outro (Habermas, 2003:68-70; Id, 1996:84-104). ${ }^{383}$

Os efeitos desse debate na filosofia política se manifestam em diversas dicotomias históricas presentes em esferas públicas políticas nacionais e transnacionais, como entre liberalismo e socialismo (Hobsbawm, 1994), os pólos ideológicos "direita" e "esquerda" (Bobbio, 1995), propriedade e liberdade e segurança contra interesse público, igualdade e solidariedade (Mesquita Neto, 2011), direitos civis e políticos versus direitos sociais e culturais (Pinheiro, 1996), bem como as teses que opõem liberdade de expressão $e$ regulação da comunicação, este grande debate que ocorre no âmbito da comunicação social e será trabalhado neste tópico como expressão concreta da esfera pública política prático-moral no Brasil.

A leitura intersubjetiva que Habermas propõe para tentar solucionar o problema, e que se buscará utilizar neste tópico, parte da tese de que não é possível fundamentar a validade e a universalidade das liberdades individuais de modo outro que num acordo democrático entre todos os real e virtualmente afetados, no que diz respeito à natureza, à extensão e às formas de garantia dessas liberdades (Habermas, 1996:102-104).

Em outras palavras, revisando as ambivalências de figuras como a "máxima medida possível de liberdades iguais" de Kant (Habermas, op. cit:93) ou a volonté général de Rousseau como um "consenso dos corações" (v. cap. 2 "c" desta tese), Habermas pretende mostrar que a partir da teoria do discurso não haveria outra saída senão pensar a autonomia individual e a autonomia política como princípios co-originários e procedimentais, isto é, de modo que se perceba como a validade (certeza legal) dos direitos positivos da autonomia individual depende da legitimidade (aceitabilidade racional) que lhe é atribuída a partir de uma constante formação democrática da opinião e da vontade políticas de todos os possivelmente concernidos. Essa formação também depende, por sua vez, do reconhecimento de liberdades e competências comunicativas entre todos.

Nos breves subtópicos que se seguem, essa co-originariedade e complementaridade entre autonomia individual e autonomia política serão abordadas a partir das relações presentes entre as liberdades de comunicação e o caráter público das suas formas de regulação no Brasil. Esse é o modo como devem ser tratadas as tensões entre essas liberdades. Caso contrário, corre-se o risco de perder tanto elas próprias quanto a exigência

383 v. caps. 2, "a" 4 "d" desta tese. 
de uma regulação pública do setor, conforme entende Fábio Konder Comparato no prefácio da obra Liberdade de expressão x Liberdade de imprensa de Venício A. de Lima (in. Lima, 2011:9-11), cujas contribuições para a discussão do tema serão importantes referências abaixo.

a) liberdade de expressão, liberdade de imprensa e liberdade de comunicação comercial: imprecisões conceituais, excessos da auto-regulamentação e a circulação constitucionalmente regulada da comunicação

A pretensão normativa a um livre fluxo de informações e comunicações na esfera pública, herdada da tese do "livre mercado de idéias", atribuída a John Milton ${ }^{384}$ e desenvolvida por John S. Mill ${ }^{385}$, quando entendida no sentido de ausência de regulamentação, é tão irrealista e normativamente indesejável quanto a ideia smithiana de auto-regulação e auto-correção naturais do mercado. ${ }^{386}$

Sem precisar explicar essa tese com casos recentes da economia internacional, como a crise do mercado imobiliário eclodida nos EUA no final de 2008, o próprio direito privado e seus institutos como o contrato são regulações das relações mercantis sem as quais não é possível o mercado. ${ }^{387}$ Da mesma forma, sem regulação da comunicação social e política, não haveria a possibilidade de se garantir juridicamente as liberdades de comunicação.

\footnotetext{
384 Milton foi escritor inglês, autor do discurso Areopagitica (1644), que propugnava a liberdade de impressão de escritos sem licença governamental. Sobre esta obra e o contexto histórico de Milton, V. Lima, 2010:22-23.

${ }^{385}$ Mesmo adepto da "livre discussão" contra as formas de imposição de verdades pela supressão de opiniões contrárias, Mill não dispensava a necessidade de normas jurídicas que garantissem essa liberdade de discussão a todos: "The liberty of expressing and publishing opinions may seem to fall under a different principle, since it belongs to that part of the conduct of an individual which concerns other people; (...) The only freedom which deserves the name, is that of pursuing our own good in our own way, so long as we do not attempt to deprive others of theirs." Mill, On Liberty, [1859] 2009:40 e 42.

${ }^{386}$ Para uma crítica da teoria naturalista do mercado livre de Adam Smith, que procura pensá-lo como uma esfera de sociabilidade isenta de normatividade, e que cria sua própria legitimação, bem como às conseqüentes teorias da escolha racional, que reduzem às faculdades de sociabilidade humana a adaptações de interesses egoísticos dos indivíduos, v. Avritzer, A moralidade da democracia, 1996:77-98.

${ }^{387}$ Diferentemente do que se possa entender a partir de Marx e de filósofos/economistas adeptos da teoria da escolha racional, com John Elster, o direito civil não é institucionalização automática das relações "naturais" de igualdade entre sujeitos que se encontram no mercado: “(...) não é possível reduzir a modernidade e a racionalidade ao surgimento do indivíduo egoísta capaz de utilizar uma faculdade cognitivo-instrumental para determinar quais são os seus interesses. Tal operação acaba nos obrigando a atribuir ao mercado aquilo que não é capaz de fazer, isto é, estabelecer as bases da relação consensual dos atores sociais em relação às regras da atividade econômica. Estas provêem da estrutura do direito civil, ou seja, de normas abstratas aceitas pelo conjunto dos atores econômicos e capazes de fornecer à atividade econômica sua natureza consensual.” (Avritzer, 1996:92 e 97). Cf. Kashiura, Crítica da Igualdade Jurídica, 2009.
} 
Antes de analisar o estado atual do tema no Brasil por meio de interpretações de casos e debates sobre conflitos entre liberdade de expressão e regulações da comunicação, cabem alguns esclarecimentos conceituais sobre os termos correntemente utilizados neste debate. As confusões e discussões terminológicas são elas mesmas consideradas fatores que dificultam a formação de consensos na área (Lima, 2010:21)

A liberdade de expressão, quando definida de modo amplo, abrange tanto o direito de manifestação e comunicação de opiniões individuais e coletivas quanto o acesso à informação de qualidade. Isso porque violar a liberdade expressão de um é negar aos outros o acesso a essa expressão, e a recíproca também é verdadeira (Mendel \& Salomon, $2011: 11){ }^{388}$

Além da Declaração Universal, que estatui o direito em seu conhecido artigo $19^{389}$, reconhecem-no de modo amplo também a Convenção Européia de Direitos Humanos (art. 10, 1950), a Convenção Inter-Americana (art. 13, 1969) e a Carta Africana de Direitos Humanos e dos Povos (art. 9, 1981). É inclusive reconhecida a importância da imprensa e dos meios de comunicação de massa na realização do direito à liberdade de expressão e dos direitos referentes debate democrático. ${ }^{390}$

É a partir dessa perspectiva que estudos recentes de consultores da UNESCO voltados para diagnósticos da regulação do setor no Brasil entendem a liberdade de expressão como princípio fundamental e razão de ser da própria regulação da comunicação social e política (Id. op. cit:9). ${ }^{391}$

\footnotetext{
${ }^{388}$ Aqui citam decisão da Corte Inter-Americana de Direitos Humanos no caso Compulsory Membership in an Association Prescribed by Law for the Practice of Journalism (nota 10, pp. 30-32).

${ }^{389}$ Declara o art. 19: "Toda pessoa tem direito à liberdade de opinião e expressão; este direito inclui a liberdade de, sem interferência, ter opiniões e de procurar, receber e transmitir informações e idéias por quaisquer meios e independentemente de fronteiras." (Declaração Universal dos Direitos Humanos. Resolução 217A (III), de 10/12/1948 da Assembléia General da ONU). In. Bittar \& Almeida (orgs), Minicódigo de Direitos Humanos, 2010:296.

${ }^{390} \mathrm{O}$ estudo da UNESCO cita para tanto o Compulsory Membership in an Association Prescribed by Law for the Practice of Journalism, nota 10, parágrafo 34, bem como a Comissão Africana sobre direitos humanos, que entendeu: "o principal papel da mídia e de outros meios de comunicação é assegurar o completo respeito à liberdade de expressão, promovendo o livre fluxo de informações e ideias, ajudando a população a tomar decisões baseadas em informações estruturadas, facilitando e fortalecendo a democracia" Declaration of Principles on Freedom of Expression in Africa, adotado pela Comissão Africana sobre Direitos Humanos e das Pessoas em sua 32 ${ }^{\mathrm{a}}$ Sessão, 17-23 de outubro de 2002. (Mendel \& Salomon. Liberdade de Expressão e Regulação da Radiodifusão, UNESCO, 2011. pp. 11). V. também a "Declaração sobre os princípios fundamentais relativos á contribuição dos meios de comunicação de massas para o fortalecimento da Paz e da cooperação internacional, para a promoção dos Direitos Humanos contra o racismo, o apartheid e o incitamento à guerra", proclamada pela UNESCO em 28/11/1978. In. Bittar \& Almeida (orgs) op. cit:773776.

391 A opinião do estudo referido segue, portanto, a defendida nesta tese: "Respecting freedom of broadcasting, although a key aspect of the guarantee of freedom of expression, does not imply that the broadcast media should be left unregulated. A wholly unregulated broadcast sector would be detrimental to free expression, since the audiovisual spectrum used for broadcasting is a limited resource and the available
} 
O mesmo estudo destaca, no entanto, que a liberdade de imprensa e a liberdade de comunicação comercial (como liberdade que tem uma empresa de veicular propagandas de seus produtos) são reconhecidas nessas normas internacionais como inerentes à liberdade de expressão, sem distinções normativas substanciais (Mendel \& Salomon, 2011:11).

Em relação à imprensa, uma das distinções ressaltadas pelo estudo é de que, a princípio, o sigilo de fonte no exercício profissional seria somente destinado àqueles que trabalham no setor, mas recomendação do Conselho da Europa sobre o tema estende a proteção a todos aqueles que realizam disseminação e circulação de informações por meios de comunicação, jornalistas ou não. ${ }^{392}$

Quanto à liberdade de expressão comercial, esta estaria também protegida pela liberdade de expressão, com decidiu o Comitê Europeu de Direitos Humanos em caso que questionava a proibição de propagandas em inglês na província de Quebec, no Canadá. Mesmo assim, diversas decisões reconhecem que essa liberdade seria mais limitada do que a liberdade de expressão referente a "assuntos de interesse público", justificando regulações mais incisivas de Estados sobre a liberdade de comunicação comercial. ${ }^{393}$

Apesar dessas distinções e outros documentos que separam liberdade de expressão como sendo liberdade de opinião da pessoa (indivíduo) e liberdade de imprensa como a liberdade de informação dos órgãos de comunicação de notícias ${ }^{394}$, Venício A. de Lima destaca que o direito à liberdade de expressão individual tem sido pretendido nos discursos de entidades de imprensa, agências de propaganda e mesmo empresas fora do ramo da comunicação social que atuam na esfera pública, quando deveriam reivindicar ao invés disso liberdade de imprensa ou de comunicação comercial.

Isso porque, apesar de a comunicação informativa da imprensa e a comunicação comercial formarem espaços públicos imprescindíveis para reprodução material e simbólica da sociedade, como ficou retratado no diagnóstico anterior (cap. 5), as liberdades comunicativas que permitem sua entrada na esfera pública não são as mesmas - e não podem receber a mesma proteção - daquelas de indivíduos e grupos que desejam expressar

bands must be distributed in a rational and fair manner to avoid interference and ensure equitable access." (Mendel \& Salomon, Liberdade de Expressão e Regulação da Radiodifusão, UNESCO, 2011:14).

${ }^{392} \mathrm{O}$ estudo indica a Recomendação n. R(2000)7, de 08/03/2000 do Conselho Europeu sobre o direito de jornalistas não exporem suas fontes de informação (Mendel \& Salomon, 2001:12).

${ }^{393}$ São indicados por Mendel \& Salomon (2011:11) os casos "Hertel v. Switzerland", de 25/08/98, Aplicação n. 25181/94. Indicam também o caso "Irwin Toy Ltd. v. Quebec" (Procuradoria Geral), [1989] 1 SCR 927 (Suprema Corte do Canadá).

${ }^{394}$ Lima destaca como o a $1^{\text {a }}$ Emenda da Constituição dos EUA separa freedom of expression e freedom of the press, bem como a Constituição Federal fala distintamente em liberdade de manifestação do pensamento (art. $5^{\circ}$, IV), que é um direito fundamental do indivíduo, e em liberdade de informação jornalística e vedação de qualquer forma de censura, presente no capítulo sobre comunicação social $\left(\operatorname{art.} 220, \S 1^{\circ}\right.$ ). 
suas opiniões sobre a realidade, sobre problemas práticos comuns, ou mesmo expressar questões pessoais ou artísticas.

A confusão entre esses direitos é sintomática dos fenômenos de publicização do privado e privatização do público já destacados por Habermas no diagnóstico de MEEP (v. cap. 2 "b" desta tese): a entrada de organizações e corporações privadas nos espaços públicos, assumindo funções importantes de coordenação social, como a distribuição da comunicação informativa e a prestação de outros serviços públicos, que passam a ser administrados pela lógica de mercado.

Curioso é que essas organizações justificam sua não submissão às exigências de publicidade e accountability da esfera pública pelo fato de serem entidades privadas, ao mesmo tempo em que, por exercerem atividades econômicas ou de informação importantes à sociedade, arrogam-se direitos fundamentais como o direito humano à opinião e manifestação do pensamento. Nos EUA, estudos jurídicos críticos e de ativismo político denominam esse fenômeno de incorporação de direitos individuais por empresas como corporate civil rights (direitos civis corporativos). ${ }^{395}$

É por isso que se torna necessário também esclarecer o que se entende por autoregulamentação com base no estudo da UNESCO, comparando seus resultados com o que entidades do setor no Brasil como o Conar e o recém fundado "Instituto Palavra Aberta" pretendem quando falam em auto-regulamentação.

Para os consultores da UNESCO Mendel e Salomon, a auto-regulamentação não significa a abstenção do cumprimento de normas públicas, e deve ser necessariamente administrado por órgão que tenha condições para que seus membros não sejam influenciados por pressões econômicas ou partidárias, isto é, que tenham seu trabalhão adequadamente financiado e sejam efetivamente independentes, protegendo-se contra pressões políticas por atuar também de modo responsivo perante o público, com compartilhamento de informações e contribuições. ${ }^{396}$

\footnotetext{
395 V. publicação sobre o tema de Miller, J. B. Corporate Civil Rights Impede Progress of Activists; Environmental and Social Justice Activists Catch on. In. Natural Learning. Volume 1, outono - 2004. Olympia - WA - EUA (Olympia Community Free School). Disponível em: http://www.dsame.com/radicalcaring/naturallearning.html (último acesso: 20/11/2011). Sobre esse papel ocupado por corporações e seus discursos, v. interessante documentário "The Corporation" (2003), dirigido por Mark Achbar e Jennifer Abbott, inspirado no livro de Joel Bakan, The Corporation: the Pathological Pursuit of Profit and Power (Free Press, 2004).

396 "Furthermore, regulation is needed to ensure plurality and diversity (...). However, due to the universally observed tendency of governments and businesses to want to minimize access of their critics and competitors to the broadcast media, it is vital that all bodies with regulatory powers in this area are protected, legally and practically, against political, commercial and other forms of interference." (Mendel \& Salomon, 2011:14).
} 
No caso do Instituto Palavra Aberta, fundado em 2010, trata-se de uma organização sem fins lucrativos que alega não ter interferências de grupos econômicos ou políticos. ${ }^{397}$ Pretende "promover e defender a liberdade comercial, de expressão e de imprensa", mas apesar de reivindicar expressamente todos esses direitos, tem foco na "informação publicitária", visto que ela garantiria o princípio da concorrência e portanto o bom funcionamento do mercado. ${ }^{398}$

Já o Conar (Conselho de auto-regulamentação publicitária), fundado 1980, é também uma associação privada sem fins lucrativos, composta em sua totalidade de proprietários de grupos de comunicação. Somente em seu conselho de ética é prevista a presença de 24 representantes da sociedade civil escolhidos pelo conselho superior da associação, enquanto que os outros 72 membros são escolhidos pelos membros fundadores e o presidente. O conselho de ética é responsável pela avaliação e julgamento das propagandas denunciadas, em sua grande maioria pelo consumidor ${ }^{399}$, por serem supostamente contra o Código Brasileiro de Auto-regulamentação Publicitária, elaborado pelo conselho superior do órgão em 1980.

Há também duas previsões de participação de representantes de consumidores no conselho de ética, por meio de entidades privadas nacionais e sem fins lucrativos, mas esta participação não é estipulada numericamente. ${ }^{400}$

\footnotetext{
${ }^{397}$ Em página eletrônica do Instituto Palavra Aberta, com os valores que defende, como a liberdade de expressão e a livre iniciativa, declara-se que a ONG “... NÃO É: Instituição setorial que serve aos interesses de um ou mais grupos. Organização política ou filiada a partidos políticos. Entidade que faz lobby ou atua para o interesse de grupos comerciais específicos." www.palavraaberta.org.br/sobre (último acesso: $30 / 11 / 2011)$.

${ }^{398}$ Informações matéria intitulada "Regulação indigesta", publicada na Doce Revista. Fev. 2011, p. 50. www.docerevista.com.br. A Presidente-Executiva do Instituto propõe em entrevista na mesma matéria que estudo encomendado por eles para analisar a "importância da informação publicitária e o impacto econômico das imposições e cerceamento da divulgação de produtos e serviços em determinados setores", recomenda aos reguladores da comunicação comercial para atenderem "...pressupostos básicos, tais como respeito ao funcionamento do mercado, neutralidade, publicidade positiva e voluntariedade." V. Guedes \& Ribeiro, 2011, citado abaixo.

${ }^{399}$ É possível verificar que, comparando dados de 1998 com 2010 o número de processos instaurados por queixas do consumidor aproximadamente quadriplicaram (44 e 163), enquanto que provenientes de autoridade (como o próprio Conar) duplicaram (6 e 12). Este dado confere o próprio Conar em seu endereço eletrônico www.conar.org.br, no tópico "Conar em números". Último acesso: 02/12/2011).

${ }^{400} \mathrm{O}$ art. 64 do Estatuto Social do Conar, um dos últimos do documento garante essa presença, que não é determinada em números. "Artigo 64. O Conselho de Ética do Conar contará sempre com a representação de consumidores, através de entidades de direito privado de âmbito nacional e de intuitos não-econômicos.". A única outra disposição sobre o tema é o art. 49 do Estatuto, que é no entanto também uma norma indeterminada:"Artigo 49. O Conselho de Ética atuará mediante representação de membro do Conselho Superior, do Vice-Presidente Executivo do Conar, de associado ou grupo de consumidores." Disponível em www.conar.org.br (último acesso 02/12/2011).
} 
Apesar do esforço do órgão para exercer algum tipo de controle interno do setor, esse desequilíbrio entre públicos afetados pela comunicação comercial na própria composição dos membros e dirigentes da associação faz com que, das decisões dos aproximadamente de 300 casos analisados por ano de 1998 a 2010, só três vezes o número de anúncios "sustados" tenha passado de $50 \%$ dos analisados ${ }^{401}$, sendo que duas delas nos dois últimos anos (em 2009, 343 casos com 268 sustados e em 2010, 376 com 221). Não seria de se estranhar, todavia, pois eventuais restrições a essa liberdade possivelmente recairiam sobre veículos e agências que são de propriedade de membros do próprio conselho.

Qual não é a surpresa ao se notar que o Conar é composto e gerido pelas mesmas entidades de mídia do Instituto Palavra Aberta: ABAP, ABERT, ANER, ANJ. ${ }^{402}$ Ou seja, o Conar é o Instituto Palavra Aberta, o que levanta sérias dúvidas a independência e a lisura tanto desse órgão de auto-regulamentação de propaganda comercial quando dessa organização não governamental sem fins lucrativos, que apresenta uma pauta pública equiparando liberdade de opinião e de imprensa com comunicação comercial e propõe que a regulamentação prejudica economicamente a atividade.

Claramente não é esse tipo de auto-regulamentação que Habermas tem em mente quando propõe a comunidade de parceiros do direito como aquela capaz de se autoorganizar e produzir leis para si mesma, pois neste caso a lei só adquire legitimidade como tal a partir do momento que todos os possivelmente afetados por ela - e não somente aqueles que fazem a lei - possam ter condições iguais de compreender seu objetivo e efeitos, e a partir dessa compreensão, aceitá-la ou não. ${ }^{403}$

O único órgão da República que até hoje efetivamente garantiu com suas ações civis públicas e outros procedimentos algumas das normas constitucionais relativas à comunicação social foi Ministério Público Federal. ${ }^{404}$ Ao tentar suprir a falta de regulamentação das normas do setor, o órgão acaba por promover o que se pode denominar

\footnotetext{
${ }^{401}$ Dados disponíveis em www.conar.org.br (opção "Conar em números”. último acesso: 01/12/2011).

402 Comparar dados do endereço eletrônico www.palavraaberta.org.br e a pesquisa

${ }^{403}$ V. Habermas (1997-II:119-121). Mendel \& Salomon fazem interessante transcrição de decisão da Corte Européia de Direitos Humanos em caso sobre esse caráter importante da publicidade, que obriga a lei a efetivamente "fazer-se conhecer" para poder ser legitimada. Citam sobre o requisito "prescrito por lei" decisão da Corte, pela qual: "[A] norm cannot be regarded as a "law" unless it is formulated with sufficient precision to enable the citizen to regulate his conduct: he must be able - if need be with appropriate advice to foresee, to a degree that is reasonable in the circumstances, the consequences which a given action may entail." (Corte Européia de Direitos Humanos. In. The Sunday Times, nota 15, p. 49.. apud. Mendel \& Salomon, 2011:13). V. tópico. 7.4 deste trabalho.

${ }^{404}$ Outro texto dos consultores da UNESCO destaca este controle social exercido pelo MPF na análise do panorama brasileiro de regulação da mídia. A atuação do órgão é retratada também por Venício A. de Lima no texto "A liberdade de comunicação social não é absoluta” (in. Lima, 2011:121-124).
} 
- a partir do modelo de circulação do poder político de Habermas em DD (1997:73-91) - a pretensão a uma circulação constitucionalmente regulada da comunicação social $e$ política.

Não há dúvida que essa pretensão seria estimulada com a aprovação de alguns dos inúmeros projetos ${ }^{405}$ de lei que tramitam atualmente no Congresso para regulamentar normas de comunicação social, mas até o momento poucas iniciativas têm tido sucesso quando advindas do legislativo. O caso da nova lei de TV paga (PL 116), que estabelece pela primeira vez percentuais da programação destinados a produções nacionais e regionais após mais de vinte anos com essa previsão no inciso III do art. 221, CF, é uma exceção, e especialmente porque toca na questão do conteúdo, que será tratada abaixo.

b) razões de fato e de direito da regulação democrática de conteúdos: o PNDH-3, discursos de ódio e um elogio aos fundamentos do "politicamente correto"

Para iniciar a discussão sobre a existência e a importância de uma regulação democrática de conteúdos na comunicação pública, será analisada uma tentativa advinda do Executivo para promover uma circulação constitucionalmente regulada da comunicação, objeto de grande polêmica na esfera pública política no início de 2010: as disposições sobre regulação da comunicação do III Plano Nacional de Direitos Humanos, conhecido como "PNDH-3".

De seu eixo orientador V, "Educação e Cultura de Direitos Humanos", a diretriz número 12 traz uma pretensão normativa muito próxima daquilo que se denominará na parte teórica desta tese o "duplo-movimento institucional do direito da comunicação" (v. cap. 9), pois reclama tanto condições para uma formação mais democrática da opinião e da vontade, garantindo maior acesso à esfera pública política, quanto mais transparência e publicidade das informações relativas ao público, especialmente de entidades públicas e privadas que influenciam a opinião pública, como a imprensa e outras empresas que trabalham com gestão de informação e comunicação. ${ }^{406}$

\footnotetext{
${ }^{405}$ Para análise de projetos de regulação da comunicação como o da deputada Jandira Feghali, que desde 1991 tramita no Congresso Nacional e até 2007 não havia sido concluído, além de lista de 16 projetos de lei que buscaram regulamentar os princípios de comunicação social da Constituição Federal de 88 entre 1999 e 2007, mas foram rejeitados pelo Congresso Nacional, v. Moraes, A Tensão entre liberdade de expressão e direito à informação, 2007:269-271.

406 O PNDH-3 propôs pretensões normativas diretamente relacionadas com as propostas do direito da comunicação (v. capítulo 9 desta tese): "Diretriz 22: Garantia do direito à comunicação democrática e ao acesso à informação para a consolidação de uma cultura em Direitos Humanos. Objetivo Estratégico I: Promover o respeito aos Direitos Humanos nos meios de comunicação e o cumprimento de seu papel na
} 
De modo geral, o programa recebeu uma reação feroz de alguns setores mais conservadores da sociedade, provocando uma intensificação do debate público sobre os direitos humanos, apesar de ter sido lançado praticamente na virada de 2009 para 2010. Formou-se um "clima de opinião" (v. capítulo 2 "b") contra o programa, alegando que este teria proposto a descriminalização do aborto sem um debate devido, além de revanchismo na proposta de abertura dos documentos da ditadura, censura prévia e o controle estatal dos meios de comunicação.

Apesar dos ataques midiáticos contra as propostas de políticas públicas na área, equiparadas com medidas autoritárias de esquerda ${ }^{407}$, uma análise de Sérgio Adorno sobre o PNDH-3 e sua repercussão mostram que o tema voltou a ser discutido como não era há tempos, ativando intensamente a expressão prático moral da esfera pública política nacional já no início de 2010.

Outra questão benéfica ao debate foi ter deslocado o problema dos direitos humanos de sua identificação limitada com as políticas criminais e de segurança pública para outros diversos temas que os envolvem, como os direitos de comunicação e informação, igualdade de direitos entre casais hétero e homoafetivos e apoio a projeto de lei para discriminalização do aborto (Adorno, 2010:5 e 14), sendo que este último que foi retirado em reformulações posteriores ao programa.

Adorno ressalta a importância da discussão ao relembrar que os planos anteriores (1996 e 2002) não haviam recebido tanta atenção de setores da sociedade civil. A existência de um debate público tão vigoroso sobre o PNDH-3 torna evidente a formação de uma esfera pública política nacional em torno de temas dos direitos humanos.

Isso poderia ter ocorrido porque o decreto presidencial que instituiu o PNDH-3 (n. 7.037 de 21/12/2009) tinha força de lei ordinária, ou seja, poderia fundamentar políticas e decisões de agentes e órgãos públicos, enquanto que os dois programas iniciais não. Mas apesar disso, os dois primeiros tinham da mesma forma a função de orientar e fundamentar a formulação de políticas públicas nos setores referidos, e já traziam propostas muito semelhantes às atuais, que foram tão duramente questionadas.

promoção da cultura em Direitos Humanos; Objetivo Estratégico II: Garantia do direito à comunicação democrática e ao acesso à informação.” Educação e Cultura dos Direitos Humanos. Cap. V. do Programa nacional de Direitos Humanos. Secretaria de Direitos Humanos da Presidência da República. Brasília, 2010, 9 e $164-168$.

407 Adorno cita como exemplos os artigos publicados no Jornal Folha de S.Paulo da senadora Kátia Abreu, líder da bancada ruralista no Congresso “Direitos Humanos ou Gato por Lebre?”(“Opinião”, de 12/01/2010), e do jurista Ives Gandra Martins "Guerrilha e redemocratização" ("Tendências e Debates", de 22/01/2010). (Adorno, S. 2010:6-8). 
Adorno analisou entre essas propostas o debate em torno da parte do programa sobre regulação da comunicação, bem como as alegações dos setores afetados, que acusavam o plano de se tratar de medidas de censura e violação da liberdade de expressão e opinião. Mas ao mostrar que o novo programa só inova ao propor a criação de um ranking com as produções que mais violam direitos humanos ${ }^{408}$, avalia que as reações do setor foram especialmente exageradas. ${ }^{409}$

Após as ruidosas reações à primeira versão do programa, algumas das propostas foram retificadas (Decreto n. 7.177/10), e no caso do direito à comunicação, manteve-se a previsão de criação de um marco legal que regulamente o art. 221 da Constituição, mas suprimiu-se a possibilidade de punições por violações dos princípios, bem como a sugestão de "critérios de acompanhamento editorial". 410

De todo modo, Adorno faz ressalva a que tipo de "controle social" poderia ser aplicado aos meios de comunicação (Adorno, 2010:16), pois se a existência de normas que regulam o conteúdo de programas, peças de propaganda e outras formas de comunicação não pode ser negada (art. 220, $\S \S 1^{\circ}$ e $4^{\circ}$ e art. $221, \mathrm{CF}$ ), a forma de aplicar essas normas e os agentes competentes para fazê-lo também precisariam respeitar os princípios de pluralidade $^{411}$ e diversidade, justificando de modo satisfatório em cada caso eventual limitação da liberdade de expressão.

Caso contrário, há risco de se provocar uma seletividade no uso da liberdade de expressão que leva ao que diversos especialistas em comunicação social e política

\footnotetext{
${ }^{408}$ Entre outras 12 propostas de ação governamental do programa na área está a n. 102: "Garantir a possibilidade de fiscalização da programação das emissoras de rádio e televisão, com vistas a assegurar o controle social sobre os meios de comunicação e a penalizar, na forma da lei, as empresas de telecomunicação que veicularem programação ou publicidade atentatória aos direitos humanos" (PNDH3:209).

409 "As criticas ao PNDH-3 são bem-vindas, porque necessárias à vida democrática. As polêmicas revelaram-se exageradas. Há mais continuidade entre as três edições do Programa Nacional de Direitos Humanos do que rupturas. Pensados na Conferência Mundial dos Direitos Humanos de Viena, esses programas foram concebidos como instrumento capaz de conferir maior unidade e coerência à proteção e à promoção desses direitos. Articulam diferentes e múltiplas iniciativas, em torno de objetivos comuns e metas programáticas, conferindo responsabilidades a agentes e agências. Não pretendem substituir os instrumentos tradicionais de fazer política institucional, tampouco os espaços onde a política é debatida, negociada e as leis são votadas. É curioso, aliás, que as criticas não tenham se detido em um quesito presente nas três edições: a exigência de monitoramento do programa, que deve ser feito periodicamente. Esse é, de fato, o espaço da critica. E nele que se pode confrontar o ideal e o real, o que se propôs e o que se fez, avanços e recuos. É por meio do monitoramento que os governos ficam sujeitos a cobranças e - mais do que isto - vulneráveis em suas tarefas de proteger a espinha dorsal da constituição política brasileira." (Adorno, S, 2010:19-20).

${ }^{410}$ V. capítulo sobre o direito à comunicação e as propostas na área de comunicação do PNDH-3 na obra Regulação das Comunicações: história, poder e direitos, de Venício A. de Lima, 2011:239-249.

${ }^{411}$ Aqui o princípio da pluralidade já não é só visto como pluralidade de visões de mundo, pertencente às pretensões cognitivas dos discursos de verdade, mas como pluralismo ético-moral, isto é, a liberdade e a coexistência de auto-compreensões sobre a vida boa e a melhor forma de vida para todos, pretensões do discurso prático, analisado nesta segunda parte do diagnóstico da esfera pública política brasileira.
} 
denominam censura privada, ou privatização da censura. Ela ocorre não somente na medida em que determinadas informações de relevância pública são omitidas pelos meios de comunicação (Bucci, 2004:252), mas também quando, em função da concentração da propriedade privada e da predominância do modelo comercial, por exemplo, a diversidade de opiniões e a pluralidade de visões de mundo - garantias intersubjetivas das liberdades de comunicação - acabam por ser prejudicadas. ${ }^{412}$

A partir da perspectiva da co-originariedade entre autonomia individual e política destacada por Habermas, pratica censura privada aquele que entende como violação de sua liberdade individual a regulação necessária à garantia de mais pluralidade e diversidade de vozes nos veículos de informação e comunicação (sentido "positivo" da liberdade de expressão"). Em outras palavras, aquele que alega ter sua liberdade de expressão violada não se dá conta de que não é possível exercê-la quando isso significa privar outros do mesmo direito. ${ }^{413}$

É por isso que a liberdade de expressão não é (e não deve ser) pensada como direito individual sobre, contra ou em oposição à sua regulação pela coletividade, mas de modo que sua inter-relação com outras liberdades de expressão possa ser aceita por esta coletividade como legítima. Seu sentido de liberdade "negativa" assim se completa quando se observa que seu exercício não é só uma abstenção de intervenção do outro sobre a manifestação individual do pensamento, mas também sobre a liberdade do outro.

O mesmo entendeu o filósofo Vladimir Safatle ao analisar o caso de intolerância praticado pelo deputado federal Jair Bolsonaro, que ofendeu homossexuais e afrodescendentes em rede pública de televisão em abril de 2011. No momento em que o deputado viola o objetivo da República de não-discriminação (art. $3^{\circ}$, IV, CF), promove atitude que não está protegida pela liberdade de manifestação do pensamento. Ou seja, não

\footnotetext{
412 "Será que a concentração da propriedade privada dos meios de comunicação tem alguma interferência na liberdade de expressão, na pluralidade de fontes e na diversidade de conteúdos, pilares da democracia representativa liberal? // Em vários países da União Européia a resposta é definitivamente 'sim'. Na Alemanha, na Espanha e em Portugal, as Constituições nacionais, além de impedir a censura estatal, trazem também provisões para que o Estado: // a) garanta a existência de uma imprensa livre e diversa; ou b) impeça a concentração da propriedade; ou c) garanta acesso a todos os grupos sociais e políticos e assegure a diversidade na mídia. (...) // Enquanto isso, entre nós, 'o mercado' continua absoluto como única forma admitida pela indústria das comunicações como critério e medida das liberdades de expressão e de imprensa. Qualquer alusão à necessidade de algum tipo de regulação democrática do setor, feita por quem quer que seja, será liminarmente estigmatizada como autoritarismo, stalinismo, totalitarismo. // Mas de 20 anos depois do fim da ditadura, em plena democracia, continuamos a ignorar, no Brasil, a evidência de que, junto com outras atividades anteriormente consideradas como exclusivas do estado, a censura também está sendo privatizada." (Lima, 2011:104-105).

${ }^{413} \mathrm{O}$ dispositivo que justifica a limitação da liberdade de expressão nesse caso é o já citado art. $5^{\circ}$, VIII, $\mathrm{CF} / 88$ : "ninguém será privado de direitos por motivo de crença religiosa ou de convicção filosófica ou política, salvo se as invocar para eximir-se de obrigação legal a todos imposta e recusar-se a cumprir prestação alternativa, fixada em lei." (grifos nossos).
} 
se trataria nem mesmo da manifestação de uma opinião, mas da reprodução de um preconceito condenado socialmente, o que permite sua responsabilização não só pelas violações da honra e da imagem social de quem ofendeu diretamente, mas por dano moral coletivo, crime de ameaça ou mesmo apologia ao crime. ${ }^{414}$

Mas é na esfera pública ampliada pelas tecnologias de informação e comunicação que práticas de intolerância simbólica, ou aquilo se nomeou a partir da doutrina dos EUA de hate speech ${ }^{415}$ ("fala de ódio", trad. livre), parecem ocorrer com mais freqüência. Do cyberbullying à criação de comunidades praticantes de discursos de ódio e discriminações de qualquer tipo, ou mesmo para a ofensa deliberada e inconseqüente, as reclamações e números de casos desse tipo de agressão na rede mundial de computadores levou até mesmo à criação de uma ONG especializada em monitoramento e prevenção contra violações de direitos humanos na internet, ligada à Universidade Federal da Bahia, única na América Latina e Caribe, a Safernet. ${ }^{416}$

Algumas matérias de jornal têm alertado como a internet tem sido utilizada não só para facilitar a comunicação e a formação de redes de cooperação sociais, mas também como espaço no qual os lados mais agressivos e obscuros da personalidade humana se expressam, provocando diversas experiências de desrespeito e intolerância entre os usuários. Talvez por trazer a falsa impressão de ser um meio privado, pela sensação de anonimato quando na verdade promove comunicações bilaterais e de massa, ou pela

${ }^{414}$ Em sua coluna de 12/04/2011 no jornal Folha de S.Paulo, Safatle tornou mais claro esse complexo argumento ao dizer que: "A democracia é o regime que reconhece o direito fundamental à liberdade de expressão e opinião. No entanto ela também reconhece que nem tudo é objeto de opinião. (...) // Por isso, há certos enunciados que simplesmente não têm o direito de circular socialmente. Por exemplo, quando alguém fala que os judeus detêm o controle financeiro do mundo, que os negros são inaptos para o trabalho intelectual, que os muçulmanos são terroristas ou que os homossexuais são promíscuos e representam uma vergonha para seus pais, não está enunciando uma opinião. // $\mathrm{Na}$ verdade, está simplesmente reiterando enunciados cuja única função é estigmatizar grupos, alimentar o desprezo e diminuir nossa indignação diante da violência contra eles. (...)."

${ }^{415}$ Dworkin trabalha este conceito analisando o contexto dos EUA que, apesar de manterem uma observância estrita da primeira emenda, condenam o hate speech, os discursos de ódio e discriminação contra indivíduos, grupos ou coletividades, minoritárias ou não, ou mesmo conteúdos considerados ofensivos à moral e aos bons costumes, como pornografia, os quais poderiam justificar limitações da liberdade de expressão. V. Dworkin, Levando os direitos a sério, 2002:396-397.

${ }^{416}$ V. trabalhos e dados da Safernet, ONG que desde 2006 mantém uma central de denúncias de violações de direitos humanos na internet, filtrando-as e encaminhando-as ao Ministério Público, bem como setor de prevenção, com campanhas para uso consciente da internet. Apesar de os dados oscilarem bastante desde 2006, comparando os dados do mês de novembro de cada ano, as denúncias de pornografia infantil lideram junto com as apologias e incitações de crimes contra a vida, a primeira na casa das 2 mil a 3 mil denúncias no mês e a segunda na casa dos mil, esta com queda de $50 \%$ no último ano. Já as denúncias de homofobia e racismo aumentaram sensivelmente em 2010 (casa dos 200 a dos 900), mas voltando a se estabilizar em torno de 200 e 300 denúncias em 2011. A xenofobia também teve aumento significativo de de 2006 para 2011, chegando a 1796 denúncias em 2010, e em 2011 ficando com 501, seu o segundo maior número. www.safernet.org.br/site/indicadores. 
utilização muitas vezes ocorrer no espaço privado da casa e quase íntimo dos quartos, quando não nas "binas" das lan houses, que funcionam como cabines telefônicas. ${ }^{417}$

Essa intolerância pode também ser provocada mesmo pela imediaticidade e a velocidade exigidas à comunicação que se dá entre os e-mails, portais, blogs e redes sociais e profissionais, vindo a estimular, como no caso dos programas humorísticos ao estilo stand up comedy, a verborragia incontida ${ }^{418}$, que precisa a toda hora gozar o outro e com isso provocar o gozo do telespectador, como no imperativo do gozo da presente na comunicação televisiva, cujos efeitos especialmente sobre crianças e adolescentes foram analisados por Maria Rita Kehl em "Imaginário e Pensamento" (1995. v. tópicos 5.2 e 5.3, acima).

Mas se proliferam de fato as práticas de intolerância a partir dessa esfera pública redimensionada pela internet, crescem ao mesmo tempo as manifestações de defesa de direitos de comunicação e reconhecimento, por meio do aumento da vigilância quanto às discriminações e preconceitos presentes nos espaços públicos gerados pelos meios de comunicação.

Nas produções culturais televisivas, na imprensa e nos novos espaços virtuais de interatividade social e política, cresce o que se convencionou denominar "movimento do politicamente correto": membros de organizações sociais - especialmente nãogovernamentais - que defendem causas políticas e monitoram seu tratamento nos veículos de comunicação mais importantes da esfera pública política nacional.

Eles escrevem para as redações, editorias, produções privadas ou públicas, exigindo retratações e ameaçando com processos judiciais, que muitas vezes são de fato ajuizados. Lançam vídeos nas redes sociais e sites do gênero, realizam protestos, e manifestações em locais públicos presenciais ou virtuais. ${ }^{419}$ 417 Matérias sobre a disseminação de crimes contra a honra pela internet cobriram duas páginas do caderno
"tec" do jornal Folha de S.Paulo em $10 / 08 / 2011$. Em análise de psicóloga sobre os porquês dessas explosões
de ódio e agressões simbólicas, os chamados "trolls", ou "haters" seriam internautas que se aproveitam do
suposto anonimato para expressar sentimentos de ódio que não expressariam em público. Essa posição de
suposto anonimato, no entanto, seria também um estímulo para essas práticas. Outra matéria sobre o assunto
intitulada "Lama On-line", sobre a facilidade que cada um tem hoje de se ter violada sua imagem social na
rede foi apresentada em $28 / 01 / 2011$ no caderno "equilíbrio" do mesmo jornal.
418 O autor Elias Thomé Saliba, de Raízes do Riso (2002) analisou episódios de excessos e violações da honra
e imagem em programas humorísticos como o CQC como "resultado de mera irreverência compulsória,
forçada pelo ambiente de público ao vivo, com claque de risadas, que estimular a irrestrição verbal dos
comentaristas". V. matéria "O humor do Coronel". Rosane Pavam. Carta Capital. Ano. XVII. N. 667,
$12 / 10 / 2011$, pp. $68-69$.
419 Um rápido exercício de memória permite trazer à mente o recente caso de propaganda com a modelo
Gisele Bündchen, que foi levada ao Conar pela Secretaria de Políticas para as Mulheres, ligada ao Governo
Federal, mas depois liberada, e outro caso também não tão antigo sobre o repúdio da opinião pública às
declarações de moradores do bairro Higienópolis, dizendo que eram contra a criação de uma estação de 
Mas dispensados os eventuais exageros, ao invés desse fenômeno ser interpretado como reflexo de um aumento da possibilidade de dissenso ou debate sobre a melhor forma de se comunicar nesses espaços públicos - e portanto, uma espécie de "maturidade" da reflexão política brasileira -, como ainda há resistências a discussões sobre questões éticomorais na esfera pública, essas iniciativas chegam a ser consideradas por filósofos de bom trânsito na imprensa somente como irritantes "patrulhas ideológicas". ${ }^{420}$

A partir dessa perspectiva, parece que a discussão sobre a correção, ou o debate sobre as melhores atitudes a se tomar no espaço público não teria mais sentido depois do "fato do pluralismo". Trata-se, no entanto, de pluralismo relativista que, segundo Habermas, advém de uma interpretação possessivo-individualista de liberdade individual (Haberms, 2007:298-299).

Mesmo com esse aumento da discussão sobre o politicamente correto, não se chegou a tratar o problema como sinal da abertura de um espaço para uma discussão prático moral sobre os conteúdos da informação, da opinião e de outras expressões que circulam por veículos privados e públicos de comunicação. Ao final, perdem a chance os próprios meios de comunicação de serem vistos como mais transparentes, pois se mostrariam mais abertos à crítica do público.

Se a comunicação que circula na esfera pública política afeta diretamente a autocompreensão dos indivíduos, contribuindo para sua formação e atuação também como seres políticos e culturais, as agências e organizações responsáveis por essa circulação precisam responder na medida da natureza (liberdade de opinião pessoal ou política, de imprensa, de expressão comercial ou artística) e da capacidade de difusão de suas expressões na esfera pública política, o que dependerá dos meios utilizados a da abrangência de seus sinais.

Para citar mais alguns exemplos, no caso dos programas humorísticos, o simples fato de o Supremo Tribunal Federal ter decidido que esse tipo de comunicação não pode ser tolhida no caso de retratar políticos em período eleitoral - revogando o inciso II do

metrô nas intermediações porque não queriam o aumento do contato do que denominam "gente diferenciada". O caso levou à rápida mobilização nas redes sociais e um "churrascão da gente diferenciada" foi organizado em protesto. V. comentários sobre os casos em: matéria de 03/10/2011 do www.observadorpolitico.org.br; e matéria de 11/05/2011 do blog do Anselmo www.globo.com.br (último acesso: 03/12/2011).

${ }^{420}$ Cf. Entrevista com filósofos Roberto Romano e Luis Felipe Pondé em Programa Caminhos Alternativos de 27/03/2011 da Rádio CBN. Disponível em www. http://silncioerudoasatiraemdenisdiderot.blogspot.com (último acesso: 03/12/2011). 
artigo 45 da Lei Eleitoral $(9.504 / 1997)^{421}$-, não significa que a própria sociedade civil, inclusive representantes do interesse econômico, como os patrocinadores de programas de comédia, não possam deixar de anunciar nesse tipo de programa em caso de excessos que venham a desagradar suas audiências e a opinião pública.

É o caso do apresentador e humorista Rafinha Bastos do programa televisivo $C Q C$, que após diversas ofensas contra pessoas e coletividades, acabou sendo demitido da produção em outubro de 2011 por pressão de anunciantes. Isso demonstra que, quando se trata da esfera pública política, até mesmo a racionalidade técnica e estratégica dos agentes econômicos não dispensa ponderações éticas nas tomadas de decisão pela continuidade de suas atividades.

A iniciativa pioneira da campanha "Ética na TV: Quem Financia a Baixaria é contra a Cidadania”, da Comissão de Direitos Humanos da Câmara dos Deputados, que monitora desde 2003 violações de direitos humanos na programação televisiva e, a partir da elaboração de rankings dos programas mais criticados pressiona anunciantes dos programas para exigir mudanças nas programações denunciadas, também pode ser entendida como exemplo da existência de elementos práticos por trás das relações econômicas (Honneth, 2008; Id, 2011). Neste caso, estimula-se o mecanismo social que ocorreu de modo mais ou menos espontâneo com o humorista do $C Q C$ : a mobilização do sistema de ação teleológico-instrumental de funcionamento normal da economia por uma coordenação a partir de seus vínculos éticos inevitáveis.

O mesmo ocorre com alguns tipos de comunicação comercial, como a propaganda para crianças. Mas apesar de reconhecida internacionalmente através de pesquisas e tratados de direitos humanos como prejudicial à sua formação psicológica, especialmente em idades que ainda não possuem capacidade de discernir o estímulo ao consumo e o entretenimento, a regulação da matéria prevista na lei brasileira por meio do art. 220, §3, CF e do Estatuto da Criança e do Adolescente ainda encontra diversas resistências na esfera pública política nacional. ${ }^{422}$ ${ }^{421}$ O inciso referido veda, a partir de $1^{\circ}$ de julho de ano eleitoral, "trucagem, montagem ou outro recurso de
áudio ou vídeo que, de qualquer forma, degradem ou ridicularizem candidato, partido ou coligação". A
decisão partiu de voto do relator Ministro Carlos Ayres Britro, que também suspendeu parte do inciso III
desse artigo, que proibia as empresas de rádio e TV de "difundir opinião favorável ou contrária a candidato,
partido, coligação, a seus órgãos ou representantes". O voto do relator foi mantido por votação de 6 a 3 , com
protestos do Procurador Geral da República.
422 Editorial da Folha de S.Paulo de 11/07/2011 reconhece que a legislação para a propaganda infantil é
permissiva demais em comparação com a de países como a Suécia e nos EUA. Mesmo assim, confia em
órgãos como o Conar para estipular limites a esse tipo de comunicação, indicando que já existe a seção de
normas do código de auto-regulamentação (art. 37) que trata do caso. Não seriam necessárias "regradas
draconianas do Estado" para regular a questão, pois segundo o jornal "...Cabe aos pais, e não ao Estado 
A partir dessas breves leituras de exemplos de embates entre as liberdades de comunicação e suas formas de regulação na esfera pública política nacional, torna-se possível visualizar desde já a compreensão intersubjetiva de liberdade individual, a qual se pretende aplicar às liberdades e aos deveres de comunicação e reconhecimento que compõem o direito da comunicação (v. tópico 9.2, abaixo). O diagnóstico prático-moral de seu domínio objetual, a esfera pública política, continua abaixo com análises sobre novos movimentos sociais ligados à luta pelos direitos à comunicação e à informação, e como eles se relacionam com pretensões atuais de exercício da soberania popular no Brasil.

6.2. Novas pretensões de comunicação e participação na formação da opinião e da vontade políticas: direitos à comunicação e à informação como garantias fundamentais da autonomia política

As transformações nos marcos institucionais da comunicação social e da comunicação política que têm tomado corpo na esfera pública política nacional, com intensificação prevista para este segundo decênio do século XXI, não foram possíveis sem uma história marcada pela atuação de diversos movimentos sociais em favor dos direitos à comunicação e à informação e por formas mais democráticas de exercício do poder político no Brasil desde a redemocratização. ${ }^{423}$

Esses movimentos estão ligados especialmente às iniciativas de comunicação popular e comunitária que buscam desde então espaços no espectro da radiodifusão, distribuídos (como já visto no cap. 3. "c"), de modo concentrado no regime militar e se perpetuando até o presente, mais de vinte anos após a promulgação da "Constituição Cidadã".

É por isso que a metáfora "reforma agrária do espaço eletromagnético" é mais do que apropriada para caracterizar a pretensão normativa à descentralização da propriedade, do acesso e das condições de produção de informação e comunicação, já discutida no capítulo 5.1 desta tese. Essa analogia entre as áreas da reprodução econômica material e comunicativa abre a possibilidade de novas descobertas a partir das relações entre as duas

decidir o que é melhor para os filhos. É sua a tarefa de incutir-lhes o discernimento necessário para navegar entre as tentações da vida, inclusive as publicitárias". Nunca é demais lembrar que a Folha de S.Paulo pertence à Associação Nacional dos Jornais, que faz parte do conselho superior do Conar.

${ }^{423}$ A obra do Coletivo Intervozes, uma associação de promoção e defesa dos direitos de comunicação e informação 
áreas, como também é foi feito nos já mencionados estudos sobre função social da propriedade intelectual. $^{424}$

Se no tópico anterior buscou-se realizar um diagnóstico das liberdades comunicativas de imprensa e de comunicação comercial e suas relações com pretensões ético-morais da comunicação, aqui terão foco formas de exercício da liberdade de opinião e manifestação do pensamento individuais ou coletivas, que assumem feição positiva com o direito à comunicação. ${ }^{425}$

Direitos à comunicação, ou o direito de comunicar, são pretensões normativas derivadas de críticas ao modelo vigente de circulação da comunicação social e política no mundo, tendo como marco histórico os trabalhos de Jean D'Arcy na Comissão McBride da UNESCO (1976). Propõe o direito de todos de acessar os meios que efetivamente garantem a produção e o acesso à informação, a emissão de opiniões e a expressão cultural de indivíduos e coletividades. $^{426}$

Atualmente, este esforço na comunidade internacional para a criação e o respeito ao direito à comunicação é representado pela Campanha Communication Rights in the Information Society (CRIS), cuja expressão mais clara no Brasil é a união da opinião formada pelas 64 entidades sociais que defendem, promovem e realizam o direito à comunicação livre desde os anos 80 no país, e apresentaram em maio de 2011 vinte

\footnotetext{
${ }^{424}$ Em outra analogia com os princípios da "reforma agrária" do espaço eletromagnético - e agora também digital - é possível propor uma "desapropriação" privada de determinados contingentes de informações, como bancos de dados privados e mesmo patentes de grande interesse público, pelo mesmo fundamento da desapropriação da propriedade territorial: “...necessidade ou utilidade pública, ou por interesse social, mediante justa e prévia indenização em dinheiro, ressalvados os casos previstos nesta Constituição" (Art. $5^{\circ}$, XXIV, CF). Há previsões na Lei de Arquivos Públicos (Lei 8.159/91) que poderiam fundamentar uma discussão nesse sentido: "Art. 12. Os arquivos privados podem ser identificados pelo Poder Público como de interesse público e social, desde que sejam considerados como conjuntos de fontes relevantes para a história e desenvolvimento científico nacional; Art. 13. Os arquivos privados identificados como de interesse público e social não poderão ser alienados com dispersão ou perda da unidade documental, nem transferidos para o exterior. § único. Na alienação desses arquivos o Poder Público exercerá preferência na aquisição; Art. 14. O acesso aos documentos de arquivos privados identificados como de interesse público e social poderá ser franqueado mediante autorização de seu proprietário ou possuidor; Art. 15. Os arquivos privados identificados como de interesse público e social poderão ser depositados a título revogável, ou doados a instituições arquivísticas públicas."

425 "O direito à comunicação significa hoje, além do direito à informação, garantir a circulação da diversidade e da pluralidade de ideias existentes na sociedade, isto é, a universalidade da liberdade de expressão individual. Essa garantia tem de ser buscada tanto 'externamente' - através da regulação do mercado (sem propriedade cruzada e sem oligopólios; priorizando a complementaridade dos sistemas público, privado e estatal) - quanto 'internamente’ à mídia - através do cumprimento dos Manuais de Redação que prometem (mas não praticam) a imparcialidade e a objetividade jornalística. E tem também de ser buscada na garantia do direito de resposta como interesse difuso, no direito de antena e no acesso universal à internet, explorando suas imensas possibilidades de quebra da uniderecionalidade da mídia tradicional pela interatividade da comunicação dialógica." (Lima, 2010:36-37).

${ }^{426}$ Para um estudo seminal e citação recorrente sobre os debates da Comissão MacBride referentes ao direito à comunicação, v. Fischer, O Direito de Comunicar. liberdade, informação e poder, 1984
} 
propostas para o marco regulatório da comunicação a ser discutido nos próximos anos (v. $5.1)$.

De modo reconstrutivo ${ }^{427}$, portanto, pode-se dizer a partir do diagnóstico realizado até o momento que a luta pelo direito à comunicação parece responder de modo amplo aos sentimentos de injustiça provocados pela concentração da propriedade dos meios de comunicação social (5.1), a predominância de uma comunicação informativa tecnificada e estetizada quando da produção dos discursos sobre a verdade, seja na ciência ou na imprensa (5.2, 5.3 e 5.4), e pelo viés mercadológico e privatista com que se exercem e defendem atualmente as liberdades de comunicação (6.1).

Tomado como direito humano fundamental, o direito à comunicação exige do Estado a garantia dos meios pelos quais todos os cidadãos possam participar das três expressões da esfera pública política (art. 5º IV, V, VI, VIII, IV, X, XII, XIV, CF, entre outros), embora o foco deste tópico seja na expressão prático-moral. Os entrecruzamentos desse discurso com os outros são inevitáveis, como se verá nos tópicos seguintes em relação à comunicação política no tópico 6.3 e às proteções necessárias contra as atuais invasões dos espaços da privacidade em 7.2.

Trata-se, portanto, de uma das pretensões mais importantes à concretização da dimensão positiva das liberdades comunicativas, ou nas palavras de Habermas, de garantia do princípio da autonomia política, pois determina que o Estado não só deixe de intervir na opinião individual, mas também garanta as condições de exercício da liberdade de expressão, ou o acesso às diversas plataformas de comunicação cuja titularidade é pública, inclusive as mídias eletrônicas. ${ }^{428}$

${ }^{427} \mathrm{O}$ método reconstrutivo aqui utilizado segue a abordagem da racionalidade comunicativa como uma "pragmática formal", pela qual Habermas procura discutir a consciência das regras fundamentais do sistema de direitos por trás de diagnósticos de seu tempo presente. Esse método é primeiramente desenvolvido da teoria da pragmática formal, em “O que é a pragmática universal?” (1976) e depois aplicado em The Theory of Communicative Action (1984), em Consciência Moral e Agir Comunicativo (1989), bem como especialmente nos capítulos 2 e 3 de Direito e Democracia (1997). Diz-se "reconstrução" porque essa perspectiva de teoria social procura aliar ciência empírica e filosofia ao tentar identificar as normas (pretensões de validade) que estão pressupostas nas aparições sempre fragmentárias e conflituosas da experiência concreta da comunicação lingüística. Com Habermas, do primeiro texto supra mencionado: "Esta é a função da compreensão reconstrutiva, ou seja, da explicação do significado no sentido de uma reconstrução racional das estruturas generativas subjacentes à produção de formações simbólicas. E, dado que a consciência de regra a reconstruir é um conhecimento categórico, esta reconstrução dependerá acima de tudo da forma como a explicação conceptual operar." (Habermas, 1996b:27. Itálicos nossos).

${ }^{428}$ V. Fischer, O Direito de Comunicar, 1984. Nunca é demais lembrar que o Plano Nacional de Banda Larga, que procura universalizar o acesso à internet rápida no país, entende o espaço digital ou ciberespaço brasileiro como um espaço de natureza jurídica pública, isto é, deve ser administrado como bem público. Devido à sua inegável utilidade social, deve ser garantido o acesso de todos a essa nova extensão do espaço público. V. documento base do Programa Nacional de Banda Larga em www4.planalto.gov.br/brasilconectado (último acesso: 05/12/2011). 
Para algumas breves análises sobre casos em que a esfera pública política se expressa no debate sobre o acesso aos meios de exercício das liberdades de comunicação, são oportunas algumas interpretações sobre os movimentos pelas rádios livres $e$ comunitárias, e a recente ampliação de suas pretensões de comunicação e reconhecimento por trás do fenômeno das redes sociais digitais.

a) rádios livres e comunitárias e redes sociais digitais

Os movimentos sociais pela radiodifusão livre e comunitária são co-originários aos movimentos sociais de trabalhadores sem terra e operários urbanos, que se formaram em meados dos anos setenta em oposição ao regime militar decadente, mas tomando volume efetivamente nos anos oitenta. ${ }^{429}$ Segundo dados do governo há atualmente no país 4.385 processos de licenciamento de rádios comunitárias em andamento, com somente 412 efetivamente autorizados (atualização de 28/11/2011). Estima-se, no entanto, que haja atualmente mais de 30 mil rádios sem autorização em funcionamento no país. ${ }^{430}$

A expressão "reforma agrária do espectro eletromagnético da comunicação" se mostra então historicamente apropriada para retratar o fenômeno das rádios livres e comunitárias. Isso porque as experiências de violência sofridas por essas iniciativas de exercício do direito à comunicação livre e comunitária são semelhantes às que acometem dos movimentos sociais de base. ${ }^{431}$

Em termos de repressão policial da atividade, a lei geral de comunicações promulgada no regime militar (Lei 4.117 de 1962), que considera crime a atividade de telecomunicação - e não radiodifusão - não autorizada (art. 70), tem servido até o presente como fundamento para o fechamento de centenas de rádios por ano. ${ }^{432}$

\footnotetext{
429 Diversos relatos sobre a construção desse movimento estão contidos no livro Vozes da Democracia, produzido pelo Coletivo Intervozes de Comunicação. A obra está disponível por meio da licença autoregulativa Creative Commons e pode $\mathrm{e}$ acessada no site: http://www.intervozes.org.br/publicacoes/livros/vozes.

${ }^{430}$ V. artigo de Mauro Sá Rego Costa. Rádios Livres e Rádios Comunitárias no Brasil. 2011. Publicado no endereço eletrônico da Federal do Rio de Janeiro. www.febf.uerj.br (último acesso: 07/12/2011).

${ }^{431}$ Dossiê da Associação Brasileira de Rádios Comunitárias (Região Campinas) revelou diversos casos de fechamentos de rádios foram de forma truculenta, com ameaças, prisões e violência física aos programadores. Documento de 61 páginas apresentado à Assembléia Legislativa do município em fevereiro de 2006, disponível em: (último acesso 06/12/2011).

432 "Art. 70. Constitui crime punível com a pena de detenção de 1 (um) a 2 (dois) anos, aumentada da metade se houver dano a terceiro, a instalação ou utilização de telecomunicações, sem observância do disposto nesta Lei e nos regulamentos." (grifos nossos). Do mesmo modo, o art. 183 da Lei 9.472/97 prevê a quem: "Desenvolver clandestinamente atividades de telecomunicação: Pena - detenção de dois a quatro anos, aumentada da metade se houver dano a terceiro, e multa de R \$ 10.000,00 (dez mil reais)." (grifos nossos).
} 
Pelas normas se referirem a serviço de telecomunicação e não radiodifusão, é possível argumentar que rádios livres e comunitárias não estariam enquadradas na hipótese do art. 70 da lei referida (ou o art. 183 da L. 9.472/97), tendo-se um caso de atipicidade na linguagem do direito penal. É o que propõe em suas sentenças a juíza Márcia de Souza e Silva de Oliveira, em posição ainda minoritária na magistratura nacional. Seu entendimento também advém da constatação que apesar dos primeiros transmissores populares (não governamentais) terem origem nos anos 30, as rádios livres e comunitárias como hoje se conhecem configuraram-se posteriormente à lei de telecomunicações de 1962, e por isso o legislador de então não teria se referido à radiodifusão. ${ }^{433}$

Além desse discurso de justificação jurídica, as buscas pela garantia do direito à comunicação na esfera pública política se baseiam na evidência da repressão excessivamente violenta do Estado contra as iniciativas de comunicação popular nãolegalizadas, sendo que ela ocorre de modo inversamente proporcional aos lentos processos de licenciamento desses serviços, como denunciou o Ministério Público Federal (MPF) por meio de Ação Civil Pública (ACP). ${ }^{434}$

Essa ação foi ajuizada contra a ANATEL em 2007, em parceria com as entidades da área, como o coletivo Intervozes e o Fórum Nacional pela Democratização da Comunicação. Exigia-se a cessação da repressão policial às rádios não licenciadas, especialmente àquelas que estavam aguardando processos de regularização, e teve o direito à comunicação como direito principal a ser tutelado.

A alegação de que rádios não legalizadas interferem nas transmissões de sinais de aeroportos e poderiam provocar acidentes aéreos é um dos exemplos das campanhas de criminalização midiática que também sofrem os indivíduos que precisam se utilizar de formas não legalizadas de comunicação para exercerem essa pretensão fundamental de comunicação.

Trabalho realizado por engenheiro do CPqD Marcus Manhães demonstrou que as possibilidades de interferência de frequiências de rádio de aeroportos dependem da amplitude e da oscilação do sinal, o que pode ocorrer mesmo por causas naturais. Isso

\footnotetext{
${ }^{433}$ Esse argumento é também trabalho por Armando Rodrigues Coelho Neto em Rádio Comunitária não é crime: direito de antena: o espectro eletromagnético como um bem difuso (2002), bem como no artigo "Liberdade de expressão: radiodifusão sofre a ação repressiva da Anatel e da PF". in. www.conjur.com.br (último acesso: 06/12/2011).

${ }^{434}$ Segundo dados da ação, de 1998 a 2005, 352 rádios haviam sido regularizadas, enquanto que 2.466 rádios irregulares foram fechadas. V. cópia da ação civil pública publicada no endereço eletrônico do MPF www.prsp.mpf.gov.br (último acesso: 06/12/2011).
} 
tornaria as rádios comerciais muito mais sujeitas a promover interferências do que as comunitárias e não regularizadas, que têm sinais bem mais fracos. ${ }^{435}$

Deve-se ressaltar, portanto, que apesar dessa suposição de interferência nunca ter sido comprovada cientificamente mesmo pela ANATEL, as rádios livres, comunitárias e não regularizadas e outras iniciativas de comunicação popular, quando não são relegadas à invisibilidade na esfera pública política, continuam a ser interpretadas erroneamente pela imprensa como criminosas, da mesma forma que ocorre com outros movimentos sociais de base. $^{436}$

Por fim, o aumento de rádios livres ou comunitárias de posse de igrejas e organizações civis de diversos ramos, como os próprios meios de comunicação eletrônicos dominantes - até mesmo as Organizações Globo tem rádio comunitária ${ }^{437}$-, confere instabilidade às análises do fenômeno, retomando-se novamente a necessidade de se exigir responsividade e transparência de todas as instituições que atuam de modo significativo na esfera pública política, sejam elas públicas ou privadas.

Se claramente configuram-se injustas a lentidão e a burocracia dos processos de regularização de rádios comunitárias, bem como a violência da repressão às rádios não licenciadas, as políticas voltadas para a comunicação pública precisam ser capazes de inverter totalmente essa lógica perversa dos processos de licenciamento, que prejudica aqueles em desvantagem e beneficia os concessionários maiores, como a regra do art. 223, $\S 2^{\circ}$ da Constituição Federal. ${ }^{438}$

A partir do princípio da igualdade proporcional, aqueles com maior dificuldade de conseguir acesso aos meios de exercício do direito à comunicação deveriam receber maior atenção e assessoramento do poder público, tendo seus processos de regularização facilitados. $^{439}$ Àqueles com mais recursos, como os meios comerciais, a fiscalização

${ }^{435}$ V. Manhães, "Desmistificando as Interferências de radiodifusão FM em Comunicações Aeronáuticas", 2006. Disponível no portal Observatório do direito à comunicação. (último acesso: 06/12/2011).

${ }^{436}$ Matéria da Folha de S.Paulo de 10/06/2007 apresentou grande exemplo de cobertura pouco científica, destorcida e preconceituosa a respeito das rádios livres. Publicado em meio à crise dos aeroportos conhecida como "Apagão Aéreo", além de imagens que retratam os radialistas como criminosos e o uso de uma linguagem informal, na chamada da matéria indicava-se: "Como funcionam as rádios piratas, que atrapalham os aeroportos em São Paulo", sendo que sobre essa questão no corpo da matéria, no interior do caderno Cotidiano, publicou-se somente diminuta nota da opinião (também sem fundamento técnico) de um especialista em telecomunicações da PUC São Paulo dizendo que os sinais podem causar interferência. V. análise sobre a matéria em: Blotta \& Quirino, 2008.

${ }^{437}$ V. endereço eletrônico Donos da Mídia www.donosdamidia.com.br.

${ }^{438}$ Não se pode esquecer da aprovação relâmpago de 38 outorgas e 65 renovações em sessão da Comissão de Constituição e Justiça da Câmara dos Deputados em 22/09/2011, com apenas dois membros presentes, já relatada neste estudo (v. tópico 5.1).

${ }^{439}$ Não é o que ocorre com a lei que regulamenta as rádios comunitárias (Lei 9.612/98). Segundo reclamações de dossiê da Associação Brasileira de Rádios Comunitárias, regional Campinas (fev. 2006:5), 
precisa ser maior, como se procurará fazer agora o Ministério das Comunicações, exigindo caução de emissoras para comprovar a capacidade econômica de executar o serviço. Isso após denúncias do jornal Folha de S.Paulo identificarem que diversas concessões, inclusive de igrejas, tinham como titulares pessoas sem condições financeiras de arcar com o serviço. ${ }^{440}$

Da forma como se projeta para o futuro próximo a questão da comunicação comunitária está muito ligada à sua interligação com as novas tecnologias de informação e comunicação. As novas plataformas que as rádios livres alcançaram com seus portais online também as inserem nas perspectivas do aumento do espectro com a tecnologia digital. $^{441} \mathrm{O}$ estudo da UNESCO já analisado no tópico 6.1 indica que essas novas possibilidades de participação trazidas pela tecnologia digital facilitarão o debate sobre o aumento do equilíbrio das liberdades de comunicação nas plataformas da esfera pública política.

Esse novo patamar tecnológico tornou possível outro fenômeno relacionado às pretensões de comunicação e informação, as redes sociais digitais, que têm sido responsáveis não só por novas relações econômicas, mas também novas formas de associativismo e mobilização política, algumas capazes de influenciar até derrubadas de governos, como ocorreu no Egito em 2011.

A princípio, as redes sociais digitais parecem ser a expressão de novos espaços públicos como descrito por Habermas em MEEP, isto é, uma reunião de privados constituindo públicos na medida em que compartilham iguais condições de trocarem informações e debater sobre as regras de seus negócios e da política, criticar as produções culturais ou simplesmente expressarem suas personalidades.

O fato de ter um número surpreendentemente elevado e crescente de usuários, sendo o Brasil destaque em de redes como Orkut e Tweeter $^{442}$, demonstra que havia uma

essa norma dificulta a existência das rádios, pois: "Destina um só canal por município (e para o país); Estabelece o alcance de $1 \mathrm{Km}$; Proíbe publicidade; Exige que a diretoria da rádio more num círculo de $1 \mathrm{Km}$; Se o sinal de uma rádio Comunitária interferir numa comercial o Estado pune, mas em caso contrário, não há punição; Proíbe as emissoras comunitárias de entrarem em cadeia; Limita a potência a 25 Watts."

${ }^{440}$ V. reportagem de capa do dia 27/03/2011 e colunas sobre o assunto, como de Carlos Heitor Cony intitulada "Laranjas de ontem e de hoje", de 29/03/2011.

${ }^{441}$ V. Manhães, A Nova Era da Radiodifusão Sonora Digital. In. Observatório do Direito à Comunicação 2007.

${ }^{442}$ Segundo pesquisa do Observatório Íbero-Americano de Telenovela publicada em 2010, o Brasil chega a $35 \%$ da população (62 milhões) com acesso à internet, sendo que se destaca como quinto que mais acessa o site Youtube e por ter 25 milhões de pessoas em redes sociais, torna-se o país que mais participa desse novo espaço público estendido no mundo. V. Lopes, Mungioli, Alves e Lemos, 2011, p. 143. Segundo recente notícia, o Brasil (99\%) só não acessa redes sociais mais do que os EUA (99,7\% dos usuários), ganhando 
demanda retida por espaços de comunicação que fossem mais interativos, nos quais as pessoas pudessem se expressar, compartilhar notícias, conhecimentos e até realizar trabalhos, o que os transforma lugares onde se produz de valor a partir das interações entre os participantes.

Se a construção dos perfis e das "contas" dos usuários dos blogs, chats, fóruns de discussão entre outras constituem algo semelhante aos espaços de expressão da subjetividade mais autêntica possível denominados por Habermas "esfera pública literária" (v. cap. 7), tornam-se possível pensar primeiramente que aquela "identidade virtual" constitui parte da imagem social da pessoa e que, portanto, direitos imediatamente passam a protegê-la ${ }^{443}$, como com a garantia do livre desenvolvimento desse tipo de “personalidade virtual” (Habermas, 2007:298-299).

Nesse sentido, a impossibilidade do usuário recuperar seus dados e de exigir ao administrador que sejam apagados podem configurar violações dessa privacidade estendida virtualmente. Os direitos da personalidade são, como os direitos humanos, indelegáveis e inalienáveis, e portanto nem mesmo o indivíduo não pode se dispor deles totalmente, o que torna anuláveis algumas cláusulas das conhecidas "políticas privacidade" das redes sociais (v. 6.4, abaixo).

Mas se há essa expressão de uma esfera pública literária a partir dos espaços de comunicação individual e coletiva proporcionados pelos blogs e redes como o Tweeter, estão também presentes condições para a formação de esferas públicas políticas em torno dos temas tratados. Não é por menos que diversas manifestações, organizações de grupos políticos e movimentos populares da Àfrica, do Oriente Médio e mais recentemente na Europa e nos EUA têm sido possíveis a partir dessas tecnologias de comunicação digital, que convergem cada vez mais formas de telecomunicação com comunicação de massa e informática. $^{444}$

ainda na média de acessos do usuário por mês (30,6 contra 30,3 dos EUA). Fonte:28/04/2011. Portal de notícias http://tecnologia.uol.com.br (último acesso: 05/12/2011).

${ }^{443} \mathrm{O}$ professor Artur Matuck, da Escola de Comunicações e Artes da USP trabalha a ideia da identidade virtual como um cíbrido (cyber + híbrido), o que também demonstraria a extensão da personalidade individual na plataforma virtual estendendo com isso também os direitos relativos a essa personalidade, como o de não ter essa identidade virtual discriminada ou eliminada pelo servidor. V. Matuck. Orkut no espaço cíbrido. Uma perspectiva política Palestra de 20 de fevereiro de 2009 no Espaço Cultural CPFL. Disponível em www.cpflcultura.com.br. (último acesso: 06/12/2011).

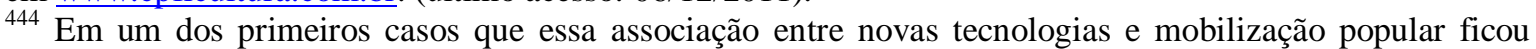
evidente, em denúncias de eleições fraudadas do Iran, a rede Tweeter foi fundamental para as trocas de informação. $\mathrm{Na}$ ocasião, as censuras impostas pelo governo ao site eram contornadas pelos próprios programadores em escritórios no ocidente, o que auxiliou as mobilizações. V. notícia de 17 /06/2009 em www.blogs.estadao.com.br (último acesso: 07/12/2011). 
Apesar dos primeiros movimentos partirem de tentativas e derrubadas de ditaduras que duraram décadas, enquanto os últimos são revoltas e protestos contra a falência das políticas sociais e as crises econômicas decorrentes de 30 anos de neoliberalismo, um dos pontos em comum foi a utilização de redes sociais digitais pelos manifestantes, em computadores ou por meio de telefone celular, pelos quais articulavam os passos das manifestações e trocavam informações de modo rápido e eficiente. Após revoltas em Londres em agosto de 2011, que receberam forte repressão policial, o primeiro ministro Cameron cogitou proibir as redes sociais, o que violaria o direito à comunicação em função de questões de segurança pública. ${ }^{445}$

No Brasil, as mobilizações políticas feitas com uso de redes sociais têm ocorrido em casos mais pontuais, mas também com grande capacidade de difusão de informações e rapidez na articulação dos protestos. São exemplos o já citado "churrascão da gente diferenciada", protesto organizado pelas redes sociais contra declarações preconceituosas de moradores de Higienópolis em São Paulo, bem como iniciativas de monitoramento e campanhas contra discursos de ódio na rede, seja no caso mais reativo da menina que manifestou em seu Tweeter diversas ofensas contra nordestinos e recebeu uma reação rápida (e também violenta) da opinião pública, ou no espaço público político mais formal que é mobilizado pelo primeiro portal de denúncias de crimes na internet, da ONG nacional Safernet, mencionada acima. ${ }^{446}$

Mas o calcanhar de Aquiles da comunicação que circula nas redes sociais não é tanto o fato de ela estar vinculada ao compartilhamento das informações privadas dos usuários com os anunciantes que têm fins comerciais (v. 5.2 e 6.4), mas nas formas de utilização das novas possibilidades de interatividade trazidas pela rede mundial de computadores. Isso porque em muitas ocasiões, essa comunicação tem servido mais para a exteriorização de impulsos negativos e desejos inconscientes que acabam incorrendo em ofensas, dramatizações e difamações etc, do que para fins de compartilhamento de informações, tomadas de decisão conjuntas e expressões estéticas e pessoais. ${ }^{447}$

\footnotetext{
445 Notícias e análises questionaram essa relação entre as manifestações sociais do presente e as novas tecnologias. Em entrevista, bloggueiro do Egito diz que utilizava as redes sociais para organizar os protestos, trocar informações e chamar a atenção da imprensa internacional para o caso. Meses depois, em manifestações violentas em Londres tinha sido organizadas por pessoas através dos aparelhos de telefone celular Blackberry. Com isso, o governo inglês passou a tentar proibir certos aplicativos do aparelho que facilitassem mobilizações políticas. V. notícia de 12/08/2011 em www.estadao.com.br (último acesso: 07/12/2011).

${ }^{446}$ Confira matéria de 16/05/2011 sobre denúncias do Safernet no portal www.terramagazine.terra.com.br

${ }^{447}$ V. estudo que identificou esse problema especialmente na rede social Orkut, que é a mais denunciada no Safernet, em Blotta, Mídia e Cidadania: contribuições de leituras habermasianas da comunicação de massa
} 
Esses desvios da comunicação, que decorrem de compreensões falsas da dimensão pública do ciberespaço, constituem-se antes na medida em que mensagens particulares de e-mail são distribuídas entre empresas que atuam no espaço público formado por relações econômicas. As experiências de violência sofridas por aqueles que foram difamados ou sofrem bullying pela internet são prejudiciais não só para os próprios indivíduos, agredidos em sua dignidade moral, mas também para a formação da esfera pública política, pois muitos acabam abandonando a utilização mais interativa da rede, enquanto que seus espaços são cada vez mais tomados por propaganda comercial, spams, pop-ups de anúncios etc.

Como se vê, portanto, estão dadas também as condições pelas quais a recém conquistada e estendida esfera de liberdade individual a partir das tecnologias digitais de comunicação possa ser rapidamente privatizada, ou mais uma vez refeudalizada a partir de um uso mais auto-interessado do que comunicativo desse espaço. Se isso ocorrer de fato, estará suspensa a chance de um agir mais reflexivo na esfera pública, embora a consciência mesma do agir interessado dominante já seja certa forma de reflexividade.

$\mathrm{Na}$ medida em que se reflete sobre as interpenetrações dos discursos dessa esfera pública política estendida e seus inevitáveis problemas prático-morais, torna-se possível discuti-los a partir das lógicas próprias, isto é, identificando quais discursos se sobrepõem aos outros e quais medidas práticas são necessárias para restaurar um equilíbrio e conferir mais publicidade a essas interpenetrações.

\section{b) escândalos midiáticos e manifestações políticas}

Quando se trata de embates práticos entre pretensões de acesso à informação e normas de sigilo com fundamento na segurança nacional, o caso do WikiLeaks é um dos mais emblemáticos, e que prepara a discussão do próximo tópico sobre as novas normas de acesso à informação pública, o direito à verdade e à memória histórica e outras iniciativas, entendidas pelo direito da comunicação como políticas de publicização ou comunicação do direito (v. 6.3, abaixo. v. também capítulo 9).

para a retomada da esfera pública em sociedades complexas (Epitc, 2008:18-25), disponível em www.eptic.com.br 
O WikiLeaks se auto-intitula uma organização não-governamental de mídia sem fins lucrativos que tem por objetivo divulgar notícias e informações ao público. ${ }^{448}$ Criado como forma de compartilhar "vazamentos" de dados, informações e notícias, gerou grande impacto na esfera pública política internacional ao divulgar documentos entre embaixadas e ministérios de diversos Estados Nacionais, incluindo o Brasil. ${ }^{449}$

As informações vão desde perfis de Ministros de Estado "em quem mais confiar", que os EUA relataram sobre o Brasil, a informações sobre supostas ligações de jornalistas brasileiros com organizações de inteligência internacionais. Essas e outras informações que invadiram a imprensa mundial desde o vazamento de documentos pelo WikiLeaks.

Essa entrada nas mídias tradicionais de um escândalo ocorrido no espaço virtual, o que amplia ainda mais o impacto das divulgações da ONG, só foi talvez superada pelas notícias posteriores sobre as acusações de crimes sexuais que sofrem seu presidente e fundador Julian Assange na Suécia, sua terra natal. Enquanto esse pede asilo na Inglaterra, ao que se sabe, estranhamente Assange ou o WikiLeaks não é alvo de nenhuma ação de órgãos e empresas das quais revelou informações. Tem-se notícia que somente os EUA, talvez o país mais atingido pelos dossiês, estudam formas de processar o WikiLeaks. Por enquanto, procura-se realizar um boicote econômico desencorajando os maiores doadores da entidade. ${ }^{450}$

Para o ex-chanceler Celso Lafer, considerando a lição sobre a publicidade dada por Kant (v. cap. 2. "c" acima), o trabalho do WikiLeaks não é ilegal. As organizações é que devem tomar medidas para manter protegidas informações que têm sigilo, mas a divulgação de algumas delas que ainda não perderam esse sigilo constrangem de modo

\footnotetext{
${ }^{448}$ Segundo propõe o WikiLeaks: "Publishing improves transparency, and this transparency creates a better society for all people. Better scrutiny leads to reduced corruption and stronger democracies in all society's institutions, including government, corporations and other organisations. A healthy, vibrant and inquisitive journalistic media plays a vital role in achieving these goals. We are part of that media." WikiLeaks, in www.wikileaks.org/about (último acesso: 07/12/2011).

${ }^{449} \mathrm{O}$ WikiLeaks mantém em seu endereço eletrônico um catálogo de 314 países sobre os quais divulga informações, notícias e documentos públicos e privados. www.wikileaks.org (último acesso: 07/12/2011).

${ }^{450} \mathrm{O}$ próprio site do WikiLeaks divulga documento que indica que a ONG teria sido investigada pelos EUA e criado plano de persecução aos delatores, dedos-duros e outros que vazam informações para prejudicar o serviço. Segundo resumo do relatório a proposta partiria do argumento de que: "Since WikiLeaks uses 'trust as a center of gravity by protecting the anonymity and identity of the insiders, leakers or whistleblowers,' the report recommends 'The identification, exposure, termination of employment, criminal prosecution, legal action against current or former insiders, leakers, or whistleblowers could potentially damage or destroy this center of gravity and deter others considering similar actions from using the WikiLeaks.org Web site. [As two years have passed since the date of the report, with no WikiLeaks' source exposed, it appears that this plan was ineffective]." WikiLeaks. U.S. Intelligence planned to destroy WikiLeaks, 18 Mar 2008. In. www.WikiLeaks.org. Publicado em 15/03/2010 Atualmente é por meio da anulação da rede de doadores ao WikiLeaks que o aqueles contrários à iniciativa têm tentado agir, isto é, utilizando o discurso técnico estratégico para promover interesses políticos.
} 
desnecessário embaixadores, ministros e instabiliza as relações entre Estados e seus líderes. $^{451}$ A regra para documentos da embaixada, segundo Lafer é de 15 anos prorrogáveis até 30, mas foi votado recentemente o fim do sigilo eterno de documentos do Estado, que podem se manter agora somente por $25 \operatorname{anos}^{452}$, apesar da posição contrária de dois ex-presidentes da república, os senadores José Sarney e Fernando Collor.

Os argumentos do último, no entanto, que escreveu até artigo na Folha de S.Paulo intitulado “"Acesso à informação é questão de Estado" (Tendências e Debates 18/06/2011) defendendo sua posição, não se distanciavam daqueles de Lafer. Somente mantinham um foco na questão da segurança nacional mais do no constrangimento das relações entre os países e seus representantes internacionais.

A ampliação do acesso a determinadas informações de interesse público é o que também tem motivado diversos movimentos e manifestações no Brasil e no mundo pelo exercício mais imediato da soberania popular. Das manifestações contra a corrupção que levou diversas vassouras à praia de Copacabana e em Brasília, em símbolo de indignação contra a corrupção, às resistências pelo fim das ditaduras ou mesmo crises sociais no Oriente Médio, ou mesmo os protestos do movimento "Ocupe Wall-Street" e diversos outros nele inspirados pelo mundo, inclusive no Brasil, todos sinalizam um clamor por maior acesso às esferas de decisão política em seus países.

Essa pretensão a uma democracia mais radical, que se mostra às vezes em exemplos extremamente negativos, como a repressão policial contra protestos pacíficos e ocupações de espaços públicos, está, portanto, intimamente ligada a esforços de publicização de informações públicas e à democratização de plataformas de debates sobre responsabilidades dos agentes políticos.

No caso em tela, a possibilidade de transformar o tópico do capitalismo financeiro novamente em tema de regulação prática serviria não só a problemas normativos, mas também à própria continuidade do modelo econômico, como ficou evidente no documentário “Trabalho Interno" (Inside Job, de Charles Ferguson, 2010), uma espécie de filme-manifesto do movimento "Ocupe Wall-Street", que utiliza um de seus bordões: "somos os 99\%", em alusão a todos aqueles que teriam sofrido com a crise no país. O filme, que ganhou Oscar de melhor documentário em 2010, explica e publiciza as causas da maior e mais globalizado "crash" financeiro da história desde 1929.

\footnotetext{
${ }^{451}$ V. entrevista de 04/12/2010 com Lafer expondo seu ponto de vista no portal de notícias da UOL.

452 Sobre a Lei de Acesso à Informação pública, o PL 41/2010 que foi aprovado e tornado, v. tópico 6.3 abaixo.
} 
Mas o que fazer se as condições de tornar efetivamente público as relações entre economia e política e o tema da moralização do mercado, como propõem Axel Honneth em sua Das Recht der Freiheit (2011:317--474) e Eduardo Bittar em sua obra Democracia, Justiça e Direitos Humanos (2010:17-38), dependem dessa mesma possibilidade de acesso aos meios de informação e comunicação que se está pleiteando?

Essa pergunta torna possível perceber que o acesso à informação - incluído o acesso aos meios de se informar na comunicação social e política - não só tornou esses movimentos sociais tecnicamente possíveis, mas está por trás de suas pretensões a uma participação mais igualitária nas esferas públicas de decisão, formando com elas uma espécie de circuito causal e normativo auto-implicado.

As manifestações sociais por uma repolitização democrática do setor após a crise financeira mostram, por exemplo, que conceber os direitos à comunicação associados à autonomia política pode ser fundamental para momentos como esse, pois quando as alternativas de ação para contornar o problema têm mais condições de se legitimar perante os diversos atores sociais direta ou indiretamente afetados, diminuem-se os riscos de aumento de tensões e novos conflitos, causados eles mesmos por déficits de legitimidade que se reforçam mutuamente (Habermas, 1996:386).

Essa relação entre direito à comunicação e movimentos de radicalização da democracia dão condições para se analisar algumas das respostas que o direito tem encontrado para essas pretensões. Serão discutidas dentre elas algumas políticas de maior transparência e acesso a informações públicas, bem como às justificações dos processos decisórios do Estado e de organizações sociais cujas atividades são de relevância pública.

6.3. Iniciativas de intersubjetivização do direito a partir da esfera pública política: procedimentalização da soberania popular e publicização do direito

Uma das contribuições mais importantes que o direito da comunicação pretende oferecer à tese habermasiana da relação interna entre direito e democracia em termos de teoria social se tornará evidente a partir deste tópico do diagnóstico da expressão práticomoral da esfera pública política brasileira. De modo simplificado, ela ressalta o segundo - e menos trabalhado - aspecto da proposição que inicia esta tese: a recíproca de que só um direito legítimo e democrático garante comunicações livres. 
Ou seja, além de analisar formas com as quais o direito procedimentaliza a soberania popular, ou reage às pretensões populares por maior participação na formação da opinião e da vontade políticas, torna-se necessário também identificar iniciativas em que o próprio procedimento jurídico ou normas sociais procuram se legitimar de modo democrático perante o público, abrindo-se à crítica na esfera pública política e expondo suas razões aos cidadãos para que eles possam entendê-las e aceitá-las como legítimas: trata-se da publicização do direito.

Apesar de essa prática semelhante à accountability também ocorrer nas iniciativas em que o direito brasileiro recepciona a soberania popular com novos procedimentos, como os orçamentos participativos, as conferências nacionais do Executivo e as audiências públicas no Judiciário e Legislativo, as iniciativas mais diretas de publicização do direito, como políticas de acesso a dados e informações públicas, contratos, decisões e outros atos oficiais, publicidade e comunicação institucional, são tão fundamentais quanto as primeiras. $^{453}$

Mas quando de trata de estados democráticos de direito, essas políticas de transparência e de abertura ao escrutínio do público não derivam de pretensões exigidas exclusivamente aos órgãos estatais, mas também a organizações sociais cuja atuação é reconhecidamente de influência pública, das executoras de contratos públicos às associações, fundações e empresas, e.g. as organizações de mídia e indústrias da cultura.

Diversos são os exemplos dessas políticas que procuram, de um lado, institucionalizar formas de participação mais direta da população na formação da opinião e da vontade política em todos os níveis do Estado, e de outro, promover políticas de acesso a informações e justificações governamentais e privadas presentes na esfera pública política. Serão analisadas algumas delas, aqui denominadas políticas de procedimentalização da soberania popular (a) e de publicização do direito (b).

Essas políticas representam, ao mesmo tempo, expressões prático-morais do que será proposto no capítulo nove como o duplo-movimento institucional do direito da comunicação, uma ferramenta de teoria social que permite analisar de modo geral as dinâmicas da esfera pública política na forma de políticas de direitos de comunicação (institucionalização de liberdades comunicativas que garantem livre acesso à esfera

${ }^{453}$ Essa tese será desenvolvida em termos de teoria normativa do direito nos capítulos 9 e 10 deste trabalho. Para algo semelhante à ideia de comunicação do direito que será desenvolvida então, ver as discussões sobre mídia e accountability em Maia (2008:297-320), e o estudo de Ericson. Why Law is Like News. in. Nelken (ed). Law as Communication, 1996, pp. 203-226. 
pública) e políticas de comunicação do direito, fornecendo ao mesmo tempo parâmetros normativos para avaliação dessas políticas (v. cap. 9.1 "b”). ${ }^{454}$

a) políticas de procedimentalização da soberania popular

A procedimentalização da soberania popular, no sentido de formas de “institucionalização de direitos comunicativos e participativos", está claro para Habermas como elas são fundamentais para garantir a criação do "código do direito" na perspectiva do princípio do discurso. ${ }^{455}$ Para o autor, sua aplicação em formas institucionais concretas deveriam ser "experimentadas de modo cauteloso", mas também com “imaginação institucional" (Habermas, 1996:440-441).

Elas cumprem, no entanto, uma exigência de 'democratização da administração', que decorre da obrigação que esta tem de apresentar aos cidadãos razões "normativas e atraentes" em seus programas legislativos. Os meios utilizados para tanto, que devem seguir os procedimentos de legitimidade constitucional, podem ser caracterizados como práticas de intersubjetivização do direito (v. parte III).

Outra questão interessante para a afirmação do paradigma procedimental do direito de Habermas é que aplicadas pelos três poderes, essas práticas de intersubjetivização impedem que sua independência institucional leve a uma autonomização em relação ao princípio da soberania popular. O vínculo que os três mantêm com esse princípio, no entanto, faz com que sua separação funcional possa ser interpretada como exigências de razões distintas que cada um deve apresentar à opinião pública para motivar suas decisões (Habermas, 1996:348).

A mais conhecida dessas práticas de intersubjetivização do direito é o Orçamento Participativo (OP). Iniciativa do poder executivo, implementada pela primeira vez em 1989 pela prefeitura de Porto Alegre como desdobramento da Constituinte de 88, este

\footnotetext{
${ }^{454}$ Nesse sentido, como se procurará demonstrar no capítulo 9, os fenômenos analisados nos capítulos deste diagnóstico da esfera pública (caps. 5-7) podem ser também relidos como expressões desse duplo movimento.

455 "'...the only regulations and ways of acting that can claim legitimacy are those to which all who are possibly affected could assent as participants in rational discourses. In the light of this 'discourse principle', citizens test which rights they should mutually accord to one another. As legal subjects, they must anchor this practice of self-legislation in the medium of law itself; they must legally institutionalize those communicative presuppositions and procedures of a political opinion and will-formation in which the discourse principle is applied. Thus the establishment of the legal code, which is undertaken with the help of the universal right to equal individual liberties, must be completed through communicative and participatory right that guarantee equal opportunities for the public use of communicative liberties. In this way, the discourse principle acquires the legal shape of a democratic principle." (Habermas, 1996:458).
} 
mecanismo que visa a aumentar a participação da população nas escolhas de prioridades orçamentárias foi reproduzida em 12 municípios nas gestões de 1989-1992 e em 104 na gestão 1997-2000 ${ }^{456}$, tendo assumido diversos formatos até o presente.

A iniciativa do OP criado em Porto Alegre foi pioneira e se tornou modelo após se institucionalizar propriamente após quatro gestões contínuas. Recebeu com isso a atenção de diversos estudiosos e gestores públicos de outros países, bem como reconhecimento da ONU (Programa de Assentamentos Humanos Habitat 1996) como uma das 40 melhores práticas de gestão urbana do mundo (Vitale, 2004:244).

Pesquisa de Denise Vitale com experiências de OP em seis municípios de grande, médio e pequeno porte do Brasil, mostra que os modelos variam de acordo com a população e o tamanho das cidades. Ela destaca que os grandes centros urbanos como Porto Alegre e Belo Horizonte, que procuraram contornar o número e a complexidade das demandas com sistemas de representação de delegados e conselheiros, atingiram resultados mais positivos do que os OPs das cidades menores, que tenderam a adotar medidas cada vez mais personalistas que às vezes acabam diminuindo o efeito democratizante da atividade (Vitale, 2004:250-251).

Isso decorreria também em grande parte pela baixa alocação de recursos para realizar as atividades do OP em municípios como Medianeira (PR) e Itapecerica da Serra (SP), pois como ainda não há uma regulamentação geral do instrumento, a flexibilidade da auto-regulamentação leva também a dependências em relação à "vontade política" dos prefeitos(as) (Id. Ibid).

Outra questão a se fazer a partir do modelo de procedimentalização da soberania popular como problema prático-moral, é que, apesar de reconhecer que o controle público do orçamento é uma das formas mais importantes de se exigir abertura da administração (Avritzer, 2004), não seria talvez limitador focar nas formas de participação popular na administração somente em deliberações orçamentárias? Isso porque alguns bens e serviços públicos deveriam ser garantidos apesar de oscilações econômicas ou dos sabores de políticos.

A saída pensada por Vitale de identificar no OP uma "dupla-democratização" a partir do aspecto formal de inclusão da participação igualitária dos cidadãos, ao lado do aspecto material da decisão sobre distribuição de recursos (Vitale, 2004:246), abre espaço

\footnotetext{
${ }^{456}$ Dados do texto de Denise Vitale. Democracia Direta e Poder Local: a experiência brasileira do orçamento participativo. In. Schattane \& Nobre (orgs), 2004:243.
} 
para que o OP inclua mais contribuições prático-morais além das técnicas nos debates. Para isso, no entanto, seus debates precisam ir além das políticas distributivas.

A forma como o OP realiza essa “dupla-democratização", no entanto, lembra o aqui se entenderá como duplo-movimento institucional do direito da comunicação, embora sem essa distinção entre garantia formal e material: de certo modo, nesta expressão práticomoral da esfera pública política, trata-se ao mesmo tempo de movimentos de procedimentalização da soberania popular e de publicização do direito. ${ }^{457}$

Já as Conferências Nacionais são instrumentos que o poder executivo tem mobilizado em termos de procedimentalização da soberania popular. Elas têm por objetivo captar necessidades e pretensões da sociedade civil em relação a temas que serão objeto de programas de governo. Essas conferências datam dos anos 40, mas 70\% de todas elas (114) foram realizadas nos últimos vinte anos, desde então com foco na formulação e na implementação de políticas públicas em diversos setores, o que trouxe o instrumento de volta para a agenda pública. ${ }^{458}$

Ainda assim, apesar de terem sido realizadas 68 conferências de janeiro de 2003 até maio de 2010 sobre os mais diversos temas - da saúde à segurança pública, dos direitos individuais aos direitos de minorias -, esses procedimentos parecem não atrair a atenção dos veículos de imprensa escrita ou eletrônica como seria exigível, pela importância pública dos eventos. Ao exercer essa função, poderiam reverberar as pautas e os argumentos dos debates como retratos da opinião pública sobre cada tema, mobilizando ainda mais a esfera pública política em torno das questões e acompanhando a recepção dos resultados pela administração.

No caso da I Conferência Nacional de Comunicação, realizada de 14 a 17 de dezembro de 2009, associações de grupos mais importantes da área, como a Abert, recusaram-se a participar, alegando que os debates eram ideologicamente enviesados e que não eram concedidas iguais oportunidades de participação. Isso fez com que essa conferência final de dezembro, que reuniu dez entidades públicas e dez entidades sociais do setor para debater pautas comuns para a área (v. resultados no tópico 5.1), passasse ao largo dos grandes noticiários, em mais um caso de informação de relevância social que é

457 "A dupla democratização tem, pois, tanto caráter formal quanto material. De um lado, a ampliação do modo de exercício da soberania popular, criando instâncias diretas de participação que se articulam às representativas. De outro, a redistribuição de bens e serviços públicos, visando democratizar o acesso aos recursos públicos." (Vitale, 2004:246. grifos nossos).

${ }^{458}$ Dados retirados do blog do jornalista Luís Nassif. Tìtulo: As Conferências Nacionais e a Democracia. (publicado em 24/06/2011) Transcrição de texto de Simone Biehler Mateos, Sinais de democracia participativa. publicado em Desafios (IPEA). www.advivo.com.br/blog/luisnassif (último acesso: 09/12/2012). 
negligenciada ao público pelos veículos de imprensa, isto é, um possível caso de "censura privada". 459

Algo completamente inverso à omissão dos grandes veículos de comunicação com as conferências nacionais é sua relação com as decisões do Supremo Tribunal Federal, especialmente quando há o uso do instrumento das Audiências Públicas.

Apesar de não serem exclusividade do STF ou do Poder Judiciário, a convocação do instrumento jurídico desde 2006 em decisões sobre temas complexos e polêmicos, como pesquisas com células-tronco, demarcação de terras indígenas e cotas para afrodescendentes no ensino superior têm gerado grande repercussão na esfera pública política, especialmente porque ganham destaque nos meios de comunicação. ${ }^{460}$

Mas a importância que o direito da comunicação destaca no instrumento da audiência pública não é tanto sua capacidade de repercutir no debate público e circular nos meios de comunicação, mas especialmente porque as audiências públicas também podem ser vistas como políticas de procedimentalização do direito de um tipo especial.

Isso porque parece clara a alusão a este procedimento quando Habermas ressalta no final de $D D$ a importância da institucionalização de esferas públicas políticas ligadas a tribunais e outras instituições. Sua eficiência dependeria da capacidade de obrigar o poder a se justificar e mobilizar as razões normativas esperadas para suas ações. Pode-se dizer, portanto, que direito se intersubjetiviza quando,

"Passando através dos canais de eleições gerais e várias formas de participação, opiniões públicas são convertidas em um poder comunicativo que autoriza a legislação e legitima as agências reguladoras, enquanto que uma crítica publicamente mobilizada de decisões judiciais impõe obrigações de justificação a um judiciário comprometido em desenvolver o direito." (Habermas, 1996:442. Itálicos nossos). ${ }^{461}$

\footnotetext{
${ }^{459}$ Ver documento da Confecom Ministério das Comunicações. Caderno $1^{a}$ Confecom. Conferência Nacional de Comunicação. 2010. Disponível em www.pfdc.pgr.mpf.gov.br (último acesso: 09/12/2011).

${ }^{460}$ Nos procedimentos previstos nas audiências públicas do Supremo, há o dever de registrar e inserir os documentos dos trabalhos das audiências nos arquivos do caso, ou quando em outra circunstância nos arquivos da presidência, bem como prevê a transmissão da audiência pública pela TV Justiça e pela Rádio Justiça, dois meios de comunicação estatais. Regimento interno do STF, art. 154, § único, I - VII, com conteúdo dado pela Emenda regimental 29/09.

461 Trad. livre do inglês: "Passing through the channels of general elections and various forms of participation, public opinions are converted into a communicative power that authorizes the legislature and legitimates regulatory agencies, while a publicly mobilized critique of judicial decisions imposes moreintense justificatory obligations on a judiciary engaged in further developing the law." (Habermas, 1996:442).
} 
Isso porque essas institucionalizações não servem só ao monitoramento da estrutura do judiciário, como no caso do Conselho Nacional de Justiça, mas também para facilitar a mobilização, o conhecimento e a crítica das razões para suas decisões (discursos de aplicação, v. Günther, 2004). Novamente, quando se trata de auto-regulamentação, não é possível conceber um espaço público político que critique livremente instituições quando este é composto majoritariamente de membros e gestores das mesmas. ${ }^{462}$

Curiosamente, problema semelhante ao do orçamento participativo fica evidente quando se avalia o desempenho das audiências públicas realizadas no STF. Trata-se do caráter facultativo da convocação do instrumento ao agente público competente, o que não colabora para que o órgão consiga compensar o déficit de legitimidade de suas decisões em relação ao princípio da soberania popular, presumido por seus membros serem indicados pelo Executivo. $^{463}$

Como já dito, essas audiências são instrumentos que podem ser utilizados pelos três poderes, e se fundam de modo geral na repercussão social e no interesse público do caso, bem como na necessidade de se ouvir especialistas e afetados direta ou indiretamente pela deliberação em pauta: a fórmula indeterminada "pessoas com experiência e autoridade em determinado assunto". ${ }^{464}$

Até junho de 2010 seis audiências públicas foram promovidas no STF. Das ainda não citadas restam a sobre aborto e a possibilidade de interrupção da gravidez de fetos anencefálicos (ADPF 54), outra relativa a importação de pneus usados (ADPF 101) e uma sobre o direito à saúde.

A criação de parâmetros para essas audiências no Supremo procuram garantir a objetividade a esse instrumento de procedimentalização da soberania popular, mas a definição de suas diretivas se mantém como atribuição do ministro que preside a audiência.

A Lei 9.868/99, que trata das ações diretas de inconstitucionalidade e declaratória de constitucionalidade, e a Emenda Regimental do STF 29/09 atribuem ao ministro-relator (ou ao presidente da Corte, no caso da Emenda) a faculdade convocar ou não a audiência após provocação ou ex-oficio, e a competência para decidir sobre os temas a serem debatidos, os casos relacionados, os expositores que serão ouvidos, sobre a organização

\footnotetext{
${ }^{462}$ V. discussão sobre o Conar acima, (tópico 6.1 "a").

${ }^{463}$ V. discussões sobre esse tema em Habermas, Era das Transições, 2003, pp. 156-173; Id. 1996:261-266.

464 Art. 20, § $1^{\circ}$, Lei 9.868/99 estabelece que: "Em caso de necessidade de esclarecimento de matéria ou circunstância de fato ou de notória insuficiência das informações existentes nos autos, poderá o relator requisitar informações adicionais, designar perito ou comissão de peritos para que emita parecer sobre a questão ou fixar data para, em audiência pública, ouvir depoimentos de pessoas com experiência e autoridade na matéria.
} 
dos depoimentos orais, se recebe por escrito outras contribuições da sociedade, como controla as sessões, entre outras funções. ${ }^{465}$

As perguntas a se fazer são se essas previsões não concentrariam muito poder discricionário ao presidente ou ao ministro relator, e se os procedimentos definidos para as audiências seriam formais o suficiente para compensarem sua dependência em relação a essa previsão de julgamento subjetivo ou atitude de protagonismo do relator ou presidente do tribunal.

Especialmente no que se refere à escolha de temas e a decisão sobre quem será o expositor, parece que essa norma poderia sem grandes problemas permitir que os participantes pudessem escolher os tópicos de sua própria argumentação, o que garantiria direitos fundamentais de liberdade comunicativa ${ }^{466}$ ao procedimento.

A inserção de critérios mais objetivos no regulamento das audiências poderia limitar esse poder discricionário do juiz relator. Quando uma matéria sob júdice no Supremo é considerada justificadamente de direitos humanos (ou toca os direitos fundamentais da Constituição), a convocação de audiência pública poderia ser mandatória, garantindo o instrumento como uma política regular de procedimentalização da soberania popular.

Como será possível discutir na parte final deste estudo (III), a procedimentalização da soberania popular e a publicização do direito (abaixo) são processos de intersubjetivização institucional que servem não só como parâmetros normativos para a democratização dos três poderes do Estado, mas também para exigir publicidade e avaliar a legitimidade das decisões e ações de todas as instituições, organizações e coletividades públicas, privadas e híbridas - e mesmo indivíduos que atuam na esfera pública política.

A responsabilidade desses atores em relação às pretensões de comunicação e de reconhecimento e os direitos e deveres que protegem e estimulam a esfera pública política

\footnotetext{
${ }^{465}$ Em 2009, a Emenda Regimental 29/09 acrescentou ao Regimento Interno da corte normas que permitem ao seu presidente "convocar audiência pública para ouvir as declarações das pessoas com experiência e autoridade em determinado assunto, sempre quando se entende a necessidade de clarificação de questões de circunstâncias de fato, com repercussão geral e interesse publico relevante, que são debatidos na Corte" e para "decidir, de forma inquestionável, sobre a manifestação de terceiros, registrados por advogado habilitado, em audiências públicas (...)” (Art. 13, XVII e XVIII, Regimento Interno do STF atualizado pela Emenda Regimental 29/09). A mesma norma estabelece que o ministro relator tem a atribuição de convocar a audiência pública e decidir sobre a manifestação de terceiros (Art. 21, XVII e XVIII, Reg. Int. do STF atualizado pela Emenda Regimental 29/09). Da mesma forma, o art. $7^{\circ}, \S 2^{\circ}$, art. $7^{\circ}$ da Lei 9868/99 prevê que: O relator, considerando a relevância da matéria e a representatividade dos postulantes, poderá, por despacho irrecorrível, admitir, observado o prazo fixado no parágrafo anterior, a manifestação de outros órgãos ou entidades.

${ }^{466}$ Este conceito é fundamental para se pensar de forma ampla os direitos de comunicação que garantem esferas públicas mais autônomas. Ele será aprofundado na terceira parte deste estudo. Para antecipar o debate, v. Günther, 1998. Habermas, 1996:125-131.
} 
deverão ser aferidos em cada caso concreto a partir da interpretação justificada da natureza de cada um - no sentido do tipo de organização, áreas de atuação e respectivas responsabilidades, de acordo com a Constituição Federal -, e da extensão e impactos de seus discursos e ações sobre a esfera pública política.

\section{b) políticas de publicização do direito}

A publicização do direito, ou a pretensão normativa institucional do princípio da publicidade, é o princípio básico da comunicação pública (aqui entendida como interface da comunicação social e a comunicação política). Isto é, toda comunicação que circula entre os três níveis da esfera pública política descritos por Habermas como "discursos institucionalizados", "comunicação de massa dos meios de comunicação" e "comunicação cotidiana da sociedade civil” (2009:158), está sujeita a essa obrigação de transparência; em última análise, de expor para o escrutínio de todos as razões que motivam suas ações e decisões que de algum modo afetam a esfera pública. ${ }^{467}$

Como foi dito no início deste tópico, o direito da comunicação procura contribuir com a teoria discursiva do direito de Habermas especialmente no que diz respeito à sua pretensão de complementar a autocompreensão do funcionamento do Estado democrático de direito, pois só é possível garantir liberdades iguais a todos por meio da institucionalização de direitos de comunicação de participação (Habermas, 1996:458), podendo-se acrescentar também direitos de reconhecimento (v. cap. 7 abaixo).

Além disso, busca-se incluir nessa teoria - ou tornar mais claro dentro da formulação de Habermas em $D D$ - o direito individual de toda pessoa ao acesso a redes de relações de reconhecimento recíproco, dentro das quais pode desenvolver livremente sua personalidade e uma autocompreensão de si mesma. ${ }^{468}$

\footnotetext{
${ }^{467}$ Habermas ressalta a importância desse aspecto da esfera pública política quando inicia uma análise das atuais "patologias da comunicação política" "Tiene aún la democracia unadimensión epistémica?" (2009:173). Mas isso ocorre somente em nota de rodapé no início da análise, demonstrando que seu enfoque está em políticas de procedimentalização da soberania popular, e não de publicização do direito: "Dado que en este momento nos movemos en el ámbito de las investigaciones científicas sobre la comunicación no puedo entrar a analizar la condición ulterior de que la esfera pública política tiene que procurar la transparência de todos los procesos relevantes de la formulación de la política. Como consecuencia de esta condición, también todas las demandas políticas que se plantean apelando a los imperativos funcionales del sistema econômico tendrían que ser encauzadas por los canales de la esfera pública. Esto afecta a la incesante discusión acerca de la relación entre la democracia y el capitalismo; cf. C. Offe, Strukturprobleme des kapitalistischen Staates, nueva ed. mod. Campus, Frankfurt a. M./New York, 2005 (la version original data de 1972)." Habermas, 2009:173.

${ }^{468}$ Essa extensão da proteção à integridade do indivíduo será desenvolvida a partir da recepção mais recente que Habermas tem feito da teoria do reconhecimento de Axel Honneth, pois ela poderia garantir no presente
} 
Mas se essa pretensão normativa sugerida no posfácio de $D D$ (1994) significa não somente a necessidade de institucionalização de liberdades comunicativas de todas as formas, mas também uma tentativa de reinterpretar o sentido do princípio da publicidade no direito contemporâneo - esforço que este estudo partilha -, as atuais pretensões normativas por acesso à informação pública, transparência e accountability e as respostas do Estado em relação a elas podem ser vistas como políticas de publicização do direito, conferindo um sentido mais procedimental ao princípio da publicidade.

Isso porque, sem se pensar nas formas com as quais se publicizam (ou se comunicam) as normas e ações políticas e sociais, não há estímulo à criação de ambientes informativos, com pluralidade de fontes e liberdades de comunicação em todas as esferas de interação social capazes de gerar uma cultura "acostumada à liberdade", requisitos para a formação de esferas públicas políticas "emancipatórias". 469

Sem uma esfera pública política envolvida por esses ambientes informativos, transparentes e regulados por direitos fundamentais, corre-se o risco de não haver condições para uma legitimação democrática do poder. E como se sabe, um poder político ilegítimo gera um estado de insegurança institucional e social que poucos governos no mundo atualmente se dispõem a enfrentar.

Por isso, qualquer Estado que se pretenda democrático ou organização social que queira atuar na esfera pública política realizando trabalhos relevantes para a reprodução material ou simbólica da sociedade precisam promover políticas de publicização do direito, sob pena de serem os responsáveis por iniciarem as crises encadeadas de legitimidade que minam suas próprias atividades e contribuem para uma radicalização do dissenso social (Habermas, 1996:386).

Respondendo, portanto a essas pretensões normativas de publicização do direito, diversas políticas nesse sentido têm sido colocadas em prática recentemente na esfera

o espaço de autonomia da subjetividade individual que nos séculos XVIII e XIX foram responsáveis pelo surgimento da esfera pública literária, condição para a formação de uma esfera pública política "autêntica", como descrita por Habermas em MEEP (2003:42-74). Isso porque em estudos mais recentes sobre filosofia política do autor esta tentativa tem se mostrado mais presente (2007:293), porém sem um desenvolvimento sistemático. V. caps. 8 e 9 desta tese.

${ }^{469}$ Em grandioso estudo sobre o sentido de justiça como emancipação na obra de Habermas, Eduardo Bittar demonstra a relação de reciprocidade entre políticas de procedimentalização da soberania popular e uma cultura de convivência democrática, esta que se torna possível a partir do direito da comunicação com políticas de publicização do direito: “...para que a esfera pública atue a contento, e possa representar um mecanismo emancipatório consistente, é de todo fundamental que a aposta seja depositada não somente na canalização de procedimentos deliberativos inclusivos, como as experiências do orçamento participativo, da plurificação de entidades e associações representativas, da consulta pública e da deliberação coletiva, mas também na expansão da educação, no estímulo à moralização do convívio social, bem como na criação de condições estruturais para o desenvolvimento de uma atitude política entre os membros da sociedade civil." (Bittar, Justiça e Emancipação, 2011:453). 
pública política nacional. Uma delas foi a iniciativa de disponibilização de dados de segurança pública, violência e criminalidade, promovida pelo governo do Estado de São Paulo para acesso contínuo de qualquer cidadão desde 15 de abril de 2011. É importante relatar que isso ocorreu após a demissão do pesquisador responsável pela coleta desses dados, que foi acusado de tê-los vendido - quando ainda eram sigilosos - a empresas privadas por meio de sua consultoria particular. ${ }^{470}$

Essa iniciativa foi seguida por notícia mais recente ${ }^{471}$ da implementação de uma política nacional de padronização e sistematização de dados sobre segurança pública, violência e criminalidade. A proposta é histórica no país, que sofre críticas da comunidade internacional, da comunidade de pesquisadores que trabalham com as áreas da segurança pública, violência e criminalidade, e de entidades e conselhos que realizam projetos de segurança cidadã no país. ${ }^{472}$

Uma das questões prático-morais complexas em relação à publicização desses dados é se eles colaboram ou não para aumentar a segurança, a sensação de segurança e a honra e privacidade dos cidadãos. Do mesmo modo que às decisões da imprensa de informar ou não sobre seqüestros em andamento - algumas deixaram de fazê-lo e outras ainda o fazem (como a Globo. v. Organizações Globo, 2011), o problema se impõe também à administração pública, que justificou até então a não-publicização desses dados em função da possibilidade de causar algum tipo de alarma social, o que é contestado por especialistas na área. ${ }^{473}$

Até o momento no Brasil esse tipo de reivindicação de informações sobre a segurança pública e criminalidade se circunscrevia somente a algumas instituições sociais, como centros de pesquisa e entidades sociais do setor. Mas sua inserção em um grupo de outras políticas mais recentes de acesso à informação pública pelo executivo, que tem nova Lei de Direito de Acesso à Informação Pública como carro-chefe reforçam as pretensões práticas de publicização do direito na esfera pública nacional, capazes de contribuir para a

\footnotetext{
${ }^{470}$ V. Reportagem sobre o caso do caderno "Cotidiano" do jornal Folha de S.Paulo de 01/03/2011.

${ }^{471}$ V. notícia do jornal Folha de S.Paulo no caderno "Cotidiano" de 07/12/2011.

${ }^{472}$ Pesquisa recente da ONG Fórum Brasileiro de Segurança mostra a precariedade dos dados nacionais no setor. V. Fórum Brasileiro de Segurança Pública. Anuário Brasileiro de Segurança Pública. Disponível em www.forumseguranca.org.br (último acesso: 13/12/2011). No caso de projetos de policiamento comunitário, o acesso a dados e informações de qualidade sobre as ocorrências de criminalidade do bairro ou região é fundamental para a elaboração das estratégias de ação, permitindo a eficácia dos planos com o mínimo de recursos utilizados. V. Núcleo de Estudos da Violência da USP Cardia. Manual de Policiamento Comunitário. Polícia e Comunidade na Construção da Segurança. Dados eletrônicos. 2009.

${ }^{473}$ V. texto elaborado por nove instituições de pesquisa e promoção de direitos humanos e violência nacionais, entre elas o Conectas Direitos Humanos, o Sou da Paz e o Núcleo de Estudos da Violência da USP, intitulado Justiça Criminal: o que fazer. Uma agenda para o próximo governo, 2010:13-14. Disponível em www.soudapaz.org.br (último acesso: 24/12/2011).
} 
formação de espaços públicos no quais se discutem as condições para se criar uma cultura acostumada a exigir e receber acesso às informações de interesse público.

No caso dessa nova Lei (n. 12.527), sancionada pela presidenta Dilma em 18 de novembro de 2011, com os 180 dias de vacatio legis, uma política de publicização do direito na forma de campanhas educativas de educação e discussão em relação à lei poderia ser promovida, como de fato se exige em termos de publicidade aos três níveis de governo que devem obediência à nova lei. ${ }^{474}$

Essas campanhas poderiam incluir formas diversas de exposição, mobilização e discussão sobre as pretensões normativas do novo marco legal, bem como também procedimentos para sua implementação, apresentados por meio de oficinas, cursos e seminários sobre o tema. Seu financiamento poderia advir das verbas de publicidade institucional de órgão obrigado à realizar a política.

Recentes declarações de agentes públicos, no entanto, mostram que não será tão fácil garantir o respeito à lei, pois não haveria ainda no país uma cultura publicística capaz de incorporar rapidamente os hábitos de trocas de informações e práticas de accountability entre servidores públicos e cidadãos. Além disso, não estariam claros quais tipos de informação seriam exigidos a cada órgão.

Essa nova interface de comunicação constante entre o serviço público e os cidadãos exigiria, portanto, alterações na própria "cultura institucional" nacional. Mas como a formação dessa cultura - ou, nos termos habermasianos, do ambiente disposto a trocas de justificações e críticas em relação à norma - é um dos efeitos da publicização do direito, neste caso, pode-se dizer que é fazendo que se aprende. ${ }^{475}$

Por ter essas características, a nova lei de acesso à informação pública pode ser comparada com a Freedom of Information Act dos EUA, norma procedimental de publicização do direito no país que obriga a divulgação ao público de informações públicas (secretas ou não) do governo após certo tempo. Essa norma paradigmática desse tipo de

\footnotetext{
${ }^{474}$ Importante salientar como as instituições responsáveis pelo cumprimento da norma de acesso a informações públicas não são somente estatais, mas também as privadas e sociais: art. $1^{\circ}$, § indica que: "Subordinam-se ao regime desta Lei: I - os órgãos públicos integrantes da administração direta dos Poderes Executivo, Legislativo, incluindo as Cortes de Contas, e Judiciário e do Ministério Público; II - as autarquias, as fundações públicas, as empresas públicas, as sociedades de economia mista e demais entidades controladas direta ou indiretamente pela União, Estados, Distrito Federal e Municípios. Art. $2^{\mathrm{o}}$ Aplicam-se as disposições desta Lei, no que couber, às entidades privadas sem fins lucrativos que recebam, para realização de ações de interesse público, recursos públicos diretamente do orçamento ou mediante subvenções sociais, contrato de gestão, termo de parceria, convênios, acordo, ajustes ou outros instrumentos congêneres (itálicos nossos).

${ }^{475}$ A nova lei de direito de acesso à informação pública, bem como outros debates e produções sobre o tema estão disponíveis no endereço da ONG Informação Pública www.informacaopublica.org.br. (último acesso: $12 / 12 / 2011$
} 
política comemorou recentemente seu aniversário de 45 anos em meio a eventos internacionais para a promoção da publicidade, transparência e accountability, pouco tempo antes da promulgação da lei brasileira.

Com uma norma dessa natureza, o Brasil se torna o $89^{\circ}$ país a adentrar um grupo seleto de nações comprometidas com a transparência e a accountability das instituições do estado e outras atuantes na esfera pública, como apontou recente reportagem da Folha de S.Paulo sobre a aprovação da nova lei. ${ }^{476}$

Uma das disposições mais polêmicas da lei de direito de acesso à informação pública é a revogação do sigilo eterno de documentos ultrassecretos do Estado - agora de 25 anos prorrogáveis somente para 50. A discussão sobre esse dispositivo reascendeu a esfera pública política em torno da questão, dando continuidade a uma série de outras iniciativas importantes do governo e da sociedade civil por mais publicidade e transparência das informações públicas, como os movimentos pela revisão do regime militar de 1964-85. Estes propugnam a abertura dos arquivos da ditadura como garantia dos direitos à memória e à verdade, primeiros passos de um processo de justiça transicional que finalmente se instaura no país. ${ }^{477}$

A institucionalização de uma Comissão da Verdade no Brasil, criada por lei federal em 18/11/2011 (Lei 12.528) para rever e documentar as violações de direitos humanos praticadas durante o período autoritário, era até 2009 uma possibilidade ainda remota. Mas os esforços coletivos e articulados da sociedade civil organizada a partir de então, especialmente da academia e grupos de parentes de vítimas do regime conseguiram, junto ao trabalho pró-ativo de órgãos governamentais da área, mobilizaram a esfera pública no final do governo Lula com diversos seminários, exposições, debates e outros eventos. Esses trabalhos deram condições para que a presidenta Dilma pudesse costurar já no seu primeiro ano de mandato um acordo entre os atores envolvidos - inclusive os militares - e aprovar a comissão, que funcionará por dois anos com início provável em 2012.

As pretensões normativas presentes no espaço público institucional formado pela comissão da verdade têm claramente entre elas a busca cooperativa pela verdade e a pluralidade de visões de mundo, analisadas nos tópicos 5.2 e 5.4 desta tese. Suas fortes ligações com as questões morais das violências políticas praticadas durante o regime, no

${ }^{476}$ V. análise do jornalista Fernando Rodrigues na edição de 26/10/2011 da Folha de S.Paulo, caderno "poder".

${ }^{477}$ Para um estudo do tema sob a perspectiva da teoria do reconhecimento de Honneth, v. Blotta, V. Levy, W. Vincenzi. Reconhecimento, Memória História e Justiça de Transição no Brasil. in. Bittar (org.) História do Direito Brasileiro, 2010. 
entanto, bem como seus procedimentos particularmente interessantes de publicização do direito, permitem esta breve exemplificação do caso como expressão prático-moral da esfera pública política.

O último caso de política publicização do direito brevemente interpretado neste tópico é um exemplo negativo da revogação da Lei de Imprensa pelo Supremo Tribunal Federal em 2009, após a ação de descumprimento de preceito fundamental n. 130 proposta pelo deputado Miro Teixeira do PDT junto à Federal Nacional de Jornalismo, a Associação Brasileira de Imprensa e a ONG Artigo 19. Esse exemplo revela um entrecruzamento aparentemente conflitivo entre liberdades comunicativas e pretensões de publicidade do direito, o que demanda uma breve análise a partir da relação entre liberdades negativas e positivas de comunicação.

A argumentação do ministro-relator Ayres Britto trata da incompatibilidade do ordenamento com uma norma criada durante o regime militar para regular uma instituição que é essencialmente democrática como a imprensa, e que por isso restringiria liberdades de comunicação, como as penas de prisão para jornalistas que excedessem a "liberdade de informar". 478

Apesar das boas intenções do Supremo, o "vácuo legislativo" criado pela revogação da lei talvez não seja a melhor forma de se garantir liberdades comunicativas. Isso porque elas atualmente significam liberdades referidas ao espaço público, sendo garantidas por meio de políticas positivas de procedimentalização da soberania popular ou de publicização do direito: são exemplos demandas por pluralidade de vozes na produção cultural, no primeiro caso, e no segundo o uso de verbas de publicidade governamental para projetos que apresentam e justificam de modo acessível ao público todas suas normas e atos administrativos de interesse público.

Ausência de regulação torna muito mais difícil a implementação de políticas positivas de publicização do direito em relação a órgãos e empresas de imprensa e comunicação social, mas ao mesmo tempo também dificulta a proteção jurídica das expressões mais diversas da liberdade comunicativa, exercidas tanto por indivíduos como

\footnotetext{
478 V. cap. III da revogada Lei 5.250/67. Ver notícias sobre decisão do STF em 30/04/2009. A ementa do voto de Ayres Britto revela a interpretação de uma oposição entre concepções negativas e positivas de liberdade de expressão: "Ponderação diretamente constitucional entre blocos de bens de personalidade: o bloco de direitos que dão conteúdo à liberdade de imprensa e o bloco dos direitos à imagem, honra, intimidade e vida privada. Precedência do primeiro bloco.” V. pp. 1-2 do Acórdão disponível no endereço eletrônico do STF.
} 
por organizações políticas e sociais que respondem pelo uso dessas liberdades na esfera pública. ${ }^{479}$

Segundo ação de inconstitucionalidade por omissão (ADO n. 9) proposta em outubro de 2010 no STF pelo jurista Fábio Konder Comparato em nome da Fenaj Federação Nacional dos Jornalistas e da Fitert - Federação Interestadual de Rádio e Televisão, a revogação total da Lei de Imprensa impõe ação imediata do Legislativo, cuja omissão até o momento gera a incapacidade do exercício de diversas liberdades que tinham regulamentação estabelecida pela lei de imprensa, como especificações do direito de resposta, valores de indenizações por dano moral e à imagem, ou mesmo formas pelas quais o indivíduo ou a família podiam se defender contra abusos dos meios de comunicação (art. 220, §3, II, CF; cap. III da Lei de imprensa). A ação foi primeiramente considerada inepta pelo STF por ilegitimidade de parte, mas depois proposta novamente pelo PSOL em novembro do mesmo ano. No momento, aguarda parecer da Procuradoria Geral da República (ADO n. 11).

Os exemplos e contra-exemplos de políticas de intersubjetivização do direito são diversos, e ao citar alguns, diversos outros ficam de fora deste espaço. Mas o que essas breves interpretações de casos recentes permitem perceber em termos de diagnóstico dessa expressão da esfera pública política nacional é que, apesar de detectada toda essa movimentação por novas formas institucionais de exercício da soberania popular ao lado de políticas de publicização do direito, ainda permanece, especialmente no setor privado, uma ideia equivocada de que desregulamentar a esfera pública política levaria a mais espaço para o uso livre dos direitos de comunicação e informação, afastando-se o perigo da censura estatal.

Ainda que, para organizações comerciais atuantes na esfera pública com plenas condições de exercitar suas liberdades comunicativas, a ausência de qualquer tipo de

\footnotetext{
${ }^{479} \mathrm{O}$ voto do Min. Joaquim Barbosa pela procedência parcial da ADPF 130 ressaltou exatamente como a ausência de regulamentação sobre o tema pode ferir os princípios de pluralismo de vozes nos meios de comunicação que são constitutivos da liberdade de expressão: "Estamos todos plenamente conscientes e acordes quanto ao papel fundamental da Imprensa na sociedade moderna, sobre a sua natureza intrinsecamente fundamental, enquanto direito fundamental de primeiríssima grandeza, e, claro da sua magna importância na evolução e na consolidação de uma democracia, especialmente de democracias ainda em flor, como a nossa. (...) // Contudo, não basta ter uma Imprensa inteiramente livre. Em primeiro lugar, é preciso que ela seja suficientemente diversa e plural, de modo a oferecer os mais variados canais de expressão de ideias e pensamentos aos mais diversos segmentos da sociedade; em segundo lugar, é preciso que essa salutar e necessária diversidade da Imprensa seja plena a ponto de impedir que haja concentração. Situações como as existentes em algumas unidades da nossa Federação, em que grupos hegemônicos dominam quase inteiramente a paisagem audiovisual e o mercado público de ideias e informações, com fins políticas, não é nada positivo para a formação da vontade pública e para a consolidação dos princípios democráticos. Noutras palavras, a concentração de mídia é algo extremamente nocivo para a democracia." (Acórdão da ADPF 130, pp. 108-109).
} 
regulamentação externa (pelo Estado ou pelo público) possa parecer o melhor dos mundos, ao longo do tempo pode gerar uma desconexão com esses atores e instâncias, com quem as organizações mantêm certos contratos e compromissos intersubjetivos que não pode descumprir sem perder sua legitimidade ou credibilidade.

Mesmo como forma de proteger a liberdade de imprensa, a desregulamentação também não é o caminho mais seguro. Sem uma norma mais específica que operacionalize certas liberdades de comunicação e reconhecimento, coloca-se em risco a circulação constitucionalmente regulada da comunicação e perde-se a previsibilidade das sentenças relativas à área.

Ao final dessa discussão sobre a expressão prático-moral da esfera pública política no Brasil, espera-se que tenham ficado claras as pretensões normativas a uma circulação constitucionalmente regulada da comunicação, que procura contornar a contradição aparente entre autonomia individual e autonomia política na área; a importância do direito à comunicação como forma positiva da liberdade de expressão que a conecta com o princípio do livre acesso à informação; e as pretensões normativas procedimentais do direito da comunicação que permitem uma crítica social da esfera pública política, quais sejam, a procedimentalização da soberania popular e a publicização do direito.

Sem a garantia dessas pretensões normativas, a esfera pública política não tem condições de mobilizar as razões prático-morais por trás das normas constitucionais da comunicação social e da comunicação política, tornando a esfera pública política suscetível especialmente a determinações econômicas. E como nem mesmo o mercado subsiste sem de regulações de fundo prático, muito menos poderá a esfera pública política.

\section{Expressões Estético-Expressivas da Esfera Pública Política no Brasil}

Este último esforço para um diagnóstico do presente da esfera pública política no Brasil propõe concentrar-se nas problematizações políticas formadas pelos discursos estético-expressivos, suas violações e afirmações, bem como suas interpenetrações com os discursos técnico-científicos e informativos e prático-morais que estão presentes em casos práticos nacionais.

Serão interpretadas, portanto, a natureza e as dimensões dos espaços públicos formados atualmente em torno de três problemas fundamentais: primeiramente, seguindo as discussões sobre as políticas de publicização do direito, será analisado de modo sucinto o impacto da comunicação estética na formação da esfera de visibilidade pública, e seus 
reflexos sobre o princípio da publicidade do direito e o fenômeno da consciência das normas (7.1). Em seguida, será trabalhado um tópico sobre comunicação expressiva que é muito ligado à razão prática: o direito ao livre desenvolvimento da personalidade no espaço privado da família, que revela a pretensão a uma proteção constitucionalmente justificada da esfera privada (7.2). Por fim, serão discutidas algumas reivindicações por liberdades de crença e autocompreensões éticas e existenciais, que ainda sofrem problemas de violência, discriminação e falta de reconhecimento na esfera pública política. Esses espaços públicos ao final poderão colaborar para o aumento de práticas daquilo que se denominará aqui "solidariedade negativa" ${ }^{480}(7.3)$.

\subsection{Comunicação icônica, visibilidade e publicização da autoridade política}

Como foi visto em algumas passagens de $M E E P^{481}$, as dimensões estética e de auto-representação que revestem os discursos públicos tiveram grande responsabilidade na formação de uma esfera pública representativa, que antecedeu a burguesa e nela se imiscuiu, mas também influenciam a fabricação de uma esfera pública refeudalizada nas democracias de massa, a partir da linguagem audiovisual da comunicação social.

Ou seja, os elementos estéticos da comunicação ou as formas que ela assume passam a se infiltrar de modo quase parasitário nos processos de argumentação pública, provocando identificações inconscientes que prejudicam sua racionalidade e acabam por determinar os juízos prático-morais, ou mesmo os cognitivo-instrumentais na esfera pública política.

Com isso, se já havia antes uma dificuldade de se abstrair os argumentos presentes na esfera pública burguesa de suas auto-representações, isto é, do papel social de quem os expunha, algo semelhante, embora ainda mais acentuado, volta a ocorrer com a mudança estrutural das esferas públicas das democracias de massa. A dominação da comunicação icônica impõe também a necessidade de se expor em um espaço de visibilidade pública as pretensões argumentativas de cada discurso, e no caso de sociedades de massa, especialmente nos meios de comunicação eletrônicos.

\footnotetext{
${ }^{480}$ P. uma análise antecipada, v. Boltanski, Distant Suffering, 2005; Blotta, The Fascination of Authority and the Authority of Fascination. 2010b.

${ }^{481}$ v. cap. 2 "b" desta tese.
} 
Mais do que isso, leva a crer também que, como afirma Gomes (Gomes \& Maia, 2008:134) ${ }^{482}$, a dimensão da visibilidade pública nunca se dissociou totalmente da esfera da discussão pública na composição da esfera pública política - a argumentação nunca dispensa totalmente alguma forma de exposição -, nem mesmo no efêmero tempo que Habermas caracterizou como "capitalismo concorrencial", quando a esfera pública teria se tornado mais argumentativa e constitucionalizado os princípios da publicidade (2003:169171).

Assim como não existe comunicação sem um suporte lingüístico, não há argumentação sem sua respectiva auto-representação estética. Esse aspecto da esfera pública política nacional será abaixo analisado num primeiro subtópico sobre a predominância da comunicação icônica na esfera pública política e sua influência na formação do espaço de visibilidade pública, este que, ao mesmo tempo em que se torna seu palco principal, contribui para o que Habermas diagnosticará em 2006 como "caos da esfera pública" (a). Em seguida, será feita uma análise de como esse espaço de visibilidade pública pode contribuir para uma crítica e um aprofundamento de políticas de publicização do direito (b).

a) predominância da comunicação icônica como elemento de desestabilização e crítica da racionalidade na esfera pública política

Nos textos mais recentes sobre esfera pública e mídia de Habermas, é possível perceber que o autor está preocupado em denotar ambivalências na comunicação pública,

\footnotetext{
482 “....sempre pareceu importante aos burgueses a proteção da esfera de visibilidade pública - da qual faz parte a cena política - de qualquer ameaça de redução ou extinção.As chamadas liberdade de expressão e de imprensa são tão-somente garantias legalizadas pelo Estado de Direito, voltadas para a proteção da publicidade social, evitando as ameaças do domínio incontrolável de um poder que pudesse ser exercido ocultamente e, portanto, insubmisso a qualquer visibilidade, a qualquer controle. A visibilidade é instrumento da perda de altura e de aura por parte do poder. A necessidade de que as posições e sujeitos em disputa se exponham - alguns exageradamente falariam de necessidade de transparência - é uma necessidade antitirânica, que substitui o temor e a veneração pela adesão consciente. (...) // O que talvez tenha escapado Habermas tenha sido o fato de que a publicidade social, enquanto esfera de visibilidade pública, sempre incluiu representações, atos e cerimoniais, entretenimento, propaganda, entre outros, e até mesmo debates mas jamais exclusivamente debates. Quem sabe se tivesse visto isso não teria podido aceitar o fato de a publicidade social, como esfera de visibilidade pública na sociedade contemporânea, organizar-se fundamentalmente segundo a lógica comercial de captura da atenção, a lógica social da produção para o tempo livre e a estética conseqüente do espetáculo, da diversão, da beleza plástica, do extraordinário. A esfera de visibilidade social nunca teve a obrigação de transformar-se em esfera do debate público e nenhuma sociedade parece ter sentido a necessidade de transformá-la nisso."” (Gomes \& Maia, 2008:134 e 137).
} 
que se tornam mais visíveis com o impacto da comunicação icônica trazida pela televisão e as recentes transformações promovidas pela internet (Habermas, 2006; Id, 2009). ${ }^{483}$

Essa preocupação de Habermas deve ser analisada com mais detalhe, no entanto, pois mesmo identificando sérias ameaças ao potencial para a formação de esferas públicas "mais ou menos racionais" (Id, 2009:132-135) com a emergência das novas tecnologias de informação e comunicação, enquanto elas continuam a depender minimamente de algum tipo de reprodução da comunicação cotidiana que emerge de contextos do mundo da vida, isto é, da própria linguagem e interação humanas, os potenciais emancipatórios e críticos da razão e do agir comunicativo estarão assegurados (Habermas, 1987-II:473-554). Isso seria verdade no contexto atual por que:

(...) por um lado, a reorientação da comunicação, da imprensa e do jornalismo escrito para a televisão e a internet conduziu a uma ampliação insuspeitada da esfera pública midiática e a uma condensação ímpar das redes de comunicação. A esfera pública, na qual os intelectuais se moviam como os peixes na água, tornou-se mais includente, o intercâmbio é mais intenso do que em qualquer época anterior. (Habermas, O Caos da Esfera Pública, 2006).

Apesar disso, há novos obstáculos à formação de uma esfera pública política capaz de gerar uma legitimação democrática do poder, como os fenômenos de "informalização" da esfera pública e de "indiferenciação" dos papéis dos atores. Mais ainda, a internet teria mostrado que o "preço a se pagar" pelo do igualitarismo nas redes seria a "descentralização do acesso a contribuições não-escritas”, o que dificultaria a formação de focos de opinião pública.

O destaque para o aumento das "contribuições não-escritas", ou o efeito extremamente importante que a comunicação imagética (ou icônica, num sentido mais semântico) exerce sobre a esfera pública política do presente, é coerente com os diagnósticos de Bucci (2002) e Schwartz (2006) sobre o tema, discutidos nos tópicos 5.2 e 4 "d" desta tese. Não é mera coincidência a divulgação recente de pesquisa indicando

\footnotetext{
${ }^{483}$ Essa tese não é só confirmada pela revisão que Habermas faz de MEEP 30 anos depois, mas também em trabalhos recentes sobre o tema, publicados em volumes como Ach, Europa (Id., 2008, German version. Spanish version, 2009:177-178). As contradições que Habermas identifica no caráter presumidamente manipulativo da comunicação de massa em The Theory of Communicative Action a partir de diversos estudos de especialistas (Habermas, 1987-II:553), podem ser resumidos em: 1. a variabilidade dos fatores que influenciam a produção de informação e a evolução técnica da mídia; 2. a existência de produções que não reafirmam os conteúdos pasteurizados e repetitivos da indústria cultural; 3. a capacidade crítica e a requalificação da informação dos contextos culturais de recepção; 4. o poder da comunicação oral e cotidiana em se opor às mensagens políticas e ideológicas da mídia. Para mais sobre essa análise Habermas, v. Blotta, Mídia e Cidadania, 2008:4-10.
} 
como a exposição de crianças à televisão - e agora a diversos outros aparelhos portáteis de comunicação audiovisual - antes dos dois anos de idade pode ser prejudicial para seu desenvolvimento lingüístico, especialmente a fala. ${ }^{484}$

Para tornar claro o diagnóstico de uma comunicação icônica expandida sobre os outros discursos da esfera pública, vale à pena reproduzir outro trecho de "O Caos da Esfera Pública":

“a televisão transformou o palco. Deve mostrar em imagens o que quer dizer, e acelerou o 'iconic turn', a virada da palavra para a imagem. Essa desvalorização relativa desloca também os pesos entre duas funções distintas da esfera pública. // Como a televisão é um meio que torna algo visível, confere celebridade no sentido de notoriedade aos que aparecem em público (...) // Mesmo se o conteúdo remete a um evento discursivo, a televisão convida os participantes à representação de si mesmos, como podemos observar em muitos 'talk shows'. O momento da auto-representação dos atores transforma inevitavelmente o público judicante -que, diante da tela, participa do debate sobre temas de interesse geral - também em um público assistente." (Habermas, O Caos da Esfera Pública .Caderno “Mais!”. Folha de S. Paulo, 13/08/2006. Itálicos e grifos nossos).

Como é possível refletir cautelosamente a partir desse redimensionamento da esfera da visibilidade pública, Habermas se esforça para conceber seu sentido pragmático, para ele, a inevitável auto-representação das pretensões de validade do ator que levanta qualquer pretensão de validade perante um espaço público. A auto-representação, no entanto, reproduziria para o autor aquela forma de representação política ligada mais ao papel social dos atores da esfera pública pré-burguesa do que à validade de seus argumentos numa "moralidade procedimental" de uma racionalidade comuncativa.

É, portanto, na passagem da ideia de auto-representação para exposição ou visibilidade que estaria um caminho para compreender num sentido mais performativo dessa dimensão inafastável da esfera pública política.

No entanto, as reflexões de Habermas sobre o tema chegam somente a concepções de racionalidade estética como formas de crítica das ambivalências da comunicação pública, pois ela permitiria evidenciar esse permanente componente estético ou autorepresentativo da comunicação, que se mistura a todo o momento com os outros discursos na esfera pública política, influenciando suas normatividades. ${ }^{485}$ Mas ao buscar o fim da

\footnotetext{
${ }^{484}$ V. reportagem de 19/10/2011 do jornal Folha de S.Paulo, caderno "Saúde".

${ }^{485}$ Desse modo, a concepção de racionalidade estética de Habermas não é tão distante da visão que Wellmer traça para o caráter "energético" da estética: "From an energetic point of view the sublime appears as shocking, shattering, moving, overpowering. If one understands the moment of aesthetic experience as one of
} 
política do segredo e do ocultamento na esfera pública, bem como o princípio da generalidade do acesso, pode-se dizer a partir de Habermas que esse elemento estético e sua influência sobre o debate argumentativo precisam se tornar mais conscientes e esclarecidos.

Para promover esse tipo de transparência, portanto, torna-se necessário prosseguir para uma concepção mais cognitiva e normativa de racionalidade estética, o que não é possível com uma perspectiva somente crítico-negativa, isto é, somente como elemento desestabilizador da racionalidade possível da esfera pública política. ${ }^{486}$

Ao manter essa visão desestabilizadora do elemento estético, os deliberacionistas procuram afastá-lo da política ao máximo, tornando os atos e procedimentos democráticos cada vez mais formais e abstratos, para não correr riscos de irracionalidade que levam à estetização e à espetacularização da política. Essa preocupação é válida, mas realizá-la pela desconsideração da estética como problema da política não elimina a importância atual da visibilidade da discussão pública.

Para Wilson Gomes e Rousiley Maia, que formulam análises críticas da esfera pública política a partir de suas relações com os meios de comunicação de massa, a esfera de visibilidade pública está ligada à acessibilidade e à disponibilidade das razões a todos, sem as quais não são possíveis os próprios debates e eventuais deliberações. E como a esfera pública política se forma atualmente através da mídia, propõem uma esfera da visibilidade midiática, capaz de influenciar diversas formações da esfera pública política, interferindo inclusive em deliberações (Gomes \& Maia, 2008:138; Maia [org], 2008). ${ }^{487}$

No Brasil - e de modo mais ou menos global - outra característica da esfera pública política também contribui para essa não-problematização dos efeitos da comunicação icônica: a continuidade de uma grande concentração da propriedade e a desigualdade aos

a condensed presence, through which the temporal continuum of ordinary experience is suspended, the experience of the sublime may be characterized by an additional element of violence, a violence that bursts into the interior space of aesthetic distance, shaking up, dislodging or disquieting the subject, generating a tremor, a vertigo, loosening the confines of the experiencing ego." (Wellmer, 1998:163).

${ }^{486}$ Esse elemento desestabilizador também pode revelar, como nos efeitos de "choque" que Benjamin analisou na linguagem cinematográfica e em obras literárias como as de Bataille, outra importante função da racionalidade estética, a abertura de mundo (world-disclosing function), que pode problematizar certezas prédefinidas a partir da mobilização de elementos dessa natureza. V. para tanto, Duvenage, Habermas and Aesthetics, 2003. v. também Habermas, 1996:24.

${ }^{487} \mathrm{Na}$ obra coletiva organizada por Rousiley Maia Mídia e Deliberação, essa esfera da visibilidade midiática é utilizada para analisar casos como do "Ônibus 174" e da "Favela Naval" (v. cap. 5.4 acima) entre outros, nos quais a ampliação da visibilidade dos acontecimentos pela mídia tornaram os casos em questões de interesse público, influenciando de certo modo em seus desdobramentos (Maia [org], 2008). 
meios de comunicação de massa, especialmente no sentido da capacidade de produção de conteúdos (direito à comunicação). ${ }^{488}$

Isto é, apesar de todos os avanços na área de inclusão digital no que diz respeito à interatividade, os déficits de acesso ${ }^{489}$ fazem com que ainda predomine o sistema "can't talk back" (telespectadores como consumidores passivos) da televisão na formação da esfera pública política. Como demonstram as negociações e modelos adotados para a implementação TV digital no Brasil, a tendência é que os oligopólios presentes na área busquem aumentar seus espectros, embora haja previsão de uma multiplicação de canais. $^{490}$

Para tentar desenvolver um sentido mais pragmático de racionalidade estética a partir da própria teoria de Habermas que colabore não somente para identificar suas interligações com os outros discursos, mas também para promover uma publicidade mais crítica nos espaços públicos nacionais, seria interessante retomar brevemente o caminho que tomaram suas reflexões sobre a racionalidade estética em TCA e em Direito $e$ Democracia.

b) visibilidade como fator de publicidade do direito: problematizando as políticas de publicização do direito a partir da expressão estética da esfera pública política

Como já foi brevemente mencionado no capítulo 4 desta tese, a descrença de Habermas nos potenciais de socialização comunicativa da racionalidade estéticoexpressiva fez com que, apesar de referendar o diagnóstico de Weber de uma desvalorização da racionalidade das esferas da política e da arte na modernidade (Habermas, 1984-I:339-355), ele acabasse concentrando na moralidade moderna (e futuramente no direito) a responsabilidade por equilibrar as tensões entre indivíduo e coletividade e promover a aceitação da autoridade política na modernidade.

\footnotetext{
488 V. Segundo o interessante documentário sobre a questão, Levante sua Voz, realizado pelo Coletivo Intervozes (Pedro Ekman, 2009) há no Brasil cerca de 20.000 pedidos de outorgas de canais de rádio comunitária, sendo que até a época do filme somente 3.652 havia sido atendidos. Disponível em Www.direitoacomunicacao.org.br (último acesso: 15/12/2011).

${ }^{489} 35 \%$ da população têm acesso à internet regular, mas não doméstico. V. capítulo 5 "b" acima.

${ }^{490}$ Segundo o estudo realizado pela UNESCO com recomendações à política de comunicações do Brasil, o país pretende até 29 de junho de 2016 universalizar a digitalização do espectro eletromagnético das comunicações, de modo que até lá será um período importante para mobilizar mais uma vez o debate em torno da questão da generalidade (ou da qualidade) do acesso à esfera pública. V. Mendel \& Salomon, The Regulatory environment for Broadcasting, 2011, p. 12.
} 
Em termos teóricos, talvez seja por isso que Habermas não deposita esperanças desde TCA no desenvolvimento de um potencial de racionalidade pública para os discursos estéticos. Sua respectiva ação comunicativa, a "ação dramatúrgica", acaba sendo reduzida em TCA à expressão individual de um ator de artes dramáticas (Habermas, 1984-I:90-94).

Já os motivos históricos dessa perspectiva podem ter advindo da crítica à apropriação do poder pela estética nazi-fascista, a "estetização da política" denunciada por Benjamin, o impacto dos estudos sobre indústria cultural de Adorno e Horkheimer sobre a formação de Habermas, a apatia do movimento estudantil diagnosticada por seus estudos empíricos no Institut für Sozialforschung que resultaram em Student und Politik (1961) ou mesmo os excessos que identificou nos movimentos culturais de 1968, os primeiros não inspirados imediatamente em questões econômicas (Habermas, 1992:437-438; 2006:91).

Em TCA, foi analisado como o elemento estético da comunicação também tinha grande importância na reprodução simbólica do poder em sociedades arcaicas e tradicionais, sendo responsáveis pela estabilização dos conflitos possíveis entre interesses pessoais e coletivos nessas ordens sociais. Segundo leitura que Habermas faz da sociologia da religião de Durkheim, essa tensão era então equilibrada por rituais religiosos de forte apelo estético e sentimental, capazes de fundir todas as pretensões de validade em uma síndrome de facticidade inquestionável, levando à aceitação da autoridade por seu caráter fascinoso, ou aurático, e não por consensos racionais sobre sua validade. ${ }^{491}$

Em Direito e Democracia, Habermas identifica que as características de atração e repulsa, medo e reverência dessa fascinação exercida pela autoridade tradicional teriam se mantido na modernidade somente nos choques estéticos do cinema destacados por Benjamin, na crítica de arte ou na recepção crítica pelo público; não teriam as condições, no entanto, de desenvolver formas públicas ou contribuir para uma teoria da moral ou do direito. $^{492}$

\footnotetext{
${ }^{491}$ Nesse sentido, até o componente performativo da linguagem, ou aquilo que orienta de modo normativo a ação conformadora (ou não) de normas de ação, teria berço nesse sentimento estético contraditório da fascinação da autoridade: "From a genetic standpoint, the performative attitude can be understood, perhaps, as the result of a secularization and generalization of that emotionally ambivalent attitude toward sacred objects that originally secured the recognition of moral authority. This transformation becomes necessary to the degree that the illocutionary components of speech acts are released from their symbiotic entanglement with archaic institutions and are differentiated so that assertoric and expressive sentences are also endowed with illocutionary forces, and in this way modalized and incorporated in communicative actions." (Habermas, 1987-II: 75-76. Italicos nossos).

492 No conhecido estudo de Habermas sobre Benjamin "Crítica Conscienciadora o Crítica Salvadora" (1975) - na opinião de Duvenage (2003) ainda o texto mais completo sobre estética em Habermas - o autor considera casos de usos públicos de uma racionalidade estética provocada pela recepção crítica do público ou a crítica especializada de arte. Ao menos, Habermas deixa claro no início de Direito e Democracia
} 
Mas se Habermas houvesse retomado mais à frente suas inquietações publicadas em "Walter Benjamin. Crítica Conscienciadora o Crítica Redentora" (1975), talvez pudesse ter pensado na "perda da aura" da obra de arte como um processo de secularização moderno mais amplo, que afeta a dimensão estética da própria política. Nesse sentido, a dimensão aurática, ou "fascinosa" dos cultos e ritos do direito tradicional também teria se secularizado - como sugere Benjamin com a obra de arte - num processo de substituição de seu valor de culto pelo seu "valor de exibição" (Benjamin, 1975:1619), isto é, por sua visibilidade.

Em outras palavras, a forma com a qual a autoridade se torna "visível", ou como que ela se publiciza representaria atualmente - de modo dessacralizado - aquela característica da comunicação da ordem que em sociedades tradicionais era responsável por provocar a relação de pertencimento do individuo a coletividade e sua obediência em relação às normas sociais (Blotta, 2010b).

Dado, então, que o "valor de exibição" ou de visibilidade da autoridade legal pode ser lido como um "valor de publicidade", torna-se possível questionar, por exemplo, se a forma com a qual jornais como o Diário Oficial publicam as normas e decisões do Estado seria "visível" (ou exposta) o suficiente para garantir seu conhecimento e compreensão por todos, a ponto de poderem rechaçá-las ou aceitá-las como legítimas por motivos; ou se seriam necessárias outras formas de exposição pública das normas e suas razões como modo de satisfazer essa obrigação de publicidade.

Quando se omitem do debate público as influências da comunicação icônica e seu caráter de auto-representação sobre a política, pode-se chegar a extremos na publicização do direito: de um lado, tem-se as formas assépticas e excessivamente formais dos procedimentos jurídicos e publicações normativas, e de outro o caráter dramatizado dos julgamentos por júri popular. ${ }^{493}$

(Habermas, 1996:xli) que não pretende desenvolver uma teoria do direito numa "reducionista" perspectiva estética, como teria feito Derrida em The Mystical Foundation of Authority, 2002.

${ }^{493}$ No caso de júris populares, o interessante estudo de Ana Lúcia Pastore Schritzmeyer (2001) mostra como elementos estéticos e ritualísticos são atualizados no direito moderno, mas têm fracas possibilidades de crítica racional: "Por serem o sistema de justiça criminal e, em seu interior, o Júri, sistemas de poder, eles produzem efeitos que se comparam às ilusões criadas pelo teatro, uma vez que a arte de governar e a arte cênica são inseparáveis. Durante os julgamentos, juiz, promotor, defensor e jurados dividem a posição de "príncipes". Enquanto o primeiro reina soberano e aparentemente neutro, o segundo acusa veementemente, o terceiro protege $\mathrm{e}$ os demais decidem, em silêncio meditativo. Como um deus que se quadriparte e com isso se fortalece, a encenação de julgar dramas de vida e morte tem como um de seus resultados mais marcantes sacralizar a instituição "Justiça" e revigorar a etiqueta e a estética sociais." (Schritzmeyer, A. L. P, 2001:2. Free translation from Brazilian version). 
Como se poder ver, recuperar o debate sobre a visibilidade da lei na esfera pública política torna-se não somente uma maneira de criticar a qualidade de iniciativas atuais de publicização do direito, mas também de recuperar esse importante aspecto da comunicação referente à publicidade, até o momento relegado à irracionalidade da mera ideologia.

Mas se a partir deste diagnóstico da expressão estética da esfera pública a visibilidade do direito surge como critério de medição de sua publicidade, resta discutir ainda que tipo de visibilidade pode ser considerado satisfatório ou suficiente para garantir a publicidade do direito.

A princípio, pode-se pensar com W. Gomes e R. Maia (2008:120) a concepção do espaço de visibilidade pública como acessibilidade ou disponibilidade das razões, informações e argumentos que são objetos de debates públicos, mas quando essa disponibilidade assume o mandado de garantir as condições pelas quais as pessoas possam entender as razões por trás das normas, isto é, tomando publicidade como exposição dos motivos pelos quais o público possa aceitar voluntariamente o direito como legítimo, torna-se necessário revisar a interpretação de normas como o art. $3^{\circ}$ da Lei de Introdução ao Código Civil.

Isso porque, assim como ninguém pode deixar de cumprir a lei alegando seu desconhecimento (com a ressalva do art. 21, CP), a lei também não pode se escusar de sua responsabilidade de se dar a conhecer - e de modo inteligível - por todos (art. $5^{\circ}, \mathrm{XXXIII,}$ LX, art. 37, $\S 1^{\circ}, \S 3^{\circ}$, II, CF), justificando seus motivos e se submetendo ao crivo da opinião pública, que poderá legitimá-la ou não.

Esse raciocínio procura mostrar como as pretensões de publicidade derivadas da expressão estética da esfera pública política colaboram para se pensar em políticas mais positivas de publicização do direito. Essas políticas cumprem ao final um dos pressupostos fundamentais do Estado democrático de direito: o de estabelecer as condições políticas e institucionais para que os cidadãos possam se reconhecer como membros de uma comunidade política auto-organizativa, dentro da qual devem decidir publicamente quais direitos querem atribuir uns aos outros e de que forma (Habermas, 1996:384).

Essa mudança de paradigma que eleva o cidadão à condição de co-autor do direito, e não mais somente um depositário das normas proferidas pelo Estado, não é, portanto, só uma demanda da teoria de Habermas, mas está inscrita na própria autocompreensão de um Estado que se propõe a equilibrar certeza legal com aceitabilidade racional, ou legalidade com legitimidade. 
Mas considerando que o Estado também protege a autonomia individual, ou em última instância a liberdade dos indivíduos de não participarem da vida pública - liberdade esta que garantirá ao final validade aos acordos (a liberdade comunicativa de "dizer não") , como fazer, de modo não-obrigatório, com que os cidadãos criem consciência das normas e, em movimentos mais ou menos espontâneos, adentrem a esfera pública política para decidir publicamente quais normas que organizarão a convivência das liberdades?

Segundo estudos de Habermas na obra Entre Naturalismo e Religião ${ }^{494}$, a consciência das normas e a solidariedade dos cidadãos formariam as bases pré-políticas dos Estados de direito, e teriam sido fomentados especialmente pelos rituais de comunicação da lei associados à religião nas sociedades pré-modernas. Mas apesar de mobilizar esses recursos culturais de base, a natureza estética "fascinosa" desses rituais dificultava a crítica ao poder e era composta por autocompreensões éticas mais densas.

Assim, como a "aura" da autoridade teria se dessacralizado a partir da separação entre Igreja e Estado, remanescendo nas formas de visibilidade e publicização do direito, caberia a estas mobilizar essas fontes culturais novamente, respeitando agora as liberdades individuais e o pluralismo cultural e moral dos indivíduos.

Exemplos de como a solidariedade entre os cidadãos pode ser fomentada sem desrespeitar essas liberdades, inclusive a de crítica, serão analisados na discussão sobre a racionalidade expressiva no tópico 7.3. Quanto ao fomento da consciência das normas, as políticas de publicização do direito encontram nas previsões de publicidade governamental (mas também na publicidade de organizações sociais) especiais condições para formar espaços públicos nos quais as normas e decisões podem ser expostas e justificadas, contribuindo para o fomento de uma cultura política acostumada ao debate, respeitosa de direitos fundamentais e que se sinta estimulada a participar voluntariamente da formação democrática da opinião e da vontade políticas.

A ausência de critérios mais específicos para a produção de publicidade dos governos e a falta de transparência nas políticas do setor ${ }^{495}$ faz com que os altos gastos entre um e dois bilhões por ano - possam ser utilizados muito mais para exaltar os feitos

\footnotetext{
${ }^{494}$ Os textos referentes da obra são: "Pluralismo Religioso e Solidariedade dos Cidadãos do Estado" e "Religious Tolerance as a Predecessor of Cultural Rights" (Habermas, 2007:115-168 e 279-392, respectivamente)

${ }^{495}$ O jornal Folha de S.Paulo tem procurado desde março de 2011 obter do governo dados sobre políticas de publicidade oficial, como valores pagos a cada veículo, mas essas informações lhe foram recusadas. O jornal impetrou então mandado de segurança no Superior Tribunal de Justiça em 04 de abril do mesmo ano e lançou uma campanha por transparência de informações públicas.
} 
das gestões (há evidências de que os gastos aumentam nos finais dos mandatos) ${ }^{496}$, do que para disponibilizar informações relevantes a respeito, como justificações e dados que poderiam estimular um aumento da consciência dos cidadãos em relação às políticas.

É por isso que as campanhas de publicização do direito precisam seguir não somente os preceitos do art. 37, $\S 1^{\circ}, \mathrm{CF}$ (“A publicidade dos atos, programas, obras, serviços e campanhas dos órgãos públicos deverá ter caráter educativo, informativo ou de orientação social, dela não podendo constar nomes, símbolos ou imagens que caracterizem promoção pessoal de autoridades ou servidores públicos."), mas além disso, devem dar visibilidade às razões e justificativas das normas, sem as quais não é possível legitimar de modo discursivo, mas somente aclamativo o poder político. ${ }^{497}$

Desse modo, pode-se concluir que a pretensão normativa da expressão estética da esfera pública política amplia as demandas de publicização do direito, mas enquanto ela não for problematizada em suas qualidades estéticas, essa atividade fundamental do poder político (ou de outros poderes sociais) continuará a parecer mais com propagandas comerciais de produtos do que a publicidade crítica exigida às instituições que se pretendam legítimas. Normas jurídicas e sociais não podem ser vendidas, compradas e nem "engolidas a seco"; contudo, só merecem o título de legítimas na medida em que puderem oferecer as condições de serem aceitas por todos os cidadãos com base em razões criticáveis.

\subsection{Invasões da privacidade por técnicas de mercado e vigilância: desafios à proteção} constitucionalmente justificada da esfera privada

Este penúltimo tópico do diagnóstico da esfera pública política no Brasil envereda para um entrecruzamento de algumas de suas manifestações e expressivas e práticas no presente: propõe-se analisar violações e problematizações da privacidade, especialmente a partir de suas relações com mercados e outros interesses que se alimentam de questões do privado, como comunicações pessoais e segurança. Esses elementos são, por sua vez,

\footnotetext{
${ }^{496}$ Segundo informações veiculadas por reportagem de 19/04/2011 no caderno "Poder" da Folha de S.Paulo, enquanto em 2007 o governo Lula gastou 1,105 bilhões, em 2010 atingiu a marca de 1,629 bi em publicidade governamental. Nos oito anos do governo Lula, segundo estima a reportagem, foram gastos ao todo 10,3 bilhões. Como os dados sobre esses gastos passaram a ser disponibilizados somente a partir de 1998 pela Secretaria de Comunicação da Presidência da República - e até hoje diversas informações importantes não estão presentes, como detalhes sobre a contratação e execução dos serviços, ou os nomes das empresas que prestam serviço -, só foram disponibilizados os valores referentes a partir de 2000. Nestes, de 2000 a 2001 houve um aumento (de 1,078bi para 1,199 bi) e uma queda em 2002 (956,4bi).

${ }^{497}$ Habermas, Mudança Estrutural, 2003:212; v. cap. 2 "b" deste estudo.
} 
garantidos por direitos de proteção da integridade da pessoa, de seu agir e suas relações sociais como indivíduo.

O tema da privacidade também esteve presente no diagnóstico prático-moral da esfera pública política, porém de modo mais indireto, relação esta que de certo modo se inverterá aqui. A escolha por analisá-lo neste diagnóstico como manifestação expressiva da esfera pública política se dá pelo fato de a esfera privada ser o espaço onde se forma a subjetividade e personalidade individual, e portanto estão presentes nas questões pessoais, biográficas, familiares e íntimas, as quais tomam corpo em diversas manifestações do que Habermas denomina comunicação expressiva. (cit, TCA)

O discurso expressivo é entendido como manifestação do "mundo subjetivo"498, aquele espaço ocupado pelos pensamentos, sentimentos, sonhos e autocompreensões pessoais que ninguém mais além do indivíduo tem acesso. Mas é por isso mesmo que suas pretensões de validade são as mais complexas de se comprovar num processo público de troca de expressões e motivações.

Nessa forma de discurso, a comprovação racional da veracidade do interlocutor quanto aos seus sentimentos pessoais precisam então ser seguidas por ações ulteriores que confirmem suas pretensões, ou por depoimentos de terceiros que possam garantir a veracidade dos sentimentos expressos pelo indivíduo (Id, 1984-I:90-101).

É por isso que a interação social que se forma a partir da comunicação expressiva é aquela especialmente baseada na confiança ${ }^{499}$, na amizade ${ }^{500}$ em outras relações nas quais

\footnotetext{
${ }^{498}$ Ao discutir a recepção de Piaget por Habermas, com o qual este pode fundamentar de modo empírico sua tese normativa da aquisição das competências comunicativas, Bárbara Freitag caracteriza a racionalidade do agir comunicativo a partir da teoria dos "três mundos". Cada um deles reflete as três diferenciações de discursos analisados neste diagnóstico, e inclui o diálogo com o "mundo subjetivo": "O ator "competente de Habermas, que coordena suas ações e busca o entendimento através da ação comunicativa, é o sujeito autônomo, socializado, comunicativo (em suma 'descentrado'), cujas estruturas lógicas e de consciência foram se construindo enquanto atuava sobre o mundo dos objetos (interiorização de ações) e interagia com outros sujeitos no mundo social (interiorrização de ações) e interagia com outros sujeitos no mundo social (interiorização ou assimilação da fala e dos pontos de vista dos outros), levando-o a reorganizar (acomodação) suas estruturas cognitivas ou esquemas (relação com o mundo subjetivo). Nas ação comunicativa, essa relação com os três mundos é preservada de forma reflexiva e consciente." Freitag, Dialogando com Jürgen Habermas, 2005:53.

499 Sobre a categoria da "confiança" na perspectiva da teoria crítica, Martin Hartmann entende que: à primeira vista pode parecer como muito claro o que está em jogo: desconfiança é ruim, confiança é bom, então devemos sobre isso pensar em seguida como a desconfiança pode ser superada, para que mais sentimentos de confiança com o o outro possam se enriquecer." (Trad. livreHartman, Wege aus dem Misstrauen Theoretische und praktische Überlegungen. [Saída da Desconfiança. Exercícios teóricos e práticos. Trad. livre], 2010:161. V. também do mesmo autor Hartmann, Vertrauen [Confiança] (Frankfurt: Campus, 2001; Id, Die Praxis des Vertrauens [A Praxis da Confiança] (Suhrkamp, 2011). Com Sérgio Adorno e Wania Pasinato a categoria também a assume uma feição pública na sociologia contemporânea, como no conceito de "confiança nas instituições". V. Adorno, S. Pasinato. Justiça no Tempo, o tempo da justiça. Tempo Social, revista de sociologia da USP, v. 19, n. 2, 2007, pp. 131-155)
} 
a afetividade está mais presente e pode se desenvolver como expressão autêntica da subjetividade individual.

Mas como já foi analisado nesta tese a partir da revisão de $M E E P$, esse espaço privado no qual os sujeitos podem desenvolver livremente sua personalidade, formar suas próprias convicções sobre si mesmo e o mundo e expressar-se publicamente, só foi alcançado a partir de sua formação, de modo co-originário à esfera pública burguesa dos séculos XVIII ao XIX, como espaço de não-intervenção do público e ao mesmo tempo emancipado das coerções do "reino das necessidades" econômicas (v. cap. 2 "a" acima).

Nunca é demais relembrar a importância da conquista e da constitucionalização desse espaço de liberdade individual para essas mesmas duas esferas, contra as quais (curiosamente) a privacidade procura se salvaguardar.

Isso porque, ao deslocar de certo modo a reprodução material da vida para o espaço público - gerando a "esfera do social" na terminologia arendtiana (Arendt, Human Condition,1998:38-78) -, a privacidade dá condições para atividades como a economia se profissionalizem e gradativamente se tornem industriais, ganhando status de grande problemas públicos.

Ao mesmo tempo, o surgimento dos direitos da personalidade significou a inversão da própria lógica de funcionamento do Estado e do exercício do poder político. Quando a subjetividade individual floresce desse novo espaço de autonomia na forma da poesia, da música e do romance que envolveram a cultura dos séculos XVIII e XIX, ela se não rebela somente contra o público, mas especialmente contra as normas sociais. Com isso, exterioriza-se como princípio moral que elege o indivíduo como prisma de quem irradiam os direitos fundamentais, e sua autodeterminação coletiva como bússola que orienta a ação do Estado. ${ }^{501}$ Sendo componente fundamental da subjetividade individual, a privacidade dá condições para o surgimento e a institucionalização da esfera pública política como pretensão normativa da modernidade (v. cap. 2 "a” acima).

\footnotetext{
500 Sobre a importância das relações de amizade para a formação da subjetividade individual, v. Honneth, 2011:237-252. Numa perspectiva aristotélica, pensando a categoria da amizade como forma racional de mediação de conflitos, v. Abrão, Mediação e Ética das Virtudes: a philia como critério de inteligibilidade da mediação comunitária, 2009.

501 "We no longer think primarily of deprivation when we use the word 'privacy,' and this is partly due to the enormous enrichment of the private sphere though modern individualism. However, it seems even more important that modern privacy is at least as sharply opposed to the social realm - unknown to the ancients who considered its content a private matter - as it is to the political, properly speaking. The decisive historical fact is that modern privacy in its most relevant function, to shelter the intimate, was discovered as the opposite not of the political sphere but of the social, to which it is therefore more closely and authentically related." Arendt, The Human Condition, 1998:38.
} 
Mas as experiências extremamente negativas da primeira metade do século $\mathrm{XX}$ e seus desdobramentos políticos levaram novamente à necessidade de se reafirmar o compromisso com a promoção de um núcleo inviolável de direitos e garantias ligadas à dignidade e à integridade da pessoa humana, que foram estendidos formalmente a todos os indivíduos do planeta com a Declaração de 1948.

No Brasil, algo semelhante só foi ocorrer 40 anos depois, com o final do regime militar e a promulgação da Constituição 1988, mas a partir de então, o processo de redemocratização do país já se dava em meio à globalização econômica capitalista e a queda dos regimes comunistas, o que imprimiu uma orientação neoliberal sobre as novas relações entre publicidade e privacidade que se formavam no país.

É partir desse contexto de liberdade individual ampliada - especialmente as liberdades econômicas, mas já colhendo os resultados de algumas décadas de neoliberalismo econômico - que se propõe analisar aqui dois exemplos de violações e problematizações dos direitos da privacidade na esfera pública política nacional: a primeira trata de algumas relações entre os direitos de privacidade e o mercado de consumo, enquanto que a segunda relaciona a privacidade com o que se tem denominado "indústria do terror", ou as relações entre segurança pessoal, mercados e políticas de vigilância e combate à violência.

a) privacidade mercadorizada: incorporação de novas expressões da subjetividade individual pelos discursos técnico-econômicos

A crítica do neoliberalismo permite vislumbrar novas interpenetrações entre público e privado e os discursos que os envolvem, mais especificamente entre a esfera da privacidade e a esfera social da economia. Essas novas interpenetrações ofuscam as delimitações entre ambas as esferas de ação, dificultando a identificação de instrumentalizações e dominações que uma pode realizar sobre a outra.

Pensar em novas formas de invasão da privacidade e da intimidade por técnicas de mercado permite entender em que medida essas atividades próprias da subjetividade individual, ligadas ao discurso expressivo, têm sido incorporadas e envolvidas pelo discurso técnico e estratégico da economia.

Como a privacidade e a intimidade são institucionalizadas na forma direitos de personalidade invioláveis e inalienáveis, em princípio, eles não poderiam ser trocados por (ou depender diretamente de) outras esferas de reprodução social para subsistir, como a 
economia. ${ }^{502}$ Cada esfera tem seu espaço, lógica de funcionamento e importância para a reprodução e a integração social.

Diante dos atuais fenômenos de ampliação da privacidade, especialmente a partir de novas tecnologias de informação e comunicação, algumas perguntas podem orientar a interpretação de exemplos concretos no Brasil: até que ponto os direitos de privacidade, intimidade, honra e imagem podem ser "licenciados" com finalidades pecuniárias? E até que ponto esses novos espaços de privacidade devem depender de sua capacidade de servirem como insumos para o próprio mercado que os torna possíveis ? ?03 $^{503}$

Em relação à utilização pelas redes sociais dos conteúdos produzido pelos usuários com suas comunicações pessoais, a rede Facebook passa atualmente por uma processo de negociação com o governo dos EUA para adequar suas políticas de privacidade às normas referentes no país. ${ }^{504}$ Essa negociação passou a ocorrer depois que uma alteração de sua política de privacidade realizada em 2009 gerou diversas críticas de advogados especializados em direitos de privacidade e direitos do consumidor.

Muitas das discussões sobre os possíveis abusos cometidos pela rede social partem da questão do consentimento dos usuários. Cada alteração nas políticas de privacidade deve ser informada e aceita por eles, segundo defendem os críticos, especialmente em relação à transparência em relação às formas com a qual o Facebook utiliza, com quem compartilha, como e para quem encaminha os dados e conteúdos produzidos na rede.

Apesar de ainda não ser comprovado que anunciar nas redes sociais gera efetivamente lucro para as empresas ${ }^{505}$, o Facebook e outros serviços do gênero, como o

502 O próprio princípio da autonomia (ou de não-instrumentalização) kantiano pode fundamentar essa pretensão, pois entende que a pessoa carrega um valor imanente de dignidade que sua existência deve ser garantida independentemente de suas relações com a economia (utilidade) ou a política (virtudes): citando Kant de Metafísica dos Costumes [1786], Freitag assevera: "Faz parte do imperativo categórico a exigência de que um ser humano jamais deve ser visto e usado como um meio, mas sim, exclusivamente, como um fim em si. Isto significa que toda a legislação decorrente da vontade legisladora dos homens precisa ter como finalidade o homem, a espécie humana enquanto tal. Mais especificamente, a vida e a dignidade (Wurde) do homem. O imperativo categórico orienta-se, pois, segundo um valor básico, inquestionável e universal: a dignidade humana" (Freitag, 2005:74).

${ }^{503} \mathrm{O}$ mesmo ocorre com o fenômeno de mercantilização do olhar e da atenção, que não deixam de ser manifestações da comunicação estético-expressiva (v. cap. 5.2 acima).

${ }^{504}$ V. notícia de 11/11/2011 sobre o caso no caderno "Tec" da Folha de S.Paulo. A reportagem utilizou informações do jornal Washington Post e da Reuters.

${ }^{505}$ Duas análises recentes sobre rentabilidade de anúncios em redes sociais destacaram os problemas dessa tese. O artigo "Social Networking May Not Be as Profitable as Many Think", de Luke Peterson, publicado em 17 de julho de 2010 no endereço, problematiza que a exposição dos usuários de redes pode não levar ao consumo das marcas, pois eles não utilizam o meio para obter informações de consumo, mas para se comunicar com os amigos (www.news.ziphone.org. último acesso: 18/12/2011). Já breve análise de associação de organizações sem fins lucrativos dos EUA que avaliava se vale à pena anunciar em redes sociais, destaca pesquisa do Instituto Forrester com 24 empresas, das quais somente $7 \%$ indicaram aumentar o número de clientes a partir de anúncios na internet. V. Barry, F. "Facebook is Great, but Does it Really 
Orkut e o Youtube sociais têm sido cotados com grandes quantias no mercado das bolsas. Segundo notícia do jornal inglês The Guardian (29/11/2011), o próprio Facebook espera se cotada na virada de 2011 para 2012 com 100 bilhões na bolsa. Notícia da BBC de abril de 2011 indicou que a rede social de mais de 800 milhões de usuários pelo mundo é avaliada em torno de 50bi, mais do que empresas como Warner Bros e quase duas vezes a empresa de computadores Dell. ${ }^{506}$

Enquanto isso, novas formas de se explorar as redes sociais, como ter seus próprios perfis, é o que empresas tem feito ultimamente ${ }^{507}$, enquanto a internet se consolida como espaço explorado pela comunicação comercial em crescimento exponencial (75\% de 2009 a 2010) nos últimos anos. No Brasil, no entanto, a televisão ainda continua majoritária como o meio que mais recebe investimentos em propaganda comercial (em torno de $52 \%$ de toda a renda, avaliada em quase 36 bilhões em 2010). ${ }^{508}$

Essa questão empírica sobre se realmente investir nas redes sociais gera retorno para as empresas se soma ao problema normativo sobre se a utilização das informações e correspondências privadas dos usuários pelas empresas para fins econômicos, ainda que consentida, é legítima.

Caso seja possível comprovar ambas as hipóteses, pode-se dizer que a valorização sem precedentes de empresas digitais como as redes constituem uma "bolha" especulativa estruturada sobre hipóteses empíricas de e-commerce contestadas e invasões problemáticas sobre a esfera da privacidade dos usuários, especialmente quando não consentidas. ${ }^{509}$

Isso porque, além dos diversos casos de ações judiciais de usuários contra o Facebook em função de problemas de privacidade e falta de transparência da empresa com informações sobre os usos e localizações de dados e conteúdos privados, caso alguns aplicativos não sejam mais de interesse comercial da rede ou provedor, as normas de

Work for Fundraising?". Publicado em 10/04/2011 no blog Online Fundraising, Social Media. (último acesso: 17/12/2011).

506 V. notícia de 15 de abril de 2011 da BBC sobre o assunto no endereço eletrônico BBC Click (último acesso: 17/12/2011).

${ }^{507}$ Cf. outro interessante artigo que questiona a viabilidade econômica de se anunciar nas redes sociais. Segundo o autor os usuários não utilizam o serviço para acessarem propaganda comercial, e por isso os anúncios não atrairiam tanta atenção. Há também aqueles que propõem que formas transparentes e acordadas de sugestão de publicidade são mais bem aceitas pelos usuários.

${ }^{508}$ Dados sobre crescimento da propaganda comercial na internet e na televisão de OBITEL. Qualidade na ficção televisiva e participação transmidiática das audiências, 2010:144.

${ }^{509}$ Ver reportagem em vídeo sobre interessante caso de ação judicial que estudante de direito de Viena que moveu contra o Facebook pelo não-apagamento definitivo de seus dados pessoais. Neste caso, trata-se de violação do próprio princípio da probidade contratual pela rede. http://www.youtube.com/watch?v=ObbiBeXevkE (último acesso: 18/12/2011). 
utilização permitem que eles possam ser extintos sem o consentimento do usuário, inclusive perdendo os dados pessoais que mantinha no serviço (v. cap. 5.2 acima).

Mas será que se de fato esse novo espaço de privacidade traz um grande ganho para a comunicação pessoal ou mesmo profissional dos indivíduos, a extinção do serviço não poderia violar esse novo espaço de privacidade alcançado? Poderia a organização social, ainda que privada, deixar de garantir a possibilidade técnica de exercício do direito individual de comunicação pessoal que concedeu ao usuário, direito este que ele não pode exercer de outra maneira por não haver no país serviço público semelhante?

Nesses casos, a hipótese de auxílio para a continuidade do serviço ou o provimento de alternativa por meio de fundos públicos, geridos por conselhos independentes e plurais do setor, seria bem vinda, como propõe Habermas em "Medios y Mercados", embora em referência à opinião de que a qualidade da imprensa não pode ser prejudicada em função de instabilidades econômicas ou a inviabilidade lucrativa da atividade (Habermas, 2009:133-135).

Outro caso interessante que retrata invasões da privacidade ampliada pelas comunicações privadas na internet são os chamados spam ou comunicação comercial ou informativa indesejada, que infiltra nas caixas de $e$-mails das pessoas todos os dias, quando não são mensagens contendo vírus de todos os tipos. Muitas deles vêm de empresas nunca antes contatadas pelo usuário e, portanto, não se sabe se são empresas parcerias do servidor, ou o se tiveram acesso ao endereço eletrônico pessoal por outros meios. Especialmente neste último caso, trata-se de invasão indevida na esfera privada do indivíduo, além de lhe gerar ônus financeiro (art. $\left.5^{\circ}, \mathrm{XII}, \mathrm{CF}\right) .{ }^{510}$

Têm-se buscado nacional e internacionalmente avanços técnicos e legislativos para conter o fenômeno do "lixo eletrônico. ${ }^{511}$ Mas apesar de algum avanço na área, as novas

${ }^{510}$ O Coletivo Intervozes considera o spam também violação do direito do consumidor. Apesar dessa omissão legislativa, considera-se comunicação pessoal eletrônica como sendo protegida pelo sigilo de correspondência, mas há importantes diferenças técnicas entre as duas formas de comunicação, como indica o Intervozes: "As características que diferenciam o e-mail da correspondência postal por natureza se encontram nos protocolos de transmissão de e-mail (IMAP, POP3 para armazenagem, SMTP para transmissão, etc.), que não garantem, por si, o sigilo da mensagem. Uma analogia válida seria dizer que enviar um e-mail é como enviar um cartão postal; o conteúdo está à mostra, não pode ser ocultado dos mecanismos que o transportarão do remetente ao destinatário. A única alternativa viável para garantir este sigilo, hoje, é o uso de softwares de criptografia - existem milhares de sistemas de criptografia, muitos inclusive em uso por parte de agências de inteligência, outros para fins comerciais. A Infra-Estrutura de Chaves Públicas (ICP-Brasil) é, hoje, o sistema de chaves criptográficas em uso por órgãos oficiais, como a Presidência da República e a Receita Federal.(Intervozes, 2005:95. nota 3. Itálicos nossos).

${ }^{511}$ V. rica pesquisa publicada na Harvard Law Review que procura aplicar os procedimentos da internet como estudo de caso da ética do discurso. Froomkin, A. M. Habermas@discourse.net: toward a critical theory of cyberspace, 2003. Ele apresenta os danos patrimoniais e os efeitos desagradáveis do spam, cujo nome viria de canção repetitiva do grupo de comédia inglês Monty Phyton: "Depending on the nature of the 
formas de interação possibilitadas pelas novas tecnologias e seus respectivos problemas são claramente mais rápidos do que as respostas estatais, o que demanda legislação mais geral integrada com políticas públicas intersetoriais. É o próprio Estado, inclusive, que tem procurado se associar às novas tecnologias para tentar desburocratizar seus procedimentos, como propõem projetos de informatização pelo próprio Poder Judiciário. ${ }^{512}$

No cenário regulativo nacional, pode-se considerar a importância da discussão e proposição do marco civil para a internet (enviada ao Congresso no final de agosto de 2011) antes da aprovação do projeto da chamada "lei Azeredo" proposto em 1999 pelo deputado do PSDB Eduardo Azeredo, que previa políticas de enrijecimento penal na rede, mas nunca efetivamente votado por ser considerado repressor de liberdades individuais de comunicação. A lei de direitos autorais também já reflete sinais do debate com a cultura do commons e opta pela proteção da liberdade individual pela rede (v. cap. 5.1 "b" acima). Do mesmo modo, resultados do Internet Governance Forum, realizado todo o ano desde que fundado 2006, também projetam orientações normativas importantes para o setor, como o princípio da "neutralidade da rede" ${ }^{513}$ e o respeito inegociável aos direitos humanos. ${ }^{514}$

Quando se trata se invasões da privacidade por organizações sociais como ou órgãos de imprensa, recentes escândalos sobre o uso de escutas ilegais pelo jornal britânico News of the World, de propriedade do estadunidense magnata da comunicação Rupert Murdoch, reascenderam a esfera pública política em torno da questão. Venício Artur de Lima, a própria publicação dos princípios editoriais das Organizações Globo, depois de mais de 80 anos de funcionamento, pode ter sido influenciada pelo escândalo.

Este caso já havia sido citado anteriormente (v. cap. 5.3 “b”), mas é aqui retomado por tratar desse tipo de invasão da privacidade em nome da liberdade de imprensa. Além das devidas punições por danos morais e materiais, o caso revela uma exigência geral de

user's Internet access, repeated spams may require the user to delete the message manually every time it appears on the screen. (...) users who pay for Internet access by the byte or the minute will be forced to pay for every incidence of the message; similarly, users who download their news from a remote computer will have to wait longer while each of the multiple copies is downloaded. If users access their news by telephone, this may cost them additional telephone charges. Whether spamming involves a financial cost or not, many people find it very annoying — the electronic equivalent of mass junk mail.” Froomkin, 2003:827.

${ }_{512}$ V. lei de informatização do Judiciário (n. 11.419/06). Este caso mostra um importante entrecruzamento das áreas da comunicação social e da comunicação política, cujas problematizações formam esferas públicas políticas, no caso mais ligada às pretensões de publicização do direito. Como se poderá ver com mais clareza na parte III, os conflitos entre as pretensões normativas presentes nessas esferas públicas políticas podem são objetos de análise do direito da comunicação.

${ }^{513}$ Trata-se de princípio de que os provedores de serviços da rede não podem tratar diferentemente os usuários, no sentido de tornar suas páginas acessíveis somente àqueles com provedores mais rápidos. O New York Times indica que a Federal Communications Commission manteve nos EUA este princípio até recentemente, quando decisão contrária ao seu poder de monitorar os serviços de banda larga questionou a validade do princípio. V. notícia de 22/12/2010 no endereço eletrônico do New York Times.

${ }^{514}$ Veja informações no endereço eletrônico do fórum. www.intgovforum.org (último acesso 18/12/2011). 
abertura e mais transparência de organismos de mídia de grande impacto na esfera pública, como a aceitação do Facebook de se submeter a auditorias e consultores independentes que podem supervisionar e criticar suas políticas de privacidade para os próximos vinte anos. ${ }^{515}$

Além dessa demanda, procurou-se reconstruir por trás das problematizações atuais da questão também a pretensão de se ter garantido acesso gratuito a esses novos espaços expandidos de privacidade. A conquista dessa autonomia individual ampliada, no entanto, não pode se dar somente enquanto atividade-meio da economia, mas sim como atividadefim daquilo que atualmente se denomina direito à autodeterminação informacional (v. tópico 9.2 desta tese). ${ }^{516}$

b) privacidade vigiada: associações entre os discursos econômicos e políticos pela administração da sensação da (in)segurança individual e social

As invasões da esfera da privacidade por órgãos de imprensa e empresas de mídia digital, como as redes sociais, geram também problematizações em relação ao direito à segurança e à proteção da integridade física e moral dos indivíduos. Diversas teorias sociais e de sociologia jurídica, como da "sociedade de risco", identificada por Giddens $(1991)^{517}$, a teoria política marxiana de Empire (2001), dos filósofos políticos Michael Hardt e Antonio Negri, e o "direito penal do inimigo" de Jakobs $(1995)^{518}$, identificam tendências de formação de Estados e ordens sociais mais autoritárias no presente, "Estados policiais", propensos a restringir liberdades individuais em nome da segurança pública e da proteção da propriedade, especialmente após os atentados de 11 de setembro em Nova York.

A justificativa utilizada por essa tendência é de modo geral a questão da insegurança pessoal e coletiva, embora sua garantia seja dada somente ao preço dessas restrições de liberdades individuais, como a de não ser revistado pela polícia na rua, caso não apresente atitude suspeita, de não ser preso antes de sentença penal condenatória

\footnotetext{
${ }^{515}$ No Brasil, há discussão semelhante no debate sobre o novo marco civil da internet que trata do tempo que os servidores e empresas de mídia precisam guardar informações para eventuais investigações em casos judiciais. V. mais sobre o marco civil em www.culturadigital/marcocivil (último acesso: 18/12/2011).

${ }_{516}$ V. tópico 7.3, em seguida, bem como algumas discussões no capítulo 9.2. Para Tércio Sampaio Ferraz Júnior o direito à autodeterminação informacional não é somente um direito negativo de não-interferência do outro no indivíduo, mas forma de garantir a participação de todos nas práticas de reprodução simbólica da sociedade. (V. Ferraz Júnior, 2011:59).

${ }^{517}$ V. Giddens, As Conseqüências da Modernidade. São Paulo, 1991.

${ }^{518}$ V. Jakobs, G. \& Cancio Meliá, M. Derecho penal del enemigo. Madrid, 2003.
} 
transitada em julgado que o determine, sigilo de correspondência ou mesmo práticas violentas de interrogatório. ${ }^{519}$

Como já foi visto (cap. 5.4), problematiza-se nessa área o tratamento dado por meios de comunicação a temas de segurança, violência e criminalidade, pois ele teria capacidade de influenciar a aceitação de políticas como essas, enquanto colabora ao mesmo tempo para um crescente mercado de equipamentos e serviços de segurança privados no Brasil. ${ }^{520}$

Também já foi mencionado (5.4) que, além da violência e insegurança "reais", políticas de segurança pública procuram realizar o que Sérgio Adorno denomina "gestão urbana do medo". Trata-se da tentativa de administrar a sensação de segurança ou insegurança que é reproduzida socialmente. A abordagem desse problema é fundamental para a formulação de políticas na área, pois um estado de insegurança plena pode levar cidades inteiras à paralisação de suas atividades. ${ }^{521}$

Foi o que de fato ocorreu em maio de 2006 na capital paulista e em algumas cidades do Estado no caso dos ataques generalizados atribuídos à facção criminosa "Primeiro Comando da Capital", o "PCC". Cada município foi levado a toques de recolher coletivos sugeridos inclusive pelas próprias autoridades públicas, em atestado de ineficiência para resolver a situação sem comprometer a segurança dos cidadãos. ${ }^{522}$

Reflexos possíveis de casos como esse sobre o exercício dos direitos de autonomia não são somente a perda do direito de ir e vir dos cidadãos em meio à sensação de insegurança generalizada, mas também as respostas do poder público e da indústria de

\footnotetext{
${ }^{519}$ Essa mudança de orientação política internacional e nacional é descrita de forma clara por Mesquita Neto: "No Estados Unidos, (...) desde 11 de setembro, a maioria da população passou a apoiar restrições de direitos civis impostas pelo governo, ou tolerar violações dos direitos humanos, inclusive a prática de tortura e detenção arbitrária de suspeitos, em troca da promessa de que tais práticas tornariam o país e o mundo mais seguro diante das ameaças do terrorismo. (...) // No Brasil, a mesa lógica levou governos estaduais e o governo federal a restringir direitos civis e tolerar execuções, torturas e prisões arbitrárias, a pretexto de combater o crime organizado e a prática do seqüestro em diversos estados do país. Instituições policiais, judiciárias e penitenciárias, e mesmo instituições de detenção de adolescentes, não ficaram imunes a essa tendência. Em 2003, no Estado de São Paulo, 975 pessoas foram mortas pela polícia, número inferior apenas aos registrados em 1991 e 1992. Em 2005, somente na Cidade do Rio de Janeiro, 1.087 pessoas foram mortas pela polícia." Mesquita Neto, 2011:119-120.

${ }_{520}$ Para uma análise de um exemplo do mercado da segurança privada no Brasil v. Cubas, V. A expansão dos serviços de proteção e vigilância em São Paulo. São Paulo, 2005.

${ }^{521}$ Segundo Wainberg em sua obra intitulada Mídia e Terror, "O terror por natureza é público. É uma fala facilmente compreensível, em especial pela comunidade-alvo da agressão, que assiste com grande espanto ao enquadramento dramático que os meios de comunicação fazem das cenas de horror. O resultado prático de tal cobertura intensiva é a propagação de uma ampla onda de medo e pavor que pode paralisar a rotina de uma comunidade, em especial, o grupo visado." (Wainberg, 2005:61). V. também tópico 5.4 "a" acima.

${ }^{522}$ Sérgio Adorno e Fernando Salla constataram em estudo que entre 12 e 20 de maio de 2006439 pessoas foram mortas por arma de fogo no Estado de São Paulo, um número excepcionalmente alto em relação ao mesmo período em outros anos. V. Adorno \& Salla, 2007. Sobre o tema, v. também Adorno, S. A Gestão Urbana do Medo e da Insegurança. Tese de Livre-Docência. FFLCH USP, 1996.
} 
equipamentos de segurança que normalmente se seguem. Essa ação praticamente coordenada entre indústria e políticas de segurança retroalimenta um estado de exceção no qual, acossados pelo medo e em busca de soluções eficazes, os cidadãos aceitam restrições de supressões de suas liberdades individuais em troca de maior sensação de segurança (Hardt \& Negri, 2001:18).

Com uma esfera privada restringida de ambos os lados, algumas das respostas da sociedade civil têm sido de retração e auto-isolamento, com aumento de condomínios fechados e gastos com equipamentos de segurança pessoal, mesmo em casos nos quais as famílias ou indivíduos não tenham sido vítimas diretas ou indiretas de atos de violência ou criminalidade.

Por outro lado, pode-se dizer que a soma das essas políticas de "tolerância zero" com a diminuição de investimentos sociais em função das recentes crises econômicas nos EUA e na Europa, desdobram-se nos atuais protestos em diversas partes do ocidente neste final da primeira década do século XXI.

É de se esperar que esses novos movimentos sociais gerassem outras reações repressivas dos Estados, como as novas tendências do governo inglês de proibir a utilização de redes sociais digitais após constatar que as manifestações e rebeliões de agosto de 2011 no país teriam se dado com o auxílio dessas redes. Como já foi visto no tópico 6.2, não se pode negar a influência dos novos espaços de comunicação tecnológica nesses movimentos.

O que cumpre aqui destacar é que esses espaços garantiram modos de comunicação social privada com capacidade se referir ao público, conectando uma esfera de livre desenvolvimento e expressão da subjetividade individual (a "esfera pública literária" burguesa) com uma esfera pública política que reivindica pleitos e manifesta sua indignação, inclusive por meio de atos de desobediência civil.

As recentes revoluções no oriente médio e as manifestações generalizadas no ocidente são talvez as mais radicais expressões da esfera pública política dos últimos tempos, tendo se nutrido dos potenciais de comunicação dos blogs, redes sociais e outros espaços capazes de tornar expressões individuais e pretensões políticas mais autênticas. Uma prova disso é que acaba de ser eleita pela revista Times, a figura do "manifestante" (the Protester) personalidade do ano de 2011. ${ }^{523}$

${ }^{523}$ V. Revista Time. Edição de 14 de dezembro de 2011. 
Do mesmo modo que nas revoluções burguesas as condições técnico-econômicas deram condições para a formação de um espaço privado que pôde se auto-compreender e a partir dessa autocompreensão expressar-se politicamente, as possibilidades tecnológicas do presente também garantem formas de circulação da comunicação entre privados que, quando organizados em atividades de associativismo também presenciais, são capazes de produzir uma crítica que mobiliza a opinião pública para suas causas, ainda que não alterando o modo de circulação do poder político.

Mas enquanto os em torno de $40 \%$ brasileiros "conectados" buscam essa autocompreensão de sua privacidade expandida pelas novas tecnologias de informação e de comunicação (v. 6.1 "b” acima), o problema da sensação de insegurança, que leva a fenômenos de retração da sociedade civil como no caso dos condomínios fechados, acaba por modificar a própria distribuição dos espaços urbanos ${ }^{524}$, do mesmo modo que se altera a natureza da esfera pública política nacional.

Essa esfera expandida da privacidade sofre constantes intervenções das esferas social e política. De um lado, é exposta a organizações do tempo livre orientadas pelo agenda setting dos meios de comunicação mais influentes, que se tornam lugares de expressão da individualidade a partir das identificações do público assistente (Habermas, 2006a) com reproduções, ou representações fabricadas da subjetividade individual, como produtos de entretenimento e propaganda comercial. ${ }^{525}$

Por outro lado, essa privacidade é vigiada cada vez mais de perto por atores de inteligência ou órgãos policiais e investigativos do Estado, bem como empresas que trabalham com gestão de informações privadas. Ambos requisitam informações das pessoas e em alguns casos tomam contato com suas correspondências particulares, como fazem algumas novas mídias (v. cap. 5.2 "a”), ou as utilizam para realizar objetivos de

\footnotetext{
${ }^{524}$ Sobre o aumento de condomínios fechados e seus significados sociais, v. D’Ottaviano, Condomínios Fechados na Região Metropolitana de São Paulo: fim do modelo centro rico versus periferia pobre? ABEP, 2006; Sobre os reflexos "das violências" sobre a reconfiguração dos espaços públicos da cidade de São Paulo, v. Endo, P. A violência no coração da cidade: um estudo psicanalítico sobre as violências na cidade de São Paulo, Escuta/Fapesp, 2005.

${ }^{525}$ Segundo Muniz Sodré, em sua perspectiva mais crítico-negativista da esfera pública contemporânea, tendo os meios de comunicação como formadores desses "lugares": "Em vez de centros, pode-se falar em 'lugares' disseminados de absorção e transformação do fluxo histórico-dinâmico da vida social em projeções fantasiosas que, no entanto, fingem dar conta da realidade em sua máxima objetivação. // São, a exemplo dos modernos meios de comunicação, lugares parasitários do social, mas estupefacientes por seus efeitos tecnológicos, sua velocidade maquinal, seu êxtase imagístico. O imaginário desses lugares é o mesmo da droga." (Sodré, 2005:30).
} 
segurança pública, como no caso da Agência Brasileira de Inteligência mesmo de órgãos de fiscalização como o Departamento Nacional de Trânsito (Detran). ${ }^{526}$

O que se pode sugerir como maneira de reverter esse processo de dupla intervenção dos discursos técnico-econômicos e políticos sobre a esfera privada dos indivíduos é, portanto, não somente uma proteção constitucionalmente justificada da esfera privada voltada para a defesa dos direitos humanos ligados à esfera da privacidade, mas também de vigilância da sociedade civil quanto ao cumprimento desses direitos. Essa vigilância pode ser traduzida na esfera pública política na forma de políticas de monitoramento - de direitos humanos, por exemplo; ${ }^{527}$ nos termos do direito da comunicação, políticas de comunicação do direito (v. cap. 9).

Quando não há alternativas de ação no espaço privado, perde-se ao final a chance de se exercitar a autonomia individual no sentido de uma liberdade comunicativa, isto é, em última instância a liberdade de não concordar e não participar de quaisquer planos de ação predeterminados pelos discursos da esfera social ou da esfera política. ${ }^{528}$

Sem a proteção desse espaço privado dentro qual o indivíduo possa tranquilamente formar e expressar suas próprias convicções sobre si mesmo e o mundo, não há como garantir a autonomia da vontade e, portanto a autenticidade dos juízos práticos ou até mesmo dos técnico-informativos dos cidadãos. Conseqüentemente, o processo de formação democrática da opinião e da vontade políticas se torna viciado desde o princípio.

\footnotetext{
${ }^{526}$ Em ranking de 2007 da ONG Privacy International, são listados os países com maiores práticas de vigilância dos cidadãos, tanto pelo Estado como por empresas. O Brasil é considerado país com "systemic failure do uphold safeguards", isto é, "falha sistêmica" de formas de proteção da privacidade. Rússia, EUA, Grã-Bretanha são considerados de sociedades de "vigilância endêmica". O Canadá lidera com "proteções e garantias significantes", mas ainda também não é considerado "consistente na proteção de direitos humanos". Comparado com índices de 2006, há uma piora geral na proteção de direitos de privacidade e na vigilância. V. Privacy International. National Privacy Ranking 2007 - Leading Surveillance Societies Around the World, 2007. Disponível em www.observatoriodeseguranca.org (último acesso: 19/12/2011).

527 O Governo Federal mantém desde 1997 um serviço de disque-denúncia nacional, promovido pela Secretaria de Direitos Humanos, especializado em receber denúncias de violações de direitos de crianças e adolescentes. Essa política permite, por exemplo a realização de um monitoramento das denúncias de violações de direitos humanos pela publicação de estatísticas das denúncias e encaminhamento. V. Relatório com dados de 2011 em www.direitoshumanos.gov.br (último acesso: 19/12/2011). Esse mecanismo foi aplicado também em São Paulo, com o disque- denúncia, criado em 2000 no Instituto São Paulo Contra a Violência. V. Mesquita Neto, 2011:330.

${ }^{528}$ A liberdade comunicativa como se manifesta no discurso expressivo pode ser apresentada teoricamente pela da associação que Klaus Günther faz de sua teoria da responsabilização jurídica com a teoria do reconhecimento, de Honneth. Para Günther, o reconhecimento da liberdade individual de escolha é fundamental para garantir que as pessoas possam ser consideradas responsáveis por suas ações. V. Günther, 2010:271. V. cap. 8 abaixo.
} 
7.3. Auto-expressão existencial e cultural como experiências de reconhecimento e suas problematizações na esfera pública política

Depois de analisar exemplos da expressão estética da esfera pública política, que leva a pretensões de visibilidade e publicização do direito, e em seguida o exemplo do discurso expressivo nas pretensões de proteção constitucional justificada da esfera privada, este diagnóstico da esfera pública política nacional termina com algumas breves análises de entrelaçamentos entre discursos expressivos e estéticos que suscitam complexos problemas práticos a serem enfrentados pelo direito da comunicação.

O primeiro deles é a relação entre liberdade de crença e de culto e liberdade de orientação sexual, cujas pretensões normativas têm entrado em conflito na esfera pública política nacional. Pretende-se provar aqui, no entanto, de modo semelhante ao raciocínio feito no capítulo 6.1, que além de partilharem o mesmo espaço social formado pelos discursos estético-expressivos, a liberdade de crença e o respeito à diversidade são cooriginários e complementares (a).

Por fim, pretende-se analisar atuais problematizações feitas a políticas de cultura, como a Lei Rouanet, demonstrando a insuficiência de políticas públicas somente redistributivas aplicadas ao setor. Isso porque as formas de se garantir direitos que são ao mesmo tempo individuais e coletivos (ou intersubjetivos, v. cap. 9.2), como o direito à cultura e à expressão cultural, precisam se estruturar também como políticas de identidade, ou de reconhecimento. Ao final, são feitas algumas considerações sobre como a comunicação estético-expressiva pode colaborar para fomentar práticas de solidariedade (b).

a) tolerar pode significar insultar, mas a recíproca não verdadeira: relações e tensões entre liberdade religiosa e liberdade de orientação sexual

Rainer Forst retomou recentemente conhecida fase de Goethe "Tolerar é Insultar", da obra XX, para discutir os problemas da prática de uma tolerância passiva em relação aos princípios da liberdade e da diversidade cultural e religiosa. O autor segue Goethe para tentar mostrar como essa tolerância poderia esconder um sentimento contrário ao respeito e 
reconhecimento que se exige a todos quando se trata de "tolerar" a liberdade religiosa e cultural. $^{529}$

Mas se é tarefa complexa distinguir a tolerância que se expressa como nãointerferência em relação à tolerância como indiferença - o que pode levar a formas de “invisibilidade", e portanto, desrespeito -, não é tão complicado entender que um insulto dificilmente pode ser interpretado como tolerância.

A partir desse debate sobre o sentido da tolerância serão abordados conflitos atuais entre pretensões de liberdade religiosa e de liberdade de orientação sexual na esfera pública política nacional. Essa análise será importante para a fundamentação teórica e prática do direito da comunicação especialmente porque torna mais clara a existência de pretensões de reconhecimento nessa expressão da esfera pública política, o que não seria possível sem uma recepção de elementos das teorias de Honneth e Forst como formas de aprofundar o caráter intersubjetivo da teoria habermasiana do direito. A fundamentação teórica dessa recepção será realizada mais propriamente no capítulo 8 .

O caso concreto em tela trata das discussões do projeto de lei 122/06 da Câmara dos Deputados, que visa alterar a lei $\mathrm{n}^{\mathbf{0}}$ 7.716/89 para definir e incluir nos crimes resultantes de preconceitos de raça, gênero ou cor, aqueles ligados à discriminação ou preconceito de gênero, sexo, orientação sexual e identidade de gênero. A proposta também pretende reformar normas trabalhistas, incluindo a não-discriminação de orientação sexual e identidade de gênero nas relações de trabalho.

De modo geral, os entraves para aprovação da norma advêm de deputados que representam interesses de comunidades religiosas, pois receiam que os discursos e pregações religiosas contrárias à liberdade de orientação sexual possam ser enquadrados nas hipóteses da lei. Para esses deputados, trata-se de violação da liberdade de expressão.

Em função disso, a relatora do projeto já em discussão no Senado, Marta Suplicy, procurou levar as partes a um consenso com a proposta de excepcionar da norma

\footnotetext{
${ }^{529}$ A frase completa de Goethe é na verdade "A tolerância deveria ser uma atitude apenas temporária: ela deve conduzir ao reconhecimento. Tolerar significa insultar" (itálico nosso), de sua obra Maximen und Reflexionen [Máximas e Reflexões], citado por Forst, Os limites da tolerância, Novos Estudos. 84, $2009: 20$. Neste texto, Forst traz sua definição sobre o conceito, objeto de sua tese de habilitação para a docência defendida em Universidade Goethe de Frankfurt em 2003: "Tolerância é o que eu chamo de um conceito normativamente dependente, o qual, para que tenha um determinado conteúdo (e limites especificáveis), carece de recursos normativos adicionais que não sejam dependentes nesse mesmo sentido. Tolerância não é, portanto, contrariamente a uma visão comum, ela mesma um valor, mas, em vez disso, uma atitude requerida por outros valores ou princípios. Além disso, a fim de evitar a acusação de arbitrariedade, os fundamentos necessários devem ser normativamente "auto-sustentáveis" e têm que possuir a qualidade de permitir que se estabeleçam divisas e limites de um modo mutuamente justificável." Forst (2009a:18); V. Também Forst. Toleranz im Konflikt. Geschichte, Gehalt und Gegegenwart eines umstrittenen Begriffs [Tolerância em Conflito. História, conteúdo e presente de um conceito discutido. Trad. livre].Suhrkamp, 2003.
} 
"manifestação pacífica de pensamento decorrente da fé e da moral fundada na liberdade de consciência, de crença e de religião", o que não surtiu efeito. Após debate acalorado e impasse dos dois lados em sessão da Comissão de Direitos Humanos e Legislação Participativa do Senado, a relatora retirou o projeto de votação para tentar novo acordo. ${ }^{530}$

De modo semelhante à relação entre autonomia individual e autonomia privada, no entanto, Habermas demonstra no texto "Tolerância religiosa como predecessora dos direitos culturais", da obra Entre Naturalismo e Religião (2007:279-300), que as liberdades de auto-expressão existencial e cultural entendidas atualmente como direitos culturais (direitos de diversidade) têm origem nas liberdades de crença, culto e de consciência primeiramente conquistadas a partir da Reforma Protestante.

Note-se, no entanto, que desde então a liberdade religiosa só faz sentido enquanto compreendida também na forma de uma pretensão de diversidade religiosa, ou o reconhecimento de outra visão de mundo ou expressão existencial como sendo tão válida quanto as demais. $^{531}$

Além disso, com o processo moderno de racionalização das compreensões tradicionais de mundo e a separação entre Igreja e Estado, a religião foi alocada para a esfera mais subjetiva do discurso estético-expressivo, tornando-se mais uma forma cultural ou visão de mundo ao lado de outras, apesar de ainda deter forte influência na esfera pública.

Nesse momento, as liberdades de crença e religião e a liberdade de orientação sexual deixam de se opor, pois além de ambas se expressarem na forma de pretensões de reconhecimento presentes esfera pública estético-expressiva, podem ser consideradas também complementares. Isso porque a contradição entre ambas só ocorre quando a liberdade de crença e religião desconsidera a pluralidade de visões de mundo que lhe é inerente (ou co-originária). ${ }^{532}$

\footnotetext{
${ }^{530}$ Veja notícias sobre os debates em torno do projeto na agência de notícias do Senado www.senado.gov.br (último acesso: 20/12/2011). Ver também notícia de 08/12/2011 da revista Veja.

${ }^{531}$ Como diz Forst, a tolerância só surge no momento em que há um sentimento de intolerância, ou uma tentativa mais reflexiva de delimitá-la, o que lança o tema à esfera pública (Forst, 2009:18-19).

532 "Os direitos culturais, do mesmo modo que o exercício da religião, têm por objetivo garantir a todos os cidadãos um acesso eqüitativo às comunicações, tradições e práticas de uma comunidade que eles julgam necessária para o exercício e a manutenção de sua identidade pessoal. (...) É certo que, em muitos casos membros de minorias nacionais, lingüísticas ou étnicas, atribuem aos meios e possibilidades da reprodução desejada dos próprios idiomas e formas de vida grande importância, a qual não é menor que a importância atribuída, por minorias religiosas, à liberdade de associação, à transmissão da doutrina religiosa e ao exercício de seu culto. Por isso, a luta pela igualdade de direitos da comunidade religiosa proporciona, seja na teoria política, seja na jurisprudência, argumentos e impulsos parar o conceito de uma "cidadania estatal multicultural'”. Habermas, 2007:298.
} 
Assim, quando se utiliza a liberdade de crença e religião para restringir a liberdade de orientação sexual, a primeira acaba violando a mesma pretensão de reconhecimento que exige para poder afirmar-se na esfera pública sem sofrer restrições.

Com isso, se a proposta de emenda da senadora procura isentar a liberdade de crença, moral e religião de reconhecer a liberdade de orientação sexual e de identidade de gênero como auto-expressões subjetivas de igual valor à própria liberdade de crença, tratase de uma emenda inconstitucional.

Em termos técnicos, e com algum esforço interpretativo, não haveria grandes problemas se a norma fosse aprovada com a emenda, pois ao excepcionar somente as "manifestações pacíficas" de opinião derivada de consciência, crença, moral e religião, ainda permite a punição daquilo que a lei pretende efetivamente enquadrar como crime: manifestações explícitas de desrespeito, discursos de ódio, disseminação pública de inverdades cientificamente comprovadas, entre outras atitudes que possam ser vistas pelos ofendidos e o Estado como violações dos princípios de reconhecimento e nãodiscriminação da liberdade de orientação sexual e identidade de gênero.

Agora, se a intenção foi de repetir um preceito constitucional para reforçar que ele deve ser considerado na aplicação da norma, o resultado é que se torna ainda mais complicado explicar em que sentido essas duas liberdades não são opostas (liberdade de expressão e respeito à diversidade), e sim são co-originárias e complementares, do mesmo modo que a autonomia individual e a autonomia política na esfera pública.

Diversos outros fatos relativos a esse debate trazem essa contradição aparente entre as pretensões dos movimentos de afirmação da diversidade de gênero e de orientação sexual com a expressão de autocompreensões éticas de mundo "dominantes".

Outros exemplos recentes no país são a iniciativa do grupo Diversidade Católica, que procura promover dentro da própria racionalidade da igreja o respeito à diversidade sexual (www.diversidadecatolica.com.br); os impactos negativos sofridos pelo "Kit Antihomofobia", lançado no início de 2011 pelo Ministério da Educação em parceria com a Secretaria de Direitos Humanos da Presidência da República; ou mesmo a tentativa de criação pelo partido DEM do "Dia do Orgulho Heterossexual" na cidade de São Paulo, vetado pelo prefeito no dia 15 de agosto de 2011.

Como diria Habermas, no final das contas a interpretação desses direitos como opostos impede que os atores envolvidos nos debates alterem o modo de interação estratégica, no qual as mudanças de perspectiva sempre serão compreendidas como concessões, e evoluam para uma interação comunicativa, quando passam a ser vistas não 
mais como limitações, e sim como correções de orientação normativa sem as quais elas mesmas tornam normas autoritárias enquanto violam preceitos fundamentais à sua própria existência.

Assim, se essa perspectiva permite problematizar os limites entre a tolerância e o insulto de modo não-dicotômico e auto-excludente, ainda assim esses limites precisam ser encontrados em cada caso dentro da esfera pública política, ou como propõe Forst, a partir do reconhecimento da necessidade de justificação pública de cada pretensão no debate argumentativo que se formado pelo "espaço social das razões".

Embora a passagem de uma tolerância/indiferença para um reconhecimento da diversidade do outro foi discutida aqui num caso de liberdade negativa (busca por direitos que protegem a não-violência ao prever punição a ela), já está mais claro como o reconhecimento no plano do direito demanda a atribuição de igual valor às diferentes expressões da identidade a partir de um princípio de respeito à diversidade que é inerente ao próprio reconhecimento.

Como propõe Honneth em sua recém publicada teoria da justiça, Das Recht der Freiheit (2011, "O Direito da Liberdade". Trad. livre), a liberdade que pode auto-refletir sobre seus próprios fundamentos para que não aja de modo a negar a si mesma se torna uma ponte necessária entre a liberdade negativa e sua concepção positiva: assume o caráter de algo semelhante àquilo que Honneth denomina liberdade reflexiva. ${ }^{533}$ Numa definição prosaica, esta chama as duas outras liberdades para conversar e propõe chegarem num acordo sobre como se articularão, visto que uma não pode viver sem a outra.

b) auto-expressão existencial e cultural e políticas de reconhecimento: por uma lógica complementar à racionalidade das políticas públicas de cultura

Fundamentada a auto-expressão existencial ou identitária (de gênero, etnia, crença, cor etc.) como uma pretensão de reconhecimento que protege o princípio da pluralidade de visões de mundo aplicado à expressão estético-expressiva da esfera pública política,

\footnotetext{
${ }^{533}$ Citando passagem do filósofo Herder (Vom Erkennen und Empfinden der menschlichen Seele [Do conhecer e reencontrar a alma humana. Trad. livre], 1982) sobre o autoconhecimento da "alma humana" individual em meio ao que este denomina "fala pública", Honneth define a ambivalência com que lida a liberdade reflexiva ou procurar distinguir entre autonomia e heteronomia: "A liberdade reflexiva, que Herder tinha diante de seus olhos, estava na consumação de uma apropriação em cujo decurso eu atravesso pela abertura universal que a fala aprende a articular, o que de um cerne autêntico minha personalidade forma." Trad. livre de: "Die reflexive Freiheit, die Herder vor Augen hat, besteht im Vollzug einer Aneignung, in deren Verlauf ich im Durchgang durchs Allgemeine der Sprache zu artikulieren lerne, was den authentischen Kern meiner Persönlichkeit ausmacht." (Honneth, Das Recht der Freiheit, 2011:66-67).
} 
cabe agora, como último esforço deste diagnóstico, discutir um exemplo mais positivo de pretensões de reconhecimento presentes na esfera pública política: a questão do acesso aos meios de auto-expressão existencial e cultural a partir de políticas de cultura.

Uma breve análise dos debates em torno das reformas da Lei Rouanet permitirá problematizar a própria natureza das políticas de cultura, e se elas devem continuar a ser pensadas somente a partir da lógica das políticas sociais redistributivas. Enfim, o que traria de novo - não somente para o fomento da cultura, mas também para o avanço da própria racionalidade das políticas públicas - a aplicação de uma concepção de políticas de identidade ou de reconhecimento sobre as áreas da cultura?

Notícia recente é interessante para introduzir o assunto. O ator Juca de Oliveira alega em entrevista de 19/12/2011 para o jornal Folha de S.Paulo que quando as empresas contratam projetos aprovados pelo mecanismo de incentivo fiscal da Lei Rouanet, elevamse os custos de produção e o preços ao público. ${ }^{534}$

$\mathrm{O}$ mesmo tem feito as redes de cinema e outras casas de shows como resposta à política de meia-entrada a estudantes, idosos e profissionais de ensino da rede pública. Os proprietários alegam que aumentam os preços não porque discordam da meia-entrada, mas por sofrerem prejuízo com falsificações das carteiras comprobatórias do benefício. Esse tipo de "retaliação" contra o poder público, no entanto, acaba tornando a medida ineficaz e encarecendo de modo geral o acesso ao bem cultural que é o cinema. ${ }^{535}$

Desde 1991, quando foi promulgada a lei de incentivo à cultura (Lei 8.313/91) idealizada pelo então ministro da cultura Sérgio Paulo Rouanet, houve grande crescimento da produção cultural, ainda que por meio de um sistema de renúncia fiscal às empresas que investissem em produções aprovadas pela lei. Até 2009, esse modelo levou à injeção de 8 bilhões no setor da cultura, o que permitiu um reflorescimento de produções de excelência, como no chamado "cinema da retomada". 536

\footnotetext{
${ }^{534}$ Segundo Oliveira: "Os custos sobem pela pressuposição de que seu espetáculo tem apoio, e, portanto, dinheiro. Então [os prestadores de serviço] sobem o preço. Os financiamentos elevaram todos os custos, sobretudo de divulgação.". Segundo a esposa de Gilberto Gil, a empresária Flora Gil, seria melhor que os artistas não dependessem desse mercado, pois não precisariam se alinhar a uma marca. V. reportagem do caderno "Ilustrada" de 19/12/2011 da Folha de S.Paulo.

${ }^{535}$ V. notícia de 26/08/2011 sobre o debate em blog de notícias $O$ Estado RJ: www.oesatadorj.com.br (último acesso: 21/12/2011).

${ }^{536}$ São dados do documento do Ministério da Cultura intitulado "Nova lei de Incentivo à Cultura. Multiplicação dos Mecanismos", 2009. Disponível em www.blogs.cultura.gov.br (último acesso: 21/12/2011).
} 
Documento de 2009 do Ministério da Cultura intitulado "Nova lei de Incentivo à Cultura. Multiplicação dos Mecanismos”, procura demonstrar, no entanto, que o modelo de renúncia fiscal está ultrapassado. Em função desse vínculo com a lógica econômica da iniciativa privada, o investimento em cultura acaba dependendo de oscilações do mercado, isto é, a política que pretende garantir direitos fundamentais de acesso à cultura e à produção cultural é envolvida pela racionalidade técnico-estratégica da economia, o que leva a produção cultural do país e as pretensões normativas estético-expressivas que ela representa a perderem seu valor intrínseco.

Segundo dados apresentados no documento, o mecanismo de renúncia fiscal se provou concentrador (de 2003 a 2007, 3\% dos proponentes concentraram 50\% do volume captado), desigual (em 2007, as regiões Sul e Sudeste ficaram com 80\% da verba captada), e ineficiente (teve baixa participação da empresas e em 2007, apenas 50\% dos projetos aprovados conseguiram), o que torna verdadeira e legítima a reclamação de Juca de Oliveira, um ator consagrado, como também de milhares de iniciativas de expressão artística, cultural e identitária de indivíduos e grupos entendidos como "minorias", ou "vulneráveis", que enfrentam grandes dificuldades de fazer parte do espaço social formado pelas expressões estético-expressivas da esfera pública política nacional. ${ }^{537}$

É por isso que se propõe analisar aqui as novas propostas e debates da reforma da lei de incentivo - que pretendem transformar o modelo de gestão da cultura - a partir das relações entre políticas culturais redistributivas e políticas culturais de reconhecimento ou identitárias. O debate teórico de fundo que informa essa análise é a conhecida discussão sobre redistribuição e reconhecimento realizada por Axel Honneth e Nancy Fraser em obra conjunta de 2006.

Ao citar ambos Fraser e Honneth, embora com uma posição mais semelhante à de Fraser nesse tema, Habermas procura distinguir as duas formas de política e aponta como devem permanecer separadas, porquanto embora imbricadas na integração social, as pretensões de "inclusão igualitária" as fundamentam também são distintas. Enquanto políticas de redistribuição buscam uma "redistribuição de chances de vida sociais" por meio da chamada justiça distributiva, a lógica das pretensões de reconhecimento está ligada ao "direito à livre associação ilimitada" (Habermas, 2007:297). ${ }^{538}$ A primeira diz

\footnotetext{
${ }^{537}$ Ministério da Cultura, op. cit:05.

${ }^{538}$ Em diálogo com a obra Das Andere der gerechtigkeit [O outro da justiça. trad. livre], 2000, de Honneth, Habermas atesta: "Mesmo que, na maior parte das vezes, a discriminação de minorias venha acompanhada também de discriminação social, recomenda-se que ambas as categorias de tratamento desigual sejam mantidas separadas (...) nas lutas pelo reconhecimento da integridade de uma determinada identidade coletiva
} 
respeito às decisões práticas sobre a melhor forma de reprodução material da sociedade, como em políticas de compensação econômica em democracias de massa, e a segunda trata de políticas de inclusão mais simbólica, orientadas pela garantia de visibilidade e reconhecimento público igualitários a todos. ${ }^{539}$

A proposta de Honneth é de conceber o mecanismo da justiça distributiva dentro de uma rede de formas normativas de reconhecimento recíproco ligadas à esfera do direito (2003:252), deriva da mesma crítica que ele realiza ao dualismo entre as categorias de "sistema" e "mundo da vida" de Habermas. 540

O dualismo, alerta Honneth, neste caso entre integração sistêmica e integração social proposta por Fraser, seria prejudicial se implicasse desconsiderar as decisões sobre a reprodução material da sociedade como decisões prático-morais, como se houvesse uma autonomização plena da esfera econômica (ou mesmo do poder), desenvolvida num sistema de merecimento auto-reproduzido e desligado de qualquer interação comunicativa.

Enfim, se as problematizações das políticas de cultura podem ser vistas a partir de entrelaçamentos e dominações do discurso estético-expressivo da cultura pelo discurso técnico-instrumental da economia, como propõe Fraser, ou se ambas dizem respeito a formas de reconhecimento recíproco que permitem tanto a inclusão igualitária no sistema social quando na esfera de visibilidade pública, como defende Honneth, talvez a questão mais importante de seja tornar evidente o caráter prático de ambas as perspectivas (Honneth \& Fraser, 2003:3).

Isso significa que se torna possível tanto fomentar uma separação entre as esferas, para que não haja dependência da cultura em relação à economia de mercado, quanto uma articulação entre ambas orientada para a finalidade da política pública.

encontra-se uma experiência de injustiça de tipo diferente, isto é, a experiência do desprezo, da marginalização ou da exclusão por razões de pertença a um grupo que, de acordo com os padrões da cultura da maioria dominante, é tida como “inferior"” (Habermas, Entre Naturalismo e Religião, 2007:297).

${ }^{539}$ Comentando sua primeira intervenção na obra Redistribution or Recognition, Honneth esclarece: “...I have let myself be guided by the general idea that the inclusion of memeber of society always takes place through the mechanism of mutual recognition. (...) This - what we call, following David Lockwood, 'social integration' as opposed to 'system integration - should in my view be understood as a result of processes of recognition through which subjects are normatively incorporated into society by learning to see themselves as recognized with respect to certain characteristics. Elsewhere [citando aqui seu: "Invisibility: on the epistemology of recognition”. in. The Aristotelian Society. s.vol. LXXV, 2001, pp:111-126). V. B.] I have tried to show that this process of inclusion can also be understood as a mechanism mediated by language, gestures, or media through which individuals achieve public "visibility'." Honneth, Capitalism and Culture. System Integration, and Perspectival Dualism. In. Fraser \& Honneth, 2003:249.

${ }_{540}$ Sobre essa crítica, v. Honneth \& Joas. Communicative action. Essays on Jürgen Habermas (MIT, 1991). V. Também Honneth, Disrespect, 2007. 
Essa separação e independência pode ser vista na proposta de setorização por área artística e a regionalização estadual do Fundo Nacional de Cultura, dando-lhe maior capacidade de captação de recursos, entre outros mecanismos que buscam facilitar o acesso a verbas públicas para a produção cultural, como previsões de parcerias público-privadas e iniciativas de micro-crédito (Ministério da Cultura, op. cit:2009:7).

Em relação a políticas que articulam ambas as áreas para o acesso à cultura, a proposta do Vale Cultura, que garante aos trabalhadores $\mathrm{R} \$ 50,00$ por mês para que atenda a produções culturais, sendo $30 \%$ de renúncia fiscal, $50 \%$ dos empregadores e $20 \%$ dos empregados, é uma forma de utilização prática não só das verbas públicas, mas da renda do próprio mercado para o incentivo à cultura, o que de certo modo inverte a lógica dominante identificada neste diagnóstico, pois procura submeter a economia às necessidades do setor da cultura.

$\mathrm{Na}$ perspectiva de políticas mais positivas de afirmação identitária e de reconhecimento cultural de grupos vulneráveis, minoritários e historicamente prejudicados, seria oportuno pensar também em cotas para produções culturais envolvendo essas culturas e grupos "invisibilizados" no presente ou historicamente injustiçados no passado. Pois a recuperação cultural da memória histórica torna-se também forma de inclusão na esfera pública estético-expressiva, o que colabora ao final para o aumento de práticas de tolerância como reconhecimento, facilitando a convivência pacífica em sociedades pluralistas.

Esse estímulo à convivência entre diferentes grupos e indivíduos que se reconhecem como iguais em condições de cidadania de uma mesma comunidade política, ou nas palavras de Habermas as fontes de uma solidariedade social necessária à integração harmônica de uma sociedade com alto nível de dissenso, poderiam também ser captadas a partir de um entrecruzamento de discursos estéticos e expressivos que produzem um sentimento específico que é denominado por Luc Boltanski de "sofrimento distante" (distant suffering) $)^{541}$

Uma breve análise desse sentimento e de como suas relações com a comunicação estético-expressiva pode colaborar para o aumento de práticas de solidariedade social, finaliza o diagnóstico do presente da esfera pública política desta tese.

O termo "sofrimento distante" é utilizado por Boltanski para caracterizar o sentimento de identificação das audiências dos meios de comunicação de massa com o

${ }^{541}$ Boltanski, Distant Suffering. New York: Cambridge University, 2005. 
sofrimento de pessoas desconhecidas que se torna visível a partir dos noticiários e outras plataformas de comunicação informativa. Sua obra sobre o tema discute o que seriam atitudes "aceitáveis" a se tomar a partir dessa identificação, que pode muitas vezes levar a sentimentos de impotência, angústia, banalização ou indiferença em relação ao sofrimento do outro.

Segundo o autor, quando se trata de audiências realmente distantes e que não há possibilidade de se fazer algo que afetasse direta ou indiretamente a situação daquele que sofre, os espectadores dos meios devem compartilhar com pessoas em seu entorno o sofrimento que testemunha e seus próprios sentimentos sobre ele. ${ }^{542}$ A comunicação afetiva desse sentimento de identificação torna possível uma forma de denúncia expressiva do sofrimento referida ao espaço público (Boltanski, 2005:114-115).

Mas além disso, a partir de uma relação estética com as imagens daqueles que sofrem através dos meios de comunicação audiovisuais, tornar-se-ia possível dar mais um passo no processo de identificação com o sofrimento do outro, pensando-o como algo sublime, no sentido de provocar no espectador a sublimação do que Boltanski denomina a partir de Hannah Arendt "políticas de pena" (politics of pity), ou desejos inconscientes de se diferenciar daqueles sofrem, ou o prazer por trás do próprio sentimento de pena etc. A política de pena, nesse sentido, seria uma forma de transfiguração do modo de encarar o problema como uma questão de justiça, ainda que fossem justificações a partir de elementos estético-expressivos (115-130 e 3-19)

Essa busca por maneiras de se conectar com o sofrimento daqueles que aparecem na televisão, jornais nos vídeos das redes sociais ou de sites de vídeos, pode ser vista como uma tentativa de se recuperar de modo secular e auto-reflexivo aquela que Habermas identificou como a segunda base pré-política do Estado democrático de direito, herdada de formas tradicionais de comunicação da autoridade política: a solidariedade entre os cidadãos do Estado.

Como se sabe, essa solidariedade não pode ser imposta aos cidadãos quando se fala numa ordem democrática e pluralista, ou isenta de uma substância ética pré-determinada como orientação normativa. Mas como diz Habermas, junto à consciência das normas (v. cap. 7.1, acima), essa fonte cultural da solidariedade, precisa ser protegida e estimulada na

\footnotetext{
542 "If the spectator of suffering, especially of suffering which is presented as real, must adopt the position of speaking to someone else about it, if He is to avoid having to lower his eyes, in what style must he couch his report for it to be acceptable? Our hypothesis is that one possibility is excluded, that of a pure and simple factual description which aims only to state things as they are, just so. The spectator of suffering cannot speak about what he has seen in objectivist terms, even if in a great many instances this seems today to be the best way to warrant the seriousness of a description which aspires the status of truth." Boltanski, 2005:23.
} 
forma de direitos culturais individuais e coletivos, sob pena de o processo de legitimação perder contato com o mundo da vida e auto-reproduzir como poder ilegítimo. ${ }^{543}$

Nessa perda de contato com o mundo da vida, os cidadãos não encontram motivos para agir como se co-autores do direito fossem; muito menos encontram estímulos para se relacionar de modo intersubjetivo com seus concidadãos ou outros seres humanos, isto é, tratando-os como pessoas dotadas das mesmas capacidades e garantias fundamentais de comunicação e reconhecimento, como a de que ninguém pode ser tomado como objeto ou meio para quaisquer fins.

O que a discussão entre estética, expressividade e moral que "sofrimento distante" de Boltanski acaba por trazer à pauta é justamente o problema de como a expressão estético-expressiva da esfera pública política - e aqui incluindo o espaço social de expressões, manifestações afetivas, identitárias, estéticas e culturais que circulam em diversos formatos nos meios de comunicação social e em outros espaços públicos - podem contribuir para que se forme uma corrente de solidariedade capaz de tornar o tecido social e a arquitetura institucional suficientemente flexíveis para não se rompam e consigam contornar seus déficits de legitimidade, apesar do aumento de diversidade e das possibilidades de dissenso trazidos por sociedades pluralistas e democráticas.

Essa solidariedade não-imposta se torna possível justamente com a abertura da esfera pública política para espaços de visibilidade nos quais as experiências de desrespeito podem encontrar o olhar social ${ }^{544}$ e gerar processos de identificação coletiva, numa espécie de solidariedade negativa. ${ }^{545}$ Esse poder de auto-representação tem a capacidade de ativar 543 Isso mostra como Habermas está ciente da importância da proteção jurídica das pretensões normativas
advindas da expressão estético-expressiva da esfera pública política, ainda que não de modo sistemático:
"Designamos como liberal uma cultura que se caracteriza por relações simétricas de reconhecimento
recíproco - mesmo entre membros de grupos de identidade diferentes. Tais condições de reconhecimento,
que sobrepujam limites subculturais, podem criadas indiretamente com os meios da política e do direito, não
diretamente. Direitos culturais e políticas de reconhecimento podem fortalecer a capacidade de auto-
afirmação de minorias discriminadas inclusive sua visibilidade na esfera pública; mesmo assim, não se pode
modificar, mediante a ameaça de sanções, o registro social de valores. O reconhecimento recíproco de
membros com iguais direitos, o qual constitui o alvo do multiculturalismo, pressupõe relações interpessoais
modificadas que se produzem pela via do agir comunicativo e do discurso e se harmonizam na esfera pública
democrática, em última instância, mediante controvérsias políticas sobre a identidade. Todavia, esses
mesmos processos desenrolam-se num espaço que constitui mediante a participação política e os direitos de
comunicação dos cidadãos do Estado." (Habermas, Entre Naturalismo e Religião, 2007:326-327. Itálicos
nossos).
544tgumas obras de autores nacionais podem contribuir para uma compreensão desse aspecto
"emancipatório" do olhar, que difere claramente do diagnóstico de sua mercantilização, como sugerido por
Bucci (2002; v. cap. 5.2 desta tese). V. para tanto Bittar, Razão e Afeto, Justiça e Direitos Humanos, 2008;
Oliveira, D. Violência midiática; a crise de uma tradição civilizatória. In. Id (org). Mídia, Cultura $e$
Violência, 2009, p. 25 .
545 Agradeço ao Professor Klaus Günther pela sugestão do termo, além de outras recomendações de leitura
em discussões relativas à natureza das expressões estético-expressivas da esfera pública, objeto do trabalho 
a esfera pública política a partir da projeção de pretensões normativas que têm origem na subjetividade mais íntima do afeto, formada na proteção da esfera privada, e que podem perpassar (não sem dificuldades) os valores e autocompreensões éticas mais densas da esfera social, atingindo a esfera pública política como expressões autênticas de poder comunicativo.

Somente com a utilização desse tipo de discurso estético-expressivo referido ao espaço público - obviamente levando em conta e procurando distingui-las das tentativas de manipulação de autobiografias pessoais e experiências de "reconhecimento como ideologia" (v. Honneth, 2010:103-130) - é que se poderá garantir, ao final, que a esfera pública política seja ativada em todas as suas potencialidades, de modo que a comunicação estético-expressiva não seja somente um fator prejudicial à racionalização do poder, mas também contribua para produzir processos de legitimidade cada vez mais democráticos.

Do outro lado, como se procurou comprovar ao longo deste diagnóstico da esfera pública política no Brasil, a concretização das pretensões normativas de comunicação e reconhecimento identificadas em cada uma de suas expressões também depende decisivamente da produção dessa legitimidade democrática.

O que se torna necessário agora, como esforço final desta tese, é demonstrar em que sentido o direito da comunicação pode, como teoria social do direito, explicar mais sistematicamente os reflexos dessa tentativa de recuperação da relação interna entre direito e esfera pública política. E ao mesmo tempo, como filosofia do direito, cabe fundamentar os impactos do direito da comunicação e dos conteúdos normativos mais concretos da esfera pública política nacional sobre alguns conceitos jusfilosóficos modernos que garantem a operacionalidade do sistema jurídico brasileiro.

"The fascination of authority and the authority of fascination: rationalization and legal theory in Habermas revised" (Blotta, 2010b), produzido como resultado do seminário "Heiligkeit des Recht und Recht der Heiligkeit" [A sacralidade do direito e o direito da sacralidade. Trad. livre], oferecida pelo mesmo professor no semestre de verão de 2010 na Faculdade de Direito da Universidade Goethe de Frankfurt. 


\section{PARTE III \\ O DIREITO DA COMUNICAÇÃO FUNDAMENTAÇÃO TEÓRICA E PRÁTICA}


Esta investigação segue para seus esforços finais com a proposta de fundamentar o direito da comunicação de modo teórico a partir do debate atual travado na teoria crítica nas áreas da filosofia política e da teoria do direito, e de modo prático com uma análise dos impactos de seus princípios estruturais sobre conceitos da filosofia do direito que são caros à operacionalidade da dogmática jurídica.

Especialmente no último capítulo, portanto, a argumentação teórica terá seus argumentos exemplificados com as próprias pretensões normativas da esfera pública política nacional identificadas na parte II. Elas serão retomadas não somente para que se possa desenvolver o direito da comunicação voltado para o direito brasileiro, mas também para demonstrar que não se trata de uma teoria idealista no sentido de desconectada de pretensões normativas concretas encontradas na realidade social e política.

Em contrário, o diagnóstico do presente da esfera pública política foi desenvolvido antes da fundamentação teórica do direito da comunicação justamente para que seus princípios estruturais e conteúdos normativos pudessem ser sistematizados depois de revelados por trás de afirmações, problematizações e violações empiricamente identificáveis de direitos de comunicação e reconhecimento.

Trata-se de apresentar agora uma fundamentação capaz de permitir uma apreensão mais consciente e sistemática do direito da comunicação, identificando-o não mais em atos reativos e ocasionais do poder público em face de pretensões normativas na esfera pública política, mas como uma teoria social do direito ${ }^{546}$ cujos princípios estruturais permitem a identificação e a explicação - a cada caso - da situação e da relação entre essas pretensões normativas (cap. 9).

Além disso, pretende-se que o direito da comunicação possa ser utilizado também como uma teoria operativa da dogmática jurídica, pois, como se verá nos tópicos do capítulo 9, ele oferece condições de justificação de políticas nas áreas da comunicação social e da comunicação política capazes de afirmar seus princípios estruturais e garantir os

\footnotetext{
${ }^{546}$ Procura-se desenvolver aqui a perspectiva de uma teoria social do direito de acordo com o definido por Eduardo Bittar, no sentido de uma filosofia crítica do direito: "Uma filosofia do direito que possui feição crítica é exatamente uma filosofia do direito voltada para a emancipação, e que cumpre sua função enquanto pensa e permite que as condições para a emancipação se dêem concretamente, no terreno das relações sociais. (...) A crítica serve como instrumento de avaliação do estado-atual-do-direito, ao modo de um diagnóstico do tempo, necessário para pensar os rumos da prática e da importância do direito no atual cenário sóciopolítico-econômico. Por isso, é um exercício intelectual que não prescinde de um certo grau de utopia, na medida em que este é um élan fundamental do pensar crítico" (Bittar, Justiça e Emancipação, 2011:89). V. também Bittar, Filosofia crítica e filosofia do direito. Por uma filosofia social do direito. in. Revista Cult, 2007.
} 
conteúdos normativos identificados como deficitários em diagnósticos da esfera pública política.

Para realizar essas duas tarefas finais, no entanto, será necessário primeiramente situar o direito da comunicação dentro do debate teórico atual da teoria crítica nas áreas da filosofia política e da filosofia do direito. Isso será feito a partir de uma breve retomada do caminho tomado por Habermas da teoria do discurso à teoria do direito e da democracia, até chegar a alguns de seus textos mais recentes sobre teoria política e teoria do direito (8.1).

Essa retomada pretende não somente delimitar de modo mais detido as revisões e atualizações sobre o sentido e as funções da esfera pública política na teoria discursiva do direito, mas também inseri-las num movimento maior de Habermas e seus interlocutores da teoria crítica em busca por interpretações mais intersubjetivas do direito(8.2), tendência para a qual o direito da comunicação pretende contribuir.

\section{Teoria do discurso, teoria discursiva do direito e suas atualizações nos presentes debates da teoria crítica: passos em direção a compreensões mais intersubjetivas do direito}

Assim como as pretensões normativas da esfera pública política nacional puderam ser identificadas por trás de diagnósticos de suas expressões concretas no presente, a teoria do direito da comunicação, que tem como objeto as problematizações e conflitos dessas mesmas pretensões, também se origina de um diagnóstico do presente do debate da teoria crítica nas áreas da teoria política e da teoria do direito.

Para chegar à tematização desse debate, serão antes discutidos os motivos que levam Habermas a buscar no direito uma forma de aplicação prática dos conceitos filosóficos da ética do discurso e da teoria do agir comunicativo, bem como por que, apesar de dar à esfera pública política um lugar especial nessa teoria, o autor não chega a reconstruir seus princípios normativos como faz com os pressupostos da autonomia política e da autonomia individual dos capítulos 3 a 6 de Direito e Democracia.

Pode-se dizer, no entanto, que novas discussões sobre o tema, como em textos de Entre Naturalismo e Religião (2007) e Ay, Europa! (2009), inauguram uma nova fase dos estudos de Habermas sobre política e direito, especialmente porque as funções da esfera pública política são redefinidas e recebem enfim um diagnóstico do presente. 
Além disso, é clara a tendência de Habermas de estender sua concepção de direito para recepcionar interpretações mais intersubjetivas de alguns institutos e garantias, como as redes de relações de reconhecimento recíproco que permitem a formação da personalidade individual (Habermas, 2007:298-300).

Para situar o direito da comunicação nessa nova orientação da teoria habermasiana do direito, terão importância fundamental os diálogos e incorporações teóricas que o autor tem feito de conceitos de outras perspectivas atuais da teoria crítica, cujas obras são em grande modo influenciadas pela sua. É o caso principalmente de Klaus Günther na teoria do direito (1998; 2005), Axel Honneth na teoria social $(2001 ; 2003 ; 2011)$ e Rainer Forst na teoria política $(1994 ; 2007)$.

Isso porque, apesar de serem de certo modo propagadores da perspectiva intersubjetivista trazida por Habermas, Günther, Forst e Honneth contribuem cada um em sua área e à sua maneira - mas não sem grandes interfaces - para esta que se poderia denominar, se não "terceira geração da teoria crítica", ao menos a sua geração atual.

A ambição da teoria do direito da comunicação (um tanto ousada, não se pode negar) é de se inscrever nas linhas desse grande debate, pensando os desdobramentos na teoria do direito quando se trata de reincorporar de uma vez por todas e no tempo presente a relação fundamental entre direito e esfera pública política, além de responder às pretensões normativas identificadas no caso brasileiro na parte II desta tese.

\subsection{Teoria do discurso, teoria discursiva do direito e o retorno incompleto do princípio da esfera pública política}

A teoria do discurso busca identificar as regras que precisam ser seguidas para que os discursos de fundamentação sobre questões comuns se dêem de modo mais ou menos racional; isto é, cujos resultados possam ser aceitos por todos os atual e possivelmente afetados com base em razões criticáveis. Se esse enunciado for verdadeiro, a teoria do discurso tem a mesma base normativa da esfera pública: o princípio de racionalização da dominação. ${ }^{547}$

\footnotetext{
${ }^{547}$ É Habermas mesmo quem prova a validade do anunciado, com foco no discurso prático: "The discoursecentered approach to ethics does not limit itself to the claim that it can derive a general principle of morality from the normative content of the indispensable pragmatic preconditions of all rational debate. Rather, this principle itself refers to the discursive redemption of normative validity claims, for it anchors the validity of norms in the possibility of a rationally founded agreement on the part of all those who might be affected [princípio "U" - V.B], insofar as they take on the role of participants in a rational debate [princípio "D" - V.B]. In this view, then, the settling of political questions, as far as their moral core is
} 
O que diferencia a esfera pública - e sua expressão política, referida a direitos de comunicação e de reconhecimento - em relação ao discurso, como primeiramente concebido por Habermas nos estudos preliminares de The Theory of Communicative Action (TCA) (Pragmatics of Social Interaction, 2001), é a extensão necessariamente pública (ou o interesse público manifesto) dos debates da primeira, pois enquanto o exercício do discurso é possível também no espaço privado, para a esfera pública, a acessibilidade de todos ao debate discursivo e a visibilidade de seus argumentos são pressupostos inegáveis (Habermas, 1996:360-361).

O ponto de partida da esfera pública e do discurso é também o mesmo: a problematização de pretensões de validade. Essas problematizações podem ser representadas por experiências de sofrimento identificadas como injustas pela vítima ou por outros, pela simples negação e crítica de algum ato ou ordem social ou política, ou por outras formas de expressão que chamam a atenção para problemas cujas respostas práticas exigem a consideração da opinião e da vontade livre dos afetados.

Assim, se o princípio da autonomia da vontade individual é garantido na teoria do discurso de Habermas por uma rede de competências, liberdades e exigências comunicativas que os membros individuais de comunidades lingüísticas devem atribuir uns aos outros, essa rede se estende à esfera pública na medida em que há uma distribuição equânime de direitos de comunicação e participação política entre todos os indivíduos que compartilham o mesmo Estado democrático de direito (Habermas, 1992:445-446) (e na mesma medida no plano internacional).

Num primeiro momento, essa argumentação apresentada em "Further Reflections on the Public Sphere" (Habermas, 1992), publicado antes de Direito e Democracia, parece afastar a suposição de alguns interlocutores como Calhoun (1992:32-33) e Kellner (2010) de que a busca de Habermas após MEEP por uma teoria da racionalidade situada em pressupostos ao mesmo tempo formais e pragmáticos da comunicação humana, seria sintoma de um abandono da esperança de concretização dos potenciais normativos de uma esfera pública democrática, especialmente após os resultados pouco animadores da obra de 1962.

Ao mesmo tempo, como aponta Calhoun em sua introdução a um debate em torno da recepção da primeira versão em língua inglesa de MEEP em 1992, o distanciamento tomado por Habermas em relação aos estudos histórico-empíricos desde MEEP também 
geraram certo prejuízo em termos da aplicabilidade da teoria do discurso em situações concretas do tempo presente, apesar de seus avanços teórico-normativos. Esse tipo de investigação normativa e ao mesmo tempo empírica característica da teoria crítica, só teria sido feito - ainda que de modo insatisfatório, de acordo com o próprio Habermas (Habermas, 1992:440-441) - na obra de 1962. ${ }^{548}$

A retomada desses estudos histórico-empíricos compreensivos viria ocorrer novamente com a publicação de Direito e Democracia (DD, original de 1992), quando os princípios da teoria do discurso são revelados e testados a partir de dois objetos historicamente determinados: o sistema de direitos e os princípios normativos dos Estados democráticos de direito contemporâneos da Alemanha e dos EUA (caps. 3-6, DD).

As reconstruções historicamente delimitadas que Habermas realiza mostram que ele ainda está preocupado em manter a perspectiva dos estudos do materialismo interdisciplinar da teoria crítica que animaram seu esforço em $M E E P$, ainda que sob as novas bases da teoria da sociedade estabelecida em TCA. Essa característica fundamental, embora não muito enfatizada de Direito e Democracia, pode também ser vista como o aspecto da filosofia hegeliana presente na obra, apesar de o autor buscar expressamente um modelo mais kantiano de teoria do direito. ${ }^{549}$

No entanto, não é por acaso que Habermas escolhe somente reconstruir o conteúdo normativo da "forma direito" e os pressupostos do Estado democrático em Direito e Democracia, deixando de fazer semelhante esforço também em relação ao conceito de esfera pública política.

548 “....Habermas has not surrendered the idea of immanent critique. Rather, he has removed the immanence from specific historical conditions to universal characteristics of human communication. This allows him to ground his normative argument, to keep it from arbitrariness, but it removes it from any clear purchase on historical progress. That is, communicative ethics does a much better job of setting out the normative ideal than of indicating what is likely to make it persuasive to people at any particular point in time an how to make judgments about better or worse communication in circumstances far from the ideal. There remain, in other words, advantages to the historical specificity of Structural Transformation even if one does not keep to a strong Hegelian-Marxist faith." (Calhoun, Introduction. In. Calhoun (org.), Habermas and the Public Sphere, 1992:40).

549 "What could once be coherently embraced in the concepts of Hegelian philosophy now demands a pluralistic approach that combines the perspectives of moral theory, social theory, legal theory and the sociology and history of law.// I welcome this as an occasion to display the often unrecognized pluralist approach of the theory of communicative action. Philosophical concepts no longer constitute an independent language, or at any rate not an encompassing system that assimilates everything into itself. Rather, they provide a means for the reconstructive appropriation of scientific knowledge. (...) Hence, the basic assumptions of the theory of communication action also branch out into various universes of discourse, where they must prove their mettle in the contexts of debate they happen to encounter." (Habermas, 1996:xxxix) 
Isso porque, enquanto o princípio do discurso implícito no conceito de esfera pública pode somente exigir moralmente (ainda que numa moral criticável, e por isso procedimental) que os cidadãos façam uso público de suas liberdades comunicativas para garantir uma integração social não-coercitiva, o diagnósticos de uma sociedade complexa, envolvida em déficits de legitimidade e perigosas "hipotecas morais", levam Habermas a buscar um meio de fazer valer, inclusive com a garantia do "uso legítimo da força", os planos de vida individuais estabelecidos publicamente. ${ }^{550}$

Essa perspectiva acaba tendo conseqüências diretas sobre o lugar ocupado pela esfera pública política na teoria do direito de Habermas em $D D$. Somente a partir de estudos publicados em Entre Naturalismo e Religião (2007) e especialmente textos de Ay, Europa! (2009) é que sua função passa a ser mais bem desenvolvida, recebendo inclusive um diagnóstico do presente - embora ainda de modo assistemático - em "Tiene la democracia aún una dimensión epistêmica?” (2009:136-183).

Essa posição específica da esfera pública política na teoria do direito, bem como suas mudanças e tendências em textos mais recentes merecem uma análise mais detalhada, a partir da qual se inicia a fundamentação teórica do direito da comunicação. Por isso, seguem abaixo dois subtópicos dedicados ao período anterior à $D D$ ( $a . D D$, analisada em “a”) e ao período posterior à obra (d.DD, em "b").

a) fase a.DD: a transferência da fonte de legitimação democrática da esfera pública política para o procedimento deliberativo

Alguns textos que antecipam e inspiram a teoria discursiva do direito e da democracia apresentada por Habermas em $D D$, especialmente "Further Reflections on the Public Sphere", tradução do prefácio da segunda edição alemã de MEEP (1990), já procuram destacar como o princípio do discurso é adequado para interpretar de modo intersubjetivo procedimentos legais e sistemas jurídicos. O mesmo é feito na obra Comentários à Ética do Discurso (1999). ${ }^{551}$

\footnotetext{
${ }^{550}$ Em entrevista à Barbara Freitag e Sérgio Paulo Rouanet publicada na obra Jürgen Habermas: 60 anos (Habermas et. ali. 1989b:20), Habermas destaca como hipotecas político-morais mundiais a fome, a tortura, o desemprego e o rearmamento atômico. Hoje essa lista poderia ser tranqüilamente acrescida dos problemas e riscos ambientais.

${ }^{551}$ Em importante passagem da obra, original de 1987, Habermas fundamenta teoricamente a passagem da ética do discurso à teoria do direito: "O problema da razoabilidade das obrigações morais motiva a transição da moral para o direito. E com a implementação de objectivos e de programas colocam-se finalmente as questões da transferência e do exercício neutro do poder político.// O direito moderno da razão respondeu a estas problematizações. Na verdade, não contemplou a natureza intersubjectiva da formação da vontade
} 
Mas para fazer isso, Habermas precisa transferir a fonte de avaliação de legitimidade da ordem política da relação anterior entre opinião pública fabricada $e$ "publicidade crítica", proposta em $M E E P^{552}$, para o procedimento deliberativo, que garante sua racionalidade a partir da falibilidade e sua presunção de expressar a formação democrática da opinião e da vontade de todos dos concernidos (Habermas, 1992:451-452).

Isso mostra que o diagnóstico sobre a dissolução do princípio da esfera pública política em MEEP afeta, sim, a concepção discursiva de direito de Habermas e as funções que ela dá ao princípio em sua teoria do direito. Aliás, não seria de todo exagerado dizer que o diagnóstico de 1962 dessa categoria fundamental de seu pensamento influencia tanto a teoria do discurso consolidada em TCA quanto sua guinada prática para uma ética do discurso $^{553}$, que se desdobra posteriormente em $D D$. Em relação à TCA, a questão mais marcante desse "desencanto" com a esfera pública política é a concepção dual de sociedade desenvolvida depois de o autor rechaçar a concepção mais "holística" que confessa ainda ter utilizado em MEEP. Com a distinção entre mundo da vida e sistema, que em direito e democracia se desdobra na tese de diferenciação funcional dos subsistemas sociais, estaria assegurada a reprodução de cada um deles sem interferências recíprocas prejudiciais ao seu funcionamento, como no caso da política em relação à economia no exemplo histórico do socialismo real (Habermas, 1992:443-444).

Mas se a esfera pública burguesa representou a possibilidade dos indivíduos privados discutirem politicamente - e como questões práticas - regulações da esfera econômica, por exemplo, a descrença em sua efetivação enquanto princípio constitucional de racionalização da dominação desde $M E E P$ acaba por dificultar de modo geral a identificação de interpenetrações e problematizações entre os diferentes discursos e pretensões de validade da comunicação pública.

Assim, diferentemente do que foi visto diversas vezes no diagnóstico da parte II desta tese, se os media "dinheiro" e "poder", ou se a esfera econômica ou a burocracia não tivessem qualquer pano de fundo comunicativo, não faria sentido algum escolher entre duas políticas econômicas a partir da avaliação de que uma levaria a resultados mais justos

colectiva, pois esta não pode ser concebida como uma formação da vontade individual em ponto grande. Temos de renunciar às premissas filosofia do sujeito que informam o direito racional. Do ponto de vista da teoria do discurso, o problema do entendimento entre partes de vontades e interesses divergentes desloca-se para o plano dos processos institucionalizados e dos pressupostos comunicativos necessários à argumentação e à negociação que devem, de facto, ser levados a cabo." (Habermas, 1999:116. Grifos nossos)

${ }^{552} \mathrm{~V}$. aqui tópico 1.2 “c”, acima.

${ }^{553}$ Para uma leitura mais sistemática dessa guinada prática da teoria de Habermas, v. Blotta, Habermas e o Direito, 2010:239-270. 
do que a outra, e da mesma forma em relação decisões sobre o que fazer quando a burocracia desconsidera peculiaridades de casos concretos. Como foi possível avaliar no diagnóstico do presente da esfera pública política no Brasil, a comunicação comum continua a problematizar questões de diferentes subsistemas como problemas práticos.

É compreensível, no entanto, a preocupação de que a intrusão exagerada de um discurso sobre o outro possa levar a prejuízos sérios no funcionamento normal (ou na perfomance) de cada "subsistema", como no caso do socialismo real. Mas o inverso também pode ocorrer, como na última crise financeira de 2008, quando o sistema econômico se autonomizou a ponto de dispensar quaisquer formas de regulação práticomoral.

É por isso que, seguindo críticas como as de Honneth (1991; 2007), Honneth \& Fraser (2003) e Kellner (2010), por exemplo, não se compartilha nesta tese a divisão entre sistema e mundo da vida trabalha por Habermas em $T C A$, bem como a incomunicabilidade quase plena (a não ser pelo médium do direito) entre determinadas esferas diferenciadas de reprodução social em relação aos mananciais culturais da comunicação cotidiana. ${ }^{554}$

Como o "domínio objetual" da teoria do direito da comunicação é a esfera pública política (v. cap. 9, abaixo), preferiu-se trabalhar o diagnóstico de suas dinâmicas na parte II como interpenetrações e influências entre discursos e pretensões de validade de diferentes discursos, os quais, apesar de informar sistemas de ação distintos, guardam consigo entrelaçamentos constitutivos e fundamentais à reprodução material e simbólica da sociedade.

\footnotetext{
${ }^{554}$ Habermas explica em "Further Reflections..." essa perspectiva adotada no decorrer de sua obra. Com algumas alterações em relação à função do direito, ela acaba compondo também o diagnostico de $D D$ : "While in Technik und Wissenschaft als 'Ideologie' (1968) I had still tried to differentiate between the action systems of state and economy on the level of a theory of action, proposing the predominance of purposive and rational (or success-oriented) action versus that of communicative action as a distinguishing criterion, this all-too-handy parallelization of action systems and action types produced some nonsensical results [aqui cita a obra "Critique of Power" de Honneth. V. B.]. This caused me , in Legitimation Crisis (1973), to link the concept of lifeworld, introduced in On the Logic of Social Sciences (1967), to that of the boundary maintaining system. From this emerged, in The Theory of Communicative Action (1981), the two-tiered concept of society as lifeworld and as system. The implications for my concept of democracy were considerable.// From that time on I have considered state apparatus and economy to be systemically integrated action fields that can no longer be transformed democratically from within, that is, be switched over to a political mode of integration, without damage to their proper systemic logic and therewith their ability to function. The abysmal collapse of state socialism has only confirmed this. Instead, radical democratization now aims for a shifting of forces within a 'separation of powers' that itself is to be maintained in principle. The new equilibrium to be attained is not one between state powers but between different resources for societal integration. The goal is no longer to supersede an economic system having a capitalist life of its own and a system of domination having a bureaucratic life of its own but to erect a democratic dam against the colonializing encroachment of system imperatives on areas of the lifeworld." (Habermas, 1992:443-444).
} 
Nesse caso, as próprias experiências de diferenciação, influência recíproca e problematização entre as pretensões de validade de cada discurso passam a ser vistas como evidências negativas da busca implícita por uma unidade originária da razão, agora passível de ser atualizada reflexivamente.

Em relação à teoria de Habermas, no entanto, mesmo com esses riscos de uma diferenciação excessiva entre sistema e mundo da vida, o potencial de racionalização da ação social que a teoria do discurso encontra na comunicação cotidiana a partir de $T C A$ acaba por liberar o princípio da esfera pública política de seus limites históricos, permitindo sua identificação em outras formações sociais (Habermas, 1992:442-443).

Além disso, de acordo com Habermas, essa identificação não seria mais aquela entre norma e realidade, como na crítica socialista da ideologia da esfera pública liberal advinda especialmente de Marx, mas uma que concebe as próprias normas como realidades concretas cuja natureza propositiva lhes permite extrapolar o presente histórico e apontar possibilidades emancipatórias.

No entanto, como Habermas decide não retornar para um novo diagnóstico da esfera pública política após a formulação da teoria do discurso em $T C A$ e da ética do discurso em Consciência Moral e Agir Comunicativo, seus princípios acabam sendo reconstruídos na teoria do direito e da democracia habermasiana na forma de procedimentos deliberativos que devem garantir formações discursivas da opinião e da vontade políticas (caps. 3 e 4 de $D D$ ).

Com isso, apesar de Habermas ter destacado a esfera pública política de seus públicos específicos, assumindo-a como "fluxos assujeitados” de comunicação, bem como considerado os entrecruzamentos de problemas políticos com outros discursos ${ }^{555}$, o fato de ele não reconstruir seus conteúdos normativos de modo sistemático no capítulo 8 de DD, faz com que o conceito continue a ser interpretado metodologicamente como uma oposição entre ideia e realidade, isto é, na forma ainda dicotômica de uma publicidade crítica (ou

\footnotetext{
555 "Of course, although issues of political principal almost always also have a moral dimension, by no means all question institutionally defined as part of the bailiwick of political decision makers are of moral nature. Political controversies frequently concern empirical questions, the interpretation of states of affairs, explanations, prognoses, etc. Also, certain problems of great significance, so-called existential issues, often concern not questions of justice but, as questions concerning the good life have to do with ethical-political self-image, be it of a whole of society, be it of some subcultures. After all, the majority of conflicts have their sources in the collision of groups interests and concerns distributive problems that can be resolved only by means of compromises. Yet this differentiation within the field of issues that require political decisions negates neither the prime importance of moral considerations nor the practicability of rational debate as the very form of political communication. Empirical and evaluative questions are frequently inseparable and evidently cannot be dealt with without reliance on arguments." (Habermas, 1992:448).
} 
comunicação livre entre esferas públicas periféricas e formais em $D D$ ) contra uma publicidade aclamatória (ou legitimidade subvertida pelos "media" poder e dinheiro).

Assim, é sobre o procedimento deliberativo que acabam se concentrando os esforços de aferição da qualidade das práticas legitimadoras do poder na teoria discursiva do direito de Habermas, e não mais na esfera pública política que se forma a partir de uma comunicação publica discursiva. Com seu poder de coercibilidade, o procedimento legal poderia além de tudo garantir a sua própria legitimidade, por assim dizer, na medida em que institucionaliza condições de debates livres, falíveis e corrigíveis, tanto dos processos de problematização quanto de tomada de decisão que formarão normas e programas legislativos (Habermas, 1992:449-450).

Diante da fragilidade das forças de "solidariedade social" e de uma esfera pública envolvida por dinâmicas de poder de complexa aferição (Habermas, 1996:386), portanto, Habermas procura reconstruir as relações entre os princípios da autonomia individual e da autonomia política as normas jurídicas mais gerais da forma direito ${ }^{556}$. Nela não estão incluídos, no entanto - ao menos não de modo explícito -, princípios referentes às pretensões normativas dos discursos existenciais e de identidade, bem como as exigentes demandas de publicização e justificação da ordem política identificadas no diagnóstico da parte II desta tese (v. cap. 7, acima).

$\mathrm{Na}$ medida em que a "dissolução" da soberania popular se concentra em procedimentos jurídicos capazes de estruturar "barreiras" (Id. op. cit:452) contra a invasão das lógicas sistêmicas no mundo da vida - ou mais adiante, de formar "eclusas" que elevam e traduzem demandas do mundo da vida ao sistema (Id, 1996:327) -, a esfera pública política continua insuficientemente protegida em sua tarefa de promover uma formação mais ou menos racional da opinião e da vontade políticas.

A partir dessas reflexões, pode-se supor que, caso Habermas houvesse retornado após $T C A$ aos problemas enfrentados em $M E E P$, a teoria do direito que poderia emergir de lá também demandaria uma reconstrução da tensão entre autonomia individual e

\footnotetext{
${ }^{556}$ A forma direito, derivada da aplicação do princípio da democracia ( princípio do discurso aplicado ao direito), é garantida a partir dos seguintes direitos básicos: 1. "direitos básicos que resultam da elaboração politicamente autônoma do direito à maior possível medida de iguais liberdades individuais," os quais pressupõem, por sua vez, direitos básicos resultantes do status de membro de uma comunidade juridicamente regulada, e direitos básicos derivados da acionalibilidade dos direitos e da proteção legal individual (Habermas,1996:122); 2. "direitos básicos de iguais oportunidades de participar em processos de formação da opinião e da vontade" políticas, a partir dos quais produzem "direito legítimo" (Id., op.cit.:123); 3. "direitos básicos para a provisão de condições de vida que são socialmente, tecnologicamente e ecologicamente protegidas", o que torna possível o exercício dos direitos anteriormente listados. (Id. ibid). V. Blotta, 2010:308-309.
} 
autonomia política no procedimento legal, mas essa operação teria de ser feita como tarefa de uma reconstrução maior, que inclui as pretensões normativas da esfera pública política, refletidas em suas respectivas instituições jurídicas.

Somente com esse esforço de reconstrução que abrange também de modo sistemático as relações entre os discursos presentes na esfera pública, torna-se possível realizar de modo completo a análise da qualidade racional dos processos de formação da opinião e da vontade políticas. O direito da comunicação pretende contribuir para completar esse processo, tornando possível identificar de modo mais preciso e sistemático a "ponte institucional" entre o que Habermas denomina "auto-interesse esclarecido" e “orientação para o bem-comum” (Habermas, 1992:449).

Como se verá de modo teórico nesta última parte da tese, essa ponte deve ser construída não somente com direitos individuais de comunicação e participação na formação livre da opinião e da vontade política, mas também com a proteção das redes de reconhecimento recíproco entre indivíduos, bem como as exigências de publicização do direito que colaboram para a formação de uma cultura política acostumada a fazer uso de suas liberdades comunicativas.

b) fase d.DD: reforço às pretensões de identidade existencial e cultural e a esfera pública política como terceiro pressuposto do Estado democrático de Direito

A fundamentação do direito da comunicação parte da hipótese de que a teoria discursiva do direito e da democracia de Habermas passa por uma nova fase, iniciada após os estudos de Habermas sobre a influência da religião na esfera pública, especialmente em Entre Naturalismo e Religião (2007).

Essa nova fase se caracteriza primeiramente por uma tentativa mais clara de recepcionar dentro da forma direito - embora ainda de modo assistemático - a necessidade de se proteger as relações de reconhecimento recíproco com as quais os indivíduos podem desenvolver suas personalidades individuais, bem como as compreensões de si mesmos e do mundo em sua volta. ${ }^{557}$

\footnotetext{
557 “Os direitos constitutivos para a proteção da integridade do indivíduo singular determinam também seu status como pessoa de direito. Tais direitos têm de ampliar-se a ponto de garantir o acesso aos contextos da experiência, da comunicação e do reconhecimento no quais uma pessoa pode articular a compreensão de si mesma, bem como desenvolver e manter uma identidade própria. De acordo com isso, os direitos culturais, exigidos e introduzidos à luz de uma 'política do reconhecimento', não podem ser entendidos como sendo naturalmente direitos coletivos. De acordo com o modelo da liberdade de religião, trata-se, antes de tudo, de direitos subjetivos que garantem uma inclusão completa. Eles garantem a todos os cidadãos um acesso
} 
Essa recepção é sugerida por Habermas especialmente em diálogo com a teoria do reconhecimento de Axel Honneth, e tem a finalidade de proteger, de modo secular e a partir de direitos individuais, as fontes culturais de solidariedade social que eram reproduzidas em sociedades tradicionais a partir do compartilhamento de autocompreensões éticas mais concretas.

Isso mostra que, além de fundamentar o caráter procedimental da formação da opinião e da vontade políticas, Habermas está agora em busca de uma especificação dos procedimentos jurídicos capazes de garantir a livre formação de identidades individuais em sociedades pluralistas, sem o que o próprio princípio da autonomia individual não pode transcender a concepção de uma liberdade negativa, talhada para funcionar somente em oposição, e não em convívio com outras liberdades.

A incorporação dessa proteção de modo interno à forma direito dar-se-ia, então, por uma ampliação do conjunto de "direitos básicos resultantes do status de membro de uma comunidade juridicamente regulada" (primeiro grupo de direitos da forma direito, v. Habermas, 1996:122) e daqueles destinados à "provisão de condições de vida socialmente protegidas" (terceiro grupo de direitos da forma direito, v. Id. op. cit:123). ${ }^{558}$

Essa concepção intersubjetiva da proteção da integridade do indivíduo se estende, então, para recepcionar as pretensões de desenvolvimento existencial e cultural presentes na esfera privada, as quais tornaram possíveis nos séculos XVIII e XIX o florescimento da subjetividade moderna, a esfera pública literária e, conseqüentemente, uma esfera pública política mais autêntica, como identificado em $M E E P$ (v. cap. 2 "a”).

No tempo presente, essa autenticidade da esfera pública política pode ser garantida na medida em que os direitos a liberdades individuais iguais e as garantias de status de membro de uma comunidade política passam a ser exigidos publicamente a partir de pretensões ao livre exercício de direitos culturais e de expressão da personalidade ou de identidades individuais e coletivas.

Porém, essa nova estratégia de Habermas poderia ser considerada uma invasão indevida do direito na esfera privada dos indivíduos, pois a princípio, relações de reconhecimento presentes nessa esfera, como os laços afetivos da família e da amizade, não podem ser impostas juridicamente, sob pena de uma juridificação (Verrechtlichung)

eqüitativo aos entorno culturais, às tradições e relações interpessoais à medida que estas são essenciais para a formação e a garantia de sua identidade pessoal." (Habermas, 2007:299. Itálicos nossos).

${ }^{558}$ V. transcrição dos direitos que compõem a "forma direito" na última nota do subtópico anterior, acima. 
que retira a espontaneidade dessas relações, e do mesmo modo a espontaneidade de suas formas de expressão pública (Habermas, 1987-II:356-373).

Não só Habermas em TCA chamou atenção para as patologias derivadas desse processo de juridificação das relações sociais, que acaba submetendo a liberdade da esfera privada à lógica de outros sistemas de reprodução social ${ }^{559}$, mas também Honneth, em discussão com Hegel, entende que as relações da família e da amizade não podem ser constituídas por normas jurídicas, ainda que estas possam garantir sua continuidade como instituição social pré-existente, bem como o direito de todos a fazer parte de suas relações de reconhecimento. ${ }^{560}$

Atualmente, no entanto, está mais clara para Honneth como para Habermas a necessidade do direito garantir não as próprias experiências de reconhecimento na esfera privada, mas as condições propiciadoras de relações de reconhecimento nessa esfera, as quais passam por essa extensão dos direitos iguais de proteção da integridade a pessoa a partir dos quais ela possa desenvolver e expressar livremente sua personalidade e identidade cultural. ${ }^{561}$

Outro desenvolvimento fundamental da teoria do direito de Habermas que permite situá-la numa nova fase está em seu mais completo estudo sobre as relações entre esfera pública política e teoria do direito e da democracia após MEEP. Trata-se do texto "Tiene aún la democracia una dimensión epistémica? Investigación empírica y teoría normativa" ${ }^{, 562}$, presente na coletânea de estudos políticos intitulada Ay, Europa! (2009, original de 2008).

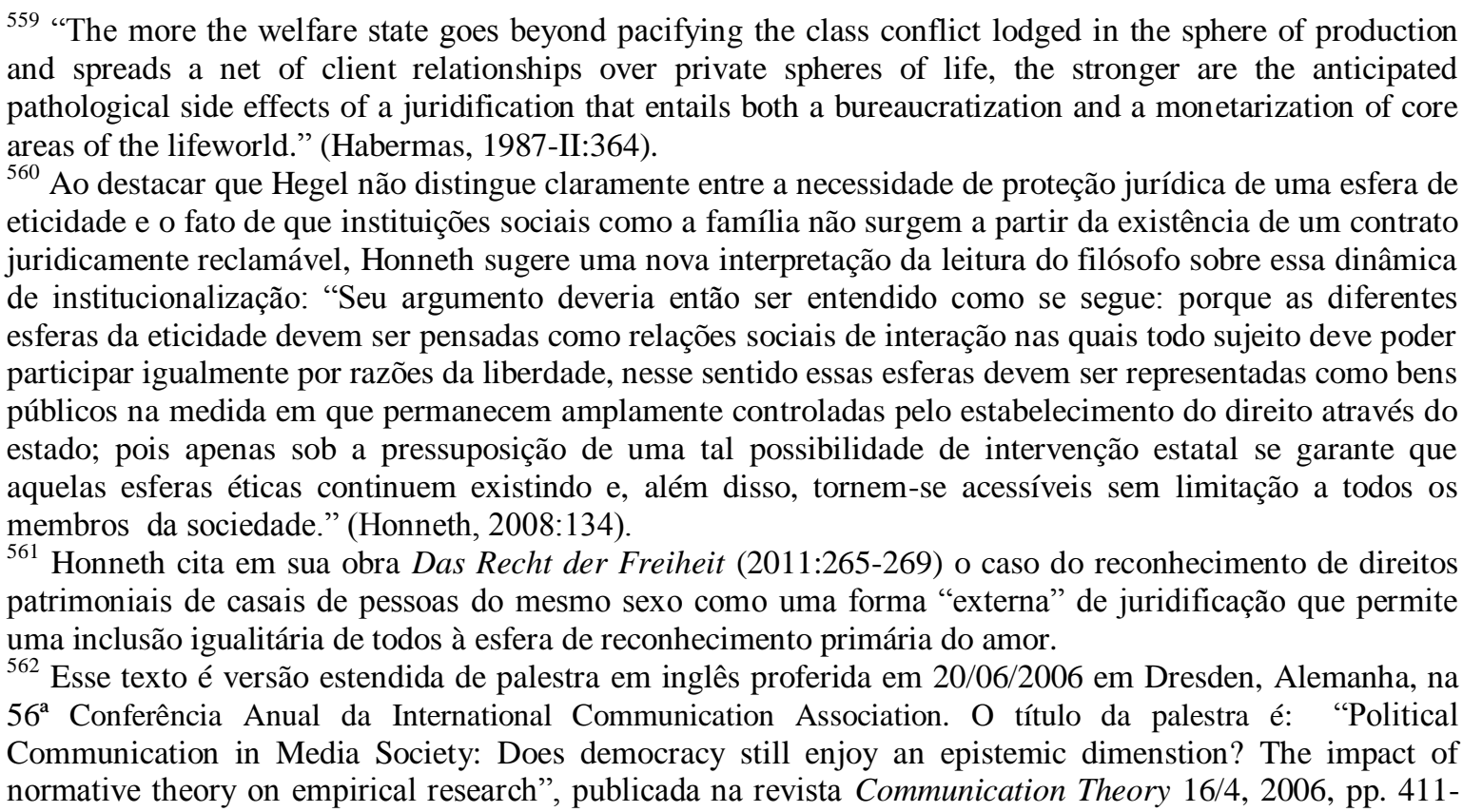


A mudança em relação à teoria elaborada em $D D$ se dá mais em relação a pressupostos do que seus desdobramentos teóricos e empíricos: a partir desse texto, uma “esfera pública política independente" passa a ser considerada, ao lado dos direitos que garantem a autonomia individual e a autonomia política dos cidadãos, como um dos três elementos normativos fundamentais dos Estados democráticos de direito.

Isso significa que, além de estabelecer normas e procedimentos que garantam liberdades jurídicas iguais e a participação democrática dos cidadãos, o "desenho institucional" do Estado democrático deve também se encarregar do "adequado funcionamento de uma esfera pública política próxima dos cidadãos, mediante:”

- a separação entre Estado fiscal e sociedade econômica (com a qual as liberdades econômicas individuais, garantidas por princípio, não se decantam por uma constituição econômica neoliberal); - a liberdade de imprensa, a pluralidade dos meios de comunicação e a liberdade de informação; - as regulações que garantem o acesso do público de massas e da sociedade civil à esfera pública política, e que evitem a captura ou o monopólio político, social ou econômico dos foros da comunicação pública. (Habermas, 2009:139. Trad. livre do espanhol. Itálicos nossos).

Apesar de Habermas não indicar que se trata de uma mudança substancial em sua teoria discursiva do direito e apontar esse "terceiro elemento" como parte do modelo deliberativo de democracia que formulou em $D D$, o diagnóstico compreensivo que realiza em seguida sobre a racionalidade da deliberação política (tópico II), sobre a relação entre discurso e comunicação de massa (tópico III), sobre a "estrutura da comunicação de massa e a formação de opiniões públicas arrazoadas" (tópico IV) e por fim sobre as "patologias da comunicação política (tópico V), indica que se trata de uma tarefa sem a qual o paradigma procedimental do direito se quedaria insuficientemente fundamentado.

Ou seja, ainda que esse diagnóstico do tempo presente da esfera pública política não tenha alterado as proposições teóricas do modelo deliberativo, este empreendimento se fez necessário como uma espécie de "tarefa final" da teoria discursiva do direito, que poderia tranquilamente ser anexado num apêndice de uma nova edição de $D D$. Esse diagnóstico cumpre, enfim, a função de não somente identificar a distância entre as expressões concretas da esfera pública política e suas expectativas normativas, mas sobretudo de comprovar empiricamente o potencial do procedimento deliberativo de

426. Essa versão pode ser encontrada no endereço eletrônico: http://my.ilstu.edu/ jkshapi/Habermas_Media\%20Society.pdf. (último acesso: 01/01/2012). 
canalizar uma formação mais ou menos racional da opinião e da vontade políticas, especialmente no contexto de "sociedades da informação" ou "sociedades midiáticas".

Ainda assim, como se argumenta nesta tese, o retorno da categoria da esfera pública política para o interior da autocompreensão normativa de Estados democráticos de direito é feito de modo incompleto, especialmente porque um de seus princípios fundamentais, a publicidade do poder, não é retomado de modo explícito no paradigma procedimental.

Em outras palavras, Habermas está preocupado em identificar quais procedimentos aplicados à comunicação pública podem tornar mais democrático o processo de formação da opinião e da vontade política dos cidadãos - especialmente em relação às tarefas de organizações sociais de comunicação -, mas pouco atenta para que tipo de comunicação o "poder administrativo" deve apresentar à esfera pública para que tornem acessíveis a todos as justificações das decisões políticas.

Não é por menos que o tópico destinado às patologias da "comunicação política" se destina somente à identificação de associações entre o poder econômico de meios de comunicação e o poder político, como nos casos paradigmáticos dos veículos de Rupert Murdoch e suas campanhas para políticos conservadores, e da (con)fusão entre monopólio da mídia e da administração pública na figura de Silvio Berlusconi (Habermas, 2009:175176).

Apesar de Habermas utilizar a expressão "comunicação política", não discute, por exemplo, o formalismo ou o legalismo jurídico como modos insuficientes de justificação da dominação, ou mesmo as formas pelas quais se devem dar processos de accountability e transparência do poder político perante a esfera pública. ${ }^{563}$

Com isso, o circuito de comunicação pública que promove os processos de legitimação parece não ter condições de se completar. Isso fica claro com a tese de que o poder comunicativo gerado pelas problematizações e formações de opinião das organizações da sociedade civil pode, através de procedimentos "eclusas", traduzir-se pelo direito em demandas "inteligíveis" ao poder administrativo (Id. op.cit:141-142), ao passo que não há, todavia, uma demanda normativa para que este poder contribua discursivamente com o ambiente informativo do qual pode se beneficiar uma cultura política "acostumada à liberdade" e capaz de dar leis a si mesma.

\footnotetext{
563 Algumas considerações são feitas nesse sentido, porém, atribui-se às "elites implicadas na comunicação pública", e não também à comunicação do poder político o papel de: "comprovar-se argumentativamente e avaliar conseqüentemente as alternativas que tiverem sido especificadas de maneira conveniente;// - e que prevaleçam as tomadas de posição racionalmente motivadas na hora de determinar as decisões corretas que obtém com base nos procedimentos.” (Habermas, 2009:161. Trad. livre do espanhol).
} 
Novamente, o diagnóstico da degradação do princípio da publicidade em MEEP, bem como a separação radical entre sistema e mundo da vida - reproduzida em $D D$ como uma incomunicabilidade entre subsistemas contornável somente pela linguagem do direito - parecem impedir que a opinião pública escoada pelos procedimentos do direito seja retribuída com justificações de decisões jurídicas e políticas passíveis de serem aceitas racionalmente por todos os concernidos.

Nesse cenário, a ponte formada pela esfera pública política entre o mundo da vida e sistema ainda se demonstra frágil e dependente de uma reestruturação profunda das assimetrias do sistema de comunicação social. Essa reestruturação só ocorrerá, no entanto, quando além de procedimentalizar a soberania popular, a esfera pública política tenha condições de obrigar concomitantemente o sistema político e outros poderes sociais a se comunicarem de modo mais discursivo com os cidadãos.

\subsection{Tendências de intersubjetivização do direito no diagnóstico do presente da teoria} crítica: o nascedouro teórico do direito da comunicação

Para que o direito da comunicação tenha condições de contribuir para um fortalecimento da esfera pública política, estimulando uma comunicação de "mão-dupla" entre Estado e sociedade capaz de aprofundar a qualidade democrática da legitimação do poder, sua teoria se beneficia de alguns conceitos provenientes do debate atual de Habermas com três de seus maiores interlocutores na teoria crítica. São eles Axel Honneth na teoria social, Rainer Forst na teoria política e Klaus Günther, na teoria do direito (o último analisado em "b", abaixo).

Este tópico se destina a situar o direito da comunicação no entrecruzamento de alguns conceitos que informam esse debate, e por isso não será realizada uma explanação extensiva das teorias de cada interlocutor. Outro objetivo é demonstrar a tendência desse debate a um aprofundamento do caráter intersubjetivo do direito, da moral e da política, de modo que, além de nutrir-se dele, o direito da comunicação possa contribuir em seguida (cap. 9) para novos desdobramentos dessa tendência.

Até o momento, alguns conceitos desenvolvidos pelos autores citados foram incorporados de modo mais episódico neste estudo, especialmente no diagnóstico do presente da esfera pública política no Brasil (parte II). A partir de agora, será possível compreender de modo mais teórico essa incorporação. 
a) a emancipação dos "filhos probos": as obras de Honneth e Forst como ramificações intersubjetivas da teoria crítica em direção a Hegel e Kant

Habermas pode ser considerado o filósofo contemporâneo que mais bem sintetiza elementos da filosofia de Kant e de Hegel. Apesar de se auto-intitular à época da publicação de Verdade e Justificação (original de 1999) como propagador de um "pragmatismo kantiano", e se dedicar a uma teoria do direito inspirada em Kant, sua concepção de "individuação pela socialização" (Id, 2007:299) e a insistência no modelo de pesquisa da teoria crítica que analisa potenciais de racionalidade e integração social a partir de reconstruções históricas, não deixam de ser perspectivas de influência hegeliana que perduram em seu pensamento. ${ }^{564}$

Mas da mesma forma que Habermas estruturou seu sistema filosófico a partir de distanciamentos teóricos significativos em relação a esses Mestres-Pensadores, incluindo Marx e os fundadores da "teoria crítica stricto sensu" Adorno e Horkheimer ${ }^{565}$, dois dos teóricos mais importantes que o sucedem atualmente na teoria crítica também desenvolvem seus pensamentos a partir de distanciamentos em relação à sua teoria. Como na parábola bíblica, os dois herdeiros se emancipam de seu "pai intelectual"; buscam, contudo novas definições de justiça, e mantêm sua obra como referência fundamental.

Pendendo para o lado hegeliano está a obra de Axel Honneth. Comprometido desde sua tese de doutoramento ${ }^{566}$ em revisar e atualizar as bases normativas da Teoria Crítica da Sociedade, as quais Habermas houvera transposto, tanto de Marx como de

564 É o próprio auto-intitulado "kantiano" Forst que indica essa característica hegeliana no projeto de $D D$ : "Para o projeto de Direito e Democracia, deu-se então a todos a pergunta sobre qual lugar seria antevisto para os princípios da justiça. Habermas entende que como princípios morais, eles teriam de ser trabalhados no lado institucional do político ao modo de uma teoria do direito e da democracia. Nisso mostrou-se um momento hegeliano na teoria de Habermas: assim, para que o conceito de justiça fosse intermediado com a realidade histórica e social e derivado da tensão interna entre norma e efetividade, a teoria normativa deveria ser utilizada nas esferas do direito e da política." (Forst. Unterwegs zu einer Diskurstheorie der Gerechtigkeit: Habermas und Rawls [No caminho de uma teoria discursiva da justiça: Habermas e Rawls. Trad. Livre]. In. Blätter für deutsche und Internationale Politik. 6/09, pp. 61-62).

565 Para uma análise sobre o desenvolvimento do pensamento de Habermas por meio de seus “distanciamentos teóricos" em relação a Kant, Hegel e Marx, além de Adorno e Horkheimer, v. Blotta, Habermas e o Direito (2010:caps 1 e 2.2).

${ }^{566}$ A obra Kritik der Macht. Reflexionsstufen einer kritischen Gesellschaftstheorie ("Crítica do Poder. Crítica do poder. Estágios de reflexão de uma teoria social crítica”), publicada em 1985, resulta da tese de doutoramento homônima de Honneth, defendida em 1983 na Universidade livre de Berlim, e tem como um de seus principais objetivos demonstrar como o modelo habermasiano, centrado nos potenciais de racionalidade presentes comunicação intersubjetiva, impedem que ele identifique outros arranjos normativos da sociedade, especialmente por trás de conflitos sociais nas esferas da economia e da formação de identidades individuais e coletivas. Para uma introdução instrutiva ao pensamento de Honneth dentro da tradição da teoria crítica, v. Nobre, Luta por Reconhecimento: Axel Honneth e a Teoria Crítica. Apresentação da obra de Honneth, Luta por Reconhecimento, 2003, pp. 7-19. 
Adorno e Horkheimer do chamado "paradigma da produção" ao "paradigma da linguagem e da comunicação", Honneth retorna à origem dessa transposição, o estudo de Habermas intitulado "Trabalho e Interação: notas sobre a filosofia do espírito de Hegel em Jena" $(1967)^{567}$, e procura destacar dele um elemento presente no conceito de interação, porém gradativamente preterido por Habermas em relação à linguagem: a luta por reconhecimento.

Essa luta, ou a "dialética da relação ética", revelar-se-ia para Hegel, ao lado do trabalho e da linguagem, como uma das expressões concretas primordiais do Espírito que permitem a formação da autoconsciência humana. A expressão "institucional" desse elemento seria a pequena família burguesa, lócus de formação da identidade dos indivíduos e dentro da qual se desenrolam as primeiras "lutas por reconhecimento" (Habermas, 2006:12)

É por isso que, apesar de essas lutas se estenderem também às relações morais e jurídicas e às relações de estima social na Filosofia do Direito de Hegel - as quais serão retomadas por Honneth no desenvolvimento de seu modelo de teoria crítica (v. Honneth, 2003) -, quando se trata de pensar na teoria do reconhecimento de modo não concorrente, mas como uma espécie complementaridade ${ }^{568}$ ao caráter mais abstrato das pretensões de validade da razão comunicativa, torna-se possível reforçar o modelo de Habermas na identificação de potenciais de integração social democrática por trás de experiências de desrespeito, especialmente na esfera privada e nas expressões da racionalidade estéticoexpressiva trabalhadas no capítulo 7 , onde se dão processos de formação de identidades.

Não se pode negar, contudo, que a discussão epistemológica desenvolvida por Honneth no terceiro capítulo da obra Reificação (Verdinglichung, 2005) - cujo objetivo é demonstrar como experiências de reconhecimento recíproco precedem a própria troca de razões do agir comunicativo - muito provavelmente desautorizaria essa interpretação complementar dos modelos. ${ }^{569}$

Mas mesmo mantendo essa questão aberta, é perfeitamente possível trabalhar a hipótese de uma esfera pública política na qual experiências de violação, desrespeito e discriminação (ou de "não-reconhecimento") se somam a práticas de comunicação

\footnotetext{
${ }^{567}$ Publicado em português como um dos textos presentes na obra Técnica e Ciência como 'Ideologia' (Habermas, 2006).

568 O estudo Empörung und Fortschritt [Indignação e Progresso. Trad. livre] (2008:365-302), de Mattias Iser é um exemplo de esforço para conciliar os modelos comunicativo e do reconhecimento. $\mathrm{O}$ autor sugere o conceito de "reconhecimento comunicativo" como uma posição intermediária entre as perspectivas de ambos os autores.

${ }_{569}$ Cf. Forst, First things first: redistribution, recognition and justification, 2007; Id. Zwei Bilder der Gerechtigkeit, 2009.
} 
distorcida e consensos irrefletidos em diagnósticos do presente, ampliando a base de relações intersubjetivas através das quais se revelam negativamente pretensões de comunicação e de reconhecimento que podem ser objetos de análise do direito da comunicação e de políticas específicas em suas áreas de atuação.

Além dessa abertura para expectativas normativas mais ligadas à esfera privada e aos processos de individuação, é importante destacar mais uma vez como a discussão sobre "mercado e moral", ou sobre o pano de fundo comunicativo por trás da racionalidade instrumental, retomada por Honneth em estudos como "Trabalho e Reconhecimento" (2008) e Das Recht der Freiheit (2011:317-470), também possibilitam uma crítica interna de estruturas diferenciadas do mundo da vida como a economia, identificadas nos diagnósticos de Habermas em TCA e DD como relações "não-comunicativas".

A outra ramificação que descende de Habermas, agora em direção à Kant, é a obra de Rainer Forst. Pesquisador e assistente do grupo de trabalho sobre teoria do direito de Habermas que resultou em $D D$, Forst elaborou no período sua tese de doutoramento, intitulada Contextos da Justiça: filosofia política para além de liberalismo e do comunitarismo $^{570}$, orientada por Habermas e defendida em 1993 na Universidade Goethe de Frankfurt.

Nesse meio-tempo, Forst realizou período de investigação em Harvard com John Rawls, quando este ainda escrevia a obra Liberalismo Político, e foi responsável pelo aprofundamento da interlocução entre o teórico político dos EUA e Habermas. Esse trânsito com a filosofia política Anglo-Saxã deu condições para que ele pudesse adaptar o pragmatismo kantiano de Habermas e com a recepção que Rawls faz de Kant, como no conceito de "social space of reasons", semelhante à categoria de esfera pública de Habermas, porém mais abstrato, e cujo método de análise mais apropriado Forst confessa ainda buscar esclarecimento (Forst, 2009b:62).

$\mathrm{O}$ resultado foi a elaboração de uma teoria própria da justiça com base nesse “diálogo intercontinental” (Id. op. cit:63), tendo o direito à justificação como categoria central. Trata-se de uma exigência moral que os indivíduos devem atribuir uns aos outros quando adentram esse "espaço social de uso público da razão", isto é, quando pretendem decidir em comum problemas práticos, de modo que precisam justificar suas decisões com base em razões que possam ser aceitas por todos.

570 Do original Kontexte der Gerechtigkeit: Politische Philosophie jenseits von Liberalismus und Kommunitarismus (Suhrkamp, 1994). Publicada em português em 2010 pela Boitempo, com tradução de Denílson Luís Werle. 
Por ser elemento de uma teoria crítica da justiça, o direito à justificação se faz presente para Forst também em interações sociais concretas das quais despontam sensações de injustiça e protestos contra experiências de injustiça. Especialmente quando se trata de uma ordem política que se pretenda vinculativa, porém não-arbitrária, esses protestos emergem como exigências de racionalidade pertencentes uma "ordem de justificação". 571

A partir de então, com sua obra de maturidade $O$ Direito à Justificação: elementos de uma teoria construtivista da justiça $(2007)^{572}$, Forst pôde retornar aos estudos concretos sobre conflitos de justiça e ao problema da tolerância, trabalhados respectivamente no doutorado e em sua tese de habilitação para a docência (esta brevemente discutida no tópico 7.2 desta tese), entendendo-os como dinâmicas sociais envolvidas por trocas de razões e motivações que realizam num sentido pós-metafísico (ou em seu caso “construtivista”) os princípios kantianos da autonomia e do uso público da razão. 573

Em relação ao direito da comunicação, a teoria de Forst é especialmente importante para fundamentar as pretensões de publicização do direito, ou de maneira mais geral de comunicação do direito (v. cap. 9). Isso porque, quando se pensa no direito à justificação não somente como uma obrigação moral decorrente da atribuição recíproca de autonomia entre indivíduos que pretendem decidir livre e conjuntamente seus planos de ação, mas também como norma jurídica atribuída tanto ao poder político quanto social, torna-se possível reforçar de modo institucional o princípio da publicidade.

Assim, além de contribuir para a aplicação e o aumento de normas jurídicas que exigem mais transparência e responsividade (accountability) do poder público e de organizações sociais com influência sobre a esfera pública, o direito à justificação pode

\footnotetext{
571 "The fundamental impulse that runs counter to injustice is not primarily that of wanting to have or have more of something, but that of no longer wanting to be oppressed, harassed, or have one's claims or basic right to justification ignored. This right demands that there be no political or social relations of governance that cannot be adequately justified to those affected by them. In whatever specific, or 'thick,' situated language this indignation - this protest - is also expressed, at its core it always goes back to the right not to be subjected to laws, structures, or institutions that are 'groundless', that is, that are regarded as an expression of power or rule without sufficient legitimation.” Forst, The Right to Justification, 2012:introdução.

${ }^{572}$ Traduzido livremente do original Das Recht auf Rechtfertigung: elemente einer konstruktivistischen Theorie der Gerechtigkeit.

${ }^{573}$ Forst também tem atuação importante no debate sobre relações internacionais, trabalhando com temas como justiça global e no intercâmbio entre diferentes concepções de justiça no mundo. Sua produção prolífica e atuação comprometida nessas áreas, destacada por representar o Cluster de excelência acadêmico "Normative Orders", fez com que recebesse recentemente o mesmo prêmio Leibniz que Habermas recebera em 1987, e com o qual organizou o grupo de trabalho que resultaria em DD. Para informações sobre o Cluster e os trabalhos do grupo, v. Forst \& Günther, Die Herausbildung normativer Ordnungen. Zur Idee eines interdisziplinären Forschungsprogramms [A formação de ordens normativas. Por uma ideia de um programa interdisciplinar de pesquisa. Normative Orders Working Paper. 01/2010. Disponível em www.normativeorders.net (último acesso: 05/01/2012).
} 
provocar também transformações na própria lógica legislativa e de aplicação do direito, como no caso do princípio da motivação das decisões judiciais (art. 93, IX, CF). ${ }^{574}$

Tanto no caso desse princípio como na exigência de publicidade de todos os poderes públicos (art. 37, LX, CF), seria possível propor a partir de então que o direito à justificação exige não somente a legalidade como fundamento da validade jurídica, mas que as motivações sejam também acompanhadas das razões pelas quais determinadas normas devem ser aplicadas ou seguidas, razões estas que não estão diretamente à disposição do sistema jurídico.

Somente então se torna factível a proposta de Habermas sobre a relação complementar entre certeza legal (legalidade) e aceitabilidade racional (legitimidade). Caso contrário, a mera legalidade torna-se critério suficiente para a validade das normas jurídicas ${ }^{575}$, e o "poder administrativo" (e o mesmo vale para organizações sociais) continua a ser visto como um subsistema auto-referencial a cuja linguagem os cidadãos devem se adaptar; sem oferecer em troca, no entanto - e embora num sistema democrático -, além da ameaça de sanções, razões pelas quais os cidadãos possam entender que "vale à pena" obedecer à lei ao invés de descumpri-la.

Naturalmente, quando se trata do plano jurídico - como se verá em seguida - não se pode esperar que somente aceitando o conteúdo dessas razões os indivíduos obedeçam à lei. Mas ao mesmo tempo, espera-se também que tais razões sejam acessíveis e inteligíveis a todos, e abertas à crítica por meio de procedimentos legais.

574 Com redação dada pela Emenda Constitucional 45/2004 (reforma do poder judiciário), o artigo 93, IX, CF versa: "todos os julgamentos dos órgãos do Poder Judiciário serão públicos, e fundamentadas todas as decisões, sob pena de nulidade, podendo a lei limitar a presença, em determinados atos, às próprias partes e a seus advogados, ou somente a estes, em casos nos quais a preservação do direito à intimidade do interessado no sigilo não prejudique o interesse público à informação". O art. 273, §1 ${ }^{\circ}, \mathrm{CPC}$ também trata do princípio da motivação, porém se limita a casos de antecipação de tutela: "Na decisão que antecipar a tutela, o juiz indicará, de modo claro e preciso, as razões do seu convencimento". Além disso, como já visto, há a previsão do inciso LX do art. 37, CF sobre a publicidade dos atos de todos os poderes, ainda que sem especificações de como esta publicidade se deve dar.

575 Apesar de ressaltar a importância da legitimidade presumida na legalidade de um sistema jurídico que transforma a soberania popular em procedimentos (Habermas, 1997-II:247), Habermas não apresenta uma reflexão detida sobre essas formas de comunicação do direito que podem ser reforçadas com uma institucionalização do direito à justificação. Ainda assim, seu entendimento é claro quanto à insuficiência da legalidade para determinar a validade de normas jurídicas. Com o autor: "A idéia do Estado de direito exige que as decisões coletivamente obrigatórias do poder político organizado que o direito precisa tomar para a realização de suas funções próprias, não revistam apenas a forma do direito, como também se legitimem pelo direito corretamente estatuído. Não é a forma do direito, enquanto tal, que legitima o exercício do poder político, e sim, a ligação como direito legitimamente estatuído. E, no nível póstradicional de justificação, só vale como legítimo o direito que conseguiu a aceitação racional por parte de todos os membros do direito, numa formação discursiva da opinião e da vontade." (Habermas, 1997-I:172). 
b) o "filho fiel" e a recepção dos emancipados pelo pai: a obra de Klaus Günther como aplicação jusfilosófica da ética do discurso e o lugar do direito da comunicação

Klaus Günther é o filósofo do direito cujas concepções mais auxiliaram a elaboração da teoria discursiva do direito de Habermas. No prefácio de $D D$, o autor reconhece de modo destacado a importância que teve a expertise jurídica de Günther nos debates e estudos do grupo de trabalho que resultariam na obra.

Günther também defendeu sua tese de doutoramento no período (na Faculdade de Direito da Universidade Goethe de Frankfurt, no verão de 1987) e pôde apresentar alguns de seus estudos preliminares nas reuniões desse grupo, publicando-a em 1988 sob o título O Senso para a Adequação: discursos de aplicação na moral e no direito. ${ }^{576}$

Este estudo inicial do autor defende que, para que se aplique a ética do discurso de Habermas sobre a filosofia do direito propriamente dita - isto é, ao conhecimento que lida não somente com a problematização das bases das ordens jurídicas, mas também com os conceitos que fundamentam a operação de sistemas legais -, torna-se necessário distinguir os discursos de justificação, que determinam a validade das normas em geral, dos discursos de aplicação, voltadas para a adequação das decisões jurídicas a casos concretos.

Isso porque, enquanto a discussão sobre a validade de uma norma jurídica permite a aplicação dos princípios "U" e "D" que informam a moralidade procedimental da ética do discurso de Habermas, os critérios a serem utilizados para a fundamentação da aplicação de normas jurídicas a casos concretos precisam levar em conta as limitações de tempo e recursos e a necessidade esforços de ponderação entre diversos dispositivos e interesses que colidem nessas situações.

Com isso, os argumentos de adequação precisam considerar o máximo possível de informações relevantes para a compreensão do caso tratado, e diante desse substrato factual fundamentar, entre uma constelação de normas jurídicas aplicáveis, a escolha da mais apropriada. ${ }^{577}$

576 Tradução livre do original Der Sinn für Angemessenheit: Anwendungdiskurse in Moral und Recht (Suhrkamp, 1988). Publicado em português como Teoria da Argumentação no Direito e na Moral: justificação e aplicação (Landy, 2004).

${ }^{577}$ Segundo Günther: "Se a racionalidade da aplicação for mensurável na sucessiva consideração ampliada de sinais característicos situacionais e na colisão, sistematicamente produzida por meio disso, de diversas normas aplicáveis, uma lógica da argumentação da adequação deverá mostrar com quais meios argumentativos nós vamos, em discursos de aplicação, aproveitar uma descrição ampliada da situação e conseguir resolver as colisões dali oriundas." (Günther, 2004:335). 
Há, no entanto, uma ligação entre essa argumentação e os discursos de fundamentação, o que permite revelar a dimensão moral da aplicação: a consideração do interesse dos afetados pelas normas. Mas embora pertencente ao princípio de universalização, ele pode ser considerado como uma característica factual de casos concretos. Assim, o princípio da imparcialidade moral do juízo de adequação “...é violado como principio de fundamentação se o interesse de um afetado houver sido desconsiderado ou recusado sem razão" (Günther, 2004:333-334).

Habermas recepciona essa tese sem ressalvas em sua teoria do direito, inclusive já desde as Tanner Lectures (1986), que precederam tanto $D D$ quanto a própria defesa do doutoramento de Günther. ${ }^{578}$ Consegue, assim, responder às criticas de teóricos dos sistemas e de relativistas quanto à aplicabilidade institucional da ética do discurso, isto é, a capacidade de os procedimentos do direito canalizarem argumentações e decisões morais em sociedades diferenciadas e atravessadas pela multiplicidade de interesses (Habermas, 1996:221-247).

Após inserir a teoria discursiva do direito nos debates sobre argumentação jurídica, tornando-a uma vertente entre teorias da área como a de Robert Alexy, Ronald Dworkin ou mesmo de Niklas Luhmann e seus seguidores ${ }^{579}$, Günther prossegue em seus estudos para pensar outro tema fundamental da filosofia do direito: a questão imputação (Zuschreibung), ou da responsabilização (Verantwortung) jurídica.

Apesar de ter como área de atuação específica o direito penal, Günther procura desenvolver a racionalidade da imputação jurídica não somente em relação às interações entre vítima e agressor, ou entre réu e poder de punir do Estado, mas também nas relações jurídicas de modo geral. Sua tarefa passa a ser então responder à pergunta sobre como se dá (ou deve se dar) a atribuição recíproca de responsabilidades jurídicas entre concidadãos a partir do modelo de interação social proposto pela teoria do agir comunicativo.

\footnotetext{
578 Habermas cita a tese de Günther, ainda não defendida, com o título "Anwendüngdiskürse", 1986, interpretando-a de modo claro em suas Tanner Lectures, oferecidas por em 1986 em Harvard, e que influenciariam Direito e Democracia: "Por isso, a fim de decidir quais normas podem ser aplicadas a determinado caso, é preciso esclarecer se a descrição da situação é completa e adequada, englobando todos os interesses afetados. Klaus Günther demonstrou que a razão prática se faz valer, em contextos de fundamentação de normas, através de uma exame da possibilidade de universalização de interesses, e em contextos de aplicação de normas, através da apreensão adequada e completa de contextos relevantes à luz de regras concorrentes. Por conseguinte, os processo jurídicos destinos a institucionalizar a imparcialidade da jurisdição têm que fazer jus a essa idéia reguladora.” (Habermas, DD, 1997-II:246).

${ }_{579}$ Infelizmente não será possível adentrar os debates que permitem distinguir a concepção de Günther dessas outras, bem como o caminho tomado por ele para chegar à tese de que é possível pensar a racionalidade da jurisdição a partir da teoria do discurso, o que lhe faz passar pelo debate sobre o evolucionismo moral desde a teoria social em Mead e Durkheim até os debates de Habermas com a psicologia ontogenética de Piaget e o evolucionismo moral de Kohlberg. V. para tanto, Günther, 2004. V. também Pedron, F. A contribuição e os limites da teoria de Klaus Günther. in. Revista da Fac. De Direito da UFPR, n. 48, 2008.
} 
É a partir do enfrentamento desse problema que o autor chega a outros dois conceitos também integralmente incorporados pela teoria discursiva do direito de Habermas, quais sejam, liberdade comunicativa e poder comunicativo. Um dos textos mais importantes em que especifica esses conceitos na discussão jusfilosófica é "Communicative Freedom, Communicative Power, and Jurisgenesis", publicado na obra Habermas on Law: Critical Exchanges (Rosenfeld \& Arato. Orgs, 1998:234-254).

A liberdade comunicativa traduz para a teoria do discurso o conceito de autonomia individual da filosofia moral kantiana. No caso mais simples, é a capacidade de dizer "não" em relação a proposições de outrem, mas se desdobra na liberdade de agir do indivíduo, o que torna possível a própria ideia de alternativas de ação, ou de que se poderia agir de outra forma.

Somente atribuindo liberdade comunicativa a alguém é possível tomá-lo(a) como moral e juridicamente responsável (Zuschreibungsfähig, ou "capaz de imputação") por suas ações. Esse tipo específico de liberdade traduz, então, para o plano das relações jurídicas, o conjunto de competências comunicativas que Habermas identificou como pressuposições pragmáticas da teoria do discurso. ${ }^{580}$

Além disso, é a atribuição recíproca da liberdade comunicativa que garante a autonomia da vontade na formação de acordos que prescrevem expectativas mútuas de comportamento. Deixa-se, assim, de considerar os sujeitos somente como um conjunto de sentimentos subjetivos e crenças, de um lado, ou como fantoches instrumentalizáveis de outrem 244.

A liberdade comunicativa oferece condições que motivam as pessoas a agir de acordo com os planos acordados, gerando o que Günther denomina poder comunicativo para Habermas a "força ilocucionária" do agir comunicativo -, o que mantém a coesão social sem ameaça ou uso da violência, como se espera em sociedades liberais. O poder comunicativo é então a própria realização factual das obrigações que foram acordadas entre sujeitos que compartilham, além da liberdade comunicativa, as expectativas de que

\footnotetext{
580 "Por 'competência comunicativa' entendemos a capacidade de um falante orientada para o entendimento, de forma a poder conceber uma frase correctamente formulada em relação com a realidade. Ou seja, i. escolher a frase proposicional de forma a que, ou as condições de verdade da proposição apresentada ou os pressupostos existenciais do conteúdo proposicional mencionados sejam satisfeitos (de forma a que o ouvinte possa partilhar dos conhecimentos do falante); ii. expressar as suas intenções de tal forma que a expressão lingüística represente aquilo que se pretende (de forma a que o ouvinte possa confiar no falante); iii. desempenhar o acto de fala em conformidade com as formas reconhecidas ou com as imagens aceites de nós próprios (de forma a que o ouvinte possa estar de acordo com o falante nas orientações de valor partilhadas)." (Habermas, Racionalidade e Comunicação, 1996:50. itálicos nossos).
} 
agirão da forma determinada pelos planos voluntariamente aceitos (Günther, 1998:247248).

Assim, se os agentes poderiam pensar e agir de outra forma (liberdade comunicativa) e ainda então aceitam as proposições dos planos comuns, torna-se possível uma atitude reflexiva do sujeito em relação à segunda pessoa do plural ("nós”). Numa comunidade concreta, abre-se a chance de se concretizar a definição que Hannah Arendt dá ao poder comunicativo, e que inspira tanto Günther quanto Habermas: um poder de "agir em concerto" (Id. op. cit:248) ${ }^{581}$.

Mas para que as atitudes contrárias e de negação dos acordos - ou o dissenso permitido pela liberdade comunicativa - não gerem uma desagregação do pacto previamente estabelecido, torna-se necessário estabelecer algum tipo de coerção que faça valer o poder comunicativo contra elas, especialmente as que são entendidas como negações injustificadas.

O poder comunicativo é institucionalizado então a partir de normas jurídicas, as quais dispensam que os motivos para sua obediência sejam os mesmos que as razões por trás delas. Por isso são "neutras" em relação à moral. Esse tipo de poder político permite a convivência de indivíduos com diferentes motivos e crenças a partir da expectativa de que agirão ao menos de modo a não violar essas normas, o que se garante pela coercibilidade do poder. $^{582}$

Mas ao mesmo tempo em que o direito violaria a liberdade comunicativa caso obrigasse que os indivíduos obedecessem às normas pelos mesmos fundamentos que levaram à sua criação, Günther também alerta para o problema de que, apesar dessa "neutralidade" em relação às motivações para seu cumprimento, as normas jurídicas e os direitos negativos correspondentes também violam a liberdade comunicativa ao “...excluir ou destruir a possibilidade de serem seguidas por razões que foram adotadas por causa de um posicionamento afirmativo". 583

\footnotetext{
${ }^{581}$ Aqui Günther cita a obra On Violence, de Arendt (1970). V. também Habermas, O conceito de poder em Hannah Arendt, 1980.

${ }^{582}$ Segundo Günther: "Coercive force cannot produce action motives as an affirmative position can, a position that was taken on the basis of reciprocally attributed communicative freedom. For this reason, legal norms do not care about the source of the motive for their observance. (...) What action motives he or she has is up to the individual - as long as he or she does not violate the legal norms. This is the meaning of the right to negative liberty or individual freedom. A legal person is no longer obliged with respect to legal norms, to trace her action motives back to an affirmative position taken on a validity claim and on the basis of communicative freedom. Therefore, a legal person may 'step out' of the obligations of communicative action and renounce the right to take an affirmative or a negative position at all." (Günther,1998:251).

${ }^{583}$ Günther, 1998:251. Trad. livre do inglês. Itálicos nossos.
} 
Para que nenhuma dessas violações ocorra, e a legitimidade do direito possa resultar do poder comunicativo gerado por normas que garantem a liberdade comunicativa, a saída encontrada por Günther é a mesma que a de Habermas: a institucionalização de direitos individuais de participação em processos democráticos de formação da opinião e da vontade políticas (ou direitos iguais de "liberdade comunicativa" a todos).

A legitimidade de um direito discursivo e ligado a um princípio democrático descansa, portanto, em normas procedimentais que permitem aos indivíduos, na condição de sujeitos privados, buscar as razões por trás delas, ainda que para rejeitá-las ou, no caso de minorias, para mobilizar seus argumentos com a finalidade de transformá-las (Id, op. cit:251-253). Para Günther, caberá ainda criar as figuras jurídicas da "pessoa de direito", e relacioná-la com a ideia de "pessoa deliberativa". 584

Como se verá no próximo e último capítulo desta tese, é nesse momento que surge a necessidade do direito da comunicação como uma teoria que complementa o direito procedimental proposto por Habermas e aprofundado por Günther na filosofia do direito. Isso porque procura ressaltar, de um lado, a importância dos direitos às condições propiciadoras de relações de reconhecimento, sem as quais se torna difícil garantir a formação de sujeitos autônomos, como sugere Habermas ao recepcionar de modo mais interno à sua teoria as reflexões de Honneth (Habermas, 2007:299).

Além disso, o direito da comunicação atribui ao poder público o dever de tornar mais acessíveis e inteligíveis aos cidadãos as razões que fundamentam as normas jurídicas, ainda que não precisem tomá-las como motivos de suas ações. E isso só é possível com procedimentos que não somente canalizem a formação da opinião e da vontade políticas por meio do "direito igual à liberdade comunicativa" (Günther, op. cit:253), mas que também institucionalizem direitos à justificação, o que é feito por uma recepção da teoria de Forst também de modo interno à teoria do direito de Habermas.

Ao emergir do entrecruzamento de conceitos provindos das obras e debates desses três "herdeiros" de Habermas, muito brevemente analisados neste tópico, a teoria do direito da comunicação ganha condições para reinserir o procedimento democrático no espaço social de onde ele próprio provém e pode ter sua legitimidade avaliada. Esse espaço é estruturado pelo leque de direitos que vai das condições da autonomia individual e chega até o direito à justificação do poder, ampliando a base intersubjetiva do direito.

\footnotetext{
${ }^{584}$ Essa discussão será brevemente retomada no tópico 9.2 abaixo. Para uma reflexão mais detida sobre o tema, v. Günther, Schuld und Kommunikative Freiheit [Culpa e Liberdade Comunicativa. Trad. livre], 2005, esp. pp. 245-258.
} 
A esfera pública política se torna então um objeto privilegiado do interesse da teoria política, da teoria social e da teoria do direito que se desenvolve atualmente na tradição da teoria crítica. A abordagem dada ao fenômeno pelo direito da comunicação encontra suas bases teóricas dentro desse debate, que revela tendências de intersubjetivização do direito provocadas por esses entrelaçamentos de conceitos de Habermas com cada um desses seus interlocutores, como representado na figura abaixo. Ao fazê-lo, promove também, seguindo a parábola bíblica utilizada como metáfora no início deste tópico, a recepção dos "filhos emancipados" pelo pai, a partir da ajuda imprescindível do "filho fiel".

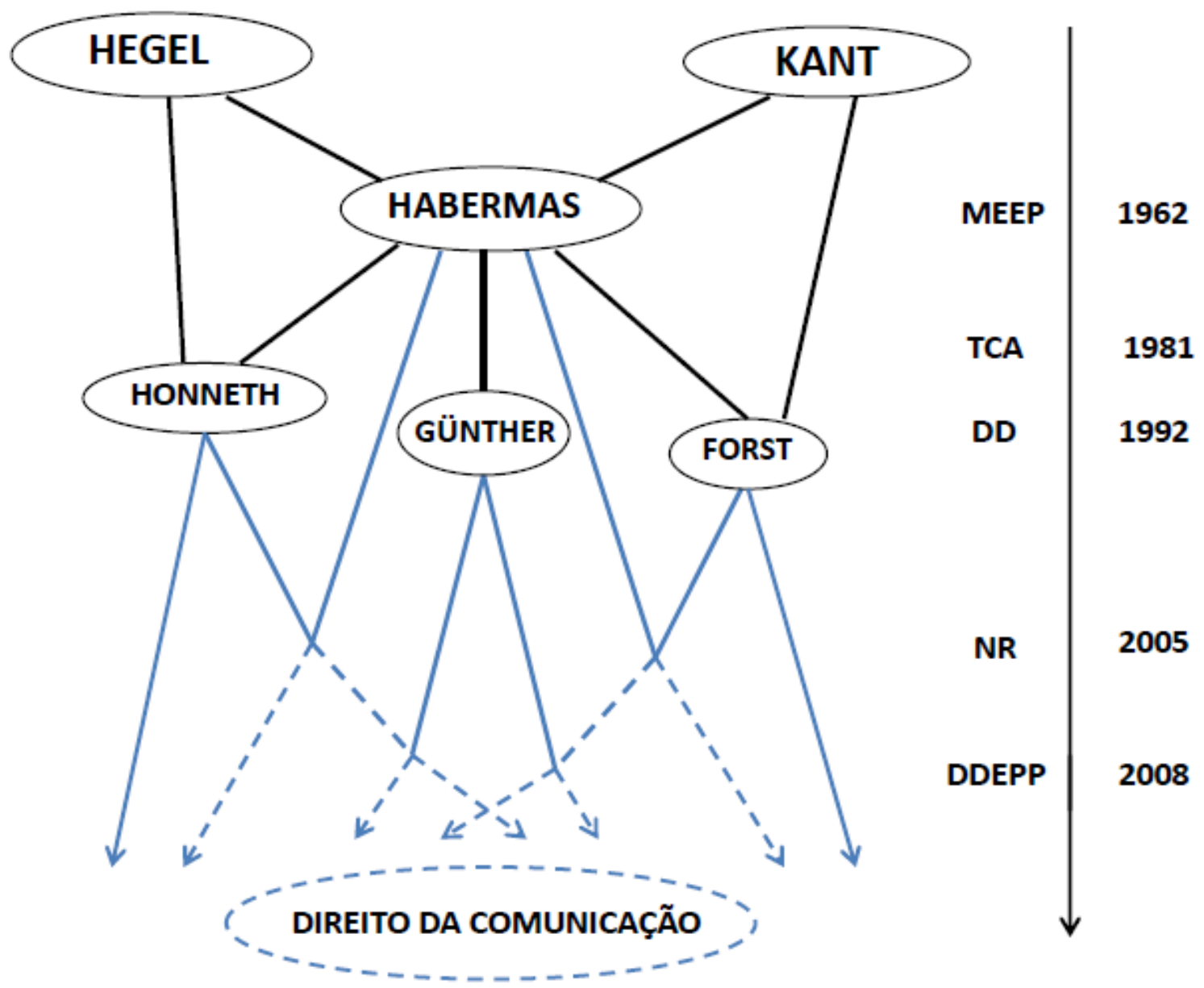

Esta figura, meramente ilustrativa, procura promover uma visualização do debate e da amarração teórica de onde surge a teoria do direito da comunicação, e como os entrecruzamentos das teorias são marcados por ampliações das concepções de 
intersubjetividade de cada autor trabalhado. As siglas da linha do tempo não conhecidas "NR" e "DDEPP" referem-se respectivamente às obras de Habermas Entre Naturalismo e Religião e seus textos mais recentes sobre Direito e Esfera Pública Política, como "Does Democracy Still Enjoy an Epistemic Dimension?”.

A imagem simboliza muito mais do que se pôde discutir neste capítulo, especialmente no que se trata das relações entre as teorias de Honneth, Günther e Forst entre si, o que não poderá ser trabalhado neste estudo. Os dois objetivos principais do último capítulo são a fundamentação do direito da comunicação como filosofia social do direito (9.1), seguida de alguns de seus possíveis impactos em conceitos da filosofia do direito que informam a dogmática jurídica (9.2), especialmente quando revistos a partir das pretensões normativas mais estruturais e mais conteudísticas encontradas na esfera pública política nacional no diagnóstico da parte II.

\section{Conceitos estruturais e jusfilosóficos do direito da comunicação}

A teoria do direito da comunicação tem uma dupla-função: como filosofia social do direito, procura-se capaz de identificar empiricamente fenômenos sociais permeados por aquilo que Axel Honneth denomina "transcendência intra-mundana" (Honneth, 2007:6366), isto é, potenciais de interações humanas livres de dominação, como pretensões de validade da razão, pretensões de reconhecimento e pretensões de legitimidade do poder, ainda que sejam encontradas na maioria das vezes de modo violado na realidade social.

Como teoria filosófica do direito, o direito da comunicação pretende ser pensado a partir de conceitos jusfilosóficos operativos, os quais podem influenciar o sistema jurídico e a dogmática jurídica que lida com os conflitos provenientes do fenômeno social analisado: a esfera pública política.

Essa teoria é normativa num sentido específico. Isso porque, como se procurou demonstrar na parte II, suas pretensões normativas emergem de um diagnóstico do tempo presente da esfera pública política, e por isso não se trata de um conjunto de princípios formulados por um "filósofo esclarecido" a partir de uma reflexão individual semelhante ao imperativo moral kantiano. Nesse sentido, é também uma teoria realista, embora examine fenômenos capazes de irromper fragmentos de idealidade em situações concretas e observáveis. 
Nos dois tópicos que se seguem, procura-se realizar um esforço final de sistematização das pretensões normativas mais estruturais e concretas do direito da comunicação, as quais serão induzidas do debate teórico analisado especialmente no capítulo 8 e dos resultados do diagnóstico da parte II. Assim, o direito da comunicação poderá cumprir o papel de uma teoria crítica capaz utilizar de modo complementar a sociologia jurídica e a filosofia do direito, como o faz Habermas em $D D$, além de esboçar seus impactos sobre conceitos jusfilosóficos aplicados na dogmática jurídica.

\subsection{Teoria discursiva do direito e o direito da comunicação: da co-originalidade entre autonomia individual e política à relação interna entre direito e esfera pública política}

A partir das reflexões teóricas realizadas na pesquisa, procurou-se demonstrar que o foco de análise da legitimidade do poder dado por Habermas a procedimentos democráticos capazes de distribuir liberdades comunicativas iguais a todos, e com isso filtrar de modo discursivo (crítico, e portanto, mais autêntico) a opinião e a vontade política dos cidadãos interessados, visa a explicar e promover ideia normativa de um sistema jurídico adequado a sociedades pluralistas. Isto é, que não dependem de uma comunidade política que compartilha autocompreensões éticas densas e as reproduz faticamente a cada ato soberano do povo, como no "consenso dos corações" e na "vontade geral” de Rousseau, segundo a leitura de Habermas (v. cap. 2 “c”, acima).

Ao mesmo tempo, buscou-se demonstrar também como essa concepção não deriva somente dessa tentativa de aplicação da teoria do discurso em arranjos institucionais, mas da constatação de uma "dissolução do princípio da publicidade" desde $M E E P$, bem como de uma concepção de sociedade que identifica as esferas de reprodução da economia e do poder burocrático como subsistemas diferenciados e sem vínculos com estruturas de compreensão do mundo da vida (v. cap. 8 “a”).

Em estudos mais recentes de Habermas sobre o tema, no entanto, como no texto “Does Democracy Still Enjoy na Epistemic Dimension?” (in. Id, 2009), identificou-se como processos de legitimação do poder só podem manter a expectativa de gerar resultados mais ou menos racionais quando essa expectativa é analisada em diagnósticos da esfera pública política (v. caps. 4 "c" e "d" e 8.1, acima), isto é, avaliando de que modo é possível comprovar a existência de formações mais ou menos discursivas da opinião pública e quais instituições e procedimentos são capazes de garanti-las. 
Ocorre que, apesar de a esfera pública política assumir a partir de então, ao lado dos direitos de autonomia individuais e de autonomia política, a condição de terceiro pressuposto do Estado democrático de direito, seu correspondente normativo, uma esfera pública "funcionando adequadamente" (Habermas, 2009:139), resulta ainda dependente de procedimentos capazes de garantir uma ponte institucional entre os dois primeiros pressupostos.

Ou seja, aquilo que antes deveria ser garantido a partir de uma comunicação pública capaz de exigir transparência e responsividade internamente e entre os atores sociais $\mathrm{e}$ políticos que se imiscuem e alternam tarefas de modo muitas vezes "não-esclarecido" na reprodução de esferas de integração social de democracias de massa (v. MEEP, cap. VII), acabou sendo transferido para um procedimento legal que, ao garantir liberdades comunicativas iguais a todos, procura satisfazer não somente o vínculo interno entre autonomia individual e política, mas também a co-originariedade entre direito e a moralidade procedimental que ainda sustentaria a autocompreensão de Estados democráticos constitucionais.

A saída encontrada por Habermas ao reinserir a categoria da esfera pública política no modelo normativo da teoria da democracia, é garantir a separação de esferas de reprodução social, como a economia e a política, além de impedir sua influência sobre os meios de comunicação a partir da liberdade de imprensa e do princípio da pluralidade de vozes, tendo em vista que esses dois setores representariam respectivamente a "medula óssea" e algo como a espinha dorsal da esfera pública política (Habermas, 2009:133 e 164).

Esses setores assumiriam então a função de realizar uma comunicação recíproca e de feedbacks com as formações mais periféricas da opinião e da vontade, procurando condensá-las e especializá-las a ponto de serem filtradas pelos procedimentos da administração. Os parlamentos, por exemplo, que eram vistos à época de $M E E P$ como instituições da esfera pública política por excelência, passam a ser considerados órgãos do Estado que praticam "discursos e negociações institucionalizadas", e não mais espaços institucionais privilegiados de problematização do poder e de politização da opinião pública. ${ }^{585}$

\footnotetext{
${ }^{585}$ Apesar disso, os partidos e os políticos ainda são inseridos ao lado dos lobbistas como atores da esfera pública política. V. figura na p. 160 de Habermas, 2009.
} 
Ao lado dessa estrutura normativa, o diagnóstico do presente da esfera pública política apresentado em "Does Democracy..." resulta na mesma impressão ambivalente identificada em MEEP a partir da crítica liberal de Mill e Tocqueville contra processos excessivos de "politização" da sociedade, que podem resultar em "ditaduras da maioria".

Essa ambivalência, encontrada atualmente por Habermas nas disputas de diversos atores da sociedade civil pela representação da opinião pública, não difere muito da abordagem do capítulo IV de MEEP, como constatado por Günther em "Communicative Freedom, Communicative Power and Jurisgenesis"586, analisado acima, talvez um dos textos que mais bem aprofundam a teoria procedimental do direito e da democracia em relação a conceitos basilares da filosofia do direito (v. também Günther, 2005).

Isso faz com que se deposite uma esperança excessiva na capacidade que têm organizações sociais como a imprensa e meios de comunicação de massa de desencadear processos públicos de discussão que resultem em críticas do poder, bastando que eles sejam mantidos a salvo de imperativos da economia e do poder político para tanto.

Contudo, se a esfera pública política assume somente a missão de colocar em movimento uma comunicação recíproca entre espaços públicos mais informais e elites intelectuais e profissionais capazes de condensar opiniões públicas - as quais só adentrarão o sistema político depois de traduzidas pela linguagem do direito -, ainda parece se tratar de uma tarefa limitada caso fosse restaurado também o princípio da publicidade como forma de racionalização do poder.

E de acordo com a discussão do tópico 8.2 "a", acima, essa restauração seria possível a partir de um princípio que pode ser assumido sem grandes problemas como uma liberdade comunicativa, que é o direito à justificação. Ao autorizar os cidadãos a receberem justificações do poder político e social, estes se tornam obrigados a práticas de transparência e disponibilização das razões que fundamentam suas atividades e decisões, ainda que os indivíduos não tenham a obrigação de tomá-las como motivos de sua obediência.

\footnotetext{
586 Ao final do texto, ao indicar que é possível garantir a legitimidade de minorias a partir de um procedimento que preveja a possibilidade de elas alterarem as normas que lhes prejudicam, Günther reconhece que se trata, "obviamente", de um argumento semelhante ao de Tocqueville em Democracy in America: "A minority is only obliged to obey the majority's law if, at the same time, there is a procedure which guarantees everybody the right to argue for his or her counterreasons. (...) Those who refuse to accept these reasons are obliged to obey the law because of the democratic procedure, and because they have the right to change the law through participation in and under the conditions of that procedure." (Günther, 1998:252-253. v. nota n. 27 no texto).
} 
A partir da institucionalização de tais procedimentos, torna-se possível compreender o processo de legitimação de modo mais amplo, além de encontrar as condições para que os poderes político e social não sejam mais vistos como subsistemas imunes a problematizações advindas da esfera pública. E isso sem que sejam restringidos direitos de autonomia individual, como a liberdade de iniciativa econômica ou de expressão, por exemplo, pois essa ampliação nada mais faz do que revelar as responsabilidades derivadas da própria autonomia individual aplicada à política e ao direito.

Assim, restaurado o princípio da publicidade de modo interno à teoria discursiva do direito e da democracia, os pressupostos da autocompreensão normativa dos Estados democráticos de direito, quais sejam, a autonomia individual, a autonomia política e os procedimentos que garantem uma formação discursiva da opinião política, precisam ser vistos dentro de uma relação mais ampla, embora também interna, entre direito e esfera pública política.

Longe de dispensar o caminho traçado por Habermas de $D D$ até a retomada da categoria da esfera pública política como terceiro pressuposto do Estado democrático, a teoria do direito da comunicação pretende reforçá-lo. É por isso que a fundamentação a ser realizada nos tópicos finais desta tese busca permitir uma identificação empírica e ao mesmo tempo normativa das relações entre direito e esfera pública política, visto que, por um lado, não adianta institucionalizar meios para a formação democrática da opinião e da vontade políticas se o espaço social onde essa opinião é formada padece de vícios que não são corrigíveis sem direitos fundamentais de comunicação e reconhecimento, inclusive aqueles que geram demandas para a democratização dos meios de comunicação.

Ao mesmo tempo, aqueles indivíduos e grupos comprometidos com uma atuação no processo de legitimação do poder político pouco podem fazer se a demanda pela tradução das opiniões públicas na linguagem do direito não é retribuída com a disponibilização, pelo mesmo poder, das razões pelas quais os indivíduos possam aceitá-lo como legítimo. ${ }^{587}$

\footnotetext{
${ }^{587}$ Em Entre Naturalismo e Religião, Habermas já se mostra mais ciente de que os discursos de justificação dos atos do poder público devem ser elaborados em linguagem acessível aos cidadãos. Faz isso citando a obra Kontexte der Gerechtigkeit [Contextos da Justiça] de Forst (1994:199-209) (Habermas, 2007:151-152). Além disso, a tese de uma separação radical, ou da impossibilidade de se influenciar de modo interno subsistemas sociais distintos sem prejudicar suas lógicas de funcionamento, como a política e a economia, já é de certo modo descartada pelo autor. Este já fala na importante tarefa dos Estados nacionais e da ordem política internacional de realizarem um controle político dessas esferas, orientado para seu "bom funcionamento". V. Habermas, 2007:361-362 e 367-369.
} 
Em outras palavras, para que não só a opinião pública possa ser filtrada pelo procedimento, mas este também possa se abrir mais à crítica dos públicos interessados, torna-se necessária uma teoria do direito que exija essa abertura. Assim, ao lado do paradigma procedimental, que tem por objeto o próprio procedimento dotado de expectativa de legitimidade, faz-se necessário um direito da comunicação, com o qual essa mesma expectativa possa ser efetivamente concretizada pelos cidadãos que o desejarem. Para tanto, como se verá em seguida, desloca seu objeto de análise do procedimento para a esfera pública política.

a) deslocamento complementar do objeto da teoria procedimental do direito. Mas por que a esfera pública política?

Uma das razões pelas quais Habermas procura desenvolver o modelo comunicativo de teoria crítica em substituição ao paradigma da produção, adotado especialmente pela primeira fase da teoria crítica de Adorno e Horkheimer ${ }^{588}$, é a ausência de um "domínio objetual" historicamente identificável na teoria do valor de Marx (Habermas, 1987-II:332356).

Para Habermas, o conceito de "práxis alienada" como uma "totalidade falsa" do sistema capitalista, radicalizada em termos filosóficos na Dialética do Esclarecimento (1947), era pouco realista, pois seu conceito normativo correspondente, a "práxis vital" ou "práxis correta", situava-se no futuro incerto do modo comunista de vida. Ou seja, não havia correspondente normativo no presente histórico contra o qual Marx pudesse identificar uma forma da vida integralmente alienada. ${ }^{589}$

Isso acabou o levando à formulação de uma filosofia materialista da história, que adia para após da auto-superação inevitável da forma de vida capitalista o encontro com uma vida não-alienada, o que Adorno e Horkheimer revisitariam posteriormente de modo “invertido" na mesma obra supracitada. Manteriam, contudo, a mesma imagem de Marx de

\footnotetext{
${ }^{588}$ Sobre a "primeira fase" da teoria crítica de Adorno e Horkheimer, iniciada em 1937 com a publicação do texto "Teoria tradicional e Teoria Crítica" e desenvolvida nos primeiros estudos do materialismo interdisciplinar, quando ainda se parecia manter a aposta em um potencial emancipatório no presente, v. Habermas, 1987-II:381-382; v. também Blotta, 2010:49-75.

589 "This concept of alienation remains indeterminate insofar as there is no historical index for the underlying concept, at times Aristotelian, at times Hegelian, of a 'life' that is reduced in its possibilities as a result of violating the ideal of justice inherent in the exchange of equivalents (...) In an extensively rationalized lifeworld, reification can be measured only against the conditions of communicative sociation, and not against the nostalgically loaded, frequently romanticized past of premodern forms of life." (Habermas, 1987-II:341. Itálicos e grifos nossos).
} 
uma sociedade administrada cuja lógica escapa à vontade dos sujeitos. Estava bloqueada no presente qualquer possibilidade de relações sociais que apontassem para formas mais emancipadas de vida.

Por isso, Habermas aposta em outro fenômeno social cujos potenciais normativos pudessem ser identificados no presente histórico: as competências de comunicação e os acordos que são reciprocamente firmados quando os agentes que compartilham uma linguagem comum discutem para compreender fatos objetivos, normas práticas e sentimentos subjetivos e expressões estéticas. O potencial que tem esse tipo de comunicação de formar de "ligaduras sociais" ausentes de coerção, torna-se o novo objeto de análise da teoria crítica, do qual deveria suceder um programa de pesquisas interdisciplinares que restaurasse os objetivos dos fundadores da teoria crítica "clássica" Horkheimer e Adorno. ${ }^{590}$

Exatamente 12 anos após a publicação original de The Theory of Communicative Action, no entanto, Axel Honneth aplica à teoria de Habermas uma operação similar àquela com a qual este "ressuscitara" a teoria crítica, depois praticamente "desenganada" pelo diagnóstico de Dialética do Esclarecimento. Em sua aula inaugural na Universidade Livre de Berlim, em 1993, Honneth procura indicar que o objeto escolhido por Habermas é abstrato demais, e por isso seu modelo de teoria crítica deixaria de considerar aspectos extremamente relevantes da realidade social dos quais despontam potenciais emancipatórios, inclusive dentro das próprias interações comunicativas: os conflitos sociais envolvidos por experiências de desrespeito, cujo respectivo conceito normativo seria o reconhecimento. ${ }^{591}$

Logicamente, seria oportuno questionar em que sentido poderia se alterar a teoria do agir comunicativo, e até mesmo o projeto da ética do discurso caso Habermas estendesse sua compreensão de comunicação para considerar, além de pretensões de

\footnotetext{
${ }^{590}$ V. Habermas, The Theory of Communicative Action, 1987-II:374-403.

${ }^{591}$ A aula inaugural de Honneth na Universidade Livre de Berlim foi publicada em inglês com o título "The Social Dynamics of Disrespect: on the location of Critical Theory Today" no volume Disrespect: the normative foundations of critical theory, 2007:63-. Trad. Kenneth Baynes. No texto, Honneth afirma: "Because the experience of social recognition represents a condition upon which the development of human identity depends, its denial, i.e., disrespect, is necessarily accompanied by the sense of a threatening loss of personality. Unlike Habermas's model, this model asserts a close connection between the kinds of violation of the normative assumptions of social interaction and the moral experiences subjects have in their everyday communication. (...) Thus a communication paradigm conceived not in terms of a theory of language, but in terms of a theory of recognition, can ultimately close the theoretical gap left open by Habermas in his further development of Horkheimer's program. The feelings of injustice that accompany structural forms of disrespect represent a pre-theoretical fact, on the basis of which a critique of the relations of recognition can identify its own theoretical perspective in social reality." (Honneth, 2007:71-72).
} 
validade presentes na linguagem, pretensões de reconhecimento referidas especialmente à formação de identidades pessoais e coletivas. ${ }^{592}$

Mas se Habermas reconhece esse problema a partir de uma recepção mais interna das preocupações da teoria social de Honneth desde Entre Naturalismo e Religião (Habermas, 2007:326) - bem como de algumas questões da teoria da justificação de Forst para pensar problemas relativos a diálogos interculturais (Id. op. cit:129-167) - isso não o leva a reformular a "forma direito" como desenvolvida em $D D$, apesar de deixar algumas pistas de como isso poderia ser feito (v. tópico 8.1 "b", acima).

É possível supor, no entanto, que caso Habermas fizesse esse retorno a $D D$, e antes disso revisasse também $M E E P$ (esforço que, de certa maneira, esta investigação tem procurado realizar), seu resultado não seria somente a reinserção da categoria da esfera pública política como terceiro pressuposto fundamental do Estado democrático de direito, e sim a elaboração de uma teoria do direito capaz de avaliar os procedimentos deliberativos para além dos três poderes do Estado, dando conta do processo de legitimação com maior amplitude.

E como já foi discutido acima (cap. 8), isso só é possível na medida em que esse processo se ligar de modo constitutivo às pretensões normativas estruturais e mais conteudísticas da esfera pública política, tomada aqui como o espaço social formado pelas problematizações dos direitos e deveres de comunicação e reconhecimento sem os quais a opinião e a vontade políticas não têm condições de representar autenticamente a soberania popular.

Mas para que essa revisão não elimine a importância do paradigma procedimental do direito, capaz de revelar o vínculo da política com uma expectativa social de legitimidade sem que isso dependa de cidadãos dispostos a perder sua autonomia individual em troca de uma vida voltada somente para o "bem comum", a elaboração de uma teoria do direito voltada para a garantia de um funcionamento adequado da esfera pública política pode de outro modo complementar o paradigma procedimental em sua tarefa de garantir o vínculo entre direito e esfera pública política, algo que antes era possível somente de forma incompleta.

\footnotetext{
${ }^{592}$ Mas obviamente, tal esforço não será empreendido aqui. Para uma tentativa de realizar esse "caminho de volta" à $T C A$ em alguns temas específicos desde as novas reflexões de Entre Naturalismo e Religião, v. Blotta, The Fascination of Authority and the Authority of Fascination. Rationalization and Legal theory in Habermas revised. 2010b.
} 
Com isso, o direito da comunicação se associa ao paradigma procedimental do direito para, além de institucionalizar processos de formação da opinião e da vontade políticas a partir da distribuição simétrica de liberdades comunicativas entre todos, garantir direitos de reconhecimento e de comunicação capazes de reinserir o princípio da publicidade na lógica interna do direito e da política.

Mas a partir dessa escolha da esfera pública política como "domínio objetual” do direito da comunicação, cuja finalidade é permitir uma avaliação mais completa do procedimento deliberativo e da circulação do poder político, dois problemas teóricos ainda precisam ser respondidos para satisfazer a validade da argumentação.

Primeiramente, pode-se perguntar por que o direito da comunicação elege a esfera pública política como objeto de análise, e não, por exemplo, uma concepção contemporânea de sociedade civil, como preferem Cohen e Arato em sua teoria política. ${ }^{593}$ Isso porque, em termos de diagnóstico do presente, pode ser considerado irrealista aquele que negar a renovação de movimentos sociais e de representações de interesses difusos em foros institucionais desde as últimas duas décadas do século XX, especialmente em função do papel desempenhado por organizações não-governamentais domésticas e internacionais na produção de críticas às formas atuais de reprodução social. ${ }^{594}$

\footnotetext{
${ }^{593}$ V. o abrangente estudo de Cohen \& Arato, Civil Society and Political Theory, 1992, que, além de analisar diversas concepções de sociedade civil na teoria política contemporânea, como de Foucault e Luhmann, analisa e adota uma concepção mais afeita aos estudos de Habermas. Com a ressalva de que se trata de uma "definição de trabalho" ("working definition"), necessária ao desenvolvimento da investigação, atestam: "We understand 'civil society' as a sphere of social interaction between economy and state, composed above all of the intimate sphere (especially the family), the sphere of associations (especially voluntary associations), social movements, and forms of public communication. Modern civil society is created through forms of selfconstitution and self-mobilization. It is institutionalized and generalized through laws, and especially subjective rights, that stabilize social differentiation. While the self-creative and institutionalized dimensions can exist separately, in the long term both independent action and institutionalization are necessary for the reproduction of civil society." (Cohen \& Arato, 1992:ix).

${ }^{594}$ V. tese de Lavalle sobre o sentido da "nova sociedade civil", inclusive com dados empíricos que comprovam o aumento das formas de associativismo referidos a questões políticas não vinculadas a instituições e interesses econômicos. Espaço e Vida Públicos, 2001:262-370. Rousiley Maia também apresenta interessante estudo sobre formas de representação política de associações e organizações civis que podem, apesar dos problemas derivados da mediação de interesses, dar visibilidade a "experiências de desrespeito" e articulá-las em "discursos de justificação" capazes de afetar diretamente o sistema político. Maia, R. Representação política de atores cívicos e esfera pública: entre a imediaticidade da experiência e os discursos de justificação. Anais do III Congresso da Compolítica, 2009.
} 
Até mesmo as concepções mais recentes de sociedade civil apresentadas por Habermas $^{595}$ poderiam sugerir sua adoção como objeto da teoria do direito da comunicação, ou ao menos como redes mais evidentes de interações sociais das quais despontam problematizações de pretensões de comunicação e reconhecimento que deveriam ser considerados pelo direito da comunicação, sejam elas de grupos de interesses privados ou públicos.

No entanto, a escolha pela esfera pública política se dá em função dos mesmos argumentos utilizados no capítulo 4 desta tese, quando se decide adotar um método de análise mais focado nos discursos e pretensões em debate do que nas características dos públicos que os proferem. Isso permite garantir o princípio da generalidade do acesso à esfera pública, pelo qual a opinião de um indivíduo singular possa ter a mesma consideração que a opinião de um grupo, além de afastar os perigos de uma compreensão dos processos de formação da opinião como "blocos homogêneos" advindos da "sociedade civil".

No texto "Further Reflections on the Public Sphere" é o próprio Habermas quem levanta argumentos capazes de fundamentar essa escolha, embora sua análise mais recente da esfera pública política ainda fique centrada em seus diferentes "atores", seguindo modelo de Peters (Habermas, 2009:158-161). Seus motivos são claros:

“A questão central em Mudança Estrutural é atualmente discutida sob a rubrica da 'redescoberta da sociedade civil'. A referência global a um espírito 'apoiador' de mundos da vida diferencialmente organizados e seu potencial para reflexão crítica não é suficiente. Ele deve ser tomado de modo mais concreto, e não somente em relação aos padrões de socialização e tradições culturais. Uma cultura política liberal enraizada em motivos e orientações de valor certamente providencia um solo favorável para comunicações públicas espontâneas. Mas as formas de intercâmbio e organização, a institucionalização de apoio a uma esfera pública política nãosubvertida pelo poder, são ainda mais importantes." (Habermas, 1992:453. Grifos e itálicos nossos). ${ }^{596}$ 595 O autor altera significativamente sua concepção de "sociedade civil" entre MEEP e $D D$, por exemplo.
Enquanto na primeira obra tratava-se - à época da esfera pública burguesa - de uma esfera ligada aos
negócios privados e cuja publicização só alcançava a esfera econômica ("setor de troca de mercadorias e de
trabalho social" - v. figura em Habermas, 2003:45), e que pouco evoluíra até meados do século XX, em $D D$
ela é vista já como grupos de interesse próprio e de interesse público capazes de mobilizar, dentro da esfera
pública política, pretensões de validade para o sistema político (Id, 1996:355-356).
596 Tradução livre de: "The central question in Structural Transformation is nowadays discussed under the
rubric of the 'rediscovery of civil society.' The global reference to a 'supportive' spirit of differentially
organized lifeworlds and their potential for critical reflection is not sufficient. It must be made more concrete,
and not only with regard to patterns of socialization and to cultural traditions. A liberal political culture
rooted in motives and value orientations certainly provides a favorable soil for spontaneous public 
Assim, como também se pôde constatar pelo diagnóstico do tópico 6.2 desta tese, não se trata de desconsiderar a importância dos movimentos sociais, associações civis, organizações privadas de interesse público e outras formas de associativismo civil cujas atuações têm robustecido o poder da esfera pública política nas democracias de massa nessa passagem de século. Em diversos momentos do diagnóstico da parte II, inclusive, foi destacado como as responsabilidades implicadas no uso de liberdades comunicativas na esfera pública política precisam ser medidas a partir da natureza e do alcance das ações e pretensões de cada participante da comunicação pública, sob pena de se equiparar, por exemplo, a liberdade de expressão de um indivíduo que escreve em um blog ou emite ondas de rádio não-regularizadas com aquela de uma empresa que presta um serviço público de comunicação social.

Esclarecida essa questão, o segundo problema teórico a ser enfrentado pela teoria do direito da comunicação trata de uma possível suspeita de super dimensionamento que sua teoria confere à esfera pública política. Afinal, onde ela começa e onde termina? É possível garantir seu funcionamento adequado sem juridificá-la, retirando sua espontaneidade? Essas questões serão enfrentadas abaixo, quando se pretende finalizar a fundamentação do direito da comunicação como uma filosofia social do direito.

b) o duplo-movimento institucional do direito da comunicação: esclarecimentos sobre as dimensões empírica e normativa do direito da comunicação

Para que o direito da comunicação se estabeleça como uma filosofia social do direito, sua teoria precisa ter condições de permitir tanto análises empíricas quanto normativas da esfera pública política, isto é, de modo que as dinâmicas e relações entre seus elementos possam ser identificados como fenômenos observáveis, enquanto que suas expectativas normativas possam ser comparadas com essas observações.

No diagnóstico da parte II desta tese, foi possível identificar dois movimentos estruturais na esfera pública política no Brasil. Por representarem, no entanto, tendências ligadas a direitos de comunicação e de reconhecimento presentes nos fundamentos 
qualquer democracia constitucional, também podem ser encontrados em outras esferas públicas políticas nacionais e em formações internacionais do fenômeno.

O primeiro movimento do direito da comunicação é representado pelas pretensões normativas contidas nas liberdades e direitos de comunicação e de reconhecimento, sendo denominado aqui movimento dos direitos de comunicação. Ele deriva das pretensões mais básicas de reconhecimento intersubjetivo necessárias à formação da identidade pessoal, e por isso dão condições para se pressupor a cada pessoa - e de modo mais amplo que na ética do discurso - direitos individuais de liberdade comunicativa (v. capítulos 7.2 e 7.3).

Como um feixe elíptico de normatividade que emerge desse pólo do reconhecimento da singularidade da pessoa humana e suas competências comunicativas, o movimento dos direitos de comunicação atravessa a esfera privada e adentra a pública ao problematizar normas relativas ao acesso dos indivíduos e à organização da área da comunicação social (v. capítulos $5,6.1,6.2$ ). Sem elas não se pode garantir as condições estruturais da autonomia política e, portanto, de crítica ao poder (cap. 6.3).

Esse primeiro movimento do direito da comunicação permite concretizar as pretensões normativas do procedimento deliberativo de Habermas, pois exige instituições capazes de sediar processos formação mais ou menos racional da opinião e da vontade políticas, a partir da garantia de direitos individuais de comunicação e participação. Por essa característica, compreende-se que Habermas possa tê-la denominado "comunicação política" sem maiores problemas (Habermas, 2009).

No entanto, para efeito de compreensão analítica de seus movimentos institucionais, a teoria do direito da comunicação prefere dar enfoque a outro tipo de comunicação presente na área da comunicação política, este menos trabalhado pelas teorias do direito e da esfera pública de Habermas. Trata-se da comunicação do direito, o segundo movimento institucional do direito da comunicação, que procura realizar deveres e responsabilidades mais gerais exigidos pelo princípio da publicidade, como a autorepresentação da ordem política (v. cap. 7.1, acima), os discursos de justificação dos atos e programas do Estado, bem como a acessibilidade a dados públicos e políticas de transparência (cap. 6.3 “b”).

Apesar dessa separação analítica, há uma ligação fundamental entre os dois movimentos. Ela é dada tanto pela expectativa normativa da relação interna entre direito e esfera pública política, analisada acima, quanto pelo diagnóstico de uma interpenetração 
recíproca das esferas do público e do privado nas democracias de massa, como identificada por Habermas em MEEP (v. caps. V e VI da obra).

Essa tendência também pôde ser verificada no cenário nacional na parte II desta tese, inclusive com sinais de aprofundamento, como em políticas interventoras do Estado na esfera social e até mesmo sobre aspectos da vida privada (v. caps. 6.3 "a" e "b" e 7.2). Sua característica mais visível, no entanto, é em relação ao aumento do poder social de organizações privadas que atuam com grande influência no espaço público, especialmente conglomerados empresariais (v. cap. 5). Infelizmente, esse aumento do poder social não tem sido acompanhado de suas responsabilidades decorrentes, como a necessidade de mais transparência dessas organizações; alguns desses atores sociais ainda lançam mão de direitos individuais de comunicação como forma de se isentar dessas responsabilidades (v. caps. 5.2, 6.1 e 6.2 ).

Contudo, como foi analisado especialmente em relação às liberdades de comunicação e seus respectivos deveres (cap. 6.1), só é possível defender a inexistência de regulação ou responsabilidades públicas de comunicação quando os direitos de autonomia individual são interpretados de modo oposto e em exclusão aos direitos de autonomia política e seus deveres correspondentes de publicidade, como no caso do direito à justificação (v. cap. 7.3 e cap. 8.2 “a”) (v. Habermas, 1996:323-324).

Essa questão revela outra ligação fundamental entre o duplo-movimento do direito da comunicação: apesar de serem dois fenômenos distintos, não se pode pensar os direitos de comunicação sem que eles estejam também ligados internamente a responsabilidades de comunicação do direito, ou aos respectivos deveres de comunicação e de reconhecimento que derivam do princípio da publicidade, mas que acompanham todo exercício da liberdade comunicativa e de liberdades de comunicação.

Essa tese explica por que uma política de procedimentalização da soberania popular, como as audiências públicas em órgãos do Estado, pode ser lida não somente como forma de realizar de direitos de comunicação e participação em processos decisórios, mas também como meio de tornar mais transparentes e criticáveis os atos do poder público e suas instituições (v. cap. 6.3 “a”). E a recíproca também é verdadeira (v. 6.3 “b”).

Pensada, então, em termos de movimentos institucionais mais amplos do direito da comunicação, torna-se possível identificar de modo mais claro a relação interna entre direito e esfera pública política, expressa na proposição que inicia esta investigação: não só uma comunicação livre é pressuposto de um direito democrático, mas um direito democrático - no sentido do exercício do poder político e social que se submete a 
exigências de publicidade - pode garantir as liberdades de comunicação que darão condições para legitimá-lo como tal.

Assim, a relação interna entre os movimentos de direitos de comunicação e a comunicação do direito, derivada daquela entre esfera pública política de direito, pode revelar seu conteúdo normativo de modo mais amplo, completando a circulação do poder político conforme proposto Habermas no capítulo 8 de $D D$ : o direito não deve só garantir as liberdades comunicativas que permitem uma avaliação livre da aceitabilidade do poder político e social (poder comunicativo tornando-se poder administrativo), mas a comunicação do direito deve ao mesmo tempo colaborar com informações públicas, a disponibilização das razões capazes de convencer os cidadãos da legitimidade do poder, além de outras atividades que contribuam para a formação de uma cultura política liberal capaz de garantir o caráter democrático dessa legitimidade.

Em outras palavras, a comunicação do direito, como movimento do direito da comunicação que permite a retomada do princípio da publicidade do poder na teoria do direito, deve também garantir condições práticas e culturais que tornam possível o pleno exercício dos direitos individuais de informação, de comunicação e de participação na esfera política, facilitando e diminuindo os custos das "escaladas" dos indivíduos à esfera pública política, como metaforiza Habermas em DD (1996:131).

Aliás, a partir de outra metáfora apresentada mais recentemente pelo autor de que a esfera pública política seria uma ponte capaz de receber essas "escaladas" dos cidadãos a partir da ligação do auto-interesse ilustrado com o interesse público, ao relacioná-la com a de que o direito funciona como um sistema de eclusas capaz de transformar poder comunicativo em poder administrativo (Habermas, 1996:356), o duplo-movimento do direito da comunicação pode ser visto como os dois "braços" uma ponte móvel que opera na forma de um sistema de eclusas, porém capaz de se retro-alimentar.

O que mantém a ligação entre os dois braços dessa ponte não é só a relação interna do duplo-movimento do direito da comunicação, mas a compreensão de que seus princípios estruturais, as liberdades comunicativas e de comunicação e as expressões do princípio da publicidade estão também presentes em cada um dos lados.

Assim, os conceitos estruturais do direito da comunicação lhe permitem complementar a teoria procedimental do direito de Habermas de modo que, além de permitir a transformação do poder comunicativo em poder administrativo, o direito também possa oferecer condições para que a comunicação política alinhe seu movimento 
com a esfera pública política, colaborando para a formação de uma cultura estruturalmente capaz fazer uso de suas liberdades comunicativas.

Mas algumas questões finais ainda permanecem como problemas possíveis ao estabelecimento da teoria do direito da comunicação como filosofia social do direito. A primeira delas retoma a discussão do tópico anterior, sobre uma eventual suspeita de super dimensionamento do fenômeno da esfera pública política.

Não se pode negar que o direito da comunicação concebe a esfera pública política de modo mais amplo do que o faz Habermas, mesmo em seus mais recentes estudos sobre o tema. Isso se dá porque, ao ressaltar especialmente a importância do movimento de comunicação do direito, torna-se claro mais uma vez como a "ponte" visualizada pelo autor parece cobrir somente "metade do caminho", quando as pretensões de comunicação e reconhecimento devem ser traduzidas na linguagem funcional do sistema político, não tendo condições para democratizá-lo "a partir de dentro". Como na parábola "Diante da Lei” de Kafka, o indivíduo sabe que tem direito de acessá-la, mas o guarda que lhe impede a entrada parece não conhecer todas as suas funções, dentre as quais, a de bem servir ao indivíduo que busca acesso à lei. ${ }^{597}$

Isso poderia ser alcançado por meio de uma análise mais aprofundada e sistemática do princípio da publicidade, o que exigiria, no entanto, conceber esse conceito estrutural do direito da comunicação na forma de pressões internas e constantes de democratização que obrigam o poder a se publicizar de modo inteligível e criticável com os cidadãos. E isso também vale para as formas de poder social que tendem a se auto-reproduzir sem cumprir seus deveres de "comunicação do direito", como a visibilidade do poder, a transparência e a inteligibilidade da comunicação entre prestadores de serviços público/privados e seus clientes.

Assim, procurou-se abordar aqui a esfera pública política desde as manifestações mais subjetivas de formação da identidade pessoal, como as pretensões de reconhecimento, atravessando todo o perímetro da elipse de pretensões normativas de comunicação que despontam dos espaços sociais formados por suas violações, afirmações, problematizações e expressões, até chegar ao outro pólo da "ponte", onde se encontram as pretensões de publicidade ou de comunicação do direito, já dentro do "sistema administrativo".

\footnotetext{
${ }^{597}$ Para uma interpretação desta conhecida parábola de Kafka, publicada no capítulo 9 da obra O Processo (1914), a partir de uma comparação entre os papéis do indivíduo que busca a lei, o guarda e a própria lei com a opinião pública, a mídia e os direitos humanos, v. Blotta, V. Opinião Pública, Mídia e Direitos Humanos: interpretações a partir de $O$ Processo de Franz Kafka. Texto a partir de conferência no I Simpósio de Direitos Humanos da Universidade do Grande ABC, 2011 (manuscrito).
} 
A mobilidade de ambos os "braços" ou movimentos dessa ponte, mantém-se única e exclusivamente como forma de garantir, embora agora de modo mais equilibrado, o "espaço entre razões e motivos" da ação que separa direito e moral e permite a existência de uma sociedade pluralista que se organiza por regras jurídicas. Diferentemente do que propõe Günther, no entanto, as trocas entre cada um dos movimentos não pode ser "interrompida", pois isso prejudicaria os desdobramentos fundamentais de sua relação de co-originariedade, como a interpretação do princípio da publicidade do poder em termos de exigência de justificação que deve transcender a mera legalidade (v. cap. 8.2 "b").

Apesar disso, esses aspectos normativos dos conceitos estruturais do direito da comunicação ainda podem levantar a suspeita de uma interpenetração excessiva entre esfera pública política e direito, especialmente em relação a teóricos mais afeitos a concepções liberais de democracia, mas também em relação às concepções procedimentais de Habermas e Günther. São esperadas, portanto, críticas advindas do argumento de que a esfera pública não pode ser concebida como uma instituição (Habermas, 1996:171 e 358359), pois perderia sua espontaneidade; em casos extremos, poderia resultar numa estatização da sociedade, como em regimes autoritários.

Mas embora a esfera pública política não possa ser institucionalizada, e o direito da comunicação partilha essa tese com Habermas, o autor chega a destacar em diversos momentos de suas obras a necessidade de ela ser protegida por direitos fundamentais, embora sem aprofundar em sua sistematização. Apesar de imprescindíveis, as propostas de direitos de comunicação e participação garantidos em processos institucionalizados de deliberação democrática, bem como princípios de "bom funcionamento" de órgãos de comunicação social ainda parecem insuficientes para dar conta das condições estruturais de formações democráticas da opinião e da vontade políticas. Isso porque uma "imunização geral" da esfera pública política contra as patologias geradas pelas invasões do poder burocrático e do poder econômico não é capaz de garantir uma comunicação pública nãosubvertida pelo poder. O problema da comunicação icônica (cap. 5.2) é só uma das provas dessa insuficiência.

Além disso, Habermas não chega a sistematizar os direitos fundamentais que devem proteger a esfera pública política (Habermas, 1996:368-369), e tampouco aprofunda sua relação com conceitos jusfilosóficos que permitem sua aplicação em casos concretos. De modo teórico, isso poderia ser feito com as pretensões normativas mais estruturais da esfera pública política, mas em relação aos conteúdos normativos mais concretos, estes precisam ser identificados em diagnósticos de expressões concretas do fenômeno. Se que a 
parte II desta tese alcança tal objetivo, no que se segue procura-se realizar uma reflexão final sobre os impactos do direito da comunicação no Brasil, com vistas à sua possível utilização de modo operacional no sistema jurídico pátrio. Antes disso, a figura abaixo especifica a anterior (cap.8) para representar visualmente o duplo-movimento institucional do direito da comunicação.

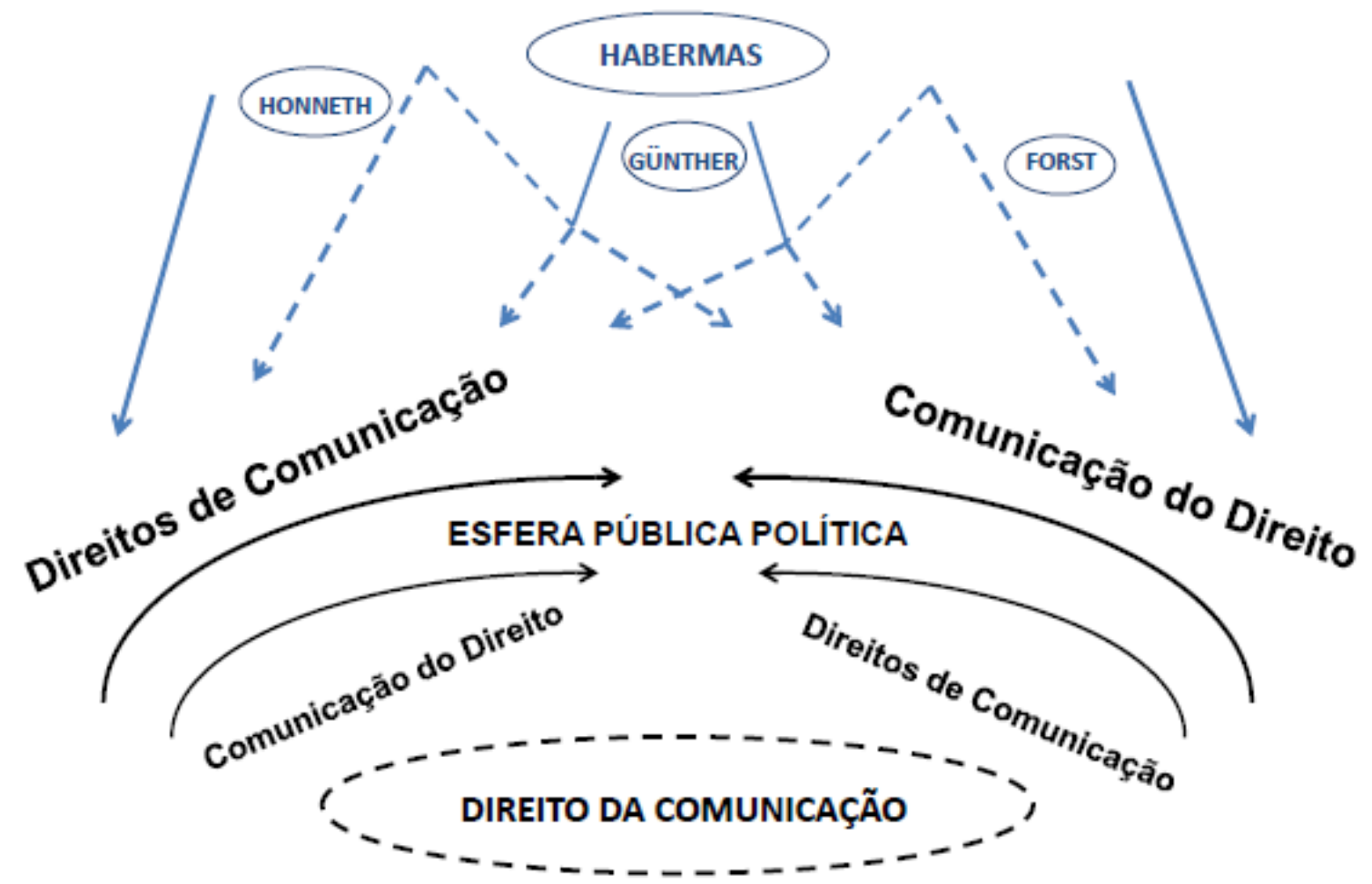

9.2. Conceitos jusfilosóficos e implicações do direito da comunicação na dogmática jurídica: aprofundando a recepção de teorias intersubjetivas do direito pela filosofia moderna do direito

O direito da comunicação não é só uma teoria crítica que busca fornecer parâmetros para análises empíricas e normativas sobre o estado atual e o papel desempenhado pela esfera pública política em Estados democráticos de direito. Ao identificar pretensões normativas que despontam de expressões desse espaço social e que refletem direitos de comunicação e de reconhecimento implícitos ou explícitos em princípios e normas jurídicas desses Estados, o direito da comunicação pretende contribuir também para o 
conhecimento que fundamenta e operacionaliza o funcionamento de seus sistemas jurídicos.

Denominado por Ferraz Júnior como “dogmática jurídica”, ou "ciência dogmática do direito", esse conhecimento deriva de preceitos da filosofia do direito que, para permitir aplicações práticas em processos decisórios, têm sua problematização suspensa (Ferraz Júnior, 1980; Id, 1984). Mas como toda reflexão filosófica se desenrola a partir da aceitação da validade de premissas precedentes, e uma separação rígida entre ciência e filosofia perde o sentido para a vertente de pensamento da teoria crítica da sociedade (Habermas, 1989:17-60), prefere-se aqui adotar a distinção de Klaus Günther entre discursos morais de justificação e discursos jurídicos de aplicação, os quais, apesar das diferenças discursivas, mantêm ligações fundamentais (v. cap. 8.2 "b”; v. também Günther, 2004).

Assim, para realizar essa "tradução" da filosofia social do direito da comunicação numa teoria filosófica do direito, cujos conceitos lhe permitem aplicações sobre conflitos de comunicação que exigem demandas ao Estado, torna-se necessário um esforço final de reflexão sobre os resultados da pesquisa que leve em conta essa distinção feita por Günther e demonstre alguns impactos dos pressupostos e pretensões normativas do direito da comunicação sobre conceitos da filosofia do direito que fundamentam a dogmática jurídica nacional.

Como a esfera pública política não constitui uma área do conhecimento jurídico - e como visto há pouco, nem poderia sê-lo (v. tópico anterior) -, as duas áreas conhecidas pela linguagem corrente do direito que mais se ligam às suas pretensões normativas são a comunicação social e a comunicação política. Mas enquanto a primeira recebeu tratamento explícito pela Constituição Federal da República de 1988, compondo inclusive um capítulo específico da chamada "Ordem Social” (Cap. V, Título VIII, CF), as normas legais referentes à comunicação política estão distribuídas de modo mais assistemático pelo texto constitucional e em normas infraconstitucionais. ${ }^{598}$

Como se pôde verificar durante o estudo, no entanto, as pretensões normativas encontradas na esfera pública política nacional não se esgotam nas previsões da comunicação social e tampouco nas normas comunicação política, mas procuram restabelecer, ao contrário, os elos fundamentais entre ambas as áreas. Aliás, a própria existência de uma área do direito denominada "comunicação social" que não inclui normas

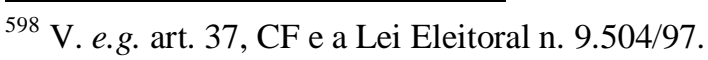


referentes à comunicação política - ou mais especificamente de comunicação do direito - é sinal de uma desconsideração pelo sistema jurídico brasileiro da relação interna entre direito e esfera pública política. ${ }^{599}$

Em relação à doutrina, os poucos - porém louváveis - esforços de sistematizar o direito da comunicação como ramo autônomo do direito enfatizaram muito mais a questão da comunicação social, dos meios de comunicação de massa e dos direitos individuais de comunicação do que a questão da comunicação do direito. A única obra jurídica sobre o direito da comunicação que se tem notícia a tratar da questão é Direito à Informação, Direito à Comunicação. Direitos fundamentais na Constituição Brasileira (1997) de Aluízio Ferreira, que o denomina “comunicação institucional” (Ferreira, 1997:236).

Apesar de não aprofundar em questões mais teóricas referentes ao problema, Ferreira apresenta esse tipo de comunicação como dever de órgãos públicos e privados com atuação na esfera pública, e delineia como seus fundamentos os princípios de acesso à informação pública, de visibilidade do poder e de publicidade, destacando sua importância para a consolidação do regime democrático. Além disso, o autor discorre de modo sistemático sobre algumas formas de operacionalização jurídica da comunicação do direito (Id, op. cit:236-270) e faz o mesmo com liberdades e direitos de comunicação.

Duas obras mais antigas também buscaram realizar uma fundamentação jurídica pela autonomia do direito da comunicação nas ciências jurídicas. São elas Direito de Comunicação (1975), de Orlando Soares, e Direito da Comunicação (1976) de Antonio Costella. Apesar de a primeira ter discussões mais críticas sobre o tema, discutindo também de modo sociológico questões como abusos da propaganda comercial, racismo e concentração da propriedade de meios de comunicação de massa (Soares, 1975:199, 203 219, 231), a segunda realiza um esforço maior para fundamentar essa autonomia disciplinar do direito da comunicação.

Apesar disso, ambas as obras entendem que é a tendência do direito da comunicação de se constituir como ramo autônomo, especialmente em função de normas e institutos jurídicos específicos como o direito de resposta e regimes de serviços de comunicação social e telecomunicações cada vez mais específicas novas tecnologias de

\footnotetext{
${ }^{599}$ A fundamentação dessa tese carece de um diagnóstico aprofundado e sistemático do tratamento dado pelo sistema jurídico nacional a normas da comunicação social e da comunicação política, o que não será feito aqui. Como se busca fundamentar neste tópico o direito da comunicação como teoria filosófica do direito, serão discutidos somente os impactos das pretensões normativas da esfera pública política - seu objeto de análise - sobre conceitos discutidos na filosofia do direito. Estudos futuros poderão, contudo, aprofundar esse diagnóstico e comprovar essa suspeita de desconsideração levantada. Sobre o tema a partir de um historicização constitucional, v. Fiorillo, O Direito de Antena em Face do Direito Ambiental no Brasil, 2009, pp. 159-240.
} 
comunicação, que à época já representavam importantes fatores da ordem social e política do país.

É interessante também notar como essas obras apresentam um enfoque diferente sobre o tema quando comparadas com o já citado Direito à Informação, Direito à Comunicação (1997) e outros dois estudos mais recentes, como $O$ Direito da Comunicação e da Comunicação Social (2004), de Marcos Bitelli, e O Direito de Antena em Face do Direito Ambiental no Brasil, de Celso Fiorillo (2009). Muito provavelmente por terem sido publicadas em meio ao regime militar, tanto a obra de Orlando Soares quanto a de Antonio Costella não trabalham a partir da perspectiva das liberdades e direitos individuais de comunicação, tomando-os praticamente como direitos derivados das regulações necessárias aos meios de comunicação de massa.

Quanto às outras três obras citadas, já é possível identificar as marcas do regime jurídico da Constituinte de 88 , que entende a dignidade da pessoa humana e os direitos humanos como os fundamentos maiores da ordem jurídica e objetivos centrais da República. Com isso, pode-se explicar como o regime democrático só é consolidado a partir da realização desses fundamentos, e que dentre suas pré-condições está um "bom funcionamento" dos sistemas de comunicação social.

Os traços e discussões iniciais de uma teoria jusfilosófica do direito da comunicação, fundamentados neste último tópico da pesquisa, não pretendem entrar no debate sobre sua autonomia entre as demais disciplinas jurídicas. A especificidade de seus impactos sobre conceitos da filosofia do direito poderá, contudo, servir de base teórica para fundamentar uma posição afirmativa em relação à questão.

A preocupação principal dos dois subtópicos que seguem abaixo é demonstrar como uma leitura das pretensões normativas da esfera pública política nacional feita a partir dos conceitos estruturais do direito da comunicação pode problematizar pressupostos básicos da filosofia moderna do direito que são caros à operacionalização da dogmática jurídica.

a) pretensões normativas de direitos de comunicação no Brasil e seus impactos sobre conceitos modernos da filosofia do direito.

A partir de uma revisão do pensamento de Habermas que não descarta seus pressupostos principais, mas que pretende aprofundá-los em relação às tendências presentes em suas obras mais recentes, procurou-se fundamentar aqui a filosofia social do 
direito da comunicação na perspectiva intersubjetivista da teoria crítica comunicativa. Mais do que isso, buscou-se também demonstrar como a fundamentação da teoria do direito da comunicação, que passa por um diagnóstico da esfera pública política para reconstruir suas pretensões normativas, colabora para um aprofundamento do caráter intersubjetivo do pensamento jurídico e político de Habermas.

Mas apesar de todas as dificuldades enfrentadas nesse percurso, uma tarefa ainda mais difícil talvez seja traduzir o conhecimento produzido no âmbito da filosofia social para a filosofia do direito, isto é, para o conhecimento que, além de problematizar questões e conceitos relativos às condições de uma ordem política justa, fornece as fundamentações necessárias para a justificação de pressupostos, princípios e normas que informam a organização e a operacionalidade de sistemas jurídicos e órgãos estatais.

Até onde foi possível identificar na pesquisa desta tese, o único jurista que realizou essa façanha foi Klaus Günther, especialmente em sua obra Der Sinn für Angemessenheit: Anwendungsdiskurse in Moral und Recht (1988, com versão brasileira de 2004), quando recepcionou os resultados da ética do discurso de Habermas no interior da filosofia do direito e, a partir da distinção entre discursos de justificação e discursos de aplicação, sedimentou a possibilidade de utilização da filosofia moral de Habermas em reflexões e em práticas jurisprudenciais.

Mas como o direito da comunicação parte de uma reavaliação da própria filosofia social de Habermas no que diz respeito às teorias da esfera pública e do direito, chegando inclusive a resultados distintos da recepção da ética do discurso pela teoria do direito de Günther (v. cap. 8.2), não se trata aqui de adotá-la sem quaisquer mudanças ou novos resultados. Se a teoria do direito da comunicação complementa o paradigma procedimental do direito de Habermas e recupera conceitos e problemas por ela desconsiderados, seus impactos sobre a filosofia do direito não poderão ser iguais aos da teoria de Günther.

Dadas essas delimitações introdutórias, inicia-se com o movimento institucional dos direitos de comunicação. A partir de agora, espera-se tornar mais claro que o predicado “institucional" do duplo-movimento representa, além de demandas advindas de expressões políticas esfera pública, ações ou omissões concretas cabíveis ao Estado. 
Se o movimento institucional dos direitos de comunicação tem origem nos direitos ligados ao indivíduo e às condições de seu desenvolvimento como sujeito autônomo, ganham destaque nessa instância três pretensões normativas identificadas no diagnóstico da esfera pública no Brasil. São elas o direito a condições propiciadoras de relações de reconhecimento, a proteção constitucionalmente justificada da esfera privada e a pluralidade de visões de mundo.

Essas pretensões problematizam a extensão do princípio da dignidade da pessoa humana, pois apesar de ser considerado o valor máximo a orientar da interpretação do ordenamento jurídico nacional e do direito internacional dos direitos humanos, tem um conteúdo hipotético indefinido. ${ }^{600}$

Ao pensar esse princípio numa dimensão mais intersubjetiva, portanto, o direito da comunicação revela primeiramente as interações inevitáveis da pessoa humana com os outros indivíduos, no sentido de práticas de "individuação pela socialização" quais não é sequer possível utilizar de modo coerente as noções de pessoa humana, ou mesmo o princípio da autonomia da vontade. Em outras palavras, se o direito pretende concretizar a dignidade humana, ele precisa garantir os espaços nos quais se podem desenvolver as relações intersubjetivas fundamentais à formação de sujeitos autônomos.

Mas a proteção dessas relações não significa imediatamente uma proibição das interferências dos outros sobre os indivíduos, e por isso não é uma liberdade negativa. Ao mesmo tempo, não pode ser considerada uma liberdade positiva em seu sentido convencional, pois como já visto acima (cap. 8.1 "b"), o Estado não pode obrigar pais a

${ }^{600}$ Sobre a compreensão do princípio da dignidade da pessoa humana como um "super princípio" que organiza os sistemas jurídicos domésticos e suas formações internacionais, além de orientar de modo vinculante os exercícios interpretativos da chamada "comunidade de intérpretes da constituição", em diálogo com o pensamento de Peter Häberle, v. Bittar, O jusnaturalismo e a filosofia moderna dos direitos: reflexão sobre o cenário filosófico da formação dos direitos humanos, Revista do Mestrado em Direito da Unifieo, 2005, pp. 87-105.

${ }^{601}$ Apesar de Honneth ter trabalhado com maior profundidade esse tema (v. Honneth, 2003; Id, 2011:233317), ele também está presente nas bases do pensamento de Habermas. Talvez uma das imagens mais interessantes de toda a obra do autor para explicar a individuação pela socialização, bem como um conceito amplo de intersubjetividade, está em texto de conferência de 2004 em Kyoto: "I am getting at here is an image of subjectivity which you may imagine as a glove turned inside out to discern the structure of its fabric, a glove woven from the strands of intersubjectivity. Inside each individual person we find a reflection of the outside social world. For the mind of the subject is imbued with meaning content by locking into the 'objective' mind of what is intersubjectively shared by socialized individuals. (...) // It never made sense to me that self-consciousness should be the original source for everything else. Do we not first become aware of ourselves under the gaze of another person? It is the gaze of the You, of the second person, who speaks to me as a first person - when in his or her eyes I first become aware not only of myself as a conscious subject but also as a unique individual. From the subjectifying gaze of the other there springs an individuating force." (Habermas, 2004:3-4). 
amar seus filhos, e menos ainda estabelecer relações de amizade ou de estima pessoal ${ }^{602}$; mas ele pode, contudo, garantir reconhecimento jurídico a relações éticas e expressivas espontâneas, como no caso do princípio do afeto no direito de família, que tem permitido equiparações de benefícios patrimoniais do casamento a uniões estáveis, inclusive entre casais de pessoas do mesmo sexo. Assim, as pretensões de reconhecimento encontradas na esfera pública política nacional também podem complementar aquelas relativas à proteção constitucionalmente justificada ${ }^{603}$ da esfera privada (v. cap. 7.2).

Mas o direito a condições propiciadoras de relações de reconhecimento não se esgota na proteção da integridade do indivíduo dentro esfera privada e da família. Pensado como acessibilidade aos "contextos de experiência, comunicação e reconhecimento" a partir dos quais o indivíduo pode articular uma autocompreensão de si mesmo, do mundo objetivo e das normas de conduta (Habermas, 2007:298-298), esse direito se desdobra em uma das pretensões normativas mais recorrentes no diagnóstico da esfera pública política no Brasil: a pluralidade de visões de mundo.

Essa pretensão estimula uma entrada mais espontânea dos indivíduos em espaços públicos, pois exige estruturas de comunicação capazes de acolher com respeito e consideração seus discursos de verdade, correção e autenticidade ou sinceridade (incluídas nestes dois últimos concepções religiosas de mundo e expressões afetivas, artísticas e culturais) (v. caps. 5.4, 6.2 e 7.3).

A importância dessa concepção de pluralidade de visões de mundo é tamanha que seu conteúdo normativo pode ser encontrado numa expressão da dignidade humana atualmente denominada direito à autodeterminação informacional. Esse novo direito tem sido trabalhado por Habermas $(2010)^{604}$ e Ferraz Júnior (2011), e embora partam de ${ }^{602}$ V. discussões sobre o tema em Honneth, Sofrimento de Indeterminação, 2008:134; Id, Das Recht der
Freiheit, 2011:265-269.
603 Utiliza-se o termo "constitucionalmente justificada" para reforçar a reflexão de Habermas quanto à
impossibilidade de se excluir a priori a problematização de questões referentes à esfera privada. Ao trabalhar
a questão, o autor utiliza, como em poucas vezes em sua teoria do direito, a relação interna entre direitos de
comunicação e comunicação do direito, esta última entendida como "regulação de poderes e distribuição de
responsabilidades". Com ele: “...We must draw the distinction between public and private matters in two
respects: accessibility and thematization, on the one hand, and the regulation of powers and
responsibilities, on the other. (...) With the help of these distinctions, one can easily show that liberal
misgivings about opening up an unrestricted spectrum of public issues and topics are not justified so long, at
least, as the personal integrity of the individual is preserved." (Habermas, 1996:313. Itálicos do autor. Grifos
nossos). O direito da comunicação procura dar maior destaque à importância dessa exigência de
"justificabilidade", de modo que ela se afigura como uma exigência de comunicação do direito que garante a
própria "proteção constitucional da esfera privada" (v. "b", abaixo).
604 Habermas cita a utilização desse novo direito pela Corte Constitucional alemã que, em decisão
considerada pioneira pelo autor, prolatada em fevereiro de 2010 sobre reclamação trabalhista, interpretou o
"mínimo existencial" (art. $1^{\circ}$ da Constituição alemã) como sendo "derivado" ("abgeleitet". aspas do original),
pois deveria favorecer também a possibilidade de o indivíduo e sua família "participarem na vida social, 
problemas distintos, ambas as concepções convergem para uma ampliação do conceito de dignidade humana característica do processo de intersubjetivização do direito. Ao procurar garantir os "ambientes" dentro dos quais liberdades individuais podem revelar seu entrelaçamento recíproco constitutivo, o princípio da dignidade humana se amplia como um direito a esferas públicas autônomas. ${ }^{605}$

A concepção de espaços públicos ou esferas públicas como "ambientes" que podem ser considerados "direitos intersubjetivos" já é articulada com facilidade a partir da teoria do direito ambiental aplicada ao campo da comunicação social, como demonstra o Celso Fiorillo em sua obra $O$ Direito de Antena em Face do Direito Ambiental no Brasil (2009:231-239).

Não se trata, no entanto de uma analogia entre áreas diferentes, mas da própria constatação de que o espectro eletromagnético gerado pelas emissões de sinais de comunicação televisiva, radiofônica, telecomunicacional, cibernética, entre outras, faz parte do meio-ambiente, sendo, por isso, "bem de uso comum e essencial à sadia qualidade de vida" (Id. op. cit:231).

Com isso, o meio-ambiente comunicacional pode ser entendido como objeto de um direito difuso, isto é, cuja titularidade é tanto individual quanto coletiva. Nesse sentido, o “direito de antena", como direito aos meios pelos quais indivíduos e coletividades possam usufruir de ambientes de transmissão e recepção de mensagens de comunicação de massa, é um claro exemplo da viabilidade da recepção pela dogmática jurídica de interpretações intersubjetivas de direitos de comunicação.

Em perspectiva semelhante, como foi discutido no tópico 5.2 "a" da parte II desta tese, o Ministério Público Federal tem considerado direitos de comunicação como tendo um caráter transindividual, de modo que sua titularidade ${ }^{606}$ é tanto dos indivíduos quanto

cultural e política da sociedade". (Habermas, Das Konzept der Menschenwürde und die realistische Utopie der Meschenrechte [O conceito de dignidade humana e a utopia realista dos direitos humanos. trad. livre], 2010:345-346. Grifos nossos).

605 “...this way, it changes the ancient principle that human dignity is focused on individual freedom and one's freedom ends where another's freedom begins. Indeed, the environment where communication and reciprocity are means for individual achievement, dignity focuses on living in open communication with each other. And here we speak of 'means' not as a 'tool' but as 'environment'. Thus, freedom in the information society could be well captured by the phrase 'one's freedom begins where the freedom of others begins'." (Ferraz Júnior. Erosion of subjective rights by reason of technical development (Patent, Copyright), 2011:59. Itálicos e grifos nossos).

606 Titularidade aqui não se confunde com a competência para o ajuizamento de ações como a mencionada Ação Civil Pública, cuja atribuição é do Ministério Público e outros entes públicos, além de associações civis sem fins lucrativos constituídas a mais de um ano e cuja finalidade precípua é a defesa de direitos difusos e coletivos (art.5\%, Lei 7.347/85). Apesar dessa descentralização da competência para entidades sociais, a orientação normativa de se estabelecer direitos individuais de autonomia política pode problematizar tanto essa quanto outras competências que concentram a determinados entes o jus postulandi, inclusive da própria 
da coletividade. Essa concepção também pode ser considerada uma tradução de um conceito de "direito intersubjetivo" dentro da dogmática jurídica.

A proposta da criação de um direito de resposta coletivo (Suiama, 2002; Comparato, 2010) como forma de regulamentar especificidades deste instituto, revogadas junto com a lei de imprensa pelo STF (v. cap. 6.3 “b”), é outra forma de estabelecer as bases de um direito intersubjetivo capaz de interferir na operacionalidade do sistema jurídico. Isso porque não se trata de uma autorização de agir dada somente ao indivíduo, e tampouco um direito que regula unicamente relações de pessoas com bens, mas instituições que garantem condições de comunicação simétrica entre os atores que interagem na esfera pública política, ainda que isso implique a utilização do princípio da isonomia proporcional.

Assim, fica evidente que as "escaladas" à esfera pública política por indivíduos e grupos da sociedade civil que não representam interesses de organizações do poder econômico ou político não podem ser protegidas, facilitadas, ou ter seus custos diminuídos sem normas jurídicas de caráter intersubjetivo que garantam o caminho a ser percorrido.

E se essa garantia pressupõe direitos que protegem a "integridade simbólica" dos indivíduos a partir de uma concepção intersubjetiva de dignidade humana, também se faz necessária, segundo autores como Häberle e Günther, a criação de "conceitos jurídicos de pessoa" (Rechtsperson ou legal person) que os torne titulares (a princípio individuais) de direitos de autonomia política significativos para as atividades de problematização e levantamento de pretensões normativas no interior de processos políticos, e por que não, também judiciais.

A diferença entre os dois é que enquanto Günther sugere a criação do conceito de "pessoa deliberativa" (deliberative Person), que atribui ao cidadão uma capacidade de realizar tomadas de posição crítica em processos legislativos para além do voto, e sem o qual a própria legitimidade do poder se compromete (Günther, 2005:245-258), Häberle procuraria estendê-lo para um "status ativo procedimental" que permitisse maior abertura ao processo de interpretação da própria Constituição (Habermas, 1996:411). ${ }^{607}$

advocacia. Isso porque, especialmente quando se trata de direitos intersubjetivos ou transindividuais, como o princípio da dignidade humana, o próprio Sistema Inter-Americano de Direitos Humanos confere competência judicante às pessoas naturais. Obviamente essa problematização demandaria uma reflexão muito mais extensa e cautelosa, que não poderá ser feita aqui. As razões por essa limitação fundadas na lógica da separação dos poderes, como defende Habermas, será brevemente problematizada em "b", abaixo.

${ }^{607}$ Habermas cita a obra Verfassung als öffentlicher Prozess (Frankfurt, 1978) de Häberle. Nota: a menção de Habermas ao jurista alemão na versão em língua inglesa de $D D$ menciona equivocadamente o primeiro nome do autor, que é Peter, e não Paul. 
Mas se Habermas poderia aceitar a proposta de Günther como mais um desdobramento de sua teoria procedimental que permite uma aplicabilidade na dogmática jurídica, enquanto considera a tese de Häberle como tendente a uma sobrecarga de politização do poder social que pode minar a espontaneidade da esfera pública política, ambas podem ser consideradas sem maiores problemas como as expressões mais políticas do movimento institucional de direitos de comunicação.

Com a finalização desse movimento, que leva o modelo procedimental do direito às suas últimas consequiências, o poder comunicativo e suas pretensões de validade podem chegar às comportas do sistema político, mas só o adentrarão se passarem por uma tradução à linguagem do direito feita pelas casas legislativas.

Contudo, para que essa tradução não permita somente um fluxo de mão única que tende a levar o poder político a um auto-fechamento, torna-se também necessário pensar em como as pretensões do movimento institucional de comunicação do direito podem ser traduzidas em conceitos jusfilosóficos aplicáveis na dogmática jurídica.

b) pretensões normativas de comunicação do direito no Brasil e seus impactos sobre conceitos modernos da filosofia do direito

O movimento institucional de comunicação do direito, que tem por pretensão normativa estrutural o princípio da publicidade do poder, é, junto à recepção interna dos direitos a condições propiciadoras de relações de reconhecimento, a contribuição mais importante que a filosofia social do direito da comunicação procura trazer para complementar e aprimorar o modelo procedimental do direito de Habermas.

Como já visto anteriormente nesta última parte (esp. caps. 8.1 e 9.1), esse movimento institucional busca, de um lado, identificar pretensões atuais de publicidade que, por força dos resultados do diagnóstico da esfera pública política em MEEP, teriam sido menos enfatizadas a partir de então no percurso filosófico de Habermas, o que influencia sua teoria crítica comunicativa e leva às insuficiências do paradigma procedimental do direito em satisfazer plenamente seus objetivos teóricos e normativos.

Por outro lado, a comunicação do direito surge como resultado de uma tentativa de reinterpretação do vínculo interno entre direito e as condições de uma formação discursiva da opinião pública, o qual se encontra na base da autocompreensão normativa de Estados 
constitucionais democráticos. Isso porque em $D D$ esse vínculo interno se expressa na garantia de direitos subjetivos de autonomia individual e autonomia política na forma de procedimentos que permitem formações não-coercitivas da opinião e da vontade políticas, mas que por dispensarem a aceitação fática dos discursos de justificação para garantir sua legitimidade, acabam enfraquecendo as exigências de publicidade que poderiam tornar o poder mais acessíveis aos cidadãos, ainda que isso não implique a necessidade de os indivíduos aceitarem as razões por trás das normas para cumpri-las.

Esse enfraquecimento das exigências de publicidade do poder fica ainda mais evidente quando se espera que o princípio da legitimidade procedimental garanta as condições de esferas públicas autônomas, demanda esta que é mais recentemente depositada por Habermas na imprensa e em sistemas de comunicação de massa protegidas contra subversões pelo poder econômico e pelo poder político (Habermas, 2009). Mas apesar da importância dessa demanda, que é também reafirmada pelo diagnóstico da esfera pública política no Brasil (v. esp. caps. 5, 6.1 e 6.2), os direitos fundamentais que deveriam proteger uma esfera pública capaz de promover uma comunicação pública discursiva são, contudo, apresentados por Habermas quase sempre de modo assistemático e sem exigências de publicidade, como o direito fundamental à justificação (v. cap. 8.2 "a").

Apesar disso, no diagnóstico da parte II, foi possível identificar em todas as expressões da esfera pública política diversas pretensões normativas relacionadas ao princípio da publicidade do poder, seja ele político ou mesmo o poder social.

Assim, o movimento institucional de comunicação do direito resulta de uma generalização dessas pretensões normativas de publicização que aqui serão analisadas de modo mais sistemático, com a finalidade de discutir seus possíveis impactos em conceitos da filosofia do direito aplicados na dogmática jurídica nacional.

Para que a comunicação do direito cumpra sua função de formar o outro "braço móvel” da ponte entre as áreas da comunicação social e da comunicação política que constitui a esfera pública política, inicia-se esta reflexão final partir das exigências de publicidade encontradas no ponto mais extremo da comunicação política: no interior do próprio Estado, onde se encontram as pretensões de publicização do direito e de visibilidade do poder, das quais deriva a publicização de informações públicas.

Mas como pretensões de comunicação do direito são também encontradas na forma de exigências de publicidade no próprio movimento de direitos de comunicação dentro do 
poder social (e a recíproca também é verdadeira), tais exigências cumprem a função fundamental de exigir, além das responsabilidades atribuídas a todos que fazem uso de suas liberdades e direitos de comunicação, a devida publicidade aos diferentes discursos que se interpenetram na comunicação social, e não raro provocam instrumentalizações uns dos outros, muitas vezes de modo não esclarecido aos interlocutores, clientes ou cidadãos.

Em termos das primeiras pretensões derivadas do Estado, as pretensões de publicização do direito encontradas na expressão prático-moral da esfera pública política podem problematizar um dos princípios fundamentais da dogmática jurídica, que é o princípio da motivação ou da justificação das decisões (v. cap. 8.2 “a”).

Isso porque, dada a ligação fundamental dos discursos de aplicação do direito com a razão prática, ou seja, a exigência de que, identificadas de modo mais exaustivo possível as características e elementos da situação concreta, cabe ao intérprete competente fundamentar a incidência da norma escolhida dentre todas as outras possíveis a partir do princípio discursivo ("U”) da consideração da aceitabilidade racional dos os real $e$ virtualmente afetados pela decisão, abre-se espaço para uma reflexão sobre a relação interna entre direito e esfera pública política no interior dos processos decisórios do direito.

O resultado dessa reflexão, ao qual se chega a partir de uma recepção institucional do direito à justificação trabalhado por Rainer Forst (v. cap. 8.2 "a"), é de que se queda insuficientemente motivada toda e qualquer decisão jurídica que se limitar à certeza legal e desconsiderar a aceitabilidade racional presente no interior da validade dos juízos de adequação, isto é, a fundamentação das decisões judiciais precisa ao menos considerar (ainda que para afastá-los com base em razões) os argumentos de pessoas e grupos interessados e possivelmente afetados pelos resultados de suas decisões, sob pena de um déficit de legitimidade interno que resulta na invalidade jurídica das decisões.

Embora em termos hipotéticos a separação funcional dos poderes do Estado implique em "tipos distintos de razões públicas", como sugere Habermas no capítulo 4 de DD (Habermas, 1996:171-176 e 192), de modo que as atividades pragmáticas do Executivo o "blindam" da tarefa de disponibilizar as razões que o legislativo já teria mobilizado na deliberação política, quando se trata de um cenário político como o nacional, no qual as trocas de funções entre os poderes parecem ser mais a regra do que a exceção, caberia no mínimo uma exigência de apresentação de razões de acordo com as 
atividades concretas e singulares de cada um, e não com base em suas funções originárias.

Não se pode negar, contudo, que Habermas trabalha de fato em alguns momentos de $D D$ aplicações do princípio da publicidade do poder sobre a comunicação política, como no capítulo 9, quando trata de exigências de "democratização da administração" derivadas do vínculo que o modelo procedimental estabelece entre a implementação de programas legislativos e a publicização de razões normativas que possam garantir sua aceitabilidade, exemplificando-as com políticas de procedimentalização da soberania popular e de publicização do direito identificadas no capítulo 6.3 desta tese (Habermas, 1996:440-441).

Além disso, indica que a própria separação dos poderes deriva desse pressuposto de divisão entre formas distintas de razões públicas, o que acaba ao final por obrigar a comunicação política ao menos a uma "distribuição das possibilidades para o acesso a diferentes tipos de razões e às correspondentes formas de comunicação que determinam como essas razões são tratadas" (Habermas, 1996:192. itálicos do autor).

Mas como no modelo de Habermas e no próprio direito brasileiro essas razões dificilmente excedem os discursos pragmático, ético e moral, os maiores impactos das pretensões de validade do movimento institucional de comunicação do direito sobre a filosofia do direito centram-se especialmente na questão da publicidade como visibilidade do poder, discutida no cap. 7.1 "b" da parte II desta tese.

Neste caso, não se trata, no entanto, de pensar em visibilidade somente no sentido de acessibilidade, disponibilidade ou exposição da comunicação política aos cidadãos, como na concepção de Wilson Gomes, que concebe essa dimensão da esfera pública de modo co-originário a uma esfera da discussão (Gomes \& Maia, 2006). Isso porque, apesar de permitir uma crítica à concepção pessimista de Habermas em relação à racionalidade da auto-representação na esfera pública política, tendo condições para conceber potenciais de publicidade a partir da "esfera pública midiática", Gomes não chega a trabalhar a questão mais normativa sobre qual seria a melhor forma de auto-representação do poder.

A partir da discussão sobre a expressão estética da esfera pública política (cap. 7.1), foi possível identificar, primeiramente como a dimensão inevitável de autorepresentação presente em qualquer forma de comunicação pode representar, além de um importante fator que estimula processos de prestação de contas de autoridades, como analisou Rousiley Maia no caso da transmissão ao vivo do seqüestro do "Ônibus 174" (Maia, 2008), um elemento de problematização de discursos que pode tornar mais evidente a influência exercida por elementos estéticos e afetivos em processos de argumentação 
pública, afastando de modo mais consciente os riscos de espetacularizações e estetizações da política.

Além disso - e essa característica é a que mais impacta conceitos da filosofia do direito aplicada à dogmática -, é possível pensar a partir da analogia feita com a tese de Benjamin sobre a perda da aura da obra de arte e sua substituição na modernidade pelo seu "valor de exposição", que não somente em termos quantitativos (tempo e dimensão de exposição), mas também em análises qualitativas de como a autoridade política se torna visível aos cidadãos, pode se aferir a qualidade da publicização, ou da comunicação do direito, o que, por sua vez, influenciará nas condições de aceitabilidade da autoridade.

A partir desse raciocínio, torna-se possível criticar formas de publicidade do poder político que, de um lado, excedem nos modelos abstratos e formais, como a própria linguagem do direito ou meios de publicidade da lei, e.g., o "Diário Oficial", ou de outro abusam dos elementos estéticos e expressivos no exercício do convencimento argumentativo, como nos casos do tribunal do júri.

A pergunta problematiza o princípio da publicidade presumida das normas jurídicas (art. $3^{\circ}$, LICC), pois nem toda e qualquer publicização do direito pode garantir por si só sua publicidade, especialmente quando os meios de formas utilizadas forem justificadamente incapazes de permitir sua compreensão pelos cidadãos interessados.

A partir dessa problematização, até mesmo a comunicação institucional do poder público (art. $5^{\circ}, \mathrm{XXXIII,} \mathrm{LX,} \mathrm{art.} 37, \S 1^{\circ}, \S 3^{\circ}, \mathrm{II}, \mathrm{CF}$ ) pode receber novas formas de crítica em relação à qualidade de sua publicidade. Seus altos gastos com o que muitas vezes pode ser considerada mais propagandas políticas do que informação e publicização de programas e normas de modo acessível, inteligível, e por que não, também aprazível aos cidadãos.

Somente então se torna possível falar em formas efetivas de acessibilidade da informação pública, as quais, se não satisfazem as exigentes demandas de comunicação do direito, violando por isso o princípio da publicidade do poder, dificilmente poderão contribuir de modo democrático com a formação de uma cultura política liberal, ou como gosta de dizer Habermas, "acostumada à liberdade” (cf. Honneth, 2011:612-624).

Para tanto, a exposição das razões pelas quais os cidadãos possam sentir que "vale à pena" cumprir a lei, incorporando-as como se efetivamente suas o fossem, precisam transcender a ameaça de punição ou mesmo políticas que pretendem garantir a obediência 
pela retirada de avisos e informações públicas dos espaços sociais de visibilidade, com é o caso de recente iniciativa do governo do Estado de São Paulo de retirar avisos de radares em estradas, sob a justificativa de que, somente em risco permanente de punição é possível gerar a obediência às leis.

A partir desse exemplo aparentemente banal, torna-se claro que os processos de procedimentalização do direito, mesmo que procurem garantir esferas de exercício cada vez maiores da liberdade comunicativa sem as quais não se pode falar em legitimidade democrática, acabam voltando-se contra seus próprios objetivos no momento em que se realizam por meio de um relaxamento, ou pela isenção do poder político em relação a seus deveres de publicidade.

A ampliação das exigências de publicidade a partir da comunicação do direito chega então ao final de seu percurso iniciado no sistema político, o outro extremo da ponte formada pela esfera pública política, para revelar-se também como extremamente funcional dentro das relações de poder social identificadas no diagnóstico da parte II.

Seu vínculo interno com o movimento dos direitos de comunicação revela, então, não somente as responsabilidades e exigências de justificação que lhes são co-originárias, e sem as quais as liberdades de comunicação se tornam autorizações para o arbítrio (e a recíproca é também verdadeira), inclusive a liberdade de expressão de um sujeito individual cujas manifestações não encontram extensões capazes de lesar imediatamente outros indivíduos. São as diversas expressões do princípio de publicidade do poder contidos no movimento de comunicação do direito que permitirão análises da natureza e da extensão das comunicações para o aferimento das devidas responsabilidades no plano do direito.

Além disso, por meio desses mesmos critérios, a comunicação do direito também oferece condições para a realização de exercícios de "desenlace" discursivo entre pretensões de validade dos discursos que se interpenetram na esfera pública política, muitas vezes de modo não-esclarecido, ou mesmo a ponto de dominar outros discursos.

Assim, ao chegar ao final deste estudo, fica finalmente evidente a partir do movimento de comunicação do direito a relação interna entre direito e esfera pública política, conforme procura mostrar a figura abaixo a partir das reflexões deste tópico. Ao acompanhar todo exercício de liberdades de comunicação, a comunicação do direito 
desvela-se como seu exato "contrário", como se seu respectivo "braço da ponte" fosse colocado diante de um espelho.

Mas a dificuldade de se concretizar efetivamente essa relação interna, da qual pode emergir quando necessário um direito intersubjetivo, talvez seja a mesma enfrentada por um indivíduo que, ao olhar sua imagem refletida num espelho, pretenda ver dentro dos contornos de sua face, além de si mesmo, todo o restante da humanidade.

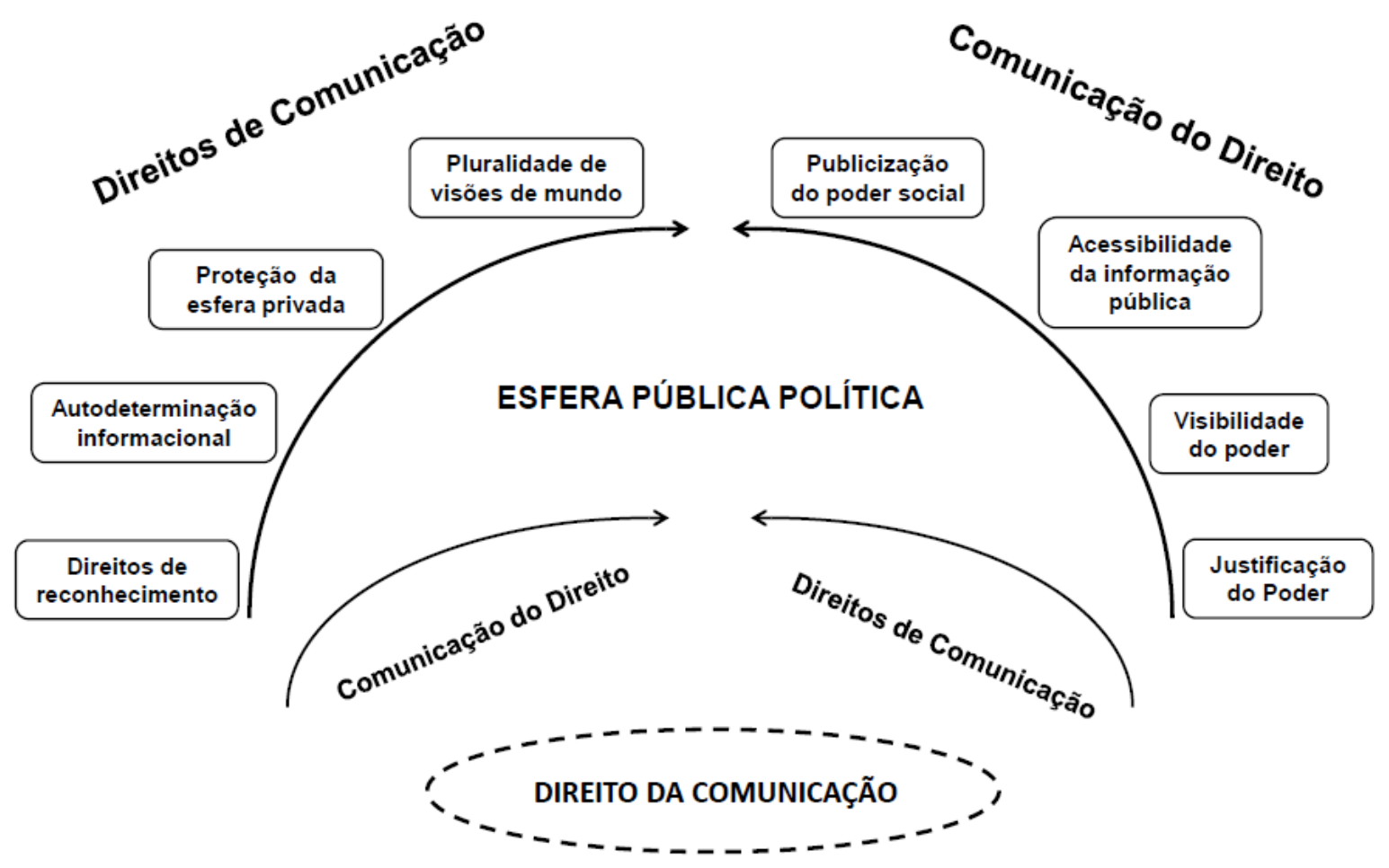




\section{CONSIDERAÇÕES FINAIS}

Essas considerações finais pretendem apresentar de modo sucinto as preocupações que deram origem à pesquisa, traçar de modo panorâmico o caminho tomado, com algumas das descobertas realizadas.

A pergunta inicial deriva do problema sobre que tipo de direito seria necessário para a formação de uma esfera pública efetivamente democrática no tempo presente, especialmente no contexto nacional.

O caminho escolhido para enfrentá-lo decorreu da continuidade de trabalhos advindos da dissertação de Mestrado do autor (2006-2008), na qual havia estudado a teoria da racionalidade e do direito de Habermas. As preocupações de base remontam, no entanto, às suas primeiras incursões na vida acadêmica. Em 2002, escreveu uma breve monografia intitulada “O Direito à Comunicação em Face à Cultura Global”, que resultaria em dois anos de pesquisa de iniciação científica sobre o tema "Economia Política da Informação e da Comunicação" (2003-2005), além de uma monografia de conclusão do bacharelado em Direito intitulada "A Comunicação Social no Atual Estado Democrático de Direito: por um Novo Controle Social da Informação" (2005).

Nesse sentido, a pesquisa realizada no Mestrado forneceu a perspectiva e a estrutura teórica necessárias para que se pudesse abordar o problema desta tese de modo original e com a pretensão de gerar resultados diferenciados, tanto na área de pesquisa e no tema tratado, como também possivelmente influenciando o debate jusfilosófico e as práticas jurídicas e políticas brasileiras em questão.

Assim, o objetivo inicial da pesquisa foi reinterpretar o sentido do conceito de esfera pública política no pensamento de Habermas desde a obra pioneira Mudança Estrutural da Esfera Pública até sua recepção por Direito e Democracia, o que se procurou realizar na parte I.

A partir de algumas revisões e atualizações que o autor realizou sobre o tema no decorrer de sua trajetória intelectual, no entanto, evidenciou-se a necessidade da elaboração de uma nova metodologia para análise do presente da esfera pública política. Isso porque, apesar de recepcionar seu conceito de forma modificada na teoria do direito e manter sua importância para a legitimidade da democracia, Habermas acaba não realizando em Direito e Democracia uma reconstrução de seus conteúdos normativos em um novo diagnóstico do presente. 
Com uma proposta de diferenciação analítica da esfera pública política em três expressões inspiradas pelas pretensões de validade da razão comunicativa, a técnicocientífica e informativa, a prático-moral e a estético-expressiva, a parte II do estudo procurou identificar por trás de experiências negativas, mas também em problematizações e afirmações, pretensões de comunicação e de reconhecimento que se referem a direitos explícitos, implícitos ou ainda inexistentes no ordenamento jurídico nacional.

Desse diagnóstico foi possível identificar algumas das dinâmicas e características importantes, como interpenetrações e instrumentalizações de discursos sobre outros, especialmente em relação à comunicação icônica e à comunicação informativa. De modo mais geral, pressões de um lado pela institucionalização de liberdades e direitos de comunicação, e de publicização do direito de outro. Destaque foi dado a expressões que a própria concepção mais atual de esfera pública política de Habermas não poderia captar, como pretensões a relações de reconhecimento e de visibilidade da autoridade política.

Após a realização do diagnóstico, retomou-se na parte III a discussão teórica para fundamentar o direito da comunicação como uma filosofia social do direito, isto é, cujos conceitos estruturais, identificados no próprio diagnóstico, são ao mesmo tempo capazes de permitir análises empíricas e normativas dos fenômenos tratados.

Essa formulação do direito da comunicação como teoria crítica do direito foi também desenvolvida a partir de um diagnóstico do presente nos debates da teoria crítica da sociedade em relação à teoria política e à teoria do direito, do modo que emergiu de uma tendência a uma expansão do caráter intersubjetivo da moral, da política e do direito discutidos por Habermas e seus sucessores, como Honneth, Günther e Forst.

Dada essa emergência de dentro do debate atual da teoria crítica, foi necessário em seguida fundamentar de modo teórico os conceitos estruturais do direito da comunicação. O primeiro deles é o próprio deslocamento complementar do objeto da teoria procedimental do direito, o que acaba representando, ao final, uma retomada da relação interna entre direito e esfera pública política que a consolida como objeto dessa teoria do direito.

Sua análise, feita de modo complementar à teoria procedimental de Habermas, permitirá completar essa relação interna, mais ampla que aquela entre autonomia individual e autonomia política, uma vez que ambas não se realizam se não tiverem condições de adentrar a esfera pública ou influenciar processos de formação da opinião e da vontade. 
Os outros dois conceitos estruturais analisados em seguida constituem o chamado duplo-movimento institucional do direito da comunicação. De um lado, representado pelas pretensões normativas a condições propiciadoras de relações de reconhecimento e outras liberdades e direitos de comunicação, está o movimento institucional de direitos de comunicação. De outro, se situam pretensões derivadas do princípio da publicidade do poder denominadas movimento institucional de comunicação do direito. Sua relação interna, dada a partir da própria co-originariedade entre direito e esfera pública política, permitem uma substituição do modelo Habermasiano pelo qual o direito funcionaria como um sistema de eclusas capazes de "filtrar" o poder comunicativo em poder administrativo.

Ao contrário, recuperando a imagem que o próprio Habermas também traz da esfera pública como uma ponte entre o auto-interesse ilustrado (autonomia individual) e as orientações para o bem comum (autonomia política), os movimentos institucionais do direito da comunicação permitem um tráfego não somente unilateral que muitas vezes faz com que o poder administrativo deixe de apresentar razões na esfera pública política, imunizando-se de pressões por maior democratização.

Especialmente em função do movimento de comunicação do direito, portanto, torna-se possível não só retomar dentro da autocompreensão dos Estados democráticos o princípio da publicidade do poder, mas também completar essa ponte ao promover uma comunicação recíproca, inteligível e equilibrada entre as pretensões de direitos de comunicação e de publicidade.

Além disso, não se corre o risco de "sobrecarregar" politicamente a esfera pública política, correndo o risco de impedir sua espontaneidade ao violar liberdades comunicativas. Em função do vínculo interno entre os dois movimentos, pode-se também revelar as pretensões de responsabilidade e publicidade (ou exigências de justificação) que sempre acompanham exercícios de liberdades comunicativas, e ao mesmo tempo, os direitos de comunicação que são garantidos com as próprias exigências de comunicação do direito, como no caso do livre acesso à informação.

Com isso, foi possível realizar um último esforço para identificar os possíveis impactos desses movimentos e suas respectivas pretensões normativas sobre conceitos da filosofia do direito utilizados na operacionalização de práticas jurisprudenciais.

Identificados os respectivos direitos e suas alterações quando analisados dentro dos movimentos institucionais, deu-se finalmente chance de se realizar uma sistematização dos resultados da pesquisa em termos de garantias capazes de proteger a esfera pública política 
a partir de direitos intersubjetivos de comunicação, como o direito à autodeterminação informacional, e de comunicação do direito, como a publicização e a visibilidade do poder.

Com isso, o modelo procedimental de Habermas pode, enfim, ter mais condições de se realizar na forma de uma interpretação efetivamente intersubjetiva, abrindo a possibilidade de o direito da comunicação ser considerado tanto uma filosofia social do direito quanto uma teoria jusfilosófica cujas funções se complementam mutuamente, fortalecendo as condições de produção de uma legitimidade democrática, e fazendo-o a partir da garantia de uma esfera pública política mais autônoma no Brasil. 


\section{REFERÊNCIAS BIBLIOGRÁFICAS}

ABRÃO, R. M. Z. B.. Mediação e ética das virtudes: a philia como critério de inteligibilidade da mediação comunitária. Tese de Doutorado. Departamento de Filosofia e Teoria Geral do Direito. Faculdade de Direito da USP, 2009.

ADORNO, S. Violência, ficção e realidade. In. SOUZA, Mauro W. de (org.). Sujeito, o Lado Oculto do Receptor. São Paulo: Brasiliense, 1995.

A Gestão Urbana do Medo e da Insegurança. Violência, Crime e Justiça Penal na Sociedade Brasileira Contemporânea. Tese de Livre docência. Dpto. Sociologia. Faculdade de Filosofia, Letras e Ciências Humanas, 1996.

Violência e o mundo da recepção televisiva. Entrevista. Revista Novos

Olhares. Escola de Comunicação e Artes da Universidade de São Paulo: São Paulo, N.1,1 sem, 1998.

. História e Desventura: o $3^{\circ}$ Programa Nacional de Direitos Humanos. In.

Novos Estudos Cebrap. N. 68, março de 2010, pp. 5-20.

ADORNO, S. \& LAMIN, C. Medo, Violência e Insegurança. In. LIMA, R. S. de. PAULA, L. de (orgs). Segurança Pública e Violência. O Estado está cumprindo seu papel? São Paulo: Contexto, 2008, pp. 151-175.

ADORNO, S. \& SALLA, F. Criminalidade organizada nas prisões e os ataques do PCC. Estudos Avançados. 21 (61), 2007.

ALENCAR, A. F de. A infoinclusão e as estatísticas para a América Latina. En publicación: Paulo Freire. Contribuciones para la pedagogía. Moacir Godotti, Margarita Victoria Gomez, Jason Mafra, Anderson Fernandes de Alencar (compiladores). CLACSO, Consejo Latinoamericano de Ciencias Sociales, Buenos Aires. Janeiro, 2008. Disponível em: http://bibliotecavirtual.clacso.org.ar/ar/libros/campus/freire/26Fernan.pdf (último acesso: 24/10/2011).

ALENCASTRO, L. F. de. Vida Privada e Ordem Privada no Império. In. NOVAIS (org) História da Vida Privada no Brasil. Vol. II. (Luis Felipe de Alencastro, org. do volume). São Paulo; Companhia das Letras, 1997, pp. 11-95.

ALENCASTRO, L. F. de. Epílogo. in. NOVAIS (org) História da Vida Privada no Brasil. Vol. II. (Luis Felipe de Alencastro, org. do volume). São Paulo; Companhia das Letras, 1997(a), pp. 438-440.

AltAVILA, J. de. Origem dos Direitos dos Povos. $5^{\text {a }}$ ed. São Paulo: Ícone, 1989. 
ALVES, C. G. O merchandising comercial e a busca pelo olhar na telenovela. A apropriação do valor no imaginário e a mercadoria dentro da mercadoria. In. Comtempo. Revista Eletrônica do Programa de Pós-graduação da Faculdade Cásper Líbero. Volume 2, número $\quad 1 \quad$ - Junho 2010, 10ps. (disponível em: http://www.revistas.univerciencia.org/index.php/comtempo/article/viewFile/6925/6491. último acesso: 19/07/2011).

ALVIM, Z. Imigrantes: a vida privada dos pobres do campo. In. História da Vida Privada no Brasil. Vol. III (Nicolau Sevcenko, org). São Paulo: Companhia das Letras, 1998, pp. 215-288.

ANDRADE, M. de. O Movimento Modernista. In. Id. Aspectos da Literatura Brasileira. $5^{a}$ ed. São Paulo: Martins, 1974.

ARENDT, H. Between Past and Future. Six Exercises in Political Thought. New York: The Viking, 1961.

. The Human Condition. $2^{\mathrm{a}}$ ed. Chicago: University of Chicago Press, [1958] 1998.

ASCENSÃO, J. de O. Direitos de autor e conexos inerentes à colocação de mensagens em rede informática à disposição do público. In. Estudos Jurídicos e Económicos em Homenagem ao Professor João Lumbrales. Ed. Faculdade de Direito de Lisboa: Coimbra Editora, 2000, pp. 411-424.

ASSOCIAÇÃO BRASILEIRA DE RADIODIFUSÃO COMUNITÁRIA. Querem Calar a Voz do Povo. A violência contra as Rádios Comunitárias na Região Metropolitana de Campinas. Fevereiro, 2006.

AVRITZER, L. A Moralidade da Democracia. São Paulo: Perspectiva. Belo Horizonte: UFMG, 1996.

AVRITZER, L. COSTA, S. Teoria Crítica, Democracia e Esfera Pública: Concepções e Usos na América Latina. In. DADOS - Revista de Ciências Sociais, Rio de Janeiro, Vol. 47, no 4, 2004, pp. 703-728.

BAKER, E. C. Viewpoint Diversity and Media Ownership. In. Federal Comunications Law Journal. V. 60. N. 3, 6751-671, 2009.

BARBOSA, R. A Imprensa e o Dever da Verdade. Rio de Janeiro: Simões, 1957.

BENHABIB, S. Models of Public Space: Hannah Arendt, the Liberal Tradition and Jürgen Habermas. In CALHOUN, C. (ed.). Habermas and the Public Sphere. Boston: MIT, 1992. 
BENJAMIN, W. A Obra de Arte na Época de suas Técnicas de Reprodução. Benjamin. In. Habermas, J. Adorno, T. W. Horkheimer, M. Benjamin, W. Textos Escolhidos. São Paulo: Victor Civita, 1975. pp. 9-34.

BENKLER, Y. The Wealth of Networks. How Social Production Transforms Markets and Freedom. New Haven/London: Yale University Press, 2006. Disponível para download em: http://www.benkler.org/Benkler_Wealth_Of_Networks.pdf (último acesso: 30/04/2011).

BITTAR, E. C. B. Metodologia da Pesquisa Jurídica. Rio de Janeiro: Forense, 2005(a). - Filosofia crítica e filosofia do direito: por uma filosofia social do direito. in. Revista Cult. Ano 10, n. 112, 2007(a), pp. 53-56.

. Razão e Afeto, Justiça e Direitos Humanos: dois paralelos cruzados para a mudança paradigmática. Reflexões frankfurtianas e a revolução pelo afeto. In. Bittar, (coord.) Educação e Metodologia para os Direitos Humanos. São Paulo: Quartier Latin, 2008, pp. 57-91.

O Direito na pós-modernidade (e reflexões frankfurtianas). $2^{\mathrm{a}}$ Ed. Rio de Janeiro: Forense, 2009.

. Os Direitos Humanos dos Intelectuais na Sociedade da Informação. In.

Revista do Instituto de Hermenêutica Jurídica, Belo Horizonte, 2009(b), pp.149-172.

Democracia, Justiça e Direitos Humanos: Estudos de Teoria Crítica.

Rio de Janeiro: Forense Universitária, 2011.

BITTAR, E. C. B. BLOTTA, V. S. L. Pesquisa científica e discriminação étnica: os limites do conhecimento, nos 100 anos de Lévi-Strauss. Revista Espaço Aberto. Universidade de São Paulo, 2008.

BLOTTA, V. S. L. 11 de setembro: Mídia, Política e Exceção. Seção de artigos científicos do Observatório do Direito à Comunicação (www.direitoacomunicacao.org.br), 2008.

- Mídia e Cidadania: contribuições de leituras habermasianas da comunicação de massa para a retomada da esfera pública em sociedades complexas. In. Revista Eptic Online. www.eptic.com.br, vol. X, n. 2, May. - Ago. / 2008.

O Direito no Divã: por uma discursivização do gozo no telespaço público. In. Anais do XIX CONPEDI, 2009.

. Habermas e o Direito. Da Normatividade da Razão à Normatividade

Jurídica. São Paulo: Quartier Latin, 2010.

. Esfera Pública Política e Mídia. In. Carlini e Nalini (orgs.). Direitos

Humanos e Formação Jurídica. São Paulo: Editora do Forense, 2010(a), pp. 56-80. 
The Fascination of Authority and the Authority of Fascination. Rationalization and Legal Theory in Habermas Revised. Anais do $25^{\circ}$ Congresso Mundial de Filosofia do Direito - IVR (no prelo). Universidade Goethe de Frankfurt, 2010(b).

Opinião Pública, Mídia e Direitos Humanos: interpretações a partir de $O$

Processo de Franz Kafka. Texto de Conferência no I Simpósio de Direitos Humanos da Universidade do Grande ABC, 2011 (manuscrito).

BLOTTA, V. QUIRINO, B. Do outro lado do apagão aéreo: a responsabilidade da grande mídia na violência contra rádios de baixa potência. Revista Jurídica da PUC-Campinas. v. 2. 2008, pp. 1-18.

BLOTTA, V. LEVY, W. VINCEZI, B. Reconhecimento, Memória Histórica e Justiça de Transição no Brasil. Argumentos Frankfurtianos para uma Comissão de Verdade sobre o período ditatorial (1964-1985). In. Bittar, E. (org) História do Direto Brasileiro. 2a . ed. revis. e ampl. São Paulo: Atlas, 2010.

BLOTTA, V. S. L. SCHWARTZ, G. Justice, Truth and Icon. Efforts for a diagnosis of the present times of the public sphere in an information society. Artigo apresentado n no Congresso da International Association for Media and Communication Research. Manuscrito, 2010.

BOLAÑO, C. Indústria Cultural: Informação e Capitalismo. São Paulo: Hucitec, 2000.

BOLAÑO, C. MATTOS, F. Conhecimento e Informação na atual Reestruturação Produtiva: para uma crítica das teorias da Gestão do Conhecimento. In. DataGramaZero Revista de Ciência da Informação - v.5 n.3 jun/04.

BOURDIEU, P. O Poder Simbólico. Trad. Fernando Tomaz. Lisboa. 1989.

BOLTANZKI, L. Distant Suffering. Morality, Media and Politics. Trad. Graham Burchell. New York: Cambridge University, 2005.

BRITTOS, V. COLlAR, M. Direito à Comunicação e democratização no Brazil. In. SAIRAIVA, E. MARTINS, E. PIERANTI, O (orgs.) Democracia e Regulação dos Meios de Comunicação de Massa. Rio de Janeiro: FGV, 2008, pp. 71-91.

BUCCI, E. (org). A TV aos 50. Criticando a televisão brasileira no seu cinqüentenário. São Paulo: Fundação Perseu Abramo, 2000.

A Televisão-objeto: a crítica e suas questões de método. Tese de Doutoramento. Departamento de Ciências da Comunicação. Escola de Comunicação e Artes da Universidade de São Paulo, 2002.

O espetáculo e a mercadoria como signo. In. NOVAES, A (org). Muito Além do Espetáculo. São Paulo: Senac, 2005, pp. 219-232. 
Em Torno de um Conceito Preliminar de Telespaço Público. In. BENEVIDES, M. V, BercovicI, G., MELO, C. Direitos Humanos, Democracia e República. Homenagem a Fábio Konder Comparato. São Paulo: Quartier Latin, 2009, pp. 399-428.

BOBBIO, N. Direita e Esquerda. Razões e Significados de uma Distinção Política. Trad. Marco Aurélio Nogueira. $2^{a}$ reimpressão. São Paulo: Unesp, 1995.

BUCCI, E. KEHL, M. R. Videologias: Ensaios sobre a Televisão. São Paulo: Boitempo, 2004.

CALHOUN, G. [ed], Habermas and the Public Sphere. Cambridge: MIT, 1996.

CASTELls, M. A Sociedade em Rede: do Conhecimento à Política In. CASTELLS, M. CARdoso, G. (orgs.). A Sociedade em Rede: Do Conhecimento à Acção Política. Debates da Presidência da República. Imprensa Nacional. Casa da Moeda. Portugal, 2005. (http://www.cies.iscte.pt/destaques/documents/Sociedade_em_Rede_CC.pdf). (último acesso: 03/10/2011).

CASTRO, H. M. M. de. Laços de família e direitos no final da escravidão. In. NOVAIS (org) História da Vida Privada no Brasil. Vol. II. (Luis Felipe de Alencastro, org. do volume). São Paulo; Companhia das Letras, 1997, pp. 337-383.

CASTRO, João C. B. M. De. Políticas nacionais de radiodifusão (1985-2001) e espaço público estudos para uma aproximação crítica. Trabalho de Conclusão de Curso. Departamento de Cinema, Rádio e Televisão da Escola de Comunicação e Artes da USP, 2002.

CARDOSO, Diego K. O impacto das redes digitais na circulação e no consumo de música. Trabalho de Conclusão de Curso. Universidade Federal do Rio Grande do Sul: Porto Alegre, 2006.

CHAUÍ, M. Simulacro e Poder: Uma Análise da Mídia. Perseu Abramo: São Paulo, 2006.

CHOMSKY, N., HERMAN, E. Manufacturing Consent: the Political Economy of the Mass Media. New York: Pantheon Books, 1988.

CHOMSKY, Noam. Understanding Power. New York: The New Press, 2002.

COHEN, J. ARATO, A. Civil Society and Political Theory. Boston: MIT, 1992.

COLLING, L. Agenda-setting e framing: reafirmando os efeitos limitados. In. Revista FAMECOS. Porto Alegre. $\mathrm{n}^{\circ}$ 14. abril 2001, pp. 88-101.

COMPARATO, F. K. “A Democratização dos Meios de Comunicação de Massa“. In.

BUCCI, E. (org.). A TV aos 50. Criticando a Televisão Brasileira no seu Cinqüentenário.

São Paulo: Ed. Fund. Perseu Abramo. 2000. 
Direito à Comunicação: liberdade, a farsa e a tragédia. Prefácio in.

LIMA, V. A de. Liberdade de Expressão $x$ Liberdade de Imprensa. Direito à Comunicação e Democracia. São Paulo: Publisher Brasil, 2010.

COSTA \& BRENER, S. e J. "Coronelismo Eletrônico". In. Comunicação e Política. N.s., v.4, n.2. Rio de Janeiro. CEBELA. 1997, pp. 29-53.

COSTElla, A. Direito da Comunicação. Doutrina - Legislação - Jurisprudência relativas a questões de jornais, rádio e televisão. São Paulo: RT, 1976.

CROSSLEY, N; ROBERTS, J. M. (eds). After Habermas. New Perspectives on the Public Sphere. Oxford: Blackwell, 2004.

CUBAS, V. A Expansão dos Serviços de Proteção e Vigilância em São Paulo. São Paulo: Humanitas, 2005.

DEBORD, Guy. A Sociedade do Espetáculo. Rio de Janeiro: Contraponto, 1997.

DERRIDA, J. The Force of Law. The "Mystical Foundation of Authority". In. Id. Acts of Religion. Gil Anidjar (ed.). London, Routledge, 2002, pp. 228-298.

DUVENAGE, P. Habermas and Aesthetics. The limits of Communicative Reason. Cambridge: Polity, 2003.

DWORKIN, Ronald. Levando os Direitos à Sério. São Paulo: Martins Fontes, 2002.

ENDO, Paulo Cesar. A violência no coração da cidade: um estudo psicanalítico sobre as violências na cidade de São Paulo. São Paulo: Escuta/Fapesp, 2005.

ERICSON, R. Why Law is Like News. in. Nelken (ed). Law as Communication. Hants: Dartmouth, 1996, pp. 203-226.

FREITAG, Bárbara. Dialogando com Jürgen Habermas. Rio de Janeiro: Tempo Brasileiro, 2005 .

FARIAS, R. Coronelismo "Eletrônico". Por um reposicionamento do problema. V. ENECULT. UFBA, 2009.

FERRAZ JÚNIOR, Tércio S. Ciência do Direito. São Paulo: Atlas, 1980. - Introdução ao Estudo do Direito: Técnica, Decisão e Dominação. São Paulo: Atlas, 1994. . "Erosion of subjective rights by reason of technical development (Patent, Copyright)" Plenary Lectures da Conferência Proferida no XXV IVR World Congress of Philosophy of Law. Universidade Goethe Frankfurt, agosto de 2011, pp. 44-63. 
FISCHER, Desmond. O Direito de Comunicar. Expressão, informação e liberdade. São Paulo: Brasiliense, 1984.

FERREIRA, A. Direito à Informação, direito à comunicação: direitos fundamentais na Constituição brasileira. - Sào Paulo: Celso Bastos Editor: Instituto Brasileiro de Direito Constitucional, 1997.

FROOMKIN, A. M. Habermas@discourse.net: toward a critical theory of cyberspace, Harvard Law Review. Vol. 116. N. 3, 2003, 122ps. Disponível em: http://personal.law.miami.edu/ froomkin/discourse/ils.pdf (último acesso: 18/12/2011).

FORST, Rainer. Kontexte der Gerechtigkeit. Frankfurt am Main: Suhrkamp, 1994. . Das Recht auf Rechtfertigung. Elemente einer konstruktivistischen Theorie der Gerechtigkeit. Frankfurt am Main: Suhrkamp, 2007.

. First things first: Redistribution, recognition and justification. in. European Journal of Political Theory. 6(3), 2007, pp. 291-304.

Os limites da tolerância. trad. Mauro Soares. in. Novos Estudos. 84, 2009(a), pp. 15-29.

. Unterwegs zu einer Diskurstheorie der Gerechtigkeit: Habermas und Rawls [No caminho de uma teoria discursiva da justiça: Habermas e Rawls. Trad. Livre]. In. Blätter für deutsche und Internationale Politik. 6/09(b), pp. 61-63.

. The Right to Justification: elements of a constructivist theory of justice.

Trad. J. Flynn. New York: Columbia, 2012.

FORST, R. GÜNTHER, K. Die Herausbildung normativer Ordnungen. Zur Idee eines interdisziplinären Forschungsprogramms [A formação de ordens normativas. Pela ideia de um programa interdisciplinar de pesquisa. Trad. livre]. Normative Orders Working Paper. 01/2010. Disponível em www.normativeorders.net (último acesso: 05/01/2012).

FRASER, Nancy. Rethinking the Public Sphere: A Contribution to the Critique of Actually Existing Democracy. In. Calhoun. G. (ed), Habermas and the Public Sphere. Boston: MIT, 1992, pp. 109-142.

Die Transnationalisierung der Öffentlichkeit. Legitimität und Effektivität der öffentlichen Meinung in einer postwetfälischen Welt. In. Niesen, P. Herborth, B. (eds.) Anarchie der kommunikativen Freiheit. Frankfurt am Main: Suhrkamp, 2007, pp. 224-253.

FROMM, E. Psicanálise da Sociedade Contemporânea. $2^{\mathrm{a}}$ ed. trad. L. A. Bahia e Giasone Rebuá. Rio de Janeiro: Zahar, 1961. . The Anatomy of Human Destructiveness. London: Jonathan Cape Ltd, 1974. 
GOMES, W., MAIA, R. Comunicação e Política. Problemas e Perspectivas. São Paulo: Paulus, 2006.

GÜNTHER, Klaus. Legal adjudication and democracy: some remarks on Dworkin and Habermas. European Journal of Philosophy. Essex: Blackwell Publishers. v. 3. n. 1. abr./1995.

Communicative Freedom, Communicative Power, and Jurisgenesis. In.

ROSENFELD, ARATO (orgs.). Habermas on Law and Democracy. Critical Exchanges.

Boston: MIT, 1998, pp. 234-254.

- Teoria da Argumentação no Direito e na Moral: Justificação e

Aplicação. Trad. Cláudio Moltz. São Paulo: Landy, 2004.

- Schuld und Kommunikativen Freiheit. Studien zur personalen

Zurechnung strafbaren Unrechts im Demokratischen Rechtsstaat. Frankfurt am Main:

Vittorio Klostermann GmbH, 2005.

. "Im Umkreis von Faktizität und Geltung" ["No Circuito de Direito $e$

Democracia", tradução livre do alemão]. In. Blätter für deutsche und internationale Politik. 6, Berlin: Blätter Verlagsgesellschaft mbH, 2009.

- Annerkenung, Verantwortung, Gerechtigkeit [Reconhecimento,

Responsabilidade e Justiça]. In. FORST, R., HARTMANN, M., JAEGGI, R., SAAR, M.

Sozialphilosophie und Kritik. Frankfurt am Main: Suhrkamp, 2009(a), pp. 269-287.

HÄBERLE, Peter. Hermenêutica Constitucional - A Sociedade Aberta dos Intérpretes da

Constituição: Contribuição para a Interpretação Pluralista e "Procedimental" da

Constituição. Trad. Gilmar Mendes. Porto Alegre: Sergio Antônio Fabris Editor, 1997.

HABERMAS, J. Kultur und Kritik. Verstreute Aufsätze. Frankfurt am Main: Suhrkamp, 1973.

. Walter Benjamin. Crítica Conscienciadora o Crítica Salvadora. In. Id.,

Perfiles Filosófico-Políticos. Madrid: Taurus, 1975, pp. 297-332.

O conceito de poder em Hannah Arendt. In: FREITAG, B. ROUANET, S.

P. (orgs.) Habermas. Coleção Grandes Cientistas Sociais. vol. 15. São Paulo: Ática, 1980, pp. 100-118.

The Theory of Communicative Action. Reason and the Rationalization of Society. Trad. Thomas McCarthy. vol. I. Boston: Beacon Press, 1984.

. The Theory of Communicative Action. Lifeworld and System. A. Critique of

functionalist reason. Trad. Thomas McCarthy. vol. II. Boston: Beacon Press, 1987.

Consciência Moral e Agir Comunicativo. Rio de Janeiro: Tempo

Brasileiro, 1989. 
Strukturwandel der Öffentlichkeit. Frankfurt am Main: Suhrkamp, 1990.

Racionalidade e Comunicação. Lisboa: Ed. 70, 1996(b).

Further Reflections on the Public Sphere. In. Calhoun [ed], Habermas and the Public Sphere. Cambridge: MIT, 1992.

. Faktizität und Geltung. Beiträge zur Diskurstheorie des rechts und des demokratischen Redchtsstaats. Suhrkamp: Frankfurt am Main, 1992(a).

Between Facts and Norms: Contributions to Discourse Theory of Law and

Democracy. Trad. William Regh. Boston: MIT, 1996;

Direito e Democracia: Entre Facticidade e Validade. II vols. Trad. Flávio Beno Siebeneichler. Rio de Janeiro: Tempo Brasileiro, 1997.

. La biologia no conoce ninguna moral. No es la naturaleza la que prohibe la clonación. Nosotros mismos tenemos que decidir. Respuesta a Dieter E. Zimmer. Trad. G. H. Vásquez. Revista Universidade Antioquia. N. 525. 1998.

. Comentários à Ética do Discurso. Lisboa: Instituto Piaget, 1999.

. On the Pragmatics of Social Interaction. Preliminary Studies in the Theory of Communicative Action. [Da Pragmática da Interação Social: Estudos Prévios à Teoria do Agir Comunicativo] Trad. Barbara Fultner. Boston: MIT, 2001.

- A Inclusão do Outro. Estudos de Teoria Política. São Paulo: Loyola, 2001a.

. Crise de Legitimação no Capitalismo Tardio. Rio de Janeiro: Tempo Brasileiro, 2002.

. O Discurso Filosófico da Modernidade. São Paulo: Martins Fontes, 2002a.

. Verdad y Justificación. Ensayos Filosóficos. Madrid: Trotta, 2002b.

. Knowledge and Human Interests [Conhecimento e Interesse]. Boston:

Beacon, 2002c.

Pensamento Pós-Metafísico. Rio de Janeiro: Tempo Brasileiro, 2002d.

. Mudança Estrutural da Esfera Pública. $2^{\mathrm{a}}$ ed. trad. Flávio R. Kothe. Rio de Janeiro: Tempo Brasileiro, 2003.

Public space and political public sphere - the biographical roots of two motifs in my thought [Espaço público e esfera pública política - as raízes biográficas de dois motifs em meu pensamento. trad. livre]. Conferência comemorativa proferida em Kyoto, Japão, em 11 de novembro de 2004.

. “O Caos da Esfera Pública”. In. Caderno "Mais!”. Folha de S. Paulo, 13/08/06(a). 
Técnica e Ciência como Ideologia. Trad. Arthur Morão. Lisboa: Edições 70, 2006.

Entre Naturalismo e Religião: Estudos Filosóficos. Trad. Flávio Beno Siebeneichler. Rio de Janeiro: Tempo Brasileiro, 2007.

Meios, Mercados y Consumidores: la prensa seria como espina dorsal de la esfera pública política. In. Id. Ay, Europa. Pequeños escritos políticos. Madrid: Trotta, 2009(b), pp. 129-135.

Ay, Europa! Pequeños Escritos Políticos. Madrid: Trotta, 2009.

Zur Legitimation durch Menschenrechte [Pela Legitimação através dos

Direitos Humanos]. In. Id. Politische Theorie. Jürgen Habermas. Philosophische Texte. Studienausgabe in fünf Bänden. Band 4. Frankfurt am Main: Suhrkamp, 2009(a), pp. 289312.

Von den Weltbildern zur Lebenswelt. [Das imagens de mundo ao mundo da vida. Trad. livre]. In. Id. Jürgen Habermas. Philosophische Texte. Studienausgabe in fünf Bänden. [Band 4. Frankfurt am Main: Suhrkamp, 2009(b), pp. 203-270.

Das Konzept der Menschenwürde und die realistische Utopie der Menschenrechte [O conceito de dignidade humana e a utopia realista dos direitos humanos. trad. livre]. In. DZPhil, Akademie Verlag, 58.3, 2010, pp. 343-357.

HABERMAS, J., FREITAG, B., ROUANET, S. P., ALMEIDA, G. A., SIEBENEICHLER, F. B. Jürgen Habermas: 60 anos. Rio de Janeiro: Tempo Brasileiro, 1989(b).

HARDT, Michael; NEGRI, Antonio. Empire (Império). Boston: Harvard, 2000.

HARTMAN, M. Hartman. Wege aus dem Misstrauen Theoretische und praktische Überlegungen [Saída da Desconfiança. Reflexões teóricas e práticas. Trad. livre]. In. PengKeller \& Hunziker (Eds). Vertrauen Verstehen. Institüt für Hermeneutics und Religionsphilosophie. Univ. Zürich., Hermeneutische Blätter. 1/2, 2010, pp. 161-171.

HEGEL, G. W. F. Frühe Politische Systeme. Frankfurt /M - Berlin - Wien, 1974, pp. 291335.

Principios de la Filosofia del Derecho o Derecho Natural y Ciencia Política. Trad. Juan Luis Vermal. Barcelona: EDHASA, 1988; Id. Grundlinien der Philosophie des Rechts. Stuttgart: Reclam, 2009.

HERSCOVICI, A. Economia da Informação, direitos de propriedade intelectual, Conhecimento e novas modalidades de re-apropriação social da Informação. In. Revista de 
Economía Política de las Tecnologías de la Información y Comunicación www.eptic.com.br, Vol. VI, n. 3, Sep. - Dec. 2004, pp. 140-172.

HOBSBAWM. E. Bandidos. Trad. Donaldson M. Garschagen. 2a ed. Rio de Janeiro: Forense Universitária, 1976.

Era dos Extremos. O breve século XX. 1914-1991. São Paulo: Companhia das Letras, 1994.

HONNETH, Axel. The Critique of Power. Reflective Stages in Critical Social Theory. Trad. Kenneth Baynes. Boston: MIT, 1991.

. Luta por reconhecimento: a gramática moral dos conflitos sociais.

Trad. de Luiz Repa. São Paulo: Editora 34, 2003.

- Disrespect. The Normative Foundations of Critical Theory.

Cambridge: Polity Press, 2007.

- Sofrimento de Indeterminação. Uma Atualização da Filosofia do

Direito de Hegel. Trad. Rúrion Soares de Melo. São Paulo: Esfera Pública, 2007(a).

Reificación. Um estudio em la teoria del reconocimiento. Trad. G.

Calderón. Buenos Aires: Katz, 2007 (c).

. Trabalho e Reconhecimento. Tentativa de uma redefinição. In. Civitas.

Porto Alegre v. 8 n. 1. jan.-abr. 2008, pp. 46-67.

Das Ich im Wir. Studien zur Anerkennungstheorie [O Eu em Nós.

Estudos para a teoria do reconhecimento. Trad. livre]. Frankfurt: Suhrkamp, 2010.

Das Recht der Freiheit. Grundriss einer demokratischen Sittlichkeit.

Berlin: Suhrkamp, 2011.

HORKHEIMER, Max, ADORNO, T. W. Dialética do Esclarecimento. Fragmentos Filosóficos. Rio de Janeiro: Jorge Zahar, 1985.

HORKHEIMER, M. "Teoria Tradicional e Teoria Crítica" In. BENJAMIN, W., HORKHEIMER, M., ADORNO, T., HABERMAS, J. Textos Escolhidos. São Paulo: Abril Cultural, 1980.

INTERVOZES. Coletivo Brasil de Comunicação Social. Vozes da Democracia. Histórias da Comunicação na Redemocratização do Brasil. São Paulo: Imprensa Oficial, 2006.

INTERNATIONAL FEDERATION OF PHONOGRAPHIC INDUSTRY. IFPI Digital Music Report 2011. Music at the touch of a button. IFPI, 2011. Disponível em: http://www.ifpi.org/content/library/DMR2011.pdf (último acesso: 28/10/2011).

JANCSÓ, I. A sedução da liberdade: cotidiano e contestação política no final do século XVIII. In. NOVAIS (org.) História da Vida Privada no Brasil. Vol. I. (Laura de Mello e 
Souza, org. do volume). São Paulo: Companhia das Letras, 1997, pp. 387-437.

JAY, Martin. Dialectical Imagination: a history of the Frankfurt School and the Institue for Social Research 1923-1950. Berkeley: University of California Press, 1996.

KANT, I. Crítica da Razão Pura. 9a Ed. Trad. J. Rodrigues de Merege. Rio de Janeiro: Ediouro, [1781] 1995.

. Crítica da Razão Prática. Trad. Valerio Rohden São Paulo: Martins Fontes, [1788] 2003.

Crítica do Juízo. Trad. Trad. Valério Rohden e Antônio Marques. 2.ed. - Rio de Janeiro: Forense Universitária, [1790] 2010.

KASHIURA, Celso. Crítica da Igualdade Jurídica. Contribuição ao pensamento jurídico marxista. São Paulo: Quartier Latin, 2009.

KEEN, A. O Culto do Amador. Como blogs, MySpace, YouTube e a pirataria digital estão destruindo nossa economia, cultura e valores. Trad. M. L. X de A. Borges. Rio de Janeiro: Zahar, 2009.

KEHL, M. R. Imaginário e Pensamento. In. SOUZA, (org.) Sujeito, o lado oculto do receptor. ECA/USP. Melhoramentos, 1995, pp. 169-180.

KELLNER, D. Habermas, the Public Sphere and Democracy. Essay section of Kellener's website. Disponível em : http://gseis.ucla.edu/faculty/kellner/papers/habermas.htm (Sema data. Último acesso em 24/08/2010).

KRAMER, L. Habermas, History and Critical Theory. In. Craig Calhoun. Habermas and the Public Sphere. Cambridge: MIT, 1992, pp. 236-268.

LAGE, Nilson, A bolha ideológica e o destino do jornalismo. in. ALCEU - v.2 - n.3 jul./dez. 2001, pp. 40-53.

LAVALLE, A. Espaço e Vida Públicos: reflexões teóricas e sobre o pensamento brasileiro. Tese de doutorado. Faculdade de Filosofia, Letras e Ciências Humanas da Universidade de São Paulo. Dpto. de Ciência Política, 2001.

LESSIG, Lawrence. The Future of Ideas: the fate of the commons in a connected world. New York: Random House, 2001.

Free Culture. How big media uses technology and the law to lock down culture and control creativity. New York: the Penguin Press, 2004.

. Prosecuting Online File Sharing Turns a Generation Criminal”. Portal eletrônico de notícias USNews (22/12/2008).

LÉVI-STRAUSS, C. Race and History. Unesco: Paris, 1952. 
LIMA, R. S. de. PAULA, L. de (orgs). Segurança Pública e Violência. O Estado está cumprindo seu papel? São Paulo: Contexto, 2008.

LIMA, V. A de. Liberdade de Expressão $x$ Liberdade de Imprensa. Direito à Comunicação e Democracia. São Paulo: Publisher Brasil, 2010.

Marco Regulatório. Mais de duas décadas depois. In. Observatório da Imprensa, 12/04/2011 (www.observatoriodaimprensa.com.br. Último acesso; 28/11/2011). Globo: os princípios, a credibilidade e a prática. In. Carta Maior, $8 / 8 / 2011$.

MAIA, Rousiley (coord). Mídia e Deliberação. Rio de Janeiro: Editora FGV, 2009. - Representação política de atores cívicos e esfera pública: entre a imediaticidade da experiência e os discursos de justificação. In: Anais do III Congresso da Compolítica. São Paulo, 2009.

MANHÃES, M. "Desmistificando as Interferências de radiodifusão FM em Comunicações Aeronáuticas”. In. Observatório do Direito à Comunicação,

A Nova Era da Radiodifusão Sonora Digital. In. Observatório do Direito à Comunicação, 2007.

MARINS, P. C. Habitação e Vizinhança. In. In. NOVAIS, F. (org.). História da Vida Privada no Brasil. Vol. III (Nicolau Sevcenko, org). São Paulo: Companhia das Letras, 1998, pp. 131-214.

MATTOS, F. A. M. de \&. XAVIER, R. C. A Comercialização da Informação e do Conhecimento. In. Revista de Economía Política de las Tecnologías de la Información y Comunicación www.eptic.com.br, vol. IX, n. 3, Sep. - Dec. /2007.

MATTOS, F. A. M de \& CHAGAS, G. Desafios para a inclusão digital no Brasil. in. Perspectivas em Ciência da Informação. V. 13. N. 1, jan-abr. 2008, pp. 67-94.

MAUAD, A. Imagem e auto-imagem do segundo reinado. In. NOVAIS (org) História da Vida Privada no Brasil. Vol. II. (Luis Felipe de Alencastro, org. do volume). São Paulo; Companhia das Letras, 1997, pp. 181-231.

McCARTHY, Thomas. Practical Discourse. On the Relation of Morality to Politics. In. CALHOUN, C. (ed). Habermas and the Public Sphere. Cambridge: MIT, 1992, pp. 51-72. McLUHAN, Marshall. "Visão, som e fúria". In. Lima, L. C. (org). Teorias da comunicação de massa, 1978.

MEIRELLES, Juliana G. Imprensa e Poder na Corte Joanina: A Gazeta do Rio de Janeiro (1808-1821). Arquivo Nacional: Rio de Janeiro, 2008. 
MELO, José M. Exclusión comunicacional y democracia mediática: dilema brasileño em el umbral de la sociedad de la información. In. MELO, José M, SATHLER, L. Direitos à Comunicação na Sociedade da Informação. Porto Alegre: São Bernardo do Campo: UMESP, 2005, pp. 237-244.

MELO, José M. SATHLER, L. Direitos à Comunicação na Sociedade da Informação. Porto Alegre: São Bernardo do Campo: UMESP, 2005.

MENDEL, T. SALOMON, E. The Regulatory Environment for Broadcasting: an international best practice survey for Brazilian stakeholders. UNESCO. Debates CI. N.7 Fevereiro, 2011(a).

Freedom of Expression and Broadcasting Regulation.

UNESCO. Debates CI. N. 8 - fevereiro de 2011.

MESQUITA NETO, Paulo de. Ensaios Sobre Segurança Cidadã. São Paulo: Quartier Latin/FAPESP, 2011.

MILLER, J. B. Corporate Civil Rights Impede Progress of Activists; Environmental and Social Justice Activists Catch on. In. Natural Learning. Vol. 1, outono - 2004. Olympia WA - EUA. Olympia Community Free School. Disponível em: http://www.dsame.com/radicalcaring/naturallearning.html (último acesso: 30/11/2011).

MINISTÉRIO DA CULTURA. Plano da Secretaria da Economia Criativa. Políticas, diretrizes e ações 2011 a 2014, 2011. Disponível em http://www.cultura.gov.br/site/wpcontent/uploads/2011/09/Plano-da-Secretaria-da-Economia-Criativa.pdf (último acesso: 27/10/2011).

MILL, John S. On Liberty/Über die Freiheit. Englisch/Deutsch. Trad. Bruno Lemke. Stutgartt: Reclam, 2009.

MORAES, R. A função social da propriedade intelectual na era das novas tecnologias. In: Ministério da Cultura. Direito Autoral. 1 ed. v. 1. Brasília: Ministério da Cultura, 2006, pp. 237-353.

NEDER, V. AGUIAR, V. Jornalismo e Exclusão: notas para a análise comparativa entre dois padrões de cobertura das questões sociais da infância e da juventude. In. Intexto. Porto Alegre: UFRGS, v. 2, n. 23, p. 236- 252, julho/dezembro 2010.

NEGT, Oskar. The Production of Counter-Publics and the Counter-Publics of Production: An Interview with Oskar Negt. In. in European Journal of Social Theory 9/1: 119-128, 2006.

NEGT, O. KLUGE, A. Public Sphere and Experience. Towards an Analysis of the Bourgeois and Proletarian Public Sphere. Trad. Peter Labanyi, Jamie Owen Daniel and 
Assenka Oksiloff. Theory and History of Literature, Vol. 85. Minneapolis/London. University of Minesotta Press, 1993.

NOBRE, M."Habermas e a teoria crítica da sociedade: sobre o sentido da introdução da categoria do direito no quadro da teoria da ação comunicativa”. In: Oliveira e Souza (orgs.) Justiça política: homenagem a Ottfried Hoffe. Porto Alegre: Edipucrs, 2003.

NOVAES, A.(org.). Muito além do espetáculo. São Paulo: Senac, 2005.

NOVAIS, F. Condições da privacidade na colônia. In. NOVAIS (org.) História da Vida Privada no Brasil. Vol. I. (Laura de Mello e Souza, org. do volume). São Paulo: Companhia das Letras, 1997.

ORGANIZAÇÃO DAS NAÇÕES UNIDAS. Intellectual property rights and human rights. Resolução 2000/7 da Sub-Comissão de Direitos Humanos. Disponível em http://www.unhchr.ch/Huridocda/Huridoca.nsf/0/c462b62cf8a07b13c12569700046704e?O pendocument (último acesso em 27/10/2011).

ORGANIZAÇÕES GLOBO. "Princípios Editoriais das Organizações Globo", 2011. Disponível em: www.g1.com.br (último acesso: 17/11/2011).

PEDRON, F. Q. A contribuição e os limites da teoria de Klaus Günther. in. Revista da Fac. De Direito da UFPR, n. 48, 2008, pp. 187-201.

PETERS, Bernhard. Der Sinn von Öffentlichkeit [O sentido da esfera pública. Trad. livre]. Frankfurt am Main: Suhrkamp, 2007.

PINHEIRO, P. S. Estratégias da Ilusão. A Revolução Mundial e o Brasil 1922-1935. São Paulo: Companhia das Letras, 1992.

PRADO JÚNIOR. Formação Econômica do Brasil. 12ª ed. atual. São Paulo: Brasiliense, 1970.

RAMOS, S., PAIVA, A. Mídia e Violência: como os jornais retratam a violência e a segurança pública no Brasil. Centro de Estudos de Segurança e Cidadania. Rio de Janeiro, 2008 .

RAWLS, John. "Reply to Habermas”. Journal of Philosophy, 92, 1995, pp. 132-180.

RIBEIRO, Darcy. O Povo Brasileiro. São Paulo: Companhia das Letras.1995.

RORTY, Richard. Verdade, universalidade e política democrática. In. José Crisóstomo de Souza (org.). Filosofia, Racionalidade e Democracia. Os debates Rorty \& Habermas. São Paulo: Unesp, 2005, pp. 103-162.

ROSA, H. Beschleunigung: die Veränderung der Zeitstrukturen in der Moderne [Aceleração: a transformação da estrutura do termpo na modernidade]. Frankfurt: Suhrkamp, 2005. 
ROSA, H. SCHEUERMAN, M. (eds.). High Speed Society: Social Acceleration, Power and Modernity. University Park: Pensilvania State University, 2008.

ROUANET, Sérgio P. "Ética Iluminista e Ética Discursiva”. In: Habermas. et al. Jürgen Habermas: 60 anos. Rio de Janeiro: Tempo Brasileiro, 1989. . Teoria Crítica e Psicanálise. Rio de Janeiro: Tempo Brasileiro, 1998. . A Razão Cativa. São Paulo: Brasiliense, 1985.

ROSENFELD, M. ARATO, A. (orgs.). Habermas on Law and Democracy. Critical Exchanges. Boston: MIT, 1998.

SACCO, Joe. Notas sobre Gaza. Trad. Alexandre Boide. São Paulo: Companhia das Letras, 2010.

SALIBA, E. A Dimensão cômica da vida privada na República. In. In. NOVAIS, F. (org.). História da Vida Privada no Brasil. Vol. III (Nicolau Sevcenko, org). São Paulo: Companhia das Letras, 1998, pp. 289-366.

SHAVER, Lea (ed.) Access to Knowlege in Brazil. New Research on Intellectual Property, Innovation and Development. Information Society Project. New Haven: Yale Law School, 2008 .

SCHRITZMEYER, A. L. P. Controlando o poder de matar. Uma leitura antropológica do Tribunal do Júri - ritual lúdico e teatralizado -. Tese de doutorado. Faculdade de Filosofia, Letras e Ciências Humanas da USP, 2001.

SCHWARTZ, G. Princípios de Iconomia. In. Revista da Associação Nacional dos Programas de Pós-Graduação em Comunicação. Dezembro 2006.

SEVCENKO, N. O prelúdio republicano, astúcias da ordem e ilusões do progresso. In. NOVAIS, F. (org.). História da Vida Privada no Brasil. Vol. III (Nicolau Sevcenko, org). São Paulo: Companhia das Letras, 1998, pp. 7-48.

A capital irradiante: técnica, ritmos e ritos do rio. In. NOVAIS, F. (org). História da Vida Privada no Brasil. Vol. III (Nicolau Sevcenko, org. do volume). São Paulo: Companhia das Letras, 1998(a), pp. 513-619.

SOARES, O. Direito de Comunicação. $2^{\mathrm{a}}$ ed. Rio de Janeiro: José Konfino, 1975.

SOUZA, D. P. de. Mídia e criminalidade: o tratamento dos casos Abílio Diniz e Daniela Perez pela imprensa e suas implicações no direito penal brasileiro. Tese de doutoramento. Pós-Graduação em Comunicação e Cultura da UFRJ. Rio de Janeiro, 2009.

SPIEGELMAN, Art. Maus. A história de um sobrevivente. Trad. Antonio de Macedo Soares. São Paulo: Companhia das Letras, 2005.

STRASSER, H. A Estrutura Normativa das Ciências Sociais: Temas Conservadores e 
Emancipacionistas no Pensamento Social. Rio de Janeiro: Zahar, 1978.

THOMPSON, John B. The New Visibility. In. Theory, Culture \& Society. SAGE: London, Thousand Oaks and New Delhi. Vol. 22(6), 2005, pp. 31-51. Disponível em: http://tcs.sagepub.com/cgi/content/abstract/22/6/31 (último acesso: 04/1/2011).

UNITED NATIONS EDUCATIONAL, SCIENTIFIC AND CULTURAL ORGANIZATION. The Race Concept. Results of an Inquiry. The race question in modern sciente. UNESCO. Paris, 1952

VILLALTA, L. C. O que se fala e o que se lê: língua, instrução e leitura. In. NOVAIS, F. A (org). História da Vida Privada no Brasil. Vol. I. (Laura de Mello e Souza, org. do volume). São Paulo: Companhia das Letras, 1997, pp. 331-385.

VOIROL, "Kulturindustrie als Missachtung. Zeitgenössische Perspektiven einer kritischen

Theorie der medialen Kommunikation". (disponível em: http://www.ifs.unifrankfurt.de/veranstaltungen/2007/voirol.html

WISSENBACH, M. C. Da escravidão à liberdade: dimensões de uma privacidade possível. In. In. NOVAIS, F. (org.). História da Vida Privada no Brasil. Vol. III (Nicolau Sevcenko, org). São Paulo: Companhia das Letras, 1998, 49-130.

WELLMER, A. Sobre la Dialéctica de Modernidad y de Posmodernidad. La crítica de la razón después de Adorno. Trad. José Luis Arántegui. Madrid: Visor Distribuciones, 1993. .Endgames. The Irreconcilable Nature of Modernity. Essays and Lectures.

Trans. David Midgley. Cambridge and London: MIT, 1998.

WHITE, S. Mapping the Global Digital Divide (manuscrito. Disponível em: http://interactivemedia.bradley.edu/ell/nmt/08/Mapping\%20the\%20Global\%20Digital\%20D ivide.pdf. Último acesso 23/10/2011)

WIGGERSHAUS, R. Escola de Frankfurt: História, desenvolvimento teórico, significação política. Rio de Janeiro: Diefel, 2002.

WINGERT, L., GÜNTHER, K. (orgs). Die Öffentlichkeit der Vernunft und die Vernunft der Öffentlichkeit. Festschrift für Jürgen Habermas. Frankfurt am Main: Suhrkamp, 2001. 


\section{RESUMO}

O presente estudo procura estabelecer, a partir de uma reavaliação e atualização dos estudos de Jürgen Habermas sobre esfera pública e direito, os fundamentos teóricos e práticos do Direito da Comunicação, uma teoria crítica do direito que restabelece o vínculo interno entre direito e esfera pública política, e com isso fornece um modelo complementar a teoria procedimental de Habermas, fortalecendo as condições para a produção de uma legitimidade democrática do poder em sociedades pluralistas.

Palavras-chave: esfera pública política, teoria discursiva do direito e da democracia, direito da comunicação, direitos de comunicação, comunicação do direito 


\begin{abstract}
The present work aims at establishing, through a reevaluation and actualization of Jürgen Habermas' studies on public sphere and law, the theoretical and practical grounds of Communication Law, a critical theory of law that recovers the internal relation between law and the political public sphere, and in doing so, provides a complementary model to Habermas' procedural theory, enhancing the conditions for the production of a democratic legitimacy of power in pluralist societies.
\end{abstract}

Key-words: political public sphere, discursive theory of law and democracy, communication law, communication rights, communication of law 
